
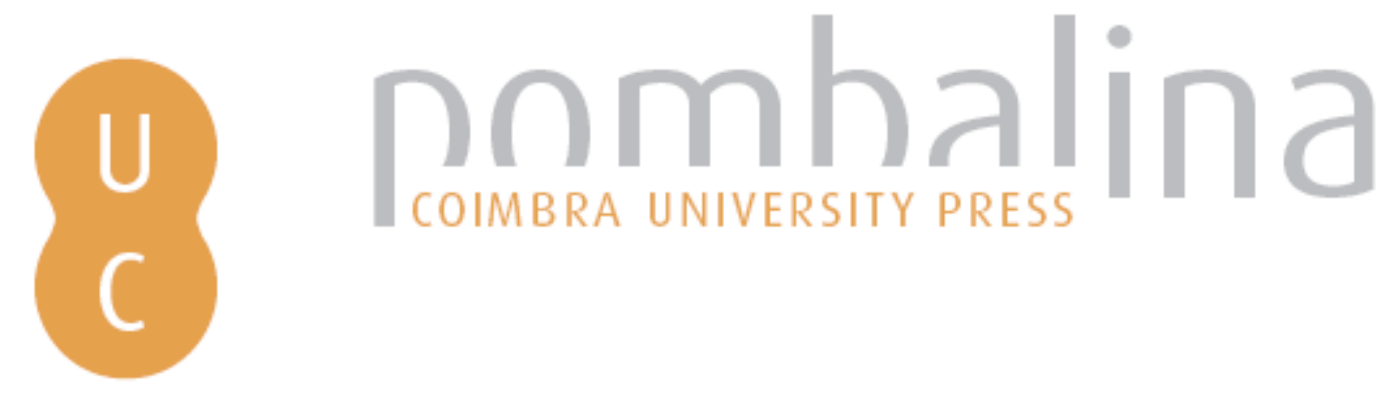

\title{
Paráfrases a Job e à sabedoria de Salomão
}
Autor(es): $\quad$ Osório, Jerónimo
Publicado por: Imprensa da Universidade de Coimbra
URL
persistente: URI:http://hdl.handle.net/10316.2/3190
DOI: $\quad$ DOI:http://dx.doi.org/10.14195/978-989-26-0457-2

Accessed : $\quad$ 26-Apr-2023 10:37:56

A navegação consulta e descarregamento dos títulos inseridos nas Bibliotecas Digitais UC Digitalis, UC Pombalina e UC Impactum, pressupõem a aceitação plena e sem reservas dos Termos e Condições de Uso destas Bibliotecas Digitais, disponíveis em https://digitalis.uc.pt/pt-pt/termos.

Conforme exposto nos referidos Termos e Condições de Uso, o descarregamento de títulos de acesso restrito requer uma licença válida de autorização devendo o utilizador aceder ao(s) documento(s) a partir de um endereço de IP da instituição detentora da supramencionada licença.

Ao utilizador é apenas permitido o descarregamento para uso pessoal, pelo que o emprego do(s) título(s) descarregado(s) para outro fim, designadamente comercial, carece de autorização do respetivo autor ou editor da obra.

Na medida em que todas as obras da UC Digitalis se encontram protegidas pelo Código do Direito de Autor e Direitos Conexos e demais legislação aplicável, toda a cópia, parcial ou total, deste documento, nos casos em que é legalmente admitida, deverá conter ou fazer-se acompanhar por este aviso.

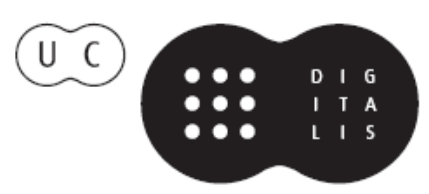




\title{
PortVgaliae
}

Monvmenta Neolatina

\author{
VOL. IV
}

D. JERónimo Osório

Opera OMnia

I

Paráfrases a Job e à

SABEDORIA DE SALOMÃO 
(Página deixada propositadamente em branco) 


\section{PORTVGaliae \\ MONVMENTA NEOLATINA}

Coordenação Científica

$\begin{array}{llllll}\text { A } & \text { P } & \text { E } & \text { N } & \text { E } & \text { L }\end{array}$

Associação Portuguesa de Estudos Neolatinos

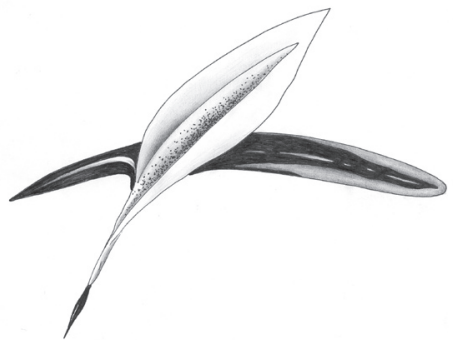

A P E N N E I 


\section{COORDENAÇÃo CIENTÍFICA}

Associação Portuguesa de Estudos Neolatinos - APENEL

\section{DIRECÇÃO}

Sebastião Tavares de Pinho, Arnaldo do Espírito Santo,

Virgínia Soares Pereira, António Manuel R. Rebelo,

João Nunes Torrão, Carlos Ascenso André,

Manuel José de Sousa Barbosa

COORDENAÇÃO EDITORIAL

Maria João Padez de Castro

CO-EDIÇÃO

Imprensa da Universidade de Coimbra

Email: imprensauc@ci.uc.pt

URL: http://www.uc.pt/imprensa_uc

Universidade do Algarve

Email: bibcentral@ualg.pt

URL: http://www.ualg.pt

CONCEPÇÃO GRÁFICA

António Barros

PRÉ-IMPRESSÃO E IMPRESSÃO

G.C. - Gráfica de Coimbra, Lda

ISBN

978-989-8074-78-2

DEPÓSITO LEGAL

$292459 / 09$

OBRA PUBLICADA COM O APOIO DE:

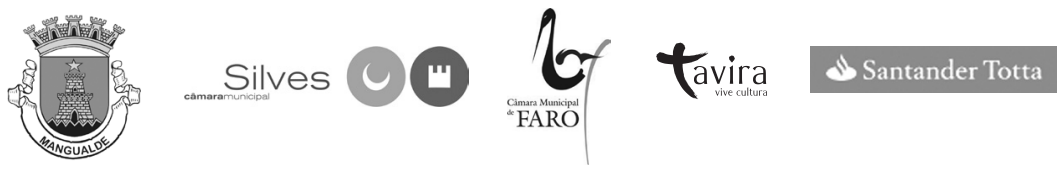


Portvgaliae Monvmenta NeOlatina

VOL. IV

D. JERÓNIMO OSÓRIO

\section{OPERA OMNIA \\ I}

Paráfrases a Job e À SABEdoria

DE SALOMÃO

Estabelecimento do texto latino, introdução, tradução e notas

ANTÓNIO GUIMARÃEs Pinto

IMPRENSA DA UNIVERSIDADE DE COIMBRA

UNIVERSIDADE DO ALGARVE 
(Página deixada propositadamente em branco) 


\section{INTRODUÇÃO}

\section{Bosquejo biográfico}

Jerónimo Osório e Jorge de Montemor partilharam a glória de serem os escritores portugueses do século XVI mais lidos pelos seus contemporâneos europeus, tendo sido alguns dos livros do primeiro, tal como La Diana do segundo, verdadeiros best-sellers. Hoje une-os a mofina sorte de se terem tornado dois quase anónimos para os seus compatriotas, com a diferença porém de que o segundo goza ainda do estatuto de conceituado e relativamente lido clássico da literatura espanhola, enquanto ao último bispo de Silves remeteu-o a um quase total olvido aquilo que foi exactamente a base principal da sua fama europeia: o ter-se servido, no seu desejo de se dirigir a um vasto auditório, do latim, a língua universal de então, posteriormente substituída nestas funções por outros idiomas, e contra a qual os Portugueses da segunda metade do século XX se ensanharam mais violentamente do que quaisquer dos seus irmãos nascidos da comum matriz romana. Talvez esta situação ajude a explicar o motivo das grandes lacunas que até hoje têm rodeado o estudo da biografia e da obra do Autor que vamos apresentar e, ao mesmo tempo, nos sirva de escusa para os deslizes em que agora incorrermos.

É escassa e parcimoniosa a documentação que os arquivos e fontes directas nos oferecem acerca da biografia de Jerónimo Osório, razão pela qual muito do que durante séculos se disse acerca dele proveio, em larga medida, da Vita que o diligente sobrinho do mesmo nome escreveu do seu ilustre tio e antepôs ao primeiro volume dos quatro in-fólios nos quais reuniu, em primorosa edição saída dos prelos romanos de Bartolomeu Bonfadini, em 1592, as obras completas (Opera Omnia) do escritor português, que falecera doze anos atrás. Já em outro lugar, recorrendo à documentação de que então pudemos dispor, traduzimos e anotámos esta biografia, ${ }^{1}$ insubstituível a muitos títulos um dos quais é precisamente o mesmo que nos leva a pôr de remissa alguns dos dados aí registados: a circunstância de o biógrafo ser parente tão próximo do biografado e

\footnotetext{
${ }^{1}$ D. Jerónimo Osório, Tratados da Nobreza Civil e Cristã. Tradução, Introdução e Anotações de A. Guimarães Pinto, Lisboa, Imprensa Nacional-Casa da Moeda, 1996, pp. 33-79.
} 
a ele ligado por vínculos afectivos muito estreitos. ${ }^{2}$ Por conseguinte, pareceu-nos mais interessante seguir aqui um caminho um pouco diferente do usualmente trilhado e cingir a nossa exposição à menção de factos biográficos documentalmente comprovados ou à sugestão de hipóteses alicerçadas na evidência histórica.

\section{a) A família. Data e local de nascimento}

Conquanto na sua primeira obra, consagrada à definição das nobrezas civil e cristã, Jerónimo Osório tenha concluído pela superioridade da segunda e assentado que nobilitatem virtutis radicibus innixam sustentari: virtute vero fracta, atque debilitata concidere ("A nobreza se conserva apoiada nas raízes da virtude, mas cai e se desvanece uma vez a virtude quebrantada e enfraquecida"), ${ }^{3}$ todavia são inequívocos os testemunhos de orgulho de linhagem de que o vemos dar prova nos momentos menos esperados, como é o caso do livro de polémica escrito contra o inglês Walter Haddon, onde podemos ler: et non essem, ut sum, antiquissima nobilitate ("e não pertencesse eu, como de facto pertenço, à mais antiga nobreza"). ${ }^{4}$ É de supor que alegasse esta antiguidade de estirpe tendo em mente ambos os progenitores: D. ${ }^{a}$ Francisca Gil de Gouveia, sua mãe, e o licenciado João Osório da Fonseca, ${ }^{5}$ seu pai, acerca de cuja actividade como ouvidor geral na Índia nos transmitem razoável informação os cronistas do século XVI ${ }^{6}$ e cuja

2 Desde tenra idade (nascera, em 1545, em Coulão, na indiana costa do Malabar, região onde decorreu grande parte da vida do seu progenitor, vindo a falecer em 1611) ficou sob os cuidados e direcção intelectual do tio homónimo, tal como reconhece na Vita do mesmo: $a$ pueritia me suis sumptibus aluit, litteris instituendum curauit, et ipse aliquando erudiuit, paterna caritate semper est amplexus, et omnia, si quae in me sunt, dignitatis ornamenta contulit. ["criou-me à sua custa desde criança, encarregou-se da minha educação literária e ele próprio me leccionou algumas vezes, sempre me votando um afecto de pai, e, se porventura em mim existem, a ele devo todos os quilates do meu prestígio."] O. c., p. 18 (paginação independente do resto do volume).

Sobre a sua obra e percurso biográfico, vide: Barbosa Machado, Biblioteca Lusitana, sub uerbo, e Sebastião Tavares de Pinho, "O Doutor Jerónimo Osório, sobrinho e editor do bispo D. Jerónimo Osório, e a fundação do Seminário de Évora (com a publicação de cartas inéditas)”, capítulo 5 do livro Humanismo em Portugal. Estudos, Lisboa, Imprensa Nacional-Casa da Moeda, 2006, tomo II, pp. 157-190.

3 Jerónimo Osório, Hieronymi Osorii Lusitani de gloria [...] eiusdem de nobilitate [...], Basileia, Petrus Perna, 1572, p. 362.

${ }^{4}$ Jerónimo Osório, Amplissimi [...] in Gualterum Haddonum [...], Lisboa, Francisco Correia, 1567 , f. 4 .

5 A linhagem dos Fonsecas aparece associada à dos Osórios a partir do casamento de Osório Dias com D. ${ }^{a}$ Beatriz da Fonseca, avós paternos do licenciado João Osório.

${ }^{6}$ Por exemplo: Fernão Lopes de Castanheda, História do descobrimento e conquista da Índia (passim, livro $8^{\circ}$ ); João de BARROS, Década $3^{a}$ (livro 9º cap. $2^{\circ}$ ); Diogo do Couto, Década $4^{a}$; Francisco de Andrada, Crónica de D. João III (passim, partes $1^{\mathrm{a}}$ e $2^{\mathrm{a}}$ ). Foi relevante a sua actuação nos acidentados episódios que caracterizaram o governo da Índia por parte de Lopo Vaz de Sampaio. 
vocação ultramarina iria continuar-se no outro filho varão, Bernardo da Fonseca, ${ }^{7}$ o pai do diligente biógrafo e editor do "Cícero lusitano", epíteto com que os contemporâneos condecoraram o nosso Autor.

Pelo lado materno, Jerónimo Osório estava vinculado por laços de parentesco mais ou menos próximo com a família dos célebres Gouveias humanistas e, muito provavelmente, com o descobridor do Brasil, Pedro Álvares Cabral. ${ }^{8}$ Por parte do pai, procedia de uma antiga família galega (Ozores) radicada desde o século XIV em terras da Beira, ${ }^{9}$ onde ostentavam o título de senhores de Figueiró da Granja. ${ }^{10}$ Apesar de o sobrinho não o afirmar, Barbosa Machado e, na sua peugada, Inocêncio, ${ }^{11}$ dão a primogenitura ao nosso Autor, opinião que nos parece razoável, olhando para o facto de usar em primeiro lugar (para não arriscarmos dizer exclusivamente) o primeiro sobrenome paterno - o qual, segundo os usos de então, cabia ao varão primogénito - e de, no brasão episcopal, composto e partido, na pala do lado direito ostentar as armas de Osórios e, na do lado esquerdo, as dos Fonsecas. ${ }^{12}$

7 Um manuscrito genealógico, existente na Biblioteca da Ajuda (49-XII-39), nos fólios 411-412, na rubrica respeitante a Bernardo da Fonseca Osório, consigna: "Foi à Índia em a nau Graça, no ano de 1531, e lá serviu alguns anos com satisfação, e vindo ao Reino, voltou por capitão de Coulão, onde esteve seis anos e defendeu valerosamente o cerco que lhe pôs o rei da pimenta; depois governou a mesma fortaleza por ordem especial del-rei e fez ũa viagem à China, e ultimamente o mandou el-rei Filipe à Índia por vedor da Fazenda."

${ }^{8}$ Dados mais completos e bibliografia in António Guimarães Pinto, Humanismo e Controvérsia Religiosa. Lusitanos e Anglicanos - A polémica Jerónimo Osório / Manuel de Almada - Walter Haddon, Lisboa, Imprensa Nacional-Casa da Moeda, 2006, tomo I, pp. 48-49.

9 Sobre a genealogia da família Osório, vejam-se as pp. 49 e 272-277 da obra e tomo citados na nota anterior.

${ }^{10}$ Antigo couto pertencente ao mosteiro de S. João de Tarouca e município, com foral concedido por D. Manuel, hoje integrado no concelho de Fornos de Algodres. "Por volta de 1392, o mosteiro de S. João de Tarouca transferiu e subemprazou por uma renda certa anual os direitos de nouea e casarias à família Osório, que em Figueiró viveu nos fins do século XIV e princípios do XV. Desde então essa família, mediante o pagamento aos Cistercienses de colheita e laudémio, passou a receber as rendas dos moradores, até aí pagas aos referidos monges. Por isso, os sucessores enfiteutas da família Osório intitulavam-se Senhores de Figueiró da Granja." Mário Guedes Real, "Pelourinho de Figueiró da Granja”, Beira Alta, 12 (2-3), Viseu, 1953, pp. 261-272. O passo citado encontra-se na p. 268.

11 Dicionário Bibliográfico Português, Lisboa, Imprensa Nacional, 1859, tomo III, p. 272.

12 Vimos este brasão estampado em dois selos pendentes: um, em um documento do Arquivo da Diocese do Algarve, e o outro na carta de D. Jerónimo Osório ao papa Pio V, cujo original se encontra no Archivio Segreto Vaticano. As armas de Fonsecas são cinco estrelas de sete pontas e as de Osórios dois lobos passantes e sotopostos. Curiosamente, numa edição conjunta das obras De gloria e De nobilitate, publicada em Alcalá de Henares, em 1572, pelo impressor Ioannes Gracianus, a página de rosto ostenta um brasão episcopal com as armas dos Ozores, que são totalmente diversas das do ramo desta família (ao qual pertencia o nosso Autor) que em Portugal adoptou no século XVI as grafias Osouro e Osório para seu sobrenome. Armas de Ozores: enxaquetadas com três peças em faxa e cinco em pala. Vide Braamcamp FREIRE, Armaria Lusitana, Lisboa, Cota de Armas, 1989, pp. 201 e 366. 
Das relações e actividades que coligimos sobre os seus maiores, pensamos poder concluir que a família de Jerónimo Osório nos aparece caracterizada por três tipos de vinculações: à nobreza rural das Beiras, à magistratura e ao serviço e círculo de influência da família real. ${ }^{13}$

Nada diz o sobrinho biógrafo sobre a localidade onde o nosso Autor terá nascido, cabendo a D. Francisco Barreto I, ${ }^{14}$ no século XVII, a primeira atribuição de naturalidade, ao escrever, na lista que elaborou dos bispos do Algarve: "37. ${ }^{\circ}$ D. Hierónimo Osório, natural de um lugar do bispado de Leiria do reino de Portugal" - informação, além de vaga, anacrónica, porquanto a diocese de Leiria só viria a ser criada a pedido de D. João III, já bem entrado o século XVI. No entanto, é também possível que com essa expressão o autor esteja mais interessado em ser claro para o leitor seu contemporâneo do que em figurar como rigoroso aos olhos do historiador futuro. Barbosa Machado, seguido por Inocêncio e pelo coro uníssono dos estudiosos posteriores, fazem de Osório lisboeta.

Pela nossa parte, só temos a acrescentar que a restante documentação que conhecemos relativa à terra que viu nascer o nosso Autor é díspar e inconclusiva: Hieronymus Osorius, nobilis Colimbricensis; Hieronymus Osorius Vlisbonensis diocesis $;{ }^{15}$ R. D. Hieronymo de Osorio presb. Visens. ${ }^{16}$ - três dioceses distintas (Coimbra, Lisboa e Viseu) apostas ao nome da mesma pessoa, em três épocas e situações diversas (matrículas na Universidade de Paris, nos dois primeiros casos, e nomeação episcopal, no último), não com certeza pelo acidente de aí ter nascido, mas, ao que supomos, por a elas se encontrar ligado, em épocas diferentes, pelo gozo de prebendas, residência dos pais, desempenho de cargos ou vínculos espirituais contraídos pela recepção de ordens eclesiásticas. A verdade é que, para quem tiver algum trato com os escritores quinhentistas, sobretudo os que escreveram em latim, sempre tão ciosos de aditarem ao seu nome de família o apelativo do torrão

\footnotetext{
13 Segundo a Vita, p. 1, o matrimónio dos pais de Jerónimo Osório foi promovido por "D. ${ }^{a}$ Leonor, esposa do rei de Portugal D. João II, e por D. ${ }^{a}$ Beatriz, esposa de D. Fernando, filho do rei D. Duarte, e que foi mãe da mesma D. ${ }^{a}$ Leonor e do rei D. Manuel." (quam Leonora Ioannis hoc nomine Secundi Regis Portugaliae vxor, et Beatrix Fernandi filii Oduardi Regis vxor, quae et Leonorae, et Emmanuelis Regis mater exstitit, in matrimonium Ioanni Osorio collocarunt.)

${ }^{14}$ P. 15 do "Catálogo dos bispos do bispado do Algarve", apenso às Constituições sinodais do bispado do Algarve novamente feitas e ordenadas pelo ilustríssimo senhor D. Francisco Barreto, segundo deste nome, bispo do reino do Algarve, Évora, Impressão da Universidade, 1676. Note-se que o autor do Catálogo é sobrinho, homónimo e imediato sucessor na mitra algarvia do D. Francisco Barreto I responsável pela trasladação do cadáver de D. Jerónimo Osório da igreja de S. Francisco, em Tavira, para um carneiro subterrâneo que mandara abrir sob a capela-mor da Sé de Faro para derradeira morada dos bispos do Algarve. Acresce que, tendo vivido em época relativamente propíngua da prelatura de Osório, é possível que tenha tido acesso a documentação ou tradições que transmitiu directamente ao sucessor e sobrinho.

15 Apud Luís de Matos, Les Portugais à l' Université de Paris entre 1500 et 1550, Coimbra, Imprensa da Universidade, 1950, pp. 84 e 92, respectivamente.
}

16 Archivio Segreto Vaticano - Archivio Concistoriale, Acta Camerarii 9, $101 v^{\circ}$. 
natal, ${ }^{17}$ não deixa de causar alguma estranheza o silêncio a que Jerónimo Osório, sempre tão ufano da sua qualidade de lusitanus, vota a sua patria chica. É provável que tal singularidade se deva ao facto de o seu nascimento se ter verificado, de forma acidental, em alguma localidade sem qualquer conexão com a sua vida posterior ou mesmo com a tradição familiar, à semelhança do que sucederá, por exemplo, com o poveiro Eça de Queirós ou o biscainho Bulhão Pato.

Quanto à data de nascimento, teve, e continua a ter, ampla circulação o ano de 1506, indicado por Barbosa Machado, a quem induziu em erro uma inadvertência de Osório Júnior, que, na p. 19 da biografia do tio, escreveu que este morrera septuagesimo quarto aetatis suae anno em vez de sexagesimo - ordinal que compaginaria com a idade de cerca de dez anos, que atribuíra ao seu tio na época em que Vasco da Gama zarpou de Lisboa na $3^{\text {a }}$ viagem à Índia (9 de Abril de 1524), ${ }^{18}$ e nos induz a situar o seu nascimento entre 1514 e 1515 , tendo em conta que o seu decesso se deu em 1580.

Não bastaram para remover essa prolongada e quase consagrada inexactidão aritmética, nem a atilada observação de Inocêncio, que escreveu: "Morreu (...) com setenta e quatro anos de idade, se devemos estar pelas contas de Barbosa, que todavia parece haver padecido algumas equivocações nesta parte, a ponto de serem inconciliáveis entre si as datas da primeira quadra da vida deste insigne varão e doutíssimo prelado", ${ }^{19}$ nem algumas afirmações e modos de dizer, que seriam incoerências, tanto do biógrafo, como de Osório e de contemporâneos, se se aceitasse como exacta aquela datação. Por exemplo: 1) Osório Júnior, na Vita, escreve que o tio partira para Salamanca aos treze anos de idade (p. 1), donde, dois anos volvidos, viera a Portugal visitar o pai recém-chegado da Índia, regressando de novo para a universidade espanhola logo após ter saudado o progenitor; andava então o moço estudante "à roda dos dezasseis anos de idade": annum aetatis fere decimum sextum agens. (p. 2) Ora, João Osório regressara a Portugal, sob prisão e na companhia de Lopo Vaz de Sampaio, na nau que D. Lopo de Almeida capitaneava e que fora despachada de Goa, pelo novo governador Nuno da Cunha, em Janeiro de 1530, tendo arribado a Lisboa sem contratempos de viagem no curso deste mesmo ano. ${ }^{20} 2$ ) Pelo seu lado, Jerónimo Osório qualifica-se a si mesmo como adolescens no seu primeiro livro (1542), ${ }^{21}$ o que não quadraria de forma alguma com o limite de trinta anos que os latinos impunham geralmente à adolescentia. 3) Finalmente, o inglês Walter Haddon de

17 Lembrem-se, a título de exemplo, os casos do André de Resende Eborensis, do Pedro Nunes Salaciencis (de Alcácer do Sal), do Jerónimo Cardoso Lamacensis, do António Pinheiro Portodemaeus (de Porto de Mós) e do António Luís Olyssiponensis.

${ }^{18}$ Mansit igitur Osorius Olysipone decimum annum fere agens. ("Por conseguinte, Osório, que tinha cerca de dez anos, permaneceu em Lisboa.") O biógrafo referira-se ao desígnio que o licenciado João Osório tivera de levar consigo os filhos varões para a Índia, no que foi impedido pelo denodado conde-almirante.

19 Obra e p. citadas.

${ }^{20}$ Frei Luís de Sousa, Anais de D. João III, Lisboa, Sá da Costa, 1951, tomo II, p. 112.

21 De nobilitate ciuili et christiana, edição citada, p. 357. Esta obra já se encontrava em fase de acabamento no Verão/Outono de 1541, como se colige de uma carta que o amigo 
forma injuriosa lança em rosto do nosso Autor a sua decrepidez, pintando-o, antes de 1572 (ano da morte de Haddon) como "teólogo já encanecido e quase sexagenário": theologo iam cano et pene sexagenario. ${ }^{22}$

\section{b) Anos de aprendizagem. A experiência europeia}

Da passagem de Osório pela Universidade de Salamanca não rasteámos vestígios nos arquivos oficiais académicos. De acordo com o sobrinho, conforme já vimos, aí permaneceu de forma contínua dos treze aos quinze anos, altura em que, por motivo do regresso do pai, volta à pátria. Pouco depois, de acordo com a Vita, retoma os estudos na cidade do Tormes, dedicando-se durante dois anos ao estudo do direito civil, actividade a que pôs termo o falecimento do progenitor: postquam patrem salutauit, iterum Salmanticam petijt [...] biennium in Iuris ciuilis studio consumpsit [...] patre mortuo, in Portugaliam reuertitur. (p. 2) Apesar do silêncio dos livros de matrículas e actos, ficou-nos prova segura de que ao ensino recebido em Salamanca deveu, pelo menos, a sua iniciação e primeiros progressos na língua helénica. De facto, em data incerta, mas certamente pouco posterior à primeira edição do seu primeiro livro (1542), o nosso escritor enviou uma carta ao teólogo e filólogo León de Castro (1509-1585), na qual, com pretexto de agradecer as palavras encomiásticas com as quais o antigo mestre salmantino lhe enaltecera o engenho, faz uma confissão da imensa dívida cultural com que o onerara:

Perfecisti, vt intra vnius anni spatium Athenas inuiserem, et illos summos doctrinarum omnium principes (...) si sum in Aristotelis disciplina, cum nonnulla ingenii laude versatus, si Platonis amplitudinem suspicere clare potui, si ausus aliquando fui Demosthenis vim mibi ad imitandum proponere, tu certe huius nostri ardoris auctor exstitisti. ["lograste que, em menos de um só ano, eu visitasse Atenas e tratasse aqueles máximos príncipes de todos os saberes. (...) se me ocupei da filosofia de Aristóteles, com não pequeno aplauso à minha inteligência; se pude aplicar-me (...) à magnificência de Platão; se, por vezes, me propus ousadamente imitar a energia de Demóstenes - foste tu, sem dúvida, o responsável por este meu entusiasmo."] ${ }^{23}$

António Agustín endereça então ao Autor, cuja tradução se pode ler nas pp. 239-240 da nossa edição deste livro

22 Contra Hieronymum Osorium, Londres, John Day, 1577, p. 41. Na edição que fizemos de todas as obras que integram a polémica religiosa que opôs Haddon a Osório, e a que já atrás fizemos referência, este passo encontra-se na p. 479 do tomo III. Haddon estava bem informado sobre particularidades físicas do contendor e é mais que provável que o seu amigo Thomas Wilson, enviado extraordinário do governo inglês à corte portuguesa em Outubro de 1567, que conhecera pessoalmente e falara com Osório em Lisboa, o tenha informado sobre a idade do bispo do Algarve.

23 Opera Omnia, o. c., I, col. 1173. - Veja-se a tradução anotada desta carta in D. Jerónimo Osório, Cartas. Tradução, Compilação e Notas de A. Guimarães Pinto, Silves, Câmara Municipal, 1995, pp. 24-26. 
Sabemos, por outro lado, que Castro foi nomeado catedrático da cadeira de iniciação ao grego em 1533, recebendo, a 26 de Julho de 1534, comissão do reitor para ler "em grego as Leis de Platão no ano vindouro", tornando-se titular da cátedra principal desta língua em Setembro de 1548, por motivo da jubilação de Hernán de Guzmán, o célebre comendador griego, que a regia desde 1523 e que, pela mera conjugação das datas, é verosímil supor que tenha sido professor do nosso Autor após o ano de iniciação: isto, todavia, somente na suposição de que, antes de 1533, Castro tenha leccionado a cadeira de iniciação ao grego a outro título que não o de catedrático, uma vez que sabemos que em 1534 Osório já frequentava a Universidade de Paris. Ora, do magistério de León de Castro, além de um perdurável amor e profundo conhecimento da língua grega, é de supor que tenham calado fundo no nosso Autor (se não de modo directo então, pelo menos sob a forma de uma certa predisposição para acatá-lo posteriormente como exemplo) o gosto do mestre pela hermenêutica bíblica em moldes modernos e um certo rigorismo ortodoxo no domínio religioso, de que o mais notório exemplo é a sanha com que perseguiu frei Luís de León, a quem denunciou à Inquisição. ${ }^{24}$

Já acima fizemos menção de dois registos da Universidade de Paris, que nos dão notícia - muito vaga, é certo - da presença aí de Jerónimo Osório nos anos de 1534 e 1538, ano aquele que combina com a informação oferecida pela biografia do sobrinho, que nos diz que o tio se dirigiu para Paris quando tinha dezanove anos: Lutetiam Parisorum se contulit, cum decem et nouem aetatis suae annos ageret. (p. 2) Também o próprio Osório se refere explicitamente à sua estadia na capital francesa como estudante, numa carta em português, datada de 7 de Fevereiro de 1571, na qual procura dissuadir a rainha D. ${ }^{a}$ Catarina de retirar-se para Castela: "Sendo estudante em Paris, ouvi dizer a um criado da rainha vossa irmã D. ${ }^{a}$ Leonor." ${ }^{25}$ Sabemos que a rainha D. ${ }^{a}$ Leonor só entrou solenemente em Paris, como rainha de França, em Março de 1531.

É de supor que em Paris se entregou sobretudo a estudos de carácter filosófico e que terá mantido contacto estreito, se não vivido na companhia do seu parente Diogo de Gouveia, o Velho ${ }^{26}$ director do Colégio de Santa Bárbara, principal casa de acolhimento dos jovens portugueses que estudavam na capital francesa, a maior parte dos quais na qualidade de bolseiros de D. João III. De facto, em célebre carta datada de 17 de Fevereiro

24 Vide José López Rueda, Helenistas españoles del siglo XVI, Madrid, Instituto Antonio de Nebrija, 1973, pp. 66-87; Marcel Bataillon, Erasmo y España, Madrid, Fondo de Cultura Económica, 1991, p. 741.

25 Vide a transcrição e anotações a esta carta, na edição do epistolário osoriano citada supra, pp. 70-72.

26 É de presumir que foi em Paris que intimou com o também seu parente António de Gouveia, odiado sobrinho do doutor Diogo de Gouveia. Como testemunho desta amizade ficou-nos um pequeno e gracioso epigrama, em que o humanista bejense pede a Osório que lhe recambie de Portugal para França "um livreco imundo, desgrenhado, apoucado de tomo. - É meu! (...) não lhe dei ainda o castigo que mereceu." António de Gouveia, Epigrammata Eiusdem epistolae quatuor, Lião, Sebastianus Gryphius, 1540, p. 17. A $1^{\text {a }}$ edição desta obra saíra em 1539 e não contém esta composição. 
de 1538, dirigida ao monarca português, o tradicionalista doutor Diogo de Gouveia refere-se às "grandes novas que Mestre Hierónimo d' Osoiro me escreveu de como os [M]alabares recebiam a fé (...)":27 termos que permitem concluir que o nosso Autor já recebera a graduação académica de "mestre" (a única que lhe conhecemos) e, muito provavelmente, se encontrava então em Portugal, onde terá colhido aquela informação sobre o fértil campo que na Índia se abria à evangelização cristã. ${ }^{28}$ Ora, o facto de aparecer inscrito na Universidade de Paris entre Junho-Outubro deste mesmo ano de 1538 pode explicar-se, a nosso ver, se pensarmos que Osório regressou a Paris, neste ano, para uma nova estadia, que se viu inopinada e prematuramente encurtada pelos acontecimentos imprevistos, aos quais ele mesmo se refere e que, ao que nós supomos, o obrigaram a regressar à pátria. ${ }^{29}$

O passo seguinte na preparação universitária do nosso Autor é a sua permanência em Bolonha, depois de uma estadia, mais ou menos longa, em Portugal, a que foi obrigado por força de problemas de ordem familiar, tal como, em coincidência com as afirmações do sobrinho, ${ }^{30}$ ele mesmo confessa na dedicatória da sua segunda obra - o tratado dialogado De gloria -, onde, dirigindo-se ao rei D. João III, escreve:

Cum igitur in Italiam me excolendi ingenii contulissem, et ex multorum sermone intellexissem, nullam tunc Italiae ciuitatem esse cum Bononia literarum gloria conferendam: eam delegi potissimum, in qua studia perturbatione rerum mearum impedita longo tandem interuallo reuocarem. ("Por conseguinte, como me tivesse passado à Itália com o fito de acepilhar o meu entendimento, e coligindo de conversas com muitas pessoas que, por essa altura, cidade alguma italiana estava em termos de levar a palma a Bolonha na glória das letras, dei-lhe a preferência da minha escolha, a fim de ali poder reatar finalmente os meus estudos, largo tempo interrompidos por força de desarranjos na minha vida privada." $)^{31}$

Ao mecenato do infante D. Luís deveu Osório a possibilidade de dar seguimento aos seus estudos - inesperada e longamente interrompidos - na célebre universidade italiana, tal como ele mesmo reconhece no começo da dedicatória da sua primeira obra a esta personagem real: Posteaquam beneficio tuo, Ludovice Princeps clarissime, consecutis sum, vt me ad pristina studia reuocarem. ("Depois que, graças a vós, ó mui

27 Marcel Bataillon, Études sur le Portugal au temps de l' humanisme, Coimbra, Imprensa da Universidade, 1952, p. 133. Sobre a importância histórica desta carta para o estabelecimento dos jesuítas em Portugal veja-se Francisco Rodrigues, História da Companbia de Jesus na Assistência de Portugal, Porto, Apostolado da Imprensa, 1931, tomo I, pp. 217 e segs.

${ }^{28}$ É verosímil supor que este informe lhe terá sido transmitido por via epistolar pelo irmão Bernardo da Fonseca, o qual, como atrás vimos, partira para a Índia em 1531, onde irá permanecer longos anos.

29 Dissentimos da interpretação que Luís de Matos deu destes factos na p. 85 do seu já citado livro. Veja-se o que escrevemos nas pp. 53-54 do tomo I da nossa obra Humanismo e Controvérsia Religiosa.

30 Parisijs Osorius discedens ob rerum suarum perturbationem, in Lusitaniam venit. ["Deixando Paris devido a desarranjos de ordem privada, veio para Portugal."] Vita, p. 3.

31 Jerónimo Osório, o. c., p. 9. 
esclarecido príncipe D. Luís, alcancei reatar os meus precedentes estudos.") ${ }^{32}$ Vai ser em Bolonha que, além de colher os ensinamentos de já reputados literatos ${ }^{33}$ e se entregar ao estudo da teologia e do hebraico, ${ }^{34}$ irá contrair amizade com dois homens com os quais, mais ou menos esporadicamente, continuará a manter relações epistolares até ao final da vida: o aragonês António Agustín e Jean Matal, natural do Franco Condado, região então pertencente ao património do imperador Carlos V. ${ }^{35}$ Aliás, é das palavras de Matal que podemos conjecturar que a permanência de Osório em Bolonha se prolongou por dois anos completos: hunc virum (...) totos duos annos ego nossem. ("intimei com este varão dois anos completos.") 36 Ora, Osório regressou a Portugal na primeira metade de 1542, datando de 28 de Junho, de Lisboa, uma carta a António Agustín que, pelos seus termos, faz supor que a sua chegada já se dera há algum tempo, o qual ele, como bom e cerimonioso português, consagrara às visitas aos familiares e amigos. ${ }^{37}$ Assim, parece-nos razoável concluir que a sua estadia em Itália decorreu entre finais de 1539 ou início de 1540 e finais de 1541 ou início de 1542 . Também nesta mesma carta lemos, com natural estranheza e suspicácia, as seguintes palavras:

Quod autem interdum ostendisti te uereri, ne maleuolorum hominum artificio esset aliquid Regis auribus inculcatum, quod difficile nobis negotium exhiberet: propter bominis illius consuetudinem, cui me et instituta iampridem amicitia, et studiorum similitudo coniunxerat; nibil est quod uereare. Intellexit enim rex me simpliciter et candide principis illius amicitiam appetiuisse: et ubi primum resciui me in eius familiaritate sine Regis ipsius offensione esse non posse, urbem continuo deseruisse. Itaque nec illa coniunctio mibi fraudi fuit: et hunc discessum spero etiam laudi fore. ("Quanto àquele receio, que por vezes me expuseste, de que, por manha de homens malévolos, houvesse sido insinuado aos ouvidos do rei algo que viesse a causar-me problemas, por motivo das minhas

32 Jerónimo Osório, De nobilitate, o. c., p. 281.

33 No diálogo De gloria, o. c., p. 11, refere-se explicitamente às suas relações com Romolo Amaseo, Achille Bocchi e Ludovico Boccadiferro.

${ }^{34}$ De gloria, o. c., pp. 14-15, onde confessa que antepôs aos estudos de direito o conhecimento das matérias mais elevadas e divinas e se consagrou àquela ciência da qual, como de uma fonte, se tiram e tomam todas as leis.

35 Sobre estas duas personagens, veja-se o que dizemos nas pp. 70-72 da nossa tradução, já citada, do De nobilitate.

36 Prefácio de Jean Matal a Jerónimo Osório, De rebus Emmanuelis gestis, Colónia, Officina Birckmannica, 1597, f. 3. Sabemos também que Osório, pelo menos durante parte deste período, compartilhou a residência com Matal e com o conhecido teórico do género dialógico Carlo Sigonio: Porro, cum Osorius istos de Nobilitate libros scriberet, cum eo eras (ita enim me ex te audisse memini) et tuus una Carolus Sigonius, Italus. ["Além disso, ao tempo que Osório escrevia esses livros acerca da nobreza, vivias tu com ele (pois recordo-me de o ter ouvido de ti) e igualmente o teu amigo Carlo Sigonio, italiano."] Bartholomaeus Bogemius, cartaprefácio, endereçada a Jean Matal, datada de 1577 , à frente de uma edição conjunta do De gloria e do De nobilitate, publicada em 1595, em Antuérpia, por Martinus Nutius, fl. 2 v.

37 Vide Cándido Flores Sellés, Epistolario de Antonio Agustín, Salamanca, Ediciones de la Universidad, 1980, pp. 119-120. A tradução portuguesa pode ver-se nas pp. 17-19 da nossa já citada edição das Cartas osorianas. 
relações com aquele homem, ao qual me unira, não apenas uma amizade contraída de longa data, mas até semelhança de interesses culturais: tenho a dizer que, sobre isso, nada há a recear. Com efeito, o rei deu-se conta de que fora de boa fé e inocentemente que eu desejara a amizade daquele príncipe, e logo que descobri que não podia manter-me na sua intimidade sem desprazimento do próprio rei, imediatamente abandonei a cidade. Por conseguinte, aquelas relações não me ocasionaram dano, e estou até esperançado de que este afastamento se há-de converter em motivo de louvor.") ${ }^{38}$

Este optimismo de recém-chegado à pátria após prolongada ausência rapidamente se desvaneceu e, em carta ao mesmo destinatário, escrita em Almeirim e datada de 16 de Fevereiro de 1543, Osório não só confirma o fundado dos receios do amigo, como sente na própria pele que, de facto, está em Portugal: quae tempestas mibi subeunda sit: quanti impetus inuidorum meorum. (...) quo genere bello premar (...) certos bomines ualde potentes omnes industriae neruos contendere (...) improbitatis. ("a grande tempestade que devo arrostar e a força enorme do ímpeto dos que me invejam. (...) vejo-me enredado em guerra descaroável. (...) certas pessoas muito poderosas atam todos os laços da intriga (...) malévola maquinação.") 39 Penso que tanto o tom sibilino da passagem da carta de Junho de 1542 como os maus momentos que a mexeriquice nacional fez viver a Osório se explicam se virmos naquele misterioso príncipe a figura do antigo escrivão da puridade de D. João III e bispo de Viseu, D. Miguel da Silva, nomeado cardeal in petto por Paulo III em 19 de Dezembro de 1539 e que, a 23 de Janeiro de 1542, recebera em Roma, no palácio apostólico, o barrete cardinalício em consistório público.

Com efeito, sabe-se que D. Miguel da Silva, ciente de que D. João III não lhe permitiria a aceitação da dignidade cardinalícia, deixou secretamente Viseu com direcção à Itália em Julho de 1540, estando documentada a sua presença em Piacenza em Setembro, daqui se transferindo para Bolonha, onde ainda se encontra a 8 de Janeiro de 1541 . No desempenho da função de legado papal passa quase todo este ano em Veneza, onde ainda se encontrava em 10 de Dezembro, para daí se dirigir a Roma a tomar posse pública da nova dignidade. ${ }^{40}$ Ora, além dos contactos comprometedores com o "ódio de estimação" de D. João III se poderem ter dado durante a permanência do purpurado luso em Bolonha, sabemos também que Osório se deslocou a Veneza em finais de Abril de 1541 - por um período inicialmente programado como curto -, porquanto ele mesmo foi portador de uma carta de recomendação escrita pelo amigo António Agustín e dirigida ao embaixador de Carlos V em Veneza, Diego Hurtado de Mendoza, varão das relações de Agustín e perante o qual o nosso compatriota é apresentado nos termos mais altamente encomiásticos:

38 P. 119 do $1^{\circ}$ livro cit. na nota antecedente. O itálico do "príncipe" é da nossa responsabilidade.

39 Cándido Flores Sellés, o. c., pp. 143-144.

${ }^{40}$ Veja-se José de Castro, Portugal no Concílio de Trento, Lisboa, União Gráfica, 1944, pp. 326-381. 
Fecit is qui ad te has litteras attulit, Hieronymus Osorius uir optimus et optime de diuina humanaque philosophia, et utriusque linguae studiis meritus, cuius consuetudine me hosce quindecim dies molestissime ferrem, nisi ad te proficisceretur: fecit inquam is, ut ad intermissam scribendi consuetudinem reuerterer. ("Deu-me azo o portador da presente carta - o excelentíssimo cavalheiro Jerónimo Osório, varão assinalado em teologia e filosofia, bem como insigne no conhecimento do grego e do latim, e de cujo trato me vendo privado, muito me custariam a passar estes quinze dias, caso não soubesse que vai encontrar-se contigo - deu-me azo, como estava dizendo, para reatar as nossas interrompidas relações." $)^{41}$

Tudo o mais que se colige das palavras da carta de Osório de Junho de 1542 ajusta-se à identificação de D. Miguel da Silva como a personagem veladamente referida como "aquele homem" ou "o príncipe", simpático e próximo ao nosso Autor em resultado de uma identidade de interesses culturais ${ }^{42}$ e longa convivência, previsível em quem, como Osório, deveria frequentar assiduamente a corte desde os anos mais moços, onde lhe seria fácil contactar e relacionar-se com D. Miguel, que aí viveria em quase permanência desde 1525, ano do seu regresso a Portugal após ter sido embaixador em Roma durante cerca de dez anos. Explicam-se também assim as palavras de frei Luís de Sousa, que parecem reflectir uma tradição bem fundada, ainda que distorcida por incoerências cronológicas. Com efeito, no capítulo $9^{\circ}$ da $2^{\mathrm{a}}$ Parte dos Anais de D. João III, escreve o escritor dominicano que D. Miguel da Silva, imediatamente após concluir os seus anos de estudo em Paris - o que se deve ter verificado à roda do virar do século XV para o XVI, como é verosímil para quem nascera cerca de 1480 - decidiu viajar pela Itália e "achou em Bolonha Jerónimo Osório, estudante também parisiense. (...) Foram-se juntos a Veneza, pera tratarem os homens insignes daquela grã cidade." ${ }^{3}$

Com os elementos de que dispomos, parece-nos, pois, que não será arriscado concluir que, em terras italianas, existiu algum trato entre ambos os ilustres portugueses, que foi seguramente breve e ao qual atalhou a pronta ausência do jovem Jerónimo Osório da cidade (Bolonha ou Veneza) onde se encontrava o novo purpurado, assim que teve notícia que este incorrera no desagrado, ou mais precisamente, descomedido ódio de D. João III.

41 Cándido Flores Sellés, o. c., pp. 101-102.

42 Sobre a personalidade literária de D. Miguel da Silva veja-se a síntese de Aires Pereira do Couto, "O grande Senhor do Fontelo do século XVI", Beira Alta, Viseu, 49 (3-4), 1990, pp. 295-310.

43 Frei Luís de Sousa, o. c., tomo II, p. 166. 
c) O período $1542-1564$

No ano do regresso definitivo de Jerónimo Osório a Portugal, vamos encontrar o seu nome no Livro das moradias da casa do infante D. Luís, recebendo tença como letrado. ${ }^{44}$ No ano seguinte, como já vimos, escreve de Almeirim para o seu amigo António Agustín uma carta na qual se queixa amargamente das maquinações de que é vítima por parte de invejosos que pretendem malquistá-lo com o rei e com o seu protector. A escassa luz, porém, que a história tem projectado sobre a figura do infante D. Luís não nos permite precisar quem seriam estas malévolas figuras, que arrastavam a sua vesânia numa casa que "competia com a real na magnificência e número de criados, que chegavam a seiscentos e trinta, entre os quais se distinguiam vinte e sete fidalgos cavaleiros, doze fidalgos escudeiros, vinte e dous moços fidalgos, trinta e dous escudeiros fidalgos e duzentos e treze moços de câmara." 45

Segundo o sobrinho, após o regresso à pátria e para aceder aos desejos de D. João III, o nosso Autor ter-se-ia instalado em Coimbra, sede da Universidade Portuguesa desde 1537, onde Isaiam, et Diui Pauli epistolam ad Romanos scriptam, singulari cum laude explicuit. ("com extraordinário aplauso se entregou à exposição do texto de Isaías e da Epístola aos Romanos, de São Paulo.” ${ }^{46}$ Diz também Osório Júnior, de modo vago, que o tio permaneceu aliquot annos ("alguns anos") na cidade do Mondego, podendo nós acrescentar que são muito escassas as referências que é possível coligir acerca das relações entre o nosso Autor e a Universidade. Com efeito, entre Novembro de 1546 e Novembro de 1547 encontra-se a sua assinatura em vinte e uma actas dos conselhos universitários, nas quais figura sem título académico e com a caracterização inexpressiva de deputado não lente. ${ }^{47}$ Também a 2 de Junho de 1549, no registo do acto em que Diogo de Paiva de Andrade recebeu o grau de mestre em Artes, lemos: "sendo-lhe primeiro feitas as orações laudatórias por os mestres Belchior Beliago e Jerónimo Osório." ${ }^{48}$ Deste mesmo ano, mas com a data de 20 de Fevereiro, temos uma carta de D. Luís, dirigida ao prior de Santa Cruz de Coimbra, acerca do seu filho D. António, que ali era educado, e na qual se encontra

${ }^{44}$ ANTT - Livro das moradias da casa do infante D. Luís desde o presente ano de 1542, $\operatorname{maço} 7^{\circ}$, liv. $1^{\circ}, \mathrm{fl} .44 v^{\circ}$ : "A Jer. ${ }^{\circ}$ do Souro".

45 Diogo Barbosa Machado, Biblioteca Lusitana, Coimbra, Coimbra Editora, 1966, tomo III, p. 47.

46 Vita, p. 4. A estes autores sagrados consagrará Osório obras de que nos ocuparemos mais à frente.

47 Vide Lígia Cruz, Actas dos conselhos da universidade de 1537 a 1557, Coimbra, Arquivo da Universidade de Coimbra, 1976, tomo III, pp. 196, 249, 342, 346, 351, 361, 362, 365, 366, 370, 378, 383, 388, 411-413, 415, 417, 418, 423, 432, 433.

48 Arquivo da Universidade de Coimbra - Livro de autos e provas de cursos de 1537 até 1550, fl. $104 v^{\circ}$. - Das relações entre D. Jerónimo Osório e o teólogo e pregador Diogo de Paiva de Andrade dão bom testemunho as palavras com que o primeiro prefaciou a Defensio tridentinae fidei catholicae et integerrimae quinque libris comprebensa, Lisboa, António Ribeiro, 1579, obra póstuma do segundo. Nas pp. 112-114 da nossa edição do epistolário osoriano traduzimos essa interessante peça liminar. 
esta referência ao nosso Autor, provável portador da missiva: "o que me parece bem que se ordene de suas lições vos dirá Jerónimo Osório." ${ }^{49}$ Dois anos passados, voltamos a encontrar Osório como enviado do infante aos educadores coimbrãos do filho: "Muito reverendo bispo: Belchior do Canto vos terá dito o fundamento que faço da vinda de D. António para Évora e o mais que sobre esta matéria mandei que vos dissesse. Agora mando Jerónimo Osório com a determinação mais pontual do que toca a este negócio, de que lhe mando que vos dê conta particularmente, e porque ele o fará assim, tenho por escusado escrevê-lo nesta."

Ora, a conjugação destes elementos talvez nos permita conjecturar que a actividade docente de Osório em Coimbra se tenha circunscrito, não às aulas da Universidade propriamente dita, mas às que eram ministradas no mosteiro de Santa Cruz: ${ }^{51}$ o que nos permitiria explicar, por um lado, a sua presença nos conselhos académicos e o papel, que tradicionalmente se lhe atribui, na formação académica de D. António, ${ }^{52}$ e, por outro, a missão que desempenhou nas relações entre D. Luís e o filho, a qual, nas palavras de Mário Brandão, se limitaria a ter o cuidado "fora do mosteiro dos negócios que lhe diziam respeito, como agente de ligação entre D. Luís e os crúzios." 53

O ano de 1552 oferece-nos um sinal da actividade oficiosa do Autor, sob a forma da aprovação, formulada na terceira pessoa e brevíssima, consignada no verso do fólio 1 do devoto Tratado do seráfico doctor São Boaventura chamado da perfeição da vida (...) convertidos em linguagem per frei Marcos de Lisboa, Lisboa, João Blávio, 1552. No ano seguinte, o seu estatuto aparece melhorado no paço do seu mecenas, pois passa a figurar como capelão no Livro das moradias do infante D. Luis. ${ }^{54}$ Dois anos depois, no ano da morte do infante, vemo-lo designado como capelão-fidalgo. ${ }^{55}$ Como fidalgo da sua corte o vemos qualificado no documento pelo qual o rei D. João III, no ano de 1556, lhe concede uma tença de cinquenta mil réis, com a qual pretendia satisfazer aos serviços que Osório prestara ao falecido infante seu irmão. ${ }^{56}$

49 Apud Mário Brandão, Coimbra e D. António Rei de Portugal. I. A educação de D. António, Coimbra, 1939, p. 71.

50 Carta de D. Luís ao bispo de Leiria, de Almeirim, 15 de Junho de 1551, obra citada na nota anterior, p. 121.

51 Já anteriormente o Professor Sebastião Tavares de Pinho nos comunicara ser esta a sua opinião, tendo-nos os seus argumentos fortemente inclinado no mesmo sentido.

52 A Ludouico Principe accersitur, qui ei Antonium filium instituendum tradidit. ["É chamado pelo infante D. Luís, que lhe confiou a educação do seu filho D. António.”] Vita, p. 4. - D. António permanece em Santa Cruz de Coimbra desde, provavelmente, Outubro de 1548, até 1551, ano em que o futuro Prior do Crato é transferido para Évora.

53 O. c., p. 86.

${ }^{54}$ ANTT - Livro das moradias da casa do infante D. Luís, a partir de 1553, maço 9, liv. 2, fl. 6 .

55 ANTT - Livro das moradias do infante D. Luís desde o presente ano de 1555, maço $10, l$. 2, fl. 7. - O infante D. Luís faleceu a 27 de Novembro de 1555.

${ }^{56}$ ANTT - Chancelaria de D. João III, Próprios, fl. $204 v^{\circ}$. 
Muito mais satisfatória, em termos de desafogo material, nos parece a situação reflectida por dois documentos de 25 de Agosto de 1557. Com efeito, nesta data foram passadas, em nome de D. Sebastião (recorde-se que D. João III falecera no dia 11 do antecedente mês de Junho), e a petição de "Jerónimo d' Osouro, clérigo de ordens menores, fidalgo de minha casa", duas cartas a legitimar dois filhos seus, um de nome Manuel e outro de nome Brás, nascidos de "ajuntamento com uma Beatriz Gonçalves, mulher solteira, filha de peão", o primeiro, e de Isabel de Portalegre, de igual estatuto social e condição civil, o segundo. ${ }^{57}$ Por este documento ficamos a saber que, por então, Osório era beneficiado do mosteiro de Águas Santas ${ }^{58}$ e reitor das igrejas de S. Martinho de Lagares ${ }^{59}$ e de Santiago de Oliveira ${ }^{60}$ todas localidades da diocese do Porto, cidade na qual o nosso Autor registara, a 9 de Agosto deste ano de 1557, os instrumentos legais respeitantes à legitimação dos filhos.

Combinando as informações de que hoje dispomos, inclinámo-nos a supor que, numa data pouco posterior a Agosto de 1557, a regência de D. ${ }^{a}$ Catarina terá nomeado Jerónimo Osório para a igreja de Santa Maria de Chãs de Tavares, ${ }^{61}$ na diocese de Viseu e do padroado real: "um dos mais opulentos benefícios deste reino". ${ }^{62}$ Por estas fragosas e

57 ANTT - Legitimações de D. João III, liv. 2, fls. $296 v^{\circ}$ - 297. - Estes documentos, que nunca anteriormente tinham sido publicados ou referidos, encontram-se transcritos na nossa obra já citada Humanismo e Controvérsia Religiosa, tomo I, pp. 281-282.

58 Situado na freguesia do mesmo nome, no concelho da Maia. O mosteiro no século XV passou a priorado secular do padroado real, cujo último prior nesta situação foi o cardeal D. Henrique, que, em 1551 (segundo Viterbo), o passou "à Ordem de Malta, que o converteu numa comenda, reunido a Cesures, da renda de 500.000 réis (frei Jerónimo da Cunha foi o seu primeiro comendador), além de quatro benefícios de 240.000 réis apresentados pelo comendador." Grande Enciclopédia Portuguesa e Brasileira, tomo I, Lisboa, s. d., p. 640. Lembre-se que o infante D. Luís, como grão-prior do Crato, era em Portugal a autoridade máxima da Ordem de Malta, sendo lógico presumir que Osório devesse este benefício à munificência do seu mecenas e protector.

59 Freguesia no actual concelho de Penafiel. O real padroado e o bispo apresentavam alternativamente o reitor, que tinha 150.000 réis anuais de renda, segundo informação do Portugal histórico, corográfico (...), Lisboa, João Romano Torres, 1909, tomo IV, p. 30.

${ }^{60}$ Apesar de este nome não corresponder na sua totalidade a nenhuma freguesia que se possa incluir no então designado termo do Porto, cremos que o documento se está a referir à freguesia de Oliveira do Douro, pertencente ao concelho de Vila Nova de Gaia, e cujo orago é Santa Eulália. Competia ao arcediago de Oliveira, dignidade da sé do Porto, a apresentação do vigário: dado que não se compagina com uma reitoria de provável nomeação régia, como seria o caso da que detinha o nosso Autor. É de notar, porém, que uma Santiago de Oliveira do Douro consta da lista de "simples capelas e curatos efémeros", registados apud Domingos Moreira, Freguesias da Diocese do Porto, Porto, sep. do "Boletim Cultural da Câmara Municipal do Porto", I, 1973, p. 162.

${ }^{61}$ No actual concelho de Mangualde, era, no século XVI, sede de um município de relativa prosperidade, ao qual o "Cadastro da População do Reino", de 1527, atribuía 311 moradores. Veja-se o artigo de Mário Guedes Real, "Pelourinho de Chãs de Tavares", Beira Alta, 12 (4), Viseu, 1953, pp. 365-374. Note-se a circunstância de esta localidade se encontrar a escassos quilómetros de Figueiró da Granja, povoação onde se encontrava o solar da família Osório.

62 Segundo Barbosa Machado, sub nomine Jacinto Freire de Andrada. 
imponentes terras dos seus maiores se deve ter mantido até ao ano de 1560, sendo de supor que entregue, além das lides literárias que nunca punha de lado, ao exercício efectivo das funções de cura de almas, para a qual já o habilitariam as ordens de presbítero que deve ter recebido por então na sé viseense. ${ }^{63}$ Deve ter renunciado por essa altura aos benefícios que possuía na diocese portuense, atitude que o sobrinho lhe gaba como demonstrativa de grande desinteresse, uma vez que ainda não vigoravam as determinações tridentinas que vieram atalhar a abusivas acumulações de rendas eclesiásticas. ${ }^{64}$

A 30 de Março de 1560 vemo-lo tomar posse do elevado cargo de arcediago do bago da sé de Évora, ${ }^{65}$ quarta dignidade desta igreja metropolitana, à testa da qual se encontrava então o cardeal-infante D. Henrique, que ao convidar o nosso Autor para estas funções deu públicas mostras do grande apreço que dele fazia, tudo também indicando que o levou consigo para Lisboa quando foi nomeado regente do reino, em Dezembro de 1562, e o manteve na sua companhia até à nomeação episcopal de Osório, que também a ele coube, como soberano de facto que então era na menoridade do sobrinho. Este período, vivido no círculo e como colaborador próximo do cardeal D. Henrique, ${ }^{66}$ no que tange a factos assinaláveis documentados, oferece-nos, além da publicação da importante Epistola ad Elisabetam (1562) e de uma pequena censura pro forma a uma obra de frei Marcos de Lisboa, ${ }^{67}$ a participação, como qualificador, entre as datas limite de 15 de Junho

63 Já atrás referimos que no documento de nomeação episcopal aparece designado como "presbítero viseense".

${ }^{64}$ Vita, p. 5. Jerónimo Osório Júnior entra mais do que uma vez em contradição ao referir-se à estadia do tio em Chãs de Tavares: por exemplo, na p. 4 da Vita começa por dizer que de Gloria Conimbricae (...) libros scripsit ["escreveu em Coimbra os livros Da glória"], para, algumas linhas abaixo, afirmar: In Tauarensem igitur Ecclesiam cum se recepisset, plurimum operae, et laboris, ad libros de Gloria conficiendos contulit, eosque in lucem edidit."'tendo-se, portanto, recolhido à igreja de Tavares, consagrou muito trabalho e desvelo em concluir os seus livros Da glória, que deu à impressão."] Ora, a $1^{\text {a }}$ edição deste livro saiu em Coimbra, em 1549

65 Barbosa Machado dá esta data precisa. Aliás, a presença de Osório está documentada em Évora no mês de Abril deste mesmo ano, pois assistiu então na Universidade alentejana a uma representação da tragédia latina do Rei Saul: "A Jerónimo Osório, que é um homem insigne em letras, contentou sumamente a representação e composição da tragédia, louvando muito os versos e sentenças dela." - Carta de 30 de Abril de 1560 do jesuíta Brás Gomes, apud Francisco Rodrigues, História da Companhia de Jesus na Assistência de Portugal, o. c., volume $2^{\circ}$ do tomo I, p. 318 .

66 Cum ipse, Henrici loco, litteras proprio nomine signaret (...) qui eidem cum Osorio, Conscientiae, vt vocant, consilio erat adscriptus. Henricum Osorius adit, cum quo in Betlemitico tunc agebat (...). ["Uma vez que ele firmava com a sua assinatura cartas em nome de D. Henrique (...) o qual [D. Manuel dos Santos] fora designado, juntamente com Osório, para a que chamam Mesa da Consciência. Osório dirige-se a D. Henrique, com quem então vivia no mosteiro de Belém (...)."] Vita, p. 5.

67 "Por mandado do Senhor Cardeal Iffante inquisidor geral em estes Reinos e senhorios de Portugal, vi este livro, intitulado Segunda Parte das Crónicas dos Frades Menores, e nele não achei cousa que seja contra a santa fé católica, nem que possa ofender os ouvidos cristãos e religiosos, mas antes que poderá frutificar e aproveitar a todo fiel cristão, assi religioso como secular. Em Lisboa. Oito de Abril 1562. Ierónimo do Souro" Frei Marcos de Lisboa, Parte 
de 1560 e 10 de Maio de 1562, no processo que a Inquisição moveu contra frei Valentim da Luz, e que concluiu com a condenação por heresia do frade agostinho. ${ }^{68}$

\section{d) O bispo (1564-1580)}

D. Jerónimo Osório foi designado para a sé de Silves no consistório secreto presidido a 21 de Junho de 1564 pelo papa Pio IV. Os documentos existentes no Arquivo do Vaticano informam-nos que a nomeação se fizera a pedido do rei de Portugal - na realidade, do cardeal D. Henrique, que detinha então a regência na menoridade do sobrinho D. Sebastião - na pessoa do "presbítero viseense Jerónimo Osório" e por vacatura ocasionada pela transferência do anterior prelado (D. João de Melo) para a igreja eborense. ${ }^{69}$ A sagração do novo prelado fez-se em 22 de Outubro de $1564,{ }^{70}$ em Lisboa, na capela-mor da igreja do convento de Santa Maria da Graça, da Ordem dos Eremitas de Santo Agostinho. A ordenação foi conferida por D. Julião de Alva, bispo capelão-mor, coadjuvado por D. Jorge de Lemos, bispo do Funchal, e D. António Pinheiro, bispo de Miranda, recém-empossado, pois fora nomeado na mesma data do seu novo colega silvense. Estiveram presentes na cerimónia D. João de Melo, arcebispo de Évora, e Diogo de Gouveia, ${ }^{71}$ prior de Palmela, além de grande número de clérigos de nomes menos sonantes. ${ }^{72}$

Segunda das Crónicas da Ordem dos Frades Menores, Lisboa, João Blávio, 1562, vº da p. de rosto.

${ }^{68}$ As peças deste processo foram publicadas por J. S. da Silva Dias, O Erasmismo e a Inquisição em Portugal - o processo de Fr. Valentim da Luz, Coimbra, Imprensa da Universidade, 1975. O texto das censuras de Osório às proposições objecto de suspeita de heresia encontramse, na sua maioria, reproduzidos por nós em notas à nossa tradução do Contra Haddon, que integra a obra Humanismo e Controvérsia Religiosa, o. c., tomo II, pp. 301-544. - Diga-se apenas que as qualificações de Osório ressumam a mais estrita ortodoxia e irada indignação contra os "desvios" do réu, que veio a morrer na fogueira. Talvez o facto de os textos dos qualificadores neste processo se encontrarem em português tenha levado o editor do mesmo a entender o que de facto pensavam homens (como é o caso de Osório) que ele mesmo, em livros anteriores de larga e ainda actual nomeada, apresentara com sumária ligeireza como "erasmistas" e "irenistas".

69 Archivio Segreto Vaticano - Archivio Consistoriale, Acta Camerarii 9, fls. 100 e $101 v^{\circ}$. Veja-se a transcrição em Humanismo e Controvérsia Religiosa, o. c., tomo I, p. 63.

$70 \mathrm{O}$ prazo dilatado que decorreu entre a nomeação e a sagração deveu-se à longa imobilidade a que D. Jerónimo Osório foi obrigado em consequência de uma grave queda de mula que sofreu e da qual deu conta, com notável expressividade, numa carta datada dos primeiros meses de 1565 e dirigida ao cardeal polaco Estanislau Hósio, cuja tradução pode ler-se na nossa edição das Cartas, pp. 42-44.

71 Parente de D. Jerónimo Osório e sobrinho dilecto do doutor parisiense do mesmo nome.

72 Instrumento notarial da consagração episcopal de D. Jerónimo Osório, Archivio Secreto Vaticano - Camera Apostolica, Divers. Camer, 220, fls. $17 v^{\circ}-19 v^{\circ}$. Pode ver-se transcrição parcial deste documento na p. 65 do tomo I da obra Humanismo e Controvérsia Religiosa. 
A grei que D. Jerónimo Osório vai passar a pastorear, conquanto ilesa de gafeiras heréticas, não lhe mereceu uma pintura de cores excessivamente encomiásticas, como pode colher-se das palavras com que a caracterizou na sua correspondência particular. ${ }^{73}$ Do ponto de vista económico e social, porém, o Algarve do período da longa prelatura osoriana, posto que sobressaltado por amiudadas incursões de corsários turcos, parece não estar ainda totalmente fora de um ciclo de prosperidade, ${ }^{74}$ de que são prova evidente não só as relações internacionais frequentes, de que nos surgem reflexos no epistolário do prelado silvense, como igualmente o papel decisivo e activo que a população algarvia continuava a desempenhar na defesa e municiamento das praças portuguesas do norte de África. ${ }^{75}$

Deu brado na época o conflito que, em 1575, opôs o poder civil, representado pelo feitor das salinas (monopólio régio) de Tavira, ao bispo D. Jerónimo Osório, intransigente defensor dos foros da Igreja, que julgou terem sido ofendidos por aquele funcionário da Coroa, a quem excomungou por se negar ao pagamento do dízimo que, segundo o prelado, desde tempos imemoriais tanto os rendeiros como os feitores das salinas pagavam à Igreja. Desta contenda violenta resultaram, por um lado, uma carta desassombrada ao rei D. Sebastião, ${ }^{76}$ e, por outro, o pretexto que o prelado algarvio alegou, perante os representantes da Santa Sé em Portugal, para deslocar-se a Roma em 1576, como se vê do passo seguinte de uma carta escrita de Lisboa, em 25 de Abril do mesmo ano, por Giovanni Andrea Calligari, colector apostólico, e dirigida ao secretário de Estado da Sé Apostólica: A dì passati, si refuggi a Roma Hieronimo Osorio, vescovo di Silves in Algarve, huomo vecchio di santa vita et di sana et eccellente dottrina et stile, per aggravi insoliti fatti alla persona et alla chiesa sua da giudici laici, come vedra V. S. Illma dalla copia d' una lettera che egli scrisse loro prima che si partisse. ${ }^{77}$

Pela correspondência de João Gomes da Silva, embaixador em Roma, para a corte portuguesa, conhecemos os movimentos do nosso Autor em Itália, para onde partira sem autorização do rei e aonde chegou em finais de Abril de 1576, desembarcando no porto

73 Vejam-se, por exemplo, a carta de 20 de Novembro de 1566, datada de Silves e endereçada ao cardeal Hósio, e a de Julho de 1573, dirigida a Estanislau Reszka. As traduções de ambas podem ler-se nas pp. 47-49 e 85-86, respectivamente, da nossa edição do epistolário osoriano.

${ }^{74}$ Veja-se Joaquim Romero de Magalhães, "Panorama social e económico do Algarve na época de D. Jerónimo Osório”, Anais do Município de Faro, 11, Faro, 1981, pp. 55-64.

75 Lembre-se, por exemplo, o pronto auxílio com que espontaneamente os fidalgos e mareantes do Algarve acudiram a Mazagão, cercada por um imenso exército chefiado pelo filho primogénito do Xerife de Marrocos em 1562. Vd. J. M. Queirós Veloso, Lisboa, D. Sebastião. 1554-1578, Empresa Nacional de Publicidade, 1935, p. 55.

${ }^{76}$ A carta na maior parte dos manuscritos aparece datada de Silves, a 13 de Dezembro de 1575. Sobre este episódio, veja-se: a) a introdução e anotações com que acompanhámos a nossa edição desta missiva, in D. Jerónimo Osório, Cartas, o. c., pp. 98-104; b) os documentos que citámos na p. 69 do tomo I de Humanismo e Controvérsia Religiosa.

77 Apud Charles-Martial de Witte, "Saint Charles Borromée et la couronne de Portugal", Boletim Internacional de Bibliografia Luso-Brasileira, 7, $\mathrm{n}^{\circ}$ 1, Lisboa, 1966, p. 130. 
de Génova. ${ }^{78}$ Daqui se dirige para Parma, onde, pelo menos até meados de Setembro, goza da hospitalidade da soberana local, a portuguesa D. ${ }^{a}$ Maria, filha do infante D. Duarte e esposa de Alexandre Farnésio. ${ }^{79}$ O próprio D. Jerónimo Osório, em carta escrita desta cidade a 24 de Maio ao papa Gregório XIII, dá como razões da sua longa viagem, além da visita pessoal, a que estava obrigado como bispo, ad limina sanctorum apostolorum Petri et Pauli e de assuntos ligados com a sua diocese - alusão muito provável, se não ao litígio com a autoridade régia, pelo menos à transferência da sede do bispado, de Silves para Faro, a qual de facto se formalizará em 30 de Março do ano seguinte -, motivações de ordem literária: a edição em Roma das suas obras, depois de convenientemente submetidas à aprovação da Santa Sé ${ }^{80}$ Deixando Parma, D. Jerónimo Osório dirige-se à cidade onde estudara, Bolonha, na qual é de presumir que permanece até aos primeiros meses de $1577 .{ }^{81}$ O regresso a Portugal dá-se na segunda metade deste ano, tendo nós notícia de que abandonou Roma no início de Junho e a 19 de Agosto se encontrava em Barcelona. ${ }^{82}$ Sabemos também que a 17 do mês de Novembro chegava a Lisboa, depois de ter feito a visitação da sua diocese. ${ }^{83}$

78 "O que pude penetrar de alguns portugueses que vieram com ele na mesma embarcação, que se deixara entender que estaria de vagar e que vinha obrigado de sua conciência por causas que pareceriam a todos justas quando se soubessem. Antre elas era ũa imprimir certos livros. Referiram-me que se doía de lhe haverem mandado absolver ũa certa pessoa que tinha excomungada." Carta de João Gomes da Silva, Roma, 18 de Maio de 1576. - Toda a correspondência do embaixador português referente a este episódio encontra-se reproduzida por Léon Bourdon, "Documentos inéditos relativos à viagem de Jerónimo Osório à Itália (1576-1577)", Ocidente, 40, Lisboa, 1950, pp. 215-226.

79 Retribuía assim a duquesa a forma como Osório, nos primeiros dias de Outubro de 1565 , a acolheu na sua inesperada escala no Algarve: dum ipsa in Galliam Belgicam ad maritum veniret, tempestateque ad Sacrum promontorium deferretur, eam iis honoribus Osorius coluit, qui solum Regina Lusitaniae a suis haberi solent ["quando ela se dirigia para a Flandres, a reunir-se com o seu noivo, uma tempestade obrigou-a a aportar a Sagres e aí Osório honrou-a com todo o acatamento e cerimónias que os súbditos só costumam mostrar às rainhas de Portugal"], aliás na sequência de relações que já vinham de trás: fuit enim Osorius Elisabethae, illius matris, sanctissimae feminae, et Odoardi fratris, immatura morte sublati, studiosissimus. [" pois Osório teve grande amizade tanto com a mãe da duquesa, a Senhora D. a Isabel, dama de apurada virtude, como com o seu irmão, o Senhor D. Duarte, precocemente falecido."] Vita, p. 13. - Para mais pormenores, vejam-se as pp. 130-134 do tomo I de Humanismo e Controvérsia Religiosa.

80 A tradução desta carta pode ver-se nas pp. 104-105 da nossa edição do epistolário osoriano. João Gomes da Silva, dando conta para Lisboa de todas as acções de Osório, afirma que Gregório XIII "do stilo da qual [carta] se mostra muito oufano." Por outro lado, quanto ao último motivo alegado para a sua deslocação a Itália, a verdade é que esta se saldou pela edição de um único livro: In Isaiam Paraphrasis libri $V$, saído dos prelos bolonheses de Alexandre Benatius, em 1577.

81 Cartas de João Gomes da Silva a D. Sebastião, de Roma, de 14 de Setembro e 21 de Dezembro de 1576 e de 16 de Janeiro de 1577, apud Léon Bourdon, o. c..

82 Com esta data e local possuímos uma carta sua dirigida ao cardeal Hósio, cuja tradução pode ver-se nas pp. 109-110 da nossa edição do seu epistolário.

83 De acordo com carta de Roberto Fontana ao cardeal de Como, datada de Lisboa, 29 de Novembro de 1577: Monsignore Osório, vescovo dell' Algarve, gionse a Lisbona li Xvii di questo, 
Entre os últimos documentos que nos dão testemunho da participação do bispo do Algarve em eventos de importância pública, acham-se a referência que a Crónica del-rei D. Sebastião faz à sua presença na cerimónia da coroação do rei D. Henrique, ${ }^{84} \mathrm{em} 29$ de Agosto de 1578, ${ }^{85}$ e uma notícia manuscrita da sua intervenção nas cortes de Almeirim/ Santarém, em 1580, como emissário do braço eclesiástico junto do braço popular. ${ }^{86}$

Os derradeiros meses da vida de D. Jerónimo Osório coincidiram com a época conturbada que se seguiu à morte do rei D. Henrique (a 31 de Janeiro de 1580) e imediatamente precedeu a entrada vitoriosa de D. Filipe em Portugal (9 de Dezembro), depois de esmagada em Alcântara (8 de Agosto) a débil resistência oposta pelos escassos seguidores de D. António às tropas do duque de Alba. Sobre a posição assumida pelo nosso Autor nesta difícil conjuntura lançaram o ferrete da traição à pátria alguns contemporâneos e especularam indiscretamente muitos pósteros menos bem informados. ${ }^{87} \mathrm{~A}$ uns e a outros

sano, et salvo, havendo prima visitato il suo vescovato. Apud Léon Bourdon, "Novas investigações sobre a viagem de Jerónimo Osório à Itália”, Ocidente, 43, Lisboa, 1952, pp. 14-15.

${ }^{84}$ Frei Bernardo da Cruz, Crónica del-rei D. Sebastião, Lisboa, 1903, II, pp. 129-139.

85 Da impressão que o desastre de Alcácer Quibir, ocorrido em 4 desse mesmo mês, causou em D. Jerónimo Osório, ficou o seguinte testemunho do sobrinho biógrafo: Quem Osorius vt accepit, multis cum lacrymis, flexis genibus, elatis in caelum manibus, Deum est suppliciter veneratus; deinde ad me, qui forte aderam, Gravissimum, inquit, ex hac Africana expeditione detrimentum nostris rebus importandum fore semper existimaui: verum Regis interitum, cum totius exercitus caede, numquam mibi persuasi. (...) bic tamen Sebastiani regis acerbissimus casus tanto cum doloris sensu affecit, vt eius valetudinnem debilitarit. ["Ao ter dele conhecimento, Osório, derramamndo copioso pranto, lançou-se de joelhos e, de mãos erguidas para o céu, humildemente orou a Deus; em seguida, disse-me a mim, que calhou de me achar junto dele: - Sempre me pareceu que desta expedição africana haveria de resultar grande malefício para o nosso país, mas nunca cuidei que o rei viesse a morrer, juntamente com o total desbarato do exército. (...) este pungentíssimo fim de D. Sebastião impressionou-o com tamanha veemência e paixão que lhe alquebrou a saúde."] Vita, p. 15. - Lembre-se que D. Jerónimo Osório, através de célebre carta escrita entre Agosto e Outubro de 1574, tentara demover o rei dos projectos de conquista africana, pelo menos antes de assegurar descendência através de casamento, ao qual aliás já o incitara por outra carta, também célebre, escrita talvez em 1570. Vide a nossa edição in D. Jerónimo Osório, Cartas, o. c., pp. 64-68 e 88-93.

86 1580, Janeiro 24, igreja de S. Francisco, Santarém - D. Jerónimo Osório e D. Amador Arrais, deputados pela consulta eclesiástica nas cortes de Santarém. Arquivo Geral da Universidade de Coimbra, ms. 667, "Lembrança do que passou nas cortes que se fizeram em Almeirim e Santarém no ano de 1580 por mandado del-rei D. Anrique que sucedeu a el-rei D. Sebastião”, fl. $84 \mathrm{v}^{\mathrm{o}}$.

87 Quanto à posição de D. Jerónimo Osório relativamente a D. Filipe ela não podia ser expressa com mais meridiana clareza do que a que se reflecte nestas linhas de uma carta original ao primeiro rei português da dinastia Áustria e que até hoje permaneceu inédita: "Y despues que fui en Almeirim per todas las vias possibles di el deuido testimonio de mi intencion, la qual era la que conuenia al remedio de los Reinos, y que, despues que uolui al Algarve, nunca perdi occasion de persuadir a todo hombre lo que nos tanto cumplia (...). Mas con todo esto entiendo que no me tiene V. M. alguna obligacion, porque mi principal fin non fue servirla, mas seruir a Nuestro Señor, y trabajar, quanto a mi fuesse possible, por la conservacion desta republica, por la qual yo pusiera la vida, y para su cura otro remedio non hallaua. Y es esto tanto segun mi juizio que, quando V. M. non pretendiera esta succession, fuera yo de parescer que nos fuessemos echar a sus pies y le pidiessemos por singular merced 
respondeu o bispo do Algarve com a sua costumada veemência e rigor lógico, tanto em português e castelhano como em latim, julgando nós que a leitura dessas peças torna ocioso qualquer comentário. ${ }^{88}$

Quanto à actividade e méritos de D. Jerónimo Osório como prelado, é justo conjecturar, atendendo aos propósitos de toda a sua obra literária e à orientação que preside ao seu rumo de homem, que não estaria muito longe da verdade o quadro traçado pela Vita escrita pelo sobrinho, feitos os necessários descontos aos excessos laudatórios, próprios não só de um parente biógrafo, como também então da praxe em escritos desta natureza. ${ }^{89}$ Infelizmente, o vandâlico assalto do conde de Essex a Faro, em Julho de 1596, destruiu por completo o paço episcopal, pelo que nos vemos quase totalmente privados da documentação respeitante aos quase dezasseis anos em que Osório esteve à testa da diocese algarvia.

No entanto, por outra via nos ficou, além das alusões que encontramos em obras suas - como é o caso, por exemplo, do Contra Haddon -, prova documental da diligência que pôs em chamar pregadores para o seu bispado, recorrendo aos serviços da Companhia de Jesus, instituto religioso pela qual sentia grande veneração e, "se não foi parte para ela ser admitida neste reino, como escreveu seu sobrinho e quantos dele tomaram a notícia, ${ }^{90}$

que acceptasse estes estados." - Fls. 1-1 vo da carta escrita de Tavira a 20 de Junho de 1580, precisamente dois meses antes da morte do bispo do Algarve, e cujo original, em perfeito estado de conservação, se encontra no Arquivo Geral de Simancas. Faço a sua publicação integral no artigo citado na nota seguinte.

88 Trata-se dos seguintes escritos osorianos: a) Defensio sui nominis, Opera Omnia, o. c., tomo I, cols. 1125-1138; b) "Traslado de ũa carta que escreveu o bispo do Algarve a el-rei D. Anrique", de Novembro de 1579, in D. Jerónimo Osório, Cartas, o. c., pp. 121-123; c) "Traslado da carta que fez D. Jerónimo Osório, bispo do Algarve, e deu a el-rei D. Anrique, que Deus tem, em Almeirim. A qual lhe deu em 4 de Janeiro, que ora passou, de 580", id., ibi., pp. 124-128; d) "Traslado de ũa carta que o bispo do Algarve escreveu aos Governadores sobre a sucessão do reino", de Maio/Junho de 1580, id., ibi., pp. 129-134; e) carta de D. Jerónimo Osório ao rei D. Filipe, datada de Tavira, 20 de Junho de 1580, cujo original se encontra no Arquivo Geral de Simancas, Estado, legajo 419, carta 152. - Todos estes documentos, além de outros correlativos, integram o nosso estudo "D. Jerónimo Osório e Filipe II - A propósito de uma carta inédita e da sucessão de Portugal”, de próxima aparição na Revista da Faculdade de Direito de Lisboa.

89 Veja-se Vita, especialmente pp. 6-10 - ou, na nossa versão, anteposta à já citada edição dos tratados De nobilitate, pp. 42-49.

90 Alusão a passagem que pode ler-se na p. 3 da Vita. Imediatamente antes, referira-se ao trato íntimo que o tio mantivera em Paris com Santo Inácio e os seus primeiros companheiros na fase de formação da Companhia de Jesus: Per id tempus Ignatius Loiola, eximiae sanctitatis vir, aliquot sibi socios Parisijs adsciuerat, qui eandem, quam ille, viuendi rationem sequerentur: cum quibus Osorius singularem init consuetudinem, et in Petri Fabrij familiaritate maxime versabatur; cuius viri pietatem, et excellens animi studium, inter omnes Ignatij socios, summis laudibus efferebat: cum quibus, dum Parisijs fuerunt, de vitae suae instituendae ratione saepius conferebat. ["Por esta altura, Inácio de Loyola, varão de extremada santidade, associou a si, em Paris, alguns companheiros, com o fim de seguirem a mesma regra de vida. Osório travou com eles grande amizade, e os vínculos da maior familiaridade ligaram-no a Pedro Fabro homem cuja piedade e excelente disposição de ânimo Osório, com grande louvores, exaltava 
certamente a autorizou com sua estima e valimento."91 No sentido de elevar o nível moral e intelectual da sua grei, D. Jerónimo Osório instou inclusivamente junto do provincial jesuíta pela fundação de um colégio inaciano na sua diocese. ${ }^{92}$

Resta-nos notícia segura de que, obedecendo às recentes determinações tridentinas, reuniu pelo menos um sínodo diocesano, em 1571 ou pouco antes, na sé de Silves, ${ }^{93}$ e, como representante do seu bispado, vemo-lo participar no concílio provincial de Évora, cuja primeira sessão se celebrou no $1^{\circ}$ de Maio de 1567 , "sendo nele presidente o reverendíssimo Senhor D. João de Melo metropolitano desta província: e sendo presentes os reverendíssimos Senhores D. Jerónimo Osório, bispo do Algarve (...)."94 Sobreviveram ao incêndio ateado pelos ingleses a Faro, em Julho de 1586, ${ }^{95}$ dois termos de visitações realizadas pessoalmente pelo bispo Osório às duas igrejas paroquiais que possuía então

sobre os demais companheiros de Inácio. Enquanto estes permaneceram em Paris, muito amiúde com eles praticava sobre o regime por que devia pautar a sua vida."] Vita, p. 3.

91 Francisco Rodrigues, o. c., tomo I, vol. $1^{\circ}$, p. 205.

92 Id., ibi., tomo II, vol. 1º 1938, pp. 128 e 432. - Apesar deste insofismável apreço pela Companhia de Jesus, uma persistente tradição atribuiu à autoria de D. Jerónimo Osório uma violentíssima carta, de ampla circulação na época, endereçada a um dos mais conspícuos membros daquela corporação religiosa: o Padre Luís Gonçalves da Câmara, mestre e confessor de D. Sebastião. Conquanto a editássemos, como apêndice, nas pp. 140-149 da nossa edição das Cartas do bispo do Algarve, sentimos dúvidas sobre a sua autoria osoriana, não pelo que toca ao conteúdo ou estilo, mas sobretudo por se apresentar como anónima, procedimento que nos parece pouco congruente com o destemor e inteireza de carácter de que o Autor deu sobejas provas em toda a sua vida e obra. Não restam, porém, quaisquer dúvidas sobre a profunda inimizade (para não chamar-lhe cego ódio) que sentiu pelo sacerdote secular Martim Gonçalves da Câmara, irmão do jesuíta e durante largo tempo escrivão da puridade e valido todo-poderoso de D. Sebastião, e a quem atribuiu grande parte da responsabilidade pelos desvarios do jovem monarca. Contra ele escreveu D. Jerónimo Osório, pouco antes de morrer, algumas das páginas mais truculentas e impiedosas da literatura portuguesa do século XVI. Vd. Cartas, "Carta aos Governadores do Reino", pp. 129-134.

93 Veja-se o documento 3 do Apêndice 6, que publicámos na p. 288 do tomo I de Humanismo e Controvérsia Religiosa.

94 Decretos do Concílio Provincial Eborense, Évora, André de Burgos, 1568, p. 3.

95 Antes de entregarem à fúria das chamas o paço episcopal, os assaltantes ingleses daqui retiraram e transportaram para as suas naus a biblioteca do então bispo do Algarve, D. Fernando Martins de Mascarenhas, antigo reitor da Universidade de Coimbra e futuro inquisidor-geral, o qual, em 10 de Agosto de 1604, se queixará deste latrocínio ao rei Filipe II de Portugal e III de Espanha, na dedicatória (que mais não é que um circunstanciado relato do ataque inglês ao litoral algarvio e a pouco modesta auto-exibição dos dotes de cabo de guerra e de expedito administrador civil deste nobilíssimo prelado) de um livro seu de tema teológico: Inter caetera subit malam fortunam Bibliotheca non uulgaris, quae mibi in pretio et delicijs; cum illa simul lucubrationes, et uigiliae longi temporis. (...) Pharensi in urbe quarto Idus Augusti anno 1604. D. Fernando Martins de Mascarenhas, Tractatus de auxiliis diuinae gratiae ad actus supernaturales, ["Entre as demais destruições, padeceu mofina sorte a minha selecta biblioteca, a que muito quero e para mim de valor inestimável, e juntamente com ela os meu trabalhos e vigílias de longa data (...) Na cidade de Faro, 10 de Agosto de 1604."] Lisboa, Pedro Crasbeck, 1604, fl. $3 \mathrm{v}^{\mathrm{o}}$. - Como se sabe, o conde de Essex presenteou o reitor oxoniense Sir Thomas Bodley com estes livros obtidos de forma tão expedita, os quais, por pouca atenção à cronologia, durante muito tempo se considerou integrarem a livraria do bispo Osório. 
a nova capital do Algarve, documentos interessantes por nos mostrarem o escrúpulo com que o nosso Autor juntava a mais remontada teoria à prática miúda dos deveres impostos pelo seu ofício pastoral. ${ }^{96}$

Após breve doença, que, pela descrição do sobrinho, apresenta todos os sintomas de uma septicemia, ${ }^{97}$ vem a falecer, aos 20 de Agosto de 1580, no Convento de São Francisco da cidade de Tavira. De acordo com o retrato físico que a Vita nos transmite:

Corpore fuit mediocri, lato pectore, manibus ad arma tractanda aptissimis, brachijs, et cruribus singulari robore firmatis, quod vsque ad vltimam senectutem in eo viguit, adspectu graui, cum singulari honestatis decore, aperta fronte, magnis, et caeruleis oculis, naso mediocriter elato, et eo, qui Lusitanis fere hominibus inest, colore. ["Foi de estatura meã, ancho de peito, com as mãos ajeitadíssimas para o manejo das armas, de braços e pernas solidamente enrijados: e manteve-se com este vigor até à derradeira idade. Era dotado de uma presença de respeito, de uma singular formosura, de fronte ampla e com olhos grandes e azuis, nariz um pouco levantado, e com a cor de tez que é corrente entre os Portugueses." $]^{8}$

\section{Obra}

Ciente da pluralidade de géneros literários ou, talvez melhor, registos de discurso que a obra do tio exemplifica, Jerónimo Osório Júnior, na Dedicatória a D. Filipe I de Portugal que antepõe ao tomo I das Obras Completas do nosso Autor, depois de assentar que omnes sapientiae laudes eloquentia sinu suo complectitur ("a eloquência abrange no seu seio todos os primores da sabedoria"), e após desenvolver, em termos aristotélicos, este conceito, pergunta retoricamente ao novo rei lusitano: Quas eloquentiae, et philosophiae, partes, ille non tractauit, aut quid in illarum tractatione desideres? ("quais foram as partes da eloquência e da filosofia que ele não tratou ou de que é que sentimos a falta na sua

96 Transcrevemos estes documentos nas pp. 284-288 da obra citada na antepenúltima nota.

97 Vlcus paruum, quod vngue in crure excitatum fuerat (...) acerbe intumuit. (...) vlcus in dies magis eum afflictabat. (...) Pridie igitur Kal. Augusti (...) eum grauissimus somnus occupauit, a quo nullis poterat vocibus excitari. (...) Febris deinde subsecuta est, quae illum intra viginti dies confecit, atque consumpsit. ["uma pequena chaga, que uma unha provocara numa perna, (...) inflamou-se violentamente. (...) a chaga cada dia o atormentava mais. (...) No dia 31 de Julho (...) caiu num sono tão pesado que nem a grandes brados era possível despertá-lo. (...) Seguiu-se uma febre que, em vinte dias, o debilitou e enfraqueceu por completo."] Vita, p. 17 .

98 Vita, p. 2. Pouco acima, Osório Júnior escrevera que a primeira vocação do tio fora a da carreira das armas, da qual virá a desistir a rogo da mãe, a qual, após a viuvez, ficou a depender dele como novo arrimo da família. Conta-nos também que, até ao fim da vida, D. Jerónimo Osório se mostrou grandemente afeiçoado aos exercícios físicos, para os quais a natureza o dotara de forma excepcional. 
abordagem destas?") 99 De facto, para além do género histórico (De rebus Emmanuelis gestis), que cultivou por imposição externa, o seu espólio literário reparte-se por grande número de sub-géneros daquilo que, para simplificar, designaremos por prosa doutrinal: 1) o filosófico, com especial incidência na ética e na teoria política (De nobilitate ciuili et christiana, De gloria, De regis institutione et disciplina, De vera sapientia); 2) o polémico ou "estilo forense elevado", na definição adoptada pelo sobrinho (Epistola ad Elisabetham, In Haddonum, Defensio sui nominis); 3) o espiritual/teológico, subdivido por: 3.a) teodiceia (De iustitia); 3.b) exegese bíblica, sob a forma de: A) paráfrases (Paraphrasis in Job, Paraphrasis in Psalmos, Paraphrasis in Sapientiam Salomonis, Paraphrasis in Isaiam); B) comentários (In Epistolam B. Pauli ad Romanos, Commentarius in Oseam, Commentarius in Zachariam, Commentaria in Parabolas Salomonis); 3.c) parenética (Oratio in laudem D. Aecatherina, In Euangelium Ioannis Orat. XXI); 4) o epistolográfico (em latim, português e espanhol).

Cumpre recordar ainda que nos resta, como único exemplo de algum fôlego do seu estro poético, ${ }^{100}$ uma composição, de oitenta hexâmetros dactílicos, com a qual celebrou a Natividade de Cristo. ${ }^{101}$ Além disso, temos a convicção de que ao nosso Autor pertence a tradução das Meditações sobre a oração do Pater noster ${ }^{102}$ do cardeal D. Henrique, longo e belo texto incluído pelos jesuítas na edição latina, que promoveram em 1576, publicada em Lisboa por Francisco Correia, de parte dos escritos espirituais do futuro e fugaz monarca, que até então se tinham publicado em português. Com efeito, o autor da introdutória Epistola ad lectorem, na p. 4 anuncia que o livro que então se apresentava ao público não se limitava à tradução dos textos que constavam da edição vernácula de 1574, pois: quibus etiam addendas esse credidimus eiusdem Principis Meditationes in Dominicam orationem conscriptas, quas iandiu in lucem editas Episcopus Syluensis, uir summa eloquentia atque eruditione Latinas fecerat. ("aos quais nos pareceu bem que

99 Fls. 5 e 6, não numerados, da Dedicatória anteposta ao tomo I dos Opera Omnia, edição romana de 1592, já citada.

100 Esta parcimónia pública da musa osoriana está em relativa contradição com as palavras do Autor, escritas em anos moços e que fazem supor alguma intimidade no trato com a poesia. De facto, agradecendo uns versos que o amigo Agustín lhe enviara, escreve: Calliope (...) habet a nobis animum alieniorem, quam habere consueuerat. Posteaquam illius numen mibi propitium reddidero (...). "Calíope mostra-se comigo mais esquiva do que era seu hábito. Logo que a inspiração me for restituída (...)."] Carta de Almeirim para Bolonha, de 16 de Fevereiro de 1543. Texto latino apud Cándido Flores Sellés, o. c., p. 143.

101 Foi publicada pela primeira vez no final da primeira edição do livro Paraphrasis in Isaiam. Dela existem duas traduções portuguesas: Sebastião Tavares de Pinho, "Poética e poesia em D. Jerónimo Osório", Humanitas, 35-36, Coimbra, 1983-1984, pp. 268-270; António Guimarães Pinto, apud D. Jerónimo Osório, Escritos Espirituais.

102 A $1^{a}$ edição, que saiu anónima, é de 1557 , e não sabemos dizer se a prioridade cabe a Lisboa ou a Évora, pois existem, com a mesma data e texto idêntico, exemplares saídos de impressores estabelecidos quer numa quer na outra cidade. Veja-se o que escrevemos acerca deste assunto na 'Nota preambular' da nossa versão de Erasmo, "Oração do Senhor, repartida em sete partes, acomodada aos sete dias", Revista Portuguesa de História do Livro, 18, Lisboa, 2006, pp. 203-209. 
se ajuntassem as Meditações sobre a oração do Pater Noster, que, há muito publicadas, traduzira para latim o bispo de Silves, varão de grande eloquência e erudição.")

Repassemos agora, com mais detença, mas fixando-nos sobretudo nas características externas, cada uma das obras ou núcleos temáticos em que o nosso Autor vazou o seu génio multímodo.

\section{Obras de carácter filosófico/ético-político}

\section{1. a) De nobilitate ciuili libri duo et de nobilitate christiana libri tres}

Primeira obra do Autor, saiu dos prelos do impressor lisboeta Luís Rodrigues, em 1542, e é dedicada ao infante D. Luís. Reparte-se por cinco livros, os dois primeiros dedicados à definição da nobreza civil e os três últimos à caracterização da nobreza cristã. Com esta obra, tal como na que publica a seguir (o diálogo De gloria), Osório insere-se numa recente tradição criada pelos grandes humanistas italianos dos séculos XIV e XV e que, fundamentalmente, visava tratar temas filosóficos (especialmente ligados com a ética social) de um modo diferente (quanto à forma e ao conteúdo) do usado até então e dirigindo-se a um público diverso daquele que tinha sido o auditório usual da aridez dogmática dos mestres escolásticos. "Obras legíveis, breves, amenas e facilmente acessíveis”, consoante escreve o grande especialista Eugenio Garin, que assim sintetiza o domínio literário em que podemos também inscrever as primícias do jovem escritor Osório: "O latim escolástico, uma horrível algaravia só para iniciados, (...) é substituído por um latim límpido e acessível, que em breve concederá um nada desprezível espaço às línguas vulgares. Quer dizer, a ciência e a filosofia, a nova ciência e a nova filosofia, dirigem-se a outro público ao qual dizer de forma diferente outras coisas."103

Ora, a verdadeira originalidade de Osório em relação a tratadistas italianos de temática congénere (por exemplo, Gian Francesco Poggio Bracciolini ou Bartolomeo Sacchi, autores de breves tratados intitulados, respectivamente, De nobilitate e de De uera nobilitate), radica sobretudo em ter transposto e elevado generalidades éticas de estirpe estóica e aristotélica (nas quais é indisputável que abundou nos dois primeiros livros, ou capítulos, consagrados à nobreza civil) a um plano moral e social de estrutura exclusivamente cristã. De qualquer modo, Osório, se, por um lado, na forma (linguagem elegante e amenidade no tratamento dos temas) e em alguns conteúdos, que não colidam com o cerne da mais estrita ortodoxia, se mostra sensível e se dobra às injunções de renovação literária e cultural do século XV e inícios do XVI, por outro lado, mostra possuir antenas apuradas para detectar e apaixonadamente increpar desvios que possam abalar e causar fracturas numa sociedade que, no plano social, se pretende rigidamente

103 Eugenio Garin, artigo "El filósofo y el mago", El Hombre del Renacimiento, ed. de id., trad. espanhola, Madrid, Alianza Editorial, 1990, p. 183. 
hierarquizada e, no moral, solidamente alicerçada em valores cristãos indiscutidos. Como é sabido, esta concepção, de matriz aristotélico-tomista, começa a sofrer os mais violentos embates precisamente no século do nosso Autor, não sendo pois de estranhar que, desde o seu primeiro escrito praticamente até ao último, tenha atacado da forma mais violenta aquelas duas personagens históricas a cujas doutrinas ele atribuía a ameaça de ruína da Cristandade: Maquiavel e Lutero, o primeiro, devido ao seu anti-cristianismo nada camuflado, e o segundo por assentar a predestinação e o livre-exame como princípios religiosos.

Precisamente nesta obra - que, convém recordar, foi muito provavelmente redigida em Bolonha entre 1540 e 1542 - encontra-se um dos primeiros ataques de autor não-italiano feito a Nicolau Maquiavel, o pensador político florentino falecido em 1527, mas cujas obras de maior repercussão ideológica, O Príncipe e Discurso sobre a $1^{a}$ Década de Tito Livio, só viram pela primeira vez a luz da publicidade em 1532 e 1531, respectivamente. A objurgatória do nosso Autor, que qualifica Maquiavel com os epítetos de: impurus quidam scriptor atque nefarius, homo consceleratus ("certo escritor perverso e sacrílego", "homem celerado"), ${ }^{104}$ visava sobretudo duas passagens deste último livro (no cap. 12 do $1 .{ }^{\circ} 1^{\circ}$ e no cap. $2^{\circ}$ do $1 .{ }^{\circ} 2^{\circ}$ ), nas quais o escritor florentino atribuíra ao cristianismo a decadência do império romano, devida em grande parte (na interpretação que Osório faz do texto de Maquiavel) à negação da virilidade e brios militares que a moral cristã inculcara entre os seus seguidores.

Aliás, logo em seguida, o nosso Autor, depois de asseverar que nibil angustum atque demissum, sed ampla omnia atque diuina in Christianis institutis reperiri: omnemque sanctissimae huius disciplinae rationem ad animi magnitudinem, et contemptionem mortis excitare ("nos ensinamentos cristãos nada se acha de acanhado e remisso, antes tudo é glorioso e alevantado, e que toda a essência desta santíssima doutrina move à grandeza de alma e ao desprezo da morte"), dirige a sua crítica e desmonta os argumentos daqueles que se mostram demasiado propensos a uma contraproducente condenação de toda a espécie de guerra. ${ }^{105}$ Conquanto o nosso Autor se abstenha de indicar nomes, a travação dos seus argumentos leva-nos a supor que o seu alvo é Erasmo, tendo ele sobretudo em mente certa passagem do Dulce Bellum inexpertis do escritor holandês. ${ }^{106}$

${ }^{104}$ D. Jerónimo Osório, De gloria (...) eiusdem de nobilitate ciuili et christiana, Basileia, Petrus Perna, 1573, pp. 468 e 469. - Para mais pormenores sobre a composição e características desta obra, veja-se a Introdução e Apêndices à nossa tradução deste tratado. Sobre as relações entre Maquiavel e D. Jerónimo Osório, só nos cabe indicar e vivamente recomendar os sérios e magistrais estudos de Martim de Albuquerque: A sombra de Maquiavel e a Ética Tradicional Portuguesa, Braga, Instituto Histórico Infante D. Henrique da F. de Letras da U. de Lisboa, 1974, pp. 70-82, e Maquiavel e Portugal, Lisboa, Alêtheia Editores, 2007, pp. 54-89, 174-180.

105 Pp. 495 a 500 da edição citada.

106 Erasmo, Opera Omnia, Leyden, Petrus Vanderaa, tomo IV, col. 963 B. Veja-se a Introdução às nossas traduções dos dois principais textos irénicos deste Autor: Erasmo, A Guerra e Queixa da Paz, Lisboa, Edições 70, 1999. 
Do texto latino desta obra fizeram-se 27 edições, sendo editadas em Portugal exclusivamente a $1^{\text {a }}$ e a última (em 1792, pela Imprensa da Universidade de Coimbra). Existem traduções para: francês (dos dois primeiros livros, em 1549; completa, em 1645), inglês (completa,1576), alemão (dos dois primeiros livros, 1828; dos três últimos, 1845), espanhol (dos dois primeiros livros, 1957-1958) e português (completa, 1996).107

\section{1. b) De gloria libri $V$}

Saiu em Junho de 1549 dos prelos conimbricenses de Francisco Correia com aparência modesta aquela que estava fadada a tornar-se a obra osoriana com maior número de edições na sua forma latina original, contribuindo assim para assegurar ao Autor uma das variedades daquela "glória" que aqui pretendeu definir analiticamente. Podemos arriscar que o livro já estaria pronto para a impressão desde o anterior ano de 1548, uma vez que, ao referir-se, na dedicatória ao rei D. João III, ao segundo cerco de Diu (1546), Osório o haver situado ab hinc triennio ("há três anos"), ${ }^{108}$ pormenor que, se tivermos em conta o tradicional modo de contar romano, fundamenta a nossa conjectura.

No De gloria Jerónimo Osório optou pela forma dialogada, género que mais tarde voltaria a adoptar no De regis institutione et disciplina e, por imposição do original que parafraseia, na obra Paraphrasis in Job que agora estamos a introduzir. ${ }^{109}$ O diálogo foi, como se sabe, um dos processos expositivos de mais ilustre e vasta linhagem na literatura humanística, conquanto a sua primeira formulação teórica e preceptística surja já na segunda metade do século XVI com a publicação, em 1562, do De dialogo liber, devido à pena de um condiscípulo italiano e, durante algum tempo, companheiro na residência bolonhesa do nosso Autor: Carlo Sigonio. ${ }^{110}$

107 A maior parte das informações que damos sobre as diferentes edições das obras de Osório procedem ou foram sugeridas pelo utilíssimo artigo de Francisco Leite de Faria, "As muitas edições de obras de D. Jerónimo Osório", Revista da Biblioteca Nacional, 1, Lisboa, 1981, pp. 116-135.

108 Jerónimo Osório, De gloria, o. c., p. 8. - A nossa versão desta obra saiu com o título Tratado da Glória. Tradução, introdução e anotações de A. Guimarães Pinto, Lisboa, Imprensa Nacional - Casa da Moeda, 2005

109 Sobre o De gloria podem ler-se os seguintes estudos, de entre os quais o primeiro nos parece notável: Davide Bigalli, "Isolle di dottrina: il dialogo 'De gloria' di Jerónimo Osório", in Davide Bigalli e Guido Canziani (coord.), Il dialogo filosofico nel' 500 europeo. Atti del convegno internazionale di studi. Milano, 28-30 maggio 1987, Milão, Franco Angeli, 1990, pp. 155-182; Jorge Alves Osório, "O diálogo no humanismo português", O Humanismo Português (1500-1600). Primeiro Simpósio Nacional. 21-25 de Outubro de 1985, Lisboa, 1988, pp. 401-404; Dietrich Briesemeister, "L' honneur comme forme de vie. Le traité De gloria de Jérôme Osório”, Humanitas, 43-44, Coimbra, 1991-1992, pp. 81-90, com algumas imprecisões e confusões.

110 Vd. Carlo Sigonio, Del dialogo. De dialogo. A cura di Franco Pignatti, Roma, Bulzoni Editore, 1993. 
Na dedicatória, o Autor narra a D. João III como a sua ida para Bolonha the deu a oportunidade de travar relações com António Agustín e Jean Matal, e é da alternada exposição dos pontos de vista sobretudo do primeiro destes dois amigo e do próprio Osório que vai resultar um esclarecimento do conceito de "glória", que na definição final, a cargo da persona do nosso Autor, recebe uma formulação cristã, ao concluir que Cristo é o restaurador e mestre da verdadeira Glória, que é a de que gozam os bem-aventurados no Céu e aquela que os homens se devem esforçar por alcançar. ${ }^{111}$

Tem interesse indicar que no De gloria o nosso Autor faz nova investida contra Maquiavel, arremetendo desta vez contra o capítulo $18^{\circ}$ da obra mais conhecida do pensador florentino, ${ }^{112}$ sintetizado da seguinte forma pela boca de Jean Matal: disputant aliqui, conuenire principi, qui magna quaedam spectat, in loco fidem fallere. Aliter enim negant eum suae dignitati et amplitudini seruire posse. ("Há quem defenda que ao príncipe que aspira a coisas verdadeiramente grandes convém-lhe, de acordo com a ocasião, faltar à palavra. É que, se não proceder assim, afirmam que não pode acautelar a sua dignidade e prestígio." ${ }^{113}$ Outro pormenor que confere a este livro um matiz de inovação na literatura nacional tem a ver com o facto de que é nele, segundo parece, que se encontra a primeira referência, e relativamente circunstanciada, à realidade chinesa feita por um português em obra impressa. ${ }^{114}$

Do texto latino deste livro existem 29 edições, sendo três impressas em Portugal (a $1^{\mathrm{a}}$; a $27^{\mathrm{a}}$, da Imprensa da Universidade de Coimbra, de 1792; e a $29^{\mathrm{a}}$ e última, de Lisboa, 2006). ${ }^{115}$ Existem duas diferentes traduções portuguesas: uma de 2005 e outra de 2006.

\section{1. c) De regis institutione et disciplina}

O tratado dialogado deste nome, dedicado ao jovem monarca D. Sebastião, dividese em oito livros e ostenta, na página de rosto da $1^{\mathrm{a}}$ edição, saída dos prelos lisboetas

\footnotetext{
111 Nas pp. 13-19 da nossa edição oferecemos ao leitor interessado um resumo da obra.

112 Nicolau Maquiavel, O Príncipe, cap. 18, subintitulado Quomodo fides a principibus sit conseruanda.

113 D. Jerónimo Osório, De gloria, o. c., p. 187. O ataque de Osório segue-se imediatamente a este comentário do amigo.

${ }^{114}$ Pp. 166-168. Veja-se, sobre este tema, o livro Enformação das Cousas da China. Textos do Século XVI, Introdução e leitura de Raffaela d' Intino, Lisboa, Imprensa Nacional - Casa da Moeda, 1989, e o artigo de João Manuel Nunes Torrão, "A China na obra de D. Jerónimo Osório”, Humanitas, 43-44, Coimbra, 1991-1992, pp. 449-460. É provável que estas informações sobre a China chegassem até Osório por via do irmão Bernardo da Fonseca, que desde tenra idade vivia no Oriente e de quem alguns documentos nos dizem, sem especificar o ano, que fez uma viagem à China.

115 Esta edição, saída dos prelos da Editorial Colibri e apresentando uma tradução efectuada por uma equipa orientada por António Moniz, reproduz a edição crítica policopiada, que constitui o $2^{\circ}$ tomo da dissertação de doutoramento de João Manuel Nunes Torrão, intitulada D. Jerónimo Osório e o tratado "De gloria", Coimbra, Faculdade de Letras, 1991.
} 
do impressor João de Espanha, a data de 1571, ainda que, estranhamente, o cólofon nos transmita uma informação diversa: Excudebat Franciscus Correa Ampliss et Sereniss Card. Infan. Typogra. An 1572. M Ianu. d. 22. ("impresso por Francisco Correia, tipógrafo de Sua Alteza Real o sereníssimo cardeal-infante, no dia 22 de Janeiro de 1572") Ao esclarecimento desta incongruência consagrámos alhures algumas páginas, bastando aqui dizer que julgamos que parte da solução do enigma tem a ver com o grande número de gralhas tipográficas que de tal forma inçaram a $1^{\text {a }}$ edição que obrigaram o indignado Autor a suster a distribuição do livro, enquanto se procurava remediar o mal pela elaboração de uma longa fé de erratas, antecedida de uma explicação que, embora atribuída ao tipógrafo, trai claramente a mão osoriana. ${ }^{116}$

Na p. 12 da Vita do tio, Jerónimo Osório Júnior consigna que, à roda de 1570, o prelado algarvio: opportunum fore existimauit, vt libros de Regis institutione, quos multos ante annos composuerat, Regi mitteret, illique dicaret. ("cuidou que seria oportuno enviar e dedicar ao rei o tratado Da Ensinança do Rei, que redigira muitos anos antes.") Ora, o De Regis institutione et disciplina, além do narrador, assimilável ao próprio Osório e por conta de quem corre a maior parte das falas que compõem o diálogo, apresenta-nos como interlocutores, mais ou menos loquazes, três personagens de grande prestígio: Francisco de Sá e Meneses, D. Francisco de Portugal e Lourenço Pires de Távora. A ponderação das circunstâncias biográficas conhecidas dos quatro interlocutores e a sua compaginação com sucessos coetâneos que o Autor deixa escapar na sua obra, criando, sem o pretender, uma coincidência entre o plano histórico e a "ficção ou mimese conversacional", permitiramnos sugerir o período que decorre entre os finais de 1562 e os inícios de 1564 como o da redacção deste tratado dialogado. ${ }^{117}$ Entre os modelos que a preceptística renascentista lhe oferecia para este género - ou seja, o platónico, o lucianesco e o ciceroniano -, o nosso Autor optou claramente pelo último, sem embargo de, nesta obra, o débito em relação a Platão ser imenso, mas, ao que nos parece, operando-se mais a nível ideológico e informativo, e não da forma ou do método dialéctico, que Osório de ordinário pospõe em favor do retórico, mais acorde com as tendências e gostos humanistas.

Não é própria deste local a síntese ou comentário dos conteúdos que integram este vasto e ambicioso livro, no qual se combinam a teorização política, a pedagogia do príncipe e a ética, ${ }^{118}$ e sobre o qual é provável que D. Jerónimo Osório depositasse algumas esperanças no sentido de desviar o rumo nefasto que pressentia que os negócios

116 Veja-se a nossa Introdução a: D. Jerónimo Osório, Da Ensinança e Educação do Rei. Tradução, introdução e anotações de A. Guimarães Pinto, Lisboa, Imprensa Nacional - Casa da Moeda, 2005.

117 Período durante o qual, consoante sugerimos ao traçar-lhe supra a biografia, deve ter vivido no círculo do cardeal-infante, por então regente do reino em nome do sobrinho.

118 Uma boa síntese da totalidade da obra pode encontrar-se em Nair de Nazaré Castro Soares, O Príncipe Ideal no Século XVI e a Obra de D. Jerónimo Osório, Coimbra, INIC, 1994, pp. 297-326. No que toca à análise dos aspectos ideológicos, além do livro acabado de citar, devem ser consultados os seguintes trabalhos: Francisco Elías de Tejada, "Las doctrinas políticas de Jerónimo Osório", Anuário de Historia del Derecho Español, Madrid, 16 (1945), pp. 341-388; 
públicos iam tomando pela época em que decidiu publicar este tratado. De facto, menos de dois anos antes de morrer, o Autor reconhecia que, mau grado seu, tinha saído profético em alguns dos seus ensinamentos:

Portugal está tal qual los peccados públicos merecían. Yo bize mi officio con el rey, que Dios tenga en Su gloria, y así lo hicieron otros muchos; mas pudieron más lisonjeros y hombres más deseosos de ayuntar dineros y juros que consejos prudentes y sanos. Pésame porque salieron verdaderas algunas sententias mias, que muchos llaman profecías, en los libros De Regis institutione et disciplina, mas son consejos de Dios y serán para Su gloria. ${ }^{119}$

Fizeram-se nove edições do texto latino deste livro, sendo portuguesas as duas primeiras e a última (saída em 1794, em dois tomos, dos prelos da Imprensa da Universidade de Coimbra). Existe uma tradução francesa (com duas edições, uma de 1582 e outra do ano seguinte) e outra portuguesa (publicada em 2005); em 1944 saiu uma versão portuguesa, que se ficou pelos cinco primeiros livros dos oito que compõem a obra.

\section{1. d) De uera sapientia}

A última obra publicada por D. Jerónimo Osório, impressa em Lisboa por Francisco Correia, saiu a lume em 1578 - dois anos antes da morte do Autor - repartida em cinco livros e antecedida por uma introdução dedicatória ao papa Gregório XIII. A censura de frei Bartolomeu Ferreira e a licença do conselho-geral do Santo Ofício têm a data de 15 e 18 de Junho do ano da impressão, enquanto, por um passo da carta há pouco citada ao amigo António Agustín, sabemos que em 11 de Novembro o livro já estava fora dos prelos: Hize imprimir mis libros de Sapientia; nuestros impressores son novicios y los que eran más exercitados hallé ocupados, y mi priessa non dió lugar a se hazer mejor obra de la que $V$. S. verá.

Não deixa de nos causar alguma perplexidade a alusão que o autor faz à "pressa" com que diligenciou oferecer à luz pública o livro que, com todo o direito, podemos considerar como o seu testamento espiritual, uma vez que possuímos alguma informação sobre a sua gestação e dilatada existência manuscrita. Com efeito, estamos em condições de poder assentar que: 1) o De uera sapientia estava, pelo menos, em fase de elaboração numa data pouco posterior a Abril de 1568; 2) o próprio Autor reconhece este livro como já concluído em Abril de 1570; 3) a derradeira obra publicada por Osório permaneceu num limbo de, na pior das hipóteses, oito anos, até ver a luz da publicidade entre

Paulo Merêa, recensão ao artigo anterior, in Boletim da Faculdade de Direito, Coimbra, 23 (1947), pp. 152-155.

119 Carta de 16 de Novembro de 1578 (três meses depois de Alcácer Quibir) para o amigo António Agustín, então arcebispo de Tarragona. Esta carta pode ler-se completa na nossa já citada edição das Cartas, pp. 110-111. 
Junho e Novembro de $1578 .{ }^{120}$ Ora, cuidamos que a urgência na publicação, com a qual D. Jerónimo Osório se procura desculpar perante o amigo dos deslizes tipográficos que maculavam a obra recém-editada, pode explicar-se sob forma hipotética, que aventamos como tal, e que se ligaria com duas ordens de factores a considerar. Por um lado, o impacto psicológico que o espectáculo da louca corrida para o suicídio colectivo poderia causar num homem impulsivo como Osório, levando-o a, numa espécie de compensação ao desatino reinante, tentar um desesperado apelo à "verdadeira sabedoria" que propugna no seu último livro. Por outro lado, o sexagenário D. Jerónimo Osório teria começado a sentir com maior pungência a realidade da morte, cada vez mais próxima e incontornável para quem já não era jovem, e teria buscado - instado também pelas circunstâncias de desabar da pátria e geral sossobro de tudo quanto o rodeava - salvaguardar pelo menos a gema mais querida do seu legado intelectual, ainda que correndo o risco (que não se atrevera a correr durante tantos anos) de entregá-la à inépcia desfiguradora dos profissionais de tipografia de que podia dispor em tão difícil conjuntura.

Livro de propósitos mais determinadamente filosóficos do que qualquer outro dos que saíram da pluma osoriana - a qual, embora tenha provado forças (como estamos a ver) numa relativamente vasta gama de domínios culturais, privilegiou sobretudo os grandes temas teológicos e o que, sem preocupação de rigor, poderíamos designar por ensaísmo ético-religioso -, o De uera sapientia não foge mesmo assim à intenção de apologética católica que subjaz a todo o percurso humano e literário do Autor. ${ }^{121}$ O seu fito é, servindo-se o mais possível das armas argumentativas dos adversários, captar para a grei cristã os judeus e os gregos, designando provavelmente com este último vocábulo alguns espíritos aos quais certas partes do aristotelismo, que a síntese-adaptação cristã de Santo Tomás não pudera assimilar, punham em risco de fazer resvalar para o ateísmo ou para a heterodoxia mais desvairada (como é caso dos arianos-socinianos, seita de repercussão quase nula no policromo espectro religioso do século XVI, certamente incluídos e atacados nesta obra por sugestão indirecta de Estanislau Hósio, cardeal polaco amigo do Autor). ${ }^{122}$

O texto original latino deste livro teve cinco edições, sendo impressas em Portugal a $1^{\text {a }}$ e a última (em 1792, pela Imprensa da Universidade de Coimbra). A única tradução publicada é a portuguesa e data de 2002.

120 Para o desenvolvimento e comprovação do que aqui damos por assente, veja-se a nossa Introdução a: D. Jerónimo Osório, Tratado da Verdadeira Sabedoria. Tradução, introdução e anotações de A. Guimarães Pinto, Lisboa, Imprensa Nacional - Casa da Moeda, 2002.

121 Este livro foi objecto de uma pequena monografia de João Ferreira: "A noção de sabedoria em Jerónimo Osório”, Itinerarium, Braga, 5 (1959), pp. 395-411. Devemos consignar a nossa convicção de que uma leitura um pouco mais aprofundada da obra permitirá acrescentar bastante ao que se diz neste estudo que, dentro da sua brevidade, nos parece sugestivo e interessante, mas que, pelos limites da sua mesma extensão, não estava obrigado a seguir algumas sendas que o texto osoriano sugere, como julgamos ser o caso, por exemplo, dos influxos do Pseudo-Dionísio e de Marsílio Ficino.

122 Damos um resumo da obra nas pp. 16-31 da nossa edição. 


\section{Obra de carácter histórico}

\section{De rebus Emmanuelis gestis}

Uma parte significativa do prestígio alcançado na Europa e em Portugal por D. Jerónimo Osório ficou a dever-se, e deve-se ainda hoje, à obra que na folha de rosto ostenta, além do nome do editor António Gonçalves, do local e data da impressão (Lisboa, 1571), o dilatado título de De rebus Emmanuelis regis Lusitaniae invictissimi virtute et auspicio gestis libri duodecim, ou, na tradução do nosso Mestre e Amigo Prof. Costa Ramalho, Os doze livros dos feitos praticados pelo valor e sob os auspícios do Invictíssimo Rei de Portugal, D. Manuel. ${ }^{123}$ No entanto, poderá causar certa estranheza o facto de que o nosso Autor, na sua restante obra, não faz qualquer alusão ao De rebus, o mais extenso dos seus livros, silêncio tanto mais de notar quanto é certo que ele não se verifica em relação à grande maioria dos seus outros trabalhos publicados em vida. Deste procedimento cremos poder tirar-se a óbvia conclusão de que D. Jerónimo Osório não se revia, ou pelo menos não sentia como sua, uma obra literária que não promanava das imposições espontâneas e irresistíveis de uma vocação cujo pendor mais evidente era a doutrinação ética e religiosa. Aliás, na dedicatória do De rebus, o bispo de Silves, dirigindo-se ao cardeal D. Henrique, revela-nos que com esta obra se limitava a satisfazer uma encomenda do régio purpurado, desejoso de glorificar a memória paterna em idioma de mais vasta repercussão do que o português. Quanto ao material de que se serviu para o desempenho da incumbência, diz-nos o seguinte:

$V t$ autem id facilius exequi possem, Damianus Goes praestit. Is enim magno labore, vigilantia, et industria ea ex quamplurimis epistolis et commentariis eruit, et monumentis suis memoriae commendauit, quae ego minime potuissem sine summo otio perscrutari. Multa etiam ex aliorum scriptis et sermonibus accepta, memoria continebam, quae minime silentio praetereunda iudicaui. ("Para nos podermos desempenhar mais facilmente desta incumbência, recorremos sobretudo a Damião de Góis. É que ele, com grande trabalho, desvelo e aplicação desentranhou de inúmera correspondência e memoriais e consignou por escrito factos que eu de modo algum teria podido investigar sem grande disponibilidade de tempo. Pela minha parte, eu também tinha memória de muitas coisas, que recolhi dos escritos e conversas de outros, e que julguei que de forma alguma deveriam ser remetidas ao silêncio.") $)^{124}$

Ora, a verdade é que no De rebus nem as adições pessoais são tão copiosas como o Autor assevera ao empregar o adjectivo substantivado multa, nem o seu trabalho é

123 Apud Américo da Costa Ramalho, Para a História do Humanismo em Portugal (IV), Lisboa, Imprensa Nacional - Casa da Moeda, 2000, p. 29.

${ }^{124}$ D. Jerónimo Osório, De rebus Emmanuelis (...) libri duodecim, Coimbra, ex Typographia Academico-Regia, 1791, tomo I, p. 5. 
uma mera tradução. ${ }^{125}$ No entanto, que não está muito longe de o ser é o que pudemos concluir do cotejo sistemático a que submetemos a Crónica do felicíssimo rei D. Manuel, de Damião de Góis, e o De rebus osoriano, dele resultando que a substância desta última obra tende a assumir, dentro de uma estrutura que é estrita e rigorosamente a da obra de Góis, uma das seguintes formas:

1) condensação do texto goisiano;

2) tradução quase literal do texto de Góis;

3) recurso directo às fontes utilizadas por Góis (João de Barros e F. L. de Castanheda);

4) a) supressão ou diminuição ostensiva de matérias ou trechos desenvolvidos em Góis;

b) sínteses ou quadros sintéticos sobre pessoas ou factos tratados por Góis de forma extensa;

5) inovação, sob a forma de contribuição informativa pessoal acrescentada ao corpo narrativo goisiano;

6) desenvolvimentos/glosas de tipo apologético, satírico, ético e doutrinário;

7) modificações ou acréscimos, relativamente ao texto de Góis, sugeridos por motivos sobretudo estéticos.

Assim, cremos que a mais justa definição do De rebus é a de uma condensação ou versão abreviada em latim do texto da Crónica goisiana, em que a contribuição pessoal do tradutor/adaptador, além da intervenção especificamente linguística e literária que este estatuto implica (por exemplo, apresentação de quadros sintéticos, processos de supressão ou amplificação, opção por uma ordem na distribuição das matérias diferente da do modelo), se ficou por: 1) cerca de dezasseis achegas informativas de colheita própria, a maioria delas de somenos importância; 2) cerca de vinte exemplos em que Osório preferiu recorrer directamente às fontes de Góis, desenvolvendo ou explicitando elementos aludidos ou subentendidos neste; 3) glosas ou comentários de tipo apologético, satírico, ético e doutrinário, um terreno mais consoante com o talante literário de Osório, e nos quais se nos deparam, de forma abreviada, alguns dos temas recorrentes no seu espólio intelectual mais conhecido; 4) incisos e à partes, em que o estilo mental do adaptador denuncia a sua bem vigorosa personalidade.

Nestas condições - que julgamos ter evidenciado no estudo que consagrámos ao tema - de grande dependência em relação à Crónica de Damião de Góis, não nos parece fazer muito sentido, não só o projecto de empreender uma nova tradução do De rebus, como o intento de uma definição dos métodos e conceito de história em Osório. É que as suas limitações e méritos neste campo são os que se encontram em Góis, e talvez não

125 O que escrevemos nesta alínea é em grande parte extractado do nosso ensaio "Damião de Góis e D. Jerónimo Osório: a Crónica de D. Manuel e o De rebus Emmanuelis gestis", Actas do Congresso Internacional "Damião de Góis na Europa do Renascimento", Braga, Publicações da Faculdade de Filosofia, 2003, pp. 307-348. 
escapem às críticas acerbas que Jorge Borges de Macedo irrogou ao labor historiográfico do cosmopolita de Alenquer. ${ }^{126}$

A composição/tradução desta volumosa obra foi realizada por D. Jerónimo Osório entre 1567, data da publicação da $3^{\mathrm{a}}$ e $4^{\mathrm{a}}$ partes da Crónica de Góis (no mês de Julho), e, pelo menos, os começos de Setembro de 1571, porquanto a censura de frei Bartolomeu Ferreira, que pode ler-se no verso da página de rosto do De rebus, está datada octana die Septembris. Estranhamente, na última folha da obra, sotoposta ao privilégio e antes de uma nótula que antecede a fé de erratas, lê-se a data mense Septemb. 1572. Aventámos a hipótese de se tratar de uma "gralha", devendo ler-se aqui 1571, como nos outros dois casos em que a data de publicação é indicada no próprio livro. Além de a coincidência dos meses e o factor percentagem militarem a favor da nossa suposição, existem argumentos externos fortes, de carácter biográfico, que podem encaminhar-se no mesmo sentido. ${ }^{127}$

Esta obra teve onze edições em latim, sendo feitas em Portugal a $1^{\text {a }}$ e as duas últimas (ambas pela Imprensa da Universidade de Coimbra, em três volumes, e editadas em 1791 e em 1923, respectivamente, conquanto esta última não tenha indicação de ano). Dela se fizeram traduções para francês (de 1581 a 1610 há 12 edições nesta língua), neerlandês (2 edições, uma em 1661 e outra em 1663), inglês (1752), alemão (1795, parcial) e português (feita por Francisco Manuel do Nascimento, o vernaculíssimo árcade Filinto Elísio: 1804, os 2 primeiros volumes, e 1806 o 3º, com uma $2^{a}$ edição, em dois volumes, em 1944).

\section{Obras de carácter polémico ou "estilo forense elevado"}

\section{3. a) Epistola ad Elisabetam Angliae Reginam}

No ano de 1562, e com a aprovação dos inquisidores, que figura no verso da última folha impressa, das 39 não numeradas que compõem o opúsculo, publica em Lisboa o tipógrafo João Blávio a Carta de Jerónimo Osório a Isabel rainha de Inglaterra.

Para a génese da redacção deste escrito terão concorrido, segundo o sobrinho biógrafo: o desejo de pagar com bons e piedosos conselhos a admiração literária que a soberana inglesa sentia pelo lusitano, o propósito de aceder à insistência de dois homens que Osório muito prezava (o cardeal D. Henrique e o dominicano frei Francisco Foreiro) e, por derradeiro, o acatamento às injunções do maravilhoso, sob a forma de um estranho sonho, no qual o nosso Autor se viu a pescar no cabo de S. Vicente e a tirar do mar um peixe de tamanho desmedido, que, arrastado para terra, se transformou

126 Jorge Borges de Macedo, Damião de Góis et l' historiographie portugaise, separata de Damião de Góis, humaniste européen, Paris, Centre de Recherches sur le Portugal de la Renaissance, 1982.

127 Veja-se a fundamentação desenvolvida desta hipótese nas pp. 312-314 do nosso estudo citado na penúltima nota. 
em formosa mulher, adornada com um diadema, a qual, posta de joelhos, lhe suplicou o baptismo. ${ }^{128}$

Não nos cabendo duvidar do peso que teria tido no ânimo de Osório qualquer uma das motivações alegadas, cremos, porém, que a mola decisiva desta empresa literária do nosso Autor foi a vontade do cardeal-infante, personalidade a tantos títulos determinante na vida e obra do grande humanista. De concreto, e restringindo-nos às suas palavras, o impulso inicial para a redacção da epístola radicaria exclusivamente na sua própria e espontânea vontade - prova de supina tolice do Autor seria confessar o contrário - e encontrar-se-ia na motivação que o sobrinho alegou em primeiro lugar e que, numa carta ao inglês Roger Ascham, datada de 13 de Dezembro de 1561, se substancia do modo seguinte:

In quo vero Principis vestrae ingenium, et eruditionem, extulisti, magnum mibi animum addidisti, vt eam per litteras salutarem, et, quam essem studio illius incensus, multis verbis ostenderem. Nec enim dubito, cum illa et natura, et studio, summam humanitatis, et clementiae laudem assecuta sit, quin litteras meas benigne, et clemente, excipiat. ("Ao exalçares a inteligência e saber da vossa princesa, deste-me alentos não pequenos para me atrever a saudá-la por carta e mostrar-lhe, com cópia de palavras, de quão grande afecto me acho animado em relação a ela. Pois, olhando a que ela, não só por natureza, como pelo estudo, se guindou ao sumo grau da afabilidade e da bondade, não tenho dúvidas de que receberá com indulgência e benignidade a minha carta.") ${ }^{129}$

Neste mesmo sentido vão, aliás, as declarações de intenção que esparziu nas duas primeiras obras que resenhamos nesta alínea, de que são exemplo os dois passos seguintes:

hoc unum scio, me ex eorum sermone magnam uoluptatem percepisse et consilium iniuisse quomodo tibi per litteras animum in te meum plenissimum pietatis et obseruatione declararem; ("sei apenas que as palavras deles ${ }^{130}$ me ocasionaram grande deleitação e que comecei a cogitar na forma por que vos tornaria manifesta, através de uma carta, a disposição do meu ânimo - transbordante de afecto e consideração - em relação a vós") sanctissimae religionis amor et studium, quo eram in reginam incensus, me incitauit ut eas "litteras" darem, quibus illam admonerem ut id discrimen uitaret quod rebus communibus imminebat. ("foram o amor da santíssima religião e os sentimentos de simpatia que me animavam relativamente à rainha que me incitaram a publicar a Carta que lhe enderecei, a fim de, através dela, aconselhá-la a evitar aquele grande perigo que ameaçava os negócios públicos.”) ${ }^{131}$

128 Vita, p. 5.

129 Jerónimo Osório, Opera Omnia, o. c., tomo I, cols. 1144-1145.

130 Referira-se imediatamente atrás às informações de certos ingleses que lhe deram a conhecer o gosto com que a rainha lera os anteriores escritos do nosso Autor.

131 Apud António Guimarães Pinto, Humanismo e Controvérsia Religiosa, tomo $3^{\circ}$, pp. 11 e 310. Neste tomo apresenta-se a edição crítica da Epistola ad Elisabetam (pp. 11-49) e do In Haddonum (pp. 229-397), de Osório, das respostas de Haddon ao nosso Autor (pp. 51-74 e 
Depois de, fiel aos cânones da retórica tradicional, ter conseguido assim a captatio beneuolentiae da destinatária, Osório vai, num longo e bem elaborado discurso de doutrinação político-religiosa, tentar persuadir a soberana inglesa da necessidade e utilidade de orientar a sua governação pelos princípios da ortodoxia católica e de afastar e reprimir as vozes insidiosas e demagógicas dos sequazes de Lutero, que, sob a máscara da lisonja, procuram insinuar-se nas boas graças da jovem e inexperiente monarca. ${ }^{132}$

O texto latino desta obra teve 14 edições, sendo portuguesas a $1^{\mathrm{a}}$, a $6^{\mathrm{a}}$ (Lisboa, António Ribeiro, 1575) e as duas últimas (1981 e 2006). Conhecemos uma tradução francesa (1563), outra inglesa (com duas edições em 1565 e uma reprodução fac-similar, de 1977) e duas portuguesas (uma de $1981^{133}$ e outra de 2006).

\section{3. b) In Gualterum Haddonum}

Com a data de impressão de Nonis Octobris ("7 de Outubro") de 1567 saíram, dos prelos lisboetas de Francisco Correia, estes Amplissimi atque doctissimi viri D. Hieronymi Osorii, episcopi Sylvensis, in Gualterum Haddonum, magistrum libellorum supplicum apud clarissimam Principem Helisabetham Angliae, Franciae et Hiberniae Reginae libri tres. ("Três livros do excelentíssimo e doutíssimo varão, o Senhor D. Jerónimo Osório, bispo de Silves, contra Walter Haddon, juiz do Tribunal da Suplicação, da ilustríssima princesa Isabel, rainha da Inglaterra, França e Irlanda") Com este livro, de 157 folhas só numeradas no recto, e de tão estirado título, procurou responder D. Jerónimo Osório a um opúsculo de 18 folhas, in octavo, do jurista inglês Walter Haddon, intitulado Responsum ad Epistolam Hieronymi Osorij Lusitani e sem indicação de ano ou lugar de edição. ${ }^{134}$

399-531) e da Epistula aduersus epistulam Gualteri Haddoni (pp. 75-228) de D. Manuel de Almada, bispo de Angra.

$132 \mathrm{Um}$ resumo desta Carta e de todas as peças que integram a polémica a que ela deu origem pode ver-se nas pp. $154-226$ do tomo $1^{\circ}$ da obra citada na nota anterior. O tomo $2^{\circ}$ da mesma obra integra as traduções de todas estas obras.

$133 \mathrm{Da}$ autoria do Prof. Sebastião Tavares de Pinho, que é o responsável também pela edição crítica do texto latino: D. Jerónimo Osório, Carta à Rainha da Inglaterra, Lisboa, Biblioteca Nacional, 1983.

${ }^{134}$ Só existe (que saibamos) um exemplar desta $1^{a}$ edição. Faz parte da Biblioteca de D. Manuel II, depositada no Paço Ducal de Vila Viçosa, e o seu título completo é o seguinte: Gvalter Haddoni Serenissimae D. Elizabethae Angliae, Franciae et Hyberniae Reginae fidei defensatricis a supplicum libellis. Responsum ad epistolam Hieronymi Osorij Lusitani. Por deficiente catalogação do opulentíssimo legado bibliográfico do nosso último Rei, hoje suprida pela excelente obra de João Ruas, Biblioteca de D. Manuel II. Impressos dos séculos XV e XVI, Fundação da Casa de Bragança, 2002, p. 178, ao tempo da preparação da nossa dissertação de doutoramento não pudemos aproveitar esta importante peça e servimo-nos, para o estabelecimento do texto, da $2^{a}$ edição do mesmo, datada de 1567 . O cotejo a que entretanto procedemos de ambas as lições, certificou-nos que nem a mais recente apresenta qualquer variante textual, nem a $1^{a}$ qualquer nova informação que nos leve a modificar quanto conjecturáramos e expuséramos nas pp. 145-147 do tomo $1^{\circ}$ do nosso trabalho. 
Ora, sabemos que o êxito clamoroso da Carta de Osório (que só em 1563 teve três edições, em Veneza, Lovaina e Paris, e uma tradução para francês) e as críticas acerbas que o nosso Autor fizera aos conselheiros da rainha Isabel, notando-os de impiedade e assacando-lhes toda a sorte de vícios morais, moveram o governo inglês, encabeçado, se não tutelado, pelo arguto secretário William Cecil, a dar uma pronta resposta que não só reivindicasse diante da Europa a honra e bom nome da Inglaterra ultrajados pelo eloquente e atrevido lusitano, mas fosse também uma espécie de manifesto da diferente situação político-religiosa instaurada neste país com a subida ao trono da nova soberana. O esboço e orientação geral do escrito ficaram provavelmente por conta de Cecil e Sir Thomas Smith, que para a forma literária e redacção latina escolheram Walter Haddon, amigo de confiança de ambos e reputado como um dos mais perfeitos imitadores do estilo de Cícero. ${ }^{135}$ Por negociações secretas, que hoje conhecemos, entre o embaixador inglês em França e o impressor Robert Estienne, este acedeu em fazer uma edição clandestina da resposta de Haddon a Osório, que já estaria concluída e pronta para ser distribuída nos começos de Abril de 1564. ${ }^{136}$

Entre princípios de Abril e finais de Maio de 1566 sai dos prelos de Guglielmus Silvius, em Antuérpia, uma Epistula (...) aduersus epistulam Gualteri Haddoni, truculenta e indigesta obra com a qual o bispo português D. Manuel de Almada, que por então se encontrava nos Países Baixos, ${ }^{137}$ procurava defender o seu confrade D. Jerónimo Osório das imputações com que Haddon replicara à Carta à Rainha Isabel. Ora, no início do seu Contra Haddon, o nosso Autor dá a conhecer ao seu opositor inglês tanto as razões que o moveram a escrever a sua própria réplica ao Responsum de 1564, quanto as circunstâncias em que deste teve notícia, e que resume assim:

Post multos tandem menses, cardinale consulto, mibi librum tuum misit, et simul admonuit ut aliquod tempus e summis occupationibus eriperem ut tibi responderem. Id etiam reliqui amici ut facerem hortabantur. Quamuis autem amicorum uoluntatem aspernari contra officium esse uideretur, illis tamen morem minime gererem, si illo opere tuo meam tantum dignitatem et non religionis sanctitatem uiolatam animaduerterem. ("Passados muitos meses [=desde o regresso a Portugal de D. Manuel de Almada] e depois de consultado o cardeal, enviou-me por fim o teu livro, do mesmo passo que me exortou

135 Acerca da biografia e actividade literária de Walter Haddon vejam-se as pp. 90-115 do tomo I da nossa já citada dissertação.

136 Neste parágrafo seguimos e fundamo-nos em grande parte nas investigações de que dá conta o excelente artigo de Léon Bourdon, "Autour de la controverse Jerónimo Osório Walter Haddon. L' édition parisienne clandestine de la réponse de Haddon à la lettre d' Osório à la Reine Elisabeth (1564)", Arquivo de Bibliografia Portuguesa, Coimbra, 3 (1957), pp. 16-42. Veja-se também, do mesmo estudioso francês: "Jerónimo Osório et les Humanistes Anglais", in L' Humanisme portugais et l' Europe - Actes du XXI Colloque International d' Études Humanistes, Tours 3-13 Juillet 1978, Paris, Gulbenkian, 1984, pp. 263-333.

137 Sobre este prelado cortesão, titular de um bispado que nunca visitou, e sobre a viagem que realizou aos Países Baixos como caudatário da Senhora D. ${ }^{a}$ Maria, a quem acompanhou até Bruxelas para a entregar ao esposo Alexandre Farnésio, vejam-se as pp. 118-137 do tomo I de Humanismo e Controvérsia Religiosa. 
a roubar algum tempo aos afazeres de mais monta a fim de te responder. Os demais amigos também me aconselhavam a que assim fizesse. Ora, ainda que semelhasse que era contra os deveres da delicadeza desprezar a vontade dos amigos, todavia não lhes obedeceria, caso não reconhecesse que com aquela tua obra fora ultrajada a santidade da religião, e não apenas a minha dignidade.") ${ }^{138}$

Supomos que o bispo de Angra deve ter chegado a Portugal entre Junho e Julho de 1566, tendo decorrido "muitos meses", de acordo com o testemunho de Osório, antes de se dispor a entregar a este um exemplar do opúsculo de Haddon. Por uma carta do mesmo Osório a um correspondente anónimo (muito provavelmente o sacerdote católico inglês Thomas Harding), que supomos datável de Outubro - ou pouco depois - de 1567, o bispo de Silves afirma que a carta a que agora responde, conquanto datada do $1^{\circ}$ de Junho do ano anterior, só lhe fora entregue por D. Manuel de Almada, seu portador, em Setembro do ano que então corria, explicando-lhe em seguida a causa da incrível demora de catorze meses. ${ }^{139}$ Em outra carta, datada de 29 de Dezembro de 1567, D. Jerónimo Osório, dirigindo-se ao cardeal Estanislau Hósio, dá-lhe conta das principais actividades desenvolvidas no ano prestes a findar, e informa-o de que, depois da assistência ao concílio provincial de Évora, se dirigira para Lisboa, local de onde a missiva era datada. ${ }^{140}$ Ora, tendo em conta que o concílio eborense (a que já atrás nos referimos) teve a primeira sessão no $1^{\circ}$ de Maio de 1567 e a segunda e última a 26 de Julho do mesmo ano; que decorreram muitos meses antes de que o livro de Haddon chegasse às mãos de Osório; que o Contra Haddon tem a data de impressão de 7 de Outubro; que o estilo da obra em nada desmerece do das outras do Autor - não podemos deixar de admirar a rapidez com que esta obra foi escrita.

Esta obra teve nove edições em latim, sendo portuguesas a primeira e a última (de 2006). Conhecemos duas traduções: uma para inglês (de 1568, reproduzida fac-similarmente em 1976) e outra para português (de 2006).

\section{3. c) Defensio sui nominis}

Ocupando as colunas $1125-1138$ do $1^{\circ}$ tomo dos Opera Omnia encontra-se o texto latino do que cremos ser o derradeiro escrito de D. Jerónimo Osório. Trata-se de obra relativamente extensa e literariamente bem elaborada, comprovativa de que até ao último alento o Autor conservou em todo o seu primor os quilates do seu latim ciceroniano. Por outro lado, a própria circunstância de ter escolhido o latim, a língua universal de então, é bem significativa do valor que pretendeu atribuir a esta reivindicação do seu bom nome,

138 Humanismo e Controvérsia Religiosa, o. c., tomo III, p. 232.

139 Cf. D. Jerónimo Osório, Opera Omnia, o. c. tomo I, col 1150, ou pp. 49-51 da nossa edição das Cartas.

140 Cf. D. Jerónimo Osório, Opera Omnia, o. c., tomo I, col 1151, ou pp. 52-54 da cit. ed. das Cartas. 
acalcanhado por mentes mal intencionadas ou pela estolidez dos malédicos nos tempos conturbados que imediatamente antecederam e se seguiram à morte do último rei da dinastia de Avis.

Além do texto impresso editado pelo sobrinho, um caderno manuscrito de 28 páginas numeradas, conservado no Arquivo Geral de Simancas (Estado, legajo 416, no 315), contém a mesma obra apologética numa redacção anterior, do punho de Osório ou do seu secretário, com ligeiras variantes, de sintaxe e vocabulário, relativamente ao texto impresso, com a diferença, porém, de que o editor das Obras Completas julgou conveniente expungir as duas páginas finais do manuscrito, nas quais se alude à presença no Algarve dos três governadores do reino que então ainda se mantinham em funções e viriam a assinar o Decreto de Castro Marim a 17 de Julho de 1580: circunstância que nos permite datar a conclusão da redacção da Defensio entre o início do mês de Julho e aquela data. Como data limite a quo para o início da redacção deste escrito talvez possamos indicar 19 de Junho de 1580, dia em que uma multidão em Santarém proclamou a D. António como rei, facto ao qual parecem referir-se as seguintes palavras: Auxit autem hanc de nomine meo apud multos querellam Antonii impetus repentinus in Regnum, quod, ut hereditarium ius, armis occupare conatur. ("Ainda que, na verdade, o que acrescentou esta queixa que muitos têm contra mim, foi o repentino ataque desencadeado por D. António contra o Reino, do qual intenta apossar-se pela força das armas, como se fora herança que lhe coubesse por direito." $)^{141}$

Do texto latino integral desta obra a $1^{\text {a }}$ edição deverá sair em breve na Revista da Faculdade de Direito de Lisboa. Existe uma tradução portuguesa, publicada em $1996 .{ }^{142}$

\section{Epistolografia}

Do vasto espólio literário de D. Jerónimo Osório, as cartas constituem certamente a porção menos importante, quer pelo número relativamente reduzido das que chegaram até nós, quer pelo carácter não essencial que o Autor lhes imprimiu como veículo de expressão de ideias, ao invés do que acontece com certos escritores - como Séneca, para não ir mais longe. Isto não significa, porém, que da leitura delas, além de algumas achegas importantes de carácter histórico-biográfico, se não desprenda também a inteira figura do homem Osório, com aqueles vincados traços de carácter que lhe eram próprios, aquelas permanentes preocupações éticas que lhe dirigiam o engenho e aquele impávido e nobilíssimo desassombro com que admoestava e verberava fosse quem fosse, quando dava voz aos controversos ditames ou à indignação da sua consciência. Nelas se descobre também, quer o fidalgo português de fino trato, sensível e cortejador com os amigos, e capaz de um grãozinho de sal malédico, como também o homem de letras, atento

141 D. Jerónimo Osório, Opera Omnia, o. c., I, col. 1125.

142 Nas pp. 266-281 da nossa já citada edição dos Tratados da Nobreza Civil e Cristã. 
aos ecos da sua produção literária e incessantemente angustiado com a incompetência dos tipógrafos portugueses, inábeis para dar às suas criações intelectuais o aprimorado escrínio que ele anelava.

Como é evidente, sob esta rubrica não se incluem aquelas partes introdutórias de alguns livros do próprio Osório que, conquanto apareçam designadas como cartas, na realidade mais não são do que dedicatórias em que abreviadamente se expõem a intenção e a doutrina da obra. Estão neste caso, por exemplo, as epístolas que encabeçam o De uera sapientia e os In Isaiam paraphrasis libri quinque, dirigidas, respectivamente, ao papa Gregório XIII e ao cardeal D. Henrique. Tão-pouco, como é manifesto, caberia na concepção corrente de género epistolar uma obra com os propósitos e dimensões da Epistola ad Elisabetam. Por conseguinte, e cingindo-nos à definiçãoo tradicional, entendemos aqui (e na edição que delas fizemos) ${ }^{143}$ por cartas as peças literárias vivas - ou seja, de facto enviadas ou dirigidas a concretos destinatários - em que, ou bem está presente o conteúdo biográfico, ou bem o Autor exprime, de forma concisa e genérica, as suas opiniões sobre aspectos mais ou menos relacionados com a realidade sua contemporânea. ${ }^{144}$

A compilação, tradução e apuramento de versões que em tempos fizemos da correspondência activa do nosso Autor permite-nos traçar o seguinte quadro sintético:

a) datas limite para as espécies: Verão / Outono de 1541 e 20 de Junho de 1580; b) número de espécies: 52 que consideramos seguras e uma duvidosa; ${ }^{145}$ c) número de destinatários: 27, assim distribuídos por nacionalidades: 6 portugueses, 5 italianos, 5 ingleses, 4 espanhóis, 3 polacos, 1 natural do Franco Condado, 3 indeterminados; d) estatuto social dos principais destinatários: 3 reis de Portugal, ${ }^{146} 1$ de Espanha e 1 da Polónia; 2 papas; 3 altos dignitários da Igreja: 2 cardeais (1 polaco e outro inglês) e o

143 A nossa edição, já várias vezes citada, do epistolário osoriano, não apresenta (por inópia orçamental da entidade editora, como é da praxe entre nós) os textos latinos das espécies que traduzimos. Os originais, porém, da correspondência epistolar trocada entre Osório e Hósio tinham sido objecto da benemérita edição de um estudioso ao qual muito devem os estudos sobre o nosso Autor: Léon Bourdon, "Jerónimo Osório et Stanislas Hosius (1565-1578)", Boletim da Biblioteca da Universidade de Coimbra, 23, Coimbra, pp. 1-105.

144 Vejam-se, sobre o tema aqui tratado, de Sebastião Tavares de Pinho, os artigos: "Epistolografia e Humanismo em D. Jerónimo Osório" e "Jerónimo Osório e António Agustín: convívio e correspondência epistolar", ambos incluídos no volume Humanismo em Portugal. Estudos II, obra e tomo citados, pp. 69-98 e 133-155, respectivamente.

145 A já atrás referida "Carta ao Padre Luís Gonçalves da Câmara", que, devo confessar, já senti mais relutância em atribuir ao Autor a quem tenho dedicado tantas horas da minha vida, razão pela qual hoje não me parece que seja nele comportamento contraditório, por um lado, verberar violentamente e até humanamente antipatizar com aquela grada figura da Companhia de Jesus, e, por outro, sentir ao mesmo tempo grande admiração por esta corporação religiosa e inclusivamente nutrir imensa simpatia e amizade pessoal por muitos dos seus membros.

146 Conta-se como portuguesa, que o era pelo casamento, a rainha D. ${ }^{a}$ Catarina. Embora não figure na estatística que se lê no corpo do texto, convém não esquecer que existe uma importante carta de Osório dirigida aos "Governadores do Reino", os quais eram então, legalmente, os detentores da soberania sobre os domínios pertencentes à coroa portuguesa. 
arcebispo de Tarragona; escritores / intelectuais: 9; e) idiomas utilizados: latim ( 42 cartas); português (8 cartas); espanhol (2 cartas).

\section{Obras de carácter espiritual/teológico}

Ironicamente, a porção do seu legado que o nosso Autor mais parecia acarinhar, vista a forma como foi retardando a sua edição, é hoje a que o manteria num limbo muito mais sombrio do que aquele que o envolve, caso a sua fama pretérita se tivesse cifrado exclusivamente nas áreas que, de modo genérico, designaremos por literatura religiosa. Se, por um lado, os novos rumos que o pensamento europeu singrou a partir do século XVII justificam em parte o progressivo olvido ou desinteresse pela literatura de espiritualidade, por outro lado a própria evolução dos métodos de crítica textual que se foi operando no domínio dos estudos teológicos acabou por entregar à voracidade das traças as obras de D. Jerónimo Osório que revestiam carácter eminentemente exegético. ${ }^{147}$

Ora, ao percorrermos o índice geral dos Opera Omnia (Roma, 1592), verificamos que ao espólio impresso, até então conhecido, de D. Jerónimo Osório, juntavam-se agora os seguintes escritos inéditos: Defensio sui nominis, Epistolae, In Epistolam B. Pauli ad Romanos Lib IIII, Paraphrasis in Job, Paraphrasis in Psalmos, Commentaria in Parabolas Salomonis, Paraphrasis in Sapientiam Salomonis, Commentarius in Oseam Prophetam, Commentarius in Zachariam, Oratio in D. Aecatherinam, In Euangelium Ioannis Orat. XXI. Além disso, já por outras vias cronologicamente anteriores poderíamos suspeitar da existência de um acervo de escritos inéditos, na posse do Autor e prontos para a edição desde uma época mais ou menos remota. Assim, por um lado, na sua epistolografia faz pelo menos quatro vezes referência a numerosos partos intelectuais que conservava inéditos em seu poder à espera de ensejo favorável para a publicação:

A me (...) multa scripta sunt, quibus nescio quando in lucem prodire licebit. ("Tenho escrito muita coisa, que ignoro quando me será possível publicar."); ${ }^{148}$ Multa habeo domi compressa quae confido nonnullam utilitatem bonis allatura. ("Tenho guardados

147 Constitui excepção a este juízo M. Augusto Rodrigues, autor dos dois seguintes artigos: "A obra exegética de D. Jerónimo Osório no contexto do Humanismo, da Reforma e da ContraReforma", Theologica, 16 (3-4), Braga, 1981, pp. 405-445, e "O livro dos Provérbios na interpretação exegética de D. Jerónimo Osório. Aspectos filológicos”, Humanitas, 43-44, Coimbra, 1991-2, pp. 343-354. - Sinto-me, porém, obrigado a dizer que na primeira parte do primeiro destes estudos o autor, além de formular perfunctoriamente opiniões com as quais não posso estar de acordo (como a que consiste em ver em Osório um irenista erasmiano), faz afirmações que estão em aberta contradição com a fria realidade dos factos, como é o caso desta: "A de regis institutione et disciplina é uma paráfrase ao livro de Job, nela procurando apresentar certas perspectivas consoladoras para os males da vida e incutir as ideias de resignação e de paciência cristãs.”, o. c., p. 406.

148 Carta a Estanislau Hósio, Lagos, 27 de Julho de 1568. Texto latino apud Léon Bourdon, "Jerónimo Osório et Stanislas Hosius (1565-1578)", artigo citado, pp. 70-71. Tradução integral portuguesa desta missiva in D. Jerónimo Osório, Cartas, o. c., pp. 59-61. 
comigo muitos escritos, que creio que não serão de pequena utilidade para os bons."); ${ }^{149}$ Attamen aliquid excogitabo ne, si me mors oppresserit, ea quae mandavi literis et domi compressa contineo, immanitate mortis ipsius obruantur. ("Excogitarei, todavia, algum meio que atalhe ao risco de, no caso de a morte me surpreender, serem enterrados, com a truculência da própria morte, estes pensamentos a que dei forma escrita e que guardo comigo."); ${ }^{150}$ Multa quidem sunt apud me, quae cupio similiter edere. Sed multa sunt impedimento quominus id, quod jamdudum conor, efficiam. ("É certo que possuo em meu poder muitos outros escritos que igualmente desejo publicar. Mas existem inúmeros empeços que me inibem de pôr por obra aquilo que intento de há muito.") ${ }^{151}$

A existência desta colecção de inéditos é, por outro lado, confirmada de modo assaz pormenorizado pela carta-prefácio, datada do $1^{\circ}$ de Agosto de 1578, com que Arnoldus Mylius introduz a $1^{\text {a }}$ edição de Colónia do osoriano In Isaiam Paraphrasis. Com efeito, dirigindo-se a Jean Matal, amigo e condiscípulo do nosso compatriota, o prologuista germânico roga-lhe: Sed age; obsecro; quas etiam in Solomonis sapientiam, Iobum, et Psalmos, Paraphrases conscripsit: eas ille tuo hortatu; tum sua in Oseam, Zachariamque, et ad Romanos Epistolam, Commentaria; vel ad te mittat, vel edere saltem ne differat. ("Mas suplico-te que também te empenhes em exortá-lo a remeter-te, ou, pelo menos, a não protelar a edição das paráfrases da Sabedoria de Salomão, do Livro de Job e dos salmos, tanto como dos seus comentários a Oseias, Zacarias e à Epístola aos Romanos." ${ }^{152}$ Vemos deste modo que, dois anos antes da morte de D. Jerónimo Osório, os meios livreiros da Europa culta estavam bem inteirados de que o Autor português tinha prontos para o prelo seis, pelo menos, de entre os oito livros que viriam a integrar a secção de inéditos da edição romana organizada pelo sobrinho, convindo, mesmo assim, ter presente que as In Euangelium Ioannis orationes XXI ficaram incompletas pelas razões que o cónego eborense alega na introdução que lhes pôs.

Que razões terão induzido um Autor de tão persistente êxito editorial a manter na gaveta uma porção significativa da sua produção intelectual? Se atentarmos nas características temáticas comuns à produção especificamente sua que lhe deu em vida a fama cosmopolita de Cícero lusitano, verificamos (como já se disse) que se inserem numa área cultural que vai da ética, em todas as dimensões do termo, à polémica/apologética religiosas, passando por duas incursões no domínio estritamente teológico. Ora, estes dois livros (De iustitia e In Isaiam Paraphrasis) foram precisamente os únicos que nunca tiveram qualquer edição portuguesa em vida do Autor, o que pode não ser mero acaso e

149 Carta ao mesmo destinatário, V. Nova de Portimão, 20 de Abril de 1570. Texto latino, Léon Bourdon, o. c., p. 73; tradução integral da carta, Cartas, o. c., pp. 61-63.

150 Carta ao mesmo, Silves, 30 de Janeiro de 1571. Texto latino, Léon Bourdon, o. c., p. 78; tradução portuguesa de toda a carta, Cartas, o. c., pp. 68-69.

151 Carta a Estanislau Reszka, V. Nova de Portimão, Julho de 1573. Texto latino, Léon Bourdon, o. c., p. 101; tradução portuguesa de toda a carta, Cartas, o. c., pp. 85-86.

152 Página 4, não numerada, da carta-prefácio anteposta a: Jerónimo Osório, In Isaiam Paraphrasis, Colónia, herdeiros de Arnaldo Birckmann, 1578 (no colofão apresenta estranhamente a data MDLXXVII). 
pôr-nos na pista da resposta à pergunta formulada, a qual, segundo pensamos, e gorando talvez a expectativa dos que estavam à espera de ver aqui a marca sinistra do Santo Ofício, nos parece estribar num motivo mais comezinho e pouco abonatório de um outro ofício português na segunda metade do século XVI: a incompetência ou inexistência dos tipógrafos. Com efeito, são inúmeros os queixumes que o bispo Osório deixou esparzidos ao longo da sua correspondência, e até nas próprias obras impressas, contra a inépcia dos impressores nacionais. Rodeado por estas limitações, portanto, parece-nos compreensível que D. Jerónimo Osório não se arriscasse a recorrer aos editores portugueses em obras nas quais, mais do que em quaisquer outras, o seu prestígio intelectual estava em jogo e para as quais se requeriam tipógrafos da máxima competência, atendendo ao delicado das matérias a tratar e à profusão de recursos técnicos que se faziam mister (por exemplo, caracteres gregos e hebraicos).

Lancemos agora um breve olhar sobre a porção da obra de D. Jerónimo Osório que a passagem do tempo tornou mais irremediavelmente distante do leitor moderno.

\subsection{Teodiceia: De iustitia}

Esta obra, talvez a de mais ambicioso escopo de todas as de Osório, viu pela primeira vez a luz da publicidade em Veneza, no ano de $1564,{ }^{153}$ apresentando uma folha de rosto em que o leitor era honestamente industriado acerca das matérias que o Autor pretendia versar: HIERONYMI OSORII DE IVSTITIA LIBRI DECEM. Hic explicantur omnia, quae de Fide et Actionibus, Meritis et Gratia, libera hominis uoluntate, et praesensione atque praescriptione Diuina hactenus disceptata sunt: Et, falsis opinionibus euulsis, omnes ad pie credendum, et bene uiuendum, instituuntur. ("Dez livros sobre a justiça de Jerónimo Osório. Aqui se expõem todas as matérias que até ao momento se disputaram acerca da fé e acções, méritos e graça, livre vontade do homem e presciência e predestinação de Deus: e, depois de extirpadas as falsas doutrinas, todos são ensinados a crerem com piedade e a bem viverem") Seguiam-se seis páginas, não numeradas, em que o italiano Agostino Valier, depois de encarecer o grande serviço que Jerónimo Osório prestava à Cristandade ao escrever uma obra com as características e propósitos desta, nos informava de que, graças

153 Os exemplares conhecidos da edição princeps, conquanto sejam idênticos do ponto de vista da impressão gráfica, têm a particularidade de poderem repartir-se por dois grupos diferenciados pela sigla do editor e pelo pé de imprensa: a) o dos que apresentam, como sigla do editor, uma lança, empunhada por duas mãos surdindo de nuvens, na qual se enroscam uma cobra e uma trepadeira, por baixo da qual se lê: Venetiis, apud Ioan. Andream Valvassorem, 1564; b) o dos que apresentam como marca tipográfica uma estrela caudata, com sete pequenas estrelas entre as pontas e o moto Inter omnes, lendo-se na parte inferior: Venetiis, ex officina Iordani Zileti, 1564. - Todos, porém, têm de comum o consignarem, em rodapé, no fl. 156 $\mathrm{v}^{\circ}$ : Venetiis Ioann. Gryphius excudebat 1564. 
à mediação de Diogo de Paiva de Andrade - então assistindo ao Concílio de Trento ${ }^{154}$ -, chegara às mãos do mesmo Valier: decem iam annos ab Osorio (...) scriptum. ("dez anos depois de Osório a ter escrito.” ${ }^{155}$ E, de facto, a conjugação de outros elementos acaba por firmar em nós a certeza de que o período de composição desta vasta obra se situa em data mais ou menos recuada, relativamente ao ano da publicação, e deverá ter como termos ad quem o ano de 1557 e a quo o de 1549, data da publicação do diálogo De gloria.

Com efeito, de acordo com a informação que Osório Júnior nos transmite na p. 4 da Vita, o tio, agradavelmente impressionado pela figura do cardeal inglês Reginald Pole, teve a intenção de provar o seu afecto dedicando-lhe o Tratado da Justiça Celeste - projecto que cumpriria, caso a morte do purpurado não se tivesse antecipado à edição do livro. ${ }^{156}$ Por outro lado, também o moveria a esta deferência a notícia do bom acolhimento dado por Pole às obras De nobilitate e De gloria. ${ }^{157}$ Ora, conquanto não figurando na primeira edição do De iustitia, existe uma epístola dedicatória deste livro a Pole, datada de 7 de Julho de 1557, e que surge, a partir da segunda edição (Colónia, 1572), nas páginas iniciais de todas as restantes. Aí o nosso Autor afirma que: decem hos libros, quos tibi mitto (...). Eos enim iampridem tibi destinaui. ("estes dez livros que vos remeto (...) É que há muito tempo tinha a intenção de vo-los dedicar.") ${ }^{158}$ No mesmo ano, mas datada de 20 de Janeiro, endereçou Osório uma carta a Alvísio Priuli, pertencente ao círculo íntimo de Pole, na qual diz, referindo-se a esta obra: proximis diebus opus absolui. ("concluí-a por estes dias.") ${ }^{159}$ Acresce que dois outros testemunhos comprovam que, pelo menos desde 1561, a obra já se encontrava em condições de ser impressa. Com efeito, em carta dirigida por Osório ao humanista inglês Roger Ascham, escrita de Lisboa a 13 de Dezembro de 1561, lemos: Spero ut (...) breui in lucem prodeant. ("Espero que em breve saiam a

154 O Concílio, como se sabe, cuja terceira e derradeira fase se iniciara a 18 de Janeiro de 1568, teve a sua sessão final em Dezembro de 1563. A todo ele esteve presente o notável teólogo e pregador português citado no texto, grande amigo de Osório, que lhe prologou a obra póstuma Defensio tridentinae fidei catbolicae, publicada em 1578.

155 Página 4, não numerada.

156 Reginald Pole, primo de Henrique VIII que sanhudamente o perseguiu, vingando-se na família mais próxima da desobediência deste leal católico-romano, faleceu em Lambeth a 17 de Novembro de 1558, poucas horas depois da morte da sua rainha, Maria Tudor, a quem acompanhara na breve restauração católica que esta empreendeu. Sobre esta notável personagem, veja-se a recente e bem documentada biografia de Tomas F. Mayer, Reginald Pole. Prince and Prophet, Cambridge, University Press, 2000.

157 Mais pormenores, sobre este e outros aspectos ligados com esta obra, podem ver-se na nossa Introdução a D. Jerónimo Osório, Tratado da Justiça. Tradução, introdução e anotações de A. Guimarães Pinto, Lisboa, Imprensa Nacional - Casa da Moeda, 1999.

158 D. Jerónimo Osório, De iustitia, Colónia, herdeiros de Arnaldo Birckmann, 1572, p. 3 (não numerada). A tradução desta epístola introdutória encontra-se nas pp. 411-413 da edição citada na nota anterior ou nas pp. 29-31 das Cartas.

159 Jerónimo Osório, Opera Omnia, o. c., I, col. 1156. Tradução integral nas pp. 414-415 da versão portuguesa ou nas pp. 26-29 das Cartas. 
lume.") ${ }^{160}$ Por outra parte, a folha de rosto da edição de Colónia de 1572 informa que o texto procedia ex auctoris codice, misso Coloniam ab hinc plus minus nouem annis. ("do manuscrito do Autor, remetido para Colónia há cerca de nove anos.")

Surgida num contexto em que já se tornara irreparável a ruptura religiosa que dividira os cristãos da Europa ocidental, esta obra de Osório persegue um duplo fito: doutrinal, por um lado, e polémico/apologético, pelo outro. Se, no primeiro aspecto, o nosso Autor não contava ainda, quando escreveu este livro, com o rígido corpus teológico que irá condensar-se nas decisões tridentinas, publicadas pela primeira vez em 1564 sob o título de Canones et decreta e que passarão a definir a ortodoxia católica nos seguintes quatrocentos anos, no segundo aspecto, a certeza da irredutibilidade da cisão religiosa oferece ao Autor, não só um conjunto de doutrinas e práticas já suficientemente definidas para com elas se criarem novas igrejas, mas também uma liberdade de linguagem que decorre do sentimento de que a polémica já não se trava entre correligionários desavindos devido a divergências sobre questões abstractas ou académicas de somenos, mas sim entre verdadeiros inimigos, apartados por concepções diferentes acerca de princípios que reputam essenciais para os respectivos credos. Tendo isto em mente, compreenderemos, em primeiro lugar, o tom por vezes passional (que adquire a forma do insulto directo quando se trata de Lutero) que o nosso Autor imprime a uma obra de amplo fôlego em que se procuram definir questões tão remontadas e discutidas como: a fé, a salvação dos não cristãos, a justiça divina, a graça, a predestinação, o livre arbítrio da vontade humana, o pecado original... ${ }^{161}$ Entenderemos também, em segundo lugar, o curioso facto de que, por se consentir na época da composição do De iustitia alguma latitude na interpretação de certos pontos doutrinais - como é o caso da matéria relativa ao pecado original -, e por haver optado por uma das soluções então admitidas pela Igreja, Jerónimo Osório viu, após a definição unívoca apresentada nos Canones et decreta tridentinos, uma parte significativa do livro $7^{\circ}$ do seu De iustitia tornar-se de um momento para o outro alvo da censura inquisitorial. ${ }^{162}$

Este livro, além da de Veneza, teve mais seis edições latinas, sendo a última impressa em Portugal (1793, Imprensa da Universidade de Coimbra, em dois tomos). A edição de Roma dos Opera Omnia, no tomo II, apresenta, nas coll. 355-359, um texto divergente em relação ao das outras edições. ${ }^{163}$ Existe uma tradução para português, publicada em 1999.

160 Jerónimo Osório, Opera Omnia, o. c., I, col. 1145. Tradução integral apud Cartas, pp. 51-52.

161 Damos um resumo da obra nas pp. 31-49 da nossa já citada edição.

162 Desenvolvemos este tema nas pp. 51-69 da Introdução à nossa tradução do De iustitia.

163 Dele damos a tradução nas pp. 447-453 da nossa edição da obra. 


\subsection{Exegese bíblica}

\subsubsection{Paráfrases}

Na dedicatória da Paráfrase a Isaías, D. Jerónimo Osório apresenta, de forma sintética, uma definição deste género literário, na sua aplicação a textos bíblicos, ${ }^{164}$ a qual não se afasta da que passamos a transcrever de um dicionário da especialidade: La paraphrase biblique est une exposition du sens de l' Écriture dans laquelle on conserve la forme même du discours de l'auteur, en y introduisant ce qui peut servir à l'expliquer. ${ }^{165}$ Modo de aproximação ao texto sagrado que permitia as expansões da afectividade religiosa, a paráfrase foi abundantemente cultivada pelos autores espirituais do século XVI, entre os quais Osório enfileira com nada menos que quatro obras desta espécie.

\subsection{1. a) Paraphrasis in Psalmos}

Esta obra, pela primeira e única vez editada no tomo terceiro dos Opera Omnia, coll. 133-528, precedida de uma dedicatória do sobrinho-editor ao cardeal-arquiduque Alberto, regente de Portugal em nome do tio D. Filipe, de entre as produções que saíram da pluma latina de D. Jerónimo Osório, só é ultrapassada em extensão pelo De rebus Emmanuelis gestis. Há alguns anos atrás seleccionámos e traduzimos vinte e dois salmos parafraseados pelo nosso Autor, os quais fazem parte de uma antologia de Escritos Espirituais em que reunimos textos provenientes de algumas das obras de que nos ocupamos nas secções 5. 2. e 6. desta Introdução. ${ }^{166}$ Como curiosidade, lembre-se que um contemporâneo de Osório, o humanista escocês Jorge Buchanan, é autor da paráfrase latina aos salmos de maior prestígio no século XVI: Psalmorum Dauidis Paraphrasis Poetica a G. B. conscripta, Antuérpia, Christophorus Plantinus, 1572, notável para nós, não só pelo primor dos seus quilates literários, mas também por ter sido parcialmente escrita, entre Agosto de 1551 e Fevereiro de 1552, durante a reclusão do antigo mestre do Colégio das Artes num mosteiro junto de Lisboa, onde lhe coube cumprir a penitência a que o condenou a sentença inquisitorial de 29 de Julho de 1551.167

164 Cum videlicet eadem sententia verbis alijs exprimitur. ["a saber, quando se exprime o mesmo sentido através de outras palavras.”] Opera Omnia, tomo IV, col. 4.

165 Dictionnaire Encyclopédique de la Théologie Catholique, Paris, Gaumes Frères et J. Duprey, 1863, t. 17, pp. 208-209.

166 Este livro, já entregue ao editor há vários anos, deverá sair em breve (Deo uolente) dos prelos da Imprensa Nacional - Casa da Moeda.

167 Veja-se: Guilherme J. C. Henriques, "Buchanan na Inquisição”, Arquivo Histórico Português, 4, n $n^{\circ}$, Lisboa, Julho de 1906, pp. 241-282. - O próprio Buchanan, na sua autobiografia, escrita na $3^{\text {a }}$ pessoa, refere-se do modo seguinte ao episódio referido no texto: Cum quaestores prope sesquiannum et se et illum fatigassent, tandem ne frustra bominem non ignotum vexasse crederentur, eum in monasterium ad aliquot menses recludunt, ut exactius erudiretur a monachis, 


\subsection{1. b) In Isaiam Paraphrasis libri $V$}

Esta obra foi editada pela primeira vez pelo editor bolonhês Alexandre Benatius no ano de 1577, durante a segunda estadia do Autor em Itália. Antes da edição romana, na qual ocupa as colunas 1-292 do tomo quarto, teve duas edições em Colónia, da responsabilidade dos herdeiros de Arnaldo Birckmann: a primeira, conquanto apresente para a carta-prefácio a data do $1^{\circ}$ de Agosto de 1578, consigna no colofão, como já atrás notámos, o ano de 1577; a segunda veio a lume já após a morte do Autor, pois inscreve na página de rosto o ano de 1584. Sabemos que o texto das edições alemãs, em nada divergente do da princeps, foi directamente enviado pelo próprio Osório para o amigo Jean Matal, seu agente literário junto dos editores de Colónia: Primum enim, quod nobilissimus auctor eam ad te, amicissimus tibi, Roma misit in Germaniam (...). ("É que, primeiramente, o distintíssimo Autor, teu grande amigo, enviou-te a Paráfrase de Roma para a Alemanha (...)." $)^{168}$

Na p. 4 da Vita, Jerónimo Osório Júnior informa-nos, consoante já vimos, que o tio, após o regresso (1542) dos seus estudos em Bolonha, Conimbricam se contulit (...) vbi Isaiam, et Diui Pauli epistolam ad Romanos scriptam, singulari cum laude explicuit. ("foi para Coimbra (...) onde, com extraordinário aplauso, se entregou à exposição do texto de Isaías e da Epístola aos Romanos, de São Paulo.") Informa-nos também, na p. 14, a propósito da viagem à Itália de 1576-1577, que D. Jerónimo Osório: Bononiam venit (...) vbi Paraphrasim in Isaiam in lucem edidit; et Henrico Cardinali, Emmanuelis regis filio, eam dicauit, cui multo antea fuerat pollicitus. ("Veio a Bolonha (...) e aqui publicou uma Paráfrase a Isaías, que dedicou ao cardeal D. Henrique, filho do rei D. Manuel, conforme promessa que lhe tinha feito muito tempo atrás.") O próprio Osório, em carta de 1572, dirigida ao mesmo cardeal D. Henrique, deixa cair de passagem, a propósito do vedor da Fazenda D. Martinho Pereira, esta preciosa informação: "Escreveu-me os dias passados ũa carta, breve e sentenciosa, celebrando a vitória de que Deus nos fez mercê, e na fim dela dizia: Isaías, Isaías, Isaías - repetindo três vezes este nome. Querendo dizer o que muitas vezes tinha dito, que com toda a pressa mandasse imprimir o que tinha escrito sobre Isaías, porque desejava muito de o ver, pela devação que tinha ao profeta."169 Em carta

hominibus quidem alioqui nec inhumanis, nec malis, sed omnis religionis ignaris. Hoc maxime tempore Psalmorum Davidicorum complures vario carminum genere in numeros redegit. ["Depois de os magistrados se terem fatigado a atormentá-lo durante cerca de ano e meio, para que não se pensasse que tinham perseguido sem motivo um homem não desconhecido, encerramno num mosteiro por alguns meses, para ser mais perfeitamente catequizado pelos frades: criaturas, de resto, nem cruéis nem ruins, mas totalmente ignorantes quanto a religião. Ocupou a maior parte do tempo a transpor para vários metros poéticos muitos dos salmos de David."] Jorge Buchanan, Georgii Buchanani Scoti Poemata quae extant, Amsterdão, apud Henricum Wetstenium, 1687, p. 4 v (não numerada).

168 Carta-prefácio de Arnoldus Mylius a Jean Matal, p. 1, não numerada.

169 Carta datada de Silves, 20 de Janeiro de 1572. Pode ver-se na íntegra na nossa edição das Cartas, pp. 74-77. 
de Diogo de Paiva de Andrade a Benito Arias Montano, datada de 15 de Abril de 1575, e de que adiante daremos mais circunstanciada relação, colhemos também informações sobre esta obra osoriana.

Na já referida antologia que fizemos de Escritos Espirituais do nosso Autor, procurámos dar uma ideia desta In Isaiam Paraphrasis, através das traduções da carta-proémio ao cardeal D. Henrique, do argumento que antecede cada um dos seus cinco livros e dos desenvolvimentos parafrásticos correspondentes aos três últimos capítulos do profeta.

\subsection{1. c) e d) Paraphrasis in Iob e In Sapientiam Salomonis Paraphrasis}

Destas obras, de que a $1^{a}$ e única edição latina é a que se encontra, respectivamente, nas coll. 9-129 e 953-1006 do tomo III dos Opera Omnia, nos ocuparemos com mais detença no final deste nosso texto introdutório, que pretende ser uma apresentação da versão que deles fizemos para português.

\subsubsection{Comentários bíblicos}

São quatro os livros de exegese bíblica de autoria osoriana que, pelas suas características formais, o sobrinho do nosso Autor integra no sub-género dos "comentários". Trata-se de exposições didácticas, que serviram provavelmente de suporte às matérias que o nosso Autor expendeu durante os anos de experiência docente na academia coimbrã: período escassamente documentado a que Osório Júnior se referiu na Vita e a que já atrás fizemos referência. O esquema a que ordinariamente se cinge na exposição do texto bíblico pode ser exemplificado pela transcrição e tradução que seguidamente fazemos do comentário osoriano a Zacarias 5. 10-11.:

"10. Et dixi ad angelum qui loquebatur in me: Quo istae deferunt amphoram? 11. Et dixit ad me: Vt aedificetur ei domus in terram Senaar, et stabiliatur, et ponatur ibi super basem suam."

Terra Senaar, est regio, pietati contraria, et inimica. Ibi enim Babel fundata fuit, quae continet scelerum, et flagitiorum, omnium colluuionem, vitaeque perturbationem, et religionis interitum. Id enim molitur, in id neruos omnes intendit, in eo summo studio pugnat, vt fidem exterminet, et perniciem Reipublicae caelesti machinetur. Est igitur Senaar, impiorum coetus, et multitudo, sceleris conspiratione sociata, in qua mundi Princeps (sic enim a Ioanne Diabolus appellatur) Regnum possidet, vt inde Christi Ecclesiam, irritis conatibus, oppugnet. In hac tandem regione volucre volumen consistet. Ibi Stygiae disciplinae studium vigebit; ibi impietas sedem collocabit; ibi Antechristo domus aedificabitur, vt impietas, ad summum perducta, summum supplicium subeat, iudicioque sanctissimi iudicis euertatur. Hic est status eorum, qui lucem fugiunt, vt tenebras amplexentur; et sponte sua oculos claudunt, ne veritatem adspiciant; Diuinisque monitis furorem insitae libidinis anteponunt; et Christo, auctori nostrae salutis, aduersantur, vt 
Antechristi tyrannidem subeant, cum quo tandem, nisi resipuerint, sempiterno supplicio mactabuntur.

("10. E eu disse ao anjo que falava em mim: Para onde levam elas a talha? 11. E o anjo me respondeu: A fim de que lhe seja edificada uma casa na terra de Chinear, e fique ali de assento, e posta sobre a sua base."

A "terra de Chinear" é uma região hostil e inimiga da religiosidade. É que foi aí que se edificou Babel, que em si encerra a mescla impura de todos os crimes e infâmias, a vida desordenada e a ruína da religião. Pois empenha-se, aplica todos os seus esforços e com o máximo desvelo se esforça por destruir a fé e ocasionar a perdição da comunidade celestial. Por conseguinte, Chinear significa a associação e turba dos ímpios, unida na conjura do crime, na qual o Príncipe do mundo (pois é deste modo que São João designa o Diabo) se apodera do Reino, para a partir daí, com vãs tentativas, atacar a Igreja de Cristo. Nesta região acabará por poisar o livro voador. Aí florescerá o amor pela doutrina infernal; aí a impiedade assentará arraiais; aí edificar-se-á casa para o Anticristo, para que a impiedade, levada ao máximo extremo, padeça o derradeiro suplício e seja destruída pelo juízo do mais santo dos juízes. É esta a condição dos que fogem da luz para abraçarem as trevas e, por livre e espontânea vontade, fecham os olhos para não contemplarem a verdade, e antepõem o desvario da sensualidade instintiva aos conselhos divinos, e se opõem a Cristo, autor da nossa salvação, para se sujeitarem à tirania do Anticristo, com o qual hão-de ser ao cabo punidos com eterno suplício, se não se arrependerem.) ${ }^{170}$

\subsection{2. a) In Epistolam B. Pauli ad Romanos Libri IV}

Estes quatro livros de comentários à Epístola aos Romanos, de São Paulo, tiveram a sua $1^{\text {a }}$ e única edição nas coll. 625-874 do tomo II dos Opera Omnia. No início deste volume, no $3^{\circ}$ fólio, não numerado, podemos ler, com data de 13 de Setembro de 1592, uma breve dedicatória desta obra ao cardeal Marco António Colonna, da autoria de Jerónimo Osório Júnior. É provável que a singularidade de colocar a peça liminar a tão grande distância da obra dedicada tenha a ver com algum percalço, que ignoramos, no processo editorial.

Como já anteriormente vimos, este livro, segundo informação do editor alemão Arnoldus Mylius, encontrava-se pronto para a edição pelo menos dois anos antes da morte do nosso Autor, e é provável que tenha como base o texto das aulas que em Coimbra, conforme ao que se lê na Vita, Osório leu sobre esta Epístola paulina pouco depois do seu regresso de Bolonha.

170 D. Jerónimo Osório, Opera Omnia, o. c., tomo IV, col. 433. 


\subsection{2. b) e c) Commentarius in Oseam Prophetam e Commentarius in Zachariam}

A $1^{a}$ e única edição destes dois livros de "comentários" a estes prophetae minores ocupam as colunas 293-392 e 393-508, respectivamente, do tomo IV dos Opera Omnia. Jerónimo Osório Júnior decidiu dedicar ambas as obras ao cardeal Pedro Décio, pelos motivos que desenvolve num texto, datado também, como o da dedicatória há pouco referida, de 13 de Setembro de 1592, e que apresenta igualmente aqui a particularidade de se encontrar no fólio, não numerado, imediatamente a seguir à página de rosto. Já atrás vimos também que, no $1^{\circ}$ de agosto de 1578 , o editor da $1^{a}$ edição coloniense da In Isaiam Paraphrasis estava inteirado de que as duas obras de que agora tratamos se encontravam prontas para a impressão.

\subsection{2. d) Commentaria in Parabolas Salomonis}

Esta longa obra ocupa as coll. 665-950 do tomo III dos Opera Omnia de D. Jerónimo Osório. Encontra-se antecedida por uma elegante carta-dedicatória, datada de 13 de Abril de 1592 e endereçada pelo sobrinho do Autor ao cardeal Gabriel Paleotti, na qual se faz uma eloquente exaltação da cidade de Bolonha, ingeniorum altrix, et artium maximarum parens, ("aleitadora das inteligências e progenitora das artes mais elevadas") onde D. Jerónimo Osório illa dicendi ornamenta, et maximarum rerum scientiam hausit, qua instructus, multis in locis hostes religionis scriptis confixit, et Ecclesiam Christi ualde uehementer illustrauit. ("bebeu aquelas graças de expressão e ciência das coisas mais importantes, com as quais aparelhado e ataviado trespassou em muitos passos nos escritos os inimigos da religião e assaz vivamente alumiou a Igreja.") No entanto, continua Osório Júnior, se a Cristandade deve atribuir a Bolonha a ventura de possuirmos um Osório, Bolonha, por seu turno, deve agradecer ao cardeal Paleotti a dita de as obras do escritor lusitano deixarem as trevas em que estavam imersas, vt enim ea in Vrbem e Lusitania adducerem, et in lucem emitterem, perfecisti.("pois fostes vós que fizestes que eu as trouxesse de Portugal para Roma e as publicasse.") $)^{171}$

Desta obra publicou-se nos Países Baixos, ainda no século XVI, uma $2^{\text {a }}$ edição, in octavo, de 859 páginas e com a seguinte página de rosto: Hieronymi Osorii Lusitani, Episcopi Algarbiensis in Parabolas Salomonis Commentarius, denuo recognitus, et ab innumeris mendis repurgatus, Antuérpia, apud Martinum Nutium, 1596.

\subsection{Parenética}

Bispo da diocese algarvia por um dilatado período de dezasseis anos, D. Jerónimo Osório deixou fama de prelado exemplar, não descurando nenhuma daquelas facetas

171 Os três passos citados procedem do fol. 660 do tomo e obra citados no corpo do texto. 
em que os teorizadores mais conspícuos do "bispo ideal" pós-tridentino cifravam o perfeito desempenho de tão importante múnus eclesiástico. Na Vita o sobrinho traça o pormenorizado retrato de Osório na sua actuação multíplice de bispo exemplar, preocupado por igual com o bem-estar espiritual e físico dos fiéis, e o próprio prelado, na sua correspondência, se refere ao desvelo com que se aplica às suas funções:

In pontifice munere perfungendo non valde negligenter me gero. Partim crebris concionibus homines ad studium pietatis alliciendo, partim fluxos mores severe coercendo, id Christi benignitate consequutus sum ut conversio multorum insignis fieret. ["No desempenho do meu cargo prelatício, tenho-me portado de modo nada remisso. Em parte atraindo, com amiudadas prédicas, os homens ao zelo da piedade, em parte reprimindo severamente os costumes relaxados, logrei, pela misericórdia de Cristo, levar a bom termo a notável conversão de não poucos."] $]^{172}$

Ora, como é sabido e também se corrobora com as palavras acabadas de citar, a pregação foi um dos deveres episcopais que as novas directrizes tridentinas inculcaram com maior insistência. ${ }^{173}$ Que o nosso Autor não se furtou a este contacto mais directo com as suas ovelhas é o que claramente diz o seu biógrafo, ao escrever:

Et ipse non solum sacris semper praesens aderat, sed ad populum orationem habebat, qua illum ad pietatis studium hortabatur: cuius muneris officio singulari cum voluptate fungebatur. ("E ele, não apenas assistia sempre às cerimónias religiosas, mas também fazia prédicas ao povo, com as quais o exortava ao zelo da religião: e não era pequeno o prazer que sentia com o desempenho desta actividade.")

A verdade, porém, é que D. Jerónimo Osório não deixou fama de pregador, ao contrário do seu íntimo amigo Diogo de Paiva de Andrade ou do seu colega no episcopado D. António Pinheiro, e supomos que uma deselegante indiscrição do seu opositor Walter Haddon nos dá a razão desta falha não esperada em quem parecia reunir excepcionais condições para brilhar no púlpito. De facto, no decurso da polémica, já aqui referida, que opôs D. Jerónimo Osório ao defensor oficioso da rainha Isabel de Inglaterra, este replica do modo seguinte aos reparos que o bispo lusitano irrogara ao seu latim enleado: Ego, Hieronyme, magno Dei beneficio, plane loquor et expedite: tuum est os titubans et haesitans, si uerum renuntiant qui tecum sunt congressi. ("Eu, Jerónimo, por grande benefício de

172 Carta de 20 de Abril de 1570, já citada.

173 Como índices desta renovada preocupação pelas funções concionatórias inerentes ao episcopado, vejam-se: de frei Luís de Granada, Concio de officio et moribus episcoporum, Lisboa, Francisco Correia, 1565, e, de Diogo de Teive, Liber tertius de perfecto episcopo, $3^{\mathrm{a}}$ parte do livro Epodon siue Iambicorum carminum Libri tres, Lisboa, Francisco Correia, 1565. $\mathrm{Na}$ p. 9 do retrato teiveano do bispo ideal pode ler-se: propria virtus praesulis / Est edocere vera Christi dogmata. / Praecepta sancta infundere animis omnium, / Hoc munus illi incumbit, haec prouincia / Deducta caelo, quam Christus prius subijt / Subeunda et illi. ["A virtude própria do prelado é ensinar a verdadeira doutrina de Cristo. Fazer penetrar os santos preceitos nas almas de todos, esta é a função que lhe cabe, este o cargo, procedente do Céu, que Cristo desempenhou primeiro e que ele deve desempenhar."] 
Deus, exprimo-me clara e expeditamente: tu é que tens uma língua tartamuda e enleada, se é verdade o que asseguram os que te trataram pessoalmente." $)^{174}$

\section{3. a) In laudem D. Aecatherinae oratio}

Este "Sermão em louvor de Santa Catarina", de que a única edição latina conhecida é o texto que ocupa as coll. 509-540 do tomo IV dos Opera Omnia, foi, pelo que se colige da leitura, pregado a um auditório verdadeiro no dia em que a Igreja celebra esta virgem e mártir (25 de Novembro). Depois da exposição do tema do Evangelho, o Autor narra a vida e martírio da santa egípcia, tomando seguramente como texto de referência a biografia escrita por Simeão Metafraste, ${ }^{175}$ a quem, por vezes, segue de modo literal. O sermão de D. Jerónimo Osório, porém, é literariamente muitíssimo mais elaborado do que a fonte, com desenvolvimentos significativos principalmente no que toca à caracterização psicológica e espacial, não deixando também de estar presente uma das características mais notórias do estilo osoriano, ou seja, a instauração de diálogo com um contraditor imaginário.

Deste panegírico fizemos a tradução integral, que inserimos na selecção de Escritos Espirituais já aqui referida.

\section{3. b) In Euangelium Ioannis orationes XXI}

Estas "21 prédicas sobre o Evangelho de São João", que, na única edição latina que possuem, ocupam as colunas 545-810 do tomo IV dos Opera Omnia, nasceram daquele pendor pedagógico a que Jerónimo Osório Júnior se refere, quando escreve na p. 7 da biografia do tio: Quorum vero animus ad maiorum rerum cognitionem adspirabat, ne praeclaram eorum studium periret, ipse magistri officii munus libenter suscipiebat: aliquos enim Graecis litteris erudiuit; aliquibus etiam Euclidis Megarensis Geometriam explicuit; nobis Diui Pauli Epistolas, ad Romanos, et ad Hebraeos, scriptas; Ioannisque Euangelium explanauit. ("Ele próprio também desempenhava de bom grado o ofício de mestre daqueles cujo espírito aspirava a um conhecimento de matérias mais elevadas, a fim de não se malograr essa vocação superior. Instruiu alguns na literatura grega, explicou a outros a geometria do megarense Euclides e a nós expôs-nos as Epístolas aos Romanos e aos Hebreus, de São Paulo, e o Evangelho de São João.") O sobrinho-editor esclarece no prefácio a estas prédicas as motivações e dramáticas circunstâncias biográficas que rodearam a sua escrita:

${ }^{174}$ P. 526 do $3^{\circ}$ volume da obra já citada Humanismo e Controvérsia Religiosa.

175 Que pode ler-se em Migne, Patrologia Graeca, tomo 114, coll. 276-301. 
Nobis autem hortatoribus, Ioannis Euangelium ea ratione explicandum suscepit, vt longiore oratione eos, qui in haec scripta inciderent, ad virtutis studium induceret, et religionis Christianae institutis erudiret. Fuit praeclarus iste Osorij conatus temporis iniuria probibitus, ne eo, quo tendebat, singulari cum Reipublicae Christianae vtilitate perueniret, haec namque Osorij aetas extrema incurrit in calamitosa Reipublicae Lusitanae tempora, in quibus, Sebastiani Regis accepta clade, erant omnia timoribus plena, lacrymis deformata, curis sollicita, et status Reipublicae desperatio omnium animos occupauerat. Quae quidem nostrarum rerum condicio, non solum a scribendi studio Osorium distraxit, sed illi vitam quoque eripuit. Quare, cum has Orationes scriberet, quasi in medio cursu constitit. ("Ora, seguindo as nossas exortações, empreendeu a exposição do Evangelho de São João, por forma a, com um discurso mais desenvolvido, levar ao amor da virtude e instruir nas doutrinas da religião cristã os que se deparassem com estes escritos. Os males da época impediram esse nobre desígnio de Osório de alcançar, com extraordinária utilidade da comunidade cristã, a pretendida concretização. Com efeito, esta derradeira fase da vida de Osório coincidiu com uma época calamitosa do Estado português, na qual, depois de conhecida a perda do rei D. Sebastião, tudo se encontrava cheio de receio, desfigurado pelas lágrimas e angustiado com cuidados, e a falta de esperança na estabilidade do país se apoderara de todos os espíritos. Esta situação dos nossos negócios públicos não apenas desviou Osório do gosto da escrita, como igualmente lhe abreviou a existência. Razão pela qual, andando a escrever estes sermões, ficou como que a meio da carreira." $)^{176}$

Ainda que as palavras de Jerónimo Osório Júnior apontem no sentido de que estes sermões não passaram do estado escrito, a verdade é que em todos eles o Autor, cingindo-se ao estilo parenético, interpela e admoesta o auditório, introduzindo por vezes notas deícticas que nos despertam a viva suspeita de que se está a dirigir a pessoas concretas, como claramente se pode coligir do exemplo seguinte, na col. 717: Olim, $v$ plerique legistis (noui enim multos bic adesse, qui non sunt litterarum sanctarum ignari) (...).("Outrora, como a maior parte de vós leu (pois sei que muitos dos que estão aqui presentes não são hóspedes nas Sagradas Escrituras) (...).”) Ter-se-á, nesta obra, D. Jerónimo Osório aproveitado de apontamentos, possivelmente em vernáculo, que lhe serviriam de tópicos de orientação em prédicas que se, algumas vezes, parecem dirigidas a um público indiferenciado, noutras têm a aparência de pertencerem a uma espécie de ciclo de conferências, provavelmente destinadas ao clero diocesano?

Cumpre também notar que, embora a linguagem de Osório pelo geral se mantenha fiel à pureza e elegância que lhe são características, uma ou outra vez todavia incorre em imperfeições facilmente explicáveis pelo facto de a execução da obra ter sido interrompida pela morte, carecendo da última demão do Autor e tendo o editor optado por não corrigir o texto original, do qual existe uma tradução integral para português, que faz parte da antologia de Escritos Espirituais osorianos da nossa autoria a que já fizemos referência.

176 Obra e lugar citados, coll. 543-544. 


\section{Este livro}

Este livro que agora apresentamos pretende oferecer ao público a reprodução do único texto latino conhecido e a tradução portuguesa de duas obras de D. Jerónimo Osório, irmanadas pela tripla circunstância de serem póstumas, se incluírem no mesmo sub-género literário e tomarem como ponto de partida dois livros que fazem parte daquele conjunto de escritos bíblicos que tradicionalmente se definem como "sapienciais". No entanto, além da evidente diferença de extensão de ambas as paráfrases objecto desta edição, a qual é mais ou menos proporcional à diferente extensão dos textos sobre os quais elas se exercem, ${ }^{177}$ temos a convicção de que, de todo o espólio literário que Osório deixou inédito ao morrer, a Paráfrase a Job seria não apenas a obra que se encontrava em mais perfeito estado de acabamento, mas também a de mais evidentes propósitos literários, não tendo visto a luz da publicidade por razões meramente acidentais que não estamos em condições de avaliar na totalidade. A esta persuasão nos conduzem indícios tanto internos como externos: os primeiros resultam da mera leitura da obra, que no seu estilo e recursos revela as características que associamos à linguagem osoriana em toda a sua plenitude de eficácia e intencionalidade artística; ${ }^{178}$ os indícios externos sãonos fornecidos, tanto pela informação do Autor, indirectamente transmitida pela voz do sobrinho, quanto por documentos de terceiros que chegaram até nós e provam que já havia notícia de que a obra estava pronta para a edição, pelo menos cinco anos antes da morte de D. Jerónimo Osório.

Com efeito, na p. 4 da Vita, imediatamente depois de se referir ao regresso de Jerónimo Osório a Portugal após os estudos em Bolonha, o cónego da Sé de Évora, consignando seguramente uma confidência do tio, escreve:

Cum vero in sermonis Latini elegantia non mediocriter excelleret, totis viribus in eo sibi laborandum statuit, vt damnum illud, quod ex Ciceronis de Gloria, de Republica, et de Consolatione, libris, iampridem temporum iniuria amissis, fuerat acceptum, resarciret. Quamobrem de Gloria Conimbricae, multos vero post annos de Regis institutione libros scripsi: de Consolatione autem nibil posse a se vel amplius, vel subtilius, excogitari, quam esset sacer ille liber Iob, tot sententiarum obscuritatibus inuolutus, existimauit: quare eo orationis genere, quod Paraphrasim Graeco nomine vocamus, eum Latinum reddidi, et explicauit. ("E como se distinguia sobremaneira pelo seu latim elegante, decidiu empenhar todas as suas forças em reparar o dano que resultara de há muito se terem perdido, por injúria do tempo, os livros que Cícero escrevera acerca da Glória, do Estado e da Consolação. Razão que o moveu a redigir, em Coimbra, o livro Sobre a Glória, e muitos anos depois o Da Ensinança do Rei. Acerca da Consolação, porém, assentou que ele, por

177 Com uma folgada diferença, porém, a favor da Paráfrase ao Livro de Job.

178 A finalidade deste livro tornaria pretensioso um tratamento circunstanciado das características estilísticas do latim osoriano. Um breve apontamento sobre o mesmo poderá encontra-se nas pp. 238-244 do $1^{\circ}$ volume da nossa dissertação: Humanismo e Controvérsia Religiosa. 
si, nada poderia imaginar de mais elevado e de mais subtil do que aquele sagrado Livro de Job, todo ele envolto num cendal de sentenças misteriosas: razão pela qual, servindo-se daquele género literário que, usando de uma palavra grega, chamamos "paráfrase", o verteu para latim e comentou.")

Informação mais concreta é a que colhemos de uma carta, dirigida, a 15 de Abril de 1575, pelo já referido amigo do Autor, Diogo de Paiva de Andrade, ao célebre biblista espanhol Benito Arias Montano, onde podemos ler o parágrafo seguinte:

"Há dias que gasto algũas horas ordinárias nos seus Comentários nos Profetas Menores, que me pareceram de maneira que desejei outros tais nos maiores, máxime em Jeremias e Ezequiel, que não estão explicados tão copiosamente como Isaías, o qual também tomou o nosso Osório para explicar, e tem feito em ele ũa paráfrase e anotações que me parece não poderão descontentar a v. m., e muitos dias há que insto que assi esse livro, como outra paráfrase e anotações, que tem feito em Job, mande a essa terra, porque me parece que haverá muitos que folguem de o imprimir, e não acaba de se satisfazer." 179

Como se vê, a osoriana Paráfrase ao Livro de Job já se encontrava pronta para a impressão muito antes ("muitos dias há") de Abril de 1575. Informação posterior ( $1^{\circ}$ de Agosto de 1578), mas no mesmo sentido, é a transmitida pelo editor de Colónia, Arnoldus Mylius, que já aqui citámos, ${ }^{180}$ e pela qual ficámos também inteirados que se encontrava igualmente pronta para os prelos a outra obra que agora se publica: in Sapientiam Salomonis Paraphrasis, ou seja, Paráfrase à Sabedoria de Salomão. Ora, neste breve livro parece-nos que o Autor se mostrou mais estritamente fiel à sua função de parafrasta, ao passo que na Paráfrase a Job se permitiu, pelo menos mediante a intercalação de textos introdutórios a cada um dos três livros/capítulos, dar livre expressão à sua voz pessoal. Aliás, a especial riqueza literária e humana do Livro de Job não necessita de qualquer encarecimento, ${ }^{181}$ bastando recordar aqui três exemplos que agora nos ocorrem da sua repercussão, sob forma directa ou indirecta, em três outros escritores

179 Carta de 15 de Abril de 1575, datada de Lisboa e dirigida a Benito Arias Montano, que o Autor supunha então em Antuérpia. O original desta importante carta encontra-se na Biblioteca Real de Estocolmo, colecção de manuscritos Sparwenféldt, pp. 63-64. Publicamos a sua reprodução integral na nossa Antologia de Diogo de Paiva de Andrade, volume de próxima publicação pela Faculdade de Ciências Humanas da Universidade Católica.

180 Veja supra, p. 45.

181 Para uma leitura actualizada e abrangente desta obra recomendamos o livro seguinte, que tem também a vantagem de oferecer uma tradução literal do original hebraico: Jean Radermakers, Deus, Job e a sabedoria (tr. port.), Lisboa, Instituto Piaget, 2004. 
portugueses: o quinhentista João de Melo e Sousa, ${ }^{182}$ o oitocentista Basílio Teles ${ }^{183}$ e o nosso contemporâneo Miguel Torga. ${ }^{184}$

As especiais características das obras que estamos a apresentar desoneram-nos da responsabilidade, por um lado, de as interpretar, visto que a perspectiva primordial por que as encaramos não é teológica, mas literário-cultural, e, por outro, de as sintetizar, porquanto pretendem ser a explanação de obras que supomos conhecidas de sobejo pelo leitor de mediana informação.

Pelo seu inegável interesse histórico-literário, pareceu-nos que devíamos incluir nesta edição a dedicatória com a qual Jerónimo Osório Júnior oferece a D. Jorge de Ataíde a Paráfrase ao Livro de Job.

O texto latino, como se disse, é o da única edição conhecida, com a uniformização ortográfica que decorre da aplicação das Normas para a edição do córpus bilingue de autores neolatinos, propostas pela APENEL. As citações, porém, em línguas que não o português, que se encontram na Introdução e notas deste livro, seguem as grafias dos respectivos textos originais, impressos ou manuscritos. No caso das transcrições de textos portugueses dos séculos XVI ou XVII, actualizamos a grafia, mas respeitando as particularidades fonéticas próprias desse estádio de evolução da nossa língua. A abertura de parágrafos e a pontuação são da minha responsabilidade. A paginação, que se refere às colunas do original, vai indicada entre parênteses rectos.

Concluo, dirigindo uma especial e sentida palavra de agradecimento ao Prof. Sebastião Tavares de Pinho, pela patriótica e corajosa iniciativa a que se votou de, através dos Portugaliae Monumenta Neolatina, restituir de novo à vida e ao conhecimento dos seus compatriotas tantos escritores portugueses aos quais o generalizado desconhecimento do latim votara a um imerecido esquecimento.

182 In librum Iob paraphrasis poetica, Lyon, apud Horatium Cardon, 1615. A $1^{\text {a }}$ edição das obras poéticas deste esquecido escritor novilatino é póstuma, pois falecera em 1575, e ficou a dever-se aos desvelos do filho. No século XVIII o $2^{\circ}$ tomo do Corpus Illustrium Poetarum Lusitanorum qui latine scripserunt, Lisboa, Typis Regalibus Sylvianis, 1745, é todo ele consagrado à reedição deste vate de inspiração exclusivamente religiosa.

183 O Livro de Job. Tradução em verso (com um estudo sobre o poema), Porto, Livraria Chardron, 1912.

184 O outro livro de Job, 1936 
(Página deixada propositadamente em branco) 
TEXTO E TRADUÇÃO 
D. JERÓNIMO OSÓRIO

PARÁFRASE A JOB

EM TRÊS LIVROS 
HIERONYMVS OSORIVS

I

PARAPHRASIS IN IOB

LIBRI III 


\title{
PREFÁCIO
}

\author{
de Jerónimo Osório Júnior \\ à Paráfrase a Job do português Jerónimo Osório, \\ ao Excelentíssimo e Reverendíssimo Senhor D. Jorge de Ataíde, ${ }^{1}$ \\ antigo bispo de Viseu, comendatário perpétuo de Alcobaça, \\ capelão e esmoler-mor de D. Filipe I de Portugal, \\ conselheiro do seu Conselho Supremo e presidente \\ da Real Mesa da Consciência
}

[1] Uma vez que são vários, excelentíssimo prelado, os acasos dos negócios humanos e muitas as enfermidades e moléstias de espírito que de mofinos modos atribulam a existência humana, aqueles antigos homens que mais se avantajaram entre os demais pelo crédito de sabedoria caíram em graves erros ao ocuparem-se da condição humana. ${ }^{2}$ De facto, sendo tão débil a natureza, quem não colocaria a infelicidade suprema nas turbulentíssimas paixões do ânimo? [2] Quem, ao reflectir sobre a constância e firmeza da virtude, não cuidaria que o homem, que está sujeito a uma espécie de incessante mutação, de tal maneira é hostil à essência da razão que nunca pode, já não digo alcançá-la, mas nem sequer contemplá-la com um olhar fixo? É que aqueles varões de superior inteligência consideravam no homem dois elementos: de ambos, um provém da agregação da massa corpórea e agita e perturba a estabilidade do espírito, ao passo que o outro, implantado pela natureza no entendimento humano, é arrebatado na direcção da sabedoria e da probidade; [3] era este o motivo pelo qual pensavam que o homem, ou governava a vida em obediência ao juízo dos sentidos, ou, tendo-os subjugados, permanecia sempre fiel a si num mesmo estado inalterável. Mas, enquanto se encontra entre os vivos, quem não há-de sentir o pungimento da dor, quem há-de reprimir por inteiro a ira, o amor, o desejo, o temor e as restantes paixões, por forma a não inquietarem sobremaneira o espírito? Com certeza que lhe seria mister despojar-se da natureza humana antes de alcançar uma tal condição firme e isenta de toda a sorte de mudança. 


\title{
$[1-2]$
}

\author{
In Hieronymi Osorii Lusitani \\ Paraphrasim in Iob Hieronymi Osorii Nepotis \\ ad Illustrissimum ac Reuerendissimum Patrem D. Georgium \\ Ataidium Episcopum olim Visiensem Perpetuum Commendatarium \\ Alcobaciencem, Capellanum et Eleemosynarium Maiorem Philippi \\ Huius Nominis Primi Regis Portugalliae Eiusque Consiliarii Supremi \\ Consiliarivm et in Regio Conscientiae Senatu Praesidem
}

\section{PRAEFATIO}

[1] Cum uarii sint rerum humanarum casus et plurimi animorum morbi atque aegritudines quibus humana uita miseris modis afflictatur, praesul illustrissime, prisci illi homines, qui inter ceteros sapientiae opinione maxime floruerunt, in graues sunt errores dilapsi, cum de hominis condicione disputarunt. Quis enim in tanta naturae imbecillitate, in turbulentissimis animi motibus, summam miseriam [2] non collocaret? Quis, dum uirtutis constantiam et firmitatem animo cogitaret, non existimaret hominem, qui perpetuae cuidam commutationi est obnoxius, ita a uirtutis ratione esse alienum ut numquam illam ne dicam consequi, sed nec possit fixis oculis contemplari? Duo enim uiri illi ingenio praestantes in homine considerabant, quorum alterum ex molis corporeae concretione proficiscitur, animi statum sollicitans atque perturbans, alterum, in humana mente a natura insitum, quo ad sapientiam et honestatem rapitur: [3] quamobrem necesse esse iudicabant ut homo uel sensuum iudicio uitam moderaretur, uel, illis oppressis, semper sibi constans in eodem statu permaneret. Verum, quis, dum est in uiuis, doloris acerbitatem non percipiet, iram, amorem, cupiditatem, timorem et ceteros animi motus omnino comprimet, ne animum grauissime sollicitent? Opus quidem illi erit naturam prius humanam exuere quam illum firmum et ab omni mutatione liberum statum consequi. 
Se quisermos olhar mais atentamente para este ponto, esta era a única razão pela qual suprimiam a virtude, porquanto no juízo dos sentidos não existe nenhum primor de honestidade, nenhuma firmeza, nenhum vestígio de sabedoria, nenhuma integridade de vida, mas, se reprimirmos os sentidos e não nos deixarmos mover pelos afectos inculcados pela natureza, qual há-de ser o merecimento e dignidade da virtude? Absolutamente nenhuns, mas forçosamente morrerá toda a essência da virtude, pois a virtude assenta sobretudo no facto de apartar-se daquilo que não está em consonância com a recta razão e de manter o meio entre os defeitos que se colocam diante de si.

Platão, o varão mais sábio da Grécia inteira, como tinha consciência de que o homem fora feito não pelo acaso, mas por deliberação divina, sustentou com muito maior sensatez que o mesmo homem, ainda que seja atormentado por terríveis dores, vexado por ultrajes e, enfim, assoberbada por toda a casta de males, mesmo assim pode ser feliz e largamente provido com os ornamentos das virtudes. É que o esplendor da virtude brilha mais nas provações e nas maiores torturas, porquanto as dores e tormentos, tal como as lágrimas derramadas devido à debilidade da natureza e os tristes queixumes, não infringem o sentimento do dever, mas comprovam de forma patente o zelo inabalável e excelente de um espírito no cumprimento do dever.

Desta doutrina, muito antes de florescer a filosofia grega, tivemos um maravilhoso mestre em Job, homem de raça árabe, ataviado com todos os merecimentos da santidade. De facto ele, embora tenha sido atormentado por pungentíssimos sofrimentos de corpo e espírito, e ainda que horríveis e inopinadas fatalidades sobre ele se arrojassem com incessante pertinácia, e conquanto soltasse palavras que delatavam as dores excruciantes com que era torturado, jamais abandonou o extraordinário comedimento de espírito que mantivera no curso da vida anterior, mas nos mais lancinantes tormentos glorificava com louvores a majestade divina e, a palavras trasbordantes de pungentíssimo queixume, misturava afirmações acerca da [4] Providência divina que muito se alçavam acima da razão humana. Com efeito, afirmava que fora a determinação e ordem divinas da Providência quem estabelecera que fosse oprimido por tão grande número de males, a fim de que ele próprio com muita antecedência representasse a imagem daquele que, embora fosse o soberano de todas as coisas, a fim de libertar o género humano tomou a fraca forma da natureza humana, pobre e indigente, e percorreu a Terra e, atormentado por um incrível sofrimento, padeceu aquele género de suplício que se aplicava aos homens mais criminosos.

Foi deveras extraordinário esse Job, que não só mostrou muito bem que a condição da natureza humana está sujeita a inumeráveis males, como também demonstrou que nela se podem conter os ornamentos de todas as virtudes mais elevadas. Para que todos pudessem disto ficar cientes, a mercê divina fez que a história de um tão grande varão fosse consignada por escrito por Moisés, consoante pensam alguns, ou, após a morte de Moisés, por algum varão notável pelos merecimentos da santidade.

Esta história, devido ao estranho tipo de linguagem utilizada, pois o autor serve-se amiúde de palavras caldaicas, e por se tratar de assuntos muitíssimo elevados, está inçada de muitas obscuridades. Jerónimo Osório, que prezava assaz o teu nome, procurou expô- 
Qua una ratione, si rem attentius uelimus considerare, uirtutem e medio tollebant, nam in sensuum iudicio nullus honestatis splendor, nulla stabilitas, nullum sapientiae uestigium, nulla uitae integritas inest, si uero sensus opprimas nec affectibus a natura insitis mouearis, quae erit uirtutis laus et dignitas? Nulla profecto, sed omnis uirtutis ratio necessario concidet, uirtus enim ea una in re maxime uersatur, ut ab iis, quae rectae rationi non sunt consentanea, discedat mediumque inter sibi opposita uitia obtineat.

Multo quidem prudentius Plato, uir totius Graeciae sapientissimus, cum non casu, sed diuino consilio, hominem ita fuisse informatum perspiceret, eum, etsi grauissimis sit doloribus affectus, contumeliis uexatus, omnibus denique malis circumsaeptus, uirtutum tamen ornamentis circumfluere et beatum esse posse disseruit. In aerumnis enim et summis cruciatibus uirtutis splendor magis elucet, nam dolores et cruciamenta ob imbecillitatemque naturae lacrimae immissae et tristes querimoniae, officium non frangunt, sed constans et excellens in officio seruando animi studium manifeste declarant.

Cuius doctrinae, multo antequam Graecorum philosophia uigeret, mirificus auctor exstitit Iobus, homo arabs, sanctimoniae laude ornatissimus. Is enim, cum acerbissimo animi et corporis dolore esset distentus, cum horribiles et repentini casus contento cursu in eum impetum facerent et orationem, summi doloris quo excruciabatur indicem, effunderet, numquam animi singularem moderationem, quam in anteactae uitae cursu seruauerat, deseruit, sed in summis cruciatibus diuinum numen laudibus efferebat et orationi acerbissima querimonia plenissimae, ea de [4] diuina Prouidentia commiscebat, quae humanam rationem longe superabant. Diuino enim illius consilio et ordine effectum fuisse asserebat ut tantis malis opprimeretur: nempe, ut ipse multo antea illius imaginem referret, qui, cum rerum omnium esset princeps, ut genus humanum in libertatem uindicaret, imbecillam humanae naturae formam induit, inops et egenus, tellurem lustrauit et, incredibili doloris sensu afflictatus, illud supplicii genus subiit quod sceleratissimis hominibus imponebatur.

Mirus profecto fuit iste Iobus, qui et naturae humanae condicionem innumerabilibus malis obnoxiam esse luculenter ostendit, et in ea omnium maximarum uirtutum ornamenta retineri posse demonstrauit. Quod ut ab omnibus perspici posset, diuino munere effectum fuit ut tanti uiri historia a Mose, ut aliqui putant, uel, posteaquam Moses e uita discessit, ab aliquo uiro sanctitatis laude florente esset monumentis commendata.

Quae, ob alienum sermonis genus, saepe enim auctor Chaldaeorum uerbis utitur et ob rerum altissimarum tractationem, est multis obscuritatibus inuoluta, quam Hieronymus Osorius, tui nominis studiosissimus, paraphrasi (ut inquiunt) 
-la através daquilo a que dão o nome de paráfrase, numa obra certamente digna de um filósofo cristão, na qual usou de admirável eloquência, superior penetração intelectual e erudição.

Ao tratar, entre outras obras dele, de dar esta à luz da publicidade, pensei que te deveria ser dedicada, por um lado, porque és uma pessoa tal que a grande debilidade do corpo nunca foi empeço à virtude do teu espírito ${ }^{3}$ e, ao longo de toda a tua vida, de modo extraordinário te mantiveste fiel àquilo de que já te compenetraras desde a infância, ou seja, em todas as reviravoltas do destino jamais dares de mão ao primor do dever e da probidade; por outro lado também, porque, embora tenhas nascido de progenitores nobilíssimos, te singularizas por uma modéstia tão grande que tens na conta de coisa nenhuma o ornamento da nobreza, algo que entre os nossos conterrâneos é olhado com a máxima veneração, e julgas que só o primor da virtude é digno de admiração, o qual tu de longe antepões a tudo o restante. Este pendor do teu espírito mostraste-o notavelmente na jornada que ainda jovem empreendeste a Trento, onde se reunia a assembleia de toda a cristandade, ${ }^{4}$ e depois que foste eleito bispo de Viseu. ${ }^{5}$

Ora, quão extraordinária foi a tua acção neste múnus proclamam-no os costumes dos súbditos mudados para melhor: [5] os quais eram desregrados em muitos lugares e a tal ponto se encontravam arreigados no espírito das pessoas que, pelo espaço de doze anos, ${ }^{6}$ te empenhaste com todas as forças em fazê-los regressar ao comedimento de uma disciplina cristã mais rigorosa. Quão grande foi a prudência, quão singular o merecimento de todas as virtudes, quão extraordinário o zelo da religião com que desempenhaste este cargo é algo de que pode dar testemunho o próprio abundantíssimo fruto de virtudes. É que os bons costumes restabeleceram-se, instaurou-se um regime de vida mais rigoroso, suprimiu-se inteiramente a liberdade para o pecado e começou a desenvolver-se no espírito das pessoas o zelo da virtude, adquirindo tamanhas forças que gerou de si frutos admiráveis. Com toda a justiça te deves ufanar deste título de louvor, porquanto não permitiste com a tua condescendência que decaíssem os costumes da diocese que estava ao teu cuidado, mas, estando eles quase perdidos, reduziste-os a um estado tal como se os implantasses de novo, e verdadeiramente cristãos, nas almas de todos. Levaste isto a cabo com grave detrimento da tua saúde, pois não te poupavas a vigílias, nem a jornadas, nem aos frios mais rigorosos que se sentem sob aqueles céus, nem a quaisquer trabalhos, ainda que penosíssimos, para cumprires com o máximo louvor aquilo que requeria o desempenho da tua obrigação.

O vigor do teu espírito, porém, não diminuiu com o debilitamento das forças do corpo nem com a saúde abalada, mas deu uma preclara demonstração da sua grandeza. Com efeito, a fim de mais desembaraçadamente viveres em espírito nos céus, desonerado dos cuidados e funções de bispo devido à saúde combalida do corpo, decidiste acolher-te a um lugar onde pudesses fruir de ti mesmo e consagrar-te à contemplação daquela santíssima divindade, à qual te entregaras por inteiro desde a mais tenra idade.

Embora os reis D. Henrique e D. Filipe te tivessem forçado a afastar-te deste santo propósito, levas uma vida de tal maneira santa e religiosa como se tivesses alcançado aquilo que acima de tudo almejavas, pois ao tempo em que, desonerado do episcopado, 
explicauit, opus quidem philosopho christiano dignum, in quo admirabili eloquentia, diuino ingenii acumine et eruditione est usus.

Quod cum inter alia illius opera in lucem emittere curarem, tibi dedicandum esse duxi, tum quia is es ut maxima corporis infirmitas animi tui uirtutem numquam retardarit et quod a pueritia iam imbiberas, ut in omni rerum fortuna officii et honestatis decus numquam desereres, in omni uitae tuae cursu mirifice seruaueris, tum etiam quod, cum ab illustrissimis parentibus sis ortus, ea modestia excellas ut nobilitatis ornamentum, quod apud nostros maxime suspicitur, pro nihilo ducas, uirtutis solum decus admiratione dignum esse iudices, quod ceteris rebus omnibus longe praeponis. Quod animi tui studium eo in itinere quod Tridentum, ubi totius rei publicae christianae conuentus agebatur, adhuc iuuenis suscepisti, et Visiensis deinde episcopus creatus, insigniter declarasti.

Quam praeclare enim in ea prouincia te gesseris, mores subditorum in melius commutati [5] praedicant: erant illi multis in locis peruersi atque in hominum animis inhaerebant ut, duodecim annorum spatio, totis uiribus in eo pugnaueris ut eos ad seuerioris disciplinae christianae moderationem reuocares. Quo in officio quanta cum prudentia, quam singulari uirtutum omnium laude, quam eximio religionis studio uersatus fueris, ipse uberrimus uirtutum fructus testatur. Mores enim sunt restituti, uiuendi seuerior disciplina constituta, peccandi licentia omnino compressa, et uirtutis studium in hominum animis coepit pullulare easque uires est adeptum ut miros ex se fructus gigneret. Merito quidem hac laude gloriari debes, non enim prouinciae tibi commissae mores indulgentia passus es in peius dilabi, sed eos fere perditos in eum statum reduxisti ac si nouos eosque uere christianos in omnium animis insereres. Quod maximo cum ualetudinis tuae detrimento es consecutus, nec enim uigiliis, nec itineribus, nec maximis frigoribus, quae sub illi caelo uigent, nec ulli, licet acerbissimo, labori parcebas ut, quod officii tui munus postulabat, summa cum laude persolueres.

Debilitatis autem corporis uiribus et infirma ualetudine non fuit animi tui uirtus imminuta, sed praeclaram suae magnitudinis significationem dedit. Nam, ut liberius in caelis mente uersarere, episcopi curis et officio ob corporis afflictam ualetudinem solutus, te eo recipere statuisti ubi te ipso frui posses et illius sanctissimi numinis contemplatione uacare, cui totum te ab ineunte aetate tradideras.

A quo sancto proposito quamuis Henricus et Philippus reges te discedere coegissent, adeo sancte et religiose uitam geris ac si illud, quod maxime optabas, fuisses consecutus, eo enim tempore quo, episcopatus onere solutus, tranquillam 
pretendias com o máximo contentamento encetar aquele tranquilo modo de vida dedicado à contemplação divina que desejavas com todas as veras do teu coração, arrancou-to de entre as mãos aquele crudelíssimo desastre africano, porquanto D. Henrique sucedeu a D. Sebastião, e manteve-te ao seu lado, escolheu-te para capelão-mor e colocou-te no Conselho de Estado. ${ }^{7}$ É que o rei D. Henrique, dotado de excepcionais merecimentos de santidade, conhecia-te e, num período dos mais turbulentos da nação portuguesa, considerou que lhe era necessário o teu conselho [6] e ajuda. Por consequência, puseste bem à frente dos teus interesses particulares o mandado do rei (cuja boa vontade para contigo sempre foi extraordinária), o luto da pátria e o desvelo pelo Estado quase arruinado.

Por conseguinte, que faria D. Filipe, o mais sábio dos reis? Porventura permitiria que tu, consoante desejavas, te consagrasses ao santíssimo ócio e sujeitar-se-ia a carecer do teu conselho e probidade na governação do seu vastíssimo império? Seguramente que não. Por conseguinte, concedeu-te as mais elevadas honrarias e serviu-se de ti nos mais importantes negócios. Não cito as inúmeras provas de singular amor, os testemunhos de boa vontade e os penhores de liberalidade com que este sapientíssimo rei revelou os seus sentimentos para contigo e nos quais mostraste em relação à sua majestade a maior lealdade, uma extraordinária força de amor e uma excepcional modéstia. ${ }^{8}$ Decerto que o tempo me faleceria se pretendesse discorrer acerca destas matérias e és dotado de tal modéstia que, se me alongasse acerca deste assunto, muito me arrecearia de incorrer no teu desagrado. Por isso contenho-me e, constrangido, pois são coisas muito dignas de ser lembradas, guardo para mim mesmo tudo o que poderia dizer-se sobre o severo regime do teu teor de vida e sobre a verdade e justiça que mostras no desempenho das funções importantíssimas que tens a teu cargo.

Por estes motivos, há-de parecer que não procedi insensatamente ao dedicar-te a ti, que tanto te avantajas na verdadeira filosofia do homem cristão, este livrinho que entre os outros livros da teologia cristã muito e sobremodo se avantaja pelo peso das opiniões, pela elevação da linguagem e pelo modo como trata as matérias. Acrescem também a estima que por ti sentia o meu tio paterno Jerónimo Osório e a tua singular benevolência para comigo. É que ele, ao ver os ornatos de toda a espécie de virtudes que em ti brilham, sentiu por ti entranhada estima e deu amiúde notáveis testemunhos da santidade da tua vida, pois era ele varão que, conforme sabes, veementemente se abrasava no amor da virtude, daí procedendo a recíproca estima que existia entre vós. Ele morreu, mas em ti continua viva a mesma estima e a mesma boa vontade, porquanto, mantendo-se inéditos na minha posse os seus preclaros escritos, envidaste esforços no sentido de que se publicassem. Só por isto não apenas honraste com o máximo serviço a memória de um homem que te prezava muitíssimo, como também beneficiaste não pouco a comunidade cristã.

E sobre a tua boa vontade para comigo é preferível guardar silêncio a dizer poucas palavras. [7] Embora sejam tantos os favores que com ardentíssimo afecto me fizeste que nem na mais pequena proporção poderia testemunhar o meu reconhecimento, todavia fica bem ciente que o testemunhamos como podemos. Para de alguma maneira o mostrar, 
illam uiuendi rationem, diuinae contemplationi dicatam, quam omnibus uotis desideraueras, summa cum laetitia inire uolebas, acerbissima africana clades illam tibi e manibus eripuit, nam Henricus Sebastiano successit, te apud se retinuit, cappellanum maiorem creauit Supremoque Senatui adscripsit. Nouerat enim te Henricus rex, sanctimoniae laude excellens, in turbulentissimisque lusitanae rei publicae temporibus, sibi tuo consilio [6] et opera opus esse existimauit. Regis igitur, cuius in te singularis semper fuit beneuolentia, imperium, patriae luctum, rei publicae prope labefactatae studium, tuis rebus longe praetulisti.

Quid igitur Philippus sapientissimus rex faceret? Num te, ut cupiebas, sanctissimo otio uacare permitteret et, in amplissimi imperii sui moderatione, tuo consilio et probitate carere pateretur? Non profecto. Te igitur summis honoribus affectum in rebus grauissimis utitur. Omitto plurima huius sapientissimi regis in te eximii amoris argumenta, beneuolentiae studia, liberalitatis munera, in quibus fidem erga illius maiestatem, maximam amoris uim singularem et animi moderationem incredibilem ostendisti. Quibus de rebus si orationem habere uoluissem, tempus quidem me deficeret, et ea est animi tui moderatio ut, si de his luculentius agerem, ne in offensionem tuam incurrerem ualde pertimescerem. Me ipsum igitur contineo. Quae de uitae tuae seueriori disciplina, de ueritate, de iustitia in muneribus amplissimis, quae sustines, administrandis dici poterant, apud me inuitus coerceo, sunt enim omni memoria dignissima.

Quamobrem non imprudenter a me factum fuisse uidebitur cum tibi, qui uera christiani hominis philosophia tantum praestas, libellum hunc consecraui, qui inter alios christianae theologiae libros sententiarum pondere, sermonis amplitudine, rerum tractandarum modo, longe multumque praestat. Accedit etiam Hieronymi Osorii, patrui mei, in te amor et tua erga me eximia beneuolentia. Ille enim, cum uirtutum omnium ornamenta, quae in te elucent, perspiceret, te ardenter amauit saepeque de tuae uitae sanctimonia luculenter testimonium dedit, uir enim ille, ut scis, uirtutis studio uehementer flagrauit: unde eximius inter uos mutuus amor oriebatur. Obiit ille, in te tamen idem amor eademque beneuolentia uiget, cum enim praeclara illius monumenta apud me compressa iacerent, operam dedisti ut in uulgus mitterentur. Qua una re, et hominis tibi deditissimi memoriam summo es officio prosecutus, et rei publicae christianae non mediocre emolumentum attulisti.

De tua uero erga me uoluntate, tacere potius libet quam pauca dicere. [7] Cum tot sint a te in me officia ardentissimo studio collata ut nec minima ex parte gratias referre possim, eas tamen quas possumus haberi certo scias. Quod ut aliqua ratione significarem, et quia Osorio tuo iucundissimum fore sperem, $[\mathbf{8}]$ et 
e porque não só creio que haveria de ser muitíssimo agradável ao teu estimado Osório, [8] mas também porque esta obra se deve acima de tudo unicamente a ti, quisemos que saísse à luz com o teu nome. Permite que assim se faça e acolhe com boa sombra a nossa afeição. Fica bem.

Em Roma, $1^{\circ}$ de Janeiro de 1592. 
tibi uni hoc opus maxime debeatur, ut tuo nomine in lucem prodiret, uoluimus. Quod ut fiat patere nostrumque studium benigne amplectere. Vale.

Romae, MDXCII. Kal. Ianuarii. 


\section{PROÉMIO \\ à Paráfrase a Job \\ do português Jerónimo Osório}

São certamente muitos os remédios que se procuraram e encontraram para a cura dos corpos; consoante diz Eurípides, porém, "para libertar as almas da enfermidade só se descobriu uma espécie de mezinha, que é aquela que se encerra nas palavras de um homem sábio e amigo." Pelo que, se assim é, que pode haver de mais admirável do que a elegância e riqueza de linguagem? É que na vida existem muitos males que atormentam o corpo com dores e acabrunham o espírito com cuidados muito pungentes. De facto, a um oprime-o a penúria, a outro aflige-o a doença, a outro atormenta-o a dor com lancinante acesso, a outro o desdouro abate-o e constrange-o a suportar os pesados embates de toda a espécie de males. Que hei-de dizer acerca das limitações, cegueira e fraqueza de um corpo mutilado? Que relatarei acerca dos restantes males, os quais foram arrojados sobre a vida humana, não pela malícia e engano de Pandora, consoante Hesíodo assevera, ${ }^{1}$ mas pela perversidade e pecado dos homens, males esses que a bem dizer são infinitos? Que dizer, quando sobre um único homem se abatem, não apenas uma única espécie de mal, mas muitos ao mesmo tempo, e lhe roubam a quietação de espírito e o prostram por completo? Por isso, se a linguagem tem tamanha eficácia que afasta todos estes males, que são de tal maneira graves e insuportáveis, e alenta o espírito abatido e derribado por tantas feridas, e lhe restaura a saúde, que poderá nesta vida imaginar-se de mais divino do que o primor $[\mathbf{1 0}]$ e atavio de linguagem?

Mas não sei se os que atribuem tamanha importância à linguagem estão a atribuir exageradamente à eloquência maior eficácia do que a recta razão consente. É que dificilmente se crê que seja possível que aquilo que atormenta e tortura se alivie com palavras. Que dizes, orador? Que função te atribuis, ó filósofo? Evidentemente esta: a de, através da linguagem, me propinares um remédio salutar, a mim que me encontro dilacerado por uma ferida gravíssima. Por conseguinte, desejo ver de mais perto essa eficácia das palavras.

- Não és o primeiro, diz ele, a quem isto acontece. Muitos mostraram outras feridas muito mais graves. 


\section{Hieronymi Osorii Lusitani In Paraphrasim in Iob}

\section{PROOEMIVM}

Multa quidem remedia curandis corporibus quaesita et inuenta sunt; animis autem aegritudine liberandis unum tantum medicinae genus, ut ait Euripides, id nempe quid hominis et amici et sapientis oratione continetur. Quod si ita est, quid orationis elegantia et ubertate fieri potest admirabilius? Multa namque mala sunt in uita quae corpus doloribus excruciant et animum acerbissimis curis exagitant. Alium enim premit egestas, alium afflictat inualetudo, alium dolor acerrimo morsu dilacerat, alium dedecus abiit maximasque malorum omnium tempestates subire compellit. Quid de orbitate, caecitate, corporis mutili debilitate sermonem faciam? Quid de reliquis malis, quae non Pandorae fraus et malignitas, ut Hesiodus asserit, sed humanum flagitium et scelus in res humanas inuexit, quae sunt propemodum infinita, dicam? Quid, cum non unum tantum mali genus, sed multa simul in unum hominem incursant eumque de mentis statu deiiciunt omninoque prosternunt? Quod, si tanta uis est in oratione ut omnia haec mala, quae sunt adeo grauia et intolerabilia, depellat, animumque tot uulneribus concisum atque iacentem excitet ad salutaremque medicinam reducat, quid excogitari in uita poterit orationis cultu et ornatu [10] diuinius?

Sed haud scio an qui tantum orationi tribuunt longe maiorem uim eloquentiae tribuant quam recta ratio patiatur. Vix enim credibile est fieri posse ut quod re angit et cruciat uerbo releuetur. Quid ais, orator? Quam prouinciam suscipis, o philosophe? Hanc uidelicet: ut mihi, grauissimo uulnere sauciato, oratione salutarem medicinam adhibeas. Istam igitur uerborum uim propius intueri cupio.

- Non, inquit, hoc tibi primum accidit. Multi alia uulnera multo grauiora protulerunt. 
- Pois quê? Porventura a desgraça dos outros há-de fazer que a minha desgraça não me seja molesta, penosa e difícil de suportar? Se estivesse fortemente possuído pelo ódio, então é possível que esse prazer que receberia com os males alheios me mitigasse em parte a dor que me fora infligida em particular. Mas, se sou homem e estou dotado de sensibilidade humana, quanto maior é o número daqueles sobre os quais se abate alguma calamidade, tanto me parece menos suportável a mesma calamidade. Diz-se que nascemos dotados de uma natureza tal que consideramos que devemos sofrer tudo aquilo que pode acontecer ao ser humano. Por consequência, que poderá existir de mais calamitoso do que a própria terrível necessidade de suportar e tolerar todos os males?

- É mais próprio da opinião do que da razão perturbar-se um pouco mais fortemente com alguma calamidade.

- Estás a zombar de mim e não a consolar-me. A dor persegue e acossa, gasta a vida, dilacera o espírito, [11] não deixa respirar, e tu hás-de sustentar que aquilo que atormenta com dor intolerável é molesto não de facto, mas por opinião?

- O gemer é próprio da fraqueza mulheril, ao passo que a tristeza e o choro constante demonstram o abatimento de um espírito débil e efeminado.

- Porventura até me hás-de roubar este único e levíssimo refrigério que me restava nas grandes provações? É que, se para obedecer à opinião pública, eu abafar com o meu silêncio a dor da alma, não a farei diminuir, mas antes pelo contrário aumentarei a sua intensidade. De facto, assim como o ar encerrado nas entranhas da Terra quanto mais estreitamente for apertado tanto mais violentamente e com maior tremor da Terra procura libertar-se, da mesma maneira a dor íntima que, como por uma espécie de respiradouro, não se alivia através de suspiros e gemidos, perturba de forma muito mais perigosa o equilíbrio do próprio espírito.

- Se és devotado ao amor da honra, pensa na grandeza da própria dignidade, por forma a compensares o pungente da dor com a doçura do louvor.

- Certamente que aumentas e não diminuis a minha dor, pois o que profundamente deploro é não ter recebido prémios dignos dos meus merecimentos.

- Mas a morte, diz, que sempre ronda por perto, põe fim a todos os males.

- É verdade, mas a mesma morte suprimirá completamente a esperança de uma condição mais feliz nesta vida. Além disso, que pode haver de mais violento do que a crueldade da própria morte? Os brutos animais desejam vivamente velar pela sua conservação; as árvores e as plantas temem a morte; as rochas e as pedras, com uma espécie de sentido oculto natural, receiam desagregar-se; enfim, todas as partes do mundo tremem com o aproximar da morte, e tu hás-de admoestar-me a não temer a morte, a mim em cujo espírito a natureza implantou um extraordinário desejo de imortalidade? A não sentir qualquer horror perante o passamento? A deixar sem dor tudo aquilo que na vida é estimável e agradável? Acaso é pouco evidente que, de todas as coisas horríveis e temíveis, a morte é a mais medonha e cruel? É que, assim como todos os males procedem da condição mortal, da mesma maneira se completam com a crueldade da morte.

- De forma alguma, retruca ele. De facto, ou após a morte nada se sente, ou a morte não é um fim, mas apenas uma passagem: destas opiniões, uma é digna de desprezo e a 
- Quid ergo? Num aliorum clades efficiet ne mea mihi clades molesta et aspera difficilisque perpessu sit? Si me uehementer uexaret inuidia, tum fortasse ea uoluptas, quam ex alienis malis caperem, dolorem mihi priuatim inustum aliqua ex parte leniret. At, si homo sum et sensibus humanitatis afficior, quo plures sumus ad quos calamitas aliqua peruasit, eo grauius eamdem calamitatem ferendam arbitror. Ea, inquiunt, lege nati sumus ut omnia, quae homini accidere possunt, nobis perferenda existimemus. Quid igitur poterit esse ipsa dirissima necessitate omnia mala ferendi atque patiendi calamitosius?

- Opinionis, inquit, non rationis est, uehementius calamitate aliqua conturbari.

- Ludis tu quidem me et non consolaris. Instat et urget dolor, uitam conficit, animum lacerat, $[\mathbf{1 1}]$ respirare non sinit, et tu quod dolore intolerabili torquet non re, sed opinione, molestum esse contendes?

- Muliebris imbecillitatis est ingemiscere, maeror autem et fletus assiduus, animi mollis et effeminati languorem coarguit.

- Etiamne tu mihi hoc reliquum et pertenue solatium in grauibus aerumnis eripies? Si enim, ut famae populari seruiam, animi dolorem taciturnitate compressero, non illum imminuam, immo illius acerbitatem amplificabo. Vt enim spiritus terrae uisceribus inclusus quo angustius coercetur, eo maiore cum terrae motu atque uiolentius erumpit, ita dolor intestinus qui non suspirio et gemitu, quasi quodam spiraculo, releuatur, multo periculosius statum ipsius animi conturbabit.

- Cogita, inquit, si honestatis studio deditus es, ipsius dignitatis amplitudinem, ut laudis dulcedine doloris acerbitatem compenses.

- Auges tu quidem mihi, non minuis dolorem. Id enim uehementer doleo, non esse digna meritis meis praemia persoluta.

- At mors, inquit, quae procul abesse non potest, finem cunctis malis imponet.

- Verum, sed eadem mors felicioris in hac uita condicionis spem prorsus incidet. Praeterea, quid esse potest ipsius mortis immanitate truculentius? Bruta animantia statum suum tueri percupiunt; arbores et plantae interitum reformidant; rupes et saxa ne dissipentur tacito quodam naturae sensu pertimescunt; omnes denique mundi partes ad mortis appropinquantis aspectum contremiscunt, et tu mihi, in cuius animo natura miram cupiditatem immortalitatis inseuit, auctor eris ne mortem timeam? Vt interitum minime perhorrescam? Vt omnia, quae sunt in uita cara atque iucunda, sine dolore relinquam? An parum liquet omnium, quae sunt horribilia atque pertimescenda, mortem esse maxime diram atque truculentam?

- Minime, inquit. Nam aut nullus post mortem sensus est, aut mors interitus non est, sed emigratio tantum: quorum alterum est contemnendum, alterum 
outra vivamente desejável. É que, se os sentidos se devem extinguir e desaparecer, não há razão para que te temas de qualquer dor após a morte; se esta morada [12] se deve trocar por outra muito superior, a própria razão aconselha a que prefiras um lugar mais agradável para onde deves ser levado depois da morte: e até, se a morte há-de suprimir todos os sentidos, sinto um forte receio do próprio perpétuo esquecimento. Mas, se me há-de lançar para outra paragem, angustiosamente recuo de pavor perante a perspectiva de que a própria paragem para a qual devo ser conduzido seja muito mais horrível do que esta que sou obrigado a deixar. Por conseguinte, o teu discurso não é de qualquer ajuda nos males. Decerto que farás negócio com o teu engenho; adornarás o tema que tomares à tua conta; obterás a reputação de orador nada desprezível; mas de forma alguma conseguirás desalojar a dor afincada no espírito, ainda que venças Demóstenes ou Cícero em eloquência.

Daqui se conclui quão vãos são todos os esforços dos que, apoiando-se nesta espécie de argumentos, empregam muito trabalho e desvelo na consolação dos homens cujas feridas não podem curar. É que a verdadeira consolação não se deve tirar da inteligência humana, mas cumpre ir procurá-la no Céu e sobretudo na majestade do próprio supremo Deus. Com efeito, onde floresce o amor da bondade sempiterna desprezam-se facilmente todos os trabalhos, dores e angústias, porquanto não se teme das privações aquele a quem o Senhor de todas as coisas se encarregou de alimentar, nem receia a nudez aquele a quem os ornatos celestiais e divinos ataviam, nem sente medo da cegueira o que contempla as riquezas imortais com os olhos de um entendimento totalmente puro, nem trepida diante do exílio o que obteve os direitos de cidadão daquela Cidade celestial, nem se atemoriza com a baixa condição o que, incitado pelo poder do Espírito divino, chama progenitor a Deus, nem se arreceia da dor o que aspira aos mais elevados e eternos prazeres, nem, por derradeiro, teme a morte o que é fortificado com o penhor da imortalidade.

Portanto, mesmo que o céu se desmorone e a terra rua abalada por um imenso tremor e tudo quanto enxergamos seja consumido por um horroroso incêndio, de forma alguma há-de sucumbir o espírito do homem que com ardente fé se consagrou a Deus: pelo contrário, quanto mais vir que tudo se perturba e confunde, tanto olhará com mais confiança para o céu e mais arrebatadamente será possuído pela expectativa de uma iminente salvação. É que as ajudas do poder celestial revelam-se mais clara e magnificamente quando se desvanecem todas as esperanças humanas. Por conseguinte, rejeitem-se todos os restantes métodos de consolar e adopte-se unicamente este que se funda na consideração da bondade divina e no ardentíssimo zelo da religião.

[13] De facto, a pessoa que fundou a fé, não nos sentidos, mas neste método, compreenderá que quem se abriga sob a tutela e guarda de Deus pode, é certo, ser atacado, porém é impossível que seja vencido e subjugado, e dar-se-á conta de que a tribulação com que por vezes é oprimido, não deve ser contada no número dos males, mas considerada como uma extraordinária colheita de glória, e reconhecerá que os trabalhos com que é inquietado se circunscrevem a um prazo breve de tempo e que o prémio há-de ser eterno, e que, enfim, Deus nunca se encontra longe daqueles que 
uehementer expetendum. Si enim sensus exstinguendi atque delendi sunt, non est cur ullum dolorem post mortem metuas; si domicilium [12] hoc est cum alio multo praestantiore commutandum, ipsa ratio admonet ut sedes commodiores, in quas es post mortem deferendus, exoptes: immo, si mors omnes sensus oppressura est, ipsam sempiternam obliuionem uehementer exhorreo. Si uero me est in aliam regionem expulsura, ne regio ipsa, in quam deducendus sum, sit hac quam relinquere compellor longe horribilior, anxie reformido. Nihil igitur malis iuuat oratio tua. Ingenium quidem uenditabis; locum, quem apprehenderis, exornabis; oratoris minime contemnendi nomen obtinebis; dolorem tamen animo infixum, etiamsi Demosthenem aut Ciceronem eloquentia uincas, minime depelles.

Vnde colligitur quam inanes sint eorum conatus qui, huiusmodi argumentis innixi, in consolandis hominibus quorum uulnera sanare nequeunt, multum operae et studii consumunt. Vera enim consolatio non est ex humano ingenio depromenda, sed e caelo atque adeo ab ipsius summi Dei numine repetenda. Vbi enim benignitatis sempiternae studium uiget, omnes labores atque dolores et angores facillime contemnuntur, nec enim egestatem metuet is quem rerum omnium Dominus alendum suscipit, neque nuditatem is quem caelestis atque diuinus cultus exornat, neque caecitatem qui purissimae mentis oculis opes immortales intuetur, nec exsilium qui est ius illius caelestis Ciuitatis assecutus, nec humilitatem qui, numine diuini Spiritus incitatus, Deum parentem appellat, neque dolorem qui ad summas atque sempiternas uoluptates aspirat, neque mortem denique qui immortalitatis pignore confirmatur.

Vt igitur caelum ruat, terra ingenti motu tremefacta desideat et omnia, quae intuemur oculis, horribili incendio deflagrent, animus hominis, qui se Deo ardente fide consecrauit, nullo modo concidet: immo, quo magis omnia perturbari et confundi perspexerit, eo confidentius in caelum respiciet et elatius exspectatione praesentissime salutis efferetur. Tunc enim clarius et magnificentius praesidia caelestis numinis afferuntur, cum humanae spes omnes infringuntur. Omnes igitur reliquae consolandi rationes respuantur et haec sola teneatur, quae in consideratione diuinae probitatis et in ardentissimo studio religionis consistit.

[13] Intelliget enim is qui non sensibus, sed hac fidem instituit, eum, qui in Dei tutela atque praesidio delitescit, oppugnari quidem posse, opprimi tamen et expugnari non posse, et aerumna, qua interdum premitur, non esse in malis numerandam, sed insignem gloriae segetem reputandam, et labores, quibus exercetur, esse breuis aeui spatium circumscriptos, mercedem uero et praemium fore sempiternum, atque postremo Deum numquam procul ab illis, quos in fidem recepit, abesse, sed eis semper adesse, ut eorum animos praesidio inuicto 
recebe sob a Sua protecção, mas está sempre ao lado deles, para fortificar os seus espíritos com uma defesa invencível e, com a doçura de uma espécie de prazer supremo, atraí-los ao amor de um estado divino.

Ora, para que isto se possa entender mais claramente, o Senhor quis outrora oferecer aos homens, para que o imitassem, um claríssimo exemplo de virtude invencível, de maneira a que tivessem por certo que não existe nenhum mal tão terrível que seja capaz de arrancar da sua firme posição o homem que se apoia na fé e na religiosidade. Ora, tal foi Job, homem nascido na Arábia e alheio dos ensinamentos da Lei antiga, no qual todavia resplandeceu uma imagem claríssima de Cristo e um exemplo da virtude divina, pois a ele nem as prosperidades o ensoberbeceram, nem as adversidades o abateram, nem houve jamais força alguma que pudesse [14] desviá-lo do seu propósito; suportou com ânimo inquebrantável a pobreza; tolerou com a máxima resignação o desamparo; padeceu incontáveis chagas e dores intoleráveis; escutou zombarias, ultrajes e baldões; rechaçou para bem longe de si todos os enganos e embustes do antiquíssimo inimigo e, enfim, todas as hostes dos manes infernais, de tal maneira que, no meio dos maiores flagelos e tormentos das tribulações, mantinha-se sempre firme na mesma determinação e opinião.

Resta, por conseguinte, que, não fazendo qualquer caso dos demais argumentos consolatórios, imitemos a fé deste varão superior, se queremos gozar do refrigério divino em todas as situações difíceis e desfrutar da maior alegria até nos maiores desastres. Para que isto se pudesse levar a cabo mais facilmente, considerei que valeria a pena que eu empreendesse expor a vida, costumes e opiniões de Job servindo-me daquele género literário que, com uma palavra grega, costumamos designar por paráfrase, a fim de que pudesse chegar a muitos o fruto da obra ilustríssima que ele para perpétua memória consignou por escrito.

Mas a razão já aconselha a que, os que se depararem com esta obra, desviem de mim a atenção e cuidem em prestar ouvidos a Job e acolham dentro dos seus espíritos e gravem nos seus entendimentos as opiniões dele. 
corroboret et, dulcedine summae cuiusdam uoluptatis, ad studium diuini status alliciat.

Hoc autem ut clarius cerni posset, uoluit olim Dominus clarissimum inuictae uirtutis exemplum hominibus ad imitandum proponere, ut exploratum haberent nullum esse tam dirum malum quod hominem, fide et pietate stabilitum, de statu conuelleret. Is autem Iobus fuit, in Arabia natus ab institutis antiquae legis alienus, in quo tamen imago clarissima Christi et specimen diuinae uirtutis eluxit. Illum enim neque res ad uoluntatem fluentes extulerunt, nec aduersae deiecerunt, nec aliqua uis umquam fuit quae illum [14] a proposito deterrere potuerit; egestatem animo inuicto sustinuit; orbitatem patientissime tolerauit; plagas innumerabiles et intolerandos dolores pertulit; derisiones, conuicia et maledicta auribus usurpauit; omnes fraudes et insidias hostis antiquissimi et omnes denique inferorum manium copias a se longissime propulsauit, ita ut, in summis aerumnarum procellis atque tempestatibus, in eadem semper mente et sententia permaneret.

Reliquum igitur est ut, reliquis argumentis ad consolandum pro nihilo habitis, huius uiri diuini fidem imitemur, si uolumus in omni rerum asperitate diuino solacio uti et in summis etiam cladibus summa iucunditate potiri. Quod ut facilius fieri posset, operae pretium me facturum existiamaui, si uitam et mores et sententias illius eo genere orationis explicarem, quod paraphrasim uerbo graeco nominare solemus, ut ad plures possit fructus operis clarissimi, quod ille litteris ad sempiternam memoriam consignauit, peruenire.

Sed ratio iam monet ut, qui in hoc opus inciderint, a me animum remoueant ipsumque Iobum audire arbitrentur sententiasque illius intimis animis memorique mente recipiant. 
(Página deixada propositadamente em branco) 


\title{
PRIMEIRO LIVRO
}

\author{
DA PARÁFRASE A JOB \\ PELO PORTUGUÊS JERÓNIMO OSÓRIO \\ LIBER PRIMVS \\ HIERONYMI OSORII LVSITANI \\ PARAPHRASIS IN IOB
}


[17] Na região oriental da Arábia existiu um varão de nome Job, dotado de inexcedível integridade, equidade, religiosidade e moderação. Ora, este homem tinha sete filhos e três filhas. Possuía também avultada quantidade de gado, pois era dono de sete mil ovelhas, três mil camelos, quinhentas juntas de bois, quinhentos burros e, além disso, uma grande quantidade de escravos, e deste modo, não apenas devido à sua virtude e religiosidade, mas também por causa das riquezas e influência, era sem contestação o homem mais importante de todos os que habitavam aquelas regiões orientais.

Por outro lado, para que a sua felicidade fosse completa, acrescia que os filhos viviam na perfeita harmonia de um amor recíproco. De facto, amiúde se convidavam mutuamente para banquetes, a fim de, mediante esta usança de comer em conjunto, se ligarem por uma espécie de vínculo mais estreito de amor. O filho mais velho, uma vez preparado o banquete, era o primeiro a convidar os irmãos e as irmãs. Depois os outros sucessivamente faziam o mesmo. Ora, de tal maneira se recebiam afectuosamente uns aos outros que tornavam cada turno destes deveras aprazível pela boa disposição e alegria. Mas o pai, depois que via completada aquela rotação de banquetes, antes que os filhos começassem de novo outra série de convívios, purificava-os através de cerimónias realizadas de acordo com os rituais. E assim, levantando-se ao amanhecer, imolava vítimas sacrificiais em proporção com o número de filhos e queimava-as no altar em honra de Deus a fim de O tornar propício aos filhos. É que o inquietava a possibilidade de os filhos, no meio daquela boa disposição e excesso de vinho dos banquetes, terem tido algum pensamento impiedoso ou proferido algum ultraje contra Deus, com o qual provocassem a Sua irritação contra eles. Por conseguinte, por esta forma o santo varão vivia no meio de grandes riquezas e na abastança de todos os bens, de maneira que não se viam quaisquer indícios de soberba ou impiedade, nem com justiça poderia ser acusado por qualquer suspeita de infâmia ou de iniquidade.

Ora, sucedeu que Satanás, posto na presença de Deus, a quem nada pode ocultar-se (pois assim como nunca desvia os olhos dos anjos santos, aos quais utiliza como servidores, do mesmo modo também exerce o poder sobre os agentes do pecado [18] e obriga-os a servi-lo), se disse a si mesmo as seguintes palavras, sob instigação do próprio Senhor que de uma certa maneira lhe impelia o pensamento:

- Percorri todo o mundo e entrei livremente por onde quer que andei. É que não existe coisa alguma capaz de resistir às minhas forças e poder. De facto, submeti todos os mortais ao jugo do meu senhorio e autoridade e consegui que, pondo de parte o 
[17] In ea Arabiae pars, quae ad orientem solem pertinet, fuit uir nomine Iobus, summa integritate et aequitate et religione et abstinentia praeditus. Huic autem erant septem filii et tres filiae. Erat ei praterea res pecuaria satis ampla, septem namque millia ouium possidebat et tria millia camelorum et quingenta paria boum et asinas quingentas et magnam praterea seruorum multitudinem itaque non uirtute tantum, sed opibus et auctoritate erat omnium hominum, qui terras illas ad orientem sitas incolebant, facile princeps.

Accedebat autem ad felicitatis cumulum quod filii erant inter se amore fraterno consentientes. Alii uero alios ad epulas frequenter inuitabant, ut ea epulandi consuetudine fortiore quodam amoris uinculo constringerentur. Primum quidem frater natu maximus, instructo conuiuio, fratres et sorores inuitabat. Reliqui deinde ordine idem faciebat. Sic autem alii alios amanter accipiebant ut orbem hilaritatis et laetitiae suae iucundum efficerent. At pater, postquam illam conuiuiorum conuersionem absolutam cernebat, antequam de integro filii epulas instaurarent, illos, sacris rite procuratis, expiabat. Itaque, mane surgens, pro liberorum numero uictimas caedebat easque in Dei honorem in ara flammis absumebat ut illius numen filiis propitium efficeret. Sollicitus enim erat ne filii, in illa epularum iucunditate et uini licentia, aliquid impium mente designarent uel maledictum aliquod in Deum conferrent, quo in se numen illius incenderent. Ad hunc igitur modum uir sanctus in magnis opibus et in omnium rerum affluentia uitam degebat, ut nulla nota insolentiae uel impietatis appareret, in nullam suspicionem flagitii uel iniquitatis uocari merito posset.

Accidit autem ut Satanas in Dei conspectu, quem nihil latere potest, constitutus (ut enim ab angelis sanctis, quibus ministris utitur, oculos numquam deiicit, ita scelerum etiam ministros agitat [18] et illos sibi seruire compellit) haec secum, ipso Domino quodam modo mentem illius commouente et instigante, loqueretur:

- Equidem orbem terrarum peragrando confeci et quacumque me contuli libere ingressus sum. Nihil est enim quod meis uiribus et potentiae possit obsistere. Omnes namque mortales sub meum imperium dicionemque subiunxi 
pudor, se escravizassem à sensualidade, e que, desprezando a lei de Deus, praticassem o engano, e que, violando a santidade da religião, adorassem a monstruosa superstição, e que por toda a parte tudo fosse inquietado pelo ódio e pela inveja e em todos os lados se cometessem assassínios.

Depois de com altivez assim discorrer, ocorreu-lhe o seguinte pensamento:

- Que se há-de fazer relativamente a Job, homem completamente contrário aos meus desígnios? É que nem consegui corromper a sua integridade, nem quebrantar a sua equidade, nem perverter a sua religiosidade, nem destruir a sua moderação. Porventura será possível? Existirá na Terra um homem capaz de enjeitar o meu senhorio? Que despreze o meu poderio? Que frustre as minhas maquinações? Hei-de acaso suportar, sem qualquer esperança de vindicta, uma desonra e desdouro tão grandes? E permitirei que fique impune e por castigar uma tamanha arrogância de um homem? De modo algum. É que, se passar por alto este seu atentado, existe o risco de que muitos, impelidos pelo seu exemplo, se desliguem de mim e cedam ao amor da piedade e aos poucos se abata o meu senhorio e acabe por ser destruído, com enorme ruína do meu prestígio. Por conseguinte, dando de mão a todos os outros cuidados, aplicar-me-ei exclusivamente a este de combatê-lo com as máximas forças, de pôr em campo todos meus recursos em ordem a quebrantá-lo e derrubá-lo, de, com o máximo esforço atacante, desviá-lo da sua atitude, para que não pareça que ele é o único a zombar de mim. Mas que posso levar a cabo pela força, uma vez que se encontra rodeado pela protecção de Deus? Com efeito, Job não persevera no seu desígnio e propósito porque é santo devido ao seu desvelo e vontade, mas cumpre os seus deveres e obrigações porque o próprio Deus o seduziu e aliciou com recompensas. Na verdade, enriqueceu-o e guarneceu com tão sólida defesa a sua posição e família que de forma alguma me é possível maquinar seja o que for em prejuízo deste homem. Acaso é virtude esta que, [19] não por própria e espontânea vontade, mas com recompensas e prémios o alicia ao zelo da santidade? Porventura não é uma espécie de negócio e um ofício que se representa por causa das mercês e se simula tendo em mira aumentar o património? Por isso, não vejo motivo para que Deus de tal maneira preze este homem que se empenhe em velar por ele com uma ajuda tão constante, a menos talvez que tenha pretendido comprar este amigo, para que não parecesse que na Terra a Sua religião fora completamente abandonada. Oxalá que me fosse dada a possibilidade de atacar este varão ensoberbecido com o vão louvor de santidade. Eu o atormentaria e atribularia com desgraças e acabrunharia com tantos males que num ápice perderia por completo a lembrança da santidade e lançaria insultos contra Deus e, ao cabo, daria a conhecer que tem um imenso amor, não pela virtude, mas pelos bens que se alcançam graças à simulação da virtude.

Isto dizia Satanás, coligindo-se das suas palavras que o seu poder é entravado pela providência de Deus e a extensão da sua possibilidade de fazer mal é aquela que lhe é consentida pela vontade e autoridade de Deus. Mas, como os desígnios de Deus se encaminham para a glória dos eleitos, acontece que, quando Deus vê que os ataques do inimigo têm por alvo abrilhantar a glória dos bons, frequentemente dá-lhe autorização para se lançar sobre a situação dos bons para que, por estes vencido e superado, se torne 
perfecique ut, pudore relicto, libidini seruirent; diuino iure neglecto, fraudes susciperent; religionis sanctitate uiolata, diram superstitionem colerent, et ubique omnia odio et inuidia turbarentur caedesque passim fierent.

Haec cum elate dissereret, occurrit illa cogitatio:

- Quid de Iobo, homine meis rationibus inimicissimo, fiet? Nec enim illius integritatem corrumpere, neque aequitatem inflectere, neque religionem contaminare, neque abstinentiam euertere quiui. Itane uero? Vnus homo erit in terris qui meum imperium detrectet? Qui meas opes contemnat? Qui meas machinas disturbet? Tantamne ignominiam atque dedecus, sine ulla spe uindictae, sustinebo? Tantamque hominis elationem inultam et impunitam patiar? Nullo modo. Si enim hoc illius facinus a me neglectum fuerit periculum est ne multi, exemplo illius incitati, a me desciscant pietatisque studium sequantur imperiumque meum paulatim labefiat et tandem, cum maximo meae dignitatis interitu, deleatur. Omnibus igitur aliis curis omissis, hanc unam suscipiam, ut illum summis uiribus oppugnem, ut omnes machinas meas ad illum conquassandum et disiiciendum admoueam, ut illius mentem, maxima belli contentione, a statu detorqueam, ne is solus mihi uideatur illudere. Sed quid efficere pugnando possum, cum Dei praesidio circumsaeptus sit? Nec enim Iobus quod sit studio atque uoluntate sanctus in proposito et consilio permanet, sed quod sit ab ipso Deo praemiis allectus et inuitatus pietatem colit. Illum enim opibus auxit, illius statum et familiam et possessiones tam firmo praesidio cinxit ut non possim ullo modo quidquam ad hominis perniciem machinari. Haecine uiri uirtus est quae [19] non sponte sua ad studium sanctitatis, sed praemiis et emolumentis allicitur? An mercatura quaedam et officium muneribus expressum et rei augendae gratia simulatum? Quare nihil uideo cur hic homo ita Deo cordi sit ut illum tam praesenti ope tuendum suscipiat, nisi fortasse hunc amicum pretio comparare uoluit, ne religio illius in terris omnino deserta uideretur. Vtinam mihi daretur facultas in hunc uirum inani laude sanctitatis elatum inuadendi. Ego profecto illum iactarem et incommodis afflictarem tantisque malis opprimerem ut memoriam repente totius sanctitatis abiiceret et in Deum contumelias intorqueret et ostenderet denique se non uirtutis, sed bonorum, quae uirtutis simulatione comparantur, amantissimum.

Haec quidem Satanas, ex quibus intelligitur potestatem illius Dei prouidentia impediri tantumque facultatis ad nocendum habere quantum illi, Dei consilio et moderatione, permittitur. Cum uero diuina consilia ad electorum gloriam referuntur, fit ut, cum Deus uidet hostis impugnationem ad bonorum gloriam illustrandam conducere, illi saepenumero potestatem faciat in statum bonorum irruendi ut, ab illis uictus atque superatus, fiat decoris et laudis eorum quos 
em instrumento da honra e louvor daqueles a quem se empenhou em destruir. Algo que então os factos comprovaram com toda a clareza. É que o Senhor, a fim de refutar a calúnia de Satanás e mostrar a força invencível da virtude e propor à imitação na vida um admirável exemplo de paciência e piedade, concedeu a Satanás a liberdade de usar o seu poder para destruir todas as riquezas de Job, concedeu-a todavia com a condição de que o monstruosíssimo inimigo de forma alguma poderia fazer mal ao corpo e saúde de Job.

Ao ouvir isto, o eterno inimigo do género humano exultou e deliberou fazer cair sobre o santo varão todas as desventuras ao mesmo tempo, porquanto se arreceava de que, se existisse algum intervalo entre as desgraças, cada uma das feridas atingiria o espírito do santo homem mais levemente do que se todas as feridas fossem infligidas simultaneamente. Em segundo lugar, logo que alguém perde uma única coisa, acontece que não sofre tanto com esse mal por causa da segurança que sente com aquelas comodidades que lhe restam, ao passo que, quando é despojado de repente de todos os bens, não fica com nada para fazer frente à violência da intolerável calamidade. Além disso, o costume de suportar os males um a um costuma criar calo contra a dor, de tal maneira que os restantes males que depois sobrevêm se suportam mais facilmente. Mas quando todos os males se abatem ao mesmo tempo sobre a situação do homem próspero e não lhe dão qualquer repouso, acontece que o espírito, atacado por todos os lados e oprimido por toda a espécie de incómodos recentes e repentinos, perde o discernimento e a prudência. Por conseguinte, pensando astutamente Satanás em tudo isto de si para consigo, decidiu acometer Job por tal forma que o obrigasse a, atribulado simultaneamente por todos os males e incómodos, lançar contra Deus algum insulto antes de poder reflectir e consultar a razão.

Ora, as coisas passaram-se assim. Correndo-lhe tudo assaz favoravelmente e celebrando os seus filhos um banquete na casa do irmão mais velho, eis que um mensageiro, sobremaneira perturbado, se dirige a Job e lhe diz:

[20] - Os teus bois encontravam-se a lavrar e as burras a pastar nos pastos do costume, quando de repente os Sabeus nos atacaram e nos roubaram as manadas e todas as burras e mataram os pastores e só eu escapei para te trazer uma notícia tão funesta.

Mal este acabara de falar, quando da mesma forma sobreveio outro dizendo:

- Um fogo caído do céu matou todos os rebanhos das tuas cabeças de gado e abrasou os pastores com o mesmo incêndio e só eu sobrevivi para te anunciar esta tamanha desgraça.

Ainda este não tinha acabado de narrar completamente aquela calamidade, quando do mesmo modo chegou outro e disse

- Os Caldeus, dispondo as tropas em três linhas, lançaram-se sobre os camelos e os roubaram, e trucidaram com as armas os seus pastores, e só eu escapei para te anunciar esta desgraça.

Mal este terminara de falar, quando se apresentou outro, consternado pela grandeza da desgraça, e disse:

- Eis que os teus filhos e filhas estavam a comer e beber na casa do irmão mais velho, quando de repente se levantou uma violenta tempestade e se precipitou sobre a casa e 
euertere conatur instrumentum. Quod tunc euentu facile comprobatum fuit. Dominus enim, ut Satanae calumniam refutaret roburque uirtutis inuictum ostenderet et mirabile patientiae atque pietatis exemplum in uita ad imitandum proponeret, Satanae uim uinculis laxauit ut omnes opes Iobi perderet, ita tamen laxauit ut illius corpus atque ualetudinem minime ab hoste immanissimo laedi permitteret.

Quod ubi hostis ille sempiternus generis humani sensit, exsultauit idque consilium iniuit ut omnibus simul ruinis uirum sanctum opprimeret, nam, si aliqua molestiae intercapedo fuisset, metuebat ne unumquodque uulnus leuius animum sancti hominis feriret, quam si omnia simul uulnera inflicta fuissent. Deinde, cum primum aliquis rei unius iacturam facit, euenit ut, eorum commodorum fiducia quae reliqua sunt, non ita dolenter id malum patiatur, at, cum repente omnibus bonis euertitur, nihil habet reliqui quo uim calamitatis intolerandae sustineat. Praeterea, consuetudo primi cuiusque mali perferendi callum dolori solet obducere, ita ut reliqua mala quae deinde accidunt leuius ferantur. At cum omnia simul mala in statum hominis florentis incurrunt nihilque laxamenti dant, euenit ut animus, undique oppugnatus et omnibus recentibus et repentinis incommodis oppressus, a mente et consilio deducatur. Haec igitur omnia Satanas astute secum recogitans, sic instituit aggredi Iobum ut, cunctis simul malis et incommodis afflictum, cogeret, antequam se recipere et rationem in consilium adhibere posset, aliquod in Deum maledictum iactare.

Ergo sic euenit. Cum essent illi res ualde secundae et illius liberi in domo fratris natu maximi conuiuium celebrarent, ecce nuntius, ad Iobum mirum in modum perturbatus accurrens, ait:

- Boues [20] tui arabant et asinae in solitis pascuis uersabantur, cum repente Sabaei nos adoriuntur et armenta et cunctas asinas abigunt et pastores ferro concidunt egoque solus euasi qui tam malum nuntium afferrem.

Vix hic orationem finierat, cum similiter alius interuenit dicens:

- Ignis e caelo demissus omnes pecudum tuorum greges confecit pastoresque tuos eodem incendio uorauit egoque solus tantae cladi superfui qui tibi malum hoc tantum annuntiarem.

Nondum hic satis illam cladem expsouerat, cum alius item uenit et ait:

- Chaldaei, triplici acie instructa, in camelos impetum fecerunt et illos captos abduxerunt illorumque pastores ferro contrucidarunt egoque solus euasi qui tibi malum hoc annuntiarem.

Vix hic orationem absoluerat, cum alius, magnitudine cladis exanimatus, ingreditur:

- Ecce filii, inquit, tui et filiae comedebant et bibebant in domo fratris natu maximi, cum repente uehemens tempestas excitata in domum irruit et angulos 
com o redemoinho derrubou os seus cunhais e destruiu os quartos e soterrou todos os teus filhos e filhas, e só eu escapei para te anunciar esta grande desgraça doméstica.

Depois de escutar estes mensageiros, Job levantou-se, rasgou a roupa e mandou que lhe rapassem a cabeça e, lançando-se no chão, adorou a Deus com palavras puríssimas. Depois pronunciou o seguinte

- Saí nu de dentro do ventre da minha mãe, da mesma maneira que devo ser sepultado nu no ventre e seio da terra, que também é minha mãe. O Senhor o deu; o Senhor, de acordo com a Sua vontade e poder, o retomou: que o Seu nome seja eternamente celebrado em todas as situações.

Nem sequer atingido por tão grandes desgraças o varão, extraordinário por um merecimento imortal de piedade, incorreu em culpa ou ultrajou a majestade de Deus com palavras inconsideradamente pronunciadas. Sem incorrer em qualquer acção culposa fez aquilo que era próprio da condição humana, quando, com todos os sinais de tristeza, deu mostras de estar abalado e abatido, mas cumpriu de forma singular os deveres da piedade ao não deixar que tão grandes procelas de males o movessem a perder o domínio sobre a razão ou a atribuir a Deus a culpa das injustiças. Por conseguinte, exprimiu como homem a violência da dor que o atribulava, e como varão de Deus manteve a firmeza no meio das maiores desgraças. E assim Satanás foi vencido e superado neste primeiro recontro.

Ora, aconteceu que, à vista de Deus, a quem nada se pode ocultar e que costuma servir-se também das obras de Satanás para Sua glória, o mesmo cruel inimigo dizia para consigo o seguinte, não sem o assentimento de Deus, que o induzia a causar maiores tribulações:

- Que faço? Para onde fui? De onde vim? Em que estado se encontra a minha situação? É certo que, por onde quer que viaje, vejo o meu reino aumentado e amplificado com muitos acréscimos, dou-me conta de que a Terra toda se acha sob o jugo do meu mando. Todavia um único homem faz frente a todo o meu poder e possui tamanha virtude e força que, ainda que o tenha combatido com enorme violência, mesmo assim conserva com a máxima constância a integridade, a equidade, a religiosidade e a moderação. Já não posso acusá-lo de simulação de piedade. Já de forma alguma é possível [21] destruir-lhe o louvor da virtude com a acusação de cobiça nem infamar a dignidade do homem, fazendo crer que honrava a justiça, não pelo zelo da santidade, mas tendo em mira os prémios e recompensas. Que é que deixei de tentar? Que pus de parte no ataque à sua firmeza? De facto, depois de a autorização me ter sido concedida pelo Senhor, que me obrigava a não lhe fazer mal, empreguei todas as minhas forças, pus em campo todos os meus exércitos e com a máxima diligência empreguei todo o meu poder - com o qual sem qualquer dificuldade sujeitei ao meu domínio toda a Terra - em abalar o espírito de um único homem e em derrubá-lo da sua firmeza, e com tamanho ímpeto me abalancei contra as suas coisas que em brevíssimo instante lhe ocasionei extraordinárias perdas. Acabei-lhe com a família; pilhei as suas manadas; devastei-lhe os rebanhos; esmaguei os filhos sob as ruínas da casa; de rico e opulento, reduzi-o à nudez e indigência; enfim, empreguei todas as minhas forças e maquinações para derrubá-lo, mas, não obstante, ele 
turbine conuellit et aedes disturbauit omnesque filios et filias tuas oppressit egoque solus euasi, qui tantum domestici mali tibi nuntiarem.

His nuntiis auditis, Iobus surrexit uestemque discidit et caput sibi attonderi iussit et, in terram abiectus, Deum oratione castissima ueneratus est. Hanc deinde sententiam protulit:

- Nudus quidem de utero matris meae egressus sum, nudus similiter utero atque gremio telluris, quae mater etiam mea est, condendus sum. Dominus donauit; Dominus, pro iure suo et imperio, repetiuit: nomen illius, in omni rerum euentu, sempiterna praedicatione celebratum.

Ne his quidem tantis cladibus affectus uir, ad immortalem laudem pietatis insignis, ullum in se crimen admisit aut Dei numen uerbo temere emisso uiolauit. Quod erat humanitatis sine ullo peccato praestitit, cum omnibus maestitiae signis se perculsum et stratum ostendit, officio uero pietatis egregie functus est, cum neque tantis malorum tempestatibus commoueri potuit ut de mentis statu demigraret aut Deo culpam iniquitatis affingeret. Vt homo igitur uim doloris, qui illum cruciabat, expressit; ut uir diuinus constantiam in maxima calamitate retinuit. Itaque in hac prima congressione Satanas uictus atque superatus est.

Accidit igitur ut in Dei oculis, quem nihil latere potest et qui ad gloriam suam Satanae etiam operis uti solet, haec secum idem hostis importunus, non sine Dei numine, mentem illius ad grauiorem cruciatum commouente, loqueretur:

- Quid ago? Quo profectus sum? Vnde redii? Quo in statu res meae sunt? Regnum quidem meum, quacumque iter institui, multis accessionibus auctum et amplificatum uideo uniuersasque terras imperio meo coerceri perspicio. Vnus tamen homo contra omnes opes meas pugnat tantumque uirtute atque robore ualet ut, cum sit a me nimis acriter oppugnatus, integritatem tamen et aequitatem et religionem et abstinentiam summa constantia retineat. Iam non possum illi simulationem pietatis obiicere. Iam non licet [21] ullo modo laudem uirtutis in illo criminatione cupiditatis obterere et, quasi non studio sanctitatis, sed mercede et praemio iustitiam colat, hominis dignitatem ignominia deformare. Quid non temptaui? Quid in illius statu impugnando praetermisi? Facta namque mihi potestate a Domino, qui me constrictum ne illi nocerem tenebat, uires omnes meas excitaui, copias omnes meas instruxi meamque potentiam, qua orbem terrarum mihi facillime subdidi, ad unius hominis animum labefactandum atque de statu conuellendum summo studio comparaui, tantoque impetu in res illius inuasi ut temporis momento miras strages ediderim. Exstinxi familiam; armenta diripui; greges absumpsi; filios ruina domus oppressi; ex diuite et opulento, nudum et inanem constitui; omnes denique uires et machinationes meas in illo euertendo consumpsi: ille tamen nihilominus eodem statu manet neque, tantis incommodis uexatus, a studio sanctitatis abducitur. Omnes igitur conatus mei ad nihilum ceciderunt. 
persevera na mesma firmeza e nem avexado por tão grandes contrariedades se afasta do zelo da santidade. Em conclusão, todos os meus esforços redundaram em coisa nenhuma.

Que hei-de fazer então? Suportarei este tão grande desdouro e desprestígio do meu poder? É impossível. Atacá-lo-ei de novo e, aquilo que não consegui fazer na primeira tentativa, talvez o leve a cabo empreendendo nova arremetida. Mas que deixei de fazer que seja agora capaz de abatê-lo e arruiná-lo? Hei-de destruir-lhe os rebanhos e lavoiras, que por completo se perderam? Hei-de matar-lhe os filhos, que já foram enterrados? Hei-de despojar das riquezas quem por obra minha foi esbulhado num mesmo momento de todas as riquezas? E assim a sua completa penúria tira-me toda a esperança de o abater e garante-lhe uma vitória certa.

Todavia, resta-me uma coisa que, se me for permitido atacar, é provável que consiga levar inteiramente a cabo o meu propósito. Qual é ela? - A integridade de um corpo assaz são e robusto. Ora, de que maneira beneficiarei? Porventura este homem que, depois de perdidas as riquezas - as quais, uma vez desaparecidas, tiram aos homens qualquer razão para quererem continuar vivos -, apesar de tudo manteve o espírito puro do contágio de toda a espécie de mancha, é de acreditar que perca a firmeza depois de enfraquecido pelas enfermidades corporais? Este homem que nem sequer pela inopinada perda de todos os filhos, a cada um dos quais amava como a si mesmo, ficou transtornado a ponto de proferir alguma palavra impiedosa, é de esperar que, atribulado pelas incomodidades do corpo, cometa algum acto sacrílego contra Deus? De qualquer maneira, ainda que tal não seja verosímil, mesmo assim não se deve pôr de parte a esperança na vitória. É que, embora Job estimasse e se agradasse assaz de tudo quanto perdeu, todavia nada the era mais estimável do que a sua pessoa, porquanto a natureza moldou os homens de tal sorte que antepõem a vida e o estado saudável do corpo a todas as comodidades da existência. Por conseguinte, de tal maneira está longe de existir algo que eles estimem mais do que a si mesmos que facilmente sacrificam todas as coisas que mais amam a troco de, com a perda delas, conservarem a sua vida. E não só qualquer um suportará a perda dos bens e a morte dos filhos, desde que se conserve a si mesmo, mas igualmente, se o risco de vida tal exigir, oferecerá parte do corpo para ser amputada, por forma a que lhe seja possível de alguma maneira desfrutar da vida com as partes que lhe restam. Daqui se conclui que [22] para os homens nada há de mais agradável do que a saúde corporal e a vida. Pelo que não causa qualquer espanto que esse varão não tenha podido ser quebrantado e debilitado pelas maiores desventuras, uma vez que o seu corpo se manteve íntegro e são por entre o destroço de tudo o mais. Oh se me fosse permitido atacar o seu corpo, como me seria fácil derribá-lo da determinação que se propôs! Teria a plena certeza de que, atribulado pela dor, haveria de ofender a majestade de Deus com algum insulto.

Tendo-se o Senhor dado conta de tudo isto, a fim de que se pudesse ver com toda a clareza que Satanás não tem qualquer poder contra a virtude protegida pela defesa divina, concedeu ao perversíssimo inimigo o poder de se arrojar contra o corpo do santo varão e atormentá-lo com as enfermidades mais molestas, com a condição todavia de não lhe tirar a vida. Portanto, Satanás preparou-se e atormentou com a doença o corpo 
Quid ergo? Hoc tantum imperii mei dedecus et ignominiam sustinebo? Fieri non potest. Illum rursus aggrediar et quod primo impetu facere nequiui, fortasse certamine rursus inito conficiam. Sed, quid illi reliquum feci, quod nunc euertere atque delere possim? Rem illius pecuariam et rusticam uastabo, quae funditus interiit? Filios illius trucidabo, qui iam sepulti sunt? Illum opibus exspoliabo, qui mea opera cunctis simul opibus euersus est? Itaque extrema illius inopia mihi spem omnem illius labefactandi praecidit et illi certam uictoriam pollicetur.

Vnum tamen restat, quod si mihi attingere liceret, forsitan negotium totum conficerem. Quid illud est? Corporis bene sani atque ualentis integritas. Quid autem proficiam? Isne qui, amissis opibus, quibus sublatis nihil est cur homines in uita manere uelint, animum tamen ab omni labis contagione purum conseruauit, credibile est ut, corporis morbo debilitatus, a constantia discedat? Is qui ne repentina quidem omnium filiorum strage, quorum singulos aeque atque se ipsum diligebat, commoueri potuit ut aliquod uerbum impium emitteret, sperandum est ut, corporis incommodo uexatus, aliquod facinus in Deum immane suscipiat? Verum enimuero, ut id uerisimile sit, uictoriae tamen spes minime deponenda est. Vt enim illa omnia, quae Iobus amisit, fuerint illi cara atque periucunda, nihil tamen umquam se ipso carius habuit, sic enim sunt homines a natura instituti ut uitam et corporis integrum statum omnibus uitae commodis anteponant. Tantum igitur abest ut quidquam sit quod pluris quam se ipsos aestiment ut etiam omnium rerum carissimarum facile iacturam faciant, ea compensatione ut uitam suam, earum interitu, ab interitu redimant. Neque solum quilibet et bonorum amissionem et filiorum mortem ea condicione sustinebit ut se ipsum seruet, uerum etiam, cum id uitae periculum flagitauerit, partem corporis secandam praebebit ut cum reliquis partibus uita frui quomodocumque liceat. Ex quo liquet nihil [22] hominibus esse corporis sanitate atque uita iucundius. Quare minime mirum est uirum istum in maximis incommodis minime frangi atque debilitari potuisse, cum corpus illius integrum atque sanum in aliarum rerum omnium calamitate permanserit. O si mihi liceret in illius corpus inuadere, quam facile illum a constituta sententia depellerem! Confiderem certe futurum ut is, dolore cruciatus, aliquo maledicto Dei numen offenderet.

Haec cum Dominus animaduerteret, ut clare cerni possit nullas uires habere Satanae potentiam contra uirtutem diuino praesidio saeptam, hosti perditissimo potestatem concessit ut in sancti uiri corpus irrueret illudque morbis molestissimis affligeret, ea tamen lege ne illi uitam auferret. Accinxit igitur se Satanas et Iobi corpus morbo oppressit illudque a capite ad pedes usque putrida nimis scabie 
de Job e desfigurou-o da cabeça aos pés com terríveis pústulas e úlceras putrefactas. E assim, atormentado o santo varão por pungentíssimas dores e por um prurido muitíssimo doloroso, frequentemente limpava com um caco de telha o pus que corria das pústulas e úlceras, e, para extinguir o prurido e limpar o pus, era para ele alívio, no meio de tão grandes tormentos, ferir mais intensamente com o caco a pele e as pústulas abertas, e, para depois provocarem maior dor, torná-las a raspar com a mão. Além disso, jazia no muladar e, com toda a postura do corpo, revelava o extraordinário comedimento e a inabalável paciência de um espírito fora do comum. Mas entretanto a mulher dele proferia insolências no meio de tamanhas desgraças, dizendo:

- Foi este porventura o fruto da tua piedade? Foi esta a utilidade que trouxeram aos teus trabalhos tão grande número de anos consagrados à religiosidade? Era esta a esperança em que te fundavas quando, pondo de parte todos os outros cuidados, trabalhavas com todo o empenho e afã unicamente em aplacar a Deus mediante a piedade e a justiça? Já te dás conta de quão grande foi a loucura que te dominou e do grande desconhecimento das coisas em que viveste? E mesmo assim, ainda que a realidade te tenha mostrado que nem a santidade nem a justiça nem a virtude são úteis para um tipo de vida afortunada, nem para construir com fundamento seguro uma condição próspera, a tal ponto és louco que sem qualquer proveito conservas a virtude? Até quando persistirás num semelhante desvario? Até onde hás-de perseverar no zelo completamente inútil da religião? Qual o prémio que recebeste de Deus em paga do santíssimo culto que Lhe prestaste? Foi este: deu os bois e os camelos aos teus inimigos; destruiu com raios as tuas ovelhas; aos teus escravos matou-os, a uns à espada, a outros com o fogo; acabou com os teus filhos através de um género de morte muito desafortunado; e a ti, não só te privou de todos os bens e te deixou nu e pobre, mas também te infectou o corpo inteiro com uma moléstia pestilenta e o manchou com úlceras purulentas e por todas as vias mostrou o grande ódio que sente por ti. E, mesmo assim, a tal ponto estás privado de entendimento que achas que deve ser adorado com o máximo amor Aquele mesmo que te causou tantas calamidades... Por que é que não bradas? Por que é que não gritas? Por que é que não te queixas com altíssimos berros da injustiça contra ti cometida? Por que é que não te lastimas sem cessar, a fim de, pelo menos através dos gemidos e dos justos queixumes, diminuíres um pouco da dor que te atribula e dar vazão ao descontentamento? Mas retrucarás que [23] abafas a voz a fim de não incorrer no desagrado de Deus. Pergunto: que te resta na vida que Ele te possa tirar, se te for muitíssimo hostil? Responder-me-ás que a vida. - É certo. Porque é tal a tua vida que na sua duradoira conservação se deve colocar a suprema felicidade... Porventura não seria preferível afrontar mil vezes a morte a viver no meio de tantas dores e padecimentos? Por isso julgo que deves dizer mal de Deus, para que, irado com este ultraje, Ele te mate. É que, se te privar dessa vida mofina não te estará a ferir com nenhum mal, mas libertar-te-á do tormento de todos os males com que és atribulado.

Depois que, incitada pelos enganos de Satanás, a mulher pronunciou estas palavras, Job refutou-lhe o desvario com o seguinte discurso:

- Essas espantosas palavras que proferiste demonstram claramente que és a mais louca de todas as mulheres. Que dizes? Não compreendes que somos servos daquele supremo 
ulceribusque grauissimis deformauit. Itaque uir sanctus, doloribus maximis et pruritu molestissimo cruciatus, saniem, quae ex pustulis et ulceribus emanabat, testa frequenter abstergebat, et hoc erat illi, in tantis cruciatibus, alleuamentum, ut pruritum exstingueret et saniem extergeret, exulcerare grauius testa cutem et inusta uulnera, ut maiorem dolorem deinde efficerent, manu refricare. In sterquilinio autem desidebat et omni corporis habitu singularem excellentis animi moderationem et inuictam patientiam declarabat. Vxor uero illius interim in tantis calamitatibus insultabat:

- Hicne, inquit illa, pietatis tuae fructus exstitit? Hancine utilitatem tot anni in religione consumpti laboribus tuis attulerunt? Haec erat illa spes qua nitebare dum, aliis curis omissis, de Deo tantum pietate atque iustitia placando omni studio et contentione laborabas? Cernisne iam quanta te oppresserit amentia et in quanta rerum ignoratione uersatus sis? Et tamen, cum rerum euentu exploratum tibi sit neque sanctitatem neque iustitiam neque innocentiam utilem esse ad beatae uitae rationem et ad florentem statum ope firma muniendum, adeo stultus es ut innocentiam sine ullo fructu retineas? Quousque tandem in eadem amentia persistes? In quem finem in uanissimo religionis studio perseuerabis? Quod praemium a Deo propter illius sanctissium cultum percepisti? Illud scilicet: boues et camelos hostibus tuis tradidit; oues fulminibus absumpsit; seruos partim gladio, partim incendio confecit; filios tuos funestissimo genere mortis exstinxit; te non solum omnibus rebus orbatum et nudum et inanem destituit, sed etiam totum corpus tuum tabe pestifera infecit et purulentis ulceribus inquinauit omnibusque rebus ostendit quanto odio tui duceretur. Et tamen adeo mentis expers es ut illum summo studio colendum putes qui tantum tibi calamitatis inuexit... cur non uociferaris? Cur non inclamas? Cur non maxima uoce de iniuria tibi illata conquereris? Cur, ut gemitu saltem et iusta querimonia aliquid de dolore, qui te premit, imminuas et indignationi satisfacias, non assidue lamentaris? Sed dices te [23] ideo uocem comprimere ne in Dei offensionem incidas. Quid tibi, quaeso, reliquum est in uita quod ille tibi possit, si tibi maxime fuerit infestus, eripere? Vitam, dices. - Recte. Ea namque uita tua est, in cuius diuturna conseruatione summa felicitas collocanda sit... An non praestaret mortem milies oppetere quam uitam in tanto dolore et acerbitate traducere? Quare censeo ut Deo maledicas ut, eo conuicio irritatus, necem tibi confestim afferat. Si enim te uita ista miserrima priuauerit nullo te malo afficiet, sed malorum omnium, quibus opprimeris, supplicio liberabit.

Haec cum mulier, Satanae fraudibus incitata, perorasset, Iobus illius amentiam hac oratione compressit:

- Ista uerborum portenta quae protulisti te certe mulierem omnium dementissimam esse declarant. Quid ais? Non intelligis nos esse seruos illius 
Senhor que tudo governa com suma inteligência e equidade? Tu hás-de impor-Lhe leis? Tu hás-de prescrever-Lhe, quase a teu talante, o modo como deve servir-se das Suas coisas? Naturalmente, há-de proceder com benignidade ou infligir golpes de acordo com a tua vontade... Porventura não Lhe consentirás que orne com benefícios aqueles a quem Lhe aprouver e atribule com dores aqueles a quem quiser? Por conseguinte, se quando Ele nos cumulava de todos os bens experimentámos com alegria a Sua benignidade, agora, quando nos fere com o Seu rigor, por que não suportamos com ânimo igual a Sua determinação?

Com palavras tais o santo varão refutou a loucura da esposa e, em meio de todas aquelas procelas de males, de tal maneira refreou a sua língua que não deixou sair da boca nenhuma palavra impiedosa.

Ora, tinha estreitíssima amizade com três homens, cada um dos quais detinha o poder na sua cidade. Um deles chamava-se Elifaz de Teman, o segundo Bildad de Chua e o terceiro Sofar de Naamá. Estes, embora habitassem em lugares apartados, todavia ao tomarem conhecimento dos grandes males que sobre ele se abateram, decidiram, através de mensageiros enviados a uns e outros, reunirem-se num único lugar com o propósito de visitá-lo. Foram, por conseguinte, ter com ele e tendo-o visto de longe não o reconheceram. Ao aproximarem-se, porém, e ao verem que o amigo que tinham conhecido abundante de bens e colocado na mais alta posição, jazia no pó, golpeado por tantas feridas e com uma aparência tão sinistramente desfigurada, soltando clamores lamentaram-no dolorosamente e cada um deles, como mostra de desgosto, deixou cair cinza sobre a cabeça.

Em seguida, sentaram-se com ele no chão durante sete dias e sete noites, sem pronunciar palavra. É que, uma vez que a violência da dor recente se mantinha tão forte, que era impossível aliviá-la com palavras, não parecia adequado mitigá-la com elas, a fim de não aumentarem a dor se aplicassem o remédio da palavra fora de tempo. Mas entretanto a dor não diminuía, mas agravava-se de dia para dia e a violência das feridas atormentava o homem mais encarniçadamente e ele não tinha consolação alguma que pudesse aliviar parcialmente a angústia de cuidados muito molestos, visto que até aquela alegria espiritual, que colhia do trato íntimo com o Espírito divino, lhe foi completamente roubada para acréscimo do tormento, consoante se pode colher das suas palavras. [24] E assim, movido pela violência de dores intoleráveis, gritou e amaldiçoou com terríveis imprecações o dia em que nasceu. Por isso disse:

- Seja maldito o dia em que nasci e seja também execrada a noite em que de mim se disse que tinha nascido um varão. Que aquele dia se cubra de trevas, que seja apagado dos fastos do altíssimo Senhor e o resplendor da luz o não ilumine. Que as trevas o manchem, sombras mortíferas o envolvam, as nuvens o obscureçam e o assoberbem com espantos nocturnos e amargores diurnos. Que seja tido na conta de noite, e não de dia, e recoberto de densíssimas trevas; que não seja numerado entre os dias do ano nem arrolado no número dos meses. E até que a própria noite seja privada de todos os bens e que nela não se escute voz alguma de júbilo e de manifestação de alegria. Que a abominem 
summi Domini qui omnia summo consilio et aequitate moderatur? Tu illi leges impones? Tu illi quemadmodum rebus suis utendum sit, quasi pro iure tuo, praescribes? Arbitratu scilicet tuo uel benigne faciet uel plagas imponet... An non licebit illi, per te, quos ei uisum fuerit ornare beneficiis et, quos uoluerit, poenis affligere? Si igitur cum is nos bonis omnibus cumulabat benignitatem illius cum gaudio experti fuimus, cur nunc, cum nos seueritate sua plectit, non illius iudicium aequo animo subeamus?

Eiusmodi uerbis uir sanctus uxoris amentiam refutauit et, in omnibus illis malorum fluctibus, ita linguam suam refrenauit ut nullum uerbum impium ex ore illius excideret.

Fuerunt autem illi tres amici amore summo coniuncti, quorum singuli in ciuitatibus suis principatum obtinebant. Vni ex illis nomen erat Heliphazius Themanita, alteri Bildadus Suhita, tertio Sopharus Nahamathita. Hi, quamuis in locis disiunctis habitarent, cum tamen accepissent quantis in malis ille uersaretur, nuntiis ultro citroque missis, statuere ut in unum locum, illius uisitandi gratia, conuenirent. Ad illum igitur se contulere, quem, cum e longinquo adspexissent, minime cognouere. At propius accedentes, cum uidissent hominem amicum, quem opibus florentem et in summo gradu dignitatis locatum agnouerant, tantis ictum uulneribus et tam lugubri habitu deformatum in puluere iacentem, sublatis clamoribus, acerbissime lamentati sunt et eorum quilibet, ad maeroris indicium, caput suum puluere in altum iactato conspersit.

Septem deinde dies et totidem noctes humi cum illo sedentes nullum uerbum fecerunt. Nec enim maturum uidebatur, cum tanta uis recentis doloris exsisteret ut uerbis leniri non posset, uerborum solacium adhibere, ne, si alieno tempore remedium orationis applicarent, dolorem augerent. At interim dolor nihil remittebat, sed in dies ingrauescebat et ardor ulcerum uehementius hominem excruciabat, nec is solacium ullum habebat quo molestissimae cogitationis angore aliqua ex parte leuaretur. Siquidem illa etiam iucunditas animi, quam ex diuini Spiritus familiaritate capiebat, ad maius supplicium, ut ex illius oratione coniici potuit, omnino detracta fuit. [24] Itaque, doloris intolerandi ui stimulatus, exclamauit diemque natalem suum diris imprecationibus detestatus est. Ait igitur:

- Nefastus ille dies sit quo natus sum et item nox illa sit diris obnoxia qua dictum est de me marem editum fuisse. Dies ille tenebricosus sit, ex altissi Domini fastis eximatur nec illius splendore collustretur. Contaminent illum tenebrae, sit umbris mortiferis inuolutus, nubes illi offusae sint eumque terroribus nocturnis et diurna acerbitate conficiant. Pro nocte, et non pro die, numeretur; densissimis tenebris oppleatur; in diebus anni non censeatur et in numero mensium minime computetur. Quin etiam nox ipsa bonis omnibus orbata sit nec ulla uox in illa laeti clamoris et exsultationis audiatur. Exsecrentur illam qui, maerore perditi, 
os que, mergulhados no desgosto, costumam abominar o dia em que nasceram com constantes imprecações, os que são atribulados pelas injustiças e cujos rogos impeliram Leviatã, com autorização do Juiz supremo, a, como um verdugo e algoz e punidor dos crimes, atacar aqueles que afligem os homens fracos e inocentes. Por conseguinte, peço que da mesma maneira que se aplicaram e ratificaram aqueles castigos, que as vítimas da injustiça irrogaram sobre aqueles por quem foram prejudicadas, da mesma forma caiam sobre aquela noite todos os males com que foi amaldiçoada. Que a sua cerração vele com trevas as estrelas, que espere a luz, e dela se aparte todo o resplendor da luz e não possa ver o brilho do nascer da aurora, pois não fechou a saída do ventre que me encerrava por forma a que de lá eu não saísse vivo, nem com a morte me arrancou das penalidades que cercam a minha vida. Por que é que não fui aniquilado pela morte no mesmo instante em que a minha mãe me deu à luz? Por que é que não morri no preciso momento em que fui parido? Oh vão desvelo daquela que primeiro pegou em mim ao colo e me apresentou os seios para que eu mamasse! É que não há dúvida que, se eu então tivesse morrido, agora jazeria tranquilo e, adormecido num sono salutar, gozaria duma quieta paz. Desfrutaria de uma condição igual à dos reis e governantes que fundaram cidades nos desertos para memória dos seus nomes, e que não obstante foram todos devorados pela morte. Teria experimentado a mesma sorte que experimentaram os grandes senhores, ensoberbecidos e altivos com os tesouros de ouro e prata escondidos em casa, mas aos quais todavia a violência da dura morte suprimiu a vida. Obscuro e ignorado assim tivesse sido apartado das moléstias da vida, como aqueles que, abortados pelas mães, morreram antes de terem podido contemplar a luz.

É que a morte iguala a riqueza de todos; acaba com todas as diferenças; consome com uma e a mesma força todas as coisas humanas. É ela que acaba com as turbas constituídas pelos homens ímpios e malfeitores; ela que extingue as forças dos que se ensoberbecem com o vigor, por forma a impedi-los de impor aos homens fracos trabalhos totalmente intoleráveis. Do mesmo modo os presos, depois de sobrevir a morte, descansam e deixam de escutar a voz do impiedoso credor. Tanto os obscuros e de baixa condição como os nobres e colocados em elevada posição caíram esmagados pela mesma violência da morte, e os escravos alcançaram a liberdade graças à morte. Por consequência, por que é que Deus concedeu o gozo da luz àquele que é atribulado por penas e prolonga a vida aos que são devorados por moléstias e angústias? É que estes esperam a morte quase como um refúgio dos males, [25] mas ela não vem; buscam-na quase como um tesouro, mas não podem alcançá-la. Decerto que exultariam de contentamento e se encheriam de alegria nada pequena se pusessem os olhos no sepulcro. Os outros, porém, que são atribulados pelos males comuns da vida, não têm motivo para desejarem tão ardentemente morrer. Mas eu, homem fortemente atribulado, a quem, aos restantes pesares, acresceu também o mal de ignorar o motivo da minha desgraça e não poder descobrir a razão pela qual Deus decidiu atingir-me, e a quem o próprio Senhor de tal maneira fechou o caminho da salvação que nela não posso entrar: eu acho que devo pedir mais ardentemente a morte. De facto, não pode dizer-se que me jactava das minhas prosperidades de forma imoderada e, como tudo corria a meu contento, me ensoberbecia insolentemente, e que 
diem suum natalem ratis imprectionibus exsecrari solent, qui iniuriis afflicti sunt et quorum precibus excitatus Leuiathan, summi iudicis permissu, tamquam tortor et carnifex et ultor scelerum in eos inuadit, qui tenues homines et innocentes affligunt. Id igitur opto ut, similiter atque rata atque fixa sunt ea quae homines iniuria oppressi illis imprecantur a quibus laesi sunt, ita mala omnia quae fuerint imprecati in illam noctem incurrant. Caligo illius tenebras stellis obducat, exspectet lucem et omnis ab illa splendor lucis abscedat lumenque orientis aurorae intueri non possit, non enim occlusit ostia uentris qui me continebat, ne ex eo uiuus exirem, neque morte me ab aerumnis, qui uitam meam circumuallant, abstraxit. Cur non, simul atque me mater enixa est, morte deletus sum? Cur non, ubi primum in lucem editus sum, confestim interiit? O illius inanem sedulitatem quae me primum genitus excepit et mammas admouit ut suggerem! Certe enim, si tunc a uita discessissem, nunc quietus iacerem et, somno salutari consopitus, tranquilla pace fruerer. Eadem condicione fuissem qua reges et rerum publicarum moderatores, qui urbes in solitudinibus, ad sui nominis memoriam condiderunt, qui tamen omnes morte consumpti sunt. Eumdem casum subiisem quem subiere principes, auri et argenti thesauris, domi reconditis, elati et inflati, quorum tamen uitam uis importuna mortis exhausit. Sic obscurus et ignotus, a uitae molestiis abductus fuissem ut illi qui, abortu matrum in terram eiecti, prius quam lucem adspicere potuissent, spiritum ediderunt.

Mors enim omnium fortunas exaequat; omnium rerum discrimen tollit; una eademque ui omnes res humanas absumit. Ea finem affert turbis, quas homines impii atque nocentes efficiunt; ea uires exstinguit eorum qui robore tument, ne possint imbecillis hominibus labores minime ferendos imponere. Similiter uincti, oblata morte, conquiescunt neque uocem acerbi creditoris audiunt. Tam humiles et obscuri quam nobiles et in alto gradu locati eadem ui mortis oppressi conciderunt, et serui mortis beneficio in libertatem em uindicati sunt. Quid igitur Deus lucis usuram concedit illi qui premitur aerumnis et uitam eis prorogat qui molestiis et angoribus exeduntur? Mortem enim quasi malorum perfugium [25] exspectant, at illa non comparet; eam quasi thesaurum exquirunt, ea tamen potiri non possunt. Certe laetitia exsultarent et non mediocri gaudio afficerentur si sepulcrum oculis adspexissent. At alii, qui communibus uitae malis afflictantur, non est cur tantopere mortem obire desiderent. Mihi uero, homini uehementer afflicto, cui, ad alias aegritudines, hoc etiam malum accedit, quod uiam meae calamitatis ignoro et rationem, qua me Deus plagis affligere constituit, explorare nequeo, et cui Dominus ipse ita uiam salutis intersaepsit ut illam inire non possim, mortem ardentius optandam iudico. Non enim hoc dici potest quod in meis rebus secundis immoderate iactabor et, cum omnia mihi ex animi sententia procederent, insolentius efferebar et ideo fuisse me propter hanc temeritatem et insolentiam de uitae dignitate deiectum. Semper enim humanae imbecillitatis 
por isso, devido a este descomedimento e irreflexão, fora despojado deste alto teor de vida. É que, sempre lembrado da fraqueza humana, tinha presente os acasos incertos e variados da vida. Por isso, antes de ingerir alimento, gemia, e os suspiros que soltava com grande abundância de lágrimas indicavam a violência da inquietação em que vivia. É que não estava tão confiante nas minhas coisas, como se tivesse a certeza de que haviam de perseverar sempre no mesmo estado, a ponto de me ensoberbecer apoiado nesta confiança. Mas agora, embora me submetesse com a máxima sujeição para não desagradar a Deus com soberba de entendimento, mesmo assim arremessaram-se contra mim todos os males de que me arreceava. Nunca me julguei feliz; nunca as minhas riquezas me provocaram arrogância; nunca o meu espírito se aquietou com as comodidades desta vida e, mesmo assim, a ira do Senhor arrojou-se contra mim como se eu fosse um homem inconsiderado e insolente.

Com estas palavras Job lamentou-se aos seus amigos da sua desgraça. Nelas, todavia, expôs, não a fé abalada, mas atacada, nem a razão abatida, mas posta à prova, não a virtude derrotada e perdida, mas sujeita a um ataque violentíssimo, e mostrou, não tanto aquilo que o entendimento pensava, quanto aquilo que sentia aquela parte do espírito que está sujeita às sensações de dor e de prazer. Com efeito, os homens santos geralmente costumam expor verbalmente, não apenas a firmeza da virtude com que se encontram fortificados, mas igualmente os pensamentos muito pungentes com que a mesma virtude é posta à prova. Algo que os amigos que se tinham sentado ao seu lado avaliaram de modo muitíssimo diferente, porquanto pensavam que, abatido pelo desespero, ele perdera o ânimo. Além disso, indignaram-se sobremaneira, por um lado pelas restantes maldições que lançara sobre o dia em que nasceu, por outro pela insolência daquelas palavras com as quais, consoante eles cuidavam, Job atestava que não compreendia a razão pela qual Deus o atribulava assim, como se Deus lhe tivesse infligido aquele castigo sem qualquer motivo. Por isso pareceu-lhes altamente censurável tanto o desvario da sanha com que, consoante pensavam, ultrajara Deus com aqueles insultos, quanto a pomposidade do discurso com que insolentemente se atribuíra a si a santidade da justiça, do mesmo passo que, conforme julgavam, acusava Deus. Por conseguinte, um de entre eles, a saber Elifaz, retorquiu do seguinte modo:

- Receio ser-te desagradável se disser aquilo que sinto, mas quem poderá reprimir durante muito tempo com o silêncio e a mudez aquilo que o espírito considera recto? Por isso, que a voz e as palavras irrompam enfim livres, de modo a proporcionarem um remédio salutar, [26] ainda que cause dor a alguém. É certo que com os teus ensinamentos instruíste muitos, fortificaste e animaste inúmeros aflitos, com o poder e eficácia da palavra levantaste muitos prostrados, com as tuas exortações fortaleceste o ânimo abatido de não poucos, e agora, mal a desgraça se lançou sobre ti, sucumbiste à dor e, assim que o mal te feriu, perturbado pela dor perdeste o ânimo. Por conseguinte, tu que ajudavas os outros, por que razão desertas de ti mesmo? Tu que davas aos outros o remédio nas adversidades, por que razão não consegues para ti mesmo ajuda na desgraça? Tu que incitavas os outros, por que razão não te sujeitas a viver durante mais tempo abatido e 
memor, uarios et incertos uitae casus animo reputabam. Idcirco antequam cibum sumerem gemitus edebam et suspiria, cum ingenti copia lacrimarum emissa, uim sollicitudinis, in qua uersabar, indicabant. Non enim rebus meis, quasi mihi esset exploratum eas eodem semper statu mansuras, confidebam ut, ea confidentia nixus, insolescerem. Nunc uero, quamuis me summa ope submitterem, ne Deum elatione mentis offenderem, omnia tamen mala quae metuebam in me inuecta sunt. Numquam me felicem iudicaui; numquam opes meae mihi spiritus attulerunt; numquam in huius uitae commodis animo conquieui, et tamen ira Domini in me, quasi in hominem temerarium et insolentem, inuasit.

Hac quidem oratione Iobus calamitatem suam apud amicos deplorauit. In qua tamen non fidem labefactatam, sed impugnatam, non rationem euersam, sed in angustias adductam, non uirtutem perditam et afflictam, sed acerbissima contentione uexatam exposuit, neque tam quid mens ipsa decerneret, quam quid animi pars illa sentiret, quae est sensibus doloris atque uoluptatis obnoxia, declarauit. Solent enim plerumque sancti homines, non solum uirtutis constantiam qua sunt communiti, sed etiam cogitationes acerbissimas, quibus uirtus ipsa temptatur, uerbis explicare. Quod quidem longe secus amicus, qui illi assidebant, existimarunt, putabant enim illum, desperatione fractum, de statu concidisse. Praeterea indigne admodum passi sunt, cum reliqua maledicta, quae in diem natalem contulerat, tum illius orationis, ut arbitrabantur, insolentiam, qua testificabatur non tenere rationem, qua Deus ita illum afflixisset, quasi sine ullo merito suo fuisset a Deo in poenam illam detrusus. Vtrumque igitur illis maxima uituperatione dignissimum uisum est, et iracundiae furor qua in Dei contumeliam, ut opinabantur, maledicta illa contulerat, et orationis magnificentia qua sibi iustitiae sanctitatem cum Dei, ut iudicabant, accusatione insolenter arrogauerat. Vnus igitur ex illis, Heliphasius nempe, in hanc sententiam respondit:

- Vereorne si quid sentio elocutus fuero tibi molestus sim, sed rectum animi sensum quis diu poterit silentio et taciturnitate comprimere? Erumpat igitur aliquando libera uox et oratio ut medicinam salutarem [26] afferat, quamuis aliquem dolorem efficiat. Multos tu quidem disciplinis tuis instruxisti; multis afflictis robur atque uires attulisti; multos iacentes ui et copia orationis erexisti; multorum animos languentes cohortatione tua confirmasti: et nunc, cum primum in te calamitas inuecta fuit, dolori succubuisti et, simul atque malum te perculit, dolore perturbatus, animum abiecisti. Qui igitur alios sustentabas, cur te ipsum deseris? Qui aliis in rebus aduersis remedium adhibebas, cur tibi ipsi opem in calamitate non comparas? Qui alios excitabas, cur te stratum et abiectum diutius esse pateris? An non est ualde pudendum ei, qui aliis opem ostentat, ipsum sibi opitulari non posse? 
aniquilado? Porventura não é vergonhoso, para quem oferece aos outros a sua ajuda, não poder valer-se a si mesmo?

Mas dizes que aquele mal que te atribula de forma alguma é comparável com qualquer outro mal que possa acontecer aos restantes homens. É que os que se cobriram de infâmias, os que se apoiam no embuste e na mentira, os que colocam no vazio a esperança das suas coisas e mancham a vida com toda a espécie de impurezas e indignidades, não é de espantar se são abatidos pelo juízo de Deus, a quem ofenderam com as suas acções vergonhosas. Mas de ti não pode dizer-se tal. Acaso não afirmaste abertamente que temeste a Deus, e que puseste unicamente no Seu poder divino a defesa da tua vida, e que n' Ele depositaste a firme esperança de salvação e com o máximo desvelo te esforçavas por não manchar com alguma infâmia ou desdouro a pureza da tua vida? Por consequência, atormenta-te o facto de, contra a tua esperança, Deus te ter ferido com uma desgraça inesperada e deixado privado da Sua ajuda, sem qualquer crime ou culpa da tua parte.

Que pode dizer-se de mais monstruoso do que isto? De tal maneira hás-de ser arrastado pela loucura que atribuis a causa da tua desgraça, não a ti mesmo, mas à injustiça d' Aquele sempiterno Juiz cuja integridade no julgar não pode ser corrompida ou dobrada? Peço-te que te recordes se há memória de jamais se ter visto ou ouvido que algum inocente pereceu ou que os justos foram destruídos pela desmesura da severidade divina. Decerto que não indicarás um único. Portanto, quem são aqueles a quem Deus derriba por completo? Certamente aqueles que se opõem com todo o empenho aos Seus santíssimos mandados. E assim vi que muitos, que cultivavam a iniquidade, que semeavam a injustiça, no tempo da colheita colheram o fruto do merecido castigo, pois, derrubados pelo sopro do Senhor, inteiramente se perderam e, precipitados pelos ventos da Sua ira, desvaneceram-se. O rugido do leão e o rosnar do leopardo abafam-se e os dentes dos leõezinhos são arrancados; os leões mais corpulentos morrem depauperados pela falta de presas e as suas crias são despedaçadas. E da mesma maneira toda a desumanidade dos tiranos, toda a crueldade dos homens perversos e toda a violência e injustiça dos ruins são abafadas pelo juízo divino e, ao cabo, a sentença de Deus pune com as merecidas penas os homens ímpios e depravados. Por conseguinte, os castigos de Deus perseguem não os inocentes, mas os que, vivendo na mais completa iniquidade, confiam excessivamente nos seus recursos.

Para falar com franqueza, reconheço que por vezes pensava igualmente que também os homens inocentes eram atormentados com imerecidos castigos e, por esse motivo, punha em causa a equidade dos juízos divinos e era torturado por um duplo cuidado, uma vez que nem me parecia lícito levantar suspeitas atinentes à iniquidade de Deus, nem ousaria condenar como ruins homens que eu mesmo sabia não terem incorrido em nenhuma falta, [27] aos quais todavia eu via serem atribulados com muitos padecimentos. Mas uma visão de origem divina acabou-me por completo com esta dúvida. De facto, compreendi uma pequena parte do segredo divino e o Espírito celestial falou-me em segredo ao ouvido.

De facto, naquela altura em que os homens têm o entendimento ocupado com vários pensamentos nascidos de visões nocturnas e o sono profundo abraça estreitamente 
Sed illud dicis malum, quo uexaris, non esse cum aliquo alio malo, quod reliquis hominibus accidere possit, ulla ratione comparandum. Illi enim qui flagitiis cooperti sunt, qui fraude et mendacio nituntur, qui spem rerum suarum in inanitate collocant et uitam omni turpitudine et impuritate contaminant, mirum non esse si Dei iudicio, quem in se foedis factis offenderant, euertuntur. De te uero id dici non posse. An illud non aperte dixisti te Deum timuisse et in illius tantum numine praesidium uitae constitutum habuisse, et in illo firmam spem salutis reposuisse idque summo studio contendisse, ne uitae tuae integritatem aliquo flagitio aut dedecore maculares? Hoc igitur te cruciat, quod sis a Deo contra spem tuam repentina clade perculsus et ab illius ope, sine ullo crimine aut culpa tua, derelictus.

Quo quid dici potest immanius? Eone te deducet amentia ut causam calamitatis tuae, non tibi ipsi, sed iniuriae illius sempiterni iudicis, cuius in iudicando constantia corrumpi aut inflecti non potest, assignes? Repete, quaeso, memoria, num uideris aut audieris umquam innocentem aliquem periisse aut iustos magnitudine seueritatis diuinae excisos. Ne unum quidem proferes. Qui sunt igitur illi quos Deus funditus euertit? Illi certe qui omni uitae studio sanctissimis illius placitis aduersantur. Itaque uidi permultos, qui exarabant iniquitatem, qui sementem faciebant iniuriae, messis tempore fructum debiti supplicii pertulisse, flatu enim Domini discussi, funditus interierunt et, spiritu irae illius iactati, extabuerunt. Rugitus leonis et fremitus leopardi comprimitur et leunculorum dentes euelluntur, maximi leones inopia praedae confecti pereunt et eorum catuli discerpuntur. Itaque omnis tyrannorum immanitas, omnis perditorum hominum truculentia, omnis improborum uis et iniuria, iudicio diuino reprimitur et debitae tandem poenae ab hominibus impiis atque sceleratis Dei sententia reposcuntur. Non igitur innocentes, sed in summa iniquitate opibus suis nimium praefidentes, sunt qui diuinis poenis exagitantur.

Equidem, ut uerum fatear, in eadem cogitatione uersabar interdum, ut suspicarer homines etiam innocentes poenis indebitis cruciari et, ea de causa, de iudiciorum diuinorum aequitate dubitabam et anticipiti cura distinebar, cum neque Deum in suspicionem iniquitatis uocare mihi fas esse uideretur, nec homines, quos ipse nulli uitio affines esse cognoueram, damnare [27] improbitatis auderem, quos tamen multis incommodis afflictari cernebam. Arcani namque diuini particulam animo complexus sum Spiritusque caelestis ad aurem meam latenter insusurrauit.

Eo namque tempore quo ex uisis nocturnis homines in uariis cogitationibus mente defixi sunt et sopor mortales arcte complectitur, ingenti horrore perfusus fui, qui omnia ossa mea pauore nimioque tremore concussit. Spiritus enim ante 
os mortais, fui tomado de um imenso terror, que, com o pânico e sobejo tremor, fez estremecer todos os meus ossos. É que diante de mim perpassava um sopro, com cuja aproximação me assustei sobremaneira. Manteve-se parado, mas não reconhecia o seu aspecto; via-se diante dos olhos uma imagem que me mandou calar por forma a que eu escutasse a sua VOz, sendo estas as suas palavras: "Porventura o homem há-de pleitear em justiça com Deus? Porventura há-de atribuir-se maior pureza a si do que Àquele supremo Criador que o moldou? O que é mais, as próprias inteligências celestiais que $\mathrm{O}$ servem não têm por natureza firmeza bastante para Lhe mostrarem a devida lealdade: de facto, Ele provou a loucura dos Seus anjos. Por conseguinte, que deve pensar-se relativamente aos que habitam as moradas terrenas, a esses cujos fundamentos estão formados de pó, e que são destruídos por inúmeros casos fortuitos antes que a velhice e os anos os possam consumir? Que pela manhã estão cheios de força e à tarde estão mortos, abatidos pelos golpes? Mas os que não se arrependem e não querem regressar ao cumprimento das suas obrigações, hão-de perecer para sempre. E não só eles mesmos serão castigados, mas a sua descendência do mesmo modo será banida e a morte suprimi-los-á com o esquecimento devido à penúria de sabedoria." - Conservo na memória estas palavras que me foram ditas por efeito da vontade divina; ensinado por elas vejo claramente que nenhum homem justo é oprimido pelo juízo de Deus. É que, caso contrário, Deus não cumpriria a função nem desempenharia a obrigação de juiz recto.

Chama, peço-te, como testemunha algum varão superior, e vê se existe alguém que pense como tu. De facto, de entre os santos varões a quem recorrerás que se atreva a corroborar a tua opinião? Por conseguinte, de forma alguma se deve atribuir ao desígnio de Deus a causa dos nossos males, mas ao nosso desatino e loucura. Com efeito, a ira de um espírito desenfreado mata o insensato e a inveja destrói o imoderado, porquanto todos os males nascem ou da conatural soberba ou da monstruosa força da sensualidade. Vi o homem desatinado e louco, próspero de bens e com uma posição fundada, ao que parecia, em fundas raízes e com sólidos esteios para ficar na lembrança da posteridade, cuja casa e família, todavia, assim que as vi, persegui com negros presságios, pois predisse que viriam a ser completamente destruídas. É que os filhos dele ficarão desamparados de socorro e serão humilhados em público e não haverá quem os salve dos maiores perigos. Os homens, abrasados por insaciável cobiça, arrojar-se-ão sobre as riquezas dele, acumuladas com enorme trabalho e desvelo, e não haverá perigos ou dificuldades capazes de impedi-los de arrebatá-las. E deste modo os homens imoderados e que ávida e raivosamente tudo desejam, hão-de acabar com as riquezas do homem avaro e injusto. É este o fruto da iniquidade: esta iniquidade todavia não deve ser imputada à natureza [28] por forma a que devamos acusar o Criador da natureza por ter sido o autor dela. Tãopouco a injustiça tem a sua origem nos torrões do húmus nem foi a terra quem produziu a cobiça e a preocupação por possuir muito, mas o homem de livre e espontânea vontade, já desde o próprio dia em que nasceu, enredou-se em desejos e moléstias, que depois, mais ardentemente acirrados pelas chamas das paixões, tomaram grande vulto.

Por conseguinte, de que modo se pode ao cabo resistir a um tamanho mal? Porventura poderemos com as forças humanas subtrair-nos a esta tão monstruosa 
me discurrebat, cuius appulsu uehementer inhorrui. Constitit ille quidem, sed speciem illius non agnoscebam; obuersabatur ante oculos meos imago, quae silentium fecit mihi ut uocem illius audirem. Cuius haec sententia fuit: "Numquid homo iustitia cum Deo certabit? Num maiorem sibi puritatem quam illi summo Conditori, qui eum finxit, attribuet? Quin ipsae mentes caelestes, quae illi ministrant, natura stabilitatem non habent ut illi fidem debitam praestent: ille namque angelos suos conuicit amentiae. Quid erit igitur de illis qui terrenas domos incolunt existimandum? Quorum fundamentum est e puluuere concretum, qui, antequam senio atque uetustate consumi possint, multis casibus exstinguuntur? Qui mane robore uigent, ad uesperum contusi plagis intereunt? Qui uero minime resipiscunt et ad officium redire nolunt, perpetuo peribunt. Neque solum ipsi poenas dabunt, sed eorum posteritas similiter emigrabit et mors illos propter sapientiae penuriam obliuione delebit." - Haec quidem mihi diuinitus effata memoria conseruo, quibus instructus plane uideo nullum hominem iustum Dei iudicio circumueniri. Aliter enim Deus recti iudicis officium minime tueretur atque sustineret.

Denuntia, quaeso, alicui praestanti uiro testimonium et animaduerte an sit aliquis qui tecum sentiat. Ad quem enim ex sanctis hominibus adibis qui tuae sententiae suffragari audeat? Nullo igitur modo est nostrorum malorum causa in Dei consilium, sed in nostram temeritatem et insaniam conferenda. Furiosum enim hominem occidit animi impotentis iracundia et intemperantem exstinguit inuidia, omnia namque mala uel ex insita superbia uel ex immani ui libidinis oriuntur. Vidi equidem hominem temerarium et insanum, opibus affluentem statumque illius altis, ut uidebatur, radicibus innixum et ad posteritatis memoriam firmo praesidio constitutum, cuius tamen domum et familiam, ubi primum illam adspexi, malis ominibus prosecutus sum, praedixi namque futurum ut funditus euerteretur. Nam illius filii erunt longe a salutis praesidio remoti et in hominum conuentu et celebritate uexati nec erit qui a summi periculi peste illos eripiat. In illius opes, summo labore et studio congestas, homines inexplebili cupiditate flagrantes inuadent, nullisque periculis aut difficultatibus impediri poterunt quominus eas diripiant. Itaque fortunas hominis auari et iniusti, homines intemperantes omniaque rabide et sitienter appetentes exhaurient. Hic quidem est iniquitatis fructus: quae tamen iniquitas non est ad naturam [28] reuocanda ut ea gratia naturae Conditorem accusare debeamus quod auctor illius exstiterit. Nec enim iniustitia ortum habet e telluris glebis neque cupiditatem et plura possidendi sollicitudinem terra protulit, sed homo, sponte sua, iam inde ab ipso natali die se cupiditatibus et molestiis implicuit, quae deinde, libidinum flammis ardentius excitatae, in altum sublatae sunt.

Huic igitur tanto malo qua tandem ratione resistendum est? Num humanis uiribus poterimus ipsi nos ab hac tam immani clade subducere? Non certe. In nobis enim est ipsius iniquitatis seminarium et effrenatae cupiditatis incendium, 
desgraça? Certamente que não. É que em nós se encontra a fonte da própria iniquidade e a chama da desenfreada cobiça, de tal sorte que se, apoiando-nos nos nossos recursos, procuramos por nós o remédio, é-nos forçoso cair no mais completo desastre e perdição. Portanto, que nos cumpre fazer? Apenas isto: refugiar-nos na clemência e ajuda de Deus. Por isso, procurarei Deus; oferecer-Lhe-ei preces; pesarei os deveres da minha existência em conformidade com o desígnio e ensinamentos d' Aquele que é o único que pode conservar em segurança a minha vida. É que só Ele faz obras magníficas cujas razões não podem ser esquadrinhadas pelas razões humanas; só Ele cria coisas admiráveis que não estão sujeitas a uma norma fixa. É Ele quem deixa cair a chuva sobre a superfície da Terra e fecunda os campos com as águas vertidas. É Ele quem coloca em posição elevada os humildes levantados do chão e ergue os abatidos aos lugares cimeiros e lhes devolve a prosperidade. É Ele quem frustra e inutiliza as manhas dos astutos, de tal maneira que nada do que urdiram alcance um resultado firme e duradouro. É Ele quem de tal forma zomba dos sábios que os enreda naquela mesma sabedoria com que se ufanam, e de tal guisa os tem acorrentados que aqueles mesmos desígnios em que se empenhavam com a maior energia com miras à prosperidade e dignidade redundam em desdouro e perdição deles. Enganar-se-ão em coisas claríssimas; durante o dia estarão mergulhados em densa cerração; e, como se uma espécie de noite horrorosa se tivesse abatido sobre os seus olhos, assim ao meio-dia se verão forçados a tentear com as mãos por onde lhes cumpre avançar. Mas o Senhor arranca dos fios da espada e das calúnias das línguas os que n'Ele põem a esperança, e com salutar socorro preserva o pobre e desvalido para que não seja oprimido pela mão e poder do inimigo poderoso. Por isso a inocência do pobre, demonstrada pela firme esperança na salvação, respira, e a impudência da iniquidade é reprimida pelo juízo de Deus. Mas entretanto, dado que é muitíssimo difícil evitar o pecado, deve ter-se na conta de bem aventurado aquele a quem não se protela o castigo que merece pelo seu delito, mas a quem, enquanto é tempo de arrepender-se, se impõe a pena que o ensine a regressar ao cumprimento das suas obrigações.

Por conseguinte, não rejeites a dádiva deste ensino que misericordiosamente Deus te concede. Com efeito, se não te mostrares desagradecido e nesses golpes sensatamente reconheceres a Sua benignidade, dessa tua desgraça colherás enormes proveitos. É que quem te inflige as feridas é o mesmo que cura as feridas infligidas, quem traspassa com o dardo é o mesmo que com a Sua mão prepara a mezinha salutar. Ele há-de libertar-te das angústias que te atribularam, não uma, mas muitas vezes, e com a Sua ajuda e determinação há-de ao cabo providenciar para que nenhum mal te atinja; no tempo da fome hás-de ser sustentado com as Suas riquezas e nos perigos da guerra te há-de ajudar o Seu socorro. [29] Quando a peçonha da maledicência ocasionar a morte de muitos, tu afastarás o perigo da desonra com o abrigo e refúgio da ajuda divina. E não sentirás qualquer receio quando um terrível desastre se abater sobre a comunidade. É que, quer os demais se vejam oprimidos pela devastação inferida, quer pela fome generalizada, mesmo assim tu viverás livre de todo o cuidado e não temerás as feras. E até celebrarás um pacto com as pedras dos campos, por forma a que não te possam fazer mal, e também as bestas ferozes e selvagens manter-se-ão sempre contigo numa inquebrantável paz, pois nenhuma 
ita ut si, per nos nixi, remedium exquirimus, sit nobis extrema calamitas atque pernicies subeunda. Quid igitur faciendum? Hoc certe, ut ad Dei clementiam et opem confugiamus. Deum igitur inquiram; ad illum preces adhibebo; ad illius mentem atque disciplinam officia uitae perpendam, qui solus potest praesidio uitam meam conseruare. Ille namque solus est qui magnifica opera facit quorum rationes humana ratione peruestigari non queunt; qui res admirabiles edit quae certo numero contineri non possunt. Qui demittit imbres in telluris superficiem et aquis effusis fecunditatem campis dat. Qui humiles humo excitatos in alto gradu collocat et maerentes in sublime tollit eisque salutem restituit. Qui hominum astutorum calliditates irritas et inanes ostendit, ita ut nihil quod designauerunt exitum firmum et stabilem consequatur. Qui ita sapientibus illudit ut eos illa ipsa sapientia, qua tument, irretiat atque ita constrictos teneat ut ea consilia, quibus ad salutem et dignitatem summa ope nitebantur, ad eorum perniciem et dedecus reuocentur. In rebus clarissimis hallucinabuntur; die in densa caligine uersabuntur; et, quasi taetra quaedam nox sit eorum oculis offusa, ita meridie manibus, qua sit illis ingrediendum, explorare conabuntur. Verum enimuero Dominus eos qui spem in illo reponunt ex acie gladii et ex linguae calumniis eripit, et hominem egenum et innocentem, ne manu atque potentia hostis potentis opprimatur, salutari praesidio conseruat. Inopis igitur innocentia, firma spe salutis ostensa, respirat, et iniquitatis impudentia iudicio diuino reprimitur. Interim uero, cum difficillimum sit peccatum uitare, ille beatus habendus est cuius delicto debitum supplicium minime differtur, sed, dum paenitendi tempus est, poena ei, qua eruditus ad officium redire possit, imponitur.

Ne igitur hoc disciplinae beneficium, quo te Deus clementer afficit, aspernere. Nam, si te minime ingratum praebueris et in istis plagis illius benignitatem sapienter agnoueris, ingentem ex ista clade fructum percipies. Ille namque est, qui uulnera infligit, idem qui inflicta uulnera sanat; ille est qui telo transuerberat et qui manu sua salutarem medicinam facit. Te quidem ille non semel, sed saepe, angoribus implicitum, liberabit, atque tandem, ne te malum aliquod attingat, consilio et ope sua prouidebit; famis tempore opibus illius sustentaberis, in belli uero discrimine praesidio illius munieris. [29] Cum maledicentiae uenenum multis necem attulerit, tu latibulo atque perfugio diuini subsidii infamiae periculum propulsabis et, cum dira calamitas res communes afflixerit, minime formidabis. Siue enim uastitate illata, siue fame dominante reliqui premantur, tu tamen omni cura solutus in tranquillitate uersabere neque belluas extimesces. Quin etiam erit tibi foedus cum agrorum lapidibus ictum, ne te laedere queant, et ferae etiam agrestes et immanes pacem tecum firmam omni tempore conseruabunt, nulla siquidem feritas illis nocere potest qui Dei praesidio fulciuntur. Itaque senties domicilium tuum, otio constituto, opibus magnis affluere, domumque 
ferocidade pode ser nociva aos que estão protegidos pela guarda de Deus. E deste modo verás a tua morada, depois de instalada a quietação, abundar em grandes riquezas, e manterás a tua casa na observância do dever, de maneira a que nela não haja ninguém que incorra em crime, porquanto quem exerce domínio sobre muitas pessoas deve acima de tudo empenhar-se unicamente, não só em desviar de si toda a suspeita de pecado, mas também em que todos os que se encontram sob a sua tutela conservem a virtude em todas as situações da vida. Se assim procederes multiplicarás a tua descendência e a tua posteridade aumentará como a erva regada. Finalmente, chegarás feliz à mais avançada velhice e, pelos teus colocado no sepulcro, serás guardado como um monte de cereal, para de lá seres retirado quando for oportuno.

Isto não o pensámos com ligeireza, mas meditámo-lo a fundo e durante muito tempo, e quisemos expô-lo diante de ti a fim de te aliviarmos desse mal que te acabrunha. E não pode dizer-se que esta nossa opinião é pouco corroborada pela justiça e pela razão. Se a seguires, nem te lamentarás chorando em demasia, nem pronunciarás palavras cheias de azedume, nem te queixarás a Deus das penas que estabeleceu para ti, como se tivesses sido injustamente punido, mas suportarás os padecimentos com grande constância e pedirás perdão a Deus, para assim recuperares com acrescida dignidade a antiga felicidade. Portanto, desejaria que reflectisses em tudo isto, para mais facilmente poderes sair desses males.

Estas as palavras de Elifaz, às quais Job respondeu dizendo:

- Oxalá fosse possível que esta minha indignação, que tanto vos escandalizou, fosse pesada juntamente com a desgraça que aquela traduziu, para que vísseis que é tamanha a grandeza do mal que me excrucia que supera de longe e incomparavelmente os meus queixumes e, pela sua multidão e peso, deve ser comparada com a areia do mar. Portanto, não é de admirar nem se deve ter na conta de abominável crime que eu tenha soltado gemidos ao ser atormentado por dores intoleráveis. É que não fui maltratado por forças humanas, mas trespassado pelos dardos e a mão de um Deus muito poderoso. As setas d' Ele prendem-se ao meu corpo e o veneno delas embebe o meu espírito, e o próprio Senhor, depois de inspirar o terror, ataca a minha alma. Posso porventura negar que sou homem e que não sou afectado por uma pungentíssima dor? A tal ponto estareis privados de sentimentos humanos que nem sequer me reconheçais o direito de chorar uma tão grande desventura? Recusar-me-eis acaso aquilo que se concede aos brutos animais: expressarem, soltando lamentos, a dor e fome que os atormentam? É que os queixumes dos animais são sinais, não de prazer, mas de dor. [30] Porventura o asno se lamenta enquanto tem alimento em abundância? Acaso o boi muge quando tem pasto à farta? Não só a falta de alimento, mas por vezes também a falta de gosto impele ao queixume. Com efeito, quão escasso é o número daqueles que não se indignam quando se apercebem que lhes é servida alguma parte de um alimento desenxabido que foi cozinhado sem sal? Alguns nem mesmo permitem que lhes sirvam a clara do ovo, por ser desenxabida. Mesmo que isto seja próprio de um paladar demasiado delicado, ainda assim todos por consenso unânime admitem que qualquer homem distinto despreze com indignação e recuse um alimento desenxabido, embora de modo algum seja amargo: mas a mim, oprimido e 
tuam in officio continebis, ne quisquam sit in illa qui in se flagitium admittat, nec enim id tantum praestare debet, qui multis imperat, ut ipse a se omnem peccati suspicionem remoueat, uerum etiam ut omnes, qui in illius tutela sunt, innocentiam in omni uita retineant. Haec si feceris sobolem multiplicem numero propagabis posteritasque tua instar herbae irriguae pullulabit. Ad summam denique senectutem cum felicitate peruenies et a tuis in sepulcrum illatus, quasi aceruus frumenti, conditus eris, ut inde, cum fuerit opportunum, depromaris.

Et haec quidem non temere a nobis cogitata, sed diu multumque meditata sunt: quae in medium afferre uoluimus ut te malo isto, quod te premit, leuaremus. Neque dici potest hanc nostram sententiam esse parum iure atque ratione confirmatam. Cui si fueris obsecutus, neque nimis flebiliter lamentabere, neque uerba stomachi plena fundes, neque cum Deo de poenis, quas tibi constituit, expostulabis, quasi fueris indebite punitus, sed aerumnam patientissime tolerabis et a Deo ueniam petes, ut ita pristinam felicitatem cum amplificata dignitate recuperes. Haec igitur omnia uelim mente recogites, ut facilius e malis istis emergere possis.

Hactenus Heliphazius. Ad quae Iobus respondens, inquit:

-Vtinam fieri posset ut haec indignatio mea, quae uobis tam grauem offensionem attulit, simul cum calamitate, quae illam expressit, appenderetur, ut cerneretis tanto grauiorem esse mali, quod me excruciat, magnitudinem ut querimoniam meam longe multumque superet atque cum arena maris multitudine et grauitate conferenda sit. Non est igitur mirandum nec in nefario crimine ponendum si, cum essem intolerando dolore cruciatus, eiulatus ediderim. Non enim humanis opibus uexatus sum, sed Dei praepotentis telis atque manu confixus. Illius enim sagittae in corpus meum adhaerescunt, quarum uenenum spiritum meum exsorbet, ipseque Dominus animum meum, terroribus iniectis, impugnat. Possumne me hominem infitiari et acerbissimo dolore minime commoueri? Adeone humanitatis expertes eritis ut ne deplorandae quidem tantae miseriae mihi potestatem fatiatis? An id etiam mihi denegabitis quod est brutis animantibus attributum, ut dolorem et inopiam, qua premuntur, clamoribus sublatis, aperiant? Nec enim animantium querelae uoluptatis, sed [30] doloris indices sunt. Numquid onager, quamdiu illi pabulum suppetit, ingemiscit? Num bos, cum gramine abundat, mugitus edit? Neque tantum cibi penuria, sed etiam insulsitas, interdum gemitus edere compellit. Quotus enim quisque est qui, cum aliquid insipidi cibi, qui sale conditus minime sit, sibi apponi cernit, non indignatur? Quidam uero ne albumen quidem uitelli sibi apponi patiuntur, eo quod insulsum sit. Sit hoc nimis delicati fastidii, id tamen omnium concessu tribuitur ut quilibet homo lautus cibum insulsum, quamuis amarus minime sit, cum indignatione aspernetur atque reiiciat: mihi uero, tantis acerbitatibus oppresso et afflicto, ne illo quidem calamitatis solacio, quod in lamentis et lugubri uociferatione consistit, per uos uti licebit? Scilicet mediocribus 
atribulado por tão grandes penalidades, nem sequer me permitireis que recorra àquele refrigério da desgraça que consiste nos lamentos e nos gritos de dor? Não há dúvida que fui atribulado por incomodidades de somenos e atingido por ferimentos ligeiros, de maneira que sem dificuldade posso suportar a dor sem soltar qualquer gemido... Aquilo que dantes, quando me encontrava de saúde, eu repelia como molesto e nocivo e os meus sentidos rejeitavam, agora, que padeço gravíssima enfermidade, tomo-o como alimento e, no descalabro e ruína de todas as minhas coisas e mergulhado na mais completa aflição, sou obrigado a sustentar esta existência mofina com coisas muito amargosas.

Já com os meus rogos não imploro a restituição dos bens que perdi, mas o termo dos males que suporto. Oxalá o Senhor aceite o meu pedido e se realize aquilo que espero: ou seja, que, do mesmo modo que se determinou a abater-me, assim estenda a Sua mão e despedace por completo o meu corpo. Que ao menos me reste esta consolação para me suster. Não peço que me perdoe e restitua a saúde ao meu corpo, mas que, matando-me, ponha fim aos males que me atribulam. Que ao menos na vida me conceda esta recompensa pela piedade e religiosidade em que perseverei. É que não fiz caso omisso das palavras do santíssimo Senhor nem critiquei, consoante falsamente me acusas, as Suas decisões, nem desatina e impiamente ultrajei a Sua potestade divina, mas dei a conhecer com os meus lamentos os grandes sofrimentos em que vivia. Vós tomais isto como um crime, como se eu tivesse cometido uma acção monstruosa e sacrílega. Mas que forças tenho eu para resistir a males tão violentos? Ou que espaço de tempo para, com ânimo e esperança, me guardar nesta vida para uma condição de vida melhor? Acaso fui feito de pedra para que me exijais a dureza da rocha? Acaso fui moldado em bronze para que me peçais uma resistência brônzea? E que dizer, se até se apartou de mim o Espírito divino, a única defesa que eu tinha em todas as adversidades? Que dizer, se Aquele sustentáculo da vida, apoiado no qual teria podido desviar o pensamento da sensação da dor, se retirou de mim?

E mesmo assim proibis que, mergulhado em tamanha desgraça e privações, eu dê largas à dor? E mesmo assim cruelmente me impedis que chore as minhas penas? Mas seja muito embora! Da forma mais mofina vi-me cercado por todos os males que podem suceder ao ser humano: mesmo assim tenho amigos sobremaneira leais, capazes de, consolando-me e quase que compartilhando da minha dor, aliviarem o meu infortúnio. Disso não há dúvida... Ao verem-me ferido e enfraquecido pelos golpes, empenharam-se totalmente em amparar-me e fortificar-me de todos os modos. Estiveram tão longe de conseguir tal que, com as suas palavras, antes [31] aumentaram a minha dor e acirraram as feridas que recebera. É que me lançam em rosto um crime tal que será impossível existir outro que acarrete maior infâmia e desdouro eternos. A somar aos meus males, ainda faltava este de não só jazer no pó privado de todos os bens e lacerado por gravíssimas feridas, mas também ser atacado pelos amigos com o maior dos desdouros. Com efeito, diziam assim: "Não mostrou nenhuma compaixão pelos próximos na desgraça, pôs totalmente de parte o temor de Deus e desrespeitou impuramente a santíssima religião, e, por esse motivo, foi violentamente castigado por Deus, tal como pediam os seus merecimentos."

E assim me foram desleais os meus irmãos, semelhantes à torrente, que secou quando teria podido ser da máxima utilidade e correndo pelo leito na altura menos oportuna, e 
incommodis affectus sum et leui uulnere percussus, ut facillime possim dolorem sine ullo gemitu tolerare... Ea quae quondam, cum sanus eram, ut acerba et noxia repellebam et sensibus aspernabar, nunc, cum morbo grauissimo laborem, mihi pro cibo sunt, et cogor, in omnium rerum mearum exitio et uastitate et in summa aegritudine, uitam hanc miserrimam rebus amarissimis sustentare.

Iam non bonorum quae amisi restitutionem, sed malorum quae patior finem precibus imploro. Vtinam postulationi meae concedat Dominus et quod spero conficiatur: nempe ut, quemadmodum me conterere instituit, ita manum suam intendat corpusque meum omnino dilaceret. Haec saltem sit mihi consolatio reliqua qua sustenter. Non postulo ut mihi ueniam tribuat et corpus meum in sanitatem reducat, sed ut, illata morte, finem malis, quibus afflictor, imponat. Hoc saltem praemium in hac uita mihi pro pietate et religione, in qua perseueraui, constituat. Nec enim suppressi uerba sanctissimi Domini aut illius consilium, ut me insimulas, accusaui, aut numen illius maledictis temere et impie lacessiui, sed, quantis in doloribus uersarer, lamentis exposui. Hoc mihi uos crimini datis, quasi scelestum et immane facinus commiserim. Verum quod est robur meum ut tantam uim mali sustineam? Aut quod aeui spatium ut me animo atque spe ad meliorem condicionem in hac uita reseruem? Num sum exculptus e silice ut in me duritiem lapidis requiratis? Num factus sum ex aere ut a me robur aeneum flagitetis? Quid, si etiam illud unicum meum diuini Spiritus in omni aduersitate subsidium a me migrauit? Quid, si illud uitae firmamentum, quo nixus cogitationem a sensu doloris abducere potuissem, se ipsum a me subduxit?

Et tamen, in tam graui calamitate et orbitate, mihi sensum doloris adimitis? Et tamen, ne aerumnas meas defleam, importune prohibetis? Sed esto! Malis omnibus, quae in hominem cadere possunt, miserrime circumuentus sum: habeo tamen amicos fide praestantes qui, me consolando et prope aeque dolendo, miseriam meam leniant. Ita sane... Cum me uiderent plagis contusum et debilitatum, omnem operam in eo posuerunt ut me fulcirent omnique ratione confirmarent. Tantum certe abfuit ut id praestarent ut potius uerbis suis [31] dolorem augerent et uulnus inustum exulcerarent. Illud enim mihi scelus obiiciunt quo nullum esse poterit ad sempiternum dedecus et infamiam efficacius. Hoc sane mali restabat ut, non solum exturbatus bonis omnibus et concisus grauissimis uulneribus in puluuere iacerem, sed etiam dedecore summo ab amicis afficerer. Sic enim inquiunt: "Proximis in aerumna misericordiam nullam adhibuit; timorem Domini prorsus abiecit religionemque sanctissimam impurissime uiolauit eaque de causa fuit a Deo, ut eius merita postulabant, acerrime flagellatus."

Itaque fratres mei fidem fefellerunt et insar torrentes qui, cum maxime utilis esse potuisset, exaruit, quasi per alueum tempore minime opportuno labuntur, deinde, cum illorum auxilium desideratur, euanescunt. Torrentes quidem hieme, 
depois, quando a ajuda deles é precisa, desaparecem. De facto, as torrentes no Inverno, com a liquefacção do gelo e das neves trasbordam com agitadas águas e, espalhando-se sobre as margens, deslocam-se com grande rapidez, mas, depois de descerem no Verão, extinguem-se secas com o calor, e abandonam por completo o lugar por onde o seu percurso seguia, de tal maneira que, à excepção da terra revolvida pelo ímpeto das águas e dos caminhos destruídos, naqueles sítios em que corriam não é possível vislumbrar qualquer vestígio delas. É que mostraram-se inchadas e, de repente, desapareceram com a estiagem. Os que empreendiam viagem para a Arábia Deserta olhavam para elas e os mercadores sabeus, para fazer aguada, a elas acudiam, a fim de poderem refazer-se e restaurar-se com as suas águas. Mas, ao verem-nas secas, acusaram-se a si mesmos de loucura por terem sido capazes de depositar esperança num socorro tão vão e enganador e, ao chegarem ao seu leito, não só viram frustradas as suas esperanças, mas dali partiram com o desdouro e a infâmia do desatino cometido. Vós sois semelhantes a estas torrentes, pois, quando eu não precisava das vossas riquezas, então mostráveis que não haveriam de faltar-me os vossos bens, ajuda e desvelo. Mas, logo que me vistes atribulado pelos trabalhos e vítima da penúria de todas as coisas, renunciastes aos vossos bons ofícios e não prestastes qualquer ajuda na adversidade.

De facto, mal pusestes os olhos sobre a desgraça que sobre mim se abateu, fugistes com horror da minha companhia. Creio que receastes que eu vos fosse uma carga e de vós exigisse mais do que vos era possível suportar. Porventura vos pedi que me socorrêsseis com os vossos presentes e dádivas? Acaso disse: "Arrancai-me das garras do monstruoso inimigo e libertai-me do senhorio dos meus contrários"? De forma alguma. Portanto, porque vos ocorre execrar-me como se eu fosse um homem sacrílego e injusto? Mostrai-me qual é o meu crime e eu calar-me-ei; provai a minha culpa, para que eu saiba qual foi a ruindade que cometi; rogo, insto e peço que me indiqueis o meu delito. Porventura ignorais que a força da justiça é tão grande que é impossível que os seus decretos sofram abalo ou enfraquecimento? Portanto, se vindes acusar-me estribados no direito, mostrai o crime e acusai-me. Ora, quem de entre vós é capaz de imputar-me um crime que possa provar com uma testemunha? Acaso decidistes acusar-me apenas com palavras e não com factos, e acabrunhar-me com falsos ultrajes e empenhar-vos com o máximo desvelo, não em que se corroborem com provas sólidas aquilo que afirmais, mas [32] em torturar-me mais com as vossas invectivas? E não pensais no grande crime de desumanidade que cometeis, pois vos abalançais contra um órfão privado de todas as coisas e aparelhais a ruína do vosso amigo.

Por isso, examinai agora mais atentamente a questão, atendei ao que vou dizer-vos e reflecti se invento alguma coisa. Reconsiderai e repeli de vós toda a mancha de iniquidade e considerai se a minha justiça ainda se mantém no seu lugar. Digo-vos: examinai se a minha língua profere palavras iníquas, e se o meu sentido do paladar de tal maneira se perverteu que já não distingue aquilo que por natureza é amargoso e áspero, da suavidade e agrado da verdadeira doçura. E, antes de mais, cumpre desarreigar aquela opinião que vos leva a pensar que nesta vida só os homens ruins são atribulados pelas penalidades, pois na vida comum também os bons estão expostos a muitos trabalhos. 
glacie atque niuibus liquefactis, redundant aquis turbidis et, super ripas effusi, magno impetu concitantur, at, postquam aestate defluxerint, ardoribus exusti deficiunt et locum, quem cursu tenebant, omnino deserunt, ita ut, praeter terram illorum impetu conuulsam et uias dissipatas, nihil in locis in quibus fluebant ex illis inspicere liceat. Se enim tumidos intulerunt et aestu repente defecerunt. Qui iter in Arabiam Desertam susceperant illos spectabant et mercatores sabaei ad illos, aquationis gratia, confluebant ut illorum aquis refici et recreari possent. At, cum arefactos animaduertissent, se ipsos amentia condemnarunt quod spem in tam uano atque fallaci praesidio posuissent neque solum, cum ad illorum alueos peruenissent, spe fraudati sunt et inde, cum dedecore et ignominia susceptae temeritatis, abierunt. Similes, inquam, illis torrentibus estis uos, cum enim minime opibus uestris indigerem, tunc et rem et operam et studium uestrum minime mihi defuturum ostendebatis. At, cum primum me laboribus confectum et omnium rerum penuria uexatum animaduertistis, officium prodidistis nec ullam opem mihi in rebus afflictis attulistis.

Vix enim cladem quam accepi oculis aspexistis, cum meum congressum exhorruistis. Id, credo, ueriti estis ne uobis oneri essem et plura a uobis exigerem quam facultas uestra ferre posset. Num dixi uobis ut me donis atque muneribus uestris iuuaretis? Num dixi: "Eripite me ex hostis immanitate libertatemque meam ex inimicorum dominatu redimite?" Minime. Quid ergo uenit uobis in mentem me, quasi hominem nefarium et iniustum, detestari? Demonstrate quodnam scelus istud meum sit et ego tacebo; peccati me conuincite ut quod sit a me commissum facinus intelligam; urgeo et insto et, ut crimen meum indicetis, efflagito. An ignoratis tantas esse iustitiae uires ut illius sententia conuelli aut labefactari non possit? Si ergo, iure nixi, ad me accusandum acceditis, intendite crimen meque reum peragite. Quis est igitur ex uobis qui mihi crimen obiicere ualeat quod teste confirmet? Numquid hoc est a uobis decretum ut me uerbis tantum et non rebus arguatis falsoque maledicto configatis neque ut ea, quae a uobis asseruntur, firma probatione confirmentur, sed ut ipse, uerbis uestris [32] increpitus, magis excrucier, summo studio laboretis? Neque reputatis animo quantum immanitatis crimen suscipiatis, in pupillum enim rebus omnibus orbatum irruitis et amico uestro ruinae periculum intenditis.

Nunc igitur rem ipsam diligentius examinate animumque ad ea, quae sum dicturus, attendite et uobiscum reputate an aliquid fingam. Redite in uiam et omnem a uobis iniquitatis labem repellite et considerate an adhuc iustitia mea suo loco maneat. Perpendite, inquam, num lingua mea uerbum iniquum proferat, et num palati mei sensus ita deprauatus sit ut iam minime quod est natura acerbum et asperum, a suauitate et iucunditate uerae dulcedinis, internoscat. Atque primum quidem illa opinio euellenda est, qua censetis homines tantum nocentes in hac uita incommodis uexari, bonis enim etiam sunt multi labores in communi uita propositi.

Est enim uita hominum instar militiae, in qua multa certamina ineunda sunt, 
Com efeito, a vida dos homens é como uma carreira militar, em que é mister arrostar muitos combates, suportar muitos trabalhos, pelejar em muitos lugares com risco de vida. Por conseguinte, como nesta guerra desempenhei a função de soldado sem cobardia nem frouxidão, era justo que a esperança da recompensa me levasse a considerar ligeiros todos os trabalhos anteriormente realizados. Logo, assim como o servo deseja ansiosamente que as sombras do Sol cresçam para repousar do trabalho com a chegada da noite e da mesma maneira que o assalariado suporta o trabalho com mira na paga, de igual modo julgava eu que, com a esperança do repouso e a consideração da recompensa prometida, todos os trabalhos seriam fáceis de aguentar. Portanto, que é que me perturba? Só isto: que é tão desmesurada a grandeza desta tribulação, que sou combatido por pensamentos muitíssimo desagradáveis, de tal maneira que por vezes hesito e duvido se despendi em vão e sem qualquer fruto os meses dos quais esperava um fruto nada pequeno, e se as noites, que haviam de trazer alívio aos incessantes trabalhos, arrastaram contra mim um intolerável ataque de inquietação e amargura. Durante a noite na minha cama sou atormentado por tamanhas dores que digo: "Quando chegará o dia, para eu me levantar?" Mas durante o dia pondero a sua grande extensão e desejo as trevas e a noite, pois durante o dia inteiro até ao crepúsculo vespertino sou atormentado por infinitas perturbações. Por conseguinte, nem de dia nem de noite se concede algum alívio à minha aflição. O meu corpo cobriu-se de vermes e, como torrões de terra, ficou em muitos lugares desfigurado com buracos e a minha pele foi de tal maneira rasgada que sou torturado não apenas pela dor, mas também pelo ódio e nojo por mim mesmo. Entretanto os meus dias passam mais rápidos do que a lançadeira do tecelão e pela pobreza da urdidura acabam a teia com maior celeridade do que alguém teria podido imaginar.

Por outro lado, de tal maneira sou puxado em direcções opostas que, por vezes, desejo morrer, a fim de me livrar de tão grandes males, mas, outras vezes, lamento-me de que a minha vida seja aniquilada tão rapidamente, porque me apercebo de que com a morte se trunca a esperança de uma condição melhor. De facto, desejava que a vida me fosse prolongada a fim de com muito maior desvelo honrar a Deus com os devidos bons ofícios e piedade. No meio de tamanhas aflições, grito a Deus que não queira privar-me da Sua ajuda:

Lembra-Te, Senhor, que a minha vida passa como o vento, mas uma vez eu destruído, os meus olhos não recuperarão a sua primitiva visão, de maneira a enxergarem os bens de que os homens gozam nesta vida. [33] Os que me olhavam não me tornarão a ver para me pedirem ajuda, mas ainda que queiras lançar os olhos sobre mim, ter-se-á perdido o ensejo para a Tua bondade em relação a mim, pois eu então já não existirei. Com efeito, assim como a nuvem se desfaz e esvai e não volta a formar-se, da mesma maneira os que foram sepultados nunca hão-de despertar para a mesma condição de vida. É que nem a pessoa que foi aniquilada pela morte há-de regressar à sua casa nem hão-de reconhecer a localização dela os homens que costumavam frequentá-la. Por conseguinte, uma vez que sou atribulado por tantas penas, que ao menos me seja permitido queixar-me dos males em que vivo. Por isso, agirei da mesma maneira como procedem os demais que estão mergulhados em males, e não refrearei a minha lingua, mas exporei todas as angústias do meu espirito e aplicar-me-ei a enumerar as penalidades da alma. 
multi labores excipiendi, multis in locis capitis periculo dimicandum. Hoc igitur in bello, cum non timidi aut ignaui militis officio functus sim, par erat ut omnes anteactos labores spe congiarii leues existimarem. Ergo, ut seruus anxie desiderat umbras diei augeri ut noctis interuentu labore releuetur, et ut mercenarius proposita mercede laborem tolerat, sic ego, et otii spe et stipendii propositi consideratione, omnem laborem perpessu facilem iudicabam. Quid ergo est quod me conturbet? Hoc nempe: quod tanta sit aegritudinis huius magnitudo ut molestissimis cogitationibus oppugner, ita ut haeream interdum et dubitem an menses, e quibus fructum non mediocrem sperabam, temere et sine ullo fructu consumpserim, et noctes, quae erant alleuamentum assiduis laboribus allaturae, intolerandam mihi uim sollicitudinis et acerbitatis inuexerint. Nocte quidem in lecto meo tantis molestiis afficior ut dicam: "Quando aduentabit dies, ut surgam?" Die uero magnitudinem illius expendo et tenebras atque noctem desidero, per totum enim diem usque ad noctis crepusculum perturbationibus infinitis exagitor. Nec nocte igitur neque die ullum mihi maeroris alleuamentum conceditur. Corpus meum est obductum uermibus et in modum glebae multis in locis hiatibus deformatum et cutis mea discissa, ita ut non dolores solum, sed odio mei ipsius et offensione discrucier. Dies interim mei uelocius radio textoris excurrunt et telam, tramae penuria, multo celerius quam suspicari quisquam potuisset, absoluunt.

Sic autem in contrarias partes distrahor ut interdum mori cupiam, ut e tantis malis eripiar, rursus autem uitam meam celeriter absumi lamenter, eo quod morte spem melioris condicionis praecisam uideam. Optabam namque uitam mihi prorogari ut Deum multo diligentius debito officio atque pietate uenerarer. In tantis angustiis ad Deum clamo ne me ope sua destituere uelit:

Memento, Domine, quod uita mea ut uentus effluit, me autem perempto, non reuocabitur in pristinum sensum oculus meus, ut bona, quibus homines in hac uita frumntur, [33] inspiciat. Qui in me intuebantur, non me ultra uidebunt ut opem meam requirant; ut autem oculos ad me adiicere uelis, erit opportunitas tuae erga me benignitatis amissa, ego enim iam tunc minime consistam. Nam, ut nubes consumitur et abscedit nec iterum cohaeret, qui sepulcro conditi sunt numquam in eumdem uitae statum excitabuntur. Nec enim is qui morte deletus est in domum suam remigrabit nec illius locum bomines, qui illius consuetudine utebantur, agnoscent. Cum igitur sim aerumnis oppressus, hoc saltem mibi liceat: mala, in quibus uersor, lamentari. Similiter igitur atque faciunt alii qui in malis sunt ita me geram, neque os meum continebo, sed omnes spiritus mei angustias explicabo et animi acerbitates recensere meditabor. 
Porventura eu sou o mar para que me circunscrevas com barreiras? Porventura sou alguma terrivel serpente para que me mantenhas encerrado com tão grande número de guardiães? É que de tal maneira fui atado pelos Teus grilhões como se, caso eu me soltasse, houvesse o perigo de invadir a terra com as minhas ondas ou de provocar a destruição dos bomens. De facto, para onde quer que me dirija, imediatamente ai acodes para me inquietares com coisas muito de temer. Na verdade, pensei que a minha cama me haveria de proporcionar algum refrigério e que nela pelo menos algumas vezes repousaria da desgraça. Mas até a cama me mortifica e atormenta e não deixa respirar e tortura o meu espirito com dolorosas preocupações, pois, quando adormeço, persegues-me nos sonhos e aterrorizas-me com horriveis visões. Por consequência, a mim, que estou assoberbado por tamanhas aflições, nem de dia nem de noite se me concede algum momento de alívio. E assim o meu espírito por vezes vê-se constrangido a pedir que uma morte violenta o separe dos meus ossos e o liberte dos sentidos corporais. Por isso estou farto da vida. Não me foi concedido alongá-la indefinidamente, pois ela, por lei da natureza, foi circunscrita a um breve período de tempo. Por conseguinte, que sucederá se de tal maneira tiver sido acorrentado pela Tua vontade que nem sequer me seja possivel empregar na justiça e na piedade esta brevíssima fruição da luz? Aparta a mão, suspende o castigo, solta-me durante o tempo necessário para fazer alguma coisa que mereça a Tua aprovação, por forma a que não fujam o tempo e a ocasião de desempenhar bem o meu dever: é que o prazo da minha vida é curtíssimo.

Acaso só para mim se há-de fechar o manancial da Tua bondade, que a todos se abre? Na verdade, pasmo ao pensar na grande preocupação que tens com a salvação $e$ dignidade do género humano. De facto, que é o homem para que o atavies com os ornatos de uma dignidade tão imponente? Que condição é a dele para que o guardes com tamanha vigilância e desvelo? É que, como um zeloso pai de família se levanta antes do romper da aurora para se ocupar do património, assim Tu desde manhã Te ocupas pessoalmente em velarpelo homem e observas a vida dele a cada hora e até a cada instante. Por conseguinte, qual a razão pela qual não afrouxas os meus pesados grilhões? Qual a razão por que não me dás a possibilidade de dar alento ao meu espírito? Mas retorquirás dizendo que, com os meus pecados, eu mereci que me impusesses castigos tão pesados. Muito embora, concedo. Mas pergunto: diante de Ti, que esquadrinhas e perscrutas os costumes dos homens e o seu interior e [34] que avalias, em conformidade com a Tua santíssima lei, o valor de todas as actividades, de que maneira posso eu, sendo tão grande a debilidade da natureza, levar ao cabo o curso da minha vida sem cair alguma vez? É que só poderia esquivar o pecado sustentado pelo Teu socorro, e nunca apoiado nos meus recursos.

Portanto, por que razão é que não realizaste aquilo que era próprio da Tua imensa misericórdia: amparar-me para eu não cair ou para não imaginar desatinadamente alguma coisa em contradição com a Tua vontade? Por que razão é que permitiste que eu sucumbisse oprimido pelos meus pecados, como sob uma intolerável carga? Mas ainda que de tal Te tenhas abstido deliberadamente e com motivo: por que razão é que agora não perdoas os mesmos pecados? Com efeito, mesmo que me encontre manchado com as maiores faltas, é próprio de Ti perdoar, encorajar os abatidos, levantar os que imploram 
Numquid ego sum mare ut me terminis circumscribas? Numquid sum immanis draco ut me tantis custodiis interclusum teneas? Sic enim sum tuis uinculis alligatus, quasi periculum esset, si laxarer, ne fluctibus terras obruerem aut bominum strages efficerem. Quocumque enim me confero, eo statim accurris ut me rebus ualde metuendis exanimes. Cogitaui enim futurum ut lectus meus solacium aliquod mibi afferret et in eo saltem aliquando a molestia conquiescerem. At ipse lectus me pungit et stimulat et respirare non sinit animumque meum acerbissimis curis excruciat, cum enim somnum capio me in somniis exagitas et borrendis uisis exterres. Non igitur neque nocte neque die mibi tantis angustis implicato quidquam laxamenti conceditur. Itaque cogitur interdum animus meus optare ut ab ossibus meis uiolenta morte separetur et e corporis sensibus abstrahatur. Taedet igitur me uitae. Non est mibi concessum in perpetuum uitam producere: est enim illa naturae lege breuis aeui spatio definita. Quid igitur fiet, si ita fuero numine tuo constrictus ut ne breuissimam quidem hanc lucis usuram possim in iustitia et pietate consumere? Amoue manum, remitte poenam, missum me fac tantisper dum aliquid efficiam quod approbatione tua dignum sit, ne tempus et occasio bene gerendi muneris elabatur: breuissimum namque est uitae meae curriculum.

An mibi soli fons benignitatis tuae, qui patet omnibus, erit occlusus? Stupeo enim cum mente recolo quantum salus atque dignitas generis bumani tibi curae sit. Quid enim est homo ut eum tam amplae dignitatis ornamentis afficias? Quae illius condicio est ut eum tanta uigilantia et sedulitate custodias? Vt enim diligens pater familias antequam dilucescat excitatur ut rem suam familiarem curet, sic tu mane uigilas ut bominem praesenti numine tuearis uitamque illius singulis horis atque adeo momentis exploras. Cur igitur me tantis impedimentum uinculis minime relaxas? Cur nullam mibi spiritus mei reficiendi potestatem facis? Sed inquies me peccatis meis commeruisse ut tu mibi tam graues poenas imponeres. Esto. Sed: quanam, quaeso, ratione coram te, qui mores bominum et intimos illorum sensus perscrutaris et excutis ad legemque tuam [34] sanctissimam officiorum omnium momenta perpendis, possum ego uitae cursum in tanta naturae imbecillitate sine aliqua prolapsione conficere? Non enim ope mea nixus, sed praesidio tuo suffultus peccatum declinare poteram.

Quare igitur id quod erat immensae clementiae minime perfecisti, ut me fulcires ne ruerem neue aliquid contra uoluntatem tuam temere designarem? Cur id permisisti, ut meis peccatis, quasi intoleranda sarcina depressus, occumberem? Sed fuerit id a te consilio et ratione praetermissum: cur nunc non ipsis peccatis ignoscis? Vt enim maximis uitiis contaminatus sim, tuum est ueniam tribuere, iacentes excitare, opem tuam implorantes erigere. Cur igitur, si in tam graue peccatum incidi, non id expiandum suscipis ut me a poenis eximas quas illius 
a Tua ajuda. Por conseguinte, por que razão é que, se caí numa culpa tão grave, não Te encarregas de resgatá-la, por forma a livrar-me das penas que padeço por causa dela? Por isso, se protelares a ajuda por mais tempo, certamente não poderei suportar um peso tão grande de todos os males. Portanto, se me procurares de manhã, já me hás-de encontrar privado de vida.

Job, com este discurso, por um lado refutou os argumentos com que Elifaz o acusara, por outro deu a conhecer, através dos lamentos e queixumes, a violência da dor com que era atormentado.

Ora, os amigos ficaram vivamente ofendidos com estas queixas; de entre eles, Bildad de Chua atacou-o com as seguintes palavras:

- Até quando falarás desse modo e perseverarás inabalável na tua obstinação? Porventura Deus perverterá a função de juiz? Porventura aquele santíssimo Senhor violará a santidade do direito? De forma alguma. Logo, uma vez que Ele é justíssimo, conclui-se de modo necessário que incorreu em culpa o homem a quem Ele castiga, pois, a não ser assim, Deus não estaria a desempenhar a função de juiz justo. Por conseguinte, se é manifesto que os teus filhos cometeram faltas contra Deus, por causa das quais foram castigados com as merecidas penas e banidos por Deus e privados da vida, não existe nenhum motivo pelo qual te lastimes da desgraça deles. E quanto ao facto de teres sido atribulado por tantos males, é a clara confirmação de que tu também sofres os merecidos castigos pelo crime perpetrado. Por outro lado, a majestade divina ofendida não se aplaca com uma piedade simulada, mas com a confissão do delito. Por isso, se regressares a Deus com pronta e rápida conversão do espírito; se dirigires súplices rogativas àquele Senhor supremo; se, impelido pelos Seus golpes, te consagrares de repente com toda a tua alma ao amor da pureza e da justiça, Ele de imediato, diante da tua justiça, restituirá a felicidade à tua casa. E assim, se abraçares a justiça com todo o teu espírito, receberás bens a vários títulos muito maiores e mais consideráveis do que aqueles de que te lastimas teres sido despojado.

Por conseguinte, se aos teus olhos não somos tão importantes que a nossa autoridade seja capaz de convencer-te, peço-te que recordes a história inteira dos antigos tempos e que examines a opinião dos nossos maiores. É que nós nascemos há pouco e em tão breve trecho de tempo não nos foi possível adquirir o conhecimento das coisas divinas. $\mathrm{E}$ os nossos dias voam na terra como sombras. Por consequência, resta que, àquela pessoa que pretender abarcar o conhecimento das coisas, lhe cumpre esquadrinhar com a razão e o entendimento todos os tempos passados a fim de conhecer tudo quanto foi procurado, descoberto e observado pelas inteligências e o ardente desvelo de muitos homens sábios. Porventura não poderás ser instruído pela ciência deles, incitado pelas suas exortações [35] e ensinado pelas suas opiniões? Ora, que é que eles ensinam? Nada mais que o seguinte: que o que dá firmeza à condição do homem não é o esforço humano, mas a ajuda divina.

Acaso vicejará o junco em lugares não pantanosos? Acaso crescerá a erva na completa ausência da água? Certamente que não, mas, pelo contrário, as suas hastes, depois de 
causa persoluo? Quod si diutius opem distuleris, certe non potero tantam malorum omnium molem sustinere. Si mane igitur me quaesieris, uita iam spoliatum reperies.

Hac quidem oratione Iobus, partim argumenta quibus Heliphasius illum accusauerat dissoluit, partim uim doloris quo torquebatur lamentis et questibus indicauit.

His autem querimoniis amici grauiter offensi sunt. E quibus Bildadus Suhita eiusmodi uerbis inuectus in illum est:

-Quousque tandem uerba ista proferes et in animi obstinati duritia perseuerabis? An Deus iudicium peruertet? An sanctissimus ille Dominus iuris sanctitatem uiolabit? Nullo modo. Ergo, cum ille iustissimus sit, necessario colligitur illum, quem is plectit, in culpa fuisse. Aliter enim Deus minime iusti iudicis officium tueretur. Si ergo constat filios tuos peccata in Deum commisisse ob quae fuerunt meritis poenis affecti et a Deo eiecti uitaque spoliati, nulla causa est cur de illorum ruina atque pernicie conqueraris. In eo uero quod tu tantis sis oppressus malis, liquido constat te etiam meritas sceleris admissi poenas pendere. Numinis autem infensi placatio non in pietatis simulatione, sed in sceleris confessione consistit. Si igitur ad Deum celeri et citata mentis conuersione redieris; si ad illum summum Dominum supplices preces adhibueris; si, plaga illius excitatus, te repente ad puritatis et iustitiae studium tota mente contuleris, is continuo domicilio tuo felicitatem ob iustitiam tuam restituet. Itaque, si toto animo iustitiam amplexatus fueris, multis partibus maiora et ampliora bona recipies illis quibus te euersum fuisse luges.

Quod, si tanti apud te non sumus ut auctoritate nostra moueare, repete, quaeso, totius antiquitatis memoriam maiorumque nostrorum sententiam peruestiga. Nos enim nuper exorti sumus nec, in tanta uitae breuitate, potuimus rerum diuinarum scientiam comparare. Diesque nostri instar umbrae in terris euolant. Restat igitur ut ei, qui rerum scientiam comprehendere uelit, sit omnis antiquitas mente atque ratione pertractanda, ut ea cognoscat quae multorum hominum prudentum ingeniis et ardenti studio quaesita, inuenta et explorata sunt. Annon illorum disciplinis institui, cohortationibus [35] excitari, sententiis erudiri facillime poteris? Quid est igitur ab illis traditum? Hoc certe: non humanam industriam, sed opem diuinam statum hominis stabilire.

Numquid iuncus in loco minime palustri uirescet? Numquid gramina aquis omnino destituta grandescent? Certe non, immo, postquam illorum culmi ad 
alcançarem as máximas dimensões que aí lhes for possível atingirem, de tal sorte surdirão minguadas que não podem ser ceifadas pela foice e secar-se-ão muito antes que as restantes ervas que se encontrarem situadas num local húmido. De modo idêntico, não terão qualquer fruto os esforços dos homens que não se lembram de Deus e extinguir-se-á por completo a confiança daqueles que fingem a piedade. A esperança deles será suprimida e as suas riquezas serão iguais a teias de aranhas. Quem se apoiar às suas casas, não se manterá de pé e quem as segurar não se erguerá. Por conseguinte, ainda que as suas riquezas semelhem brilhantes e consideráveis, e as suas fortunas pareçam firmes e inabaláveis, todavia são completamente vãs e falazes e num ápice são destruídas. É a esta a firme condição do homem que não se fortificou com a verdadeira virtude nem se muniu com a graça de Deus. Mas, usando da mesma comparação, quando há água em abundância, a hortaliça viceja até nas mais ardentes solheiras e os seus rebentos espalham-se largamente pela horta. E até aquela que foi semeada num montão de pedras lançará profundas raízes e enroscar-se-á nele com cerrados filamentos e apossar-se-á do domicílio edificado pelas pedras. Pelo que, se for arrancada, de tal maneira que dela não fique nenhum vestígio, a fim de transferi-la para outro lugar, nem sequer assim perderá a sua formosura e brilho, mas germinará de modo mais fecundo na terra alheia.

Ora, por esta forma a verdadeira piedade, que não se dissimula com mentiras, nem busca alcançar a popularidade, nem se procura fazer valer aos olhos dos homens, uma vez que, à semelhança de águas perenes, a alimenta a abundância do Espírito divino, conserva o viço nos maiores ardores, a fecundidade num solo estéril, no exílio frutos fecundos, aumentados com muitos acréscimos, e mantém a firmeza da sua condição em toda a espécie de adversidades e nos embates de todos os males. É que tão-pouco Deus priva da Sua ajuda os interesses dos homens que O adoram com espírito puro, casto e íntegro, nem os abandona à crueldade e capricho dos inimigos, mas protege-os com singular socorro e vigilância. Por isso, se com uma falsa religiosidade cometeste alguma falta, expia-a com uma sincera prática da piedade e consagra-te a Deus com a totalidade do teu espírito, para que assim saias finalmente destes males que te oprimem por todos os lados e te enchas de imenso contentamento. É que não há dúvida que, se tal fizeres, o Senhor levantará o teu espírito abatido pela tristeza e enchê-lo-á com tantas dádivas e mercês que exultarás de alegria e celebrarás com grandes brados os Seus louvores, os teus inimigos serão aviltados e serão derrubados do seu estado os ímpios que te são hostis.

Depois de Bildad pronunciar estas palavras, Job respondeu-lhe o seguinte:

- É verdade que aos olhos de Deus ninguém pode estar livre de toda a espécie de faltas. De facto, qual de entre os homens estará dotado de tal inteireza de vida que possa afirmar diante de Deus que nunca faltou ao seu dever? Pelo que, se existir alguma pessoa [36] audaciosa que queira disputar em juízo com o Senhor, nem sequer absolverá de toda a culpa a milésima parte daquelas coisas que pretender defender. É superior em sabedoria e em força, por consequência quem é que, com impudência ou atrevimento, desafiou a Sua divindade que não tenha recebido o castigo de tamanho desatino e loucura? Na verdade, Ele é quem instantaneamente leva de um lugar para o outro as montanhas e as destrói com a procela e a tempestade da Sua indignação; Ele é quem abala a Terra com 
summam magnitudinem, quam assequi poterunt, aliquando peruenerint, ita erunt humiles ut falce succidi non possint et multo ante reliquas herbas, quae in humido loco sitae fuerint, exarescent. Similiter hominum studia qui Dei immemores sunt fructu suo priuabuntur et confidentia illorum qui pietatem ementiuntur funditus interibit. Illorum spes erit incisa et eorum opes erunt domiciliis araneorum simillimae. Qui domibus illorum nixus fuerit, minime consistet et qui illas apprehenderit non erigetur. Vt igitur illorum opes ad speciem illustres et amplae sint eorumque fortunae fixae et optime constitutae uideantur, uanissimae tamen sunt et fallacissimae unoque temporis momento peruertuntur. Hic est eorum status qui non uera uirtute firmatus neque Dei gratia communitus est. At uero, ut in eodem simili uerser, ubi humor suppetit, olus in maximis etiam ardoribus solis uirescit illiusque propagines in horto late funduntur. Quin etiam in lapidum aceruo consitum altas radices aget seque in illo densis fibris implicabit domiciliumque saxis exstructum possidebit. Quod, si fuerit euulsum ita ut nullum sui uestigium relinquat, ut alium in locum transferatur, neque sic quidem speciem et nitorem suum amittet, sed laetius in aliena tellure germinabit.

Ad hunc autem modum uera pietas, quae non est fucata mendaciis, nec auram popularem captat, neque se oculis hominum uenditat, cum sit diuini Spiritus affluentia, quasi perennibus aquis, enutrita, in maximis ardoribus uiriditatem, in solo sterili fecunditatem, in exsilio uberrimum fructum, multis accessionibus amplificatum, retinet statumque suum, in omni rerum asperitate malorumque omnium tempestate, conseruat. Nec enim Deus res hominum, qui illum pura et casta et integra mente uenerantur, ope sua destituit nec illos hostium immanitati atque libidini permisit, sed singulari praesidio atque uigilantia protexit. Quare, si quid est a te ementita religione uiolatum, id uerissimo cultu sanctitatis expia teque ad Deum tota mente conuerte, ut sic tandem ex his malis quae te undique premunt emergas et ingenti gaudio cumuleris. Certe enim si id feceris, Dominus animum tuum maerore deiectum excitabit tantisque donis atque muneribus explebit ut laetitia exsultes maximaque uoce laudes illius celebres, hostes tui ignominia deformabuntur et status impiorum, qui tibi infesti sunt, euertetur.

Haec Bildadus cum dixisset, Iobus ita respondit:

- Verum quidem id est neminem in Dei conspectu posse crimine omni liberari. Quis enim inter homines erit tanta uitae integritate praeditus ut possit apud Deum asserere se numquam in officio deliquisse? Quod si quisquam [36] tam confidens exstiterit ut cum Domino iudicio decertare uelit, ne millesimam quidem partem earum rerum quas defendere uoluerit omni culpa uacare peruincet. Sapientia praecellit et robore: quis igitur illius numen uel impudentia uel audacia concitauit quin tantae temeritatis et amentiae poenas exsoluerit? Is enim est qui montes improuiso transfert et indignationis suae procella atque tempestate peruertit; qui terram ingenti motu concutit atque sede conuellit illiusque columnas et 
um violento movimento e a arranca do lugar e derruba os seus fundamentos e solidez. É obedecendo ao Seu poder que o Sol se abstém de espalhar a luz sobre a Terra e as estrelas recebem o sinal de não iluminarem os mortais com o seu resplendor. Foi só Ele quem com as Suas mãos ornamentou o céu; quem caminha através da superfície do mar, pois se estende por tudo, por forma a tudo governar com a Sua divindade; quem criou o Arcturo, a Ursa Maior, as Plêiadas e os astros que, ocultos no recôndito do Sul, se encontram apartados da vista dos nossos olhos. Fez obras imensas, cuja natureza ninguém alcança mediante a inteligência e o entendimento; criou coisas admiráveis a vários títulos, cujo grande número não há ninguém que possa enumerar. Passará diante de mim, todavia não O contemplarei; irá de um lado para outro, de tal modo todavia que eu não veja o Seu caminhar e as Suas pegadas. Se quiser despojar alguém de todos os bens, quem há-de reprimir a Sua força e ímpeto? Quem lhe há-de perguntar a razão pela qual procede assim? Deus é quem tudo abarca com a Sua imensa potestade, não há nenhumas forças capazes de fazerem frente e resistir à Sua ira e a Sua divindade e poder facilmente derrubam os grandes príncipes ligados por aliança com o potentíssimo tirano.

Por conseguinte, quem sou eu para Lhe responder e conceber a forma que me permita defender a minha causa diante d' Ele? Por isso, ainda que não seja culpado de nenhuma infâmia nem me atemorize o espírito a consciência de nenhuma malfeitoria, mesmo assim não me atreverei a expor-me ao Seu juízo e não estribarei a solidez da minha causa na equidade do direito, mas na benignidade do juiz, a quem implorarei perdão com palavras suplicantes. Se O invoco, ainda que Ele escute misericordiosamente as minhas palavras, todavia não posso estar seguro de que Ele não rejeitou as minhas preces. De facto, aniquilou-me com o turbilhão e, sem poder reconhecer-se qualquer grave motivo de malfeitorias, desfigurou-me com muitas feridas. Não me concede qualquer permissão de tomar fôlego e assoberba-me com inumeráveis suplícios pungentes. Se é mister agir pela força, avantaja-se por uma força imensa; se cumpre pleitear em juízo, a que advogado hei-de recorrer? Se alegar que sou justo, condenar-me-á por impiedade; se eu a mim mesmo me atribuir pureza de vida e costumes impolutos, a minha culpabilidade será provada pelo Seu juízo. Por outro lado, não tenho a certeza de que aos seus olhos sou puro e íntegro. Se Lhe parecer, embora eu seja puro no mais alto grau, mesmo assim há-de condenar-me como malvado e injusto. Por isso acontece que sinto enfado pela vida, pois nem posso estar certo se Ele me castiga como culpado ou, com trabalhos e tribulações, me atormenta como justo.

Por consequência, não me considero justo nem faço recair sobre o Senhor a suspeita de injusto, como vós me lançais em rosto, mas de qualquer maneira afirmo que é [37] por deliberação e vontade do próprio Senhor que não só os ímpios são destruídos, mas também por vezes asperamente atribulados com suplícios os homens santos. Pelo que não há motivo para do meu suplício extrairdes a prova de que vivi uma vida de pecado nem para me acusardes pelo facto de, no meio de tão grandes dores, fazer aquilo a que os ferimentos infligidos me constrangem: soltar brados sobremaneira aflitivos e com chorosos queixumes rogar a Deus que ponha fim a tão grandes tormentos. 
soliditatem labefactat. Cuius imperio sol se continet ne lucem in terras spargat et stellae ne splendore suo mortales illuminent obsignantur. Qui solus manibus caelum expoliuit; qui per mare summum ingreditur, per omnia siquidem pertinet, ut omnia numine suo moderetur; qui condidit Arcturum, Cynosuram et Pleiades et sidera quae, Austri penetralibus abstrusa, ab oculorum nostrorum aspectu remota sunt. Opera ingentia perficit, quarum rationem nemo intelligentia et mente consequitur; res multis modis admirandis edit, quarum multitudinem nemo est qui ennumerando recenseat. Praeteribit quidem me, illum tamen haud intuebor; ultro citroque commeabit, ita tamen ut ipse illius uestigia et ingressum non uideam. Si quempiam bonis omnibus spoliare uoluerit, quis illius uim et impetum coercebit? Quis de illo rationem quare id faciat percontabitur? Deus est qui omnia potestate immensa complectitur, cuius irae nullis uiribus obsisti atque repugnari potest, cuius numine et imperio magni principes foedere cum potentissimo tyranno deuincti facillime prosternuntur.

Quis igitur ego sum ut illi respondeam et rationem mediter qua possim apud illum causam meam tueri? Quod, si nulli flagitio affinis sim neque animum meum alicuius maleficii conscientia perterreat, illius tamen iudicium subire non audebo neque causae meae firmamentum in iuris aequitate, sed in iudicis benignitate constituam, a quo ueniam supplicibus uerbis implorabo. Si illum inuoco, quamuis ille orationem meam clementer exaudiat, non tamen certus esse possum illum preces meas minime repudiasse. Me namque turbine peruertit multisque uulneribus, sine ulla graui, quae constare possit, maleficiorum causa, deformauit. Nullam mihi respirandi potestatem facit multisque me suppliciorum acerbitatibus exsaturat. Si uiribus agendum est, robore immenso praestat; si iure litigandum, quem mihi aduocatum adhibebo? Si me iustum esse defendero, me impietate condemnabit; si mihi uitae puritatem et integros mores assumpsero, illius iudicio conuincar. Vt autem in illius conspectu castus et integer sim, id tamen exploratum non habeo. Si illi uisum fuerit, quamuis integritate summa sim, me tamen ut maleficum et iniustum iudicio persequetur. Idcirco fit ut me taedium uitae capiat, nec enim certus esse possum an is me ut sontem puniat aut ut iustum laboribus et aerumnis exerceat.

Non igitur mihi iustitiam attribuo neque Dominum in iniuriae suspicionem uoco, quod uos mihi obiicitis, sed hoc tamen dico [37] Domini ipsius mente atque numine, non solum impios euerti, uerum etiam interdum homines sanctos suppliciis uehementer affligi. Quare non est cur ex meo supplicio argumentum uitae a me turpiter actae depromatis neque mihi crimini detis quod, in tanto dolore quod inflictum uulnus me facere cogit, uoces adeo flebiles emittam et Deum lugubri querimonia obtester ut finem tantis cruciatibus imponat. 
Sem embargo, Deus não aniquila os culpados pelo mesmo motivo por que permite que os inocentes sejam atribulados. É que golpeará os culpados de maneira a destrui-los mediante um suplício inesperado, mas aos inocentes, a fim de pôr à prova a sua fé, atacálos-á com tribulações, como se estivesse irado com eles e escarnecesse da sua desgraça. Na verdade, se Deus estabelecesse sempre os suplícios como castigo do pecado e do crime, seguir-se-ia que uma condição afortunada e próspera encerraria uma prova indubitável de piedade e de justiça. Mas vemos que amiúde as coisas sucedem diferentemente. De facto, concede-se ao ímpio o poder supremo da Terra e os intérpretes da lei oferecem a impunidade aos crimes e fecham os olhos para as infâmias dos poderosos. Se isto não é tolerado pelo juízo de Deus, é-o pelo juízo de quem? Na realidade, que outro poder existe capaz de reprimir a tirania, punir as más acções e estabelecer suplícios para os sacrílegos e ímpios? Por conseguinte, resta que durante a vida os perversos e depravados gozam de abundantes comodidades, ao mesmo tempo que os bons são atribulados por muitas provações.

E assim não há razão para que me odieis como a homem ímpio e injusto pelo facto de ter recebido golpes tão violentos, mas há-a sim para que vos condoais da minha sorte. É que os meus dias se precipitam com muita mais rapidez do que um corredor e ao fugirem adquirem uma extraordinária celeridade e não deixam ver na vida bem algum. São levados por uma marcha assaz impetuosa, como naus impelidas por um vento de feição, que com as velas desfraldadas se dirigem para o desejado porto e, na extraordinária velocidade, rivalizam em ligeireza com a águia que se precipita sobre a presa.

Por outro lado, tendo-me decidido a apartar o espírito de tristíssimos cuidados e a encobrir a dor com um semblante sereno e a, até onde fosse possível, fortificar o ânimo para suportar as tribulações, de súbito aquela inquietação derrubava-me da minha postura, porque angustiosamente me arreceava de que talvez estas penalidades me tivessem sido causadas devido a algum crime.

É que sei, ó Senhor, que não deixas nenhum delito sem castigo e punição. Por conseguinte, o que atormentava o meu espírito não era tanto a dor em si, quanto a causa da dor que temia. Por isso, embora eu não tenha consciência de ser culpado de nenhum crime, todavia se, depois de tanto trabalho e tanto desvelo despendido na prática da piedade, ainda me encontro manchado com a nódoa da impiedade, que fruto me trouxe tão grande número de trabalhos? De facto, se me lavar com as águas que jorram das neves descongeladas; se limpar cuidadosamente as minhas mãos de maneira a que brilhem de puras, mesmo assim aos Teus olhos considerar-me-ei de tal maneira sujo e manchado como se, submergido num fosso, as minhas roupas se tivessem impregnado com lamacentas sujidades.

É que, quem é que, postado diante d' Ele, se atreverá a confessar-se isento de todo o pecado? Tão-pouco é Ele um homem e meu semelhante em natureza e condição, [38] para que eu possa alegar em processo contra Ele e disputar judicialmente com Ele. E, de resto, não existe ninguém que possa mediar, a fim de com a sua arbitragem pôr termo à nossa contenda. Que Ele aparte de mim a Sua severidade na punição do crime; que ponha termo ao terror com que amiúde me inquieta; adopte uma postura de doçura e 
Attamen non eadem ratione qua Deus nocentes perdit innocentes uexari permittit. Nocentes enim plagis insequetur ut eos inopinato supplicio mactet, innocentes uero, ut illorum fidem probet, aerumnis, quasi sit iratus illis et illorum calamitate ludat, afficiet. Si enim supplicia semper in peccati et sceleris poenam fuissent a Deo constituta, sequeretur ut florens atque felix status pietatis atque iustitiae certissimum testimonium continerer. Atqui secus euenire saepe conspicimus. Terrae namque summa potestas impio permissa est et, qui ius dicunt, sceleribus impunitatem tribuunt et in potentium flagitiis coniuent. Si haec non Dei iudicio tolerantur, cuius iudicio tolerantur? Quae enim alia potestas est quae possit coercere tyrannidem, uindicare facinora debitumque sceleratis et impiis sancire supplicium? Restat igitur ut profligati atque perditi multis in uita commodis abundent, cum interim boni multis aerumnis exerciti sint.

Itaque non est cur me ut hominem impium et iniustum detestamini eo quod tam graues plagas acceperim, sed quod uicem meam doleatis. Dies namque mei multo celerius cursore properant et insignem celeritatem in fugiendo suscipiunt nullumque bonum in uita intueri concedunt. Cursu nimis incitato feruntur, ut naues uento secundo delatae, quae in optatum portum pansis uelis inuehuntur et cum aquilae pernicitate, qua in escam uolat, admirabili uelocitate contendunt.

Cum autem statuerem mentem a curis tristissimis abducere doloremque uultus serenitate tegere et animum, quoad fieri possit, ad aerumnas perferendas confirmare, illa me repente sollicitudo de statu deiiciebat, quod anxie formidabam ne fortasse dolores hi essent mihi propter aliquod scelus inusti.

Scio enim, Domine, quod nullum crimen inultum et impunitum relinquis. Non igitur tantum me dolor ipse, quantum doloris causa, quam uerebar, animum meum excruciabat. Quod si, quamuis ipse nullius mibi sceleris conscius sim, tamen post tantam operam tantumque studium, in pietatis exercitatione consumptum, adbuc impietatis labe contaminatus sum, quem fructum mibi tam multi labores attulere? Si enim me aquis quae ex liquefactis niuibus emanant abluero; si manus meas, ut puritate niteant, diligenter extersero, in oculis tamen tuis ita me sordidum et inquinatum reputabo atque si, in fouea demersus, omnes uestes meas sordibus lutulentis infecissem.

Quis enim in conspectu illius positus se omni scelere uacuum profiteri audebit? Nec enim ille est homo mihique natura et condicione similis, [38] ut aduersus illum causam dicere et cum illo iure decertare ualeam. Neque est interim qui se medium interponat, ut arbitratu suo controuersiam nostram dirimat. Remoueat a me suam in crimine uindicando seueritatem; auferat terrorem quo me frequenter exagitat; lenitatis et mansuetudinis personam induat: et tum demum loqui potero 
mansidão: e só então poderei falar e ter confiança na minha causa. É que, assim como, se pesar os meus serviços com os pesos da Sua justiça, há-de encontrar-me culpado de muitos delitos, da mesma maneira, se tiver em conta a minha fraqueza, provavelmente há-de ilibar-me de todo o crime sacrílego. Por consequência, então não temeria nem seria atribulado por aquele cuidado que perturba o meu espírito nem viveria na apreensão de $\mathrm{O}$ ter ultrajado com alguma mancha de iniquidade. E assim o meu espírito sente enfado pela vida e não me empenho em repelir o cuidado que me atormenta e, acabrunhado pela violência desta tão grande dor, solto brados conformes com a presente infelicidade. Por conseguinte hei-de dizer a Deus:

Senhor, não desistirei de Te rogar que não me condenes como sacrílego e ímpio. Por isso, que esta desgraça em que me encontro seja uma prova à fé e não um castigo pelo pecado. Pelo que, se sou atormentado por estas penalidades por causa das faltas cometidas, ao menos concede-me mostrar-me a própria falta devido à qual Te arrebatas contra mim. É que eu agora hesito, sinto dúvidas e grande perplexidade por não poder discernir o motivo pelo qual me encontro cercado por tantos males. Porventura parece-Te conveniente oprimir violentamente sem causa um homem e desprezar a obra das Tuas mãos e levar a bom termo o desígnio dos impios que maquinam a perdição dos bons? Porventura tens olhos humanos? Porventura olhas ao modo dos homens? Porventura permites que no Teu juizo esteja presente o engano e se ocultem os segredos da mente? Acaso a Tua idade se encontra delimitada pelo prazo da idade bumana e os Teus anos se acham circunscritos pelas mesmas balizas dentro das quais se encerra a vida de um qualquer varão? Logo, por que é que esquadrinhas tão escrupulosamente a minha vida e inquires se em mim existe algum defeito, como se disso não estivesses informado ou tivesses perdido o poder de esquadrinhar e de observar? E isto, embora saibas e Te seja notório que eu não cometi nenhum acto impiedoso e que não existe ninguém que me possa arrancar das Tuas mãos, a mim a quem Tu atribulaste com tantas desgraças.

Portanto, por que razão é que despendeste tanto trabalho em criar-me e me moldaste inteiramente com as Tuas mãos de modo tal que nada existe, quer interiormente no espirito, quer por fora no meu corpo, que não tenha sido feito pela perícia e bondade da Tua inteligência? Acaso para me destruíres e aniquilares de repente uma obra Tua já concluída? Peço-Te que Te lembres quão breve é o curso desta minha existência. É que, assim como moldaste com lama o meu corpo, da mesma maneira o reduzes a pó. E todavia é admirável o grande trabalho e desvelo que consumiste em criar-me. Porventura a semente, de que nasci, em conformidade com a ordem da natureza que de modo maravilhoso estabeleceste, não foi derramada à semelhança de leite? Mas depois assentou num lugar onde a amassaste e coagulaste como se fosse queijo. Em seguida decidiste, a partir dela, revestir-me de carne e pele; fortificaste o meu corpo com ossos e músculos, [39] por forma a que pudesse, com membros diferenciados e sólidos, desempenhar variadas funções. Seguidamente deste-me a vida e abraçaste-me com a Tua misericórdia e conservaste a minha inteligência com extraordinária providência e prudência. Mas o modo como Te achas presente e dispões, realizas e levas a cabo tudo isto, esconde-se dentro de Ti e não pode ser compreendido pelo entendimento humano. Todavia eu sei e confesso que tudo 
et causae meae confidere. Vt enim, si officia mea iustitiae suae ponderibus examinauerit, multis me delictis astrictum reperiet, ita, si imbecillitatis meae rationem duxerit, omni me fortasse nefario crimine liberabit. Non igitur tunc timerem neque me illa cura uexaret qua incertus animi sum et uereor ne illum aliqua iniquitatis labe uiolarim. Itaque taedet animum meum uitae meae et curam quae me lacerat minime reprimendam suscipio et, hac tanta doloris acerbitate confectus, uoces miseriae praesenti consentaneas emitto. Dicam igitur Deo:

Domine, hoc a te contendere non desistam ne me ut scelestum et impium damnes. Haec igitur calamitas, in qua uersor, fidei probatio, non sceleris poena sit. Quod, si propter admissum scelus his poenis excrucior, id saltem mibi tribue, ut scelus ipsum, ob quod in me inueberis, ostendas. Nunc enim haereo et dubito ualdeque sollicitor eo quod causam, quare tantis malis circumuentus sim, explicare non possum. Num uidetur tibi commodum hominem sine causa uiolenter opprimere opusque manuum tuarum aspernari et consilium impiorum, qui de bonorum interitu cogitant, ad exitum perducere? Num oculi tibi bumani sunt? Num bominum more contueris? Num in iudicio tuo uersari fraudem et arcana mentis occultari permittis? Numquid aetas tua est bumani aeui spatio definita annique tui eodem termino circumscripti quo uiri cuiuslibet uita concluditur? Quid ergo tam diligenter in uitam meam inquiris et an sit aliqua in me prauitas inuestigas, quasi id tibi minime compertum sit aut inquirendi et animaduertendi facultas elabatur? Et hoc, quamuis tibi perspectum et cognitum sit me nullum impium facinus commisisse neminemque esse qui me tantis a te calamitatibus afflictum e manibus tuis possit eripere.

Cur igitur tantum in me formando laborem suscepisti meque totum manibus tuis ita effinxisti ut nibil insit, uel intus in animo, uel extra in corpore meo, quod non sit artificio et benignitate mentis tuae perfectum? Numquid ut me perderes opusque tuum iam absolutum repente dissipares? Recordare, quaeso, quam breuis sit buius uitae meae cursus. Vt enim corpus meum e luto finxisti, ita illud in puluerem redigis. Et tamen mirum est quantam in me creando operam et laborem insumpseris. Annon semen, quo genitus sum, ordine naturae a te mirifice constituto, fuit instar lactis infusum? Deinde locis insedit ubi per te, ad casei similitudinem, coagmentatum est et concretum. Ex illo deinde carnibus et cute me uestire instituisti; ossibus atque neruis corpus meum [39] muniuisti, ut artubus distinctis atque stabilitis posset uaria munera sustinere. Vitam deinde mibi dedisti et misericordia tua me complexus es mentemque meam singulari moderatione et prouidentia conseruasti. Ratio uero qua praesens ades et haec omnia designas, moliris, efficis, penes te ipsum latet nec intelligentia bumana percipitur. Ego tamen scio et confiteor haec omnia numine tuo fieri. Quid ergo opus tuum tanta cura perfectum, tanta uigilatione conseruatum euertis? 
isto foi feito pelo Teu poder divino. Então por que é que destróis a Tua obra, realizada com tamanho cuidado e conservada com tão grande vigilância?

Se na vida pública em algo atentei contra a sociedade humana, acaso por isso me hásde condenar a prisão sempiterna e não concederás que expie com nenhuns actos religiosos a minha falta? Mas se atentei, não contra os homens, mas contra a Tua majestade divina e com o meu delito ultrajei a santíssima religião, infeliz de mim! Se, pelo contrário, sempre honrei zelosamente a justiça: e nem sequer assim hei-de levantar a cabeça e, além disso, hei-de ser atacado com inúmeros baldões! Peço-Te, Senhor, que ponhas os olhos nesta minha mofina e que consideres com misericórdia o grande número de desgraças que me derribaram. Como Te recusas a fazer isto, e adias a Tua clemência, e me apavoras com tormentos, não é de espantar se sou perturbado por alguma comoção de ânimo. É que a dor vai-se tornando mais pungente de dia para dia, ao inflamares as Tuas forças de maneira a que Te precipitas sobre mim como um leão e me fazes em pedaços com venenos e mordidas, e, depois de cessares por um pouco, de novo violentamente atacas e Te assanhas de modos espantosos. E, não satisfeito com este tormento, arranjas incessantemente novas testemunhas para me censurarem o crime. Enterras no meu corpo a espada da Tua ira e aos antigos males acrescentas os recentes e, formando as tropas em linha de batalha, pelejas contra mim. Por que é que me tiraste do ventre da minha mãe?

Na verdade, se então tivesse morrido e na Terra ninguém me visse vivo, teria escapado a todas estas desgraças que me acabrunham por todos os lados. Se, logo que nasci, de imediato tivesse sido sepultado, como se nunca tivesse sido gerado no útero, desse modo teria sido completamente suprimido de toda a lembrança. Porventura o que me resta de vida não deve restringir-se a um brevíssimo período? Então, porque ocorre ao Senhor torturar-me com tantas dores num prazo de vida tão estreito? É que persegue-me, acossa-me e não afrouxa, e não me concede nenhum alívio para que eu possa alentar o meu espírito. Antes que parta, sem qualquer esperança de regresso, para a região tenebrosa e mergulhada em sombras mortíferas, para uma região, insisto, coberta por tão densa cerração que a própria cerração não pode ser mais horrível. Aí as trevas são mortíferas e perpétuas; aí não vigora nenhuma ordem, nenhuma lei, nenhuma harmonia, mas tudo é tão corrupto, desordenado e confuso e cheio de trevas tão medonhas e sinistras que, se lá existe algo de luz daninha, esta mais deve ser tida na conta de horrenda cerração do que de luz.

Estas as palavras de Job, o qual, consoante parece, antes de chegar à parte final do seu discurso, com o aumento da dor sentiu estímulos muito mais violentos do que no princípio e, por isso, foi constrangido a proferir um epílogo tão patético. Mas uma vez que este seu parecer exprimia, não o juízo de um entendimento são, mas o sentir de um corpo severamente atormentado, [40] mais merecia compaixão do que vitupério. É que tão-pouco foi vedado aos santos homens nas situações penosas não lastimarem a sua desgraça e expressarem por vezes por palavras, não aquilo que a sua fé se determina a seguir, mas os pensamentos com que são tentados. Os amigos dele, porém, tomaram este discurso à pior parte e com ele se escandalizaram muito mais fortemente. E por isso 
Si quidquam in communi uita contra hominum societatem deliqui, num propterea me in custodiam sempiternam trades nec ullis sacris peccatum meum expiari concedes? Si uero non homines, sed numen tuum offendi religionemque sanctissimam scelere meo uiolaui, uae misero mibi! Sin autem iustitia semper a me sancte culta fuit: neque sic quidem caput erigam et multis praeterea contumeliis onerabor! Respice iam, quaeso, Domine, cladem hanc meam et quantis calamitatibus abiectus sim benigne considera. Quod cum facere recusas clementiamque tuam differs et me suppliciis exterres, mirum non est si quodam animi motu conturbor. Nam dolor grauior in dies fit, ut tu uires tuas excites ut in me tamquam leo insilias meque uenenis atque morsu dilaceres, paulisper omissum iterum uiolenter arripias mirisque modis exagites. Neque boc supplicio contentus, nouos identidem testes instruis qui mibi scelus obiiciant. Iracundiae tuae gladium in corpore meo defigis et recentia mala uetustis accumulas et mecum, acie instructa, congrederis. Cur me de uentre meae matris eduxisti?

Si enim tunc me uita defecisset neque me quisquam uiuum in terris aspexisset, has omnes clades, quae me undique premunt, uitauissem. Si, cum primum editus sum, in sepulcrum illatus continuo fuissem, quasi numquam utero susceptus exstitissem, ita fuissem ex omni memoria penitus euulsus. An reliqua uita mea non est breuissimo spatio terminanda? Quid ergo uenit in mentem Domino tantis me doloribus in tam angusto uitae termino torquere? Instat enim et urget et nihil remittit nec ullum aleuamentum mihi concedit, ut animum confirmare possim. Priusquam abeam, sine ulla spe reditus, in regionem tenebricosam et mortiferis umbris inuolutam, in regionem, inquam, tam densa caligine obductam ut caligo ipsa taetrior esse non possit. Ibi mortiferae atque sempiternae tenebrae sunt; ibi nullus ordo, nullus modus, nulla conuenientia uiget, sed omnia sunt inquinata, perturbata atque confusa et tam diris et exsecrandis tenebris oppleta ut, si quidquam illic malignae lucis inest, ea sit magis horrenda caligo quam lux existimanda.

Hactenus quidem Iobus, qui quidem, ut uidetur, antequam perorasset, fuit amplificatione doloris multo uehementius quam in principio stimulatus, et idcirco tam miserabili epilogo uti coactus est. Cum uero haec illius sententia, non integrae mentis iudicium, sed corporis acerbissime cruciati sensum [40] contineret, magis erat misericordia quam uituperatione digna. Nec enim est sanctis hominibus interdictum ne in rebus asperis calamitatem suam deplorent et aliquando, non quid eorum fides in decernendo sequatur, sed qualibus cogitationibus attentetur, uerbis exprimant. Amici uero illius hanc orationem in peiorem partem acceperunt illaque multo grauius offensi sunt. Ita igitur in illum inuehuntur, quasi in hominem, 
de tal maneira o invectivaram, como se se tratasse de um homem que, com indignas injúrias contra Deus, não hesitava em aumentar os crimes já perpetrados. Um dentre eles, chamado Sofar, de Naamá, falou do seguinte modo:

- Porventura é justo que ninguém refute este falador copioso? Acaso é lícito e de direito que um homem loquaz oculte o crime com a grande abundância de palavras e ganhe em juízo a sua causa? Naturalmente, tu és o único diante de quem todos os mortais se calam, de tal maneira que, ainda que digas algo de modo desatinado e insolente, a ninguém é lícito refutar com algum desdouro teu uma opinião totalmente criminosa... Mas embora tenhas dito muita coisa de forma assaz impudente e ímpia, o que sobremaneira me espantou foi o teres declarado que jamais estragaste com alguma falta, que conheças, a inteireza de princípios da tua vida, mas que sempre viveste pura e santamente aos olhos de Deus. Estas palavras, trasbordantes de desatino e atrevimento, puderam sair da tua boca? Atrever-se-ia algum homem sábio a pretender asseverar em altos brados que na vida não cometeu nenhuma falta aos olhos de Deus, a quem nada se pode esconder? Oxalá que o próprio Deus falasse e quisesse há pouco disputar contigo. É que te patentearia os segredos da sabedoria, para que entendesses que nos Seus juízos não pode ter lugar o erro, uma vez que a lei d' Ele tem como sólidos fundamentos a luz do entendimento e a força da constância, e então verias claramente que Ele te castigou com penas muito menores do que tinhas merecido devido à tua iniquidade.

Acaso poderás esquadrinhar e investigar a fundo os desígnios de Deus? Acaso com a inteligência penetrarás na perfeição daquele Senhor supremo? A imensidade da Sua altura supera o cume do céu: de que maneira pois hás-de ter pretensões a atingi-Lo? É mais profundo do que a parte mais funda do Inferno: de que forma hás-de perscrutar o Seu pensamento? A extensão do Seu comprimento vence o comprimento da Terra; a Sua largura avantaja-se incomparavelmente à largura do mar. Se mudar todas as coisas e esconder nas trevas o que é visível e puser à mostra o que está escondido, quem há-de desviá-Lo da determinação que tomou? Dir-me-ás: por que é que não desvenda todos os Seus desígnios e não mostra sempre os motivos por que está irado contra os homens? - Porque conhece a vaidade dos mortais e vê que a iniquidade dos homens e a natureza humana, indóceis aos Seus ensinamentos, não compreendem o que é útil para a salvação. É que o varão privado de entendimento, ao rejeitar os ensinamentos, é facilmente induzido em erro, e os homens foram formados pela natureza de tal maneira que, tal como as crias dos onagros, com o máximo empenho procuram movimentos livres e isentos de toda a lei. Por conseguinte, quanto mais estreita é a atadura que os prende, tanto mais obstinadamente se esforçam por, quebradas as ataduras, [41] algum dia se escapulirem e mais desenfreadamente errarem por toda a sorte de paixões.

Não é por isso justa a queixa dos que muito contristadamente se lamentam de que o juízo de Deus lhes seja completamente desconhecido. É que Ele, quando é conveniente, oculta-o aos homens, mas quando the parece adequado, dá a conhecer aquilo que anteriormente estava escondido. Portanto, por que é que não pões de parte essas coisas de que não tirarás qualquer proveito e fazes antes aquilo que te há-de restituir à dignidade e à saúde? Com efeito, se com todo o coração te virares para Deus e de modo suplicante 
qui scelera commissa indignis in Deum maledictis, amplificare non dubitaret. E quibus unus, Sopharus nomine, Nahamathita natione, in hanc sententiam locutus est:

- Numquid par est ut eum qui multis uerbis abundat nemo refellat? An ius et fas est ut homo loquax uerborum multitudine scelus contegat atque in iudicio causam obtineat? Scilicet tu solus es coram quo mortales omnes conticescant, ita ut, etiamsi quid a te fuerit petulanter atque temere dictum, nemini licitum sit, cum aliqua ignominia tua, sceleris plenam sententiam refutare... Cum uero multa dicta sint a te satis impudenter et impie, tum illud maxime admiratus sum in quo testificatus es, te nullo umquam, quod scias, crimine uitae tuae disciplinam corrupisse, sed pure semper et sancte in Dei oculis uixisse. Haecine uerba, temeritatis et audaciae plenissima, ex ore tuo excidere potuerunt? Hocne quisquam homo sapiens sibi assumere auderet, ut nullum a se in uita commissum flagitium coram Deo, quem nihil latere potest, maxima uoce testaretur? Vtinam Deus ipse loqueretur et oratione tecum modo certare uellet. Aperiret enim tibi arcana sapientiae, ut intelligeres in illius iudicio errorem uersari non posse, cum lex illius et mentis luce et constantiae robore stabilita firmissime sit, et tunc plane cerneres illum multo minus poenarum a te, quam propter iniquitatem tuam meritus fueras, expetiuisse.

Num Dei consilia peruestigare atque penitus explorare poteris? Num in illius summi Domini perfectionem mente et consilio penetrabis? Altitudinis immensitate caeli fastigia superat: quomodo tandem ad illum aspirabis? Profundior est infima Tartari regione: quo pacto mentem illius perscrutabere? Mensura longitudinis illius longitudinem terrae uincit; latitudo illius maris latitudini multis partibus antecellit. Si res omnes immutauerit et prompta tenebris abdiderit et abdita in apertum protulerit, quis illum ab instituto consilio deterrebit? Cur, inquies, non omnia consilia sua patefacit et causas quare sit hominibus iratus non semper exponit? - Quia nouit mortalium uanitatem et uidet hominum iniquitatem et naturam humanam, ad disciplinam illius indocilem, minime, quid saluti expediat, intelligentem. Vir enim mente uacuus, cum disciplinam repudiet, facile in fraudem impellitur, et homines ita natura constituti sunt ut, tamquam onagrorum pulli, uagos motus omnique lege solutos summo studio requirant. Quo igitur artiore uinculo constringuntur, eo pertinacius laborant ut, perruptis [41] uinculis, erumpant aliquando licentiusque per omnia libidinum genera uagentur.

Non est igitur eorum iusta querella qui sibi Dei iudicium esse penitus ignotum miseris modis lamentantur. Ille enim, cum est commodum, id homines celat, cum rursus illi uidetur ea, quae ante latebant, enuntiat. Quin igitur ista omittis, e quibus nullam utilitatem capies, et illud potius agis, quod te in salutem et dignitatem restituet? Si enim toto corde ad Deum conuersus fueris et suppliciter ad illum manus intenderis; si omnem iniquitatis labem a te longe repuleris nec 
Lhe estenderes as mãos; se afastares para longe de ti toda a mancha de iniquidade e não permitires que o teu tabernáculo seja aviltado e contaminado por qualquer contágio de impureza, serás liberto de toda a mácula de desdouro e infâmia, ver-te-ás protegido por uma sólida defesa e não sentirás medo de nenhum suplício. Esquecerás a tribulação e não terás mais lembrança dela do que das águas depois de se terem escoado. Serás iluminado durante todo o decorrer da tua vida, como pela luz do meio-dia, e se em algum momento cair sobre ti um pouco de trevas, saindo de repente da cerração verás a luz. Sentirás confiança porque colherás em segurança o fruto que esperavas. Por isso, se cultivares o campo, deitar-te-ás no teu leito sem qualquer receio externo e dormirás sem qualquer preocupação. E não haverá ninguém capaz de te meter medo e serão muitos os que em atitude suplicante se dirigirão a ti com pedidos. Os olhos dos ímpios mirrarão com o ódio, não escaparão à violência iminente do desastre e padecerão enganados por uma esperança totalmente infundada.

Job, ripostando a esta fala, disse:

- Não há dúvida, pelo que depreendo das vossas palavras, que a razão suprema e o juízo de todo o género humano residem apenas em vós e convosco irá para o sepulcro toda a sabedoria... É que de tal maneira vos ufanais e de tal maneira vos comprazeis convosco, como se fôsseis os únicos a ter alcançado a ciência dessas coisas. Mas, acreditai em mim, não tenho menos capacidades intelectuais do que qualquer um de vós e a nenhum de vós concedo a primazia no conhecimento desses assuntos. De resto, isso que dizeis não é tão secreto e difícil de entender como cuidais, mas quase faz parte dos conhecimentos comummente vulgarizados. De facto, quão poucos são aqueles para quem isso não seja óbvio? Todavia, ao assim vos jactardes da vossa reputação de sábios, não tendes qualquer preocupação nem com a humanidade nem com a religião: pois, que crueldade tão grande é a vossa que vos leva a zombar de um homem a vós ligado por uma aliança e a insultá-lo na sua tristíssima adversidade? E não vedes que ele há-de dirigir preces a Deus e algum dia há-de finalmente obter ajuda e auxílio d' Aquele que na desgraça nunca despreza as vítimas da injustiça? É assim que vos apraz zombar na maior das desgraças de um homem justo e íntegro? Desprezar a tocha que resplandecia com tanta luz que também recebiam a sua luz aqueles que eram considerados prósperos e afortunados, e escandalizar-se com a desgraça dele de maneira tal que, aqueles que o virem atribulado, caem e se abatem, pois empenhais-vos em fazer que os que se lançarem sobre mim, escandalizados com a minha pobreza e indigência, cambaleiem e caiam.

Não podeis, porém, contestar aquilo que eu disse atrás, ou seja, acontecer frequentemente [42] que perversíssimos ladrões prosperam em riquezas, e que alegres e altivos se movimentam em todas as direcções os que com acções repugnantes concitam contra si as iras de Deus, e que abundam de todas as prosperidades da vida os que, desprezando o verdadeiro Deus, fingem um deus à medida das suas paixões, para o transportarem nas mãos e o adorarem com sacrílega superstição. Pelo que nem sempre é verdade o que asseverais, dizendo que a abundância desses bens acompanha a piedade e a justiça. 
ulla impuritatis contagiome tabernaculum tuum infici et contaminari permiseris, omni dedecoris et ignominiae macula liberaberis firmaque munitione uallaberis nec ullum supplicium exhorrebis. Immemor eris aerumnae neque magis illius recordaberis quam aquarum postquam effluxerint. Per omne uitae tuae tempus, quasi meridiana luce, collustraberis, et si ad aliquod tempus quidquam tibi caliginis offusum fuerit, e tenebris repente emersus lucem conspicies. Confidens eris eo quod fructum quem exspectabas secure percipies. Quod, si agrum colueris, sine ullo timore foris in lecto tuo cubabis, sine ulla cura dormies. Nec erit qui tibi timorem iniiciat multique ad te supplices cum postulatis adibunt. Oculi impiorum inuidia contabescent nec impendentem uim cladis effugient fallacissimaque spe delusi capientur.

Ad haec respondens, Iobus inquit:

Profecto, quantum ex oratione uestra colligo, in uobis solis humani generis uniuersi consilium et ratio summa consistit et uobiscum omnis sapientia morietur... Sic enim exsurgitis et sic uobis placetis, quasi soli rerum istarum scientiam animis comprehensam teneatis. Sed, mihi credite, non minus ingenio ualeo quam quilibet uestrum neminique ex uobis istarum rerum discipliam concedo. Quamquam ista, quae dicitis, non ita recondita et abstrusa sunt, ut existimatis, sed potius omnium ferme sermone peruulgata. Quotus enim quisque est, cui haec in promptu non sint? Attamen, cum ita uos in sapientiae opinione iactaris, nec humanitatis neque religionis ullam curam suscipitis: quae tanta enim uestra immanitas est ut hominem, uobiscum foedere sociatum, ludibrio habeatis et in grauissimo casu illius insultetis? Neque respicitis futurum ut ille preces ad Deum fundat et opem et auxilium ab eo, qui numquam iniuria laesos in calamitate neglexit, tandem aliquando consequatur? Sicine iuuat hominem iustum et integrum in summa calamitate deludere? Lampadem tanta luce splendentem ut lumen ab eo etiam illi, qui florentes atque beati putabantur, acciperent contemnere, et offensam ex illius calamitate sumere, ita ut, qui illum afflictum aspexerint, labantur et corruant, id enim uos efficere contenditis ut, qui in me inciderint, offensi inopia et indigentia mea, nutent et corruant.

At id, quod ante dixi, minime infitiari potestis, euenire saepenumero [42] ut perditissimi latrones opibus floreant et, qui Deum in se foedissimis factis irritant, alacres et erecti passim uolitent, et qui, uero Deo neglecto, deum ad suam libidinem fingunt, quem manibus gestent atque nefaria superstitione uenerentur, uitae commodis abundent. Quare non semper uerum est quod asseritis, nempe bonorum istorum affluentiam esse pietatis atque iustitiae comitem. 
Ora vós, ainda que não possais refutar esta opinião, mesmo assim repetis a mesma coisa de duas em duas palavras, dizendo entretanto aquilo que não há ninguém que não saiba. Interroga, peço-te, os quadrúpedes, e eles vos hão-de relembrar estas coisas; pergunta às aves, e hão-de fazer-vos saber isso mesmo. Entra à fala com a terra, e ensinarte-á; consulta os peixes do mar, que também te hão-de falar da admirável potência e bondade de Deus. Por consequência, quem ignora que todas as partes da natureza soltam esta única voz e clara e abertamente testemunham unicamente isto: que foram feitas pela mão de Deus todas as coisas que existem nas alturas e nas profundezas; e que as vidas de todos os seres vivos e as inteligências dos homens se conservam graças à Sua vontade e poder? Por conseguinte, é bastante para se alcançar o título de sabedoria algo que se encontra gravado no espírito de todos? Em parte alguma! É que precisamos de ouvir muitas coisas, para, instruídos por elas, podermos mais facilmente ajuizar dos bens e dos males e daquilo que se deve desejar ou de que cumpre fugir. Assim como o paladar do homem são distingue as coisas amargas e azedas das doces, do mesmo modo o ouvido acostumado às boas doutrinas destrinça o prejudicial do salutar.

Mas pergunto: a que mestres se deve enfim recorrer para alcançarmos a sabedoria? Porventura aos moços, que ainda não puderam ser instruídos pela prática das coisas e mais obedecem à paixão e ao desejo do que aos preceitos dos sábios? De forma alguma. Então a quem? Certamente que aos velhos que, ensinados não apenas pelos ensinamentos da sabedoria, mas também por grande número de exemplos, no regular a vida seguem a razão e não a paixão. E, assim, nos velhos tem a primazia o amor da sabedoria e não o desatino da mocidade: mas a prudência de uma provecta idade será capaz de ensinar-te a compreender as coisas? Ora, quem quiser alcançar a verdadeira sabedoria não tem motivo para tomar como mestre os velhos de preferência ao próprio Deus.

É que Ele é o único que detém o tesouro da sabedoria, que alia a ciência com a força da virtude, que dota de prudência todos os que d' Ele se aproximam e que transmite o conhecimento das coisas mais profundas. Ninguém torna a edificar aquilo que Ele derruba, e ninguém liberta dos grilhões aquele a quem Ele encerra no cárcere. Quando quer reter as águas, de imediato secam, se de novo as deixar escapar, invadirão impetuosamente a terra. A Sua força é invencível, é eterna a Sua constância. Na Sua mão estão tanto o que se engana como o que maquina o engano. Ele deixa para presa dos inimigos os homens que se apoiam num conselho que deveria prever os males com muita antecipação e ocasiona e agita com a demência os governantes dos Estados. Destrói as leis e disposições dos reis e ata com grilhões o poder deles, porquanto aniquila os injustos senhorios e arranca os tiranos de toda a prosperidade. [43] Entrega os sacerdotes como presa aos inimigos e quebra as forças e vigor dos poderosos. Despoja dos recursos da eloquência os que com conselhos leais velam pela república e priva os anciãos de bom senso e de capacidade crítica. Grava nos príncipes o labéu do desdouro e da infâmia e efemina a valentia e debilita a coragem dos homens fortes. Traz à luz aquilo que se encontrava mergulhado nas profundezas e coloca diante dos olhos dos homens o que estava oculto por densíssimas trevas. Multiplica os povos e destrói-os depois de multiplicados; dilata o senhorio das nações e depois obriga-as a regressar a um território limitado. Priva de 
Vos autem, cum hanc sententiam infirmare nequeatis, idem tamen altero quoque uerbo repetitis et illa interim dicitis quae nemo est qui nesciat. Sciscitare, quaeso, quadrupedes, et illi te de his rebus admonebunt; uolucres interroga, et eadem ista tibi nuntiabunt. Institue sermonem cum terra, et erudiet te; pisces maris consule, qui tibi etiam mira de potentia atque benignitate diuina loquentur. Quis igitur ignorat omnes uniuersae naturae partes hanc unam uocem mittere et hoc unum clare et aperte testificari: omnia quae super subterque sunt fuisse Dei manu perfecta; illiusque numine et potestate cunctorum animantium uitas et hominum mentes contineri? Hoc igitur, quod est omnium animis insculptum, estne satis ad sapientiam comparandam? Minime gentium! Sunt enim multa auribus accipienda, quibus instructi facilius de bonis atque malis de rebus expetendis atque fugiendis iudicium faciamus, ut enim gustus hominis sani amara et acerba a dulcibus internoscit, sic auris assuefacta bonis disciplinis a salutaribus noxia secernit.

Sed quaeso: quibus tandem magistris utendum est ut nobis sapientiam paremus? Num adulescentibus, qui nondum usu rerum instrui potuere suntque magis libidini et cupiditati quam sapientum iussis obsequentes? Nequaquam. Quibus ergo? Senibus certe qui, et sapientiae disciplinis et innumerabilibus exemplis eruditi, non libidinem, sed rationem sequuntur. Itaque in senibus sapientiae studium uiget neque adulescentiae temeritas: sed aetatis longae grauitas te poterit ad rerum intelligentiam erudire? Quamquam, qui ad ueram sapientiam peruenire uelit, non est cur tam senes quam Deum ipsum sibi magistrum adhibeat.

Is enim solus est qui sapientiae thesaurum possidet, qui scientiam cum uirtutis robore coniungit, qui consilio omnes ad illum adeuntes instruit, qui rerum altissimarum cognitionem tradit. Quod ille demolitur nemo rursus aedificat, quem carcere includit nemo ex uinculis emittit. Cum aquas arcere uult, confestim exsiccantur, si eas rursus emiserit, impetu terras inuertent. Illius est robur inuictum, illius constantia sempiterna. In illius manu est tam is qui in fraudem inducitur, quam ille qui fraudem machinatur. Is homines consilio ad mala multo ante praecauenda nixos hostium praedae relinquit et rerum publicarum moderatores afficit et uexat amentia. Regum leges et instituta dissoluit eorumque robur uinculis astringit, imperia namque iniusta peruertit et tyrannos fortunis omnibus exturbat. [43] Tradit sacerdotes hostibus in praedam et potentium uires atque robur infringit. Spoliat opibus eloquentiae eos qui rei publicae consilio fideli prospiciunt et senes mentis sensu atque iudicio priuat. Maculam dedecoris et ignominiae principibus inurit robustorumque hominum uirtutem effeminat animumque debilitat. Quae erant in profundo demersa in lucem profert et tenebris densissimis abstrusa in hominum conspectu proponit. Gentes multiplicat, multiplicatas euertit; nationum imperium dilatat easque rursus in locum angustum compellit. Rectoribus mentem et rationem eripit multisque erroribus inflatos in 
inteligência e razão os dirigentes e, aos ensoberbecidos com muitos erros, repele-os para ermos desertos sem saída. Mergulhados nas trevas, tentearão com as mãos por onde lhes cumpre avançar e, como se estivessem embriagados com muito vinho, hão-de cambalear e de nenhuma forma hão-de pôr de parte os erros em que caíram.

E deste modo a vontade divina acaba com a insolente ostentação de inteligência, com a arrogância do poder humano, com a intolerável altivez da soberba, com a impureza de uma religião fingida e com toda a força, engano e injustiça. Já vos dais conta das grandes trevas em que decorre a vida dos homens? E de quão poucos são os que possuem a verdadeira sabedoria? De que maneira acontece que, quanto mais alguma pessoa tem confiança na sua inteligência, tanto dá maiores indícios de estupidez e de loucura? Já vos apercebeis como os únicos que sabem são os que se entregaram aos ensinamentos de Deus? Ora, tudo isto, para que não penseis que sou muito ignorante, vi-o com os olhos, escutei-os com os ouvidos e alcancei-o com a inteligência. Sei perfeitamente essas mesmas coisas que sabeis e não achareis que em inteligência e sensatez sou inferior a qualquer um de vós. Todavia, embargado pela dor, dirijo-me com pesar a Deus, em quem unicamente ponho os olhos, e desejo disputar diante de Deus, de quem se deve esperar toda a salvação. Vós considerais isso como um grande crime, como se não fosse lícito a um homem atribulado implorar a ajuda de Deus com lágrimas e lamentos. E todavia, ao cometerdes com essa acção um crime de impiedade contra Deus e de desumanidade contra mim, acobertais o vosso delito com o nome de religião e de humanidade. É que discorreis de tal modo que parece que a mais nada atendeis do que à glória de Deus e que velais pela minha salvação. Mas a verdade é que acumulais mentiras na causa de Deus e ofereceis para as minhas feridas um remédio totalmente inútil.

Oxalá que vos caláreis por completo, uma vez que nada dizeis que mereça ser posto entre os louvores da verdadeira sabedoria: atitude que decerto deveria atribuir-se à sabedoria. É que não cumpre considerar-se como ignorante aquela pessoa que, ao não ser ainda capaz de falar com sabedoria, ao calar-se não menospreza o louvor de modesto. E tão-pouco merece ser louvada com o título de sábio aquela pessoa que desatinadamente diz tudo quanto lhe acode ao espírito, mas merece-o a que dá ouvidos a quem lhe é muito superior em idade, conhecimentos e sabedoria. Por conseguinte, exorto-vos e admoestovos a que tomeis à boa parte aquilo que vou dizer e a que, enquanto me queixo a vós, presteis atenção às minhas palavras. É que creio que não haveis de colher pequeno fruto deste comedimento de espírito.

Porventura vos figurareis Deus à imagem da natureza dos homens para que penseis que Ele [44] fica lisonjeado com a iniquidade forjada para Lhe agradar e se recreia com os enganos e embustes inventados pelo amor e zelo d' Ele? Acaso vos esforçais por agradar-Lhe e adulá-Lo e por insinuar-vos no Seu ânimo mediante lisonjas? Acaso vos entremeteis na causa de Deus, como se fôsseis defensores e advogados do direito divino, e vos empenhais com todo o esforço para que Ele não fique vencido em juízo? Sem dúvida, estais inquietados com essa preocupação porque julgais que Ele, se não vos apresentar como patronos, há-de perder por completo a demanda, e por isso, como se a causa d' Ele não pudesse ser defendida de acordo com o direito, aparelhais o refúgio da mentira. 
uastam solitudinem exitum nullum habentem expellit. Immersi tenebris, qua sit illis eundum manibus explorabunt et, quasi ebrii multo uino, languidi titubabunt nec errores quibus imbuti sunt ulla ratione depellent.

Itaque ingenii insolens ostentatio humanique principatus elatio, superbiae intolerandum fastidium, assimulatae religionis impuritas omnisque uis et fraus et iniuria numine illius exstinguitur. Cernitis iam animo quantis in tenebris hominum uita uersetur? Quam pauci sint uerae sapientiae compotes? Qua ratione fiat ut, quo magis ingenio suo confidit, eo maiorem stuporis et amentiae significationem det? Quomodo illi soli sapiant qui se Deo in disciplinam tradiderunt? Haec quidem omnia, ne me adeo imperium arbitremini, et oculis aspexi et auribus usurpaui et mente complexus sum. Eadem ista, quae nostis, probe noui neque me ingenio et prudentia uestrum quolibet inferiorem esse reperietis. Dolore tamen interclusus, Dominum, in quem unum respicio, dolenter alloquar et apud Deum, a quo salus omnis exspectanda est, disceptare cupio. Id uos in magno scelere ponitis, quasi non liceat homini afflicto lacrimis atque lamentis Dei fidem implorare. Et tamen, cum eadem opera crimen impietatis in Deum et inhumanitatis in me suscipiatis, sceleri uestro nomen religionis et humanitatis obtenditis. Ita enim disputatis ut appareat uos nihil aliud quam Dei gloriam spectare et saluti meae consulere. Sed certe uos in Dei causa mendacia continuatis uulneribusque meis inutilem prorsus medicinam adhibetis.

Vtinam, quando nihil dicitis quod in uerae sapientiae laude ponendum sit, omnino taceretis: quod quidem fuisset sapientiae tribuendum. Nec enim insipiens ille habendus est qui, cum nondum sapienter eloqui possit, tacendo, modestiae laudem non aspernatur. Nec enim is qui temere effutit quidquid illi in mentem uenit, sed qui aures illi praebet qui multum aetate et disciplina et sapientia antecedit, sapientiae nomine laudandus est. Vos igitur hortor et admoneo ut quae dicturus sum in bonam partem accipiatis et, dum uobiscum expostulo, ad orationem meam attentis sitis. Non mediocrem enim opinor fructum ex ea animorum moderatione capietis.

Numquid Deum ex hominum natura fingetis ut arbitremini illum [44] iniquitate in gratiam illius conflata deleniri et dolis atque fraudibus eius amore et studio compositis oblectari? An illi blandiri et adulari in animumque illius assentationibus insinuari contenditis? An uos, tamquam iuris diuini cognitores et aduocatos, in Dei causa interponetis et, ne ille uictus in iudicio sit, omni contentione pugnabitis? Scilicet, ea uos cura sollicitat quod existimetis illum, nisi uos patronos adhibuerit, litem omnino perditurum et idcirco, quasi illius causa iure defendi non possit, mendacii perfugia comparatis. An hoc mediocre scelus existimatis, eam opinionem de Deo recipere quae de perditis atque profligatis hominibus 
Porventura considerais que é pequeno crime ter acerca de Deus a mesma opinião que é costume perfilhar-se acerca dos homens perversos e depravados? Acaso vos será útil esse engano com que vos esforçais por entrar na Sua graça, quando Ele vos castigar mais severamente por este mesmo motivo de O terdes figurado, não menos do que os homens dementes, sujeito às adulações e enganos?

Pois quê? Se vós estabelecerdes que no juízo a causa deve ser avaliada às ocultas e de modo fraudulento, e não em conformidade com o direito, mas com o favor, e que deve ser decidida em favor da pessoa poderosa ou amiga, porventura o Senhor há-de deixar por castigar um tão grande crime? Certamente que não. De facto, tão-pouco aquele supremo Pai da justiça quer que no juízo o favor, por grande que seja, tenha qualquer peso, mas que o princípio do direito prevaleça, e não que se atenda ao prestígio e posição do homem, mas que tudo seja regulado em conformidade com a invariabilidade da lei eterna. Por isso, se procederdes diferentemente, Ele punir-vos-á com a máxima severidade. Pois quê? Consentirá Ele em tornar-se co-réu daquele crime que pune de modo rigorosíssimo? E tolerará que o Seu nome seja afrontosamente manchado e infamado com o labéu de uma tamanha acção criminosa? Ousastes imputar àquele supremo Senhor um desdouro tão grande como este? E entretanto não sentireis receio da Sua extraordinária majestade divina? Não estremecereis, estarrecidos com o medo d' Ele? Não vos lembrais de que sois semelhantes à cinza e de que os vossos corpos são comparáveis com imagens modeladas com lama e argila? Seguramente, se olhardes para a fraqueza da vossa natureza e para o poder e grandeza do Senhor, compreendereis mais profundamente o grande delito que cometeis ao proferirdes estas palavras que redundam no maior dos ultrajes contra Ele.

Desejaria que vos calásseis enquanto digo o que falta e que não me interrompêsseis. Se vos preocupais com o meu interesse, no sentido de que da minha boca não saiam palavras que mais violentamente concitem a ira de Deus contra mim, liberto-vos desse cuidado: se em alguma coisa prejudicarem, prejudicar-me-ão a mim mesmo, e o meu discurso não vos acarretará mal algum, mas apenas a mim, se for caso disso. Escandaliza-vos que eu seja atormentado pela dor, que me lastime de modo assaz pesaroso, que lamente a minha desventura com queixumes muito doridos, e entretanto nem prestais atenção à violência dos males que me assoberbam nem considerais a grandeza da desgraça que me aniquila, mas, como se eu fosse o responsável e autor da minha tribulação, invectivais-me com os vossos discursos. Imaginais-me dotado de um entendimento a tal ponto dementado que por minha espontânea vontade maquine contra mim mesmo a perdição? [45] Por que laceraria as minhas carnes com os meus dentes? Por que a cada hora poria a minha vida no maior risco? Não sou louco e vesânico a tal ponto que provoque a minha própria perdição. "Então por que é que", dirá algum de vós, "és atribulado pela aflição e te queixas do juízo de Deus?" - Também vos esforçais por arrancar-me e privar-me desta única consolação nas angústias, ajuda nos perigos e remédio nas desgraças, por forma a que não grite por Deus? Eis que sou ameaçado de morte: por que não hei-de dirigir-Lhe súplicas? Por que não hei-de perguntar, lamentando-me, acerca da situação da minha vida, levada à mais extrema angústia para além do que era de esperar? 
haberi solet? Numquid erit uobis ista fraus qua in gratiam illius irrepere conamini, cum is in uos ob eam ipsam causam acrius animaduerterit quod illum finxeritis, non minus quam homines insanos, adulationibus et fallaciis obnoxium?

Quid? Si uos in iudicio causam occulte atque fraudulenter, non iure, sed gratia ponderandam et homini uel potenti uel necessario adiudicandam statueritis, num Dominus id tantum scelus inultum relinquet? Non profecto. Nec enim summus ille iustitiae parens uult ut in iudicio gratiae magnitudo quidquam ualeat, sed ut iuris ratio dominetur, nec ut hominis dignitas et persona respiciatur, sed ut aequitatis ueritas elimetur, nec ut sit uanitati et mendacio locus, sed ut omnia ad sempiternae legis constantiam dirigantur. Quod, si secus a uobis factum fuerit, id ille acerrime uindicabit. Quid igitur? Sceleris illius, cuius ille uindex est, se fieri participem sustinebit? Nomenque suum tanti facinoris infamia notari et indignissime maculari patietur? Hoc tantum dedecus illi summo domino ausi fuistis affingere? Nec interim praecellentissimum illius numen expauebitis? Non, illius metu perterriti, trepidabitis? Non uenit uobis in mentem uos esse cineri simillimos et corpora uestra cum imaginibus ex luto et argilla fictis comparanda? Profecto, si et naturae uestrae imbecillitatem et Domini potentiam et amplitudinem respexeritis, acutius intelligetis quantum facinus a uobis commissum sit cum eam orationem habueritis quae in maximam illius contumeliam redundet.

Velim tantisper sileatis dum eloquar quae restant neque mihi impedimento sitis. Si mea causa laboratis, ne uidelicet ex ore meo uerbum excidat quo uehementius iram Domini in me concitem, libero uos ista cura: mihi ipsi nocebit, si quid nocebit, neque oratio mea uobis ullum malum, sed mihi ipsi tantum, si res ita tulerit, importabit. Id uos offendit quod dolore crucier, quod nimis dolenter ingemiscam, quod ualde lugubri querimonia casum meum lamenter, et interim neque uim malorum quae me premit respicitis neque magnitudinem calamitatis, quae me peruertit, consideratis, sed, quasi ipse mei doloris auctor et architectus sim, ita in me orationibus uestris inuehimini. Adeone me uesana mente praeditum arbitramini ut in me ipsum sponte mea pestem machiner? [45] Cur ego carnes meas dentibus meis lacerarem? Cur uitam meam horis singulis in summum discrimen iniicerem? Non sum, non sum ita furiosus et amens ut mihi ipsi perniciem moliar. "Quid ergo", inquiet aliquis ex uobis, "ita maerore conficeris et de Domini iudicio lamentaris?" - Etiamne hoc unicum solacium in angoribus, subsidium in periculis, remedium in calamitatibus eripere et extorquere contenditis, ut ad Deum non inclamem? Ecce mihi necem comminatur: cur non eum deprecabor? Cur non apud illum de uitae meae rationibus, praeter opinionem in summas angustias adductis, conquerar? 
Por conseguinte, se achais as minhas esperanças completamente truncadas, ou suspeitais que eu desesperei por completo de me salvar, estais muitíssimo enganados, pois confio em que o Senhor me há-de oferecer a salvação. É que não O adorei com uma religiosidade momentaneamente simulada; não me aproximei a Ele com um espírito falso e dissimulado; não fingi a virtude e a religiosidade, para por este motivo me arrecear de que há-de rejeitar as minhas preces, tal como costuma fazer quando alguém de modo fraudulento d' Ele se aproxima com uma fingida aparência de piedade, mas com verdade e sinceridade consagrei a minha inteira existência ao zelo da mais genuína religiosidade. Por isso, escutai o conteúdo das minhas palavras e prestai a máxima atenção àquilo que digo.

Ora, do meu discurso confiadamente farei constar que, se se fizer julgamento, a decisão e sentença do próprio Deus me há-de ilibar de todas as acusações de crime. Porquanto, existe alguém que me possa mover processo? Alguém que me possa acusar de crime? Alguém que, com verdade, me possa imputar uma acção delituosa? Que se apresente para, arguindo, confutar o meu crime, e eu, se se provar a minha culpa, perderei a fala e o ânimo.

"Pois quê?", retrucará alguém. "Ousarás expor-te ao juízo de Deus? Tanto presumes de ti mesmo que estás confiante em que hás-de ser completamente ilibado de todo o crime também naquele supremo esplendor, no qual todas as coisas se iluminam, diante daquela pureza suma, em comparação da qual até aquilo que brilha com uma beleza e claridade celeste parece coberto de sujidade?" - Com certeza, contanto que não use comigo do direito mais elevado e me julgue com aquela moderação de equidade com que julga a condição da vida humana.

Por conseguinte, Senhor, pedir-Te-ei duas coisas, a fim de poder apresentar-me no Teu juízo. Uma é que apartes para longe a Tua mão, para não me ferires e enfraqueceres com golpes; a outra, que não me atemorizes com a grandeza da Tua imensa majestade. Com efeito, se repassares em juizo a minha vida em conformidade com uma lei muito rigorosa e por esse motivo me atormentares com golpes, ou se mostrares aos meus olhos a grandeza da Tua majestade, certamente que, ou oprimido pela dor ou perturbado pelo temor, não me atreverei a abrir a boca. Mas se procederes comigo de modo mais indulgente e afastares estes dois impedimentos, de forma alguma me esquivarei ao juizo. E assim, suprimidos estes dois medos, defendo-me como me for possivel. Tu, ou intenta processo contra mim, e eu responderei, ou tomarei a iniciativa de mover a acção, e Tu, se te aprouver, refutarás o meu discurso.

Por conseguinte, começando por aqui, de bom grado te perguntaria por que é que me atormentas com tantos golpes? Porventura cometi tão grande número de crimes e tão monstruosos que mereça ser castigado com penas tão terriveis? Que fiz? De que sou culpado? Que [46] infâmia e ignomínia tão grande pratiquei que por causa dela Tu permitas que eu seja atormentado e dilacerado com tamanha crueldade? Se sou atormentado com justiça, pelo menos Te peço, rogo e imploro que demonstres a minha impiedade e infâmia. Por que desvias de mim a Tua face? Por que é que no meio de tantos males privas o meu espírito do sopro da Tua alegria? Por que é que ao mofino de mim retiras o consolo da Tua graça? 
Quod, si spes meas omnino praecisas arbitramini, aut me salutem omnino desperasse suspicamini, longe uos fallit opinio, confido namque futurum ut Dominus mihi salutem afferat. Non enim illum simulata ad tempus religione colui; non animo ficto atque fallaci ad illum adiit; non sum uirtutem atque religionem ementitus, ut ea causa uerear ne is preces meas repudiet, quemadmodum facere solet cum aliquis in ficta pietatis specie ad illum fraudulenter accedit, sed uere et ex animo totam uitam meam ad studium purissimae religionis applicui. Audite igitur orationis meae sententiam et quae dico attentissima consideratione percipite.

Hoc autem confidenter in oratione mea ponam, fore nempe, si fuerit iudicium constitutum, ut omni crimine Dei ipsius iudicio atque sententia liberer. Quis enim est qui mihi litem intendat? Qui sceleris arguat? Qui mihi uere crimen obiiciat? Prodeat in medium, ut scelus meum redarguet, et ego, si fuero conuictus, obmutescam animoque deficiam.

"Quid ergo?", dicet aliquis. "Tu Dei iudicium subire audebis? Tantumne tibi arrogabis ut etiam in illo summo splendore, in quo omnia dilucescunt, coram illa summa puritate, cuius comparatione illa etiam quae caelesti specie atque claritate nitent, sordibus illita uidentur, te omni prorsus crimine absolutum iri confidas?" - Ego uero, dummodo ne summo iure mecum agat et ea aequitatis moderatione, qua de humanae uitae ratione iudicat, de me iudicium instituat.

Duo igitur a te, Domine, petam, ut possim in iudicio tuo consistere. Vnum, ut manum tuam longe remoueas, ne me plagis contundas atque debilites; alterum, ne me magnitudine tuae imensae maiestatis exterreas. Si enim uitam meam ad exactissimi iuris examen reuocaueris meque ob eam causam plagis afflixeris, uel si oculis meis amplitudinem tuae maiestatis obtuleris, certe uel dolore oppressus uel formidine conturbatus hiscere non audebo. Si uero mitius mecum egeris et haec duo impedimenta submoueris, iudicium minime detrectabo. Itaque, duobus his terroribus sublatis, ut libuerit mecum agito. Vel tu mibi litem intende et ego respondebo, uel ego primus causam agam et tu, si placuerit, orationem meam refelles.

Vt igitur hinc exordiar, libenter a te quaesierim cur me tantis plagis afficias? Num tam multa scelera atque tam immania suscepit ut tam dirae poenae mibi luendae sint? Quid feci? Quid commerui? Quodnam [46] tantum flagitium atque dedecus admisi ob quod me tanta crudelitate lacerari atque distrabi patiaris? Si meriti afflictus sum, id saltem oro, imploro et obtestor ut mibi impietatem meam atque flagitia demonstres. Cur a me faciem tuam auertis? Cur in tantis malis animum meum spiritus tui iucunditate priuas? Cur me miserum solacio gratiae tuae destituis? Cur me a familiaritate pristina atque suauissima consuetudine, ut 
Por que é que, como a um inimigo, me repeles da antiga familiaridade e agradabilíssima convivência? Acaso é próprio da Tua majestade perseguir com a máxima violência uma folha impelida pelos ventos? Acaso é próprio dessa imensa dignidade fazer guerra a uma palha seca? Porventura é função da Tua bondade e clemência lembrar-se durante tanto tempo das faltas que outrora eu cometi?

Com efeito, gravaste-as em caracteres para prolongada lembrança a fim de ao cabo me castigares por elas e, por causa dos delitos da mocidade, que já cuidava reduzidos a pó pelo esquecimento, me despojares de todos os bens. Ataste com cadeias os meus pés para que eu não pudesse deslocar-me. Observaste todos os meus caminhos e diligentemente esquadrinhaste todos os lugares em que deixei impressas as minhas pegadas, de tal maneira que, de tudo quanto eu fiz ou pensei, ou deixei de fazer por omissão ou negligência ou esquecimento, nada escapa à Tua atenção. É assim que Te apraz agir comigo? Acaso fica bem a essa inteligência tão superior informar-se tão pormenorizadamente acerca de uma natureza tão fraca e frágil? Quem sou eu ou qual é a minha condição para que com tanto cuidado e desvelo e tão atentamente apliques o espírito a todas as minhas coisas? É que este homem a quem persegues desfaz-se como que comido pela podridão e como uma roupa roída pela traça.

De resto, que importa discutir acerca da minha condição em particular, uma vez que nada existe de mais frágil do que toda a natureza do género bumano? É que o homem, logo que nasce da mulher, imediatamente penetra numa vida breve e atribulada. De facto, ainda que a vida dele esteja limitada por um prazo de tempo brevíssimo, mesmo assim, numa vida tão breve, não existe nenhuma hora, em tamanha brevidade, isenta de medo e inquietação, mas é agitada por cuidados e perturbações quase infinitos. Nasce como a flor, mas de repente é cortado; desaparece rapidamente como uma sombra e nunca permanece no mesmo lugar. E, não obstante, consideras que o homem, dotado de uma natureza tão fraca, é merecedor de que sobre ele lances os Teus olhos? De que examines a sua vida e costumes? De que, enfim, o chames a juizo?

Ora, que é aquilo acerca do qual devemos disputar contigo em juízo? A pureza de vida, a inteireza de costumes e a castidade de corpo e espírito. De facto, impões-nos como dever, exiges e pedes de nós que levemos uma vida puríssima e santíssima e que não permitamos que nenhuma sujidade de infâmias recubra os nossos espíritos. Ora, pode conseguir alguma diligência bumana que nós nos mantenhamos puros de toda a mancha de sujidade? Certamente que não! É que nascemos corrompidos pelos pecados, somos abrasados pelas chamas das paixões, impregnamo-nos de infinitos erros e, por uma espécie de perversão instintiva, somos inclinados a todos os defeitos. Logo, existe alguém que, a partir de um tão grande viveiro de depravação, possa por si [47] levar a cabo uma obra santa e pura e completamente incontaminada de qualquer mancha de impureza? Absolutamente ninguém! E assim sucede que, se quiseres dirigir rigorosamente os deveres dos homens em conformidade com as regras da Tua lei, ninguém pode esquivar-se ao castigo eterno. Mas quando não procedes assim, mas atendes à Tua bondade, não vejo por que razão não hei-de comparecer com segurança no Teu juizo. 
bostem, repellis? An est maiestatis tuae folium uentis impulsum summis uiribus insectari? An est istius dignitatis amplissimae aridam stipulam bello persequi? Numquid est officium benignitatis et clementiae tuae tamdiu peccatorum, quae fuerunt olim a me commissa, recordari?

Ea namque litteris ad diuturnam memoriam consignasti ut illorum tandem poenas a me repeteres et propter adulescentiae delicta, quae iam obliuione contrita suspicabar, me bonis omnibus euerteres. Neruo pedes meos deuinxisti ne me commonere possem. Cunctas uias meas obseruasti et omnem locum ubicumque impressi uestigia diligenter annotasti, ita ut nibil sit a me gestum, uel cogitatum uel omissum, uel negligentia et obliuione praeteritum, quod animaduersionem tuam effugiat. Sicine agere mecum placet? Decetne istam praecellentissimae mentis altitudinem in tam imbecillam fragilemque naturam tam diligenter inquirere? Quis enim ego sum aut quis meus status est ut tanta cura et studio mentem in omnes meas res atque tam uigilanter intendas? Is enim quem persequeris quasi putredine corruptus intabescit et instar uestis a tinea exesae consumitur.

Quamquam, quid attinet de mea praecipue condicione disputare, cum nibil sit uniuersa natura generis humani fragilius? Homo namque, cum primum e muliere nascitur, in uitam continuo exiguam et aerumnosam ingreditur. Cum enim illius aetas sit breuissimo spatio circumscripta, nullam tamen horam habet, in tanta uitae breuitate, metu atque sollicitudine liberam, sed infinitis prope curis atque perturbationibus agitatur. Vt flos quidem exoritur, sed repente succiditur; uelut umbra festinanter abscedit et numquam eodem loco manet. Et tamen hominem, tam imbecilla natura praeditum, dignum reputas in quem oculos tuos coniicias? Cuius uitam et mores examines? Quem denique in iudicium uoces?

Quid est autem de quo tecum in iudicio disceptare debeamus? Nempe, de uitae puritate, de morum integritate, de corporis et animi castimonia. Hoc enim nobis munus assignas, boc requiris, boc efflagitas ut purissime atque sanctissime uitam instituamus nullasque flagitiorum sordes animis nostris allini patiamur. Num fieri igitur ulla bumana industria potest ut nos ab omnium sordium macula puros conseruemus? Non certe! Nam peccatis infecti nascimur, libidinum ardoribus inflammamur, erroribus infinitis imbuimur, insita quadam prauitate ad omnia uitia propensi natura sumus. Quis ergo est qui, e tanto flagitiorum seminario, per se possit [47] opus sanctum et castum nullaque omnino labe impuritatis aspersum efficere? Nemo prorsus! Itaque efficitur, si uelis hominum officia ad normam tuae legis exacte dirigere, ut nemo possit poenam sempiternam declinare. Cum uero id non facis, sed benignitati tuae consulis, haud uideo cur non in indicio tuo recte consistam. 
Mas, regressando à queixa que formulava, se os dias do homem se limitam a um número tão reduzido, se os seus meses, de acordo com a medida que estabeleceste, se concluem dentro de um prazo sobremodo estreito, se o termo da vida bumana, que ninguém há-de transpor, foi por Ti predeterminado de uma forma e modo invariáveis: por que é que aos homens ao menos não concedeste que passassem esta brevíssima vida sem tribulações e angústias? Por isso, alivia-os de cuidados, liberta-os de enfermidades, permite que passem a existência com menores pesares. Já se aproximará o momento em que de muito bom grado troquem a vida pela morte e, como mercenários, esperem o fim do dia que há-de trazer o fim a todas as incomodidades da vida.

Ainda que se cortem as árvores, todavia não se mata a esperança delas, pois do tronco decepado hão-de nascer abundantes rebentos e dele há-de voltar a crescer folhagem. A raiz, consumida pela velhice, que parecia ter causado a morte ao seu tronco em seco pó, enviará de novo a seiva e produzirá rebentos e folhagem, tal como fazem as plantas viçosas. O homem, porém, quando, destruído pela doença, morrer, e soltar o último suspiro, e acabar por completo, em que lugar passa a existir? Ou, de que maneira há- de voltar de novo à vida, de modo a produzir algum fruto? As águas procedem do mar através de canais ocultos, mas quando se separam dele correm de tal maneira que não aparecem em nenhuma parte; certos rios de tal maneira secam e deixam de correr com as águas engolidas por alguma voragem que nunca mais voltam a aparecer: de modo idêntico a vida bumana corre e flui e o homem, logo que morre, de tal modo jaz que não volta a recuperar a mesma condição. E tão-pouco despertará do sono enquanto o céu e toda a natureza não mudarem esta condição que actualmente possuem. Por conseguinte, a estreiteza dos limites que os encerram impedem-nos de cumprir a sua obrigação.

Oxalá eu pertencesse ao número dos que morreram e foram sepultados com excelente esperança. É que foste rigoroso com eles enquanto, no tempo oportuno e com moderação, lhes infligias as penas determinadas para expiar os pecados, por forma a provê-los com os novos ornamentos da vida imortal, depois de purificados com os suplícios comuns. [48] Ob se do mesmo modo com a Tua guarda me escondesses e ocultasses nas profundezas enquanto a Tua ira se mitigava, e me estabelecesses um tempo certo para nele misericordiosamente me tornares a levantar! Entretanto, que nos cumpre pensar acerca da condição do corpo sepultado? Porventura o homem será de novo chamado à vida? Não com certeza para uma vida idêntica a esta, atormentada e atribulada por inúmeros males, mas para uma outra muitíssimo mais desejável.

Por consequência, é esta a esperança que me ampara em todas as adversidades e, em todos os dias em que suporto o peso desta carga, fortifica-me este pensamento, porque confio em que chegará finalmente aquele tempo em que a condição da minha vida felizmente há-de mudar. Então chamar-me-ás e eu imediatamente acorrerei, incitado pela força da Tua voz, e estenderás a dextra para a obra das Tuas mãos e manterás plenamente a Tua palavra, visto que também agora contas os meus passos e concedes o perdão às minhas faltas. É que, às minhas infâmias, Tu as manténs como que encerradas e fechadas dentro de uma bolsa, a fim de que não irrompam para perdição minha, e compassivamente encobres a minha iniquidade, a fim de que não me manche com a eterna ignomínia. 
Sed, ut ad institutam querelam reuertar, si dies hominis tam exiguo numero circumscribuntur, si menses illius ordine, quem statuisti, angusto admodum spatio concluduntur, si bumanae uitae terminus, quem nullus transiliet, est a te certo modo et ratione praefinitus: cur hominibus hoc saltem minime praestitisti, ut hanc breuissimam uitam sine cruciatu et angore traducerent? Leua igitur illos curis, libera morbis, permitte ut minore cum molestia uitam exigant. Iam appropinquabit tempus quo uitam cum morte libentissime commutent et, tamquam mercenarii, diei finem exspectent qui est finem omnibus uitae molestiis allaturus.

Cum exciduuntur arbores, illarum tamen spes non exciditur, ab exciso enim trunco surculi pullulabunt ex illoque frondes rursus exsistet. Radix uetustate consumpta, quae uidebatur stirpi suae in sicco puluere interitum attulisse, bumorem rursus eliciet et ex se stolones atque frondes effundet, quemadmodum uirides plantae faciunt. At bomo, cum, languore confectus, interierit et extremum spiritum ediderit et omnino defecerit, quo in loco deinde consistit? Aut, qua ratione rursus in uitam, ut fructum aliquem edat, remigrabit? Aquae ex mari occultis meatibus oriuntur, cum uero ab illo seclusae sunt, ita defluunt ut nusquam appareant; flumina quaedam aquis aliqua uoragine absorptis ita exsiccantur et arescunt ut numquam rursus emineant: similiter bumana uita labitur et fluit et bomo, ubi primum uita functus occumbit, ita iacet ut numquam rursus in eumdem statum exsurgat. Nec enim umquam de somno suscitabitur quamdiu caelum uniuersaque natura minime statum bunc, quem nunc tenet, immutauerit. Angustis igitur spatiis ne officio fungi possint excluduntur.

Vtinam illis annumerer qui cum optima spe a uita excesserunt atque sepulti sunt. In illos enim saeuitiam tantisper adbibuisti, dum peccatis eorum expiandis poenas modo et tempore definitas imponeres, ut illos, supplicis communibus expiatos, nouis uitae immortalis ornamentis [48] afficeres. O si me similiter in inferorum regione praesidio tuo contegeres et occultares, dum ira tua deferuesceret, certumque mibi tempus statueres in quo me rursus clementer erigeres! Quid est interim de corporis sepulti condicione statuendum? Num mortuus bomo in uitam reuocabitur? Non quidem in huius uitae condicionem, innumerabilibus malis exercitam et afflictam, sed in aliam multo uebementius expetendam.

Haec igitur spes me in omni rerum asperitate sustentat et omnibus diebus, quibus huius militiae laborem tolero, hac cogitatione confirmor, quod confido futurum ut ueniat tandem tempus illud quo uitae meae status feliciter immutandus est. Vocabis tunc me et ego confestim, ui tuae uocis excitatus, accurram, et operi manuum tuarum dexteram porriges et fidem cumulate praestabis, siquidem nunc etiam gressus meos dinumeras erratisque meis ueniam impertis. Flagitia namque mea quasi saculo inclusa et obsignata contines, ne in meam perdiciem erumpant, et inuolucra iniquitati meae clementer obtendis, ne me ignominia sempiterna commaculet. Quod quidem minime illis eueniet qui te minime 
Algo que certamente não há-de suceder aos que não olham para Ti e com todo o desvelo se aplicam às coisas terrenas. Na Terra não há coisa tão solidamente firmada que não acabe por cair e ser destruída. Com efeito, não só os montes são arrancados do seu sítio, como também as pedras, batidas pelos golpes das águas, são aos poucos consumidas, e, ó Senhor, fazes desaparecer a terra com frequentes inundações: do mesmo modo, acabas com a esperança do homem que parecia ter a sua existência estabelecida sobre fundamentos inabaláveis, e mostras o quão loucos são todos os que fazem depender a salvaguarda da vida das riquezas humanas. É que precipitas na desgraça sempiterna o homem que se apoia nas riquezas humanas, e de tal modo acaba abatido e the mudas a sorte $e$ condição que, em vez das riquezas, que possuía em abundância, é atribulado com a máxima pobreza e severidade. Expulsa-lo e bane-lo e não o deixas fixar-se em nenhum lugar. Se os seus filhos nesta vida forem muito ricos, não o saberá; se padecerem da falta de todas as coisas, de modo nenhum disso terá conhecimento, e coisa alguma daquelas que se produzem na Terra servirá quer para diminuir o seu suplício, quer para aumentá-lo com grandes acréscimos, ao passo que ele, entretanto, não só com o corpo morto, mas também com o espírito atormentado por dores eternas, receberá o castigo do desvario e loucura. 
intuentur et omni cura in res terrenas incumbunt. Nibil est in terris tanta soliditate firmatum quod non tandem concidat atque dissipetur. Nam et montes de loco conuelluntur, et lapides, aquarum ictu percussae, paulatim exeduntur et tellurem, o Domine, crebris alluuionibus absumis: similiter spem hominis, qui res suas optime fundatas et constitutas habere uidebatur, adimis, et ostendis quam amentes omnes sint qui praesidia uitae in opibus bumanis constituunt. Hominem namque terrenis opibus innixum in miseriam sempiternam detrudis, et sic tandem euersus excedit statumque illius immutas ita ut, pro opibus, quibus affluebat, cum summa inopia et acerbitate conflictetur. Illum expellis et eiicis nec ullo in loco consistere sinis. Siue illius filit in hac uita diuitiis abundauerint, id minime sciet; siue inopia rerum omnium uexati fuerint, id haudquaquam intelliget, nec ad illius supplicium uel imminuendum uel magnis accessionibus amplificandum quidquam eorum, quae in terris geruntur, ualde pertinebit; ille tamen interim, et perempto corpore et animo doloribus sempiternis afflicto, furoris atque dementiae poenas dabit. 
(Página deixada propositadamente em branco) 


\title{
SEGUNDO LIVRO
}

\author{
DA PARÁFRASE AJOB \\ DO PORTUGUÊS JERÓNIMO OSÓRIO
}

LIBER SECVNDVS

HIERONYMI OSORII LVSITANI

PARAPHRASIS IN IOB 


\author{
Segundo Livro \\ da Paráfrase a Job \\ do português Jerónimo Osório
}

\title{
PROÉMIO
}

São, sem dúvida, tão grandes o esplendor e a grandeza da virtude, que até a imagem dela (porquanto a sua real e concreta aparência não poderiam ser vistas claramente naquelas sombras) foi outrora excelentemente festejada e honrada pelos escritos dos varões gregos e latinos. É que muitos homens, dotados de elevada inteligência, estimulados pelos ensinamentos da natureza, compreenderam que na Terra não pode imaginar-se nada de mais divino do que a virtude. De facto, não só é extraordinária e aprazível e agradável devido ao seu aspecto formoso, mas também, provida das riquezas divinas e singularmente forte contra todas as hostes dos inimigos, sai sempre vencedora do ataque de toda a sorte de adversidades, pois a ela não a abala a agressão do tempo, nem a perverte e atribula a perda de uma condição próspera, nem a destrói a privação nem a nudez nem o exílio nem, em suma, qualquer monstruosa e terrível calamidade. A própria coorte das Fúrias, armada e cingida com as hidras, é totalmente incapaz de causar o mínimo abalo à força da mesma virtude. Por derradeiro, não existe nenhum mal, quer na terra, quer debaixo dela, quer urdido pela diligência dos homens, quer aprontado pelos embustes e violência de Satanás, capaz de vergar a virtude e de quebrar a sua resistência. É que aquilo que tem o seu esteio nos poderes celestiais e divinos não pode ser despedaçado por nenhumas forças terrenas ou infernais.

É certo que antigamente os homens mais doutos e eloquentes pensavam tudo isto, mas não apresentavam um exemplo claro e evidente que contivesse toda a harmonia e beleza perfeita da mais verdadeira virtude. Por isso, penso que só este Livro de Job, que apresenta de forma assaz nítida a verdadeira e perfeita essência da virtude, deve de longe ser anteposto a todos os escritos dos Gregos em que vemos encarecida a formosura da virtude. Na realidade, não é tanto através de argumentos que procura convencer, mas põe-nos antes diante da vista e dos olhos um claríssimo modelo de beleza moral e honestidade, assim como da imensa força da virtude. É que o mesmo varão, nascido para 


\section{Hieronymi Osorii Lusitani \\ Paraphrasis in Iob \\ Liber Secundus}

\section{PROOEMIVM}

Virtutis quidem splendor et magnificentia tanta est ut illius etiam imago (uera namque et solida illius species in tenebris illis clare uideri non poterat) scriptis graecorum et latinorum hominum luculenter olim illustrata et celebrata fuerit. Naturae namque disciplinis admoniti multi uiri, summo ingenio praediti, intellexerunt nihil in terris illa posse cogitari diuinius. Nec enim solum est pulchritudinis specie praecellens et amabilis atque iucunda, uerum et, opibus diuinis instructa et contra omnes hostium copias egregie fortis, in omnique bellorum tempestate semper inuicta, eam enim neque temporis labefactat iniuria, neque perdit et affligit status florentis euersio, nec orbitas neque nuditas neque exsilium neque ulla denique calamitas immanis et dira peruertit. Ipsa Furiarum cohors, hydris succincta et armata, non potest ullo modo uirtutis ipsius uim de statu aliqua ex parte conuellere. Nullum denique malum est, siue in terris, siue sub terram, siue hominum industria comparatum, siue Satanae fraudibus et uiolentia constitutum, quod uirtutem molliat illiusque neruos elidat. Nec enim potest ullis terrestribus aut stygiis opibus infringi quod est caelestibus atque diuinis stabilitum.

Haec quidem homines olim doctissimi et eloquentissimi disputabant, sed exemplum clarum et illustre quod omnes uerissimae uirtutis numeros et absolutam speciem contineret minime proponebant. Quocirca unum hunc Iobi Librum, qui uerissimam et absolutissimam uirtutis rationem ualde luculenter exprimit, omnibus Graecorum monumentis, quibus uirtutis decus exaggeratum cernimus, longe praferendum arbitror. Non enim tam argumentis pugnat, quam clarissimum specimen decoris et honestatis uirtutisque robur immensum in oculis et aspectu constituit. Ipse namque uir, ad sempiternam gloriam natus, non 
a glória eterna, em si mostra não só com hábitos e costumes divinos, mas igualmente através de uma constância extraordinária e invencível, as grandes forças que possui a virtude. Na verdade, despojado de grandes riquezas, privado de todos os filhos, [50] de uma condição muitíssimo próspera reduzido à mais completa pobreza, desfigurado por gravíssimas chagas, assediado por dores lancinantes, e, num único momento, atacado por todas estas penalidades por obra do nosso maior inimigo, o Demónio, de tal maneira manteve a sua firmeza que com a máxima glória triunfava de todos os ataques do perversíssimo inimigo.

- Pelo contrário, retorquirá porventura alguém. Sucumbiu à desgraça, porquanto as lágrimas, uns lamentos chorosos e os amiudados suspiros são prova de uma coragem efeminada. E vemos quão incessante foi a aflição de Job e divisamos claramente a grande e constante miséria em que viveu.

Oh opinião disparatada de homens ignorantes! Acaso é obrigação da virtude transformar a sensibilidade da natureza humana na natureza de uma pedra? Ou porventura arrancar os sentidos e conseguir que as feridas infligidas não produzam dor? Ou porventura lograr que a dor causada não provoque aquilo que são as suas forçosas consequências: lágrimas e gemidos? Certamente que não. Tão-pouco alguém, que fosse provido de entendimento são, impôs como dever à virtude o ser insensível à dor, mas sim que fizesse frente à dor, não deixando de se lamentar, contanto que não incorresse em qualquer infâmia devido à violência da dor. É que não somos talhados em pedra e, por isso, é impossível que a dor de uma ferida muito forte nos não atormente. Se isso fosse possível, o valor da própria virtude desvanecer-se-ia. Pois, qual seria a força da própria virtude se a sensação de dor não atribulasse violentamente o espírito? Por consequência, a virtude só mostra a sua força quando existe primeiro uma fortíssima dor a que uma firmeza constante leva de vencida e supera.

Entretanto, os gemidos e suspiros não provam que a virtude foi derrotada, mas dão testemunho da grande violência com que foi posta à prova. Por isso é possível que, quanto mais violenta é a dor, mais reluz a força e dignidade da mesma virtude, pois patenteará que foi atacada por maiores males. É que, se a dor debilitasse a fé do justo, se lhe enfraquecesse a esperança, se lhe apartasse o espírito do zelo da piedade, se lhe introduzisse no entendimento erros perniciosos, então poder-se-ia dizer com razão que a virtude sucumbira vencida pela grandeza da dor. Mas, uma vez que a piedade, a religiosidade, a santidade e, enfim, a virtude em toda [51] a sua extensão se mantêm íntegras, poderá acaso dizer-se (ainda que um pranto incessante abertamente dê a conhecer como é grande a dor infligida ao espírito) que a firmeza do homem justo foi abalada pela grandeza da dor? De forma alguma. Bem pelo contrário, houve nele tamanha força e firmeza que não puderam ser quebrantadas por uma insuportável calamidade.

Mas a muitos pode parecer assaz digno de admiração o facto de que, embora Job tivesse suportado incontáveis e enormes desgraças e experimentado as mais terríveis calamidades, nada the tenha causado mais indignação do que os insultos com que os seus amigos o acabrunhavam. É que, perante as chagas com que o viam atormentado, se obstinavam em demonstrar que ele fora perverso e injusto e, sob uma falsa aparência de piedade, incorrera em desmedidos crimes e infâmias. 
modo diuinis institutis et moribus, sed etiam admirabili et inuicta constantia in se, quantas uires uirtus haberet, ostendit. Magnis enim opibus spoliatus, liberis omnibus orbatus, a [50] florentissima fortuna ad extremam inopiam redactus, ulceribus grauissimis deformatus, doloribus summis interclusus et his omnibus aerumnis, opera Daemonis infestissimi, uno momento temporis oppressus, sic statum suum conseruauit ut de omnibus hostis perditissimi conatibus summa cum gloria triumpharet.

- Immo, inquiet fortasse aliquis, calamitati succubuit, lacrimae namque et lugubris quaedam lamentatio et crebra suspiria continent effeminatae uirtutis argumentum. At quam assiduus maeror Iobi fuerit aspicimus et quantis et quam diuturnis sordibus uersatus sit clare cernimus.

O peruersam hominum imperitorum sententiam! Num uirtutis officium est humanae naturae mollitiem in saxi naturam conuertere? Num sensus extorquere et efficere ne uulnus inflictum dolorem efficiat? Num hoc praestare ne dolor inustus, quod consequens necessario est, lacrimas et gemitus eliciat? Non certe. Nec enim quisquam, qui sana mente praeditus esset, hoc uirtuti munus imposuit ut dolorem minime sentiret, sed ut dolori repugnaret, non nihil dolendo, sed nullum in se flagitium propter uim doloris admittendo. Non sumus enim e silice exculpti et ideo fieri non potest ne nos grauissimi uulneris dolor excruciet. Quod si fieri posset, uirtutis ipsius decus interiret. Quod enim uirtutis ipsius robur esset, si doloris sensus non animum uehementer excruciaret? Tunc igitur demum uirtus uim suam indicat, cum grauissimus dolor antegreditur, quem roboris constantia uincat et superet.

Gemitus interim atque suspiria non stratam uirtutem ostendunt, sed quantis uiribus sit oppugnata testificantur. Quocirca fieri potest ut, quo maeror grauior est, magis uirtutis ipsius uis et dignitas elucescat, maioribus enim malis oppugnatam esse declarabit. Si enim dolor iusti fidem infirmaret, si spem debilitaret, si animum a studio pietatis auocaret, si mentem erroribus perniciosis imbueret, tum merito dici posset uirtutem, doloris magnitudine superatam, concidisse. At, cum in summis doloribus pietas et religio et sanctitas et uniuersae denique uirtutis [51] amplitudo suo statu maneat, poteritne dici (quamuis fletus assiduus, quantus dolor inustus animo sit, aperte demonstret) statu hominis iusti fuisse doloris magnitudine conuulsum? Non prorsus. Immo tam fuisse in illo roboris atque firmamenti ut nec intolerabili calamitate frangi potuerit.

Sed illud ualde admirandum multis uideri potest quod, cum Iobus multa et maxima incommoda pertulisset et calamitates dirissimas hausisset, nihil indignius passus sit quam maledicta quibus illius amici eum configebant. In eo enim perseuerabant ut ex plagis, quibus afflictum aspiciebant, conuincerent illum fuisse maleficum et iniustum et, in ficta specie pietatis, infinita flagitia et scelera suscepisse. 
Não falou nas riquezas, em parte queimadas, em parte destruídas pelas armas, em parte saqueadas; não soltou nenhuma palavra de queixume pelos filhos mortos por um terrível acidente; aceitou golpes intoleráveis e de modo lastimável todo o seu corpo foi retalhado por chagas, e sem embargo tudo aguentou com admirável paciência: só de muito mau talante suportou a mancha do desdouro e o insulto indigno da virtude de que estava provido. É certo que arrostou os ultrajes dos amigos com a mesma coragem com que arrostou tudo o resto, mas fê-lo todavia de tal maneira que não só mostrava a dor que os insultos lhe causavam, mas também com enérgico esforço impedia que caísse sobre o seu nome a infâmia do desdouro e os ataques de uma linguagem muitíssimo violenta.

Daqui se conclui que, para as almas superiores, em todas as coisas humanas nada existe de mais perturbador do que a infâmia do desdouro ou de mais agradável do que o belo parecer e prestígio da dignidade. E decerto que com toda a justiça. É que, em primeiro lugar, a própria honra nasce da fonte da mais verdadeira virtude; depois, impele muitos mortais ao zelo da honestidade; em terceiro lugar, atrai para si o amor e afeição dos homens; finalmente, faz que o nome e a glória de Deus se tornem mais brilhantes. Por conseguinte, que poderá existir de mais grandioso do que a verdadeira glória, uma vez que é um excelente fruto da honestidade, produz a honestidade, atrai o amor dos homens e concorre para a glória da majestade divina? Por isso não é de admirar que o santíssimo varão se empenhe com tão nobre denodo em prol da honra e dignidade, na defesa da sua justiça e a bem dos ornamentos da virtude de que estava dotado.

Todavia é mister notar qual é a consolação com que ao cabo se mitiga esta pungentíssima dor que se despertara com a indigníssima injúria que os amigos lhe tinham lançado em rosto. “- Que consolação é essa?”, perguntais-me. - Sem dúvida que o testemunho divino, no qual consiste a mais verdadeira glória. É que os homens, cegos pelo amor, ou pelo ódio, ou pelo desejo, ou pela ambição, ou perturbados por outras paixões [52] e profundamente desviados da verdade, falham no seu ajuizar. Muitos encontram-se de tal maneira submetidos às opiniões do vulgo que só aprovam aquilo que virem que é louvado pela multidão ignorante, só criticam aquilo que o desatino e desvario da multidão julgar merecedor de crítica. Além disso, como ninguém pode esquadrinhar o recesso íntimo dos espíritos e a natureza de cada um se encontra oculta por infindos envoltórios, sucede que muitos obtêm aquilo, que deveria ser obtido mediante a virtude, recorrendo à simulação da virtude, e não poucos, que se apoiam na verdadeira virtude, são agredidos com indignos insultos. Por derradeiro, ainda que na vida não existissem erros, mesmo assim nas coisas humanas não há nada capaz de conceder um prazer firme e estável a espíritos nascidos para a imortalidade. É que a morte, a duração do tempo e as frequentes e variadas transformações dos Estados ocasionam o fim até dos maiores impérios e dos mais ilustres monumentos e acabam por tudo aniquilar e lançar no esquecimento.

Logo, uma vez que todo o louvor e dignidade desta vida ou são vãos e falsos ou devem inevitavelmente ser destruídos pela idade e velhice, resta que todos os que desejam a honra e dignidade aspiram àquela glória que em tempo algum há-de morrer: ou seja, a que se funda no julgamento e público pregão de Deus. De facto, a Sua sabedoria não pode ser enganada com embustes, nem a Sua equidade torcida pela simpatia por alguém, 
Opibus partim incensis, partim ferro trucidatis, partim direptis conticuit; liberis horribili casu peremptis nullam uocem lugubrem emisit; plagas intolerandas accepit et ulceribus miserandum in modum discissus toto corpore fuit, et tamen omnia mirabili patientia tolerauit: solam dedecoris maculam et indignam insita uirtute contumeliam dolenter admodum tulit. Sustinuit ille quidem eadem uirtute qua reliqua omnia, amicorum conuicia, ita tamen sustinuit ut et dolorem quem ex probris accipiebat indicaret, et acri contentione a nomine suo dedecoris ignominiam et acerbissimae orationis impetum reprimeret.

Vnde colligitur animis excelsis nihil esse in rebus humanis uel dedecoris infamia turbulentius uel dignitatis specie et fama iucundius. Et iure quidem. Primum enim decus ipsum ex fonte uerissimae uirtutis exoritur; deinde, multos mortales ad studium honestatis impellit; deinde, hominum sibi amorem et beneuolentiam conciliat; postremo, facit ut Dei nomen et gloria clarius illustretur. Quid igitur poterit esse gloria uera magnificentius, cum honestatis partus excellens sit et honestatem pariat et hominum caritatem alliciat et ad numinis diuini gloriam referatur? Quare mirandum non est si uir sanctissimus pro decore atque dignitate, pro iustitiae suae defensione, pro insitae uirtutis ornamentis tam claram contentionem suscipiat.

Illud tamen est animaduertendum, quo tandem solacio hunc dolorem acerbissimum, qui ex indignissimo probro sibi, ab amicis obiecto, emerserat, consoletur. "- Quod solacium”, inquis, "illud est?" - Testimonium certe diuinum, in quo uerissima gloria consistit. Homines enim aut amore aut odio aut cupiditate aut ambitione caecati, aut aliis pestibus [52] agitati et a uero penitus auersi, in iudicando falluntur. Sunt multi ita uulgi opinionibus addicti ut nihil approbent nisi quod ab imperita multitudine laudari uiderint, nihil uituperent nisi quod multitudinis furor et amentia uituperandum iudicauerit. Praeterea, cum nemo possit intimos animorum recessus inspicere et infinitis inuolucris uniuscuiusque natura tegatur, euenit ut multi, quod erat uirtute parandum, uirtutis simulatione consequantur, et non pauci, uera uirtute nixi, indigna contumelia lacerentur. Postremo, ut nullus error in uita uersaretur, tamen nihil est in rebus humanis quod, animos ad immortalitatem natos, firma et stabili uoluptate possit afficere. Mors enim et temporis uetustas et frequentes et uariae rerum publicarum conuersiones, summis etiam imperiis et clarissimis monumentis interitum afferunt, omniaque tandem obliuione conterunt atque consumunt.

Ergo, cum omnis huius uitae laus et dignitas uel inanis et falsa sit, uel certe senio atque uetustate delendam, reliquum est ut omnes qui decus et gloriam appetunt ad illam gloriam aspirent quae nullis est saeculis interitura: nempe, quae in Dei iudicio et praedicatione consistat. Nec enim sapientia illius fraudibus eludi, neque aequitas gratia ullius inflecti, neque testimonium corrumpi, neque 
nem o Seu testemunho subornado, nem o Seu juízo mudar-se e variar, de tal maneira que só está largamente provido daquela verdadeira e imortal glória quem obtém a aprovação da inteligência divina. Como a esta todos os justos a obtêm, enquanto sustentam a sua posição, ainda que por vezes sofram com a falsa e infamante acusação de perversos, e por este motivo sejam atormentados por uma dor nada pequena: quando reflectem e compreendem que só deve desejar-se vivamente aquela glória que é concedida por Deus, facilmente desprezam o gozo da glória humana.

Ora, em Job podem ver-se ambas as coisas: por um lado, a justa dor que recebeu do indigníssimo ultraje ao seu bom nome, por outro, o refrigério com que afasta a pungentíssima dor; destas duas coisas, uma é atribuível aos sentidos humanos, e a outra à influência do entendimento divino. Mas para que possa ver-se que Deus nunca há-de descurar a dignidade dos homens piedosos, a este santíssimo varão, por todos os lados atacado e atormentado pelos espinhos dos insultos, mostrou-se-lhe a majestade divina, que dele afastou o ataque dos amigos e, como veremos depois, diante dos amigos adornou a mesma dignidade com os maiores louvores. ${ }^{1}$ Para podermos ver isto melhor é conveniente que retornemos à discussão que estavam a travar.

[53] Elifaz de Teman, não pouco perturbado com as palavras de Job, respondeu-lhe por este teor:

- Porventura fica bem que uma pessoa, que quer ser tida por sábio, mostre com as suas palavras quão falsa e vã é a sua sabedoria, de tal maneira que o discurso facilmente demonstra o seu atrevimento? Acaso o sábio há-de ostentar uma ciência oca? Acaso há-de sustentar que o seu espírito se encontra corrompido e ocupado com confusos erros? Acaso disputará com argumentos incoerentes e com uma linguagem imprópria? Acaso avançará opiniões ineptas sem qualquer utilidade? Peço-te que consideres, tu que te jactas do título de sábio, e desprezas os demais como ignorantes, como é grande a demência e loucura que te dominam e que atentes nas palavras monstruosas que saíram dessa boca. Com efeito, não só suprimiste por completo o temor de Deus, como também sacrilegamente desprezaste o zelo da santíssima religião, que se funda nas orações puras, na confissão dos pecados e na consideração da bondade divina.

Que pode imaginar-se de mais ímpio e irracional do que isto? É que do mesmo passo destróis as obras e a religião e deixas manifesta aos olhos de todos a tua loucura, uma vez que dizes tais coisas impelido pelas Fúrias da iniquidade, e não instruído pelos ensinamentos da verdadeira ciência, e te serves, não da linguagem do homem recto e sincero, mas da do astuto e velhaco. Não sou eu, para que não te irrites comigo, não sou eu, mas as tuas palavras quem refuta o teu crime, e és tu mesmo quem testemunha contra ti. Ora, pergunto: porventura nasceste muito antes do começo da espécie humana? Porventura exististe antes que todos os montes fossem criados? É que, assim, seria justo que, do mesmo modo que superas em antiguidade os restantes homens, assim te avantajasses a todos em sabedoria. Embora não te escudes muito na autoridade da velhice, todavia vanglorias-te do grande peso de uma espécie de sabedoria divina, como se tivesses tido ao próprio Deus como mestre desse admirável saber. E uma tal atitude 
iudicium immutari atque uariari potest, ita ut illa solum gloria uera et immortali circumfluat qui testimonium mentis diuinae consequitur. Quod cum omnes iusti, quamdiu statum suum tuentur, obtineant, quamuis interdum falsa improbitatis infamia laborent et ea de causa non mediocri dolore torqueantur, ubi se colligunt et intelligunt eam demum gloriam esse acriter expetendam quae a Deo confertur, humanae gloriae fructum facile contemnunt.

Vtrumque autem in Iobo perspici potest: et iustus dolor quem ex nominis sui indignissima contumelia capit, et solacium quo dolorem acerbissimum depellit, quorum alterum est humanitatis sensibus, alterum diuinae mentis uiribus ad scribendum. Vt uero cerni posset piorum hominum dignitatem numquam a Deo neglectum iri, huic sanctissimo uiro, contumeliarum aculeis undique petito et stimulato, diuinum numen affulsit, quod amicorum ab illo impetum repressit eamque coram amicis ut postea uidebimus. Quod, ut melius intueri possimus, commodum est ut ad institutum eorum sermonem redeamus.

[53] Ad Iobi orationem Heliphazius Themanita non mediocriter commotus in hanc sententiam respondit:

- An decet eum, qui sapiens haberi uult, quam fallax et inanis illius sapientia sit uerbis ostendere, ita ut facile oratio temeritatem illius coarguat? Num sapiens uentosam scientiam ostentabit? Num animum suum erroribus turbidis infici et compleri sustinebit? Num argumentis minime cohaerentibus et inutili oratione contendet? Num sententias ineptas sine ullo fructu proferet? Considera, quaeso, et alios, ut stultos, spernis, quanto furore et amentia flagres et quae uerborum portenta ex ore isto prodierint. Nam, et Dei timorem funditus sustulisti, et studium sanctissimae religionis, quod in castis precibus et in erratorum confessione et in diuinae benignitatis consideratione situm est, nefarie contempsisti.

Quo quid uel scelestius uel amentius fingi potest? Eadem enim opera et religionem euertis et dementiam tuam apud omnes testatem relinquis, iniquitatis enim Furiis instinctus, non uerae scientiae praeceptis imbutus, ista dicis, nec orationem hominis recti atque simplicis, sed callidi et ueteratoris usurpas. Non ego, ne tu mihi suscenseas, sed oratio tua scelus tuum redarguit, et tu ipse contra te testimonium dicis. Sed quaero: num tu multo ante generis humani primordium natus es? Num antequam omnes colles fundarentur exstitisti? Sic enim par esset ut, quantum reliquos homines antiquitate superares, tantum sapientia omnibus anteires. Quamquam tu non multum senectutis auctoritate pugnas, sed prae te fers diuinae cuiusdam sapientiae magnitudinem, quasi Deum ipsum magistrum admirandae istius eruditionis habueris. Et hoc in quanto intolerandae superbiae crimine ponendum est? Fuistine tu in intimum consilium diuinae mentis admissus? 
deve atribuir-se a um crime de soberba de que dimensões? Porventura Deus te admitiu na intimidade do conselho das Suas deliberações? Porventura Deus partilhou contigo os segredos da Sua sabedoria? Porventura Ele te considerou como dotado de capacidades excepcionais para, excluindo os demais, te instruir nas riquezas divinas e admiráveis da sabedoria? Por conseguinte, dá a conhecer algo de ti por meio do qual comproves essa tão grande sabedoria.

Pergunto-te: em que é que sobressais tanto entre todos? Que é que entendes que nós ignoremos? Que é que compreendes que nós não percebamos? Também entre nós existem ancião sábios com quem aprendemos; também há entre nós um homem de provecta idade, respeitável pela sua autoridade, que vence e supera em idade o teu pai. Tão-pouco aquilo que dizemos se aparta da inteligência divina, da qual, como é óbvio, procede e se extrai toda a sabedoria. Portanto, porque tens na conta de coisa nenhuma as consolações de Deus? Por que é que desprezas os nossos conselhos e avisos? Por que é que desdenhas as opiniões que se apoiam na lei e razão divinas?

Mas retrucarás, dizendo que gozas da conversação íntima com Deus e que Ele mesmo te ensinou secretamente outra espécie de doutrinas à qual os restantes homens não podem aspirar. Por conseguinte, pretendes que nós consideremos que o teu entendimento é iluminado por aquelas luzes da sabedoria e, por obra do Espírito divino, se instrui naqueles ensinamentos que não podem ser alcançados e abarcados por nenhum esforço humano. E isto que é senão [54] um indício da mais rematada loucura e uma prova de um entendimento vesânico e louco? De facto, que outra coisa fazem os que deliram e estão fora de si? Com efeito, depois de terem perdido todos os sentidos humanos, asseguram que são animados por sentidos divinos e, caídos na mais completa demência, com desmedida insolência ensoberbecem-se com o título da máxima sabedoria.

Portanto, que causa apontarei para que tenhas caído em opiniões tão estultas e ineptas? Sem dúvida que a causa é esta. O teu espírito, cego devido às indignidades, impele-te para o engano: e até os teus olhos, pelos seus trejeitos, mostram com toda a evidência que a soberba do entendimento te incita loucamente a precipitar-te. E foram tamanhos o teu desatino e insolência que te ensoberbeceste contra Deus e o desafiaste para a luta e proferiste muitas injúrias contra a Sua equidade e sentido de justiça. Ora, tu a grandes brados asseveras que à face de Deus estás isento de todo o crime. Pergunto: qual é a natureza do homem, para que alguém se atreva a afirmar que nunca se manchou com a nódoa de nenhuma impureza? O homem, a quem a mulher trouxe no ventre, a quem a mulher deu à luz, que desde o nascimento contraiu a enfermidade e a fraqueza, acaso poderá ser sempre fiel à justiça e por decisão de Deus ser isento de toda a espécie de faltas? Que dizer do facto de que nem sequer os Seus santos anjos, que incessantemente O serviam, conseguiram manter-Lhe a devida lealdade, tal como por direito estavam obrigados, e desempenhar perfeitamente a devida obrigação? Que dizer do facto de que aos Seus olhos nem sequer a natureza celestial é pura? Por consequência, que se deve pensar acerca do homem, que foi contaminado pela natureza e corrompido pela infâmia, e com tamanho desprezo pratica a injustiça como se estivesse a beber água? 
Num Deus tecum arcana sapientiae suae communicauit? Tene ille eximium habuit, quem facillime praeter ceteros sapientiae opibus diuinis et admirandis instrueret? Prome igitur ex te aliquid, quo istius tantae sapientiae documentum statuas.

Quid est illud, quaeso, in quo tantum inter omnes excellas? Quid intelligis quod nos ignoremus? Quid mente comprehendis quod non percipiamus? Sunt et apud nos senes sapientes unde discamus; est et apud nos homo grandis natu, auctoritate grauis, qui patrem tuum aetate uincit et superat. Nec ea, quae dicimus, a diuina mente aliena sunt, a qua nempe omnis sapientia hausta atque delibata sit. Quid ergo Dei consolationes pro nihilo putas? Cur nostra consilia et monita contemnis? Cur sententias, diuina lege atque ratione nixas, aspernaris?

Sed inquies, te arcano Dei colloquio frui et alio doctrinae genere ab ipso latenter institui, ad quod reliqui homines aspirare nequeunt. Hoc igitur a nobis existimari cupis, mentem tuam illis sapientiae luminibus illustrari et illis disciplinis, opera diuini Spiritus, institui quae nulla humana industria parari atque comprehendi possint. Et hoc quid aliud est quam extremi [54] furoris indicium et mentis uesanae atque uecoris argumentum? Quid enim aliud faciunt, qui uaticinantur et insaniunt? Nam, postquam omnes humanos sensus amiserunt, se diuinis sensibus incitari confirmant et, in summa dementia constituti, summae sapientiae nomine nimis insolenter efferuntur.

Quid igitur esse causae dicam ut in tam ineptas et stultas sententias incideris? Nimirum illud est. Animus tuus, flagitiis excaecatus, te in fraudem impelli: quin et oculi tui nutu aperte significant te mentis elatione praecipitem furenter incitari. Tantaque fuit temeritas et insolentia tua ut spiritus contra Deum sumpseris illumque ad certamen prouocaueris multaque in illius aequitatem et iudicium maledicta congesseris. Hoc autem afferis, hoc maxima uoce confirmas, te in Dei conspectu omni scelere uacare. Quaeso: quae natura hominis est, ut audeat quisquam asserere se nulla impuritatis labe maculatum? Homo, quem mulier aluo gestauit, quem mulier enixa est, qui morbum et imbecillitatem ex ortu contraxit, poteritne iustitiam perpetuo retinere et, Dei sententia, crimine omni liberari? Quid quod ne illius quidem angeli sancti, qui ei perpetuo ministrabant, hoc assecuti sunt, ut illi debitam fidem, perinde atque iure obligati erant, praestarent et debito officio perfecte fungerentur? Quid quod ne caelestis quidem natura in illius conspectu pura est? Quid est igitur de homine existimandum, qui natura contaminatus et flagitio corruptus est, et iniquitatem adeo contemptim suscipit quasi aquam bibat? 
Desejaria que escutasses atentamente aquilo que pretendo dizer-te. É que vou expor-te, não uma opinião vaga e incerta, mas uma doutrina segura e firme, resultante de quanto eu vi e experimentei. Tão-pouco me reputo como autor do que disser, pois direi o que transmitiram os sábios, que por sua vez o receberam dos seus antepassados e em seguida, de muito boa fé, o ensinaram aos seus descendentes. Ora, que é que disseram aqueles homens dotados de inteligência divina? Acaso que a Terra, consoante afirmavas, tinha sido confiada ao capricho e poder dos homens ímpios? De forma alguma. Bem pelo contrário, disseram que o senhorio firme e estável da Terra tinha sido entregue exclusivamente àqueles que foram muitíssimo instruídos pelos ensinamentos da sabedoria. Aqueles, sem dúvida, que de tal maneira desempenharam a sua função que, durante o tempo em que seguraram o leme do Estado, nunca o inimigo invadiu as territórios confiados ao seu governo. E mesmo assim abates a condição dos que vivem com justiça e piedade e elogias a prosperidade dos ímpios, e não compreendes que na vida não pode imaginar-se nada de mais mofino e desgraçado do que o homem ímpio.

Com efeito, o ímpio expia as suas culpas com uma angústia e tormento de alma incessantes e, quem detém o poder tirânico, como desconhece o dia em que deve ser derribado, é inquietado pelo medo da funesta ruína e dia e noite vive no receio angustiado do fatal fim. Os seus ouvidos costumam ser frequentemente aturdidos por vozes horrendas e sobremaneira assustadoras e, quando parece gozar da paz mais tranquila, os inimigos atacam-no de repente para causar a sua destruição. Quando for encerrado nas trevas, não será alentado por nenhuma esperança de ver de novo a luz [55] e aterrar-se-á ao imaginar as espadas apontadas contra si, há-de vaguear a tremer e, transido de medo e com espírito desassossegado, há-de mendigar o pão e compreenderá perfeitamente que por suas próprias mãos aparelhou contra si a perdição para o dia fixado pelo juízo de Deus, será atormentado por terríveis angústias, será protegido por uma defesa hostil e será oprimido pelo assédio de todos os males, como pelas tropas reais postadas em roda para perdê-lo. De tal maneira há-de ser imobilizado por todos os lados que não sinta que alguma brisa sopra sobre si ou que lhe trazem alguma ajuda ou the nasce alguma luz. É que aprontou contra o Senhor uma guerra manchada de abominável crime e aplicou todas as energias do espírito na destruição da Sua lei. Por conseguinte, o Senhor atacará as suas riquezas, que o tornavam altivo e hostil, e tirar-lhe-á as armaduras e escudos com que confiava que estava muito bem defendido, e arrebatar-lhe-á todos os ornamentos da dignidade. Com efeito, ensoberbecido com as riquezas, perdeu a vergonha e, cheio de prodigiosos bens, mostrou em todas as situações uma altivez e obstinação intoleráveis. Por consequência, as cidades que habita serão destruídas; as casas onde mora serão arruinadas e transformadas num monte de pedras. As suas riquezas não serão estáveis, nunca recobrará a dignidade perdida nem deixará sobre a Terra uma descendência com prestígio. Nunca sairá das trevas, a sua posteridade será abrasada pelas chamas que lhe forem lançadas e será arrancado da sua posição pela insolência e vaidade das palavras com que ele mesmo impiamente provocou contra si a majestade divina. É que mostrou deslealdade para com Deus; enganado pelo erro do entendimento, apoiou-se na mentira e, por isso, a sua posição foi invertida e modificada por obra da sua própria vaidade, e 
Quod tibi exponere instituo uelim attente audias. Non enim uagam et incertam opinionem, sed firmam stabilemque sententiam, de rebus a me perspectis et exploratis, explicabo. Nec earum rerum, quas dixero, me auctorem profiteor, ea enim dicam quae a sapientibus tradita sunt, quae ipsi a maioribus suis acceperunt, et deinde posteris suis optima fide prodiderunt. Quid est autem ab illis hominibus diuino ingenio praeditis dictum? Num terram, ut dicebas, esse hominum impiorum libidini atque potestati permissam? Minime. Immo, ad eos solos fuisse firmum et stabile terrarum imperium delatum qui sapientiae disciplinis fuerunt instructissimi. Qui quidem sic munere suo perfuncti sunt ut, quamdiu illi clauum tenuerunt, numquam in terras eorum moderationi commissas hostis inuaserit. Et tamen eorum condicionem, qui cum iustitia et pietate uiuunt, deprimis et impiorum res secundas uerbis extollis, nec intelligis nihil in uita cogitari posse homine impio miserius et calamitosius.

Perpetuo namque animi angore et cruciatu poenas pendit impius et, qui tyrannidem occupauit, cum diem, quo de medio tollendus est, ignoret, metu pestiferae cladis exanimatur et dies atque noctes exitialem exitum anxie reformidat. Aures illius horrendis atque ualde metuendis uocibus frequenter obtundi solent et, cum maxime pace tranquilla frui uidetur, illum improuiso hostis, ut uastationem inferat, adoritur. Cum fuerit tenebris inclusus, nulla spe lucis rursus [55] aspiciendae tenebitur et gladios in se intentos animo prospiciens extimescet, horrens et tremens uagabitur et panem, animo sollicito, mendicabit et intelliget plane ipsum sibi manibus suis pestem ad constitutam diuino iudicio diem comparauisse, terrificis angustiis afflictabitur, hostili munitione uallabitur et, tamquam regis copiis ad perniciem illius circumdatis, malorum omnium obsidione premetur. Ita tenebitur undique ut nullam sibi auram afflari, nullam opem afferri, nullam lucem exoriri sentiat. Bellum enim infando scelere imbutum contra Dominum comparauit omnesque neruos animi ad euertendam legem illius intendit. Dominus igitur in illius opes, quae illum ferocem et infestum faciebant, inuadet, eique corporis integumenta et scuta, quibus se egregie munitum confidebat, detrahet, omniaque illi dignitatis ornamenta diripiet. Opibus enim inflatus, pudorem amisit, immanibusque diuitiis expletus, intolerandum fastum et contumaciam in omnibus rebus adhibuit. Vrbes igitur, quas incolit, exscindentur; domus, in quibus habitat, euertentur et in aceruos lapidum redigentur. Non erunt illius opes stabiles, numquam dignitatem amissam recipiet neque florentem in terra subolem propagabit. Numquam e tenebris emerget, posteritas illius iniectis flammis exardescet et orationis insolentia et uanitate, qua impius ipse numen in se diuinum concitauit, de omni statu suo conuelletur. Deo enim fidem non adhibuit; mentis errore deceptus, mendacio nixus est et idcirco status illius opera ipsius uanitatis inuersus et immutatus est, omnesque illius cogitationes ad nihilum reciderunt. Excidetur ante fatalem diem nec ex illius trunco rami, qui locum ullum umbris opacare possint, orientur. Vt uitis acerbi botrui ante maturitatem 
todos os seus pensamentos redundaram em coisa nenhuma. Morrerá antes do dia fixado e os ramos do seu tronco não nascerão de modo a poderem cobrir com a sua sombra algum lugar. Assim como os cachos verdes da videira cortados antes do tempo e como as flores da oliveira deitadas abaixo antes que apareçam as azeitonas, assim por juízo de Deus ele será destruído antes de conseguir chegar ao lugar para onde se dirige e assim as suas esperanças serão vãs e totalmente inúteis os seus pensamentos.

Na verdade, a numerosa família dos que sacrilegamente simulam a virtude e, por trás da catadura e ar severo, ocultam as infâmias no interior do espírito, será transformada num ermo deserto e o fogo abrasará com um incêndio as casas dos que se deixam corromper com dádivas e, contra o direito e o que é justo, sentenciam a favor dos sacrílegos e criminosos. Portanto, a vida do ímpio é em grande parte espantosamente atormentada e sujeita a incessantes tribulações. É que concebeu a inquietação; pariu a iniquidade; guardou no seu seio enganos e embustes por forma a usar das maquinações para perdição dos homens.

Ora, com estas palavras Elifaz não só se esforçou por refutar a opinião de Job, mas também pretendeu censurá-lo como simulador da virtude e acusá-lo do crime de iniquidade e injustiça, a fim de mostrá-lo, por um lado, como ensoberbecido com a infundada superioridade da sabedoria, por outro, ensinado pelo artifício de uma religiosidade simulada, corrompido nos seus juízos pela avareza e pela maldade.

Job, porém, respondeu do modo seguinte:

- Já frequentemente ouvi esses raciocínios e muitos do mesmo género. [56] Portanto, qual o interesse de lembrar coisas que foram tão repisadas? Não há dúvida que sois consoladores muitíssimo molestos. De facto, com as vossas palavras empenhais-vos, não em aliviar a minha dor, mas em torná-la ainda mais pungente. Não estais decididos a, por uma vez, pôr fim a palavras sem qualquer fundamento? Adquires tamanha firmeza e força com o meu sofrimento que queres que, por causa dela, eu seja inquietado e aviltado com toda a espécie de ultrajes?

Ora, quanto disseste acerca das atribulações dos tiranos é não só verdade como do meu conhecimento, e acerca desses assuntos e opiniões desse género posso dissertar com elegância e abundância não inferiores às de qualquer um de vós. Mas tais coisas nem são oportunas, nem servem para refutar aquilo que eu disse, nem são adequadas para mitigar a dor. Oh se um desgosto semelhante ao meu atribulasse os vossos espíritos, como seriam diferentes as reflexões com que vos consolaria! Sem dúvida associar-me-ia convosco na mesma dor e com todos os sinais de pesar demonstraria que tinha sido afectado pelo mesmo sentimento de aflição; depois, esforçar-vos-ia com o meu discurso e, com palavras apropriadas para consolar, repeliria a grande tristeza e, na medida das minhas possibilidades, diminuiria com as minhas palavras o vosso desgosto. Mas vós não mostrais nenhum sinal de dor pela minha adversidade, sendo certo que fui golpeado por uma ferida não de somenos, mas quase incurável. E não encontro qualquer refrigério para tamanhos males, pois a minha dor não se pode diminuir quando falo, nem, quando acabo de falar, acalmar-se, mas tortura-me sempre com a mesma violência. É que o Senhor agora 
temporis excisi et ut oleae flores antequam bacae appareant decussae, sic ille antequam eo, quo intendit, peruenire queat, Dei iudicio peruertetur itaque spes illius erunt inanes et cogitationes uanissimae.

Multiplex namque eorum familia qui uirtutem nefarie simulant et inclusa mente flagitia, fronte et supercilio, contegunt, erit in uastam solitudinem conuersa et ignis eorum tabernacula, qui muneribus corrumpuntur et causas, contra ius et fas, improbis atque sceleratis adiudicant, incendio consumet. Est igitur impii uita maxima ex parte mirabiliter afflicta et cruciatibus assiduis obnoxia. Concepit enim sollicitudinem; partu edidit iniquitatem; dolos et fraudes utero continuit, ut machinationes ad hominum perniciem adhiberet.

Hac quidem oratione Heliphazius non modo Iobi sententiam refutare nixus est, uerum etiam illum ut simulatorem uirtutis insectari et ei iniquitatis et iniuriae scelus obiicere uoluit, ut illum non solum inani sapientiae numine tumentem, uerum etiam assimulatae religionis artificio eruditum, in iudiciis auaritia et improbitate corruptum ostenderet.

At Iobus ita respondit:

- Haec quidem et multa praeterea illorum similia frequenter audiui. [56] Quid igitur conuenit ea, quae sint adeo trita, commemorare? Certe uos consolatores estis acerbissimi. Non enim ut dolorem meum leniatis, sed ut uehementius augeatis oratione contenditis. Non tandem aliquando finem uerbis uanissimis statuetis? Tantumne tibi ex aerumna mea roboris atque firmitatis accedit ut, ea gratia, me pressum et contumelia omni deformatum esse uelis?

Quae enim dixisti de tyrannorum supplicio et uera sunt et mihi non inaudita, et, de locis atque sententiis huiusmodi, non minus ornate et copiose quam quilibet uestrum disputare possum. Sed ea neque temporis sunt, neque ad ea, quae disserui, infirmanda pertinent, neque sunt ad mitigandum dolorem accommodata. O si uestros animos similis aerumna uexaret, quam dispari ratione ad uos consolandos accederem! Profecto societatem uobiscum eiusdem doloris inirem omnibusque maeroris signis me eodem prope sensu aegritudinis affectum demonstrarem; deinde uos oratione mea confirmarem et a maestitiae magnitudine, uerbis ad consolandum appositis, auocarem et, quantum possem, luctum uestrum oratione minuerem. At uos in meo grauissimo casu nullum signum doloris ostenditis, cum ipse non sim mediocri uulnere, sed propemodum insanabili percussus. Nec ullum tantis malis solacium inuenio, nec enim dolor meus uel cum loquor, imminui, uel cum finem loquendi facio, sedari potest, sed eadem semper acerbitate me lacerat. Dominus enim nunc etiam me non minus 
também me atribula com não menor violência e não deixa que o meu espírito sinta algum alívio na tristeza.

Senhor, oprimiste-me com pesadissimas calamidades, causaste a ruina e a devastação a todos os meus empregados e propriedades; sulcaste de rugas o meu rosto para que pudesse provar como é grande a tribulação que padeço; do mesmo modo, a magreza que desfigura a minha face indica quão grande é a violência da doença que me vexa.

Abrasado em ira, o Senhor arremete contra mim e ataca-me com sobeja severidade; e lança-se sobre mim rangendo os dentes; e como meu inimigo fulmina-me e dardejame com o Seu olhar; e apavora-me só com a Sua presença ameaçadora. E isto não é bastante, mas também os meus amigos acirram a minha ferida e aumentam violentamente a minha dor. Com efeito, atassalham-me com ultrajes e ferem a minha face com insultos e, depois de me atacarem, lançam-se ao mesmo tempo sobre mim de maneira a poderem saciar e fartar o espírito com as minhas desgraças. O Senhor agarrou-me e entregou-me à crueldade dos ímpios. E, como eu possuía abundantes riquezas, precipitou-me da minha posição e, torcendo-me o pescoço, violentamente me arrebatou e dilacerou e colocou-me como uma espécie de alvo contra o qual se arremessam os dardos. Fui trespassado pelas setas d' Ele, lançadas de todos os lados; também feriu cruelmente os meus rins e não estabeleceu qualquer limite para a Sua ira até derramar sobre a terra o meu fel. Não satisfeito com as feridas infligidas, golpeou-me com mais e mais feridas; com fogosa persistência e empenho, arremeteu sobre mim como se fosse um homem violento armado e desejoso de combater. Cosi um saco para com ele limpar a minha pele e abateu-se no pó a minha grande superioridade, que tanto sobressaía pela riqueza. [57] O meu rosto está inchado devido ao incessante pranto e aflição e as pálpebras dos meus olhos estão rodeadas de negra escuridão. E tudo isto padeço sem qualquer culpa minha, pois não cometi injustiças contra os homens nem violei com crimes a religião, mas adorei a Deus com preces puras e espírito limpo.

Ó Terra, se maquinei o assassínio de alguém ou lhe inferi a morte, não o ocultes, mas revela-o à vista de todos. Se incorri em algum crime capital, que não haja lugar para os meus brados nem o Senhor dê nos Seus ouvidos entrada às minhas palavras. Tenho no Céu uma testemunha da minha inocência e piedade: refiro-me Àquele que habita nas moradas celestiais e tudo claramente divisa, Aquele que sabe o quão puramente pratiquei a justiça. Mas os meus amigos, que me deveriam ajudar, aumentam a minha dor e lançam-se contra mim com discursos elaborados e preparados. Eu, porém, com muitas lágrimas, que incessantemente correm dos meus olhos, imploro o socorro de Deus e ponho a causa da minha dignidade no juízo íntegro e constante daquele Senhor supremo que vê todas as coisas humanas. E oxalá que este, que falsamente acusa de crime um homem, se apresente em juízo diante de Deus e, quando como homem intenta processo contra outro homem, a verdade se dê a conhecer na presença d' Aquele Juiz a quem nada se pode esconder.

Por conseguinte, sou atormentado cruelmente por a verdade permanecer oculta e vós me infamardes com a nota de crime: situação desvantajosa que não posso rebater numa vida tão breve. É que os anos que me restam de vida são em número reduzido 
uehementer affligit neque animum meum maestitia aliqua ex parte releuari concedit.

Grauissimisme, Domine, calamitatibus oppressisti, euersionem etpopulationem omnibus meis operis atque possessionibus intulisti; rugis faciem meam arauisti ut quanto in cruciatu sim testari possit; macies similiter, quae faciem meam deformat, quanta uis me morbi uexet indicat.

Incensus ira Dominus me corripit et nimis acriter impugnat; dentibusque frendens irruit; hostisque meus oculis suis micat et uibrat; meque solo aspectu minaciter exterret. Nec hoc satis est, sed etiam amici mei uulnus meum exagitant doloremque uehementer amplificant. Me enim conscindunt maledictis faciemque meam contumeliis lacerant, impetuque facto in me, simul inuehuntur ut calamitatibus meis animos explere atque satiare possint. Constrinxit me Dominus et impiorum immanitati tradidit. Et, cum multis opibus affluerem, e statu deturbauit et, obtorto collo, uiolenter arripuit et dilacerauit et quasi signum constituit in quod tela iacerentur. Sagittis illius undique emissis confixus sum; renes etiam meos concidit iraeque suae modum nullum statuit, usque eo dum fel meum in terram effunderet. Vulneribus impositis minime contentus, alia atque alia uulnera meis artubus inflixit; contento studio et cursu, in me, quasi uir acer in ferro et bellandi cupidus, inuasit. Saccum consui ut eo cutem meam abstergerem et principatus ille meus, qui tantum opibus eminebat, in puluerem abiectus est. [57] Facies mea assiduo fletu et squalore tumescit et palpebrae oculorum meorum atra caligine circumfusae sunt. Et haec quidem omnia patiar nullo merito meo, nec enim homines iniuriis affeci neque religionem scelere uiolaui, sed Deum semper castis precibus et pura mente ueneratus sum.

O terra, si caedem alicui machinatus sum aut perniciem intuli, id ne celes, sed in omnium aspectu propone. Si aliquod in me capitale facinus admisi, ne sit clamori meo locus neque Dominus meas uoces ad aures suas admittat. Testem in caelo innocentiae et pietatis habeo: illum nempe qui in excelsis sedibus habitat et omnia clare cernit, qui quidem scit quam pure iustitiam coluerim. Amici uero mei, qui me subleuare debuerant, augent dolorem meum et in me accuratis et meditatis orationibus incitantur. At ego cum multis lacrimis, quae perpetuo e meis oculis emanant, opem diuinam imploro illiusque summi Domini integro et constanti iudicio, qui omnes res humanas intuetur, meae dignitatis causam committo. Atque utinam is, qui uirum sceleris insimulat, apud Deum iudicio contenderet et, cum homo homini litem intendit, ueritas coram illo iudice, quem nihil latere potest, appareret.

Hoc igitur discrucior quod ueritas in occulto lateat et uos maculam mihi sceleris inuratis: quam importunitatem non possum in tanta uitae breuitate reprimere. Anni siquidem reliqui uitae meae numero exiguo continentur et finis 
e o fim aproxima-se, de tal maneira que estou a entrar naquela derradeira jornada e nunca voltarei de novo a este modo de vida e aos mesmos costumes e usanças dos homens.

Na verdade, o meu fôlego aos poucos vai-se esgotando e os meus dias vão falhando, à semelhança de uma lanterna a que o azeite acabou, e não me resta outra coisa senão ser sepultado. Pelo que, se às demais minhas penalidades não se juntasse esta desonra com que me oprimem homens arrastados pelo erro, e não se empenhassem tão pertinazmente em acusar-me de crime, os meus olhos veriam que eles acarretavam e lançavam sobre mim uma carga de males suficientemente grande, pois não apenas abandonado por eles, mas também infamado pela desonra, lastimaria de modo assaz pungente as minhas tribulações. Mas, uma vez que persistem nesta acusação e não aceitam nenhuma satisfação, as minhas primeiras tribulações recebem um acréscimo extraordinariamente violento. Por isso, impelido por uma tão excepcional desonra, dirijo-me a Deus e, apoiado na consciência da minha justiça, desejo que todos os serviços da minha vida sejam pesados diante do Seu tribunal.

Portanto, Senhor, peço-Te que me seja permitido apresentar diante de Ti um fiador, se não Te adorei pura a e santamente e se não me mantive inocente com a máxima diligência. Mas existirá alguém que queira ser meu fiador, especialmente quando até aqueles de quem me prometia todos os bons oficios do amor, me julgam um homem criminoso e culpado de muitos delitos? É que tornaste os seus entendimentos desprovidos de inteligência e, por isso, não os colocarás numa alta posição de dignidade, porquanto a glória imortal adquire-se não pela vaidade e loucura, [58] mas pela verdade e sabedoria.

Por conseguinte, as pessoas que são assim tão longe estão de poderem obter para si riquezas estáveis, que os seus descendentes são os que mais correm o risco de serem atribulados pela mais completa pobreza. Esta a razão por que, os que generosa e abundantemente prometem uma parte dos despojos aos seus companheiros, e atraem muitos mortais para segui-los e obedecer-lhes, caem em tão grande pobreza que os filhos deles, privados dos bens dos pais, são constrangidos a olhar com dor para as riquezas alheias e sentem-se devorados pela inveja. Eu, porém, a quem desprezais e desdenhais e a quem lançais em rosto acções criminosas e delitos, fui apresentado pelo Senhor a muitos povos como exemplo e modelo a imitar da máxima virtude e probidade, e de excepcional justiça e piedade.

Ora, isto parecer-vos-á incrível, ao verdes esta aparência de um homem que respira desfigurada por tamanha miséria. De facto, a acuidade dos meus olhos embota-se e é obscurecida pelas trevas devido à grandeza dos prantos e aflitos queixumes, e a configuração do meu corpo desvanece-se por completo como uma sombra. Todavia os homens justos, impressionados pela fama do meu nome, hão-de pasmar, e o inocente, com as suas riquezas e virtude, há-de superar o que simula a inocência, e o justo com a máxima constância há-de chegar ao termo da jornada da justiça, e o que quiser manter a pureza, há-de fortificar-se de dia para dia com maior vigor e coragem. Ora, isto escapa à vossa compreensão e não entendeis o desígnio com que Deus alenta de novo o inocente vexado e abatido, por forma a pôr à vista bem alto um exemplo de virtude e de 
appropinquat, ut iter illud ultimum ingrediar et numquam rursus ad hanc uitae rationem et ad eosdem hominum mores et instituta redeam.

Spiritus enim meus paulatim absumitur et dies mei, instar lucernae oleo consumpto, deficiunt, neque quidquam aliud superest quam ut sepulcro condar. Quod, si ad reliquas aerumnas meas haec ignominia qua me homines, errore ducti, afficiunt, non accederet, et non adeo pertinaciter in eo contenderent ut me sceleris rerum peragerent, satis magnum malorum pondus oculi mei mihi ab illis inuehi et importari perspicerent, nec enim solum ab illis desertus, sed ignominia notatus, aerumnas meas acerbissime lamentarer. Sed, cum in ea accusatione perseuerent nec ullam satisfactionem accipiant, incredibilis acerbitatis cumulus ad meas pristinas aerumnas accedit. Hac igitur tam insigni ignominia stimulatus, Deum appello et, recti conscientia fretus, ad illius iudicium omnia uitae meae officia perpendi cupio.

Hoc igitur a te peto, Domine, ut liceat mibi per te sponsionem tecum facere, ni te caste atque sancte coluerim et innocentiam summo studio conseruarim. Sed quis erit qui pro me sponsor esse uelit, maxime cum illi etiam, a quibus omnia amoris officia mibi pollicebar, me hominem facinorosum et multis criminibus alligatum arbitrentur? Eorum namque mentes expertes intelligentiae reddidisti et idcirco illos in alto dignitatis gradu minime collocabis, non enim uanitate et amentia, [58] sed ueritate atque sapientia, gloria immortalis acquiritur.

Tantum igitur abest ut, qui huiusmodi sunt, opes sibi stabiles parare queant ut potius eorum posteri extrema inopia uexandi sint. Inde fit ut, qui comitibis suis praedae partem ample atque magnifice pollicentur et ad ductum et imperium suum multos mortales alliciunt, in tantam inopiam incidant ut eorum filii, bonis patriis exclusi, alienas opes cum dolore intueri cogantur illosque inuidia contabefaciat. At ego, quem despicitis atque contemnitis et cui crimen et scelus exprobratis, sum a Domino, ut summae uirtutis atque probitatis exemplum et singulare iustitiae et pietatis specimen, multis populis ad imitandum propositus.

Hoc autem incredibile uobis uidebitur, cum hanc spirantis hominis imaginem tanto squalore deformatam uideatis. Oculorum enim meorum acies hebescit et, propter magnitudinem fletus et lugubris querimoniae, tenebris obscuratur, totaque forma corporis mei uelut umbra dilabitur. Attamen homines iusti, nominis mei fama commoti, obstupescent, et innocens innocentiae simulatorem opibus et uirtute superabit, et iustus iter iustitiae constantia summa conficiet, et qui puritatem conseruare uelit, maiore in dies robore atque uirtute firmabitur. Hoc autem intelligentiam uestram fugit neque percipitis consilium quo Deus innocentem perculsum et abiectum rursus excitat, ut uirtutis et patientiae monumentum, multis gloriae ornamentis amplificatum, in sublime proponat. 
paciência, engrandecido com muitos ornamentos de glória. Por isso vos aconselho a que reconsidereis e presteis atenção àquilo que digo, pois tão-pouco vejo que algum de vós com justiça possa ser designado como sábio.

Ora, perturba-vos o facto de que toda esta visão de um homem abatido e atormentado, que contemplais com os vossos olhos, está em contradição com esta minha predição, e não compreendeis como é fácil para aquele Senhor, que é tutor e pai dos inocentes, refazer o que caiu e restaurar o que se arruinou e restitui-lo à forma original, acrescentada com riquezas muito maiores. De facto, se a minha esperança estivesse circunscrita pelos limites desta vida e se o mesmo sepulcro que me há-de cobrir pudesse aniquilar, simultaneamente com o corpo, todos os meus pensamentos, decerto que reconheceria que tinha sido muitíssimo louco. É que os meus dias passaram e os meus pensamentos tornaram-se inúteis e o meu espírito, abalado pela grandeza da desgraça, perdeu a sua firmeza. Por outro lado, pensava que à noite se seguiria o dia, e que a luz da aurora dissiparia todas as trevas, e que à tribulação que me atormenta sucederia a felicidade: mas a verdade é que esta persuasão me enganou, pois ainda me encontro mergulhado nas mesmas trevas. Só me resta, por conseguinte, esperar o sepulcro, e nele estabelecer a minha morada e domicílio, e estender o meu leito em lugares horríveis e tenebrosos. E assim chamarei à cova "pai", e darei o nome de "mãe" e "irmã" ao verme que há-de fartar-se com a minha carne.

Por conseguinte, depois de ter vivido e ter sido enterrado e transformado em pó, perguntará alguém: que tempo há-de restar-me para o gozo da minha esperança? Ou quem poderá ver o motivo da expectativa e confiança em que me apoio? [59] Queria, todavia, que soubésseis que, ainda que todos os meus membros se encontrem sepultados no túmulo, mesmo assim a minha esperança não há-de morrer e no próprio pó hei-de estar tranquilo com a expectativa da imortalidade.

Pretendendo Job continuar a desenvolver este ponto de visto, Bildad de Chua interrompeu-o, dizendo:

- Por que é que o vosso discurso vai divagando tão às cegas que não pára em nenhum sítio? Ora, isto acontece porque, agitados pela perturbação do espírito, falais com entendimento precipitado e desenfreado antes de terdes compreendido bem o que quer que outrem tenha afirmado. Ora, convém primeiro perceber com atenção o que se afirmou, e seguidamente, se for caso disso, refutar o que foi exposto. Mas, antes de vos dar a conhecer qual é a minha opinião, parece não vir a despropósito queixar-me da injúria que Job nos inferiu. Com efeito, pergunto: que encontras em nós que com justiça mereça ser desprezado, quer tu investigues a nossa vida e costumes, quer examines os nossos conhecimentos e saber, quer aprecies as nossas riquezas e dignidade? Por que é que ele nos teve na conta de jumentos? Por que é que diante de vós não teve qualquer hesitação em negar-nos o conhecimento de todos os bens, como se estivéssemos privados de entendimento? Por isso pergunto-te, a ti que, atacado pela demência, despedaças e dilaceras o teu espírito, se és tu o único com quem Deus se preocupa? Se foi exclusivamente por causa de ti que criou o mundo, por tal forma que, 
Quocirca uos admoneo ut in uiam redeatis et ad ea quae dico animis attenti sitis, neque enim uideo in uobis qui sapiens appellari merito possit.

Hoc autem uos conturbat, quod omnis haec species hominis euersi et afflicti, quam cernitis oculis, cum hac mea praedictione pugnat, et non percipitis animo quam facile sit illi Domino, qui innocentium tutor et parens est, collapsa reficere et euersa instaurare in pristinamque formam multo maioribus opibus auctam reducere. Si enim spes mea fuisset terminis huius uitae definita et idem sepulcrum, quod me conteget, posset simul cum corpore omnes meas cogitationes obruere, certe faterer me nimis amentem exstitisse. Dies namque mei praeterierunt et cogitationes meae irritae factae sunt animusque meus, magnitudine calamitatis impulsus, de statu suo demigrauit. Opinabar autem, ut dies noctem sequeretur, et lux exoriens tenebras omnes discuteret, et aerumnae, quae me uexat, felicitas succederet: quae quidem opinio me fefellit, iisdem enim adhuc tenebris immersus sum. Reliquum igitur est ut nihil exspectem nisi sepulcrum, in eoque mihi sedem et domicilium constituam, et in locis taetris atque tenebricosis lectum meum insternam. Itaque foueam "patrem" appellabo, et uermi, qui meis carnibus saturandus est, "matris" atque "sororis" nomen imponam.

Postquam igitur uita perfunctus, humo conditus, in puluerem conuersus exstitero, ad quod tempus, inquiet aliquis, fructus spei meae reseruandus est? Aut quis poterit rationem exspectationis et fiduciae, qua nitor, oculis intueri? [59] Hoc tamen uelim sciatis, ut omnia membra mea tumulo sepulta sint, spes tamen mea non interibit et in ipso puluere immortalitatis exspectatione conquiescam.

Cum plura in hanc sententiam Iobus dicere uellet, Bildadus Suhita, orationem illius interrumpens, ait:

- Cur ita tandem oratio uestra temere uagatur, ita ut nullo in loco consistat? Hoc autem ideo accidit quia, perturbatione animorum commoti, priusquam quid ab alio dictum sit exacte percipiatis, praecipiti et effrenata mente disseritis. Oportet autem prius diligenter ea, quae dicta sunt, intelligere, deinde, si commodum fuerit, obiecta refellere. Sed, antequam uobis exponam quis sit animi mei sensus, de iniuria a Iobo nobis illata conqueri non alienum uidetur. Quaero enim: quid est in nobis, uel tu in uitam et mores inquiras, uel studia atque disciplinas examines, uel opes atque dignitatem expendas, quod despici merito possit? Cur pro iumentis ab illo habiti fuimus? Cur in oculis uestris minime ueritus est nos, ut mentis expertes, ab omnium bonorum cognitione remouere? De te igitur quaero qui, furore percitus, animum tuum discerpis atque dilaceras, an tu solus Deo curae sis? An tui solius gratia terrarum orbem condidit, ita ut, si de medio fueris amotus, in uastitatem redigendus sit? An rupes etiam tui gratia sedibus suis conuellentur? Num leges naturae, stabiles atque sempiternae, tui 
se fores arredado, se deva converter num deserto? Se porventura também por causa de ti os rochedos hão-de ser arrancados dos seus lugares? Acaso em atenção a ti se hão-de modificar as leis da natureza, estáveis e sempiternas? Que prova mais evidente poderá existir de uma conatural soberba e desatino?

Por conseguinte, toma atenção ao grande perigo que aparelhas contra ti mesmo com esta manifestação de cólera e impiedade. É que há-de extinguir-se por completo a luz do homem ímpio e do seu fogo não hão-de voltar a brotar centelhas. A claridade, com que a sua tenda se ilumina, será obscurecida pelas trevas e também se apagará o brilho da sua lâmpada. Quando, apoiado na sua própria virtude, se propuser avançar, será impelido para os desfiladeiros e, empurrado pelas suas próprias deliberações, precipitar-se-á do alto; lançar-se-á na rede e será envolvido pelas suas malhas; embaraçará os seus pés no laço e será roubado pelo ladrão; na terra, por onde avança, se oculta a corda que o deve amarrar, e na própria estrada, por onde caminha, se encontra armado o laço, para apanhá-lo. Por todos os lados coisas assustadoras o aterrarão e forçá-lo-ão a andar de modo vacilante e hesitante. A indigência e a fome destruirão as suas forças e a tribulação, estabelecida para perdição da impiedade, há-de bater e ferir o seu flanco. O príncipe do terrível Érebo, que é o flagelo da vida, há-de devorar de repente os seus formosos membros e matar toda a sua descendência. Da sua tenda será arrancada a falsa esperança em que se apoiara o seu lar, a qual há-de entregá-lo, arrebatado pela loucura, nas mãos do funesto rei, cuja função é castigar as culpas com horrendos suplícios e tormentos. $\mathrm{Na}$ sua tenda hão-de estabelecer morada, não os seus descendentes, mas os de outrem, e a sua casa será abrasada com um incêndio de enxofre. As suas raízes, avançando por baixo, secar-se-ão, e os seus ramos, crescendo para o alto, hão-de cair. O nome dele há-de ser completamente esquecido e não será mencionado [60] pela multidão nem celebrado pelo povo. Da luz será lançado nas trevas e há-de ser desterrado das fronteiras da terra. Não engendrará filho nem neto no seu povo para continuação do seu nome nem para as suas riquezas instituirá legítimo herdeiro, que possa sobreviver à ruína de toda a família.

Os vindouros ficarão transidos de espanto com a menção da horrível desgraça, que há-de destruir os ímpios, e também os homens de hoje hão-de espantar-se ao verem persistentemente com os seus olhos a terrível destruição deles. Este fim terão todas as riquezas, recursos e domicílios dos que com a paixão pela iniquidade ultrajam a sociedade humana e com estes suplícios são atormentados todos os que são sacrílegos contra Deus. Por isso importa que se compreenda quão desatinados são os que consideram que é próspera a condição do homem malvado e injusto.

Bildad pronunciou estas palavras, não só com o desígnio de refutar o discurso de Job, em que dizia que a condição dos homens ímpios era largamente provida de riquezas, mas também a fim de amedrontá-lo, como a homem sacrílego e impiedoso, com a ameaça do juízo divino. A tudo isto Job respondeu da maneira seguinte:

- Qual é o vosso fito ao atormentardes o meu espírito e ao afligirdes-me vivamente com essas molestíssimas palavras? Já por dez vezes me atacastes com os mesmos insultos 
gratia mutabuntur? Quod clarius esse poterit insitae superbiae atque temeritatis argumentum?

Respice igitur quantum tibi ipsi periculum ea significatione furoris et impietatis intendas. Lux enim hominis impii prorsus exstinguetur nec ex illius igne scintilla rursus excitabitur. Lumen, quo tabernaculum illius collucet, tenebris obruetur et lucernae etiam illius splendor interibit. Cum, propria uirtute nixus, ingredi statuerit, in angustias compelletur et, proprio consilio impulsus, se ex alto praecipitabit; ipse se in rete induet et illius maculis implicabitur; laqueo pedes suos impediet et a latrone expoliabitur; funis, quo est astringendus, in terra qua ille incedit occulitur, et in ipsa uia, in qua ambulat, est exstructa decipula, ut ea illaqueatus capiatur. Iniecti undique terrores illum exanimabunt et pedibus titubare atque uacillare compellent. Illius uires egestas et fames conficiet illiusque latera contundet et debilitabit afflictio, ad impietatis exitium constituta. Membra illius speciosa princeps immanis Erebi, qui uitae pestis est, subito uorabit omnemque propaginem illius absumet. E tabernaculo illius fallax spes, qua domus illius erat innixa, praecidetur, quae illum, furore praecipitem, in pestiferi regis manus tradet, cuius officium est horrendis suppliciis et cruciatibus maleficia uindicare. In illius tabernaculo non illius posteri, sed alieni domicilium collocabunt, aedesque illius sulfuris incendio conflagrabunt. Radices illius subter emissae exarescent, rami illius in altum elati praecidentur. Euelletur ex omni memoria illius nomen nec in ore $[\mathbf{6 0}]$ multitudinis et populi celebritate uersabitur. E luce eiicietur in tenebras et ex orbis terrarum finibus exturbabitur. Non filium, non nepotem ad nominis posteritatem in populo suo propagabit neque legitimum heredem opibus suis instituet, qui familiae totius exitio superstes esse possit.

Posteri mentione horribilis illius cladis, quae uastabit impios, obstupescent, et praesentes etiam, cum dirum illorum exitium oculis acerrime contemplati fuerint, exterrebuntur. Hunc casum subeunt omnes opes et facultates et domicilia eorum qui societatem generis humani iniquitatis studio uiolant et his suppliciis excruciantur omnes qui in Deum scelerati sunt. Ex quo intelligi oportet quam amentes sint omnes qui statum hominis malefici et iniusti florentem existimant.

Haec quidem Bildadus, non eo solum consilio dixit ut Iobi orationem refutaret, qua dicebat impiorum hominum statum opibus circumfluere, sed etiam ut illum, quasi scelestum et impium, diuini iudicii denuntiatione perterreret. Ad quae Iobus ita respondit:

- Ad quem tandem finem animum meum cruciabitis et uerbis istis molestissimis me uehementer affligetis? Easdem iam contumelias mihi decies intulistis, nec 
e, apesar disso, não tendes vergonha dessa desumanidade com que hostilmente me tratais e porfiais comigo de modo assaz agressivo e avesso, como se estivésseis a tratar com um desconhecido e inimigo do culto da religião. Pergunto-vos: por que motivo envidais tantos esforços para arguir-me de actos criminosos? Acaso isso tem a ver com a vossa salvação? Certamente que não. É que, se delinqui no cumprimento das minhas obrigações, o crime que cometi há-de pesar sobre mim, e não sobre as vossas almas. Então quê? Porventura cuidais que vos há-de ser motivo de glória se por vós for refutado e com indigno ultraje por vós vexado? Nem sequer isso é uma façanha a tal ponto ilustre que dela vos devais ufanar. Com efeito, não deve ser motivo de um grande louvor atacar um homem desesperado e atribulado, fazer cair o abalado por uma grande desgraça e empurrar quem está a cair.

E a verdade é que os males que me oprimem não são pequenos, mas os maiores e intoleráveis. É que quem me derrotou e abateu não foram forças humanas, mas foi o próprio Deus quem me aniquilou com um desastre terrível e, como numa aparatosa caçada, me atormentou com dardos lançados de todos os lados. Se me queixo da violência com que sou atacado e apelo para a Sua protecção, não me responde; se peço justiça e grito pelos foros da piedade e equidade divinas, não acorre. Fechou o meu caminho, para que eu não possa caminhar, e cobriu de trevas todos os pensamentos da minha vida, a tal ponto que não posso pensar nem decidir o que me cumpre fazer em tão grande calamidade. É que nem gozo daquela luz com que anteriormente era iluminado nem possuo aquelas riquezas que antes possuía em abundância, pois Deus despiu-me de todos os ornamentos e privou-me da ajuda activa do Seu poder. Despojou-me da glória; arrancou-me a coroa da minha cabeça; tirou em toda a volta todos os alicerces da minha firmeza, para que eu caísse, e, como a uma árvore arrancada, cortou-me por completo a esperança de voltar a germinar e de propagar a descendência. A Sua ira inflama-se violentamente contra mim e [61] arremete contra a minha vida e condição como contra um inimigo. Os Seus soldados vieram em formatura de combate, construíram a estrada por onde se dirigiram até mim e mantiveram a minha tenda cercada com o seu acampamento.

Por outro lado, apartou para longe de mim os meus irmãos, a quem com toda a justiça eu deveria pedir ajuda no meio de tamanhos perigos, e desviou os meus amigos da minha intimidade e convívio, e afastou-os do cuidado com a minha salvação. E deste modo fui abandonado, perdi os parentes, fui deixado pelos amigos e não houve ninguém que conservasse alguma lembrança quer do parentesco, quer da amizade, quer dos favores. E até os meus escravos e criadas me têm na conta de estranho e não sentem mais respeito pela minha autoridade do que se eu lhes fosse alheio e estranho. Chamei o meu criado e não the ordenei o que, de acordo com o meu direito, ele deveria fazer, mas com os meus rogos pedi-lhe que me servisse: ele, todavia, desdenhou prestar atenção aos meus rogos. A minha mulher enoja-se e evita o meu bafo, como repugnante e corrupto; sou constrangido a dirigir-me como suplicante àqueles a quem, com amor paternal, cuidava como filhos. Até os homens infamados e totalmente envilecidos pela desonra me desprezam e insultam-me e de mim escarnecem sempre que me levanto. Os amigos, para quem não guardava segredos e com quem partilhava todas as minhas decisões, 
interim pudet uos istius inhumanitatis, qua animis alienissimis mecum agitis et quasi cum homine uobis ignoto et a cultu religionis abhorrente, satis acerbe et importune contenditis. Quid est, quaeso, quod tantos conatus ad me sceleris arguendum comparetis? Numquid in eo uestra salus agitur? Non profecto. Si enim in officio deliqui, crimen a me commissum in me, et non in animis uestris, inhaerebit. Quid igitur? Num gloriosum uobis fore iudicatis, si opera uestra fuero redargutus et indigna contumelia uexatus? Ne id quidem adeo clarum facinus est ut in eo gloriari debeatis. Non enim amplissimae laudi tribuendum est in hominem perditum et afflictum irruere et insigni calamitate percussum labefactare et praecipitantem impellere.

Nec enim mediocribus malis oppressus sum, sed maximis et intolerandis. Nam me non opes humanae perculerunt et abiecerunt, sed Deus ipse dirissima calamitate peruertit et, quasi apparata uenatione, telis undique coniectis afflixit. Si uim mihi inferri conqueror et fidem illius imploro, responsum minime reddit; si iudicium postulo et iura diuinae pietatis et aequitatis inclamo, non accurrit. Viam meam saepsit, ne ingredi possim, omnesque uitae meae rationes tenebris obscurauit, adeo ut, quid mihi faciendum in tanta clade sit, mente et consilio explicare nequeam. Nec enim luce illa fruor qua antea illustrabar nec opes illas habeo quibus antea circumfluebat, Deus enim me nudauit omnibus ornamentis numinisque sui praesenti ope destituit. Gloria me spoliauit; coronam e capite meo detraxit; omnia mei status firmamenta circumquaque reuellit, ut labarem et, tamquam arbori euulsae, mihi spem rursus germinandi atque subolis propagandae omnino praecidit. Ira illius in me acriter exarsit et, tamquam [61] in hostem, in meam uitam et statum impetum fecit. Milites illius, acie instructa, uenerunt et uiam qua ad me contenderent egregie munierunt castrisque suis meum tabernaculum obsessum tenuerunt.

Fratres autem meos, a quibus erat auxilium in tantis periculis optimo iure flagitandum, a me longe segregauit, et amicos meos a mea coniunctione et familiaritate disiunxit, et a studio meae salutis auertit. Itaque fui desertus et perditus a cognatis, destitutus ab amicis nemoque fuit qui ullam uel propinquitatis, uel amicitiae, uel gratiae memoriam conseruaret. Quin etiam uernae mei et ancillae meae loco peregrini me numerant neque magis imperium meum uerentur quam si alienus et ignotus illis essem. Vocaui seruum meum neque, pro iure meo, quid illi faciendum esset praescripsi, sed precibus ab eo contendi ut operam mihi daret: qui tamen preces meas audire contempsit. Vxor spiritum meum ut taetrum et contaminatum aspernatur et respuit; illis, quibus, ut filiis, amore patrio consulebam, supplex esse cogor. Homines etiam flagitiis infames et uilissimi me despiciunt et, quotiens assurgo, me contumeliis et ludibriis insectantur. Amici a quibus nihil secreti habebam et cum quibus omnia mea consilia communicabam et quos non mediocriter amabam, animis immutati, me odio persequuntur. Ossa 
e a quem sobremaneira amava, perseguem-me com ódio. Os meus ossos colaram-se simultaneamente à pele e à carne, quase consumida pela magreza, e os meus dentes mal são recobertos pelos lábios assaz adelgaçados. Por consequência, batido por Deus, desamparado pelos homens, despojado de todos os bens, envolvido por inúmeros males, mofinamente atribulado pela dor, de tal maneira sou atormentado que não mereço ser humilhado pelo vitupério e o insulto, mas sim que me aliviem com a compaixão e a misericórdia.

Compadecei-vos de mim, meus amigos, de mim a quem vistes próspero com riquezas, e a quem agora contemplais abatido e derrubado, pois fui ferido por um golpe nada ligeiro, mas fortíssimo. É que quem me feriu não foi força humana, mas as mãos do próprio Deus. Porventura é humano, sendo vós homens e sujeitos às mesmas enfermidades com que agora sou atormentado, não mostrar qualquer compaixão por um homem amigo, atribulado por tão terríveis calamidades? Por que é que, ferindo-me com toda a crueldade, contra mim vos empenhais em imitar a ira de Deus? Por que é que os vossos olhos já não se saciaram com este indigno suplício do meu corpo? Mas retorquis que ao homem mofino e maltratado não é lícito ultrajar a majestade de Deus com injúrias e bolsar esta peçonha de azedume, que não só atenta contra a piedade de Deus, como também provoca grave escândalo entre os homens. Oxalá estas palavras, que vos parecem cheias de crime, sejam registadas por escrito e consignadas nos livros, para eterna lembrança dos homens. Oxalá com estilete de ferro se gravem em lâminas de chumbo ou se esculpam na pedra, para que possa permanecer para sempre uma prova da minha piedade e inocência.

Mas se me acusais de renunciar a toda a esperança de salvação e de me lastimar de tal maneira como se não confiasse em que hei-de emergir deste turbilhão de males que agora me submerge, falsamente me estais a acusar de um delito que não se ajusta à minha fé. É que tenho por certo, sabido e seguro, [62] e desta opinião não pode arrancar-me nenhuma perturbação do espírito, que o fiador da minha salvação, assim como goza de vida sempiterna, assim está dotado de lealdade sempiterna e é impossível que despreze aqueles que se consagraram ao Seu nome e zelo, e que permita que sejam destruídos pela morte eterna. Por conseguinte, embora na Terra e na presente condição das coisas humanas Ele nunca me restitua as riquezas perdidas, todavia nem por isso a minha esperança há-de enfraquecer e desvanecer-se, mas conservará a sua firmeza em todas as situações difíceis. É que mais me cumpre pensar acerca daquela vida sempiterna, que constitui o alvo dos desejos dos homens piedosos, do que acerca desta, mortal e exígua.

Por isso, confio que o próprio Deus há-de olhar e velar não apenas pelo meu espírito, mas igualmente pelo meu corpo. Com efeito, no fim dos tempos aplicará a Sua força sobre o pó em que os nossos corpos se hão-de desfazer e oferecer-lhes-á e renovar-lhes-á a vida, e deste modo, por Sua vontade, sucederá que, embora a minha pele seja destruída pelos vermes e o meu corpo, totalmente despedaçado, seja por eles devorado, todavia a minha esperança de modo algum pode enfraquecer e desvanecer-se, pois eu hei-de ver claramente a Deus com esta minha carne novamente chamada à vida. Eu mesmo 
mea cuti simul et carnibus, macie paene consumptis, adhaeserunt, dentesque mei labiis uehementer extenuatis uix obteguntur. Igitur, a Deo percussus, ab hominibus derelictus, bonis omnibus spoliatus, malis innumerabilibus implicatus, dolore miserabiliter afflictus ita iactor ut non uituperatione et conuicio deprimendus, sed misericordia et benignitate subleuandus sim.

Miseremini mei, amici mei, quem florentem opibus aspexistis, quem nunc euersum et abiectum uidetis, non enim leui plaga, sed grauissima sauciatus sum. Non enim humana uis, sed Dei ipsius manus mihi uulnus inflixit. Num humanum est, cum homines sitis eisdemque morbis, quibus nunc uexor, obnoxii, nullam humanitatem homini amico, tam diris cladibus afflicto, impertire? Cur in me, omni crudelitate lacerando, Dei iram imitari contenditis? Cur non sunt iam oculi uestri hoc indigno corporis mei supplicio satiati? Sed illud dicitis, non licere homini misero et saucio conuiciis Dei numen laedere idque uirus acerbitatis euomere, quod non solum pietatem in Deum uiolet, sed etiam hominibus offensionem grauem afferat. Vtinam haec uerba, quae uobis sceleris plena uidentur, litteris mandentur atque monumentis consignentur ad memoriam hominum sempiternam. Vtinam stilo ferreo incidantur in plumbi lamina uel insculpantur in silice, ut exstare perpetuo possit meae pietatis et innocentiae testimonium.

Sin autem id mihi crimini datis, quod omnem spem salutis abiiciam et ita lamenter quasi minime confidam me ex his malorum fluctibus quibus nunc obruor emersurum, illius me criminis insimulatis quod in fidem meam non conuenit. Hoc enim certum, cognitum et constitutum [62] habeo et ab hac sententia non possum ulla animi perturbatione depelli: uindicem nempe salutis meae, ut uita sempiterna fruitur, ita fide sempiterna praeditum esse neque fieri posse ut eos, qui se ad illius nomen et studium contulere, despiciat aut morte sempiterna deleri patiatur. Licet igitur in terris et in hoc rerum humanarum statu is me numquam in opes amissas restituat, non ob id tamen spes mea extenuabitur et euanescet, sed in omni rerum asperitate constantiam suam retinebit. Magis enim est mihi de illa sempiterna uita, ad quam piorum hominum uota referuntur, quam de hac mortali et exigua cogitandum.

Confido igitur futurum ut Deus ipse non animo tantum meo, sed corpori etiam consulat atque prospiciat. Vltimis enim temporibus uim suam in puluerem, in quem corpora nostra dilabentur, intendet eorumque uitam instaurabit atque renouabit, itaque numine illius fiet ut, licet pellis mea a uermibus absumatur et hoc corpus totum ab illis concisum deuoretur, spes tamen mea extenuari et euanescere nullo modo possit, ipse namque hac mea carne, in uitam reuocata, Deum clare cernam. Ego, inquam, ipse illum his meis oculis, non alienis, aspiciam, nec illius assimulatam speciem, sed naturam et claritatem uidebo. Huc 
hei-de contemplá-Lo com estes meus olhos, não com outros, e verei, não a Sua simulada imagem, mas a Sua natureza e brilho. Ora, a isto visa a totalidade dos meus desejos; a este fim se encaminham todos os desvelos da minha vida; este pensamento do mais íntimo do meu espírito fortifica-me em todas as adversidades.

Por conseguinte, se nem cometi indignidades, nem manchei a religião, nem atraiçoei a lealdade jurada, por que é que atormentais um homem inocente esmagado sob o peso da desventura? Por que é que tramais a minha perdição e ruína? Por que é que por vezes não vos ocorre dizer: "Por que nos lembramos de perseguir aquele cujo espírito e opinião se apoiam nas raízes da própria verdade?" - Por isso, arreceai-vos da espada, pois as próprias iniquidades e injustiças que se praticam contra os inocentes são afiadíssimas espadas para trespassar os culpados. É que Deus não deixa por castigar e impune nenhum crime e delito desta espécie. Por conseguinte, temei e arrependei-vos, pois o Senhor estabeleceu um julgamento rigoroso para aqueles que violam as leis da piedade e da humanidade.

Tendo Job concluído com estas palavras, Sofar de Naamá, ofendido com o motivo pelo qual Job dissera que ele e os companheiros estavam destituídos de sabedoria, empenhou-se em salvaguardar a sua dignidade e em dar uma prova de sabedoria mediante a qual pudesse perceber-se que Job cometera uma injustiça, e dirigiu os seus dardos principalmente na direcção daquela parte do discurso na qual Job afirmara que a sorte dos ímpios era muitas vezes próspera. Ora, não é totalmente sem razão que tanto ele como os seus companheiros insistem com mais frequência neste mesmo ponto, porquanto pensavam que nele assentava por inteiro o esteio em que Job apoiava a sua opinião, o qual, uma vez minado e derrubado, seria forçoso que toda a sua causa se desmoronasse de raiz. Com efeito, se fosse certo que os maus não abundam em bens nem - algo que se segue logicamente - os bons são oprimidos pelos males, só os ruins e perversos poderiam padecer os males.

[63] Por conseguinte, depois disto firmemente estabelecido, pensavam que era possível demonstrarem que Job era sacrílego e injusto. Por isso disse:

- É indubitável que por vezes a situação dos ímpios parece sobremaneira próspera e que algumas vezes os homens impuros detêm o poder na Terra. Por isso no passado reflexões muito desagradáveis me afastavam do entendimento correcto. Mas, ao pensar com mais profundidade e atenção no que me cumpria julgar acerca desta questão, de súbito ocorreram-me as razões com que refutar o argumento com que objectaste. Ora, gostaria que recebesses como bom e justo aquilo que vou dizer, uma vez que eu também escutei pacientemente a tua exposição, que unia a si um grande desdouro meu, conquanto não me perturba mesmo nada o teres-me negado sabedoria, pois não pendo da opinião externa dos outros, mas sou fortificado pela íntima compreensão e avaliação crítica do entendimento. Pelo que, se possuo alguma sabedoria, isso manifestar-se-á não tanto por palavras quanto pelos próprios factos. Por outro lado, ainda que me negues o conhecimento das outras coisas, certamente que não poderás arrancar-me aquele sentimento que, depois do nascimento, foi gravado nas almas de todos, ou seja, que a prosperidade dos homens ímpios termina em breve e que toda a alegria do que alcança 
autem summa uotorum meorum pertinet; in hunc finem omnia meae uitae studia diriguntur; haec mentis intimae cogitatio me in omni tempestate confirmat.

Si igitur neque flagitium commisi, neque sacra contaminaui, neque fidem datam prodidi, cur hominem innocentem, oppressum ruinis, affligitis? Cur de mea pernicie et interitu coniuratis? Cur non eam aliquando cogitationem suscipis ut dicatis: "Quid nobis uenit in mentem illum persequi, cuius mens et sententia radicibus ipsius ueritatis innititur?" - Gladium igitur extimescite, ipsae namque iniquitates et iniuriae, quae in innocentes suscipiuntur, acutissimi gladii sunt qui nocentes contrucidant. Deus enim nullum eiusmodi scelus et maleficium inultum et impunitum dimittet. Pauete igitur atque resipiscite, seuerum enim iudicium est a Domino in eos, qui pietatis et humanitatis iura uiolant, constitutum.

Haec cum Iobus perorasset, Sopharius Nahamathita, offensus ea ratione qua Iobus illum et socios sapientiae expertes esse dixerat, in eo pugnauit ut dignitatem suam tueretur idque sapientiae documentum daret ex quo intelligi posset illum iniuria notatum fuisse. Ad illam autem sententiam potissimum orationis tela dirigit qua Iobus asseruerat impiorum fortunas saepenumero ualde florentes esse. Non autem omnino absque ratione tam ille quam socii hunc eumdem locum saepius urgent, in eo enim putabant omnino firmamentum, quo Iobi sententia nitebatur, esse positum, quo labefacto et conuulso, suspicabantur omnem illius causam funditus euertendam. Nam, si constaret malos non affluere bonis neque, quod est consequens, bonos opprimi malis, efficeretur neminem posse in malis uersari qui non esset nequam et improbus.

[63] Hoc igitur firme constituto, opinabantur fieri posse ut Iobum esse nefarium et iniustum conuincerent. Inquit igitur:

- Verum quidem est impiorum res ualde secundas aliquando uideri et ab hominibus impuris interdum dominatum in terris occupari. Idcirco me cogitationes olim molestissimae a recta mente deducebant. Sed mihi, quid de hac quaestione iudicandum esset, diligentius et acutius consideranti, occurrit subito ratio qua obiectum argumentum diluerem. Quod autem dicturus sum uelim boni et aequi consulas, siquidem ego etiam disciplinam tuam, cum ignominia mea coniunctam, patienter audiui, quamquam in eo quod detrahis mihi sapientiam non sane multum conturbor, non enim extrinsecus ex aliorum opinione pendeo, sed intima mentis intelligentia atque iudicio confirmor. Quod, si in me est aliquid sapientiae, id non tam uerbis quam rebus ipsis apparebit. Vt autem aliarum rerum scientiam mihi detrahas, illum certe sensum mihi extorquere non ${ }^{1}$ poteris qui est post homines

${ }^{1}$ non] om. editio Romana 
as honrarias através da simulação da piedade se termina num ápice com um final terrível e funesto. Se o seu prestígio for tão considerável e elevado que a voz pública e a nomeada o exaltem aos céus; se o seu poder se encontrar acrescentado com tão grandes recursos que pareça tocar as mais elevadas nuvens, todavia sucumbirá de repente e perecerá para sempre.

Ora, todos os que reflectirem acerca daquela queda e ruína, perguntarão: "Onde está aquele que em tamanha abundância possuía toda a espécie de riquezas? Quão subitamente lhe foi arrancada a vida, destruído o poder, tirado o prestígio, obliterada a lembrança do nome, a tal ponto que nem sequer se pode ver e notar o rasto dele na terra?" Voará como um sonho e não permanecerá em nenhum lugar onde possa ser achado; desvanecer-se-á como uma visão nocturna; os olhos que o tinham visto não só não mais o verão, mas nem sequer reconhecerão o local em que ele tinha falado. Os filhos dele, que eram o terror dos indigentes, pedirão aos mesmos indigentes e serão obrigados a restituir as riquezas injustamente subtraídas. Pelo que, se outro mal não o atormentasse, este certamente é tão grande que na vida é impossível existir um mais pesado: ou seja, o facto de as infâmias da mocidade perversamente vivida ocuparem e estarem profundamente arreigadas no seu espírito, e estarem ligadas aos seus ossos e o seguirem depois de receber as honras fúnebres e ser enterrado, por forma a inquietá-lo com terrores sempiternos.

Ora, embora pareça recrear-se com as más acções e não sejam visíveis nem se manifestem as penas dos crimes que oprimem a alma, não obstante a peçonha que se dissimula na sua língua, atormenta-o, enfraquece-o e não o deixa respirar. E mesmo assim é complacente com o mal que lhe torna a vida tão amarga e não quer repeli-lo, mas, como se fosse um manjar muito saboroso, degusta-o no céu da boca. Até aquilo que é agradável por natureza lhe será funesto e pernicioso. O pão transformar-se-á nas suas entranhas e, como se fosse [64] veneno de cobras, destruirá as suas entranhas com uma doença terrível e abominável, porquanto se serve de todos os bens para a sua própria perdição e ruína. Com cobiça insaciável devorará as riquezas alheias e há-de vomitá-las de novo, pois Deus tirá-las-á do seu ventre e arrancará e espalhará tudo quanto ele tinha entesoirado. Beberá o veneno das cobras e morrerá ferido pela língua da víbora.

A doçura transportada pelos rios não correrá para alegria sua nem terá cópia e abundância de manteiga; e não sentirá nenhum gosto de verdadeira suavidade nem será invadido por aquela doçura e deleitação de que gozam as almas dos homens piedosos. $\mathrm{E}$ assim, quando os justos forem abundantemente providos de todos os bens e cumulados de uma alegria extraordinária, o ímpio há-de arrastar a mais indigente e penosa das vidas. Contra a sua vontade há-de restituir tudo que procurara obter com o máximo esforço e não receberá disso qualquer proveito, mas, como mercadoria que recebeu de alguém como caução até um prazo fixo, será obrigado a devolvê-lo, de tal maneira que nunca com a sua abundância pode sentir contentamento nem encher-se de uma alegria genuína, porquanto atormentou os necessitados e pobres, abandonou os que lhe imploravam ajuda, assolou e arruinou as casas e não se preocupou em reconstrui-las depois de destruídas. Por outro 
natos in omnium animis impressus: nempe, res laetas impiorum hominum breui terminari omnemque illius iucunditatem, qui simulatione pietatis ad honores obrepit, uno momento temporis exitu diro atque luctuoso concludi. Si illius dignitas tam ampla et excelsa fuerit ut hominum fama atque celebritate in caelum efferatur; si illius imperium tantis opibus exaggeratum exstiterit ut altissimas nubes attingere uideatur: repente tamen concidet atque perpetuo peribit.

Omnes autem qui illius casum et ruinam animis secum reputauerint, inquient: "Vbinam est ille qui tantis opibus in omni genere redundabat? Quam subito illi uita erepta fuit, imperium deletum, decus exstinctum, memoria nominis oblitterata, usque adeo ut ne uestigium quidem illius in terris notari et animaduerti possit?" Vt somnium auolabit nec ullo in loco, ubi possit inueniri, consistet; ut nocturnum uisum euanescet; oculus, qui eum uiderat, non modo eum amplius non uidebit, sed ne sedem quidem, in qua is erat locutus, agnoscet. Liberi eius, qui erant egentibus formidini, ipsis egentibus supplicabunt et opes, per iniuriam auersas, reddere compellentur. Quod, si non aliud malum eum uexaret, id certe tantum est ut in uita grauius esse non possit: quod adulescentiae turpiter actae flagitia illius animo penitus insident et inhaerent, ossibus illius implicata sunt, eum, funere elatum atque humo tumulatum, insequuntur, ut terroribus sempiternis exagitent.

Quamuis autem maleficiis oblectari uideatur et scelerum poenae, quibus animus afficitur, non exstent et emineant, nihilominus tamen uirus, quod lingua illius occulitur, eum lacerat et conficit et respirare non sinit. Et tamen malo, quod eius uitam tam acerbam reddit, indulget nec illud depellere uult, sed, quasi cibum iucundissimum, medio palato complectitur. Ea etiam quae natura iucunda sunt erunt illi exitiosa et pestifera. Panis in uisceribus illius immutabitur et, perinde atque si foret [64] uenenum aspidum, illius intestina taetra et detestabili lue conficiet, omnibus enim bonis ad suam ipsius pestem atque perniciem abutetur. Alienas opes inexplebili cupiditate uorabit easque rursus euomet, Deus enim eas ex uentre illius extrahet et omnia, quae in thesaurum ab illo congesta fuerant, eripiet atque dissipabit. Venenum aspidum hauriet uiperaeque lingua percussus interibit.

Non mella riuis diducta ad illius iucunditatem emanabunt neque butyri affluentia et copia redundabit; nullum gustum uerae suauitatis habebit nec erit illa dulcedine atque uoluptate perfusus qua piorum animi fruuntur. Itaque, cum iusti bonorum omnium ubertate completi et incredibili gaudio cumulati fuerint, impius in summa egestate et acerbitate uersabitur. Reddet inuitus omnia quae summo labore quaesierat et nec ex illis fructum ullum percipiet, sed, quasi merces ad certum tempum fide ab aliquo sumptas, ea restituere cogetur, ita ut illorum copia numquam exsultare et solido gaudio efferri queat, inopes enim et egentes afflixit, opem illius implorantes deseruit, domos uexauit atque diripuit nec euersas reficere curauit. Vt autem multis lautus et copiosus et opulentus uideretur, numquam sibi ipsi uisus fuit nec in partis opibus ullo modo conquieuit, 
lado, embora a muitos parecesse opulento, rico e abastado, nunca a si mesmo the pareceu que o era nem de forma alguma se contentou com as riquezas obtidas, nem intimamente se julgou rico. É que a sua infinita cobiça nunca pôde saciar-se. Por conseguinte, lutou sempre com a penúria e a indigência, viveu na mais extrema mendicidade e quanto mais prosperamente tudo the sucedeu, tanto se abrasou numa sede mais ardente e consumiu em vão todo o seu desvelo em ajuntar riqueza, pois nem com a ajuda desta poderá libertar-se deste flagelo e afastar os perigos que ameaçam a vida. Não ficarão nenhuns restos de alimento com que alimentar os descendentes, pois os bens do homem impuro não poderão ser aumentados. Também quando possui abundantes riquezas e está repleto de tudo quanto vivamente desejava, mesmo assim aflige-se e é inquietado por múltiplos cuidados e preocupações e consome-se com a tristeza que nasce de todos os lados.

Por conseguinte, é oprimido de todas as partes por tão grandes males que, mesmo que não sobreviesse nenhum outro suplício, mesmo assim expiaria os seus crimes com penas assaz pesadas. Mas não só será atormentado pela ansiedade do espírito e pelo suplício do crime, mas também sofrerá outras torturas assaz terríveis. É que, quando estiver cumulado de todas as comodidades da vida por tal forma que pareça que alcançou aquele supremo poderio que a sua vontade e esperança acalentaram, Deus há-de provocar de repente contra ele a chama e o incêndio da Sua ira e, lançando a tempestade e procela, destruirá a sua condição e todas as suas riquezas. Por isso, se o ímpio fugir da mão armada de ferro, será trespassado por setas violentamente despedidas do arco de bronze e, se se livrar da primeira demonstração hostil de Deus, cairá em desgraças muito piores, que nenhuma precaução e vigilância serão capazes de evitar. É que a desembainhada espada do Senhor luzirá para destrui-lo e embeber-se-á nas suas entranhas e destruirá o homem perverso e aflito com o horror da morte iminente.

[65] Ao mesmo tempo, todas as trevas, ocultas nas entranhas da terra, que com o seu crime ajuntara para si, hão-de lançar-se sobre ele, e o fogo, não atiçado pelos foles (pois é sempiterno), há-de destruí-lo, e todos os que permanecerem nas moradas dele hão-de ser atacados por incessantes males. É que os herdeiros dos homens perversos, juntamente com o nome e a imitação do crime, apossam-se da herança da funesta desgraça, e o exemplo da raça impura e sacrílega é ao cabo aniquilado. Por conseguinte, o homem sacrílego não poderá durante muito tempo enganar os ignorantes com a simulação da honestidade, por forma a que o tenham na conta de santo, apesar de ser culpado de muitos crimes, pois o Céu mostrará aos olhos e vista de todos a sua iniquidade e a Terra preparará contra ele uma guerra cheia de sanha. É que sempre que, por decisão divina, toda a natureza conspira para a ruína de alguém, fica à mostra o crime, que anteriormente estava oculto, do homem infame e impuro, e na ruína dele são condenados pelo julgamento de todos os crimes que perpetrara. E não só perecerá ele juntamente com a sua descendência, mas também as suas riquezas hão-de desaparecer e desvanecer-se à semelhança das águas, no momento em que o Senhor manifestar o Seu ódio contra os inimigos da religião. É esta a herança que os ímpios devem receber e é este o património que com rectíssimo juízo estabeleceu para os que com indigno ultraje desafiam a Sua majestade. 
nec animus ipse se diuitem iudicauit. Numquam enim illius infinita cupiditas expleri potuit. Semper igitur inopia et indigentia laborauit, in summa mendicitate uersatus est et, quo affluentius illi omnia prouenerunt, eo siti ardentiore flagrauit frustraque omne studium sum in coaceruanda pecunia consumpsit, nec enim poterit, illius ope, hac peste redimi impendentiaque uitae pericula propulsare. Nullae ciborum reliquiae, quibus alantur posteri, remanebunt, bona siquidem hominis impuri amplificari non poterunt. Etiam cum affluit opibus et omnibus rebus, quas uehementer appetebat, expletus est, angitur tamen et multiplici cura et sollicitudine conturbatur et illata omni ex parte maestitia contabescit.

Tantis igitur malis undique premitur ut, si nullum aliud supplicium accederet, satis tamen acerbas scelerum poenas exsolueret. Sed non solum animi angore et fraudis cruciatu torquebitur, uerum alia ualde dira supplicia subibit. Nam, cum omnibus uitae commodis ita cumulatus exstiterit ut uideatur ad illam summam potentiam quam animo atque spe sibi finxerat peruenisse, Deus repente in illum irae suae flammam et incendium concitabit illiusque statum et opes uniuersas, demissa tempestate atque procella, peruertet. Quod, si impius armatam ferro manum effugerit, sagittas arcu aeneo uiolenter emissas excipiet et, si primam Dei comminationem euaserit, in multo grauiores plagas incidet, quas nulla uigilantia et sedulitate depellet. Strictus enim Domini gladius in illius exitium micabit et in uisceribus adhaerebit hominemque perditum et afflictum appropinquantis mortis horrore [65] conficiet.

Omnes simul tenebrae, terrae penetralibus abstrusae, quas ipse sibi scelere suo condiderat, in eum irruent, et ignis, non follibus incitatus (est enim sempiternus), illum populabitur, et omnes, qui relicti in sedibus illius exstiterint, assiduis malis agitabuntur. Hominum enim perditorum heredes, simul cum nomine et scelerum imitatione, funestae cladis hereditatem adeunt, et exemplum tandem nationis impurae atque scelestae perimitur. Non igitur diu poterit homo nefarius, simulatione probitatis, imperitis errorem obiicere ut, cum sit multis sceleribus inquinatus, sanctus tamen existimetur, caelum enim illius iniquitatem in omnium oculis et aspectu constituet et terra contra eum bellum omni odio imbutum comparabit. Quotiens enim uniuersa natura diuino iudicio ad alicuius exitium conspirat, totiens hominis flagitiosi et impuri scelus, quod antea latebat, aperitur et in illius uastitate crimina, quibus se astrinxerat, omnium iudicio conuicta tenentur. Neque solum ipse cum posteritate sua peribit, uerum et illius opes ad similitudinem aquarum emigrabunt atque diffluent, eo tempore quo Dominus odium suum in religionis hostes exprompserit. Haec est hereditas impiis hominibus adeunda et hoc est patrimonium a Deo iis, qui numen illius indigno conuicio prouocant, rectissimo iudicio constitutum. 
Assim falou Sofar, cujas palavras, tal como acima se disse acerca de Bildad, não só persistiram em provar, opondo-se a Job, que todos os ímpios eram desgraçados e mofinos, como se ele tivesse afirmado o contrário, mas também em mostrar-lhe que deveria ser contado no número dos homens ímpios e perversos. É que, à semelhança destes, como eles mesmos pensavam, fora derribado da sua posição, as suas riquezas tinham desaparecido, a sua saúde tinha sido atacada, a sua descendência aniquilada e, mediante toda a espécie de infortúnios, sofrera o castigo dos ímpios; com isto esforçavamse por demonstrar que ele, embora tivesse alcançado fama de justo e piedoso, todavia nunca fora deveras justo, mas um simulador da justiça. Ora, a estes argumentos Job respondeu do modo seguinte:

- Suplico-vos e rogo-vos que me escuteis atentamente e não vos pedirei que neste momento me deis outro alívio. E não vos sintais incomodados se proferir alguma palavra que não julgueis digna dos vossos ouvidos. Mas suportai isto com espírito imparcial e depois de eu acabar de expor a minha opinião, então fareis, de acordo com a vossa vontade, aquilo que vos parecer justo, e podereis então mais comodamente atacar o meu discurso, se assim vos aprouver. Portanto, para começar a partir deste ponto, desejaria saber qual é o motivo pelo qual vos causou tão grande escândalo o meu incessante pesar? Porventura estou-me a queixar excessivamente por os homens me infligirem alguma ferida grave? Ou não é antes porque fui golpeado e atribulado pelo próprio Deus? Por conseguinte, se me golpearam não forças humanas, mas divinas, é de toda a evidência que a dor com que sou atormentado é fortíssima. Portanto, que razão há para admiração se, ao ser ferido pela mão de Deus, o meu espírito é atormentado de modo muitíssimo doloroso? Por isso, se lanço gemidos, se me queixo da minha desgraça, se lastimo o meu infortúnio [66] e ruína, todos os meus pensamentos encaminham-se, não aos homens, mas a Deus, que violentamente me atribula e a quem peço remédio: é que imploro a clemência d' Ele, e não a ajuda dos homens, e entretanto não posso deixar de estar mergulhado numa pungentíssima dor.

De facto, ao pensar na majestade de Deus, ao meditar sobre a Sua equidade e justiça, ao ponderar a grandeza da clemência com que sobressai de modo maravilhoso, ao não ter consciência de nenhum crime de sacrilégio e impiedade, ao não conseguir explicar a razão e deliberação que seguiu para me atacar com tantos golpes: que é o que devo fazer? Qual é o vosso conselho? Que é que julgaríeis dever fazer se estivésseis neste lugar? Posso porventura esmagar todos os sentidos? Posso acaso desviar o pensamento de tantos males que me cercam por todos os lados? É evidente que não. Por conseguinte, resta que a Deus, que é o único de quem devo esperar remédio, dirija preces com lágrimas e também com queixumes, que resultam, não de qualquer impiedade, mas da grandeza da dor. Portanto, não há motivo para considerardes como um grande delito os meus gemidos e palavras chorosas dirigidas a Deus, mas antes para condenardes a vossa desumanidade, ao proibirdes-me a possibilidade de me queixar da minha desgraça e de por todas as vias pedir ajuda a Deus.

Mas repetidas vezes dizeis nos vossos discursos que não foi sem razão que Deus me feriu, mas que fui despojado de todos os bens e dilacerado pelas feridas devido às infâmias que pratiquei na Sua presença. - Nunca pensareis alguma vez em como é grande o crime 
Hactenus quidem Sopharius, cuius quidem oratio, ut de Bildado superius dictum est, non solum in eo perstitit ut, contra Iobum, probaret omnes impios esse miseros et calamitosos, quasi ille contrarium asseruisset, sed etiam ut illum ostenderet esse hominibus impiis atque perditis annumerandum. Similiter enim, ut ipsi rebantur, fuerat status illius euersus, opes comminutae, salus afflicta, genus exstinctum et, in omni genere calamitatis, impiorum poenam sustinuerat; ex quo effici contendebant illum, quamuis iustitiae atque pietatis nomine celebratus, numquam tamen se uere iustum, sed iustitiae simulatorem, praebuisse. Ad haec autem Iobus ita respondit:

- Vos oro et obtestor ut me attente audiatis nec aliud a uobis mihi in praesentia solacium dari postulabo. Neque uos conturbet si uocem aliquam misero quam minime dignam auribus uestris arbitremini. Sed id aequis animis ferte, postquam uero meam sententiam exposuero, tum, pro arbitratu uestro, quidquid uobis rectum uidebitur, facietis, et poteritis tunc commodius orationem meam, si uobis ita libuerit, insectari. Vt igitur hinc exordiar, uelim scire quid est in causa cur tam grauem uobis offensionem maeror meus assiduus attulerit? Num, quod homines mihi graue aliquod uulnus inflixerint, nimium lamentor? An potius quod ab ipso Deo percussus et afflictus sim? Si igitur non opes humanae, sed diuinae me perculerunt, constat certe dolorem quo torqueor esse grauissimum. Quid igitur mirum est si, cum sim Dei manu sauciatus, animus meus acerbissime conflictatur? Si igitur gemitus edo, si cladem meam lamentor, si meum casum et [66] ruinam deploro, omnes meae cogitationes ad Deum, qui me grauiter afflixit, a quo medicinam postulo, non ad homines, referuntur: illius enim clementiam, non hominum opem, imploro, et interim non possum non in magna doloris acerbitate uersari.

Nam, cum Dei maiestatem animo considerem, cum illius aequitatem et iustitiam mecum ipse reputem, cum clementiae magnitudinem, qua mirabiliter excellit, mente recogitem, cum mihi sceleris nullius impii atque nefarii conscius sim, cum rationem et consilium, quod secutus est ut me tantis plagis afficeret, explicare non possim: quid est quod facere debeam? Quod est uestrum consilium? Quid, si hoc loco essetis, uobis faciendum putaretis? Possumne sensus omnes opprimere? Possumne cogitationem a tantis malis, quae me undique circumstant, abducere? Non profecto. Restat igitur ut ad Deum, a quo solo remedium exspectandum est, preces cum lacrimis et querellis etiam, quas non impietas ulla, sed magnitudo doloris exprimit, adhibeam. Non igitur est cur eiulatus meos uocesque lugubres ad Deum fusas in magno crimine ponatis, sed potius ut inhumanitatem uestram damnetis, cum mihi, calamitatis meae deplorandae et remedii modis omnibus a Deo flagitandi, potestatem adimitis.

Sed illud identidem in oratione uestra ponitis, me non immerito fuisse a Deo sauciatum, sed propter flagitia in conspectu illius admissa bonis omnibus 
de acusar de crime e delito um homem inocente? Por isso, olhai para mim e pasmai-vos ao pensar nesse desatino e atrevimento e refreai essa licença para dizer mal. Com efeito, até eu me sinto perturbado com a lembrança de um crime tão grande e, invadido pelo horror, sinto todos os meus membros tremer. É que quem diz mal dos homens probos, está de uma forma impudentíssima a dizer mal, não dos homens, mas de Deus, sob cuja guarda eles se encontram. Mas, quão amiúde repetis aquele único argumento de que não é próprio da equidade divina fazer cair sobre os homens probos os castigos devidos aos ímprobos! É que dizeis que Deus sempre olha benignamente pelos bons e castiga e arruina os maus, sucedendo por isso que os maus são atribulados pelos males e os bons abundam em bens. Daqui concluís que a pessoa que é oprimida por males se aviltou com toda a sorte de infâmias e é culpada de não poucos crimes.

Por conseguinte, pergunto: porventura os homens ímpios foram afastados de todas as comodidades desta vida? Então por que é que os ímpios vivem? Por que é que chegam à velhice? Por que é que são fortificados com riquezas e poderio? Por que é que, muitas vezes com eles ainda vivos, os seus filhos prosperam e, à vista deles, gozam de abundantes riquezas e dignidade? Amiúde a casa deles, livre de qualquer receio, desfruta de paz e quietação e entretanto nenhum castigo divino, que se possa ver, os persegue. E os touros deles não são postos a procriar sem fruto nem as suas vacas são infecundas nem abortam fetos informes. As crianças que eles geraram correm como rebanhos de ovelhas e os seus filhos alegram-se brincando. Ao som do tambor [67] e da cítara dançam e celebram os dias de festa e acompanham o baile com a música das liras. Passam os dias satisfeitos com este género de bens e sem longas moléstias partem desta vida e são enterrados.

E assim os ímpios não são sempre oprimidos por todos os males, contrariamente ao que dizeis, pois é grande o número dos que abundam destas comodidades que referi, embora sejam detestáveis devido a toda a espécie de abominações e desprezem a majestade de Deus com impudente atrevimento e intolerável monstruosidade. É que regulam a vida de tal maneira que parecem com toda a clareza dizer isto e afastar Deus para muitíssimo longe de si com palavras como estas:

"Aparta-Te de nós, pois com os ouvidos e o espírito desprezamos os ensinamentos da Tua lei e achamos que não devemos preocupar-nos com o que ordenaste e prescreveste, mas com o que a nossa ingénita cobiça nos aconselha a fazer. Pois quem é o Senhor para que toleremos o Seu domínio? Ou, que utilidade tiraremos da Sua religião, se estendermos para Ele as mãos? Porventura está pouco comprovado pela experiência que não é pela religião e pela equidade, mas pelo desprezo da divindade e pela injustiça, que as riquezas se aumentam e acrescentam? Acaso não vemos ordinariamente acontecer que os que praticam com muita santidade a justiça estão sujeitos às injustiças e os seus bens todos os dias mais diminuem, e só são muito opulentos aqueles que avaliam as actividades da vida, não em função da justiça, mas da utilidade? Porventura é pouco evidente que à tontice e ao apoucamento se deu o nome de religiosidade para que pareça que, aquilo que os homens não vêem porque os cega a estupidez ou não ousam porque os impede a fraqueza, se abstiveram de o fazer por respeito pelo dever? 
exclusum et uulneribus concisum exstitisse. - Nonne tandem aliquando reputabitis quantum crimen sit homini innocenti scelus et crimen obiicere? Respicite igitur in me et cogitatione istius audaciae et temeritatis obstupescite istamque maledicendi licentiam refrenate. Nam et ipse tanti sceleris recordatione perturbor et, horrore perfusus, totis artubus contremisco. Qui enim probis hominibus maledicit, non hominibus, sed Deo, in cuius tutela sunt, impudentissime maledicit. At, quam crebro illud unum argumentum repetitis, non esse aequitatis diuinae poenas improbis debitas probis hominibus irrogare! Deum namque dicitis semper bonis benigne consulere et malos profligare atque perdere, ideo autem fieri ut mali malis uexati sint et boni multis bonis abundent. Vnde concluditis eum, qui malis premitur, esse omni flagitio corruptum et non paucis criminibus alligatum.

Quaero igitur: num homines impii ex omnibus huius uitae commodis expulsi sunt? Cur igitur impii uiuunt? Cur ad senectutem perueniunt? Cur opibus et potentia roborantur? Cur, ipsis saepe uiuentibus, eorum liberi florentes sunt et in oculis eorum opibus et dignitate circumfluunt? Illorum saepe domus, omni metu uacua, pace et otio perfruitur nec interim ulla poena diuina, quae uideri possit, illis insequitur. Nec illorum tauri sine fructu ad suscipiendam subolem admittuntur neque uaccae sunt infecundae nec, abortione perculsae, fetum informem eiiciunt. Infantes illorum satu procreati ut ouium greges incedunt eorumque liberi ludis exsultant. Ad tympanum [67] atque citharam choros ducunt festosque dies agitant et saltationem ad fidium sonitum modulantur. Eiusmodi bonis expleti dies transigunt neque diuturnis morbis intabescunt, sed tempestiue atque sine longa molestia e uita discedunt et sepulcro conduntur.

Itaque non semper, ut dicitis, malis omnibus opprimuntur impii, multi enim sunt qui abundant his commodis quae commemoraui, quamuis sint omni diritate taeterrimi sanctissimumque Dei numen, cum proiecta audacia et immanitate minime toleranda, despiciant. Ita enim uitam instituunt ut hoc plane dicere uideantur et huiusmodi uerbis Deum a se longissime segregare:

"Abscede a nobis, omnem enim legis tuae disciplinam auribus et animis aspernamur neque quid a te praescriptum et imperatum sit, sed quod nos insita cupiditas facere admonet, curandum ducimus. Quis enim Dominus est, ut illius dominatum patiamur? Aut, quam utilitatem, si manus ad illum tetenderimus, ex ea religione capiemus? Parumne rebus exploratum est non religione et aequitate, sed numinis contemptu et iniustitia, opes augeri et amplificari? An id non plerumque accidere uidemus ut, qui nimis sancte iustitiam colunt, sint iniuriis obnoxii resque illorum quotidie magis imminuatur, illique tantum opulentissimi sint qui officia uitae non iure, sed utilitate, metiuntur? An id minime perspicuum est stultitiae et timiditati fuisse religionis nomen impositum ut, quod homines uel stultitia caecati non uident uel imbecillitate impediti non audent, id officii religione praetermisisse uideantur? 
"Por conseguinte, de bom grado lhes concedemos este vão nome de justiça, que esvazia as suas casas e enche as nossas. Suportamos muitíssimo bem que a religião os retenha, para que, obrigados por ela, não se oponham a nós e assim mais facilmente façamos presa nos seus bens, através da força ou do embuste. Por conseguinte, perseguimos com justo ódio o direito divino, que tanto prejuízo nos teria acarretado; com razão abominamos o zelo da religião, que tanto poderia obstar aos nossos desígnios; e com a máxima vontade abandonamos o caminho que o Senhor mostra, como inteiramente desprovido de utilidade e prazer, para caminharmos livremente pelos nossos caminhos, que nos oferecem uma grande esperança de ganho e de gozo."

Este é o pensar dos homens ímpios, esta a opinião e parecer dos que muitas vezes vemos possuírem abundantes riquezas. Todavia a sua felicidade não está colocada nas suas mãos, mas amiúde é destruída por muitos acidentes horríveis e repentinos. Por conseguinte, abomino os seus conselhos, pois ressumam crime e loucura. De facto, quão prestes se apaga a luz da lanterna com que resplandecem os ímpios? É que de improviso cairá sobre eles a perdição e a ruína, e a irritada majestade divina preparar-lhes-á uma herança e um património de dor imensa e sempiterna. Serão dispersos como palhas fortemente impelidas pelo vento e espalhados à semelhança de espigas arrebatadas num enorme redemoinho; Deus tirará aos filhos do ímpio - que, como ordinariamente acontece, imitam o crime do pai - as riquezas e poderio paternos, e [68] punirá severamente o seu crime, e o homem perverso só compreenderá a grande loucura em que esteve mergulhado quando for castigado pelo seu crime e desumanidade. Divisará com os seus olhos a ruína que com o seu crime aprontou para si mesmo e será constrangido a beber a taça da ira divina.

Depois da morte dele, na sua casa que pôde ver-se restar de tão grandes riquezas, de tantos refinamentos da vida, de tantas seduções do prazer, de tamanho esplendor de dignidade? Enfim, de que modo, no meio da carreira da felicidade, ao tempo em que parecia abundar de todos os recursos e ornamentos de uma vida muitíssimo próspera, sucumbe de um golpe repentino e é arrancado de todas as comodidades da vida pela inesperada arremetida da morte no melhor e mais firme da sua situação? É que tão-pouco jamais a morte pode vir na altura própria para aqueles cujo espírito está dedicado às cousas terrenas, das quais sucede serem arrancados a qualquer momento, e, como se morressem brutalmente a meio da carreira da vida, choram a vida perdida e queixam-se da violência da cruel morte.

Pois quê? Porventura existirá alguém tão desprovido de entendimento que queira instruir Deus na ciência das coisas, ao ver que Ele de modo tão extraordinário julga os homens colocados em posições elevadas? Todavia o processo que Deus segue em praticar a justiça não é o mesmo em todas as punições dos pecados. De facto, ora mostra rapidez no castigo, ora adia e difere, consoante o pedem os diferentes motivos e conveniências, a nós desconhecidos. Por isso daí resulta que um deixa a vida, gozando de perfeita saúde, vivendo tranquilamente na maior abundância de bens, para que os filhos possam alimentar-se dos recursos e riquezas deste morto, e deles encher-se como de abundante leite e cevar-se dos copiosos despojos como 
"Libenter igitur illis hoc inane nomen iustitiae concedimus, quod eorum domos exhaurit et nostras explet. Illos religione distineri non aegerrime patimur, ut, ea constricti, nobis minime repugnent et ita facilius ex illorum bonis, per uim aut fraudem, praedas asportemus. Ius igitur diuinum, quod tantum nobis detrimentum attulisset, odio iusto persequimur; religionis studium, quod tantum nostris rationibus obstare potuisset, merito detestamur; et uiam quam Dominus monstrat, ut totius utilitatis atque uoluptatis expertem, summa uoluntate deserimus, ut uiis nostris, quae magnam sane nobis spem emolumenti et iucunditatis ostendunt, libere ingrediamur."

Haec est impiorum hominum cogitatio, haec eorum, quos saepe multis opibus affluere cernimus, mens et sententia. Eorum tamen felicitas non est in eorum manu posita, sed multis saepe casibus horribilibus atque repentinis inuertitur. Eorum igitur consilia, cum sint sceleris et amentiae plena, detestor. Quam subito enim lucernae lumen, quo impii splendent, exstinguitur? Irruet enim in eos de improuiso pestis atque pernicies, infensumque Dei numen illis hereditatem et patrimonium doloris immensi atque sempiterni constituet. Vt paleae, uento uehementer agitatae, dispellentur et, tamquam aristae turbine maximo correptae, dissipabuntur; Deus ab impii filiis - qui patris, ut plerumque fit, scelus imitantur patris opes atque potentiam remouebit, in illiusque [68] scelus seuere uindicabit, et, tum demum cum perditus homo poenas sceleris et immanitatis exsoluerit, intelliget quanta amentia oppressus exstiterit. Cernet oculis suis pestem quam sibi ipse scelere suo comparauit et diuini furoris poculum haurire compelletur.

Quid ex tantis uitae deliciis, ex tantis uoluptatis illecebris, ex tanto dignitatis splendore reliquum post illius mortem in illius domo conspici potuit? Quomodo tandem, in medio felicitatis cursu, eo tempore quo maxime uidebatur omnibus florentissimae uitae praesidiis et ornamentis redundare, ictu repentino concidit et, in ipso status flore atque robore, ab omnibus uitae commodis intempestiuae mortis impetu diuulsus est? Nec enim umquam illorum mors matura esse potest, quorum animi rebus terrenis addicti sunt, a quibus quocumque tempore eos auelli contingat, quasi in medio uitae cursu uiolenter excisi sint, amissam uitam lugent et de ui importuna mortis conqueruntur.

Quid ergo? An erit quisquam tam sine mente qui Deum rerum scientia instruere uelit, cum uideat ab illo tam singulari ratione iudicium contra homines in alto gradu locatos exerceri? Attamen ratio quam Deus in iudicio constituendo sequitur non eadem est in omni peccatorum animaduersione. Nunc enim celeritatem in uindicando suscipit, nunc differt atque procrastinat, prout uariae rationes et opportunitates, minime compertae nobis, efflagitant. Inde adeo fit ut alius, integra ualetudine, in summa rerum affluentia et tranquillitate uitam degens, e uita discedat, cuius etiam defuncti facultatibus atque diuitiis nutriri queant liberi et, tamquam lactis ubertate, compleri et opimis spoliis, quasi medullis 
de medulas de ossos. Outro, pelo seu lado, ao longo de toda a vida de tal maneira é atribulado pela calamidade e pobreza de todas as coisas que nunca goza de porção alguma de felicidade. Todavia ambos de modo idêntico ao morrerem jazem no pó e são cobertos por igual vestimenta de vermes.

E, assim, isso que dizeis acerca da ruína dos ímpios é verdadeiro e não discrepa muito do que exponho, mas não serve para refutar-me. É que sei a que alvo visam as vossas palavras e o que tendes em mente e como endereçais todos os vossos esforços a derrubarme. Com efeito, quando discorreis acerca da morte e miséria do homem desgraçado, afirmais o seguinte: "Onde está agora a casa daquele homem que pelas suas riquezas, honra e poder facilmente ocupava o primeiro lugar? Onde está agora a localização daquele vastíssimo lugar em que estiveram colocadas as tendas dos ímpios?" - Ora, isto que dizeis é proferido contra mim como se eu tivesse caído da minha situação devido à impiedade, e não compreendeis que, depois do final desta vida, há-de haver um julgamento em que deverão ser pesadas as acções de cada um e os ímpios castigados com a merecida pena. Portanto, assim como nesta vida uma condição próspera não pode ser indício de genuína probidade, da mesma maneira tão-pouco uma condição atribulada e abatida encerra em si alguma sólida prova de impiedade e perfídia.

Porventura esta doutrina é demasiado abstrusa e difícil de compreender? Acaso [69] não está antes assaz vulgarizada e gravada no senso comum de quase todos os homens? Porventura, se quiserdes perguntar aos viajantes com que sinais distinguem os justos dos injustos, acaso apontarão as prosperidades ou adversidades como sinal distintivo da justiça ou da injustiça? Certamente que não, mas indicarão uma vida santa ou impiedosamente vivida. Se perguntardes de que maneira Deus permite que os maus abundem em bens, unanimemente hão-de asseverar que o suplício dos ímpios está reservado para aquele dia de infelicidade sempiterna, em que aquele santíssimo Juiz há-de lançar contra os homens sacrílegos todas as forças da Sua ira. Por conseguinte, se não são punidos nesta vida, é para depois serem atormentados muito mais rigorosamente por toda a eternidade. Com efeito, que outro ser poderá fazer a acusação de um crime oculto e fixar diante dos olhos e entendimento de todos uma existência infamemente transcorrida nas trevas e pagar a cada um os seus merecimentos, em proporção com o que cada um fez, senão somente Aquele cuja inteligência não pode falhar, cujo juízo não pode enganar-se e cujo rigor não pode ser dobrado?

$\mathrm{Na}$ presente condição da realidade não se vê muito claramente como Deus é hostil e contrário aos maus, devido ao facto de que não só muitas vezes possuem em abundância todas as coisas apropriadas para a subsistência, o vestuário e o luxo, mas também na morte são honrados com um enterro imponente. Portanto, aquele que devido ao seu monstruoso crime deve padecer suplícios eternos, não é enterrado num túmulo corrente nem numa terra pobre, mas é sepultado pelos seus num sepulcro sumptuosamente edificado, que ele mesmo enquanto vivo construíra com o máximo desvelo e cuidado num solo fértil e fecundo, para aí todos os anos, nos elevados montões de produções da terra, a sua memória poder ser celebrada pelas turbas de homens. E deste modo muitos hão-de frequentar com aprazimento aqueles terrenos, arrancados às torrentes e 
ossium, saginari. Alius rursus ita per omnem uitam cum omnium rerum inopia et acerbitate conflictatus est, ut numquam ulla iucunditatis parte frueretur. Vterque tamen simili ratione e uita excedens in puluere decumbit et simili uermium integumento contegitur.

Itaque ea quae de impiorum exitio dicitis uere dicta sunt et ab iis, quae disputo, non ualde discrepantia, minime tamen ad me arguendum cohaerentia. Noui enim quo uestra tendat oratio et quid animo designetis et quomodo omnes conatus uestros ad me deiiciendum comparetis. Sic enim dicitis, cum de miseri hominis interitu et calamitate disseritis: "Vbi nunc est domus hominis illius, qui erat opibus et honore et imperio facile princeps? Vbi nunc est illius amplissimi loci designatio qua fuerunt tabernacula impiorum collocata?" - Haec autem a uobis dicta in me ita iaciuntur quasi ipse de statu meo propter impietatem conciderim, et non intelligitis fore, post huius uitae finem, iudicium, quo sunt tandem facta cuiuslibet examinanda et meritae poenae impiis persoluendae. Vt igitur in hac uita florens status nullum certum afferre potest ingenuae probitatis indicium, ita nec euersus et afflictus continet ullum firmum impietatis atque fraudis argumentum.

Num haec doctrina est abstrusa nimis atque recondita? An potius ualde [69] peruulgata omniumque ferme hominum communibus sensibus infixa? An, si de uiatoribus quaerere uoletis quibus signis iustos a iustis internoscant, num res secundas aut aduersas proferent ob iustitiae aut iniustiae discrimen? Non certe, sed uitae sancte aut impie actae rationem. Si quaesieritis quomodo permittit Deus ut improbi bonis affluant, summa consensione decernent impiorum supplicium in illum diem calamitatis sempiternae reseruari, quo sanctissimus ille iudex omnes irae suae uires in sceleratos homines profundet. Si igitur in hac uita minime puniuntur, idcirco fit ut tunc multo acerbius aeuo sempiterno crucientur. Quis enim alius poterit occultum scelus arguere et uitam in tenebris turpiter actam in omnium oculis atque mente defigere et merita unicuique, pro rerum a quolibet gestarum ratione, persoluere, nisi ille tantum cuius nec mens falli neque iudicium eludi neque seueritas inflecti potest?

Quam inimicus et infensus sit Deus improbis in hoc rerum statu non ita clare cernitur, eo quod saepenumero non solum abundant rebus omnibus ad uictum et cultum et elegantiam accommodatis, uerum etiam in morte funere amplissimo cohonestantur. Is igitur cui, propter scelus immane, sempiterna supplicia subeunda sunt, non in uulgari tumulo nec in macro solo sepelitur, sed in sepulcrum magnifice aedificatum, quod ipse summo studio et uigilantia in fertili et opima tellure uiuens exstruxerat, a suis infertur, ubi in exstructis frugum aceruis possit illius memoria quotannis hominum frequentia celebrari. Itaque multi glebas illas, e torrente auulsas et in aggerem congestas, in quibus ille humanatus est, cum iucunditate frequentabunt, hominisque impuri nomen, quasi 
terraplanados, nos quais ele foi enterrado, e exaltarão com louvores o nome de um homem impuro, como se se tratasse de um varão de ilustre e excelente memória. Depois, com o seu exemplo de crime e iniquidade, precipitará no mesmo castigo todos os homens que puderem imitar a sua tirania. E muito antes de ele ter começado a viver, inúmeros homens, seduzidos pela esperança de um enorme proveito e seguindo o mesmo caminho, experimentaram o mesmo fim. É que, ao darem-se conta de que muitos destes que tinham aumentado as riquezas através da violência e engano não sofreram nesta vida a punição pelas acções sacrílegas, com maior audácia e impudência perpetraram atentados capitais para ocuparem o poder tirânico.

Por conseguinte, não é sempre verdade a vossa afirmação de que o poder de Deus se manifesta no castigo dos crimes, porquanto muitos delitos merecedores de severo castigo estão reservados para aquele juízo final. Portanto, por que quereis consolar-me com palavras completamente inúteis? Por que é que, ao esforçardes-vos por diminuir-me a aflição em que me encontro, aumentais muito mais a minha dor? É que nas vossas respostas sempre se encerra algo que fere mais dolorosamente o meu espírito. Por isso rogo-vos que definitivamente ponhais de lado a opinião que perfilhastes a meu respeito, como se eu fosse um homem perverso, e que abandoneis a causa do juízo divino, a qual não precisa do vosso patrocínio, e que penseis incessantemente, não já nos exemplos quotidianos, que por vezes costumam acarretar os maiores erros, mas na vida eterna, [70] na qual não existe nenhuma variação e inconstância.

Com esta argumentação de Job os seus amigos não mudaram de opinião. Por conseguinte, Elifaz atacou-o com as seguintes palavras:

- Acaso Deus terá algum proveito com os homens? De facto, ainda que olhes com grande saber pelas tuas coisas, que lucro ao cabo lhe advirá a Ele da tua prudência? Certamente que nenhum. Portanto, que grande desejo da tua justiça o pode dominar a Ele, como se dela houvesse de receber um extraordinário prazer? Ou que proveito obterá para Si da inteireza dos teus sentimentos? Mas concedamos que assim seja! De ti nada pode esperar-se que seja inteiramente bom. Mas Ele talvez vele para que não Lhe atribuas o mal, e por isso cuida zelosamente de afastar-te do crime encetado, não decerto para que Lhe sejas útil, mas para não te prejudicares em nada. Que dizes? Porventura porque se arreceia das tuas forças, te acusa e chama a juízo, por forma a atar-te com as leis, a fim de que não possas ser-Lhe molesto? De forma alguma. Pois quê? Se nem teve em vista o Seu proveito, nem se arreceou de mal para Si, de que outro motivo podes com razão suspeitar para Ele te ter atacado com uma tamanha desgraça, que não seja o de benignamente velar por ti e, através dos golpes desferidos, desviar o teu espírito do crime?

Por conseguinte, porque usas de subterfúgios? Por que é que te lamentas por não conhecer as causas dessa desgraça? Por que é que em vão te esforças por justificar-te? Porventura não resulta assaz claro da violência do desastre que te prostrou que tu foste esmagado por tão grandes ruínas devido a inúmeras infâmias e a injustiças sem conto? Com efeito, arruinaste sem qualquer motivo os teus irmãos arrebatando-lhes os penhores, de modo muitíssimo desumano arrancaste aos necessitados as roupas com que se protegiam 
uiri magni et excellentis memoriam, laudibus ornabunt. Exemplo deinde sceleris et iniquitatis omnes homines, qui potuerint tyrannidem illius imitari, in eamdem poenam detrudet. Et multo ante quam ille esset in uitam ingressus, innumerabiles homines, spe amplissimae utilitatis illecti et eamdem sectam consecuti, eumdem finem subierunt. Nam, cum animaduertissent multos eorum, qui per uim et fraudem opes auxissent, minime poenas in hac uita facinoris scelesti pependisse, maiore quadam audacia et impudentia, ut tyrannidem occuparent, facinora capitalia moliri sunt.

Non igitur semper uerum est quod asseritis, Dei numen sceleribus ulciscendis apparere, multa namque facinora seuerissime uindicanda ad illum extremum iudicium reseruata sunt. Quid igitur me uerbis uanissimis consolari uultis? Cur, dum mihi maerorem, in quo sum, minuere studetis, multo magis dolorem amplificatis? Semper enim in responsionibus uestris residet aliquid quod grauius animum meum exulceret. Vos igitur oro ut opinionem quam de me, quasi de homine facinoroso, recepistis, tandem aliquando deponatis et causam diuini iudicii, quae uestro patrocinio minime indiget, omittatis, neque iam de quotidianis exemplis, quae maximos errores interdum afferre solent, sed de sempiterna uita, in [70] qua nulla uarietas et inconstantia uersatur, assidue cogitetis.

Hac Iobi ratione amici illius minime de sententia destiterunt. Heliphasius igitur in illum huiusmodi uerbis inuectus est:

- Num Deus a uiris aliquam utilitatem capiet? Vt enim rebus tuis sapienter admodum consulas, quod tandem ex prudentia tua emolumentum ad illum perueniet? Nullum sane. Quae igitur tanta illum cupiditas iustitiae tuae tenere potest, quasi sit ex illa uoluptatem eximiam percepturus? Aut quem fructum sibi ex integritate studiorum tuorum comparabit? Sed esto. Nihil est omnino boni quod a te exspectare possit. Sed, ne illi malum inferas, fortasse cauet, et ideo sedulo curat ut te a scelere instituto deterreat, non quidem ut illi prosis, sed ne aliqua ex parte noceas. Quid ais? Idcircone, quod uires tuas metuat, tibi crimen intendit et te in iudicium uocat, ut legibus astringat, ne illi molestus esse possis? Minime. Quid ergo? Si neque suum commodum exspectauit, neque sibi malum metuit, quanam alia de causa suspicari merito potes, illum tibi tantum calamitatis inuexisse, nisi ut tibi benigne consuleret impositisque plagis animum tuum a scelere reuocaret?

Quid igitur tergiuersaris? Cur causas cladis istius tibi minime notas esse lamentaris? Cur te purgare frustra contendis? Annon satis constat ex ui calamitatis quae te peruertit, te propter flagitia quam plurima et iniurias innumerabiles fuisse tantis ruinis oppressum? Fratres namque tuos absque ulla causa, pignoribus ablatis, euertisti, egentibus uestimenta, quibus frigus depellebant, immanissime detraxisti, aquae poculum sitienti minime porrexisti neque panem ei, qui 
do frio, não ofereceste um copo de água a quem tinha sede nem deste pão a quem padecia fome. Guindaste-te às mais elevadas dignidades, não por virtude e merecimento, mas mediante a força e poderio. É que as mais das vezes acontece que o domínio da Terra é concedido pelo desatino da multidão, não aos homens bons e estimáveis, mas àqueles que têm muito poder, e que quem principalmente detém a soberania são os que se avantajam aos demais, não em verdadeira dignidade, mas em riquezas.

Por conseguinte, o facto de teres sido colocado numa elevada posição de dignidade e poder pelo voto unânime de todos os teus concidadãos, deveu-se, não à tua virtude, mas ao teu poderio. Com efeito, no que tange à virtude, qual o exemplo que ofereceste que nos pudesse dar a conhecer o esplendor da mais verdadeira honestidade? Com efeito, mandaste embora as viúvas de mãos vazias e pobres e maltrataste as débeis forças dos órfãos. Por isso foste enredado por laços colocados a todo o teu redor e um terror súbito apoderou-se da tua condição. Acaso, olhando em volta, não te dás conta do lugar em que te encontras? Das infelicidades que te cercam? Das horríveis tribulações em que caíste? $\mathrm{Na}$ verdade, medonhas trevas espalham-se sobre as tuas coisas, uma inundação de águas envolveu-te e engoliu-te e, mesmo assim, falas de tal modo pomposo, como se tivesses sido atingido por um mal não muito grande. Não hesitas em entrar em disputa com o próprio Deus. Acaso não vês que a grandeza de Deus ultrapassa em imensidade as alturas do céu? Põe os olhos nos astros, peço-te, e apercebe-te do alto lugar que ocupam na natureza celeste: os quais, todavia, na sua totalidade, se encontram sujeitos ao domínio e poderio do Senhor.

Então, porque é que não te arreceias da Sua majestade divina, tão fortemente hostil aos maus? Mas [71] se calhar o que te encoraja a teres tamanha confiança é pensares que Deus não pode dar-se conta dos crimes que perpetraste nas trevas. É que falas do modo seguinte contigo mesmo:

"Acaso pode Deus passar com os olhos por todas as coisas? Acaso pode também ver as coisas que se ocultam sob as trevas e sombras? As nuvens estendem-se debaixo dos Seus olhos impedindo-O de ver o que se faz na Terra e encontra-se ocupado com actividades tais que não Lhe permitem contemplar os negócios humanos. É que o globo celeste gira em torno do eixo e uma tarefa tão grande como esta não Lhe deixa qualquer espaço para, de ânimo livre, se poder ocupar com aquilo que os homens fazem."

Que crime é este? Que infâmia é esta? Acaso, enganados por essa opinião, não se arruinaram todos os que, precipitando-se no desatino, violaram todas as leis, divinas e humanas, e perpetraram muitos crimes capitais, com grande prejuízo da espécie humana? É que quase todos os que praticam crimes medonhos e impuros, praticam-nos porque pensam que Deus não os vê nem deles se apercebe. Por conseguinte, apraz-te entrar no mesmo caminho que seguiram os homens mais ruins, ligados às coisas terrenas e totalmente esquecidos das celestiais? E entretanto não pensas no quão vãos e inúteis foram os seus esforços, quão falazes as suas esperanças, quão fundados no vazio os seus desvelos? Com efeito, muito antes do tempo são enfraquecidos pela disforme velhice e o seu alicerce desaparece de súbito, à semelhança de uma torrente que rapidamente se espalha. O atrevimento destes foi tão grande que lançaram injúrias intoleráveis contra o 
fame uexabatur, apposuisti. Non uirtute et merito tuo, sed uiribus et potentia, ad honores summos euectus es. Hoc enim fieri plerumque solet ut terrarum imperium, non ad bonos et spectatos homines, sed ad illos qui multum possunt, multitudinis amentia deferatur, et ii potissimum regnum possideant qui reliquis non uera dignitate, sed opibus, antecellunt.

Quod igitur omnium ciuium tuorum consensu in alto gradu dignitate et imperii locatus es, id non fuit uirtuti tuae, sed potentiae tributum. Nam, quod ad uirtutem attinet, quod specimen illius dedisti ex quo uerissimae honestatis splendorem possemus cognoscere? Viduas enim uacuas et inanes dimisisti, tenues pupillorum uires afflixisti. Idcirco laqueis circumquaque propositis irretitus es et in statum tuum repentinus terror inuasit. Annon circumspicis quo in loco sis? Quae te miseriae circumuallent? In quam horribiles aerumnas incideris? Taetrae namque tenebrae rebus tuis offusae sunt, eluuio aquarum te depressit et obruit, et tamen, quasi mediocre te malum perculerit, ita magnifice loqueris. Cum ipso Deo certamen inire non dubitas. Nonne uides Deum altitudinis immensitate caeli fastigia superare? Respice, quaeso, sidera, quam altum locum in caelesti natura teneant: quae tamen omnia ipsius Domini ui et potentia coercentur.

Quid igitur illius numen, improbis grauiter infensum, non extimescis? Sed [71] ea fortasse confidentia tibi animos affert, quod opineris ea crimina, quae in tenebris commisisti, a Deo animaduerti non posse. Sic enim ipse tecum loqueris:

"An Deus potest oculis omnia perlustrare? An ea etiam, quae tenebris et caligine demersa latent, inspicere? Nubes oculis illius obtenduntur ne quae geruntur in terris aspiciat et iis negotiis implicatus est ut res humanas intueri non possit. Globum enim caelestem circum axem uersat nec huius tanti muneris ullam uacationem habet ut, animo libero, quae ab hominibus fiunt curare possit."

Haecine scelera? Haecine flagitia? Annon, eadem ista opinione decepti, corruerunt omnes qui, praecipites amentia, iura omnia diuina et humana uiolarunt multaque facinora capitalia, cum magna generis humani pernicie, susceperunt? Omnes enim ferme qui taetra et impura facinora moliuntur, ideo ea moliuntur quod se a Deo minime uideri et animaduerti arbitrentur. Placetne igitur tibi eamdem uiam ingredi quam nequissimi homines, rebus terrenis addicti et caelestium prorsus immemores, inierunt? Nec interim recolis animo quam irriti et inanes fuerint illorum conatus, quam fallaces spes, quam plena uanitatis studia? Nam, multo ante tempus deformi senio confecti sunt et illorum fundamentum, instar torrentis celeriter effusi, subito defluxit. Quorum tanta audacia fuit ut in praepotentem Dominum contumelias minime ferendas intorserint. Dicebant enim 
Senhor todo-poderoso. Com efeito, diziam a Deus: "Aparta-Te de nós, pois os homens aplicados a adquirir riquezas, que proveito puderam receber de Deus?" E mesmo assim o próprio Deus, a quem desafiavam contra si com o crime da ingratidão, enchera as suas casas de riquezas, visto que todos os bens se encerram na Sua imensa benignidade.

Por isso, abomino o crime deles, execro a sua loucura e detesto as suas decisões. É que, ainda que durante algum tempo prosperem em riquezas, todavia em breve serão derribados da sua posição e atormentados pelos merecidos castigos. Os justos verão e exultarão de alegria e regozijar-se-ão com as desgraças dos homens ímpios. Algo que nos sucederá bem ao invés, a nós que odiamos o crime e nos estribamos no amor à justiça e pomos a nossa esperança, não nas riquezas passageiras, mas na bondade de Deus. É que a defesa e sustentáculo da nossa salvação não poderão ser destruídos, mas o fogo há-de consumir até os restos dos ímpios. Pelo que, levado pela amizade, peço-te e rogo-te que olhes por ti, veles pela tua salvação, rejeites os conselhos dos ruins, não desprezes a amizade dos bons, reprime a soberba, abate-te a ti mesmo o mais que puderes e estriba todas as tuas defesas, não na tua virtude, mas na misericórdia e bondade de Deus.

Por conseguinte, com palavras suplicantes pede-Lhe paz e perdão, ajusta todas as actividades da vida à Sua lei e deste modo não apenas Lhe pedirás perdão, mas serás abundantemente cumulado de todos os bens. Recebe d' Ele os ensinamentos da santíssima lei, guarda no teu espírito as Suas palavras e que elas sempre se mantenham gravadas e impressas na tua alma. É que, se com todo o teu espírito te voltares para Deus, graças ao Seu poder e bondade recuperarás as riquezas e dignidade anteriores e deixarás uma descendência próspera e afastarás da tua tenda toda a mancha de injustiça. [72] Na verdade, sob a Sua direcção, hás-de desenterrar extraordinárias riquezas escondidas debaixo da terra, e da rocha fendida hão-de jorrar para ti, como águas perenes, veios do ouro mais puro. Serás então rodeado pela defesa de Deus omnipotente e por todos os lados provido com as riquezas por Ele ajuntadas para salvaguarda da tua salvação.

E, assim, não só possuirás em abundância os bens divinos, como também estarás protegido pela guarda e força divinas. Então também abundarás dos prazeres sempiternos e deleitar-te-ás mui amorosamente com o próprio Senhor e não olharás transido de receio para a terra, mas confiadamente levantarás o teu olhar para a visão de Deus. Sempre que implorares a Sua ajuda, escutar-te-á e verás satisfeitos os desejos que formulares, pois Ele sempre atenderá aos teus desejos e rogativas. Tudo a que te decidires terá feliz conclusão e todos os teus caminhos serão iluminados pelo resplendor divino. É que todos aqueles que se abatem e humilham diante de Deus, ainda que tenham sido desapossados das suas riquezas, d' Ele obterão de súbito a salvação e a quietação de espírito.

Ora, assim como levanta os abatidos e os provê de dádivas e mercês, da mesma maneira preserva a condição dos que conservam a inocência e mantém seguros e incólumes os que não deixam que as suas almas se manchem e contaminem com o crime. De facto, embora pareça que a condição do inocente é atacada pela procela por todos os lados, nunca poderá ser esmagada, mas permanecerá segura e imóvel no meio de todas as adversidades. É que a pureza de vida é uma sólida e invencível defesa da dignidade e da vida em todas as situações de perigo. Ora, para que não possas cair 
Deo: "Secede a nobis. Quem enim fructum poterunt homines, opibus parandis atque fruendis intenti, a Deo percipere?" Et tamen ipse Deus, quem animi ingrati scelere in se prouocabant, eorum domos opibus expleuerat, omnia siquidem bona illius immensa benignitate continentur.

Illorum igitur scelus exhorreo, amentiam exsecror consiliumque detestor. Vt enim ad aliquod tempus opibus floreant, breui tamen de statu conuellentur et debitis poenis agitabuntur. Videbunt iusti et laetitia efferentur et in impiorum hominum calamitatibus insultabunt. Quod longe secus nobis eueniet, qui scelus odio habemus et iustitiae studio nitimur et spem nostram non in opibus fluxis, sed in Dei bonitate reponimus. Nec enim salutis nostrae praesidium atque firmamentum exscindi poterit, at illorum etiam reliquias ignis absumet. Quare te, per amicitiam, oro et obsecro ut te respicias, saluti tuae consulas, improborum consilia repudies, bonorum studia non aspernere, comprime tumorem animi, te ipsum, quantum potes, abiice, nec in uirtute tua, sed in Dei clementia et bonitate, omnia praesidia uitae constitue.

Supplicibus igitur uerbis ab illo pacem et ueniam pete, omnia studia uitae ad legem illius accommoda, et sic non modo ueniam impetrabis, sed bonorum omnium copia cumulabere. Accipe ab illo legis sanctissimae disciplinam illiusque uerba mente complectere animoque tuo semper impressa et insculpta sint. Si enim ad Deum toto animo conuersus fueris, illius numine et beneficio pristinas opes et dignitatem recuperabis et subolem ex te florentem propagabis omnemque iniustitiae labem e tabernaculo [72] tuo repelles. Illius enim ductu, opes eximias sub terram aditas effodies, et ab excisa silice auri purissimi uenae tibi, quasi aquae perennes, emanabunt. Tunc igitur eris Dei omnipotentis praesidio circumsaeptus et opibus ab illo ad salutis tuae custodiam exaggeratis omni ex parte munitus.

Itaque non solum bonorum diuinorum copia redundabis, sed etiam diuino praesidio atque robore saepieris. Tunc etiam deliciis sempiternis afflues et te cum ipso Domino peramanter oblectabis neque timore perterritus terram intuebere, sed ad Dei conspectum faciem tuam fidenter attolles. Quotiens opem illius imploraueris, exaudiet te et uota, quae nuncupaueris, solues, is enim tibi semper in precibus atque uotis occurret. Quidquid animo decreueris exitus felices habebit omnesque uiae tuae splendore diuino collucebunt. Omnes enim illi qui se coram Deo abiiciunt atque demittunt, quamuis eorum opes excisae sint, salutem ab illo et animorum tranquillitatem repente consequuntur.

Vt autem abiectos excitat et donis atque muneribus afficit, ita eorum statum, qui retinent innocentiam nec animos suos scelere pollui et contaminari patiuntur, tutos et incolumes ab omni calamitate conseruat. Quamuis enim innocentis status undique fluctibus oppugnari uideatur, numquam obrui poterit, sed securus et immobilis in omni tempestate permanebit. Est enim uitae castimonia firmum et inuictum, in omni rerum discrimine, dignitatis et uitae propugnaculum. Ne autem deinceps labi queas, summam in omni uitae officio puritatem perpetuo 
depois, conservarás incessantemente a máxima pureza em todas as situações da vida. Deste modo, portanto, possuirás abundantemente as máximas riquezas e extraordinários prazeres, serás defendido pela protecção de Deus, gozarás da Sua intimidade e viverás na paz mais imperturbável. E assim penso que nem deves pôr de parte a esperança de salvação nem ufanar-te vãmente do merecimento da pureza. Com efeito, se com o zelo da piedade lavares as primitivas manchas da vida, Deus ser-te-á muito propício, mas se te arrogares a justiça e afirmares incessantemente que és vítima de golpes sem qualquer culpa tua, senti-Lo-ás assaz irado.

Job respondeu a estas palavras dizendo:

- Ainda agora o mesmo tormento atribula o meu espírito, a mesma pungente desgraça me inquieta com cuidados e me enche de tristeza, pois a violência da desgraça que me assoberba é muito mais forte do que o podem demonstrar aqueles suspiros e gemidos. Além disso, àquele que me oprimiu com tão grandes desgraças pareceu-Lhe que seria pouco afligir-me com tamanhos males, se também não permitisse que o meu nome fosse manchado pelos amigos com tão indignos insultos. Não lhes consigo provar a minha inocência, e insistem em acusar-me de crime e arrogância. Para onde hei-de voltar-me? Com que argumentos hei-de refutar os delitos que me são assacados? A que homens darei testemunho da minha inteireza? É que, se aqueles que me conhecem bem e podiam estar certos de que eu nunca fui sacrílego nem infame, me atacam com tantos ultrajes, com a ajuda de que homens posso velar pela minha fama e consideração?

Portanto, uma vez que não posso conseguir que os homens aprovem a minha vida, resta-me remeter todo o julgamento da minha vida para aquele Senhor que é o único que conhece o meu espírito. [73] Oxalá pudesse de alguma maneira conhecer o lugar que agora ocupa; oxalá me fosse permitido encontrá-Lo e aproximar-me do Seu sólio. Então certamente preparar-me-ia para enfrentar o Seu juízo e encheria o meu discurso não apenas com argumentos, mas também com muitas queixas. Saberia com que palavras deveria tratar com Ele e responder-Lhe-ia por minha vez ao que me objectasse e só assim saberia da Sua boca a causa desta minha tribulação. Pois quê? Porventura é desejável que Ele entre em litígio comigo com o máximo empenhamento de forças? De forma alguma, mas é desejável sim que fortifique o meu espírito com o contributo de uma energia que me permita defender em juízo a minha causa com determinação. Então certamente naquele juízo, no qual não existe nenhuma sombra de engano e calúnia, o homem justo, sem razão golpeado pelos insultos, obteria um lugar para a sua querela. Aí teria plena confiança em que, competindo a deliberação àquele Juiz a quem absolutamente ninguém engana, hei-de conservar para sempre o meu direito.

Mas agora estou indeciso acerca do que farei. Acusado pelos amigos de delitos imaginários, indignissimamente ultrajado pela boca daqueles que nunca deveriam fazer tal coisa, vítima de uma falsa imputação da maior das infâmias e desdouros, invoco Deus como testemunha e imploro a Sua protecção, e não obstante não vejo apresentar-se ao meu lado Aquele que é o único que conhece a justiça que me assiste. Se me volto para 
conseruabis. Sic igitur et opibus summis et eximiis uoluptatibus afflues, et Dei praesidio munieris, et illius familiaritate perfrueris et in tranquillissimam pace uersaberis. Itaque censeo neque spem salutis esse tibi deponendam nec integritatis laudem inaniter assumendam. Si enim pristinas uitae labes studio pietatis elueris, Deum ualde propitium habebis, si uero tibi iustitiam arrogaueris teque nullo merito tuo plagis affectum perpetuo dixeris, non mediocriter iratum senties.

Ad haec Iobus respondens, ait:

- Idem etiam nunc doloris stimulus animum meum lacerat, eadem calamitatis acerbitas me curis agitat atque maerore conficit, uis enim aerumnae, quae me premit, multo grauior est quam ut illis suspiriis atque gemitibus demonstrari possit. Parum deinde uisum fuit illi, qui me tantis oppressit aerumnis, his tantis malis affligere, nisi etiam nomen meum tam indignis contumeliis maculari ab amicis sineret. Non probo illis innocentiam meam, sed in eo perseuerant ut me sceleris et arrogantiae conuincant. Quo me uertam? Quibus argumentis obiecta crimina diluam? Quibus hominibus integritatis meae testimonium denuntiabo? Si enim illi qui me probe norunt et qui certi esse poterant me neque flagitiosum neque sceleratum esse, tantis me conuiciis incessunt, quorum hominum ope famam et existimationem meam tueri possum?

Reliquum igitur est, cum hominibus uitam meam probare non queam, ut illi Domino, qui solus animi mei conscius est, omne uitae meae iudicium committam. [73] Vtinam locum, quo se nunc tenet, nosse aliquo modo possem; utinam illum inuenirem et mihi ad solium illius adire liceret. Tunc certe me ad iudicium illius subeundum animo compararem orationemque meam non argumentis tantum, sed multis etiam querellis infarcire. Scirem quibus uerbis mihi cum illo agendum esset et ille uicissim ad obiecta responderet et sic demum causam huius aerumnae meae ab illo perdiscerem. Quid ergo? Num ut ille summa uirium contentione mecum litiget optandum est? Minime, immo ut animum meum allato robore confirmet quo possim in iudicio constanter causam sustinere. Tunc certe in illo iudicio, in quo nullus est fraudi et calumniae locus, homo iustus, maledictis immerito concisus, litem suam obtineret. Ibi profecto confiderem, iudice illo, quem nihil omnino fallit, iudicante, me ius meum perpetuo retenturum.

Nunc uero quid faciam incertus sum. Fictis criminibus ab amicis accusatus, illorum uoce a quibus id minime fieri oportebat indignissime uiolatus, maximi probri atque dedecoris insimulatus, Deum testor, fidem illius imploro, et tamen illum, unicum iuris mei cognitorem, mihi adesse non uideo. Si ad orientem Solem me confero, nusquam apparet; si ad occidentem, ne uestigium quidem illius 
o nascente, em nenhuma parte aparece; se para o poente, nem mesmo me apercebo do Seu rosto. Se presto atenção às obras que realiza no setentrião, não consigo apreendê-Lo; se me viro para o austro, com o propósito de procurar os lugares em que se escondeu, nem aí o diviso. Mas só posso gozar da consolação de que Ele está bem inteirado do teor da minha vida e conhece o quão pura e castamente reverenciei a Sua majestade. Mas quis pôr-me à prova para que, à semelhança do ouro fundido pelas chamas do forno, eu saísse muito mais puro destas chamas de tribulação com que sou atormentado. É que os meus pés sempre seguiram as Suas pegadas; zelosamente segui o Seu caminho e jamais d' Ele me apartei neste ou naquele sentido; nunca recusei o Seu senhorio; no mais íntimo do meu espírito abracei as ordens que a Sua boca proferiu.

Todavia, uma vez que se mantém o mesmo e igual a Si mesmo por toda a eternidade, quem há-de afastá-Lo de uma decisão que ratificou e tomou? É que seguramente levará a cabo tudo quanto a Sua inteligência decidiu e a Sua vontade e querer aprovaram. Por conseguinte, a mim impôs-me o fardo que Lhe pareceu e atribuiu-mo como se fosse a tarefa inerente a um certo trabalho. Nem eu fui o primeiro em quem Ele seguiu os desígnios de demonstrar que a virtude deve ser exercitada com trabalhos e posta à prova com dores, mas fê-lo também com muitos homens dotados de superior piedade, aos quais pelo mesmo motivo permitiu que fossem atribulados por muitos incómodos.

Por consequência, este modo de agir de Deus não é novo nem inusitado nem desconhecido nos tempos antigos, para que por este motivo devais perturbar-vos e acusardes a minha vida, mas é um procedimento que seguiu frequentemente e em muitos lugares. Por isso, mesmo naquele tempo em que a minha existência decorria em grande prosperidade, por vezes sentia-me inquietado pelo medo da desgraça que me teria podido acontecer por deliberação d' Ele e, ao pensar no desastre, angustiava-me e [74] sentia receio do Seu poder divino. Mas Deus (embora nada tenha acontecido que, para além das minhas suposições, anteriormente me tenha capacitado e preparado para suportar todos os males) a tal ponto me oprimiu violentamente que quebrou todas as minhas forças e perturbou o meu estado. E assim esta desgraça abateu-se e caiu sobre mim de forma não inopinada, pois nem quaisquer trevas me perderam nem nenhuma névoa me impediu de ver muito antecipadamente aquilo que aconteceu.

Sendo esta a realidade, por que vos ocorreu argumentar tão amiúde com o mesmo raciocínio, que não tem vigor absolutamente nenhum? Com efeito, se do facto de me verdes esmagado pela tribulação se pudesse concluir que eu era um homem ruim e injusto, seguir-se-ia inevitavelmente que Deus não conhece os momentos oportunos em que os homens injustos devem ser destruídos pelo Seu juízo e os justos de novo levantados, por forma a verem aproximar-se os dias salutares. É que, se a desgraça desta vida é prova de crime, logo a felicidade constitui um indício de probidade. Por conseguinte, como vemos que Deus fecha os olhos para os crimes dos perversos e por vezes persegue violentissimamente os justos com incómodos, poderia concluir-se de modo forçoso que muita coisa escapa a Deus e que a Sua ciência não abarca tudo. Porventura não são conhecidos e observados os crimes e infâmias que por toda a parte cometem os homens perversos e depravados? Acaso as abomináveis acções que praticam costumam ser pouco 
inspicio. Si ad opera, quae in septemtrione gerit, animum intendo, compos illius fieri non possum; si me ad austrum refero, ut in quae loca se abdiderit inuestigem, nec ibi illum cerno. Verum enimuero hoc solacio uti possum, quod is meae uitae rationem exploratam habet et nouit quam pure et caste numen illius ueneratus sim. Sed probare me uoluit ut, tamquam aurum fornacis incendio conflatum, multo purior ex his aerumnarum flammis, quibus crucior, exirem. Pedes namque mei semper illius uestigiis institere; uiam illius diligenter obseruaui nec ab ea umquam in alterutram partem declinaui; numquam detrectaui imperium illius; sanctiones, quas ore protulit, intima mente complexus sum.

Attamen, cum idem et sibi similis in omni aeternitate permaneat, quis eum a rata atque fixa sententia depellet? Quaecumque enim mente designauit et animi uoluntate et studio comprobauit certe perficiet. Mihi igitur id quod illi uisum fuit onus imposuit et, quasi certi operis pensum, assignauit. Nec in me primum hoc consilium secutus est, ut uirtutem laboribus exercendam et doloribus probandam esse demonstraret, sed in multis etiam hominibus pietate excellentibus, quos ob eamdem causam multis incommodis affligi permisit.

Non est igitur hoc opus Domini nouum et inusitatum et priscis temporibus inauditum, ut ea ratione conturbari meamque uitam criminari debeatis, sed saepe atque multis in locis ab eo perfectum. Idcirco eo tempore quo res meae erant ualde secundae, metu tamen interdum cladis quae mihi consilio illius accidere potuisset animo conturbar et, prae meditatione calamitatis, angebar [74] et numen illius metuebam. Verum Deus (quamuis mihi nihil, praeter opinionem, acciderit et ad omnia mala perferenda animo meditatus atque paratus ante fuerim) adeo me uiolenter oppressit ut omnes animi mei uires elideret et statum meum perturbaret. Itaque non inopinato mihi calamitas haec inuecta et importata fuit, nec enim ullae me tenebrae perdiderunt nec ulla caligine impeditus fui quominus ea, quae euenere, multo ante prospicerem.

Haec cum ita sint, quid uobis in mentem uenit tam saepe eodem argumento pugnare, quod nullas omnino uires habet? Si enim ex eo quod me aerumnis oppressum cernitis me esse maleficum hominem et iniustum colligi posset, Deum minime nosse temporum opportunitates, quibus homines iniusti illius iudicio peruertendi sunt et iusti rursus excitandi, ut dies salutares aduentare conspiciant, omnino sequeretur. Si enim calamitas huius uitae scelus arguit, ergo felicitas probitatis indicium facit. Cum igitur Deum uideamus in perditorum sceleribus coniuere et iustos incommodis acerbissime interdum uexari, concludi necessario posset Deum multa fugere neque scientiam illius omnia complecti. Num scelera et flagitia, quae homines perditi atque profligati passim suscipiunt, minime explorata et cognita sunt? An infanda facinora quae moliuntur parum omnium oculis notari solent? An non quotidianas 
notórias aos olhos de todos? Acaso os nossos ouvidos não se enchem com as queixas diárias dos pobres, que sofrem as inumeráveis injustiças dos maus?

Os maus arrancam as marcas das terras, para delas expulsarem os mais fracos, apoderam-se dos rebanhos dos outros para encerrá-los nos seus pastos, roubam os jumentos dos órfãos, apossam-se como penhor dos bois das viúvas, obrigam os indigentes a sair do caminho e incutem aos homens pobres tamanho temor que estes se apressam a esconder-se em refúgios para não verem o vulto daqueles por quem são espoliados. Certos, como onagros, erram pelo deserto e, como se não tivessem nenhum outro trabalho, observam atentamente de onde podem colher presas, levantando-se de manhã para alimentarem de rapinas os seus filhos. Os ímpios ceifam as searas nos campos alheios, vindimam impunemente as vinhas alheias, ao passo que os pobres, por eles privados da roupa, pernoitam ao frio e não têm nenhuma vestimenta com que se protejam da chuva que cai nos montes e, molhados pelas violentas bátegas e privados de todo o resguardo das roupas, refugiam-se nos penhascos. Mas os impuríssimos homens abrasam-se em tamanha crueldade que ao órfão, já esbulhado e expropriado de bens, roubamlhe até os escassos restos do património, e consideram como penhor e apossam-se de quanto vêem que resta dos bens do homem pobre e atribulado; ao necessitado banem-no e expulsam-no, depois de lhe arrancarem toda a roupa, e tiram das mãos do faminto um punhado de cereal. Dentro de muros jorra para eles uma grande abundância de azeite e são atormentados pela sede nas prensas que lhes espremem o vinho. Portanto, gozam do maior descanso graças à actividade e trabalho dos outros, [75] uma vez que os mesmos que os servem e se cansam com trabalho não colhem qualquer proveito do esforço despendido.

Do meio da cidade os infelizes mortais gritam e queixam-se das injustiças infligidas e, os que foram trespassados pelas feridas, com grande angústia soltam clamores, e, mesmo assim, Deus contém a Sua ira, de tal maneira que nem sequer fere com castigos os homens sacrílegos. Afastaram-se da luz pelo supremo crime da deslealdade; abandonaram os caminhos que o resplendor da lei divina lhes mostrava e, embora tivessem avançado muito no erro pestilencial, todavia de modo algum quiseram regressar ao caminho. Os assassinos estão acordados antes do nascer do dia para com as armas arrancarem a vida aos homens satisfeitos com um modesto passadio, e, como ladrões, aproveitam-se da noite para roubar as riquezas dos outros.

Por outro lado, o adúltero está atento às primeiras sombras da noite, a fim de evitar os olhos dos homens, e também tapa a cabeça, para não ser reconhecido ao tempo em que maquina um tão grande crime. Durante o dia observa as casas que à noite pretende assaltar, odeia a luz, como inimiga e contrária à perversidade. Pensa que o nascer da luz matutina é como a morte e, se for apanhado em flagrante, entra em pânico e aterroriza-se com o medo da morte. É leviano e volúvel e mais inconstante que a superfície da água do rio impetuoso e, por isso, nem ele nem as suas coisas poderão ter estabilidade, mas cairão e escapar-se-ão e desaparecerão e não permanecerão em nenhum lugar: todavia, o seu crime não ficará impune, ao contrário do que pensam os ignorantes. É que Deus nem se esquece do direito nem ignora os desígnios dos homens impuros. E, assim, o património 
egentium querellas, qui ab improbis innumerabiles iniurias patiuntur, non auribus usurpamus?

Improbi terminos euellunt, ut eos, qui minus possunt, agris expellant, greges aliorum rapiunt, quos in pascuis suis contineant, pupillorum asinos abigunt, uiduarum boues loco pignoris abripiunt, pauperes uia cedere cogunt tantumque timorem hominibus egentibus incutiunt ut se in latebras abdere festinent ne uultum eorum, a quibus spoliantur, aspiciant. Quidam, uelut onagri, in solitudine discurrunt et, quasi nihil aliud operis habeant, unde praedas agere possint uigilanter explorant atque mane surgunt ut rapinis liberos suos alant. In alienis fundis segetes demetunt impii, uineas alienas impune uindemiant; homines egentes, ab illis nudati, pernoctant in frigore nec ullum habent integumentum quo, imbrem effusum in montibus, arceant et, immodica pluuia madefacti omnique uestium praesidio destituti, saxorum sibi perfugia comparant. Tanta uero crudelitate flagrant homines impurissimi ut pupillo, iam bonis euerso et spoliato, tenues etiam patrimonii reliquias detrahant, et quidquid reliquum esse uident, in bonis hominis egentis et afflicti, pro pignore putent et auferant; inopem, detractis omnibus uestimentis, nudum expellunt et eiiciunt, et e manibus famelici manipulum frugis extorqueant. Intra muros olei uis ingens et in torcularibus, qui eis uinum exprimunt, siti cruciantur. In summo igitur otio, aliorum operis atque laboribus, [75] perfruuntur, cum ipsi, qui eis seruiunt et labore defatigantur, nullum fructum ex impenso labore percipiant.

E media ciuitate miseri mortales inclamant et de iniuriis illatis queruntur et, qui uulneribus confossi sunt, animo nimis anxio clamores edunt, et tamen Deus iram suam continet, ita ut homines sceleratos ne minimis quidem poenis afficiat. A luce per summum perfidiae scelus desciuerunt; uias, quas diuinae legis splendor illis monstrabat, deseruerunt et, cum multum progressi in errore pestifero fuissent, non tamen ullo modo in uiam redire uoluerunt. Ante lucem uigilant sicarii ut ferro uitam hominibus tenui uictu contentis eripiant, opportunitate uero noctis, tamquam fures, ad aliorum opes diripiendas abutuntur.

Porro autem adulter primas noctis tenebras obseruat, ut oculos hominum uitet, et caput etiam inuoluit ne, dum tantum scelus machinatur, agnosci possit. Die notat oculis domos quas nocte perfodiat, lucem, ut nequitiae contrariam et inimicam, detestatur. Matutinae lucis exortum instar mortis esse putat et, si fuerit manifesto deprehensus, exhorret et mortis formidine perterretur. Leuis est et inconstans et aqua summa fluminis incitati mobilior et idcirco nec ille neque res illius stabilitatem habere poterunt, sed labentur et effluent neque ullo in loco consistent: attamen eorum scelus non erit impunitum, ut imperiti suspicantur. Nec enim Deus iuris obliuiscitur neque quae ab impuris hominibus designentur ignorat. Itaque hominis scelerati patrimonium in terra erit detestabile et exsecrandum, 
do homem sacrílego será na Terra odioso e execrável, pois ao tempo que procurou prazeres vãos e fúteis, ignorou o caminho do mais verdadeiro prazer e contentamento. E não pôde ser levado para as vinhas de que se colhe um suavíssimo fruto, mas lançouse em local escarpado, de onde caía em toda a sorte de aflições e desgraças, e não quis beber o dulcíssimo vinho dos ensinamentos divinos e, por isso, bebeu o amaríssimo cálice da vingança de Deus.

Ora, assim como a terra árida e queimada pelo Sol absorve toda a água que nasce da neve derretida, do mesmo modo o Érebo há-de engolir os que se mancharam com os pecados. Por conseguinte, para eles está fechado o acesso à clemência do Senhor, pois não tiveram qualquer preocupação com o espírito, mas consagraram todas as actividades da vida ao corpo, com o qual os vermes se hão-de locupletar como com um manjar muitíssimo agradável. O nome deles será completamente arrancado da memória dos homens e a obra da iniquidade há-de acabar por quebrar-se, à semelhança de um lenho seco. É que o homem ruim não teve qualquer compaixão daqueles que estavam privados de toda a ajuda e auxílio dos seus: de facto, perseguiu a mulher sem filhos e não socorreu a viúva atribulada pelos males. E por vezes é tamanho o seu poder que até submete homens poderosos: e, todavia, embora possua tão grandes recursos, nunca pode gozar de tranquilidade de espírito. [76] É que não acredita em ninguém, imagina que todos urdem ciladas contra a sua vida, vive no profundo medo do assassínio e da tortura, e muitas vezes este receio obriga-o a maquinar a destruição daqueles de quem se teme. Com efeito, embora alguma pessoa se empenhe em insinuar-se-lhe através de presentes e, apoiando-se nesta astúcia, tenha confiança em que não lhe há-de advir nenhum incómodo da parte de quem obrigou com dádivas, todavia o ruim sacrilegamente há-de preparar uma armadilha contra o que imaginou ligá-lo a si mediante favores, e de tal maneira há-de vigiar os seus caminhos que lhe maquine a ruína e perdição.

Por conseguinte, a condição dos maus, embora muitos pensem que é elevada e se guinda ao mais alto fastígio da honra, é detestável e digna de execração. Vê-los-emos alcandorados à posição mais elevada e, de repente, divisá-los-emos abatidos no chão, de tal maneira que desaparece por completo qualquer vestígio do primitivo esplendor. Os que tinham sido muitíssimo opulentos são reduzidos à mais extrema pobreza; as suas riquezas, como todas as restantes coisas humanas, são devoradas pela morte e, como espigas de fim imprevisto, são ceifados pela foice.

Não acuso falsamente Deus de iniquidade, não proclamo a condição feliz dos ímpios, mas abomino o crime deles, refuto o seu desatino e, com as palavras que posso, exponho o quão mofinos, infelizes e atribulados são. Todavia afirmo e testifico e sustento com a máxima energia que nem aquela sorte, aparentemente muito próspera, de que muitos gozam, embora pareça que os segue também na morte, constitui uma prova de honestidade, nem, por outro lado, as desgraças e tribulações provam a desonestidade do homem atribulado. É que os ruins, embora sejam tidos pelo comum da gente na conta de afortunados, todavia nesta vida estão sujeitos a terríveis desgraças, e são abalados pelos incessantes castigos das malfeitorias, e sofrem depois desta vida a merecida punição pelos seus crimes, ao passo que os honestos, exercitados pelas tribulações e vencedores 
dum enim futiles et inanes uoluptates exquisiuit, uiam uerissimae uoluptatis atque iucunditatis ignorauit. Nec in uineas, quibus suauissimus fructus excipitur, deduci potuit, sed in locum praecipitem se dedit, unde in omnem acerbitatis et miseriae colluuionem decideret, neque dulcissimum diuinae disciplinae uinum bibere uoluit et, ideo, poculum amarissimum diuinae ultionis exhausit.

Vt autem tellus arida solibusque perusta omnes aquas quae ex liquatis niuibus emanant absumit, ita Erebus eos, qui se peccatis inquinauerunt, exsorbebit. Erit igitur illis ad clementiam Domini aditus praeclusus, nec enim animi curam ullam habuerunt, sed omnia uitae studia ad corpus contulerunt, quo quidem uermes, quasi pabulo iucundissimo, saginandi sunt. Eorum nomen ex hominum memoria penitus euelletur et iniquitatis opus tandem, instar aridi ligni, perfringetur. Homo enim maleficus nullam misericordiam tribuit illis qui erant omni suorum ope et auxilio orbati: mulierem enim infecundam afflixit et uiduam malis oppressam minime subleuauit. Tantum uero interdum uiribus pollet ut homines etiam potentes sibi subiiciat: et tamen, cum tantas opes habeat, numquam animi tranquilitate frui potest. [76] Nemini enim credit, insidias ab omnibus uitae suae fieri suspicatur, et necem et cruciatum uehementer exhorret, et eo metu cogitur saepenumero illis, a quibus sibi timet, perniciem moliri. Quamuis enim aliquis se illi muneribus insinuare studeat et, ea calliditate nixus, confidat sibi nullum, ex eo quem donis obstrinxit, incommodum euenturum, is tamen insidias illi, qui eum sibi obsequio deuincire statuit, nefarie comparabit, itaque uias illius obseruabit ut in illum pestem et exitium machinetur.

Improborum igitur status, quamuis extolli et ad summum honoris fastigium euehi a multis existimetur, detestabilis et exsecrandus est. Eos elatos sublime conspicies atque repente deiectos animaduertes, ita ut nihil omnino pristini splendoris appareat. Qui fuerant opulentissimi ad summam inopiam rediguntur; illorum opes, ut reliqua humana omnia, morte consumuntur et, quasi spicae necis improuisae, falce demetuntur.

Non Deum iniquitatis insimulo, non impiorum statum felicem praedico, sed eorum scelus exsector, amentiam conuinco, quam miseri, quam infelices et aerumnosi sint, quibus possim uerbis, explano. Id tamen dico et testificor et quam maxime possum contendo nec illam fortunam, ad speciem ualde florentem, in qua multi sunt, quamuis eos in funere etiam consequi uideatur, dare testimonium probitatis, neque rursus aerumnas et calamitates, improbitatem hominis afflicti conuincere. Nam et improbi, quamuis uulgo beati reputentur, in hac tamen uita sunt diris casibus obnoxii, et assiduis maleficiorum poenis agitantur, et post hanc uitam debita sceleribus eorum supplicia persoluent, et probi, aerumnis exerciti et multis in omni malorum tempestate argumentis examinati, uerissimae 
de muitas provas em todas as tempestades de males, todavia conservam os ornamentos da mais verdadeira dignidade e hão-de, ao cabo, alcançar prémios imortais e divinos. Por conseguinte, não têm qualquer força os argumentos com que, partindo da desgraça que me atribula, vos esforçais por provar que eu sou criminoso. Pelo que, se não aprovais isto, gostaria de saber onde está a pessoa capaz de refutar o meu discurso e de provar que eu falei mentira.

Pelo seu lado, Bildad de Suás respondeu a estas palavras, dizendo:

- Ninguém em seu juízo pode ser levado por quaisquer razões a imaginar afim da iniquidade Aquele supremo Senhor, em cujas mãos se encontra o supremo poder, pois nem se arreceia seja de quem for nem é por natureza propenso à crueldade. É que é o Senhor supremo de todas as coisas, dotado de infinito poder, o único a quem se deve temer e merecedor da adoração de todos. Por outro lado, aquela paz que Ele estabeleceu na natureza celeste mostra assaz claramente o quanto por natureza Ele é benévolo. Daqui pode concluir-se que, quando perturba a paz na Terra e causa dor a muitos, isso provém de que muitos se apartam dos Seus ensinamentos e governo. Acaso se podem contar as Suas tropas celestiais? Acaso o resplendor do Seu dia se nega a nascer para algum povo? Logo, uma vez que aquelas [77] mostram a força ilimitada do Seu poder, e este nos põe diante dos olhos a Sua imensa bondade, sucedendo deste modo que nos Seus julgamentos não pode prevalecer o medo, nem o ódio, nem qualquer sentimento perverso, somos necessariamente forçados a reconhecer que, sempre que vemos que a condição do homem é perturbada e embaraçada com penalidades, todas estas desgraças provêm da fonte do crime humano.

E todavia atrever-se-á alguém, ao ser esmagado pelas desgraças, a afirmar que não mereceu aquele castigo que sofre por juízo de Deus? Incitados pela indignidade do facto, somos obrigados a repetir mais frequentemente a mesma opinião. Com efeito, que é o homem para, no juízo de Deus, poder eximir-se de todo o crime? Qual é a natureza daquele que foi dado à luz pelo ventre da mulher para na vida poder perpetuamente conservar a pureza? Qual o motivo pelo qual o mesmo Senhor dá trevas à Lua e mostra que à Sua vista as estrelas não são puras? Por conseguinte, que cumprirá crer-se acerca do homem, que não dista muito da fraqueza e podridão dos vermes? Ou que deve julgar o homem sábio e moderado acerca da natureza humana, que em firmeza e constância não se avantaja muito a qualquer espécie de insecto? E assim, uma vez que é assaz manifesto que o homem, não só por propensão natural, mas também por vontade e deliberação, vive no pecado, daqui se conclui que com razão e merecidamente é castigado por Deus sempre que os golpes o atingem.

Job respondeu:

- Dás uma boa ajuda, não há dúvida, ao empenhares-te em acudir Àquele que não é capaz de defender a sua causa... Que é isto? Tu hás-de apresentar-te como advogado de Deus, como se não tivesse quaisquer recursos com que reivindicar o Seu direito? Tu, graças à tua diligência, hás-de obter para Ele a salvação numa situação de risco capital, como se 
tamen dignitatis ornamenta retinent et praemia tandem immortalia atque diuina consequentur. Nullam igitur habent uim argumenta quibus, ex calamitate quae me uexat, me sceleratum esse contenditis. Quod, si haec uobis minime probantur, uelim intelligere ubinam ille est qui orationem meam refellat meque falsum dixisse peruincat.

Ad haec autem Bildadus Hasuitha respondens, inquit:

- Nemo sanus potest ullis rationibus adduci ut summum illum Dominum, penes quem summa potestas est, iniquitati affinem suspicetur, nec enim metuit quemquam nec natura ad saeuitiam propensus est. Est enim summus rerum omnium Dominus, imperio infinito praeditus, solus metuendus omniumque ueneratione colendus. Quam sit autem natura beneficus ex ea pace, quam in caelesti natura constituit, admodum clare perspicitur. Vnde concludi potest, cum ille in terris pacem turbat et dolorem multis efficit, id ex eo prouenire quod multi ab illius institutis atque moderatione deficiunt. Num caelestia illius agmina numero definiri possunt? Num splendor illius exoriens, gentibus ullis denegatur? Ergo, cum [77] unum uim infinitam potentiae declaret, alterum immensam illius benignitatem oculis subiciat, et ita efficiatur neque metum, nec inuidiam, nec ullam malignitatem in iudicio illius dominari posse, restat necessario ut fateamur, quotiens statum hominis turbari et doloribus implicari perspicimus, eas omnes clades ex humani sceleris fonte profluere.

Et tamen audebit quisquam, cum calamitatibus obruitur, asserere se poenam illam, quam iudicio diuino sustinet, minime commeruisse? Indignitate rei permoti, cogimur eamdem saepius iterare sententiam. Quid enim est homo ut possit in Dei iudicio solui omni scelere? Quae natura illius est qui fuit ex aluo mulieris in lucem editus ut queat puritatem in uita perpetuo retinere? Quid illud quod idem Dominus lunae tenebras affert et stellas in illius conspectu minime puras esse demonstrat? Quid igitur erit de homine, non multum ab imbecillitate atque putredine uermium distante, statuendum? Aut quid est de humana natura, quae non multum quodlibet insecti genus constantia et firmitate superat, ab homine sapiente atque moderato iudicandum? Vnde concluditur, cum adeo constet hominem et naturae propensione et uoluntate et studio in peccatis uersari, iure atque merito, quotiens plagis afficitur, a Deo puniri.

- Recte operam tuam ponis, inquit Iobus. Illi uidelicet, qui causam suam tueri nequi, subsidio uenire contendis... Quid hoc est? Tu te Deo, quasi nullae opes illi sint quibus suum ius obtineat, aduocatum exhibebis? Tune illi, tamquam homini imbecillo, salutem in capitis periculo, industria tua, comparabis? Quem 
se tratasse de um homem fraco?! A quem te esforças por fortalecer com o teu conselho? Porventura a quem foi privado do socorro da sabedoria? Instruirás com ensinamentos quem se avantaja pelas riquezas sempiternas de uma sabedoria multiforme? Finalmente, diante de quem te decidiste a fazer valer a tua inteligência e ostentar a tua eloquência? Com que inspiração proferiste essas palavras pronunciadas de modo assaz inconsiderado? Reconhece o poder d' Aquele em cuja defesa te entremetes com atrevimento sobejo. Os gigantes, mergulhados no abismo, foram aniquilados, e são torturados com os mesmos tormentos os que, pela imitação da mesma monstruosa soberba, se juntaram a eles. A região infernal está nua e patente aos Seus olhos e para o Seu olhar o Tártaro não tem qualquer véu. Ele com o Seu sopro dilatou o setentrião por uma região deserta e informe e fez que o peso da Terra não se apoiasse sobre nenhuma base. Encerrou nas nuvens a força das águas e sem ordem Sua a chuva não cai da rasgada nuvem. Ergueu no éter o Seu majestoso sólio e por todos os lados o cobriu com nuvens estendidas. Estabeleceu às águas limites para além dos quais nunca pudessem passar, enquanto se mantiver neste mesmo estado esta alternância de luz e trevas, com que os dias e as noites se sucedem uns aos outros mediante um ritmo uniforme e invariável. [78] As colunas do céu abalam-se ao Seu aceno e tremem cheias de espanto com a Sua indignação. Com o Seu poder abre o mar e com a Sua sabedoria trespassa o cruel tirano. Com o Seu sopro aperfeiçoou a forma e beleza do céu e até toca com as Suas mãos naquela terrível serpente que com as suas múltiplas roscas envolve tudo o que pode arrebatar.

E, contudo, estas são como que as Suas obras menos importantes e de somenos, e não passam de uma espécie de pegadas superficialmente gravadas da Sua virtude e poder, cuja fama pudemos escutar de modo ténue através dos ouvidos, porquanto não nos é possível atingir com o entendimento as Suas obras mais perfeitas. Com efeito, quem alcançará pela inteligência o trovão do Seu poder, a admirável imensidade da Sua virtude e a exactíssima disposição do Seu senhorio sempiterno?

Quando Job acabou de pronunciar estas palavras, encetou em seguida outro discurso deste teor:

- Tomo como testemunha Deus, que está presente, e que permite que o julgamento da minha inocência seja perturbado e que me recusa o testemunho de justiça, que venerei de modo exclusivo; invoco como testemunha aquele Senhor todo-poderoso, que atribulou a minha vida com tantas contrariedades e juro pelo Seu santíssimo nome que eu, enquanto respirar e tiver fôlego, nunca hei-de consentir que saia da minha boca uma palavra iníqua e que a minha língua urda o engano e a maldade. Por conseguinte, uma vez que esta é a minha disposição, que Deus impeça que, movido pela vossa influência e contra o testemunho da minha consciência, eu me invente um crime. Pelo contrário: até ao meu último suspiro hei-de conservar a minha inteireza isenta de toda a mancha de infâmia. Afirmo que abraçarei estreitamente a minha justiça e não me desviarei da sua dignidade e firmeza, uma vez que, desde os meus primeiros anos, regulei a minha vida de maneira a que consciência de nenhum crime me inquiete o espírito. Portanto, quem se opõe a mim, torna-se culpado de um crime ímpio, e, quem me persegue com todas as 
firmare consilio niteris? Eumne qui praesidio sapientiae orbatus est? Illum tu disciplinis instrues qui opibus sempiternis sapientiae multiplicis antecellit? Cui tandem ingenium uenditare et eloquentiam ostentare decreuisti? Quo spiritu uerba ista nimis inconsiderate missa protulisti? Recognosce potentiam illius in cuius te causa nimis insolenter interponis. Gigantes, aquarum profundo gurgite demersi internecioneque deleti sunt, et qui sese, eiusdem superbiae immanitatis similitudine, ad eorum nomen adiunxere, eisdem tormentis excruciantur. Inferorum regio nuda et aperta in oculis illius est nec habet ullum in illius aspectu Tartarus integumentum. Ipse septemtrionem in regione uasta et informi spiritu suo dilatauit terrarumque pondus nullo iacto fundamento stabiliuit. Aquarum uim in nubes inclusit nec illius iniussu ex nube discissa nimbus effunditur. Solii sui maiestatem extruxit in aethere illudque expansis undique nubibus obtexit. Aquas terminis circumscripsit quos numquam transilient, dum haec lucis atque tenebrarum uicissitudo, qua dies atque noctes sibi inuicem rata et aequabili numerorum ratione succedunt, in hoc eodem statu permanserit. [78] Columnae caeli nutu illius concutiuntur eiusque indignatione obstupefactae contremiscunt. Fortitudine sua mare discindit sapientiaque sua tyrannum importunum transuerberat. Spiritu suo caeli formam speciemque expoliuit, quin etiam serpentem illum immanem, tortu multiplici omnia, quae potest arripere, circumplicantem, manibus suis attingit.

Et haec quidem sunt extrema quaedam et infima illius opera et quasi quaedam uirtutis et potentiae illius leuiter impressa uestigia, cuius tenuem famam auribus accipere potuimus, nam ad summa atque perfectissima illius opera mente aspirare non possumus. Quis enim illius potentiae tonitrum admirabilemque uirtutis immensitatem exactissimamque imperii sempiterni rationem intelligentia consequetur?

Haec ubi Iobus dixit, aliud deinde orationis cepit exordium in hanc sententiam:

- Praesentem Deum testor, qui meae innocentiae iudicium disturbari permittit mihique denegat iustitiae, quam unice colui, testimonium; illum praepotentem Dominum testem inuoco, qui uitam meam tantis acerbitatibus afflixit, atque per sanctissimum illius numen iuro, me, dum spirauero animamque de caelo duxero, numquam passurum ut ex ore meo uerbum iniquum prodeat et lingua mea fraudem et malitiam machinetur. Cum igitur hoc animo sim, auertat Deus ut, contra meae conscientiae testimonium, auctoritate uestra commotus, mihi scelus affingam. Immo: usque ad extremum spiritum integritatem meam puram ab omni infamiae labe conseruabo. Iustitiam, inquam, meam arte complectar nec ab illius dignitate et constantia deducar, cum sic a primis annis uitam instituerim ut nullius sceleris conscientia carpat animum meum. Qui igitur mihi aduersatur, impium in se scelus admittit, et, qui me totis uiribus oppugnat, crimen nefarium suscipit, nam contra ius et fas hominem iustum persequitur. 
forças, comete um sacrílego atentado, porquanto, contra o que é de justiça e sagrado, está a perseguir um homem justo.

A tal ponto me credes demente e louco que julgais que até ao dia de hoje adquiri fama de varão bom e santo simulando a piedade e mediante uma aparência falsa de religiosidade? Porventura sou tão desprovido de inteligência, experiência ou saber que não veja claramente que da mentira e da falsidade não se obtém em absoluto fruto algum de vida? Com efeito, pergunto: que esperança teria podido oferecer-me a mim mesmo na vida, se me tivesse apoiado nos embustes de uma virtude simulada? Porventura poderá ser firme e constante a esperança daquele que sacrilegamente finge a piedade? Porventura o homem que se esforça por chegar à dignidade através da simulação da virtude receberá algum proveito de uma maquinação tão criminosa? Certamente que não, pois, como pensou que obteria o máximo lucro com a desonestidade, a divindade arrebatar-lhe-á de repente a alma.

Pois quê? Quando, chegado a situação difícil, bradar por Deus, há-de ser escutado o homem que escondeu sob uma falsa aparência de virtude as paixões que encerrava no peito? Acaso poderá alguma vez sentir o verdadeiro prazer e [79] recrear a sua alma com alguma deleitação do Espírito de Deus? Acaso poderá ser movido e incitado pelo direito de acesso ao Espírito divino, para em qualquer momento se dirigir a Deus e implorar confiadamente a sua ajuda? Jamais. Então quê? A tal ponto vos pareço estúpido e louco que, por minha livre e espontânea vontade, mediante uma única acção, tenha acabado para mim mesmo com toda a esperança de proveito, da mais genuína dignidade, de tranquilidade, de solidíssima protecção, de inacabável prazer e de intimidade e união com Deus? Não vi nada? Não aprendi nada dos mais velhos? De um tão grande trato com as coisas divinas não alcancei nada para a prática da vida, por forma a entender que não existe coisa mais desonrosa ou mais funesta que a mentira, que se opõe à essência da vida bem-aventurada?

Ora, para que vejais mais claramente que eu não estou atacado de loucura nem sou movido pelo ódio a mim mesmo, por forma a maquinar contra mim mesmo a minha perdição, expor-vos-ei aquilo que não recebi dos homens, mas aprendi do Espírito divino, e não vos esconderei os ensinamentos que o próprio Senhor me ensinou. Por outro lado, falarei mais resolutamente porque esta fala não deve dirigir-se a homens ignorantes das coisas divinas, mas a pessoas que passaram boa parte da vida na investigação das matérias celestiais. Pelo que mais admira que, sendo vós pessoas que tanto adiantastes na sabedoria e possuindo tamanha penetração para outras coisas, neste ponto tenhais caído em opiniões tão superficiais e fúteis. Por conseguinte, explicar-vos-ei qual a mercê que o ímpio recebe ao cabo de Deus e qual a herança que, por decisão da divindade, os homens ruins devem aceitar.

Ora, em primeiro lugar, embora a prole do ímpio seja numerosa, todavia será cortada pelo ferro e os seus descendentes acabarão destruídos pela fome. Mas os restantes, que escaparem ao ferro ou à fome, hão-de perecer consumidos pela peste e serão lançados no sepulcro devorados pelo pior género de morte: no funeral deles nem sequer as suas mulheres os hão-de chorar, pois todos os hão-de odiar e detestar intensamente. Se o 
Adeone me furiosum et insanum existimatis ut ad hunc usque diem simulatione pietatis et ficta specie religionis boni atque sancti uiri famam collegisse putetis? Ne tantum quidem uel ingenio uel usu uel disciplina ualeo ut non plane uideam nullum omnino solidum uitae fructum mendacio et uanitate comparari? Quam enim, quaeso, mihi spem in uita proponere potuissem, si uirtutis ementitae fraudibus innixus fuissem? Num spes illius, qui pietatem nefarie simulat, firma et constans esse poterit? Num is, qui uirtutis simulatione ad dignitatem obrepere contendit, aliquam utilitatem ex machinatione tam scelerata percipiet? Non profecto, cum enim maximum sibi lucrum ex improbitate fecisse putauerit, animam illi repente diuinum numen eripiet.

Quid ergo? Num, cum is, qui libidines inclusas fallaci uirtutis specie contegit, in angustias adductus ad Deum clamauerit, audietur? Num poterit aliquando ueram uoluptatem percipere animumque [79] suum cum aliqua iucunditate diuini Spiritus oblectare? Num diuini Spiritus appulsu commoueri et incitari poterit, ut in omni tempore ad Deum clamet et illius opem fidenter imploret? Minime gentium. Quid igitur? Adeone uobis stultus et amens esse uideor ut, una opera, spem mihi totius utilitatis, et uerissimae dignitatis et tranquillitatis, firmissimique praesidii, sempiternaeque uoluptatis, diuinaeque familiaritatis et coniunctionis sponte mea praeciderim? Nihil uidi? Nihil a maioribus accepi? Nihil ex tanto rerum diuinarum studio mihi ad usum uitae comparaui, ut intelligerem nihil esse mendacio flagitiosius aut quod beatae uitae rationi aduersetur infensius?

Vt autem clarius uideatis me nec amentia uexari neque mei ipsius odio commoueri, ut in me ipsum pestem machiner, exponam uobis ea quae non ab hominibus accepi, sed a diuino Spiritu didici, et disciplinam, quam Dominus ipse mihi tradidit, haud occultabo. Confidentius autem loquar quod oratio haec mea non est habenda cum hominibus rerum diuinarum ignaris, sed cum iis qui bonam uitae partem in rerum caelestium peruestigatione consumpserunt. Quo magis mirandum est uos, cum tantum sitis in sapientia progressi et alia tam acute uideatis, hoc in loco in tam leues et inanes sententias incidisse. Exponam igitur uobis quam mercedem impius a Deo tandem accipiat et quae hereditas maleficis hominibus, decreto numinis, adeunda sit.

Primum quidem, licet impii suboles multiplex exsistat, ea tamen ferro praecidetur et posteri illius fame confecti deficient. Reliquiae uero, quae uel ferrum uel famem effugerint, lue tabescentes interibunt pessimoque genere mortis absumptae in sepulcrum deiicientur: ne uxores quidem illorum in eorum funere lamentabuntur, erunt namque omnibus uehementer odiosi et inuisi. Si 
varão sacrílego acumular montes de prata, tão grandes que sejam comparáveis a uma grande mole de terra amontoada, se tiver tão numerosa e variada mobília que, como areia, seja impossível contá-la, todavia todas estas coisas que alcançara com enorme desvelo, actividade e cuidado, que ajuntara e acumulara em casa e mantivera resguardadas com toda a segurança, hão-de ser desviadas para proveito dos homens piedosos. O iníquo comprará roupas que o justo vestirá, o homem impuro acumulará prata que o varão puro e íntegro há-de distribuir com largueza. É que Deus estabeleceu que os homens ímpios sirvam à glória dos piedosos e que as riquezas, actividades, capacidades, esforços e até maquinações de crimes dos desonestos, se enderecem ao proveito, engrandecimento e glória eterna dos bons.

Ora, assim como a traça aos poucos rói e vai rasgando com a sua mordida a roupa em que se oculta, do mesmo modo o desonesto provoca a ruína e destruição da casa que construiu para si, e o que edificou não há-de durar mais do que a cabana [80] feita para guardar a vinha durante um prazo de tempo assaz limitado. O homem que se ocupa em guardar atentamente as suas riquezas há-de acabar por morrer e a grande quantidade de bens não o livrará da morte. E, ao falecer, não poderá juntar-se ao número dos que gozam da verdadeira vida e, quem puser os olhos sobre ele, não verá nem sequer vestígios da sua primitiva opulência. O terror atacá-lo-á como chuvas imoderadas e repentinas e durante a noite a tempestade e a procela hão-de aniquilá-lo, a ele que nada suspeitava de hostil. O vento de leste lançar-se-á sobre ele e arrancará o homem da sua posição e turbilhões violentíssimos hão-de precipitá-lo do lugar em que lhe parecia que estava muitíssimo seguro. O Senhor enviará contra ele uma grande quantidade de males e não lhe concederá perdão. E assim o mofino, oprimido por desgraças perpétuas, assustado e angustiado com o medo dos suplícios que lhe foram estabelecidos, ainda que se esforce por escapar através da fuga e, atormentado pelo medo, corra em todas as direcções, todavia não poderá de nenhuma forma evitar o juízo do Senhor nem fugir ao castigo. Quem vir a ruína e fim do ímpio há-de aplaudir e dirigir-lhe insultos e invectivá-lo e cuspir-1 -he a partir deste mesmo lugar em que ele, ensoberbecido com as riquezas, perpetrara tão grande número de crimes. Por consequência, não digo que a vida do homem ruim é feliz, mas penosa e desgraçada e digna da maior execração por parte de todos os que possuem um entendimento são; todavia afirmo que é difícil de averiguar a razão pela qual Deus por vezes permite que eles possuam em abundância as comodidades da vida e os bons sejam atribulados por incómodos.

Com efeito, as causas de muitas coisas encontram-se ocultas e envoltas em tão grande obscuridade que é muitíssimo difícil arrancá-las das trevas e investigá-las: as quais, sem embargo, com o andar do tempo fornecem algumas pistas para o seu conhecimento. É que existem certos sinais mediante os quais por vezes se acaba por chegar à compreensão de algumas coisas que estão afastadas dos sentidos. De facto, através da sugestão de certos indícios conhecem-se os veios da prata e extrai-se e funde-se o oiro que se oculta sob a terra. Do mesmo modo, o ferro é arrancado das entranhas da Terra e, a partir da rocha aquecida e posta ao rubro, produz-se o duro bronze. É que o Senhor estabeleceu às trevas um limite, para que não ocultassem para sempre o que fora encerrado dentro 
uir nefarius argenti tantos aceruos exstruat, ut sint cum magna telluris congestae mole comparandi, si tam uaria atque multiplex supellex illa sit ut, instar arenae, dinumerari non possit, ea tamen omnia quae summo studio, cura, sollicitudine quaesierat, domum congesserat et cumulauerat et omni custodia saepta tenuerat, ad piorum hominum utilitatem reuocabuntur. Comparabit iniquus uestes quas iustus induet, argentum coaceruabit homo impurus quod uir castus et integer large distribuet. Sic enim est a Deo constitutum ut impii homines piorum gloriae seruiant improborumque opes, studia, facultates, contentiones atque adeo scelerum machinationes ad bonorum fructum et amplitudinem sempiternamque gloriam referantur.

Vt autem tinea uestem, in quam se abdit, paulatim arrodit atque morsu dilacerat, similiter improbus domui, quam sibi aedificauit, exitium et interitum molietur, neque longius aedificium illius durabit quam tugurium [80] uineae custodiendae gratia ad breue admodum tempus erectum. Is qui diuitiis suis asseruandis uigilanter incumbit, morietur tandem nec eum pecuniarum multitudo ab interitu uindicabit. Et, dum occumbit, minime ad eorum coetum qui uera uita fruuntur aggregari poterit et, qui oculos in illum intenderit, opulentiae pristinae ne uestigium quidem intuebitur. Terrores illum, ut imbres immodici atque repentini, exagitabunt nocteque, nihil hostile suspicantem, tempestas atque procella peruertet. Eurus in illum ruet hominemque de statu conuellet et de loco, in quo optime consistere uidebatur, turbines uehementissimi deturbabunt. Magnam uim malorum immittet in illum Dominus nec ei ueniam tribuet. Itaque miser, calamitatibus sempiternis oppressus metuque suppliciorum, quae sunt illi constituta, trepidus et anxius, ut fuga se proripere contendat et in omnes partes, exanimatus formidine, discurrat, non tamen iudicium Domini declinare neque cruciatum effugere ullo modo poterit. Qui impii ruinam et occasum mente perspexerit, manibus plaudet in eumque maledicta conferet et ex eo ipso loco, in quo is, opibus inflatus, tanta scelera molitus fuerat, illum conuiciis atque sibilis insectabitur. Non igitur dico hominis scelerati uitam esse beatam, sed acerbam et calamitosam et omnibus, qui sana mente sunt, ualde exsecrandam; hoc tamen affero, rationem quare Deus illos interdum uitae commodis affluere et bonos incommodis afflictari patiatur, esse exploratu difficilem.

Multarum enim rerum causae latent tantis obscuritatibus inuolutae ut illas e tenebris eruere atque peruestigare difficillimum sit: quae tamen temporis progressu dant aliquas ad sui cognitionem uias. Sunt enim notae quaedam, quibus ad aliquarum rerum intelligentiam, quae sunt a sensibus remotae, aliquando tandem peruenitur. Signorum enim quorumdam admonitu, argenti uenae cognoscuntur et aurum sub terra latens effoditur atque conflatur. Ferrum similter e terrae uisceribus expromitur et ex lapide concalefacto et incenso uis aeris effunditur. Dominus enim finem tenebris statuit, ne perpetuo occultarent quod illis fuerat inclusum. Vt enim rerum formas absoluat atque perficiat, rupes 
delas. Na verdade, a fim de levar a cabo e criar as formas das coisas, sonda as rochas encerradas nas trevas profundas e penetra com a inteligência a densíssima cerração, para daí fazer sair coisas admiráveis.

O rio precipita-se trasbordante de tamanha abundância de água que os viajantes não podem vadeá-lo, pois corre por um leito tão profundo e com uma corrente tão rápida que ninguém o atravessa a pé. O mesmo rio torna a reduzir o caudal e, tomando debaixo de terra um outro curso, desaparece da vista dos homens. A terra dá abundantes produções, mas, noutras alturas, sacudida por abalos sísmicos, abre fendas e é devorada pelas chamas, como pelo incêndio do fogo interno. Existe um lugar abundante de tamanhas riquezas que $[\mathbf{8 1}]$ as suas pedras são safiras e está cheio de terra aurífera. E todavia nem mesmo as aves conhecem o caminho que leva até lá e é completamente desconhecido até para os olhos das pegas, que gostam de ouro. A ferocidade da ambição humana ainda não entrou naquele caminho nem a violência do leão deixou pegadas naqueles lugares. E assim nem a vaidade, nem a soberba, nem a crueldade puderam de algum modo apoderar-se daquelas riquezas. Quando o Senhor estende a Sua mão as pedras saltam quebradas e os montes são arrancados dos seus lugares. Os rios correm e manam dos penedos fendidos e coisas muitíssimo preciosas, que se escondem encerradas na prisão da Terra, estão colocadas diante dos Seus olhos e vista. Tudo isto se faz por deliberação e governo do Senhor, o qual até das gotas que pingam de todos os lados e correm para um certo sítio faz sair rios sobre a face da terra e mostra à luz muitas coisas escondidas debaixo dela.

Ora, quem possui tamanha inteligência ou se singulariza por tais dotes de sabedoria que seja capaz de abarcar com o entendimento e explicar por palavras esta tão grande variedade e beleza das coisas e a admirável ordem em todas as partes da natureza? Quem tinha examinado as coisas que se encontravam ocultas pela terra? Quem pôde oferecer o modo e caminho pelos quais, depois de patenteada a entrada, se mostrassem à luz? Quem compreenderá, mediante palavras e razão, aquela força e razão com que o governante do mundo inteiro cria, altera, muda, junta, retira e faz sair das trevas e põe à luz tudo o que vemos? Logo, se não compreendemos o que vemos com os olhos, apalpamos com as mãos e o que faz parte da nossa experiência, e não podemos apontar os motivos pelos quais certas coisas se escondem e outras estão à vista, e as que estavam ocultas se revelam e as que eram patentes se ocultam, de que modo poderemos, ao cabo, abarcar facilmente com o entendimento e a razão os desígnios a que o Senhor atende ao tolerar durante algum tempo os ruins e fazer passar provações aos bons?

Por conseguinte, resta que ninguém deve julgar acerca de coisa alguma deliberada por Deus, se primeiro não escutar e provar d' Ele os ensinamentos da mais verdadeira sabedoria. Acaso a sabedoria deve procurar-se noutro lugar? Acaso existe outra origem de onde nos mane a compreensão? Certamente que não. Mas os homens ignoram quão grande é o valor da sabedoria porque não vêem a fonte de onde nasce, pois não se encontra na terra cultivada pela actividade humana, para que seja possível obter-se mediante o trabalho e diligência dos homens.

Logo, se apoiado em ti, estenderes o espírito por todas as partes da natureza para encontrar a sabedoria, não a encontrarás em nenhum sítio, porquanto a imensidão das 
profunda caligine demersas scrutatur et densissimas tenebras mente penetrat, ut inde res admirandas eliciat.

Erumpit fluuius tanta aquarum copia redundans ut a peregrinis uado transiri non possit, alueo enim profundo et gurgite rapido fertur, ita ut nemo pedibus illum traiiciat. Idem rursus attenuatur et, sub terram in alium cursum deflexus, ab hominum oculis remouetur. Tellus fruges laetas effundit, alio uero tempore, terraemotu conquassata, dehiscit et, tamquam ignis inclusi incendio, deflagrat. Est locus tantis diuitiis abundans ut lapides [81] illius sint sapphiri et glebis aureis expletus sit. Et tamen ne uolucres quidem adhuc uiam tenent quae ad illum ferat et est oculis etiam picarum, quae auro gaudent, prorsus incognitus. Non est adhuc ingressa in illam uiam ambitionis humanae feritas neque leonis truculentia in locis illis uestigium impressit. Itaque nem leuitas, neque insolentia, neque crudelitas opibus illis potiri ullo modo potuit. Cum Dominus intendit manum suam silices perfracti desiliunt et montes sedibus suis conuelluntur. E saxis discissis flumina labuntur et fluunt et res pretiosissimae, quae terrae claustris inclusae latitant, sunt in illius oculis et aspectu constitutae. Haec omnia Domini consilio et moderatione fiunt, qui etiam ex guttis, undique sillantibus et in certum locum influentibus, fluuios in terrae faciem elicit multasque res, sub terram absconditas, in lucem profert.

Quis autem tantum ualet ingenio aut tantis sapientiae opibus excellit ut hanc tantam rerum uarietatem et pulchritudinem et admirabilem, in omnibus naturae partibus, rationem, et mente comprehendere et uerbis explanare queat? Quis ea, quae erant occultata terris, inspexerat? Quis modum et uiam qua, patefacto aditu, in lucem prodirent largiri potuit? Quis illam uim et rationem, qua mundi uniuersi moderator omnia, quae cernimus, creat, uersat, immutat, condit et promit et tenebris abdit et in lucem educit, uerbis et ratione consequetur? Si ergo quae uidemus oculis, quae contrectamus manibus, quae sunt usibus nostris exposita non intelligimus, neque rationes quibus res quaedam latent, quaedam in oculis sunt et, quae recondita erant, aperiuntur, et, quae aperta, conduntur, assignare possumus, quo tandem modo consilia, quibus Dominus in improbis aliquo tempore tolerandis et in bonis probandis utitur, facile complecti mente et ratione poterimus?

Reliquum igitur est ut nemo debeat de re qualibet a Deo designata iudicare, nisi prius ab illo uerissimae sapientiae disciplinam hauserit atque delibauerit. Num aliunde petenda sapientia est? Num est locus alius unde ad nos intelligentia permanet? Non certe. Quantum uero sapientiae pretium sit ignorant homines quia fontem unde ortum habet minime uident, nec enim in terris humana industria cultis inuenitur, ut possit hominum labore et studio comparari.

Ergo, si per te nixus, in omnes naturae partes animum intenderis ut sapientiam inuestiges, eam nusquam reperies, aquarum enim immensitas dicet: 
águas há-de dizer: "Não a tenho" e o imenso e profundo mar negará que viu a sua forma. É que, embora as águas contenham a natureza da terra e na superfície se mostrem simples e nas profundezas estejam cheias de tantos e tão variados monstros e seres vivos, todavia não conseguiram alcançar nenhum conhecimento da sabedoria. Ela não se comprará pelo preço de um tesouro escondido e selado; não será avaliada pelas mais elevadas quantias de prata. Ela superará em muito o ouro trazido das regiões orientais. O brilho e formosura do ónix e da safira de forma alguma se podem comparar com o resplendor e dignidade da sabedoria. [82] O fulgor do ouro e o diamante não resplandecem tanto que possam aspirar ao fulgor e ornato da sabedoria, nem ela pode ser trocada, em perfeita igualdade de condições, com taças feitas do mais puro ouro. Cotejadas com ela as pedras de imenso preço serão de nenhum valor e em dignidade avantajar-se-á muito e de longe a todas as gemas de brilho mais intenso. O topázio da Etiópia ser-lhe-á muito inferior em dignidade e o ouro puro e sem mistura não lhe disputará a superioridade do valor.

Logo, uma vez que em utilidade, graça e beleza vence e se avantaja a todas as riquezas, bens e recursos, conclui-se que todos os que têm os olhos postos na verdadeira utilidade e no prazer firme, a queiram e amem e desejem alcançar e consagrem todos os desvelos da vida para consegui-la e gozá-la e que, por causa do amor dela, desprezem e desdenhem todas as restantes coisas que aos homens parecem cómodas, agradáveis e muitos ilustres.

Mas, pergunto, donde nos será possível mandar vir uma coisa tão ilustre e sublime, na qual exclusivamente se funda toda a essência da vida bem-aventurada? Qual é a sua origem e fonte? Donde provém para os homens? Qual é o lugar que a ciência escolheu para seu poiso e domicílio? Não está à vista nem sobressai, para que os olhos dos seres vivos a não possam divisar. Não a avistam as aves, que gozam livremente do céu, esvoaçam por todo o ar e têm uma vista muitíssimo penetrante. A região dos infernos, na qual impera a devastação e a ruína, na qual são precipitados inúmeros homens conceituados pelo prestígio de sábios, dirá que conhece o nome da sabedoria só de fama e ouvido, mas que não pôde abarcar a sua essência e natureza. Por conseguinte, nem o céu, nem a Terra, nem as regiões mais elevadas, nem as inferiores, nem as coisas mais pequenas, nem as eternas, nem as mortais, nem a totalidade da natureza, nem quaisquer partes principais dela podem reivindicar para si a origem da sabedoria e ensoberbecer-se com o seu nome. Só Deus conhece o caminho para ela e abarca com o entendimento e razão o lugar e morada dela.

É que Ele, atento a toda a natureza e estendendo-se por todas as coisas, esquadrinha as regiões mais remotas da Terra e divisa todas as formas das coisas que se encerram no âmbito do céu, a fim de tudo regular de modo muitíssimo hábil. Com efeito, pesou os ventos com pesos certos e mediu as águas de forma rigorosa e justa; igualmente, determinou limites para a chuva e estabeleceu uma certa região no céu, para que os relâmpagos e trovões nela se deslocassem. Finalmente, Ele é quem ligou todas as coisas mediante uma ordem, uma harmonia, uma lei, um equilíbrio e uma disposição, e as ajustou com tão grande perícia que, por uma aliança da mais completa concórdia, uniu entre si todas as partes do mundo que por natureza se repelem. E, assim, Ele é o único 
"Expers illius sum" et uastum atque profundum mare negabit se formam illius aspexisse. Quamuis enim aquae terrarum naturam coerceant et in sublime etiam attenuate ferantur et tantis tamque uariis in profundo monstris et animantibus expletae sint, non tamen ullam sapientiae rationem attingere potuerunt. Illa non gazae reconditae et obsignatae pretio comparabitur; non argenti ponderibus maximis aestimabitur. Aurum ex orientis regionibus allatum multis partibus ab illa superabitur. Nec onychis neque sapphiri claritas et pulchritudo est ullo modo cum sapientiae splendore et dignitate conferenda. [82] Nec auri fulgor nec adamas tantum splendet ut ad sapientiae fulgorem et decus aspiret, nec ea cum uasis ex auro purissimo factis permutari ulla aequabili condicione potest. Ad illam collati lapides ingentis pretii nullius aestimationis erunt et omnes gemmas clarissimas longe multumque dignitate superabit. Topazius Aethiopiae illi multum de dignitate concedet nec aurum purum putumque cum illa pretii magnitudine certabit.

Ergo, cum omnes opes et possessiones et facultates utilitate et iucunditate et elegantia uincat et superet, restat ut omnes qui ueram utilitatem et stabilem uoluptatem et sempiternum decus intuentur, illam uelint et ament et adipisci cupiant omniaque uitae studia ad illam parandam et fruendam conferant atque, prae illius amore, reliqua omnia, quae commoda, iucunda et praeclara hominibus apparent, contemnant atque despiciant.

Sed unde, quaeso, rem tam praeclaram et excelsam, in qua una omnis beatae uitae ratio consistit, arcessere nobis licebit? Quae est illius origo et fons? Vnde ad homines peruenit? Quis est locus in quo scientia sibi sedem et domicilium delegit? Non exstat, non eminet, multis difficultatibus obstruitur, ne possit animantium oculis usurpari. Volucres, qui caelo libero fruuntur et toto aere uolitant et acutissime uident, illam minime contuentur. Inferorum regio, in qua uastitas et exitium dominatur, in quam innumerabiles homines, opinione sapientiae praestantes, deiiciuntur, dicet se quidem sapientiae nomen fama tantum et auditione percepisse, uim tamen illius et rationem minime complecti potuisse. Non igitur caelum, neque terra, neque supera, nec infima, neque sempiterna, neque mortalia, nec natura uniuersa, nec ullae partes illius praecipuae possunt ortum sapientiae ad se reuocare nomineque illius insolenter efferri. Solus Deus uiam illius nouit et locum et sedem illius mente et ratione complectitur.

Is enim, in omnem naturam intentus atque per omnia pertinens, extremas orbis terrarum regiones explorat et omnes rerum formas, quae caeli ambitu coercentur, inspicit, ut cuncta sollertissima ratione constituat. Ventos enim certis ponderibus examinauit et aquas rata et aequabili mensura definiuit; pluuiae similiter modum statuit et certam in aere regionem designauit, qua fulgura et tonitrua discurrerent. Is denique est qui omnia ordine, modo, lege, pondere, ratione deuinxit et tanto artificio concinnauit ut omnes mundi partes, natura repugnantes, uno inter se summae consensionis foedere colligaret. Itaque is solus est qui, ex omni aeternitate, sapientiam uidit, explicuit, informauit intimaque mente complexus est. 
que desde toda a eternidade viu, interpretou, descreveu e abarcou no interior do Seu espírito a sabedoria. Por conseguinte, Ele é o único que por natureza deve ser tido por sábio e até por autor e progenitor da sabedoria, merecendo ser celebrado por todos os séculos da eternidade com o nome de Sabedoria.

Mas vejamos. Porventura Ele quis que os homens fossem totalmente excluídos do acesso à sabedoria? De forma alguma, pois tornou possuidores de sabedoria todos os que se quiseram consagrar aos Seus ensinamentos. [83] Mas uma coisa é a sabedoria que reside no entendimento do supremo Criador e governador, outra a que se requer de um homem puro e íntegro. Com efeito, Deus não exige dos homens a actividade de percorrerem com o espírito a Terra, de cruzarem com o entendimento os mares, de delimitarem os espaços celestes e de investigarem as coisas recônditas e ocultas para examinarem aquilo que se esconde nos esconderijos secretos. Então qual é o ponto principal daquela doutrina que Deus deu aos homens? - Nada mais nada menos que aquela que se cifra no piedoso temor da divindade e na pureza e inocência de vida. É que Deus falou aos homens do seguinte modo: "Fiz consistir a vossa sabedoria unicamente no temor a Deus e a essência da vossa inteligência funda-se em que vos aparteis de toda a infâmia e impureza." Por conseguinte, tal como concluímos deste ensinamento do Senhor, toda a sabedoria dos homens que se entregaram à doutrina do Senhor funda-se na Sua santíssima adoração e temor, e no ódio do mal, que naturalmente nasce do temor. Portanto, só devem ser tidos na conta de sábios, não os que procuram o louvor de sábios, ensoberbecidos com os argumentos concluídos por uma razão fraca, mas os que temem a Deus e se abstêm de maldades e adoram a inteligência divina com um espírito incorrupto. ${ }^{2}$

Ora, quando concluiu com estas palavras, deu de novo começo a outro discurso dizendo o seguinte:

- Oxalá veja algum dia a minha condição restituída àquela primitiva época em que Deus me defendia com a Sua guarda e protecção. É que então Ele levava a luz diante do meu entendimento e, apoiado nesta luz, até nas trevas caminhava e destramente me desembaraçava em caminhos obscuros e incertos e em lugares muitíssimo difíceis por onde me era mister ir. Oxalá estivesse naquele lugar em que estava naquela idade que é perturbada pelo flagelo de muitas inquietações, como pelos turbilhões e procelas da pior das invernias, na qual, apesar de tudo, o meu espírito gozava de paz e tranquilidade, pois entregava-me, não à sensualidade, mas à religião, e já então o Senhor partilhava comigo os Seus segredos e protegia a minha tenda com a Sua graça e bondade. Então estava rodeado pela protecção do Senhor todo-poderoso e cercado pela guarda fiel dos meus criados. Para onde quer que me dirigia, tudo trasbordava de manteiga, e o azeite, como que espremido das pedras, à semelhança de rios correndo de fonte perene, manava para meu proveito de modo assaz abundante. E quando me dirigia para a porta da cidade a fim de participar nas sessões judiciais nos ajuntamentos de homens, mandava colocar a minha cadeira na praça. Os jovens escondiam-se atemorizados com a presença da minha gravidade e firmeza e os velhos levantavam-se em sinal de respeito; diante de mim as pessoas principais mantinham-se em silêncio acerca de todos os assuntos. É que era tão 
Solus igitur est natura sapiens atque adeo sapientiae auctor et parens habendus et in omni saeculorum aeternitate Sapientiae nomine celebrandus.

Sed uideamus. Num is homines aditu sapientiae penitus exclusos esse uoluit? Minime, omnibus enim, qui sese in illius disciplinam conferre uoluerunt, sapientiae compotes effecit. [83] Sed alia est sapientia quae in mente summi conditoris atque moderatoris insidet, alia quae ab homine casto et integro flagitatur. Nec enim hanc operam exigit Deus ab hominibus, ut terras animo lustrent, maria mente peragrent, caeli spatia definiant et abstrusa atque recondita peruestigent ut, quae obscuritatis latebris occultantur, inspiciant. Quaenam est igitur illius disciplinae summa quam Deus hominibus dedit? - Haec plane quae pio numinis metu et uitae puritate et innocentia continetur. Sic enim Deus homines est allocutus: "Vestra sapientia in hoc tota consistit, ut Deum timeatis, intelligentiaeque uestrae uis in eo posita est, ut ab omni flagitio et impuritate declinetis." Vt igitur ex hac Domini traditione colligimus, omnis hominum sapientia qui se Deo in disciplinam tradiderunt, in illius sanctissimo cultu atque metu, et in odio improbitatis, quod quidem ex eo metu nascitur, est constituta. Non igitur qui, argumentis infirma ratione conclusis inflati, sapientiae laudem uenantur, sed qui Deum timent et a maleficiis abstinent mentemque diuinam incorrupta mente uenerantur, sapientes habendi sunt.

Haec autem ubi perorauit, aliud rursus exordium orationis instituit. Sic igitur inquit:

- Vtinam uideam aliquando statum meum ad illa pristina tempora reuocatum, quibus me Deus custodia sua atque praesidio muniebat. Tunc enim ille lumen menti meae praeferebat, eoque lumine fretus, etiam in tenebris iter faciebam et in uiis obscuris et incertis locisque difficillimus, qua mihi esset eundum, sapienter explicabam. Vtinam eo loco essem quo eram ea aetate quae est multis perturbationum tempestatibus, quasi hiemis maximi turbinibus atque procellis, agitata, in qua tamen animus meus pace et tranquillitate fruebatur, nec enim libidini, sed religioni seruiebam, et iam tunc Dominus mecum arcana sua communicabat et tabernaculum meum gratia et benignitate sua protegebat. Eram autem tunc et praepotentis Domini praesidio cinctus et seruorum meorum fideli custodia circumsaeptus. Quocumque me contuleram, omnia mihi butyro circumfluebant, et oleum, similiter saxo expressum, quasi riuis a perenni fonte deductis, ad usus meos admodum late dimanabat. Cum uero in portam ciuitatis prodibam ut in celebri hominum conuentu ius dicerem, in foro sellam meam collocari iubebam. Iuuenes, meae grauitatis et constantiae praesentia deterriti, se occultabant, senes mihi assurgentes assistebant; principes de rebus omnibus in conspectu meo silebant. Tanta enim illorum erat erga me obseruantia ut non auderent inter se, 
grande a consideração que tinham por mim que, estando eu presente, não se atreviam a falar e conversar uns com os outros. Os próceres, transidos de admiração, calavam-se e as suas línguas colavam-se imóveis ao céu da boca. Os que escutavam as minhas palavras desejavam-me todas as prosperidades e felicidades e os que viam as minhas obras testificavam a minha equidade e constância. É que defendia da iniquidade e injustiça o pobre atribulado que implorava a minha ajuda contra as iniquidades dos poderosos e [84] auxiliava o órfão, privado do socorro de todos. Muitos, contra quem se aparelhava a ruína, defendidos pela minha equidade, exaltavam-me com os maiores louvores; do mesmo modo as viúvas, que com a minha defesa apartava da aflição e da miséria, declaravam com alegres clamores que tinham sido defendidas com a minha ajuda.

Os meus grandes esforços não eram para andar ornado com vestes e roupagens régias nem para trazer na cabeça um extraordinário diadema, mas sim para me ataviar com os ornamentos da justiça. Por conseguinte, as minhas vestes e roupagens foram a justiça e, como com um manto, cobria-me com a beleza da equidade e, em vez do diadema e das insígnias da dignidade régia, ornava-me com a imparcialidade das sentenças. Servi de olhos ao cego e fiz as vezes de pés ao coxo; ensinei os ignorantes; alentei os que estavam prostrados; olhei com benignidade para os que careciam de pátria. Nos julgamentos nunca atendi às ofensas ou à amizade nem proferi sentença com espírito precipitado, mas indaguei escrupulosamente a essência e sentido da lei. Por conseguinte, examinava escrupulosamente a causa que não conhecia, por forma a, depois de estudada e conhecida, poder julgar do modo mais recto. Contive a violência e crueldade do homem ruim, fosse ele qual fosse, e arranquei-lhe a presa das fauces.

Mas a esperança que me sustentava era pensar que, consumido pela velhice, haveria de soltar o último suspiro na minha cama e não viria a morrer esmagado por nenhuma violência ou desgraça. É que me prometia a mim mesmo paz, quietação e uma vida prolongada, uma vez que me abrasava em tão grande amor da equidade e da beneficência. De facto, julgava muito firmes as minhas raízes, como se se estendessem para a água, e nunca imaginei que as minhas searas deixariam de receber o orvalho do céu, porquanto não punha a minha confiança na mentira e na falsidade, mas, apoiado na lealdade e no devido sentido do dever, colocava toda a esperança das minhas coisas na ajuda d' Aquele que, como com águas de levada, torna próspera e frutuosa a condição dos justos e com a Sua graça alegra a vida deles como com orvalho caído das alturas.

Aumentava a minha glória com novos ornamentos e de dia para dia adquiria maiores forças o arco que trazia na mão, de tal modo que não só na paz dirigia a comunidade com extraordinária moderação, mas também na guerra destruía os inimigos com invencível denodo. Os meus concidadãos escutavam-me atentamente e aguardavam com ansiedade a sentença que eu dava e, calados, acatavam sem qualquer oposição o meu parecer. Ninguém refutava os meus discursos e as minhas palavras tinham uma extraordinária influência sobre o espírito deles. Com efeito, esperavam ansiosamente pela minha sensatez como pela chuva do Outono e pediam a minha palavra não menos avidamente do que os aguaceiros da Primavera. Se sorrisse moderadamente, dificilmente o tomavam como sinal de alegria e procuravam com uma vontade sumamente agradecida a jovialidade do meu 
me praesente, colloqui atque sermocinari. Proceres, admiratione defixi, tacebant eorumque lingua palato immobilis adhaerebat. Qui orationem meam auribus accipiebant mihi omnia felicia et fausta precabantur et qui oculis opera mea cernebant, aequitatis et constantiae mihi testimonium dabant. Nam pauperem afflictum, operam meam contra potentium iniurias implorantem, ab iniquitate et iniuria uindicabam et [84] pupillo, omnium praesidio destituto, subsidium afferebam. Multi, quibus exitium parabatur, aequitate mea defensi, me summis laudibus extollebant; uiduae similiter, quas meo patrocinio a maerore atque sordibus auocabam, laetis clamoribus se ope mea defensas fuisse declarabant.

Non ualde laborabam ut uestitu et cultu regio ornatus incederem nec ut insigne diadema capite gestarem, sed ut iustitiae ornamentis excolerer. Cultus igitur atque uestitus meus iustitia fuit et aequitatis elegantia, quasi pallio, amiciebat et, pro diademate et regiae dignitatis insignibus, aequabilitate iudiciorum exornabar. Oculus fui caeco et uice pedum claudo; imperitos instruxi; iacentes excitaui; egentibus patria benignitate prospexi. Numquam in iudiciis aliquid uel offensioni uel gratiae concessi neque mente praecipiti sententiam tuli, sed iuris uim et rationem diligenter inuestigaui. Causam igitur quam ignorabam, diligenter examinabam, ut, ea perspecta et cognita, rectissime iudicarem. Cuiuslibet hominis improbi truculentiam et immanitatem compressi praedamque ex faucibus illius eripui.

Ea uero spe sustentabar quod existimabam fore ut, senio consumptus, in lecto meo extremum spiritum ederem nec ulla ui aut calamitate oppressus interirem. Mihi enim, eo quod tanto studio aequitatis et benignitatis incensus essem, pacem et otium et uitae diuturnitatem pollicebar. Radices namque meas, quasi essent ad aquas diffusae, admodum firmas arbitrabar, segetesque meas numquam a rore caelesti deserendas esse suspicatus sum, nec enim uanitate et mendacio confidebam, sed, fide et officio debito nixus, omnem spem rerum mearum in illius ope reponebam, qui iustorum statum, quasi inductis aquis, florentem atque fructuosum efficit illorumque uitam gratia sua, quasi rore superne demisso, laetificat.

Gloria mea nouis ornamentis augebatur et arcus, quem manu gestebam, maiores uires in dies colligebat, ita ut non solum in pace rem publicam singulari moderatione temperarem, uerum et in bello hostes inuicta uirtute conciderem. Me ciues attente audiebant et quam sententiam dicerem, suspensis animis exspectabant et consilio meo, taciti, sine ulla recusatione parebant. Orationem meam nemo refellebat sermoque meus in eorum animos mirabiliter influebat. Meam namque prudentiam, quasi autumni pluuiam, sollicite exspectabant et, non minus auide quam primi ueris imbrem, eloquium meum requirebant. Si leniter arrisissem, id prae gaudio uix credebant meique uultus hilaritatem grata admodum uoluntate prosequebantur. Itaque sic naturam meam temperabam ut 
semblante. E assim regulava de tal modo a minha natureza que, por um lado, os refreava com o rigor e a firmeza, por outro, com a mansidão e afabilidade os cativava e atraía as suas vontades. É que, até onde era lícito, adaptava-me aos costumes deles. No sólio ocupava o lugar principal, e caminhava como um rei, rodeado pela multidão dos homens fortes, e, com a maior boa vontade, ofereciam-me as mais elevadas honrarias, como a pessoa que [85] tivesse sido colocada no mando supremo, não por causa do seu proveito e vantagem pessoais, mas para alívio público de todos os infelizes. Esta foi a minha condição, excepcionalmente cumulada de todas as coisas, quer as que pertenciam à formosura e ornamento de espírito, quer ao aparato e esplendor de vida, quer à dignidade do poder e ao prestígio do nome.

Agora, porém, sou escarnecido por homens muito mais jovens do que eu, a cujos pais eu nem sequer entregaria o cuidado de guardarem os meus rebanhos juntamente com os meus cães. Ora, ainda que muitos de entre eles possuíram grandes riquezas, não dou qualquer valor a isso. É que é manifesto que o tempo passou por eles de modo tal que na vida não deixaram nenhum testemunho de virtude e os seus nomes se desvaneceram, uma vez eles desaparecidos. Portanto, não são dignos de ser tidos como grandes varões aqueles que, ainda que tenham desfrutado de recursos e poder, deixaram que a vida se passasse sem qualquer fruto: conquanto nem sequer isto seja verdade, antes a maior parte deles foi miseravelmente atribulada, com escassez de todas as coisas. Com efeito, obrigados pela necessidade e pela fome, deixados e abandonados por todos, não há muito tempo, fugindo para o deserto ermo e assustador, viviam na mais completa infelicidade e miséria. No meio dos bosques avidamente apanhavam ervas para comerem e alimentavam-se de raízes de zimbros como de pão. E nem mesmo aí se encontravam em segurança, pois do meio do povoado saíam homens ofendidos com os roubos, para os expulsarem e lançarem fora dos lugares em que se escondiam e os perseguirem com brados, como a ladrões desonrados por muitas infâmias. Habitavam nos sítios em que a violência e ímpeto das torrentes tinham causado grandes desabamentos de terra, em cavernas cavadas a grande profundidade e nos picos mais elevados das rochas, a fim de evitarem o olhar dos homens e protegerem a sua segurança nos esconderijos ou em locais inacessíveis. Viviam ao modo de feras no meio dos bosques e soltavam bramidos como animais selvagens e, abatidos pelo medo, encolhiam-se debaixo dos espinheiros.

E, assim, os filhos destes que - insensatos e infames, e atingidos por muitas feridas, e aviltados por gravíssimas manchas de indignidade - levaram uma existência torpe e, banidos e errantes, suportaram a mais completa indigência, com supremo desdouro e ignomínia, os filhos destes agora insultam a minha desgraça, compõem cantos contra o meu desdouro, tagarelam alegremente acerca da minha desventura. Todos me odeiam como a um mau agoiro e afastam-se para muito longe do meu contacto e, os que se encontram comigo, não têm qualquer pejo em cuspir-me na cara. É que, uma vez que a minha dignidade foi abatida por decisão de Deus e os Seus dardos se cravaram violentamente em mim, os homens mais perversos, ao verem a minha condição miseravelmente atribulada, perdendo por completo a vergonha arremetem desenfreada e violentamente contra mim. A flor da juventude lança-se contra o meu lado direito e esforça-se por fazer tropeçar os meus pés, 
eos, partim seueritate et constantia refrenarem, partim mansuetudine et lenitate permulcerem eorumque uoluntates allicerem. Me namque, quoad fas erat, eorum moribus accommodabam. Et in solio principem locum tenebam et, tamquam rex, hominum fortium multitudine constipatus, incedebam omnesque ad me summos honores summa uoluntate deferebant, quasi ad illum qui non esset [85] proprii commodi et emolumenti gratia, sed propter publicum omnium miserorum solacium, in summo imperio constitutus. Hic fuit status meus, omnibus rebus, siue quae ad animi decus et elegantiam, siue quae ad uitae cultum et magnificentiam, siue quae ad imperii dignitatem et nominis celebritatem pertinerent, egregie cumulatus.

At nunc ludibrio sum hominibus multo me iunioribus, quorum patribus nec eam quidem curam dedissem ut, canibus meis adiuncti, greges meos custodirent. Vt autem multi ex illis opes magnas habuerint, nihil mea refert. Constat enim illos ita senio consumptos fuisse ut nullum in uita uirtutis monumentum reliquerint nomenque eorum, illis exstinctis, euanuerit. Non sunt igitur digni qui in magnis uiris habeantur illi qui, cum opibus et potentia florerent, uitam sine ullo fructu consumi permisere: quamquam ne id quidem uerum est, immo plerique eorum cum omnium rerum penuria miserrime conflictati sunt. Nam, egestate et fame compulsi, ab omnibus deserti atque relicti, non ita pridem in uastam et horridam solitudinem profugientes, uitam in summa miseria et calamitate degebant. Herbas in mediis arbustis auide colligebant ut manderent et iuniperorum radicibus ut pane uescebantur. Nec ibi quidem tuto consistebant, e medio namque populi exibant homines furtis offensi qui eos, e locis in quibus se occultabant, expellerent et eiicerent, et clamoribus, tamquam fures multis flagitiis infames, insequerentur. In locis, ubi ui et impetu torrentium magnae labes terrae factae fuerant, in speluncis in magnam altitudinem depressis, in rupium summis uerticibus habitabant, ut oculos hominum uitarent et salutem latebris aut locorum asperitate defenderent. Inter arbusta uitam ritu ferino propagabant et clamores, instar siluestris animantis, edebant seseque sub densis uaepribus, abiecti formidine, colligebant.

Itaque eorum filii qui, stulti et ignobiles multisque uulneribus saucii infamiaeque grauissimis notis inusti, uitam turpiter egere et, extorres et uagi, extremam mendicitatem, cum summo dedecore et ignominia pertulere, nunc in meas clades insultant, in meum dedecus carmina componunt, de meo casu iucundissime fabulantur. Omnes me, ut malum auspicium, detestantur et a meo contagio se longissime remouent et, qui in me incidunt, faciem meam consputare minime uerentur. Cum enim Dei consilio mea dignitas euersa sit telaque illius in me uehementer adhaeserint ${ }^{2}$ hominesque profligatissimi uideant statum meum

2 adhaeserint] adhaeserunt editio Romana 
para que eu caia, e fecha-me todos os caminhos, para que não possa avançar para onde me dirijo, e de modo sacrílego urde a minha perdição. Empenham-se em impedir todas as minhas actividades e conjuram-se para me perder aqueles que anteriormente não se encontravam unidos por nenhum pacto de aliança e associação. [86] Assim como, depois de os obstáculos destruídos e a passagem franca, o rio ganha um ímpeto de tal maneira violento que facilmente derriba tudo sobre o qual se arroja, assim esses se lançam sobre mim e me atacam com a máxima violência, esforçando-se por destruir todas as minhas coisas e aniquilar por completo a minha posição.

Vítima de uma tão grande crueldade dos homens ruins, que outra coisa me cumpria fazer senão implorar a Tua ajuda, Senhor, que és o mais seguro refúgio da vida inocente? Mas Tu viraste contra mim a Tua ira e inspiraste-me os maiores terrores e feriste com o ímpeto do Teu espírito a minha alma, abrasada no amor da bondade, e por fim fizeste que a minha salvação, como uma nuvem, se afastasse a grande velocidade. Por isso a minha alma se mantém impedida, enleada por enfadosíssimos cuidados e oprimida por situações muitíssimo dolorosas. Durante a noite uma dor violentíssima penetra os meus ossos e os quebra e enfraquece e, entretanto, os que me odeiam de forma alguma desistem de atribular-me e perseguir-me. A intensidade da dor e do calor obrigam-me a despir a minha roupa a cada hora, pois não consigo suportá-la por cima de todo o corpo durante muito tempo. Isto faz que, despido na parte superior, cinja o ventre com a abertura e gola da própria túnica.

Já estou reduzido a tal estado que sou semelhante à lama e comparável ao pó e à cinza. E todavia, apesar de, no meio de tamanhas angústias e sofrimentos, Te invocar, Senhor, única protecção da minha saúde, Tu não me escutas. Insisto e incessantemente peço ajuda, e todavia não afastas com auxílio pronto estes meus males que não se Te ocultam, mas, como que deliberando maduramente sobre o que Te cumpre fazer, adias a Tua ajuda, com o que pareces satisfazer plenamente aos meus inimigos. Por conseguinte, o ódio que anteriormente sentiras contra os ruins, mostraste-o inteiramente contra mim e atacaste o meu espírito com a máxima violência. Levantaste-me ao alto, para que eu fosse disperso pelo vento, e obrigaste o meu estado a desfazer-se e desvanecer-se. A morte, a que já me destinaste há muito, apresenta-se à minha vista e espero este fim, que por lei comum foi imposto a todos os que vivem. É que a morte é um refúgio e um abrigo do sofrimento e um refrigério de toda a desgraça que aflige esta vida, pois o Senhor não costuma ensanhar-se contra os túmulos nem os consumidos cadáveres hão-de bradar por auxílio.

Que hei-de dizer? Ou que causa hei-de atribuir a esta minha desgraça? Com que crime meu se sentiu o Senhor tão indignado para me atacar com uma infelicidade tão grande? Acaso usei de crueldade e desumanidade contra os meus? Maldito seja eu se não me comovia e derramava lágrimas sempre que via alguém derrubado pela desgraça e se a condição do pobre atribulado não feria o meu espírito com uma dor quase igual àquela com que ele era atormentado. Por isso o meu espírito levava-me a ter confiança nos acontecimentos futuros e sentia-me incitado a esperar a mais completa felicidade: porém, em vez de felicidade, abateu-se sobre mim a desgraça; esperava a luz, mas em vez de luz 
miserabiliter afflictum, omni pudore sublato, in me effrenata mente rapiuntur. Iuuentutis flos in dextrum meum latus inuadit pedesque meos labefactare contendit, ut me praecipitem exturbet, omnesque uias meas obstruxit, ne eo quo intendo progredi queam, et in me pestem nefarie machinetur. Omnia studia mea impedire conantur et de mea pernicie coniurant illi qui antea nullo fuerant inter se societatis et consensionis [86] foedere coniuncti. Vt fluuius, molibus disiectis et ostio late patefacto, se adeo uehementer incitat ut omnia in quae tulerit impetum facile prosternat, sic isti in me influentes et, ui maxima concitati, omnes res meas obruere statumque meum funditus euertere nituntur.

In hac tanta improborum hominum crudelitate, quid aliud erat mihi faciendum quam ut opem tuam, Domine, qui es tutissimum innocentis uitae perfugium, implorarem? At tu iram tuam in me conuertisti terroresque mihi maximos obiecisti animumque meum, studio benignitatis incensum, spiritus tui impetu perculisti, perfecisti denique ut salus mea, quasi nubes, celeriter emigraret. Idcirco anima mea, molestissimis curis implicita et luctuosissimis temporibus oppressa, distinetur. Nocte uis ingens doloris in ossa mea penetrat eaque frangit et debilitat et, interim, qui me odio persequuntur, nullo pacto me uexare et insectari desistunt. Cogit me doloris et ardoris uehementia uestem meam singulis horis inuertere, cum eam toti corpori iniectam tolerare diu non possim. Eoque fit ut, superiore parte nudus, uentrem summo ipsius tunicae ambitu et ore praecingam.

Iam eo deductus sum ut sim luto simillimus et cum puluuere atque cinere comparandus. Et tamen, cum in tantis angustiis et acerbitatibus, te, Domine, unicum praesidium meae salutis, inclamem, non exaudis. Insto et opem assidue flagito, et tamen haec mala mea, quae te minime latent, non celeri praesidio repellis, sed, quasi consultans quid tibi sit agendum, auxilium tuum differs, in quo quidem uideris hostibus meis cumulate satisfacere. Odium igitur, quod in improbos ante susceperas, in me totum exprompsisti animumque meum summis uiribus oppugnasti. In altum me sustulisti, ut a uento dispellerer, statumque meum liquefieri atque dilabi compulisti. Mors, cui iampridem a te destinatus sum, mihi ante oculos obuersatur et hunc finem, qui est omnibus qui uiuunt communi lege propositus, exspecto. Est enim mors perfugium portusque supplicii totiusque miseriae, quae uitam hanc circumuenit, alleuamentum, non enim Dominus saeuitiam adhibere solet in tumulos nec attrita cadauera auxilium clamoribus implorabunt.

Quid dicam? Aut quam huius meae cladis causam assignabo? Quonam meo scelere Dominus prouocatus tantum mihi calamitatis inuexit? Num crudelitate et inhumanitate in meos usus sum? Male peream si non commouebar animo atque lacrimas profundebam quotiens aliquem calamitate disiectum animaduertebam et si non pauperis afflicti condicio meum animum eodem prope sensu doloris, quo ille angebatur, afficiebat. Idcirco res mihi euenturas ex animi sententia confidebam et ad spem summae felicitatis excitabar: at mihi pro felicitate calamitas importata est; lucem sperabam, pro luce uero caligine circumfusus sum. 
fiquei cercado pelas trevas. As minhas entranhas fervem com as chamas que ardem por baixo e não sentem qualquer descanso, porque tempos desgraçados me oprimiram sem eu contar. [87] Caminhei contrariado, evitei a luz do Sol e, ao encontrar-me no meio de um grupo de homens, não pude conter-me sem deixar de soltar palavras tristes. Imitei o gemido das serpentes e, semelhante à avestruz, enchi tudo com gritos lamentosos. A minha pele tornou-se de cor negra e os meus ossos secaram com o calor excessivo. A cítara com que me recreava na prosperidade toca acordes tristonhos e, em vez dos instrumentos musicais, que eu tangia, escutam-se os sons de um pranto muitíssimo pungente.

Todavia, nem no meio de tão grandes inquietações me convence de culpa a lembrança de algum crime por causa do qual pareça que com justiça eu deva ser castigado desta maneira. Primeiramente refreei a sensualidade e obriguei e comprometi os meus olhos a não olharem impudentemente para nenhuma donzela, por forma a que mais tarde não pensasse nela com alguma consciência de infâmia. Com efeito, se tivesse incorrido em tão grande desdouro, que prémio me poderia prometer de Deus durante a vida? Que recompensa esperaria dos Céus? Que herança poderia esperar vir a receber do Senhor? Porventura é pouco evidente que Ele odeia os que desonram os puros e os que não reprimem a sacrílega sensualidade? Porventura não é manifesto que pela Sua lei e sentença a perdição está aparelhada para todos os que cometem este crime?

Mas alguém retrucará que durante a noite se praticam muitas infâmias deste género que não podem surpreender-se às claras: como se para aquele Senhor não fossem patentes e manifestas todas as coisas, mesmo que estejam envoltas nas trevas. Acaso não observará todos os meus movimentos e actividades e não examinará todos os meus passos?

E não só refreei a sensualidade, mas também me abstive das restantes indignidades. Com efeito, que o Senhor se encolerize contra mim se incorri em mentira e falsidade e se em alguma coisa me apressei para conceber o embuste. Ele com a balança da justiça pesará o meu espírito e avaliará os meus serviços de acordo com o estalão da lei sempiterna e conhecerá sem engano como em toda a minha vida agi com espírito simples. Se me desviei do caminho da verdade e da justiça, se condescendi com os apetites dos olhos, se manchei as minhas mãos com o crime e a infâmia, que eu semeie e outro coma e que toda a minha descendência seja por completo suprimida. Se me abrasei em desejo da mulher alheia, se armei ciladas à porta do meu vizinho, para atentar contra o pudor daquela que era legítima esposa de alguém, que alguém viole a minha mulher e ela se prostitua à sensualidade de muitos. É que o crime de adultério é um atentado sacrílego e monstruoso e que deve ser punido em juízo com o máximo rigor. Além disso, existe nele um incêndio que devora e consome todos em quem penetrar, a tal ponto que os precipita no suplício do fogo eterno e extingue toda a descendência que proviera do seu tronco.

Igualmente, maldito seja eu se desprezei os rogos dos meus criados ou criadas, quando eles se dirigiam a mim com palavras suplicantes a fim de obterem a sua justiça. Com efeito, se com soberba rejeitar os pedidos dos meus servos, que poderei responder a Deus quando Ele se levantar para, depois de estabelecido o tribunal, castigar o crime dos homens? Acaso quem me formou no ventre da minha mãe não é o mesmo que do mesmo 
Intestina mea subiectis flammis ebulliunt neque laxamentum ullum sentiunt, eo quod me calamitosa tempora nec opinantem oppresserint. [87] Attractus incessi, solis lucem uitaui, stans in hominum conuentu me continere non potui quin lugubres uoces emitterem. Serpentum gemitus imitatus sum atque, struthocameli similis, maestis clamoribus omnia compleui. Cutis mea in nigrum colorem uersa est ossaque mea ardore nimio arefacta sunt. Cithara qua me in rebus secundis oblectabam lugubres modos concinit et, pro musicis instrumentis, quibus utebar, fletus acerbissimi uoces audiuntur.

Neque tamen in his tantis anxietatibus ulla sceleris recordatio me conuicit ob quod merito ad hunc modum plectendus esse uidear. Primum quidem libidinem refrenaui et oculos meos foedere et exsecratione deuinxi ne uirginem aliquam petulanter aspicerem, de qua postea cum aliqua flagitii nota cogitarem. Si enim hoc in me tantum dedecus admisissem, quodnam mihi in uita a Deo praemium pollicerer? Quem fructum e caelis exspectarem? Quam hereditatem mihi a Domino uenturam confiderem? An parum constat illum esse eis, qui labem castis inferunt nefariamque libidinem minime coercent, infensum? Annon perspicuum est omnibus, qui scelus hoc suspiciunt, esse perniciem lege illius atque iudicio comparatam?

Sed dicet aliquis, multa eiusmodi flagitia nocte fieri quae non possint manifesto deprehendi: quasi non omnia, quamuis sint tenebris inuoluta, illi Domino pateant atque dilucescant. Numquid non omnes meas actiones et studia speculabitur omnesque gradus meos recensebit?

Neque solum libidinem compressi, sed a reliquis etiam flagitiis abstinui. Iratus enim mihi sit Dominus si uanitate et mendacio usus sum et si aliqua in re, fraudis concipiendae gratia, festinaui. Is trutina iustitiae examinet mentem meam et ad normam legis sempiternae officia mea perpendat et explorate cognoscet quam simplici animo me in omni uita gesserim. Si de uia ueritatis atque iustitiae deflexi, si oculorum libidinibus obsecutus sum, si manus meas scelere et flagitio maculaui, ego seminem et alius comedat omnisque posteritas mea radicibus euellatur. Si animus meus uxoris alienae cupiditate flagrauit, si foribus proximi mei insidias collocaui ut pudicitiam illi, qui legitimum uiri matrimonium tenebat, eriperem, alius uxori meae stuprum inferat sitque illa multorum libidini prostituta. Est enim adulterii crimen scelestum et immane facinus et iudicio seuerissime uindicandum. Est praeterea in illo ignis incendium deuorans et consumens omnes in quibus fuerit implicatus, usque eo dum illos in ignis sempiterni supplicium detrudat omnemque subolem, quae ex illius stirpe fusa fuerat, exstinguat.

Similiter, male mihi sit si serui mei aut ancillae meae preces aspernatus sum, ut ius suum obtinerent, a me supplici oratione contenderent. Si enim seruorum meorum postulata superbe reiiciam, quid potero, cum Deus se excitauerit ut, constituto iudicio, in hominum scelus animaduertat, illi respondere? Annon idem qui me in utero matris meae finxit seruum meum similiter $[\mathbf{8 8}]$ informauit? Annon 
modo [88] moldou o meu criado? Acaso não é o mesmo Senhor de todos, por mercê do qual tanto os escravos como os homens livres fomos criados e começamos a viver?

Além disso, que tudo me corra mal se não me mostrei generoso com os pobres, se iludi as viúvas com falsas esperanças de liberalidade, se devorei sozinho a minha comida, se não dei boa parte dela aos órfãos para que se alimentassem. É que desde a minha mocidade coloquei uma afeição paternal no culto da bondade e já desde o tempo em que fui dado à luz seguia-a de todo o coração, como a uma mãe. Se vi um pobre nu, inteiriçado com o frio, e de imediato não lhe dei uma cobertura de roupa com que afastasse o frio; se me não desejaram todos os bens muitos cujos corpos foram aquecidos pelas peles das minhas ovelhas; se atemorizei com ameaças o órfão e se abusei do meu poder no foro e nos tribunais, para arruinar aqueles que estavam privados de pais: que o meu ombro se solte da sua parte superior e que se partam os ossos do meu braço. Com efeito, é justo que seja despojado de todos os bens o homem que cuida que as riquezas lhe foram concedidas, não para aliviar a desgraça dos infelizes, mas para atribular a fraqueza dos que podem muito pouco. Se tivesse cometido este crime, com certeza que era de temer que Deus lançasse sobre mim uma desgraça tal que eu não poderia suportar nem aguentar.

Que eu também morra de má morte se pus a esperança no grande peso do oiro, se coloquei a guarda da vida num grande tesoiro, se, ao cercarem-me abundantes riquezas por todos os lados, me alegrei desmedidamente e me ensoberbeci como se tivessem sido obtidas graças à minha actividade, e se, ao olhar para a luz do Sol e contemplar a claridade da Lua, e ao considerar a rotação regular e uniforme de ambos, fiquei estupefacto e em silêncio pensei para comigo se neles residiria uma divindade digna da máxima veneração e que devia ser propiciada mediante preces e culto. Teria sido uma acção sacrílega e monstruosa, merecedora de ser punida com severo suplício, transferir para os astros a honra que se deve exclusivamente a Deus e atribuir divindade às obras de Deus.

Se me alegrei com a adversidade do meu inimigo e exultei de contentamento por lhe ter sobrevindo algum mal e não impedi a minha língua de falar e proceder mal contra ele, que eu mesmo cause prazer aos meus inimigos e também me atassalhem com insultos. Se a disciplina da minha casa não foi de tal maneira severa que por vezes despertava contra mim o ódio dos meus, a tal ponto que muitos desejavam fartar-se das minhas carnes e saciar-se com o meu sangue, que sofra os castigos do homem negligente e descuidado. Nunca permiti que o estrangeiro passasse a noite fora da minha casa, pois ela sempre esteve aberta para os viajantes.

Se ocultei a minha infâmia, como fazem os restantes homens, e escondi no íntimo recesso do espírito o crime pensado e projectado, a fim de conseguir fama de varão bom através de uma fingida aparência de virtude; se a opinião da multidão ignorante me desviou e o medo do desprezo e da ignomínia, com que as famílias me teriam podido prejudicar, me impediram de dizer aquilo que pertencia às obrigações da piedade e de sair de casa [89] para me consagrar àquela coisa que redundaria em glória de Deus, embora os homens não considerassem que isso era digno nem ficava bem à minha 
est idem Dominus omnium, cuius beneficio tam serui quam liberi generati et in uitam ingressi sumus?

Male praeterea mihi omnia procedant si pauperibus me minime benignum praebui, si uiduas uana spe liberalitatis meae lactaui, si solus dapes meas absumpsi, si non bonam earum partem pupillis, ut alerentur, attribui. Ab adulescentia namque mea patriam pietatem in colenda benignitate constitui eamque iam ab eo tempore quo sum in lucem editus, ut matrem, summa uoluntate prosecutus sum. Si uidi pauperem, nudum frigore rigentem, et non continuo illi uestis integumentum praebui quo frigus depelleret; si non multi, quorum latera ouium mearum uelleribus concalefacta fuere, mihi non omnia bona precati sunt; si puppillum minis exterrui et potentia mea in foro atque iudiciis ad eorum euersionem, qui erant orbati parentibus, abusus sum: humerus meus a summa illius parte praecisus excidat et ossa brachii mei perfringantur. Iustum enim est ut omnibus opibus spolieturis qui non ad leuandam miserorum calamitatem, sed ad affligendam eorum, qui minimum possunt, imbecillitatem sibi datas opes existimat. Quod quidem scelus si commisissem, metuendum certe erat ne Deus mihi importaret calamitatem quam ferre atque sustinere non possem.

Item male peream si spem in auri grandi pondere collocaui, si in thesauri magnitudine praesidium uitae constitui, si, cum undique mihi opes affluerent, laetitia intemperanter elatus sum et ita mihi animos extulerunt atque si mea industria partae fuissent, si, cum lucem solis aspicerem et lunae claritatem animaduerterem eorumque ratas et aequabiles in omni tempore conuersiones animo considerantem, admiratione perculsus, obstupui et tacitus mecum cogitaui num inesset illis numen, ueneratione summa dignum et precibus atque religione placandum. Fuisset hoc quidem scelestum et immane facinus, acri supplicio puniendum, honorem Deo tantum debitum ad sidera transferre operibusque diuinis diuinitatem tribuere.

Si laetatus sum rebus aduersis inimici mei et gaudio exsultaui quod ei malum aliquod obuenisset linguamque meam minime continui ne quid peccaret et illi malediceret, sim ipse uoluptati hostibus meis et me maledictis etiam conscindant. Si non fuit ita seuera domus meae disciplina ut meorum interdum odium in me concitarem, usque adeo ut cuperent multi carnibus meis expleri et sanguine meo satiari, poenas hominis neglegentis atque dissoluti sustineam. Numquam permisi ut hospes foris pernoctaret, semper enim domus mea patuit peregrinis.

Si flagitium meum, ut homines reliqui faciunt, celaui et in intimo animi recessu cogitatum atque meditatum scelus abscondi, ut, ficta specie uirtutis atque pietatis, boni uiri famam colligerem; si multitudinis imperitae opinione deterritus et metu contemptus et ignominiae, qua me familiae afficere potuissent, impeditus fui quominus ea loquerer quae ad pietatis officium pertinebant et domo exirem [89] ut illi rei operam darem quae in Dei gloriam redundaret, quamuis homines id neque dignitatis esse neque personam meam decere arbitrarentur; si denique 
posição; se, finalmente, receei a opinião pública e segui o erro popular, que sofra o castigo reservado para uma tão grande infâmia. É que não é pequena infâmia desdenhar a verdadeira dignidade e com a máxima diligência correr atrás da vaidade e, por medo de descontentar o povo, desprezar a glória eterna e, por derradeiro, pensar que é pouco digno algo que foi estabelecido pela lei divina e que se encaminha à glória de Deus.

Oxalá algum dia o Senhor escute as minhas preces e satisfaça o meu desejo e seja Ele mesmo o juiz da minha causa e que, para memória dos homens, registe por escrito a acusação quem me acusa de crime capital, a fim de que a causa, decidida na presença do mais sábio dos juízes, possa permanecer como um testemunho eterno da minha piedade e inocência. Certamente que aquele livro que o meu acusador dava a público, cheio de toda a espécie de insultos e ultrajes, eu de livre e espontânea vontade levá-lo-ia sobre os ombros como um extraordinário ornamento da minha dignidade e colocá-lo-ia de bom grado sobre a minha cabeça como uma coroa de ouro indicadora da honra adquirida. De facto, que existe de mais honroso para o lustre do nome do que, tendo Deus como juiz e contra todas as afrontas e baldões dos adversários, conservar a dignidade limpa de qualquer nódoa e imaculada de qualquer verdadeiro desdouro?

Pelo que, se agora, tal como Lhe suplico, quisesse julgar a minha causa, dar-Lhe-ia conta do direito que me assiste através de cada um dos passos da minha vida, depois de pesados com todo o escrúpulo todos os meus actos e pensamentos: dar-Lha-ia todavia de modo tal que Ele [90] pensasse que não é pequeno o papel da Sua clemência. É que me aproximaria d' Ele, não com fronte altiva e rosto atrevido, mas humilde e suplicante e em postura de veneração, como quem se aproxima do Senhor e Príncipe da natureza inteira.

Ora, para concluir todo o discurso, se a terra que me pertence se queixa da minha maldade, se brada contra mim, se os regos dela lastimam a devastação que causei às searas, se tratei mal os meus rendeiros, se roubei os jornaleiros da devida paga, se comi sem qualquer despesa os frutos que as minhas propriedades produziram, se oprimi com injustiças os cultivadores da própria terra: que eu colha paliúro em vez de trigo, joio em vez de cevada e desdouro e tortura em vez de glória e ganho sempiternos.

Até aqui discorreu Job acerca da justiça e equidade da sua causa e com este discurso refutou com grande vigor a acusação dos seus amigos. É que, tal como se disse mais do que uma vez, a acusação continha dois pontos importantes: um tinha a ver com o amaldiçoar da dor, como se Job suportasse a desgraça com um espírito demasiado fraco; o segundo atacava-o duramente, como se de modo sacrílego fingisse sentimentos religiosos e não quisesse confessar as infâmias perpetradas por forma a, com esta confissão, pedir perdão, e, ao mesmo tempo, enquanto se defendia a si, assacava falsamente a Deus o delito da iniquidade. Refutou brilhantemente o primeiro ponto quando expôs a grandeza da intolerável dor; e o segundo, quando, de modo notável, mostrou a sua inocência e do mesmo passo provou que a glória de Deus não pode ser manchada por nenhuma suspeita de iniquidade, mas, com várias razões e exemplos, fez somente ver que em muitas coisas as deliberações d' Ele se encontram ocultas. 
auram popularem extimui erroremque uulgi secutus sum, poenas luam tanto flagitio constitutas. Nec enim leue flagitium est aspernari ueram dignitatem et consectari summo studio uanitatem et, popularis offensionis metu, gloriam sempiternam contemnere et aliquid denique parum decorum arbitrari quod sit lege diuina sancitum et ad Dei gloriam conferatur.

Vtinam aliquando preces meas audiat Dominus et desiderio meo satisfaciat et mei iuris cognitor ipse sit et, qui me capitis arcessit, litteris accusationem, ad hominum memoriam, commendet, ut causa, coram iudice sapientissimo tractata, sempiternum exstare posset meae pietatis et innocentiae testimonium. Librum certe illum, quem accusator meus omnibus probris et contumeliis plenum ederet, ego meis humeris, tamquam insigne meae dignitatis ornamentum, sponte mea gestarem et capiti meo, ut auream coronam parti decoris indicem, libenter imponerem. Quid enim ad claritatem nominis illustrius quam, contra omnes aduersariorum contumelias atque conuicia, dignitatem, Deo iudice, nulla aspersam labe aut uera maculatam infamia conseruare?

Quod, si nunc, ut illum precor, causam meam cognoscere uellet, illi, per singulos uitae meae gradus, omnibus actionum et cogitationum mearum momentis diligentissime ponderatis, rationem iuris mei redderem, ita tamen redderem ut ille [90] tamen non mediocres esse clementiae suae partes arbitraretur. Non enim ad illum erecto uultu et audaci fronte, sed humilis et supplex atque uenerabundus, quasi ad totius naturae rectorem et principem, adirem.

Vt autem totam iam orationem concludam, si tellus mea de mea immanitate conqueritur, si contra me clamores edit, si sulci eius ${ }^{3}$ uastitatem per me frugibus illatam deplorant, si colonos meos afflixi, si mercenarios debita mercede defraudaui, si fructus quos fundi mei extulerunt sine ulla impensa comedi, si telluris ipsius cultores iniuriis oppressi: proueniat mihi pro frumento paliurus, pro hordeo lolium et pro fructu gloriae et emolumenti sempiterni dedecus atque supplicium.

Hactenus quidem Iob de causae suae iure et aequitate disseruit, qua quidem oratione amicorum accusationem acerrime confutauit. Nam accusatio duo, ut non semel dictum est, capita continebat: unum in luctus detestatione uersabatur, quasi is nimis animo molli calamitatem pateretur; alterum illum inclementer urgebat, quasi pietatem nefarie simularet et insita flagitia confiteri nollet ut, ea confessione, ueniam impetraret, et, interim dum se tueretur, Deo crimen iniquitatis affingeret. Primum caput egregie refutauit cum magnitudinem intolerandi doloris expressit; alterum uero, cum innocentiam suam luculentissime descripsit et interim Dei gloriam nulla iniquitatis suspicione maculari posse demonstrauit, sed tantum illius consilia multis in rebus occultari uariis rationibus et exemplis ostendit.

3 eius] mei editio Romana 
(Página deixada propositadamente em branco) 


\title{
TERCEIRO LIVRO
}

\author{
DA PARAFRASE A JOB \\ DO PORTUGUÊS JERÓNIMO OSÓRIO
}

LIBER TERTIVS

HIERONYMI OSORII LVSITANI

PARAPHRASIS IN IOB 


\section{PROÉMIO}

O varão justo e sábio concluiu por tal forma a defesa da sua causa que com grande facilidade, contrariando as palavras dos amigos, defendeu a sua inocência e provou que não é verdade que da sorte atribulada de qualquer pessoa se possa tirar a prova de haver incorrido em crime e avaliar a grandeza das infâmias pelo peso da desgraça. É que a vida humana é um exercício e uma luta, e até uma actividade e aprendizagem da coragem militar, ${ }^{1}$ na qual, através dos perigos, trabalhos e dores frequentemente se conhece de forma segura a piedade dos melhores homens e, deste modo, se alcança o elevadíssimo prémio da glória eterna. Por isso, deve ser declarado culpado de crime como homem ímpio, sacrílego e inimigo de toda a religiosidade e santidade, não quem é atribulado por incessantes trabalhos e penalidades, mas quem cede à sensualidade, se entrega à avareza, se deixa arrastar pela ira e segue os conselhos ímpios dos homens perversos.

Por conseguinte, uma vez que a virtude, superior perseverança para alcançar a glória imortal e extraordinária beleza moral deste santíssimo varão se mostram com toda a evidência nas dores com que foi provado, e ninguém o pode com justiça desonrar com algum labéu de impureza, desumanidade ou de uma religiosidade pouco contrita, restava que todos os que falsamente o acusavam de crime se calassem e acabassem por ilibá-lo de todo o delito. Mas, para que ele fosse atormentado durante mais tempo e assim adquirisse para si maior glória, Deus permitiu que certo homem, jovem, cultivado, eloquente, dotado de natureza arrebatada e ardente, se sentisse impelido a atacar Job com maior impetuosidade e a increpá-lo com duríssimas palavras, como a homem desonrado pelas infâmias e culpado de inúmeros crimes.

[92] Apresentou-se-lhe depois a divindade, a qual de tal modo o aterrorizou que o espírito, o semblante e a língua sucumbiram e assim se viu constrangido a reconhecer as marcas gravadas de antigas infâmias e a excessiva intemperança de linguagem. É que, com esta luz mais clara oferecida subitamente aos entendimentos piedosos, as palavras tornam-se obscuras, a inocência humilha-se sentindo-se culpada, o espírito superior e excepcional roja-se no chão; a inteligência, atónita com a grandeza do extraordinário resplendor, fica completamente transida de pasmo e tudo o que parecia claro e luminoso fica escurecido pela magnitude da luz divina e torna-se vil aquilo que anteriormente não tinha preço. Com efeito, assim como vemos volitar nos raios do Sol os corpúsculos que 


\section{PROOEMIVM}

Causam quidem suam uir iustus et sapiens ita perorauit ut facillime suam innocentiam, contra amicorum orationem, tueretur et ostenderet non esse uerum ex afflicta cuiusque fortuna suscepti sceleris argumentum sumere et pro grauitate calamitatis flagitiorum magnitudinem ponderare. Est enim humana uita ludus et palaestra, atque adeo militaris uirtutis officium et disciplina, in qua periculis et laboribus et doloribus summorum hominum saepenumero pietas explorate cognoscitur, et ita praemium amplissimum gloriae sempiternae consequitur. Quocirca non qui laboribus et aerumnis assiduis conflictatur, sed qui libidini cedit, auaritiae studet, iracundiae succumbit et impiis perditorum hominum consiliis obsequitur, est, ut homo impius atque nefarius totiusque religionis et sanctitatis inimicus, scelere condemnandus.

Cum igitur huius uiri sanctissimi uirtus et diuina constantia ad immortalem gloriam et decus insignis in doloribus, quibus exercebatur, clare cerneretur, et nemo posset illi merito labem aliquam impuritatis aut immanitatis aut parum sanctae cultae religionis aspergere, reliquum erat ut omnes, qui illum sceleris insimulabant, obmutescerent eumque tandem omni crimine liberarent. Sed, ut ille diutius torqueretur et ita ampliorem sibi gloriam pareret, Dei permissu excitatus fuit uir quidam, aetate iuuenis, eruditione politus, oratione disertus, natura uehemens et acer, qui maiore quodam impetu in Iobum inueheretur illumque, ut hominem flagitiis infamem et sceleribus multis astrictum, asperrimis uerbis increparet.

[92] Accessit deinde numinis diuini praesentia, quae illum adeo terruit ut animus, uultus, lingua concideret et ita cogeretur de flagitiorum antiquorum impresso uestigio atque de nonnulla in uerbis intemperantia confiteri. Hoc enim clariore lumine, subito piis mentibus oblato, oratio tenebris obscuratur, innocentia conuicta deprimitur, animi excellentis altitudo prosternitur; mens, magnitudine insoliti splendoris attonita, penitus obstupescit et omnia, quae clara et illustria uidebantur, magnitudine diuinae lucis obruuntur et sordibus, quae antea minime comparebant, obsolescunt. Vt enim in solis radiis corpuscula, quae minime cernebantur, uolitare conspicimus, ita, cum diuinum lumen in animis piis 
mal se distinguiam, da mesma maneira, quando a luz divina ilumina as almas piedosas, tornam-se visíveis muitos defeitos que anteriormente estavam ocultos, os quais, numa primeira impressão, as consternam, ao darem-se conta da fraqueza e impureza humanas, visto como toda a força da virtude é frágil, quando posta diante da visão da virtude divina, e nos raios da divina e imensa pureza se reconhece que toda a pureza se encontra manchada por defeitos torpes. Com efeito, que é que existe dotado de tão grande firmeza que imediatamente não caia abatido e derrubado e perca todo o seu poder, mal a beleza e grandeza de Deus se apresentarem aos olhos do entendimento? Que é que pode imaginar-se de tão puro, tão casto, tão santo, tão augusto e tão religioso que não se mostre desonroso na presença do esplendor daquela pureza sempiterna?

Por consequência, quando um varão de Deus é de repente inundado por alguma luz mais clara, é forçoso suceder que sinta desprezo por si mesmo, se recrimine e acuse de crime, ainda que anteriormente não tivesse consciência de nenhum crime, e que, transido de admiração pela luz de Deus, fique estupefacto [93] e seja privado dos sentidos. E, primeiramente, o varão piedoso, atónito com a grande claridade, fica mudo e privado de fala, porquanto é pouco e escasso o que expressam os homens mais eloquentes, pois o artifício da linguagem humana não pode expor as coisas divinas. Por isso, quando grandes e excelsos varões contemplam a luz divina ficam com os espíritos perturbados e não são capazes de pronunciar palavra. Por este motivo Moisés recusava obstinadamente a missão, porquanto dizia que, depois de ter falado com Deus, tinha perdido por completo a capacidade de falar. [Êx 4. 10.] E não só é impedido pela língua, mas também a inteligência, ofuscada pela grandeza da luz, que não consegue suportar e como que invadida por trevas, fica privada de actividade. Isto impeliu outro varão de Deus a dizer: Diante de Ti sou como um jumento. [Sl 73. 22.]

Todavia, só os que ficam neste estado de diante de Deus se julgarem manchados e sentirem a língua enleada e a inteligência esmagada pelo pasmo, só eles brilham com a máxima pureza, só eles discorrem amplamente acerca das matérias mais alevantadas, só eles possuem em abundância as supremas riquezas da sabedoria e são largamente providos da glória imortal. Com efeito, quem poderá ser puro e inocente senão aquele a quem o Espírito divino purificar? Quem há-de falar com gravidade, elegância e fluidez senão aquele a quem a divindade celestial inspirar? Quem gozará da luz da sabedoria senão aquele em cuja alma o esplendor divino brilhar?

Mas, dirá porventura alguém: "Por que motivo é que os homens mais santos chamam cegueira, pasmo e até demência e loucura a isso que encerra a mais pura essência da sabedoria? É que os varões de Deus a este estado elevadíssimo costumam por vezes designá-lo por cegueira e loucura e densas trevas, que parecem tolher por completo a visão." - Sem dúvida porque, quando o varão superior, vivamente abrasado no desejo da mais verdadeira sabedoria, mergulhar totalmente com a inteligência no profundo pélago da imensurável virtude e compreender que a natureza, essência, luz, sabedoria, formosura, bondade, misericórdia e grandeza da inteligência divina são tais que nem as próprias inteligências bem-aventuradas, iluminadas incessantemente pela luz divina, as podem abranger perfeitamente com o pensamento (pois a luz infinita não pode ser abarcada por nenhuma capacidade 
exoritur, multa uitia, quae antea latebant, oculis obiiciuntur, quae pios animos, primo impetu, consideratione humanae imbecillitatis et impuritatis, exanimant, omne siquidem uirtutis robur imbecillum est, cum in aspectum diuinae uirtutis incurrit, et omnis puritas, in diuinae et immensae puritatis radiis, lutulentis uitiis infecta deprehenditur. Quid enim est tanta firmitate praeditum quod, ubi primum diuina species et amplitudo mentis oculis obuersata fuerit, non continuo perculsum et stratum concidat omnesque uires amittat? Quid tam purum, tam castum, tam sanctum, augustum et religiosum excogitari potest quod non, in splendore illius sempiternae puritatis atque iustitiae, flagitiosum appareat?

Vtrumque igitur fieri necesse est, cum uir diuinus improuiso clariore aliqua luce perfunditur, ut se ipsum abiiciat, se uituperet et scelere condemnet, licet antea nullius sceleris sibi conscius exstitisset et, admiratione diunae lucis defixus, stupeat [93] et sensibus spolietur. Atque primum uir pius, amplitudine claritatis attonitus, mutus et elinguis efficitur, parua namque et exigua sunt quae ab hominibus eloquentissimis exprimuntur, diuina enim artificio humanae elocutionis explicari non possunt. Idcirco, cum uiri magni et excelsi diuinum lumen aspiciunt, animis conturbantur et uocem mittere nequeunt. Ea de causa Moses legationem obstinate recusabat, dicebat enim se, post sermonem cum Deo institutum, dicendi facultatem penitus amisisse. Neque lingua tantum impeditur, uerum et mens, magnitudine lucis, quam sustinere nequit, obcaecata et quasi caligine circumfusa, iudicio spoliatur. Id impulit alium diuinum uirum ut diceret: Vt iumentum sum apud te.

Hunc tamen statum qui assequuntur ut coram Deo se pollutos arbitrentur, ut linguae haesitantia laborent, ut stupore mentis opprimantur, ii demum summa puritate nitent, ii de rebus altissimis amplissime disserunt, ii summis sapientiae opibus affluunt et gloria immortali circumfluunt. Quis enim purus et innocens esse poterit nisi quem Spiritus diuinus expurgauerit? Quis grauiter, eleganter et expedite loquetur nisi cuius linguam caeleste numen incitauerit? Quis luce sapientiae perfruetur nisi is cuius animo splendor diuinus affulserit?

Sed, inquiet fortasse aliquis: "Cur caecitas et stupor atque adeo furor et stultitia a sanctis hominibus appelletur id quod absolutissimam sapientiae rationem continet? Hic enim status amplissimus a uiris diuinis interdum caecitas et furor appellari solet atque densa caligo, quae aspectum prorsus eripere uidetur." - Nimirum ob eam causam quod, cum se uir magnus, cupiditate uerissimae sapientiae uehementer incensus, mente penitus in profundum pelagus immensae uirtutis immerserit, et naturam, uim, lumen, sapientiam, pulchritudinem, probitatem, beneficentiam, amplitudinem diuinae mentis eam esse perceperit, quam neque mentes ipsae beatissimae, diuina luce perpetuo collucentes, perfecte complecti cogitatione possint (infinitum namque lumen definita uidendi 
finita de visão), ao ver como todas as coisas são pequenas, escassas e obscuras, quando [94] se comparam com a grandeza da imensa majestade e com a desmesura da inexplicável luz, sentir-se-á esmagado pela consideração da mesma infinidade, pois compreenderá que o que não vê nem compreende é infinitamente superior às coisas que abarca com um entendimento iluminado, de maneira que julga, com razão, que a sua visão deve ser tida na conta de cegueira e a sua sabedoria na de loucura e desatino.

Daqui nasce aquela demência divina que leva o espírito a, arrebatando-se para muito fora de si, aspirar àquele lugar aonde não pode chegar, a admirar aquilo que não vê, a amar aquilo que não entende, a abrasar-se em desejo ardentíssimo da beleza que não divisa e a, quanto menos compreende intelectualmente o quão brilhante, amável e deleitável é aquela forma que causa a beleza a todas as coisas belas, tanto mais ardentemente se inflamar no seu amor. ${ }^{2}$

Retomando o fio ao tema de que nos desviámos: era este o estado em que se encontrava Job, tal como muito facilmente se pode conjecturar, quando ficou transido de espanto diante da presença de Deus, quando se acusou a si mesmo de loucura e quando, espojando-se no pó e nas cinzas, pediu perdão pelos seus erros. Entretanto deve notarse que, depois da sua defesa, com a qual refutou a acusação dos amigos e, com a prova da mais verdadeira inocência, contestou a repreensão que lhe fora feita com palavras sobremaneira violentas, se empreendeu uma tripla censura à sua vida e um juízo tríplice contra ele. Com efeito, em primeiro lugar, foi mui violentamente atacado pelas palavras de um homem ensoberbecido e arrogante; em seguida, a majestade do próprio Deus em pessoa espantou-o com uma brilhantíssima luz e intimou-o a juízo; finalmente, ele acusou-se a si mesmo e proferiu contra si uma severíssima sentença.

Ora, que cumpre fazer-se? Ilibaremos de culpa um homem condenado por juízo humano e divino e, por fim, até por sua própria sentença? Dificilmente tal pode fazerse. Mas, na verdade, se o próprio Juiz supremo o absolver, será um acto sacrílego e monstruoso empenharmo-nos em apresentá-lo como culpado. Com efeito, Deus, ao acusar os amigos de Job de desvario e injustiça, falou a Elifaz nestes termos: "Enfureci-me contra ti e os teus dois amigos, pois não falastes bem na Minha presença, como o Meu servo Job", naquele passo em que vimos que Deus, a quem nada pode esconder-se, deu a Job testemunho de equidade e inocência. Ele, por conseguinte, com a maior facilidade teria podido, através das palavras do próprio Deus, repelir quer os ataques do desatino, quer o ardor maldizente com que [95] Eliú arremeteu contra ele.

Mas, quanto ao que toca ao juízo divino, deve entender-se que ninguém haveria de ganhar a demanda se o Senhor supremo tivesse querido pesar todas as acções da vida e o desempenho dos deveres de acordo com as disposições rigorosíssimas da lei eterna e, quando alguém comete uma falta, aplicar de imediato aos pecados humanos o devido castigo. Com efeito, existiu jamais alguém que nunca tivesse caído? Que por vezes não se desviasse do caminho? Que com alguma indignidade não atentasse amiúde contra a religião? Mas, tal como diz David, conservamo-nos sãos e incólumes porque Aquele excelente Pai não procede para connosco com o máximo rigor da lei, mas misericordiosamente perdoa os delitos e absolve do crime todos os que imploram a 
facultate comprehendi non potest), cum uiderit quam sint omnia parua, exsilia et obscura, dum cum [94] immensae maiestatis amplitudine et inexplicabilis lucis immensitate conferuntur, consideratione ipsius infinitatis obruetur, intelliget enim partibus infinitis excellere quod nec uidet nec intelligit rebus, quas mente illustri complectitur, ut merito iudicet aspectum suum pro caecitate reputandum et sapientiam in loco stultiae et temeritatis habendam.

Vnde furor ille diuinus exoritur ut animus, extra se longius euectus, eo quo peruenire non potest, aspiret, quod non uidet, admiretur, quod non intelligit, amet, pulchritudinis, quam minime cernit, ardentissima cupiditate flagret et, quo minus cernit animo quam illustris et amabilis atque iucunda sit illa species, quae rebus omnibus pulchris pulchritudinis causam affert, eo amore illius ardentius inflammetur.

In hoc statu, ut eo redeat unde deflexit oratio, Iobus erat, ut coniici facillime potest, cum ad Dei conspectum animo consternatus est, cum se ipsum damnauit amentiae, cum, in puluere et cinere prouolutus, errati ueniam postulauit. Id interim animaduertendum est, post illius defensionem, qua amicorum accusationem compressit et uituperationem asperis admodum uerbis institutam, cum innocentiae uerissima testificatione refutauit, triplicem uitae reprehensionem triplexque iudicium contra illum institutum fuisse. Primum enim, hominis elati et confidentis oratio in illum nimis acriter inuasit; deinde, ipsius Dei praesentis numen illum clarissima luce perterruit in iudiciumque uocauit; postremo, ipse sibi crimen intulit et contra se sententiam seuerissime protulit.

Fieri uix potest. Verum enimuero, cum summus ipse iudex eum absoluerit, scelestum et immane facinus erit reum illum peragere conari. Sic enim Deus, cum amicos Iobi furoris et iniquitatis argueret, Heliphazium allocutus est: "Ira mea exarsit in te et duos amicos tuos, non enim recte locuti estis apud me, ut seruus meus Iob", quo in loco Deum, quem nihil latere potest, Iobo aequitatis et innocentiae testimonium dedisse conspicimus. Ille igitur, siue temeritatis impetus, siue maledicentiae studium quo Helius in eum [95] impetum dedit, facillime ipsius Dei ${ }^{1}$ oratione reprimi atque restingui potuisset.

Quod uero ad diuinum iudicium attinet intelligendum est neminem litem obtenturum fuisse, si summus Dominus omnia uitae studia officiorumque momenta uoluisset ad exactissimam legis aeternae rationem perpendere et, ubi quisque delinquit, debitum continuo supplicium peccatis humanis irrogare. Quis enim umquam fuit qui numquam laberetur? Qui non interdum a uia deflecteret? Qui non saepe religionem flagitio aliquo uiolaret? Sed ideo, ut Dauid ait, salutem et

\footnotetext{
1 Dei] Iobi editio Romana
} 
Sua clemência, ainda que sejam culpados de inúmeras acções criminosas. [Sl 130. 3-8.] Procedimento que Deus muito mais facilmente deveria seguir com aquele homem que consumira toda a vida na dedicação às máximas virtudes.

Além disso, as palavras de Deus não acusavam a deslealdade de Job, mas tinham por alvo os pensamentos que penetravam no seu espírito e punham à prova a sua fé, a fim de que, depois de estes dominados e reprimidos, o espírito se tornasse mais elevado e a virtude se fortalecesse com uma espécie de defesa maior. Portanto, o discurso de Deus não ia na mesma linha do sentir dos amigos de Job, os quais manchavam o seu nome com um gravíssimo desdouro e afirmavam que ele tinha sido muitíssimo ímpio.

Finalmente, a consciência do mesmo santíssimo varão comprova que ele não era criminoso, mas envolto em tamanha luz e dotado de tão singular comedimento que dava o nome de gravíssimo crime até a ligeiríssimas faltas. Este comedimento, quanto maior foi, tanto mais atraiu para si a divindade, de maneira a mais rapidamente alentar o homem prostrado e galardoá-lo com riquezas e ornamentos mais lustrosos. E assim, como pode reconhecer-se com a máxima evidência, vemos que o homem santo, provado pelas tribulações, desonrado pelos insultos, esmagado ao mesmo tempo por todas as ruínas, foi não só restituído pela divina clemência à sua condição original, com enorme acréscimo de todos os bens, mas julgado como muitíssimo santo por sentença do próprio Deus. Por consequência, se Deus tomou a sua defesa, quem possui atrevimento e impudência tão desmarcados que o acuse de crime? Se o iliba de crime, quem é que há-de atrever-se a condená-lo? Se Deus o [96] cobre de louvores, quem é tão ousado que o trespasse com insultos?

Alonguei-me um pouco nestas reflexões porque no nosso tempo não faltaram certas pessoas abomináveis capazes de incriminar violentamente Job, como se ele tivesse lançado gravíssimos ultrajes contra Deus. Ora, esses tais estão em oposição com o testemunho de Deus e imprimem um grave labéu ao Seu juízo. Todavia, não deve causar espanto o facto de homens santos serem acusados por pessoas como eles, que acusam de iniquidade, capricho e maldade o supremo arquitecto de toda a santidade, tal como alhures mostramos em muitos lugares. Mas, pondo-os de lado, segue-se logicamente que ouçamos com toda a atenção esta derradeira parte do magnífico diálogo.

Neste último discurso de Job, que pronunciou acerca da sua justiça, os seus três amigos calaram-se impressionados, e de tal modo se calaram que com este silêncio pareciam darlhe um testemunho de justiça e santidade. Ora, estivera presente às falas deles um homem notável pela fama de sabedoria, chamado Eliú, filho de um prócere que se chamou Baraquel, natural da Mesopotâmia, que descendia da linhagem de Rame. Eliú encolerizou-se contra o mesmo Job porque lhe parecia que de modo obstinado defendia a sua causa contra o juízo de Deus e que afirmava que era mais justo do que Deus. Por outro lado, a sua ira acendeu-se igualmente contra aqueles três companheiros de Job, porque desconfiavam de encontrar argumentos para vencer o homem e refutar o seu discurso, e já não o condenavam como 
incolumitatem retinemus, quia non agit optimus ille parens summo iure nobiscum, sed delictis clementer ignoscit et omnes, qui clementiam illius implorant, scelere soluit, quamuis sint multis criminibus alligati. Quod eo facilius erat a Deo cum homine illo faciendum, cuius omnis uitae pars fuerat in maximarum uirtutum studio consumpta.

Praeterea, Dei oratio non Iobi perfidiam arguebat, sed cogitationes, quae animum illius peruagabantur et fidem illius attentabant, coercebat, ut, illis edomitis atque compressis, animus altior fieret et uirtus maiore quodam praesidio firmaretur. Non igitur Dei oratio cum Iobi amicis faciebat, qui nomen illius grauissimo dedecore maculabant eumque scelestissimum fuisse statuebant.

Ipsius postremo sanctissimi uiri conscientia illum minime sceleratum esse demonstrat, sed tanto lumine circumfusum et tam singulari moderatione praeditum ut leuissimis etiam erratis grauissimi criminis nomen imponeret. Quae moderatio, quo maior fuit, eo magis ad se diuinum numen allexit, ut hominem iacentem citius excitaret et clarioribus opibus et ornamentis afficeret. Itaque, ut cerni clarissime potest, uidemus hominem sanctum, aerumnis exercitum, conuiciis deformatum, omnibus simul ruinis oppressum, non solum diuina clementia in statum pristinum, cum summa bonorum omnium amplificatione restitutum, uerum etiam, Dei ipsius sententia, sanctissimum iudicatum. Si igitur Deus illius patrocinium suscipit, quis tam proiecta audacia et impudentia est ut illi crimen intendat? Si crimine liberat, quis tandem est qui illum condemnare audeat? Si Deus illum [96] laudibus ornat, quis tam petulans est ut maledicto configat?

Haec quidem fusius persecutus sum quia non defuerunt nostris temporibus homines taeterrimi qui Iobum grauiter accusarent, quasi grauissimas in Deum contumelias intorsisset. Qui quidem cum Dei testimonium pugnant et illius iudicio grauem contumeliam inurunt. Mirum tamen uideri non debet sanctos homines ab illis accusari qui summum totius sanctitatis architectum iniquitatis, temeritatis, immanitatis insimulant, ut alibi multis in locis ostendimus. Sed, his omissis, consequens est ut hanc postremam luculentissimi dialogi partem attentissimis animis audiamus.

Hac quidem extrema Iobi orationem, quam de iustitia sua habuit, tres illius amici commoti siluerunt, et ita siluerunt ut ea taciturnitate uiderentur illi testimonium iustitiae atque sanctitatis impertire. Interfuerat autem illorum sermoni uir sapientiae opinione praestans, Helius nomine, filius uiri primarii, cui nomen fuit Barachelus, in Mesopotamia natus, qui erat ex Rami stirpe oriundus. Hic uero iratus est acriter ipsi Iobo eo quod uideretur causam suam contra Dei iudicium obstinate defendere seseque Deo iustiorem asseuerare. Similiter autem contra illos tres Iobi socios ira illius exarsit, quod argumentum hominis comprimendi orationisque illius refutandae se reperire diffiderent, eumque iam impietatis et 
ímpio e louco. E quando Job concluiu a sua fala manteve-se em silêncio até ver se havia alguém para refutar a sua opinião. É que era muito mais jovem e a boa educação exigia que se calasse em presença dos mais velhos. Ora, ao ver que eles se mantinham em silêncio, inflamou-se de cólera. Depois, começou a falar assim:

- Como sou muito mais novo do que vós, contive-me e não expus o que sentia, para que me não criticassem como mal educado. É que tinha para mim que a eloquência se adquire com os anos e que se chega à sabedoria com os dilatados anos. Por isso, não era lícito aos moços gabarem-se de eloquência ou ufanarem-se com o título de sábios, uma vez que ambas as coisas eram próprias da velhice, ensinada pelo prolongado estudo das ciências e pelos inumeráveis exemplos da vida corrente. Mas agora vejo-me obrigado a mudar de parecer, pois vejo que a sabedoria não é fruto da idade, mas uma mercê do Espírito divino, e que não são sábios os que, durante uma vida muitíssimo longa, adquiriram mediante os sentidos conhecimento de muitas coisas, mas sim os que beberam de Deus o saber e foram ornados com as Suas dádivas. E, assim, é a inteligência divina quem transmite a sabedoria aos homens, e são inspirados pelo Espírito de Deus todo-poderoso os que sabem, entendem e conhecem as coisas celestiais e divinas.

Não é próprio da multidão saber nem da velhice avaliar com a capacidade crítica e razão o que mais cumpre fazer-se, mas toda a sabedoria [97] deve atribuir-se à bondade de Deus, a qual não depende de quaisquer cargos ou idades dos homens. Daqui se segue que nem podem os velhos, como por um direito de propriedade, reclamar para si a sabedoria, nem os jovens ser inteiramente excluídos do gozo dela, mas devem ser considerados sábios apenas aqueles, quer sejam velhos, quer sejam moços, a quem Deus quis cumular com uma tão grande dádiva. Pelo que não há motivo para que considereis o meu discurso indigno dos vossos ouvidos devido ao facto de eu não ter muita idade, porquanto pode suceder que eu tenha bebido da fonte da sabedoria alguma coisa que possa redundar em proveito de muitos.

Por conseguinte, escutai-me, para que vos mostre um exemplo da sabedoria com que fui instruído. É que nenhum de vós poderá acusar-me de desatino e impudência, por me ter antecipado ou interrompido os vossos discursos e não ter esperado a que qualquer um de vós expressasse o seu sentir. Com efeito, mantive-me calado e fiquei de orelhas fitas para ouvir as vossas opiniões e assegurar-me das conclusões a que tínheis chegado graças às perquirições e desvelo da inteligência. Enquanto olho para vós, enquanto estou à espera do que dizeis, enquanto presto atenção ao que reprime o desvario de Job, senti goradas as minhas expectativas, pois não vejo ninguém capaz de refutar as palavras atrevidas e impiedosas deste homem. Por conseguinte, não há motivo para que arrogantemente vos ufaneis de sábios, ao aprovardes aquela razão, quase como se fosse o máximo testemunho da sua justiça: é que ele afirma o seguinte: "Quem o fere é Deus, e não o homem", como se esta opinião não encerrasse uma maior prova de impiedade e loucura do que de religião e sabedoria, ou como se fosse pouco evidente que Deus não é hostil aos bons, mas aos ruins e criminosos.

Ora, uma vez que o discurso que dirigiu contra vós vos emudeceu, ao passo que a mim seguramente não me quebrantou nem fez mudar da minha primitiva opinião, por 
amentiae minime condemnarent. Vbi uero Iobus perorauit tantisper silentium tenuit, dum animaduerteret an esset qui sententiam illius refutaret. Erat enim multo iunior et ratio modestiae postulabat ut grandioribus natu cederet. Cum igitur uideret illos obmutescere, excanduit. Sic deinde exorsus est:

- Equidem, cum aetate sim multo uobis inferior, continebam me neque quid ipse sentirem in medium afferebam, ne me immodestiae uituperationem ullam susciperem. Sic enim mecum statuebam annis eloquentiam comparari et uitae longitudine ad sapientiam perueniri. Non igitur licere adulescentibus uel eloquentiae laudem assumere uel sapientiae nomine gloriari, cum utrumque esset senectutis, diuturno disciplinarum studio et quam plurimis uitae communis exemplis eruditae. At nunc sententiam mutare compellor, uideo enim sapientiam non aetatis esse fructum, sed Spiritus diuini beneficium, nec eos sapientes esse qui in longissima uita multa sensibus usurparunt, sed qui disciplinam a Deo hauserunt muneribusque illius exculti sunt. Itaque mens diuina est quae sapientiam hominibus tradit et Spiritu Dei praepotentis inflati sunt qui sapiunt et intelligunt et caelestia atque diuina percipiunt.

Non multitudinis est sapere neque senectutis quid optimum factu sit iudicio et ratione perpendere, sed omnis sapientia est, ad [97] Dei benignitatem referenda, quae non est ullis hominum personis aut aetatibus obligata. Vnde sequitur neque senes sibi sapientiam, quasi iure mancipii, uindicare posse, neque iuuenes omnino fructu illius excludi, sed eos tantum sapientes habendos esse, siue senes, siue adulescentes illi sint, quos Deus tanto dono cumulare uoluit. Quare non est cur orationem meam eo quod non ita grandis natu sim auribus uestris indignam reputetis, fieri namque potest ut ipse a sapientiae fonte aliquid hauserim, quod ad multorum utilitatem redundare possit.

Audite igitur me, ut sapientiae qua instructus sum specimen uobis exhibeam. Nec enim quisquam uestrum me temeritatis et impudentiae poterit insimulare, quasi anteuerterim aut orationem uestram interruperim et non exspectarim, dum quilibet uestrum sensum mentis suae expromeret. Tacuit enim attentasque aures praebui ut sententias uestras exciperem et, quid mentis studio et peruestigatione consecuti essetis, explorarem. Dum uos intueor, dum quid dicatis exspecto, dum qui Iobi licentiam coerceat attendo, opinione deceptus sum, neminem enim, qui audacem et impiam hominis orationem, refellat inspicio. Non est igitur quod uobis sapientiam insolenter assumatis, cum illa rationem, quasi maximum iustitiae illius testimonium, comprobetis: sic enim dicit: "Deus illum perculit, et non homo", quasi uero ea sententia non maius argumentum impietatis et amentiae quam religionis et sapientiae contineat, aut obscurum sit Deum non esse bonis, sed improbis et sceleratis infensum.

Vt igitur oratio, quam contra uos instruxit, uos elingues reddiderit, me certe non infregit nec de sententia pristina deduxit, illum igitur non oratione uestra, 
isso acho que devo ser refutado, não pelos vossos discursos, mas por argumentação muito mais apurada. Que fraqueza tão grande é esta? Que perturbação tão vergonhosa dos espíritos é esta? Que medo tão grande é este, despertado em homens nem obscuros nem ignorantes? Que homens instruídos nos mais elevados saberes, muito e longamente versados na arte oratória, que tais homens tão subitamente tenham renunciado a uma causa tão boa? Apavorados, calaram-se e não deram nenhuma resposta, nem sequer pronunciaram uma palavra. Tendo-se feito um extraordinário silêncio e não respondendo ninguém, não obstante fiquei na expectativa de se alguém falaria. Mas não houve ninguém que o quisesse fazer.

Por conseguinte, é justo que, no meio de tão grande silêncio e reserva dos homens, eu por minha parte tome a palavra e de livre e espontânea vontade me encarregue de uma causa tão piedosa, abandonada por aqueles que menos o deveriam fazer, e enfim alguma vez exprima por palavras a força da sabedoria que me abrasa e impele. É que tenho a alma cheia de incontáveis opiniões e a inteligência a trasbordar de argumentos, de tal maneira que o desejo de me pronunciar me põe numa grande ansiedade. Com efeito, assim como os odres, ainda que sejam muito novos, se estiverem muito cheios e não tiverem nenhuma abertura, rebentam, da mesma maneira o meu espírito, a trasbordar de opiniões e argumentos, de uma certa forma há-de despedaçar-se se não exteriorizar o que se mantém comprimido. Por isso não sou capaz de aguentar o silêncio; não posso ser impedido de falar; que a voz, emitida pelo sentir íntimo do espírito, revele o que se esconde no interior. E falarei de modo a, em alguma medida, me aliviar deste cuidado que me dilacera o espírito [98] e preparar-me-ei para discursar, por forma a responder àquilo que ignorantemente se disse. Não atenderei à posição e dignidade dos homens nem com lisonjas e títulos honrosos me insinuarei na graça de algum varão, pois não sei, caso queira adular e lisonjear com palavras, se por este motivo o meu Criador me há-de destruir por completo.

Por conseguinte, desejaria que, como a homem alheio a enganos e embustes e muito apartado da preocupação de lisonjear, me escutasses aplicadamente e prestasses atenção ao que vou dizer. Ora, já declararei qual é o meu sentir e darei claramente a conhecer o que entendo. É recto e íntegro o coração do qual saem estas coisas e do mesmo modo as próprias palavras hão-de inculcar a doutrina da mais pura ciência. É que de um espírito impuro e manchado não pode sair uma linguagem pura e simples, como de um espírito casto e íntegro é impossível provir uma linguagem enganosa. Todavia não atribuo esta inteireza de vida e pureza de alma aos meus esforços, mas a dádiva e mercê d' Aquele que me moldou e criou, pois fui criado pelo Espírito do Senhor e gozo da vida aviventado pelo Seu sopro, de tal maneira que é por benefício Seu que sei e compreendo aquilo que é recto.

Se é tão grande a tua inteligência, dispõe as tuas hostes e peleja comigo; rechaça os argumentos com que pretendo combater-te; entra na pugna e defende a tua posição com ânimo decidido. Em mim nada há para que me desprezes nem, por outro lado, nada para que me temas. É que, se perguntas pela capacidade oratória, eu não sou incapaz nem peco no falar, pois o mesmo Senhor que te dotou com essa abundância e facilidade 
sed alia multo magis exquisita ratione mihi refutandum existimo. Quaenam haec tanta imbecillitas est? Quae tam foeda animorum perturbatio? Quis tantus timor, hominibus nec obscuris nec imperitis iniectus? Homines disciplinis maximis instructos, in dicendi studio multum diuque uersatos, in tam bona causa tam subito defecisse? Exterriti, siluerunt, nullum responsum dederunt, ne uerbum quidem ullum fecerunt. Cum mirum silentium fuisset nemoque responderet, exspectabam nihilominus an aliquis loqueretur. Sed nemo fuit qui id facere uellet.

Par igitur est ut, in tanta hominum taciturnitate et silentio, ipse pro mea parte loquar et causam tam piam, ab iis a quibus minime oportebat desertam, sponte mea suscipiam et uim sapientiae, quae me incendit et incitat, tandem aliquando uerbis enuntiem. Animum enim gero sententiarum multitudine distentum mentemque argumentorum copia redundantem, ita ut erumpendi desiderio in angustias compellatur. Vt enim utres, quamuis noui sint, si musto pleni fuerint et nullum spiraculum habuerint, dilacerabuntur, sic animus meus, sententiarum et argumentorum copia refertus, si non foras, quod compressum continet, emiserit, quodammodo disrumpetur. Silentium igitur ferre non queo; quin eloquar, contineri non possum; uox, ex intimis animi sensibus emissa, quod inclusum latet, aperiat. Itaque loquar, ut ea cura, quae distringit animum, aliqua ex parte relaxer [98] et me ad dicendum comparabo, ut ad ea quae sunt imperite dicta respondeam. Non respiciam hominum personam et dignitatem nec in gratiam uiri alicuius me assentationibus et honorificis titulis insinuabo, haud enim scio, si uerbis adulari et assentari uoluero, an ob eam causam me conditor meus funditus euersurus sit.

Me igitur, ut hominem a dolis et fraudibus alienum et ab adulandi studio ualde remotum, uelim ut attente audias et ea, quae dicturus sum, mente percipias. Iam enim quis sit meus sensus aperiam et prompte quod animo complector uerbis enuntiabo. Cor ex quo haec depromuntur rectum et integrum est et similiter uerba ipsa purissimae scientiae disciplinam inculcabunt. Nec enim ex animo impuro et contaminato uerum et simplex uerbum emitti potest, nec ex casto et integro fraudulentum. Non tamen hanc uitae integritatem et animi castimoniam meis studiis, sed dono atque muneri illius qui me finxit et informauit assigno, Spiritu enim Domini creatus sum illiusque afflatu excitatus uita fruor, ita ut illius beneficio recta sentiam atque sapiam.

Si tantum uales ingenio, mecum, acie instructa, congredere; mucronem orationis, quo te sum petiturus, retunde; confer pedem et constanti animo in gradu consiste. Nihil est in me quod contemnere possis, nihil rursus quod extimescas. Nam, si de dicendi facultate quaeris, nec infans nec in dicendo ieiunus sum, idem enim Dominus, qui te ista dicendi copia et ubertate muniuit, 
oratória, também a mim me proveu com os dons e recursos da eloquência. Se olhas para a condição da natureza, tal como tu fui feito de pó. Não há razão para te perturbares com medo de mim e de alguma maneira te sentires deprimido pelo peso inteiro da minha veemência, mesmo que se abata totalmente sobre ti. É que dizias que havias de fazer aprovar a tua causa diante de Deus, a quem te queixavas das injustiças cometidas contra ti, desde que Ele afastasse do Seu tribunal o terror da Sua divindade e majestade, com que perturbava o teu espírito. Avança! Já experimentarei se és capaz de me fazer aprovar a tua causa, a mim que não sou Deus nem te posso intimidar com uma majestade deveras extraordinária. Por consequência, se não puderes responder-me, de que maneira hás-de suportar no juízo a catadura do próprio Deus?

Ora, para começar já a responder ao que disseste, certamente que deste uma intolerável demonstração de arrogância quando afirmaste que nunca te mancharas com alguma nódoa de impureza nem de forma alguma incorreras em algum crime de iniquidade. E assim aturdiste os nossos ouvidos e ouvimos-te isto mais do que uma vez, quando dizias: "Sou puro e íntegro; jamais me manchei com alguma indignidade; não fui culpado de nenhum crime; durante toda a vida não cometi nenhuma iniquidade. E, apesar disso, Deus achou pretexto para me oprimir como a homem malvado e injusto e para me perseguir como a inimigo. Atou os meus pés com cadeias e espiou todos os meus caminhos, para que não pudesse fugir." - Não foi assim? Com este tão monstruoso atentado, pelo qual atribuíste a Deus iniquidade, conjecturavas limpar a sujidade da tua vida?

Mas vê quão grande é o erro e loucura em que te encontras, porquanto com esse discurso não conseguiste apagar o teu crime, mas trouxeste a este o acréscimo de um crime novo e inaudito. Ora, com uma única palavra posso cortar, como com um machado, toda a eficácia do teu discurso. [99] “- Que palavra é essa?”, perguntar-me-ás. - Que Deus, em equidade, honestidade e rectidão de juízo se avantaja tanto aos homens quanto é impossível exprimi-lo através de palavras. Por conseguinte, quando se reconhecer que algo foi feito por Deus, mesmo que não se alegue nenhuma razão, deve presumir-se que se trata de uma obra santa, realizada com a deliberação e motivo mais perfeitos, e inexcedível em todas as suas partes e componentes, pois nem aquela suma sabedoria pode traçar algo ao acaso nem a suma justiça decidir seja o que for de modo injusto.

Portanto, porque te lembraste de pleitear com aquele que é o mais sábio dos governantes e o mais santo dos juízes? Mas dizes que não compreendes o motivo pelo qual te é tão violentamente hostil. - Acaso é Ele obrigado a apresentar a um homenzinho os motivos das Suas obras? Moves-Lhe processo por não te revelar todos os desígnios da Sua inteligência? Porventura, se não te expuser a causa pela qual atribula com penalidades os mortais, torna-se imediatamente razoável que O acuses de iniquidade? Conquanto nem sequer disso com razão te podes queixar, pois é próprio da Sua imensa bondade manifestar frequentemente aos homens a Sua divindade pela revelação das coisas ocultas e anunciar o que há-de acontecer até com muita antecipação. É que Deus umas vezes fala de uma maneira, e outras de outra, que os homens, devido à sua congénita loucura, de modo algum compreendem. 
me etiam eloquentiae muneribus atque praesidiis instruxit. Si ad naturae condicionem respicis, e puluere similiter effectus sum. Non est cur mei timore conturberis et pondere totius meae uehementiae, quamuis in te tota ruat, aliqua ratione deprimaris. Dicebas enim te apud Deum, cum quo de iniuriis tibi illatis expostulabas, causam tuam probaturum, dummodo is terrorem numinis atque maiestatis suae, quo tuum animum conturbabat, e iudicio suo remoueret. Age! Iam experiar an causam tuam mihi probare queas, qui Deus non sum neque te possum insolita quadam maiestate perterrere. Quod, si mihi respondere non poteris, quomodo Dei ipsius uultum in iudicio sustinebis?

Vt autem iam ad ea quae dixisti respondeam, illa certe fuit intolerabilis arrogantiae significatio cum dixisti te nulla impuritatis labe aspersum esse nulloque omnino scelere iniquitatis alligatum. Itaque aures nostras obtudisti et hoc a te non semel audiuimus, cum diceres: "Purus et integer sum; nullo me umquam flagitio inquinaui; nullo me scelere astrinxi; nullam in omni uita iniquitatem suscepi. Et tamen Deus occasionem nactus est qua me, ut hominem maleficum et iniustum, opprimeret et uelut hostem persequeretur. Deuinxit neruo pedes meos omnesque uias meas, ne elabi possem, speculatus est." - Itane uero? Hoc tam immani facinore, quo Deo iniquitatem affinxisti, uitae tuae sordes elui suspicabere?

At uide quanto in errore et amentia uerseris, non enim oratione ista scelus tuum oblitterare potuisti, sed non mediocrem ad illud accessionem noui et inauditi sceleris attulisti. Vno autem uerbo possum omnem uim orationis tuae, [99] quasi securi, praecidere. "- Quod", inquies, "illud est?" - Hoc nempe quod Deus tantum aequitate atque iudiciorum fide et constantia homines superat, quantum uerbis explicari non potest. Vbi igitur a Deo aliquid factum fuisse constiterit, etiam nulla ratione adhibita statuendum est id officium esse sanctum et summo consilio atque ratione perfectum, omnibusque suis numeris et partibus absolutum, nec enim a summa illa sapientia temere quidquam designari nec a summa iustitia quidquam nefarie constitui potest.

Quid igitur tibi uenit in mentem cum illo sapientissimo rectore et sanctissimo iudice litigare? At inquis te non tenere rationem qua tibi adeo acriter infensus sit. - An ille rationem operum suorum homuncioni reddere compelletur? Illine tu litem intendes quod non omnia tibi consilia suae mentis aperiat? An nisi is tibi causam quare mortales poenis afficiat exposuerit, uerum continuo est ut illum iniquitatis insimules? Quamquam ne id quidem iure conqueri potes, est enim hoc illius immensae benignitatis, ut saepenumero hominibus numen suum rerum occultarum significatione declaret et euentura etiam multo ante praenuntiet. Vna quidem ratione loquitur interdum Deus, et altera etiam, quam homines, propter insitam dementiam, haudquaquam animaduertunt. 
A primeira espécie de linguagem divina é a aproximação do Espírito divino, com a qual os espíritos são abalados e instruídos acerca das coisas afastadas da compreensão humana, como geralmente costuma acontecer nos sonhos. É que, através de uma visão nocturna, quando os homens estão deitados nas suas camas mergulhados num sono pesado, Deus desperta os seus entendimentos para escutarem e transmite-lhes ensinamentos salutares e, como se gravasse com um sinete, imprime uma marca, para que o homem se desvie das indignidades e o varão se afaste da soberba e da presunção. Ora, assim sucede que evita os males iminentes, foge das ciladas e enganos que estão aparelhados contra a sua vida e se desvia dos dardos arremessados pelos inimigos.

A outra espécie de linguagem com que Deus revela a Sua inteligência é a doença com que atribula o homem culpado e o obriga a jazer na cama e experimentar grandes dores, contundindo-lhe e enfraquecendo-lhe todos os ossos. Portanto, o homem a quem Deus persegue desta maneira, repele com enorme fastio todos os alimentos e sente asco pelas iguarias que antes vivamente apetecia. O corpo é consumido aos poucos e perde a primitiva aparência. E os ossos, que recobertos pela carne não podiam ver-se, destacam-se e avultam devido à grande magreza. A sua vida aproxima-se do supremo perigo da morte e ele mesmo é quase que obrigado a olhar para os encarregados do funeral.

Ora, nesta tribulação e angústia, se de entre o grande número dos anjos se erguer pelo menos um que interprete o sentido da lei divina e ensine ao homem com quão justo juízo de Deus ele caíra doente, e o inflame no ódio da maldade praticada e o incite ao zelo da piedade e lhe mostre o caminho da justiça e da inocência, o Senhor aplaca-se de imediato com esta conversão de vida e ordena ao anjo que arranque da ruína do perigo supremo o homem já quase destruído pelas mortíferas doenças e lhe devolva a saúde perdida. Com efeito, diz: "Dá-te pressa, salva-o imediatamente para que a morte o não destrua, pois com as dores que [100] padeceu pelas infâmias outrora perpetradas, já expiou os crimes contra os quais Me encolerizava." E deste modo, por mercê do Senhor, recupera a saúde e a primitiva aparência. De facto, a carne dele restaura-se e renova-se e, em lustro e maciez, imita o viço da infância e retorna ao antigo vigor da mocidade. Ele dirige preces ao Senhor, que se lhe apresenta propício e lhe mostra um rosto muito alegre e faz que o homem recupere os ornamentos da justiça há muito perdida.

O Senhor observa os homens e vela bondosamente pelas coisas deles e, quando falham no cumprimento dos seus deveres, exige-lhes a confissão do delito por forma a que, convertidos a Ele, peçam perdão e, de novo restituídos à Sua graça, qualquer um deles diga: "Pequei, violei a santidade da justiça e não me consagrei ao zelo dela, motivo pelo qual fui atribulado por golpes muito mais leves do que tinha merecido. Todavia o Senhor libertou-me da perdição e, saído das trevas graças à Sua bondade, contemplo a luz." Assim acolhe o Senhor os homens, assim os atribula, assim levanta os atribulados, assim os desvia das infâmias e os recebe de novo na Sua confiança e amizade. E faz isto não uma única vez, mas duas e três, de maneira a arrancar das fauces da morte os homens votados à perdição e ruína e iluminá-los com o resplendor da luz de que gozam os vivos. Logo, quando o Senhor oprime com incómodos o homem, está a depor; quando o dobra, 
Primum orationis diuinae genus est diuini Spiritus appulsus, quo animi commouentur et de rebus ab humana intelligentia remotis erudiuntur, ut in somniis fieri plerumque solet. Per nocturnum enim uisum, cum homines in lectis suis graui somno consopiti iacent, Deus illorum mentes ad audiendum excitat illisque disciplinam salutarem tradit et, quasi impresso sigillo, consignat, ut hominem a flagitiis auocet et uirum a superbia et elatione deterreat. Sic autem fit ut impendentia mala uitet et dolos et insidias, uitae suae comparatas, effugiat et tela, ab hostibus emissa, declinet.

Alterum genus orationis quo Deus mentem suam aperit est morbus, quo nocentem hominem affligit et in lecto decumbere grauemque dolorem subire compellit, omniaque ossa illius contundit atque debilitat. Is igitur, qui ad hunc modum a Deo uexatur, omnes cibos cum summo fastidio repellit et dapes, quas antea uehementer appetebat, exsecratur. Corpus paulatim absumitur et speciem pristinam amittit. Et ossa, quae carnibus obducta uideri non poterant, ob grandem maciem exstant et eminent. Vita illius ad summum periculum mortis accedit et ipse funeris curatores propemodum intueri compellitur.

In hoc autem angore et cruciatu, si ex magno angelorum numero unus saltem astiterit qui uim diuinae legis interpretetur hominemque doceat quam iusto Dei iudicio in morbum illum inciderit, qui illum odio susceptae improbitatis accendat et ad studium pietatis excitet illique iuris et innocentiae uiam monstret, Dominus repente ea uitae conuersione placatur angeloque praecipit ut a summi periculi peste hominem, prope iam mortiferis morbis exstinctum, eripiat et in ualetudinem amissam reuocet. Inquit enim: "Accelera, illum confestim redime ne morte deleatur, iam enim dolore, quem ex [100] flagitiis olim admissis percepit, scelera, quibus eram infensus, expiauit." Itaque Domini beneficio sanitatem et pristinam speciem recuperat. Caro enim illius instauratur atque renouatur et nitore atque mollitudine pueritiae florem imitatur et in antiquum adulescentiae robur adducitur. Is enim ad Dominum preces adhibet, qui illi se propitium exhibet faciemque suam ualde laetam ostendit et facit ut homo iustitiae pridem amissae ornamenta recuperet.

Homines respicit Dominus eorumque rebus benigne consulit et, cum in officio delinquunt, ab eis delicti confessionem requirit ut, ad illum conuersi, ueniam flagitent et, cum illo rursus in gratia positi, dicat quilibet eorum: "Peccaui, iustitiae sanctitatem uiolaui neque me ad studium illius applicui, propter quod plagis multo lenioribus quam fueram meritus afflictus sum. Attamen Dominus me ex exitio redemit illiusque benignitate e tenebris emersus lucem respicio." Sic homines accipit Dominus, sic affligit, sic erigit afflictos, sic auertit a flagitiis et in suam rursus fidem et amicitiam recipit. Et hoc non semel, sed iterum et tertio facit, ut homines, pesti et exitio deuotos, e mortis faucibus eripiat et splendore lucis, qua uiui fruuntur, illuminet. Ergo, cum Dominus incommodis hominem afficit, testimonium dicit; cum plectit, loquitur; cum ei graue uulnus inurit, satis aperte se iratum esse pronuntiat. 
está a falar; quando o marca com uma grande ferida, está a afirmar com sobeja evidência que está encolerizado.

Portanto, porque te queixas de ignorares a causa da tua desgraça? É que, em primeiro lugar, não existe nenhuma lei que obrigue o Senhor de todas as coisas a dar o motivo daquilo que delibera e realiza. Em segundo lugar, está a expor-te assaz a razão do Seu juízo quando te oprime com essa desgraça: algo que não teria feito se não se tivesse apercebido de que tu eras culpado de muitos crimes. Por conseguinte, que existe de mais impudente do que, contra o claro testemunho de Deus, querer encobrir com uma inocência simulada os crimes cometidos? Ou que há de mais desatinado do que, o homem condenado pelo juízo de Deus chamar a juízo o próprio Deus? Algo que não diminui com certeza o crime perpetrado, mas aumenta os crimes cometidos com o aditamento de um novo crime.

Por consequência, resta que te compenetres de que o remédio da tua salvação deve colocar-se, não na falsa defesa das infâmias, mas na verdadeira confissão dos pecados. Por isso, Job, toma atenção e ouve com cuidado o que te digo e cala enquanto eu digo o que quero. Em seguida, se tens palavras, ser-te-á permitido responder. É que tenho grande vontade de ver com que argumentos defendes a tua justiça. Mas se não te ocorre nada para dizeres neste momento, escuta e, calado, toma atenção, para obteres algum proveito da minha sabedoria. Dou-te a escolher a opção que preferires entre estas duas: ou falas tu, ou escutas-me a mim a falar.

Neste ponto, tendo-se seguido um silêncio e Job nada dizendo, Eliú prosseguiu a sua fala do modo seguinte:

- Escutai, sábios varões, o meu discurso, e vós, que fostes instruídos nos mais elevados conhecimentos, prestai a máxima atenção ao que vou dizer, para que possais ajuizar acerca da minha opinião. É que, assim como, pela degustação, o paladar avalia o sabor agradável dos alimentos, da mesma forma o ouvido do homem inteligente julga o discurso sensato. Formemos para nós um tribunal, a fim de, relativamente a este debate, avaliarmos a favor de qual de nós os dois se deve decidir a contenda. Ora, em primeiro lugar, que Job relembre as suas palavras, [101] para que saibais com que é que os meus argumentos devem comparar-se. É que ele disse: "Sou justo, todavia não me é lícito reclamar o meu direito diante de Deus, e deste modo há falsidade no Seu juízo. Com efeito, recebe-me de maneira indigna como a culpado e criminoso e não dá ouvidos às minhas palavras, que imploram a Sua ajuda. Por conseguinte, ainda que não tenha cometido nenhum crime ou pecado, mesmo assim sou atormentado por incuráveis dores e trespassado por uma seta mortífera." - Esta é a opinião dele e amiúde se queixa de ter sido ferido por Deus sem qualquer razão de legítimo direito.

Que hei-de responder a isto? A tanto chega a audácia do homem? A tanto a altivez de um ânimo arrogante e soberbo? Parece que é impossível acrescentar-se seja o que for a uma tamanha monstruosidade de insolência e desatino. Na verdade, desde que existe o género humano, quem é que se aplicou, enquanto defendia a sua justiça, a ter como divertimento zombar dos juízos divinos e, como se bebesse água, a saciar, com insultos 
Quid igitur quereris esse ignotam tibi calamitatis tuae causam? Primum enim nulla iura sunt quae cogant rerum omnium Dominum reddere eorum, quae designat et efficit, rationem. Deinde, satis tibi iudicii sui rationem exponit cum te clade ista pressit: quod non fecisset, nisi te multis criminibus alligatum animaduertisset. Quid igitur impudentius quam, contra tam clarum Domini testimonium, uelle, innocentiae simulatione, admissa flagitia tegere? Aut quid amentius quam hominem, Dei iudicio conuictum, ipsum Deum ad iudicium prouocare? Quod quidem non susceptum scelus imminuit, sed commissa scelera accessione noui sceleris amplificat.

Reliquum igitur est ut non in falsa flagitiorum defensione, sed in uera peccatorum confessione salutis tuae remedium collocandum existimes. Quocirca animum aduerte, Iobe, et ad ea quae dico diligenter attende atque tantisper sile, dum eloquar quod uolo. Licebit deinde tibi, si uerba suppetunt, respondere. Cupio enim uidere penitus quibus argumentis iustitiam tuam defendas. Si uero non occurrit tibi quid in praesentia dicas, ausculta et tacitus animaduerte, ut aliquem fructum ex sapientia mea consequaris. Optionem tibi do ut eligas utrum uelis: uel ipse loquare, uel me loquentem audias.

Hic, cum silentium fuisset consecutum et Iobus nihil diceret, Helius rursus ad hunc modum sermonem instituit:

- Audite, uiri sapientes, orationem meam, et qui estis maximis disciplinis eruditi, quid dicam, attentissima consideratione, percipite, ut de sententia mea iudicium faciatis. Vt enim palatum ciborum suauitatem gustu diiudicat, sic hominis intelligentis auditus prudentem orationem probat. Iudicium nobis constituamus, ut, de hac disceptatione, utri ex nobis duobus causa sit adiudicanda consideremus. Primum autem uerba sua $[\mathbf{1 0 1}]$ recognoscat Iobus, ut teneatis quo argumenta mea conferenda sint. Sic enim dixit: "Iustus quidem sum, per Deum tamen mihi ius meum persequi non licet, itaque mendacium in iudicio illius uersatur. Vt sontem enim et sceleratum me indignis modis accipit neque meam orationem, opem illius implorantem, ad aures admittit. Cum igitur in me nullum scelus aut peccatum haereat, insanabili tamen dolore crucior atque sagitta mortifera confixus sum." - Haec est illius sententia et hoc saepe conqueritur, fuisse se a Deo sine ulla iuris legitimi ratione uulneratum.

Quid ad haec dicam? Tantamne esse hominis audaciam? Tantum animi arrogantis et elati fastidium? Iam nihil addi posse uidetur ad tantam insolentiae et temeritatis immanitatem? Quis enim post homines natos hoc sibi assumpsit ut, dum iustitiam suam tueretur, pro delectamento haberet diuinis iudiciis illudere et, perinde atque si aquam biberet, ita maledicendi cupiditatem et sitim, qua flagrat, 
lançados contra Deus, a sede e desejo de maledicência em que se abrasa? Ora, deste modo juntou-se à raça e grupo dos que, por um lado, pela iniquidade violam o direito da sociedade humana e, por outro, pela impiedade mancham criminosamente a religião.

É que das palavras dele extrai-se a opinião de que nenhum proveito é oferecido aos homens que respeitam de um modo extraordinário a justiça e veneram a Deus com uma adoração santíssima e trasbordante de piedade. É que se exprime nestes termos: "Ainda que, no amor da justiça e da humanidade, o homem se comporte de modo muito mais excelente do que os restantes homens, e, em todas as situações da vida, obedeça a Deus com espírito inflamado, e com zelo e perseverança ardentes se esforce por aprazer-Lhe, todavia não obterá nenhum proveito desta virtude e piedade."

Ora, que é isto senão arrancar a Deus a equidade, a Ele que liga todas as coisas através de uma lei e governo santíssimos? E assim sucede que, quando Job se empenha em ornar-se com falsos merecimentos de justiça, está a esforçar-se por despojar Deus dos mais verdadeiros merecimentos de justiça. Que pode imaginar-se de mais indigno do que este atentado? Por isso, sensatos varões, prestai atenção, afastai o agoiro, repeli o flagelo, fortificai com defesas o vosso espírito para que um crime tão pestilencial não o invada. Que o poder divino d' Aquele santíssimo Senhor nos guarde de tornarmos o nosso espírito culpado de um crime tão monstruoso que nos leve a afirmar que Ele é o autor da impiedade e da iniquidade. É que Ele é o Criador da lei, o pai da justiça, a regra e norma sempiternas do juízo, que não pode ser dobrado nem mudar nem variar. Por conseguinte, sempre estabelece recompensas aos homens em proporção com as obras e actividades, de tal forma que paga aos maus com males e aos bons com bens, que é a função e ofício da justiça. Por isso de modo algum se deve tolerar o que Job afirmou, pois Deus não condena os inocentes nem volta às avessas o juízo da equidade.

De facto, que O desviaria da justiça? Algum medo e a ignorância? Porventura alguém sente justificadamente a falta da sabedoria no Senhor supremo de todas as coisas, que governa a totalidade da natureza com tão admirável discernimento e razão? Existe acaso alguém que se intrometa nas obras tão grandiosas da sempiterna divindade? Que procure ensiná-Lo com o seu conselho ou emendar as obras d' Ele? Pois quem é que juntamente com Ele iluminou a Terra com o seu poder divino? Quem é que serviu de apoio sobre o qual se firmou toda a Terra? [102] Porventura é possível que viole a lei e a equidade quem construiu o mundo com uma lei, ordem, harmonia e regularidade tão admiráveis?

Retorquirás talvez que o medo O desviará do que é justo. - De quem se arreceou Aquele que com poder infinito abarca a vida de todos os seres vivos? Se assim Lhe aprouvesse privaria do alento vital todos os seres animados, pois assim como a todos comunicou a vida, da mesma maneira, quando tal decidir, como se tivesse sido concedida por empréstimo, reclamá-la-á e chamará a Si toda a capacidade de respirar. Por consequência, então todos os seres vivos se extinguirão e o homem será reduzido a pó, visto que é do Seu poder divino, inteligência, vontade e razão que dependem tanto a vida e salvação como a morte e perdição.

Se és dotado de entendimento, procede como homem provido de inteligência, de modo a escutar-me atentamente e a compreenderes com a mente e a razão aquilo que 
coniectis in Deum conuiciis exstinguere? Sic autem sese ad eorum nomen atque coetum adiungit qui, et iniquitate ius societatis humanae uiolant, et impietate religionem scelerate contaminant.

Haec enim sententia ex illius uerbis elicitur, nullum fructum esse propositum hominibus qui iustitiam unice colunt et Deum cultu sanctissimo pietatisque plenissimo uenerantur. Sic enim ait: "Vt homo, in iustitiae et humanitatis studio, multo excellentius quam reliqui homines se gerat, et Deum, in omni uitae, animo inflammato sequatur, et contento studio cursuque, ut illi placeat, elaboret, nullam tamen utilitatem ex ea uirtute et pietate consequetur."

Hoc autem quid aliud est quam Deo, qui omnia sanctissimo iure et moderatione deuincit, aequitatem detrahere? Ita uero fit ut, dum Iobus se falsis iustitiae laudibus ornare studet, Deum uerissimis iustitiae laudibus spoliare conetur. Quo quidem facinore quid animo cogitari potest indignius? Idcirco, uiri prudentes, attendite, omen detestamini, pestem arcete, animos firmate praesidiis, ne tam pestiferum scelus in eos inuadat. Contineat nos illius Domini santissimi numen, ne tam immani scelere animos nostros alligemus ut illum auctorem impietatis et iniquitatis asseramus. Est enim ille iuris conditor, iustitiae parens, iudicii regula atque norma sempiterna, quae neque inflecti neque immutari neque uariari potest. Semper igitur hominibus pro operum et studiorum ratione mercedem constituit, ita ut malis mala, bonis uero bona rependat, quod est iustitiae officium et munus. Nullo igitur modo ferendum est quod Iobus asseruit, nec enim Deus innocentes condemnat aut aequitatis iudicium peruertit.

Quid enim illum a iusticia deduceret? Error aliquis et inscitia? Num aliquis sapientiam in summo rectore rerum omnium, qui tam admirabili consilio et ratione naturam uniuersam moderatur, merito requirat? Estne quisquam qui se in tam praeclara opera sempiterni numinis interponat? Qui illum consilio instruere aut opera illius emendare studeat? Quis enim cum illo terram numine suo lustrauit? Quis uniuersum terrarum orbem praesidio suo stabiliuit? [102] Qui igitur tam admirabili lege et ordine, modo et aequabilitate mundum construxit, fierine potest ut ius et aequitatem uiolet?

Metu forsitan, inquies, a iure discedet. - Quem metuit qui omnium animantium uitam potestate infinita complectitur? Si illi ita uisum fuerit, cunctis animantibus spiritum uitalem eripiet. Vt enim uitam cunctis impertiuit, ita, cum id statuerit, eam, quasi mutuo datam, repetet et ad se omnem uim spirabilem reuocabit. Tunc igitur animantia cuncta deficient et homo in puluerem redigetur, illius siquidem numine, mente, uoluntate, ratione uel uita et salus uel mors et exitium continetur.

Si mentis compos es, cogitationem intelligentis hominis suscipe, ut me attente audias et quae dixero mente et ratione comprehendas. Num qui uerum iudicium 
te disser. Acaso quem odeia o julgamento verdadeiro há-de curar os ferimentos que infligiu? Certamente que não. Ora, se sara prontamente aqueles a quem fere por causa das infâmias que cometeram, assim que eles se arrependem de uma existência vivida de forma vergonhosa, como golpearia os homens que durante a vida não tinham cometido absolutamente infâmia alguma? Logo, quando pensa as feridas, está a mostrar de sobejo que não odeia o que o juízo determinou, mas que tem a máxima preocupação com a justiça. Por conseguinte, que atrevimento tão impudente foi esse teu, que te levou a acusar de injustiça aquele santíssimo e justíssimo Juiz, dotado de imensurável poder? Portanto, se as obras da natureza mostram a Sua sabedoria; se com o Seu imenso poder conserva a vida de tudo quanto existe; se dá um remédio salutar às feridas dos que se decidem a regressar ao cumprimento do dever; se no Seu juízo não pode haver nem erro, nem debilidade, nem desumanidade, como é que se conclui que Ele perverte a justiça e golpeia os inocentes? Por isso jamais permitirá que, contra o que é justo e de direito, os bons sejam atribulados, nem concederá aos ruins as máximas riquezas e todos os ornamentos da dignidade.

Por conseguinte, não é verdade a tua afirmação de que ao ímpio se concede o poder e senhorio da Terra. Pode caber na cabeça de um homem em seu perfeito juízo que, quem governa o mundo com a máxima equidade e senhorio eterno, conserve na posição de rei supremo o mais hostil inimigo de toda a equidade? Que dê as posições primaciais ao ímpio merecedor do sempiterno suplício? De forma alguma. Portanto, com que intento afirmaste que é por Sua vontade que os ímpios detêm o senhorio da Terra? Naturalmente, porque quem costuma movê-Lo são aqueles que muito se avantajam em riquezas, e atribui esse poder, a que te referes, não aos merecimentos dos homens, mas à notoriedade popular dos homens... Ele, porém, não dá qualquer importância às nomeadas concedidas pelos homens, nem atende à posição que as pessoas detêm, nem antepõe os ricos aos pobres, uma vez que a todos criou de modo idêntico. Com efeito, diante de quem abrange com o Seu poder imenso tudo quanto existe por cima e por baixo, que influência e autoridade podem ter as vãs riquezas, as falsas honrarias e todas as ilusões do acaso e da sorte?

Retorques porém dizendo que por vezes muitos homens criminosos e injustos possuem as maiores riquezas. É certo. Mas atenta não tanto na aparência de uma fortuna próspera, quanto no seu súbito fim e ruína. É que os homens injustos, inchados e ensoberbecidos com as riquezas, morrem vítimas de uma desgraça repentina, são consumidos por um mal imprevisto e inopinado; o desvario da multidão desperta e arremete como uma espécie de turbulenta tempestade e, com a maior das facilidades, derruba o tirano e com furioso ímpeto deita por terra o que cai, pois as riquezas [103] adquiridas através do crime não podem ter estabilidade, e até quando parecem possuir fundamentos muitíssimo sólidos, é quando são completamente destruídas por uma calamidade repentina, pois o juízo de Deus abate-se violentamente sobre elas. É que os Seus olhos observam todas as actividades e obras dos homens e vêem claramente qual o caminho que cada um toma e para onde dirige o seu espírito. Não existem nenhumas trevas tão densas, nem nenhuma escuridão tão medonha e assustadora, nem nenhum esconderijo de tão mortífera cerração capazes de ocultarem os homens ímpios e injustos. 
odio persequitur inflicta uulnera curabit? Non certe. Nam, si eos quos propter admissa flagitia uulnerat, cum primum illos uitae turpiter actae paenitet, repente sanat, quo tandem modo eos, qui nullum omnino flagitium in uita susceperant, sauciaret? Ergo, cum uulnus obligat satis ostendit se minime iudicium odio habere, sed summam iustitiae curam suscipere. Quae tam proiecta igitur audacia ista tua fuit, ut sanctissimum et iustissimum illum iudicem, immensa potestate praeditum, iniustitia condemnares? Si igitur opera naturae sapientiam illius ostendunt; si uita omnium potestate illius immensa continetur; si eorum uulneribus, qui ad officium redire statuunt, salutare remedium adhibet; si nec error, nec imbecillitas, nec immanitas in iudicio illius uersari potest, ut is iudicium inuertat et innocentibus plagas imponat? Quare nec umquam bonos contra ius et fas affligi permittet, nec improbos opibus summis omnibusque dignitatis ornamentis afficiet.

Non est igitur uerum quod dixisti, impio terrae potestatem et imperium permitti. Idne potest in hominis sani mentem intrare ut is, qui mundum summa aequitate et aeterno imperio regit, infestissimum totius aequitatis hostem in loco summi regis habeat? Vt impium supplicio sempiterno dignissimum principibus annumeret? Nullo modo. Qua mente igitur hoc asseruisti, impios illius uoluntate terras imperio coercere? Scilicet, eorum gratia, qui multum opibus antecellunt, moueri solet et eam potentiam, quam dicis, non hominum meritis, sed hominum populari nobilitati concedit... At is nullam rationem humanae dignitatis habet, neque quam personam quisque gerit expendit, neque diuites egentibus anteponit, cum ab illo similiter omnes effecti sint. Quid enim apud illum qui omnia, quae supra subterque sunt, potestate immensa complectitur, ualere gratia et auctoritate possunt opes inanes, honores fallaces omniaque temeritatis et fortunae ludibria?

At inquis, multos homines maleficos et iniustos summas interdum opes habere. Verum. Sed tu non tam fortunae florentis speciem, quam subitum illius occasum et ruinam, considera. Homines enim iniusti, opibus elati et inflati, repentina clade oppressi moriuntur, improuiso inopinatoque malo consumuntur; multitudinis furor incitatur et, quasi turbida quaedam tempestas, inuehitur facillimoque negotio tyranni statum labefactat atque praecipitantem impetu furibundo prosternit, opes namque [103] maleficio partae stabilitatem habere non possunt, immo cum firmissime fundate uidentur, tum repentina calamitate funditus euertuntur, Dei namque iudicium in illas uiolenter incurrit. Oculi enim illius omnia hominum studia et opera contuentur et quam quisque uiam ineat et quo intendat animum clare uident. Nullae sunt tam densae tenebrae, nulla adeo taetra et horrenda caligo, nullae mortiferae obscuritatis latebrae quibus se occultare queant homines nefarii et iniusti. 
"- Mas, por que é que," dirás tu, "não chama os homens a juízo e os ouve antes de pronunciar a sentença?" Porque tal procedimento é próprio da fraqueza humana, a qual só consegue julgar depois de a causa lida e ouvida e escrupulosamente examinada. Mas Aquele que observa, vê e olha para todas as coisas e esquadrinha o que se esconde nas trevas, não tem necessidade de fixar um dia, de formular a acusação, de interrogar as testemunhas, de ver-se constrangido pelo conselho nem de deliberar muito e durante muito tempo, para só então condenar à morte os culpados de crime. Por isso, não permite aos homens que vão com Ele a tribunal, com Ele pleiteiem em justiça, apresentem diante d' Ele advogados, refutem testemunhos, para pronunciar sentença só depois de a culpabilidade haver sido legitimamente comprovada. E assim em qualquer causa estuda a questão a fundo, examinando-a sem testemunho de homens, e deste modo destrói e abate com rectíssimo juízo os tiranos, substituindo-os por outros homens que obtêm o poder em vez deles.

Ora, é pelo critério e motivo mais elevados que faz que homens colocados num elevadíssimo lugar caiam da sua posição e eleva às supremas honrarias os que eram humildes e obscuros, de maneira a, através deles, castigar a maldade dos homens soberbos. E quanto ao facto de destruir os homens ímpios e soberbos, procede assim para pôr diante dos olhos e vista de todos as suas abomináveis acções, e arranca-lhes a luz e faz abaterem-se sobre eles as terríveis trevas da noite para que de forma alguma possam prometer-se de alhures ajuda e auxílio. Por conseguinte, os homens infames pelos crimes padecerão o castigo dos ímpios no mesmo lugar em que viveram na maior prosperidade, para que os demais, que virem aquele exemplo do rigor divino, exultem de contentamento com a ruína dos que os oprimiram e se alegrem com a justíssima punição do crime e da impiedade. É que os celeradíssimos homens afastaram-se de modo sacrílego e ímpio do governo do Senhor e, precipitando-se na loucura, apartaram-se das Suas vias, para, desprezando a causa da salvação, vesanicamente se arrojarem na perdição, de maneira a assim acabarem por pagar as penas dos crimes com os quais obrigaram a gritar os pobres vexados pela injustiça, pois o Senhor escutará os brados e queixumes dos pobres que são oprimidos pelos ruins, por forma a, no ensejo oportuno, castigar o crime dos homens malvados.

Quando Ele acalma a tempestade, quem há-de provocar as vagas? E quando retira a Sua ajuda e priva de socorro, quer todo o povo, quer cada um dos homens, quem háde tornar a pôr nas Suas boas graças os que estão destituídos do Seu auxílio? Portanto, não será destruído por nenhumas forças o homem a quem Ele protege, nem conservará uma condição isenta de desgraça o homem a quem despojou da Sua ajuda poderosa. E até aquilo que parece depender da deliberação e poder dos homens de tal maneira, por juízo de Deus, frequentemente se modifica por causa dos crimes cometidos, [104] que semelha que é por sua livre e espontânea vontade que eles caem naquele mal que, mais que nada, desejavam evitar. De facto, os homens cobertos de ignomínias não conseguirão impedir, com nenhuns planos e maquinações, que o homem malvado e injusto, confiante na falsa aparência de bondade, alcance as honrarias e se aposse da autoridade real, por forma a enredar nas suas ciladas o povo, embaído pelos embustes, e com um domínio 
"- At", inquies, "cur non homines in iudicium uocat eosque audit antequam sententiam ferat?" Quia hoc est imbecillitatis humanae, quae non potest, nisi recitata et audita causa et diligenter examinata, iudicare. Illi uero qui omnia speculatur, animaduertit, inspicit et, quae tenebris inclusa latent, explorat, minime opus est ut diem dicat, crimen intendat, testes interroget, consilium cogat et multum diuque deliberet, ut tum demum sceleris conuictos capite condemnet. Non igitur hoc hominibus permittit, ut cum illo in ius ambulent, iudicio certent, aduocatos adhibeant, testimonia refellant ut tum demum sententiam ferat, cum causa fuerit legitima probatione conuicta. Itaque causa qualibet, minime hominum testimonio peruestigata, rem penitus explorat et sic rectissimo iudicio perdit et affligit tyrannos, alios substituit qui illorum uice rerum potiantur.

Vtrumque autem summo consilio et ratione facit ut homines, in altissimo gradu locatos, e gradu deiiciat et qui erant humiles et obscuri ad summos honores extollat, ut, illorum opera, sumat de hominum superborum immanitate supplicium. In eo uero, quod homines impios et insolentes euertit, eorum studia nefaria in omnium oculis et aspectu proponit, lucemque eis eripit taetrasque noctis tenebras offendit, ne sibi queant ullo modo opem aliunde et auxilium polliceri. Homines igitur sceleribus infames impiorum poenam in eodem loco, in quo maxime florentes exstiterant, sustinebunt, ut reliqui, qui exemplum illud diuinae seueritatis aspexerint in eorum ruina, a quibus oppressi fuerant, gaudio efferentur et in iustissima uindicta sceleris et impietatis exsultent. Ab imperio namque Domini scelestissimi homines nefarie et impie defecerunt amentiaque praecipites ab illius uiis aberrauerunt, ut, neglecta salutis ratione, in pestem furenter irruerent, ut sic tandem luerent poenas scelerum quibus pauperes iniuria uexatos uociferari compulerant, Dominus enim uoces et querellas pauperum, qui ab improbis uexantur, exaudiet, ut, opportuno tempore, maleficorum hominum scelus ulciscatur.

Cum is tempestatem sedat, quis fluctus excitabit? Cum uero opem suam remouet et siue gentem uniuersam, siue homines singulos praesidio nudat, quis eos, qui illius auxilio orbati sunt, in gratiam illius restituet? Non igitur is, quem ille tuetur, uiribus ullis euertetur, nec is, quem praesenti ope destituit, statum a calamitate incolumem retinebit. Quin etiam id, quod uidetur esse in hominum consilio atque potestate positum, ita, Dei iudicio, propter scelera commissa frequenter [104] immutatur ut appareat illos sponte sua in id malum, quod uitare maxime cupiebant, incurrere. Nec enim ullis consiliis et machinis impedimento esse poterunt homines cooperti flagitiis quominus homo maleficus et iniustus, ficta bonitatis specie commendatus, ad honores obrepat regnumque possideat, ut populum, fraudibus illectum, laqueis impediat, et acerbissimo dominatu oppressum in potestate contineat. Sic autem hominum peccatis euenit ut, cum 
violentíssimo mantê-lo sob o seu poder. Ora, deste modo, devido aos pecados dos homens, sucede que, embora nada temam mais do que a servidão e vivamente abominem a tirania, todavia são eles mesmos quem impõe sobre as suas cabeças o jugo do tirano e, quanto mais se empenham em alcançar a liberdade e uma licença desenfreada, tanto mais rapidamente a perdem e são mantidos na violenta opressão de um duríssimo domínio.

É que ninguém poderá evitar a desgraça ou afastar o perigo ou conservar a liberdade se não obtiver do Senhor o perdão dos delitos, visto que só Ele pode dizer: "Perdoo o castigo aos que cometeram crimes e não assolarei a terra." - O sentido destas palavras é que não deve pensar-se que nem a guerra, nem a doença, nem a fome, nem a devastação, nem a servidão, nem, em suma, mal algum sobrevindo aos negócios humanos nasce de outra origem que não seja o santíssimo e justíssimo Senhor, inimigo dos pecados dos homens, de tal maneira que, sempre que nos vemos atribulados, devemos recordar-nos dos nossos crimes, por causa dos quais sofremos esses males, e não pensemos que para os repelir a todos se estabeleceu outro remédio que não seja rogarmos com todo o espírito o perdão dos nossos erros.

Se não penso correctamente, quero que me refutem. Por conseguinte, gostaria que me ensinasses e me mostrasses as faltas que se acham no meu discurso, a fim de que, por ti convencido, não diga mais nada. É que, caso contrário, continuarei a manter a minha opinião, porquanto não é justo que o homem que pretende investigar a verdade, quando discute por dever, ponha termo à sua discussão, como se tivesse mudado de opinião, antes de chegar ao fim, pelo único motivo de recear o revés. Pois quê? Porventura porque desprezas e rejeitas estas opiniões (pois são-te desagradáveis) é justo que se ponha termo à discussão? Certamente que não, pelo que cabe-te a ti escolher qual destas duas alternativas preferes: ou refutar-me ou escutar o que me resta por dizer. Portanto, se sabes alguma coisa com que possas refutar a minha opinião, fala imediatamente, para que eu emudeça, vencido por ti. Mas, ainda que nada respondas ao que digo, mesmo assim não aprovas isso que eu digo. Que importa? Pois os homens deveras experientes e inteligentes pensarão como eu e o homem sábio acreditar-me-á e não haverá ninguém, contanto que possua uma mente sã, a quem eu não esteja seguro de que hei-de provar a minha opinião.

Ora, Job, o único que se arroga a máxima sabedoria, há-de não só rejeitar uma opinião totalmente verdadeira, mas também falar com impudência e desatino e pronunciar palavras tais que, por elas, se reconheça a sua loucura. Portanto, para onde hei-de voltar-me? Que remédio descobrirei para esse mal? Com que socorros hei-de arrancar-te desse flagelo que te mantém em estado mofino? Desejo deveras que recuperes o são entendimento para que, depois dele recuperado, readquiras a saúde perdida. E, assim, empenho os máximos esforços e aplico todas as forças no sentido de desviar-te desse desvario: mas não obtenho quaisquer resultados. Todavia não admira que as minhas palavras não te curem, uma vez que nem mesmo esses golpes, que te infligiu a irada divindade, devolveram a sanidade ao teu entendimento.

Ó Pai santíssimo, [105] que com tanto cuidado, desvelo, providência e benignidade olhas pelas coisas humanas, que só pela Tua bondade foste levado a ensinar Job através 
nihil magis quam seruitutem exhorreant et tyrannidem uehementer exsecrentur, ipsi tamen tyrannum suis capitibus imponant et, quo magis libertatem et impunitam licentiam obtinere student, eo citius illam amittant durissimoque dominatu uiolenter oppressi teneantur.

Nemo enim poterit uitare calamitatem aut propulsare periculum aut libertatem tueri nisi fuerit a Domino delicti ueniam consecutus, siquidem ille solus potest dicere: "Poenam remitto iis qui se sceleribus astrinxerant neque terram uastabo." - Summa orationis haec est ut neque bellum, neque morbus, neque fames, neque uastitas, neque seruitus, nec ullum denique malum in res humanas inuectum, aliunde nasci putandum sit quam a sanctissimo et iustissimo Domino, hominum peccatis infenso, ita ut, quotiens nos afflictos cernimus, totiens scelerum nostrorum, propter quae ea mala patimur, recordari debeamus, nec aliud ad ea omnia depellenda remedium institutum esse sentiamus, quam ut tota mente erratorum ueniam flagitemus.

Si non recte sentio, cupio refelli. Velim igitur me doceas et, quae uitia in oratione mea sint posita, demonstres, ut, a te conuictus, nihil amplius dicam. Aliter enim in sententia mea permanebo, nec enim aequum est ut is, qui uerum inquirere uult, cum de officio disputat, non aliam ob causam nisi quod offensionem uereatur, quasi de sententia deductus sit, antequam ad exitum perueniat, disputationi suae finem imponat. Quid igitur? Num ob id quod has sententias aspernaris atque repudias (molestae namque tibi sunt) par est ut finem habeat disputatio? Non certe, idcirco tuum erit eligere utrum uelis: uel me refellere, uel, quae mihi dicenda restant, audire. Si igitur aliquid nosti quo possis sententiam meam refutare, confestim eloquere, ut ipse, a te conuictus, obmutescam. Verum, cum ad haec, quae dico, nihil respondeas, ista tamen, quae dico, minime probas. Quid refert? Homines enim profecto rerum periti et intelligentes mecum sentient et uir sapiens mihi auscultabit nemoque erit, modo sana mente sit, cui non me sententiam meam probaturum confidam.

Iobus autem, solus qui sibi summam sapientiam arrogat, non modo sententiam uerissimam improbabit, sed etiam impudenter et temere loquetur eaque uerba fundet, ex quibus illius amentia cognoscatur. Quo me igitur uertam? Quod remedium isti malo inueniam? Quibus te praesidiis ab ista peste, quae te miserum tenet, eripiam? Cupio quidem te in bonam mentem restitui ut, ea recepta, salutem amissam recuperes. Itaque summa ope nitor et neruos omnes intendo ut te ab isto furore deterream: sed nihil proficio. Nec mirum tamen est te oratione mea minime sanari, cum neque plagis quidem istis, quas tibi iratum numen inflixit, in mentis sanitatem reuocatus sis.

O Pater [105] sanctissime, qui tanta cura, studio, prouidentia, benignitate, rebus humanis consulis, qui tua tantum bonitate illectus es ut istis poenis, quas 
dessas penas que lhe infligiste e a tirares do seu espírito as enfermidades de alma que o enleavam, visto que ele nem com tão grande número de golpes pode renunciar a uma opinião ímpia e readquirir a saúde, peço-Te e rogo-Te que não abrandes seja o que for no Teu rigor punitivo, mas que violentamente o atormentes, enquanto perseverar no crime, para que, com este excepcional exemplo de severidade, os homens injustos sejam levados a passar da iniquidade para a piedade e para a justiça. É que Job não cometeu um crime mediano e usual entre os homens ruins, mas diante dos nossos olhos perpetrou um delito novo e inaudito e ajuntou às infâmias anteriores o crime de uma impiedade inqualificável. Com efeito, conquanto seja culpado de muitos e abomináveis crimes, todavia aplaude-se a si mesmo como se tivesse excelentes merecimentos e incha-se com tamanha soberba e arrogância que não tem escrúpulo em chamar Deus a juízo. Que pode imaginar-se mais indigno e criminoso do que isto? Porquanto, pelo mesmo acto com que alega a favor da sua excepcional santidade, condena por crime e injustiça o supremo e santíssimo Senhor e justíssimo governante.

Eliú, depois de pronunciar estas palavras, continuou a falar neste teor:

- Porventura, mesmo depois de haver sido derrotado por tão grande número de argumentos, ainda persistes no propósito de entrar em disputa com Deus num juízo legal? Porventura estás confiante em que, se pleiteares com Ele, hás-de sair vencedor do julgamento e ganhar a questão? É que afirmaste: "Que proveito me há-de resultar de ter sido escrupulosamente piedoso? Ou que ganho obterei, se expiar o crime? Com efeito, Deus não destrói unicamente os culpados, mas também vemos frequentemente que Ele atribula com as maiores penas os homens puros e santos."

Por isso, responder-te-ei, a ti e aos teus amigos, que estão presentes: Olha, peço-te, para o céu, contempla os astros, fixa a tua atenção nas figuras aéreas e repara que todas estas coisas ocupam na natureza um lugar tão alto que não te é possível elevar-te a elas através do espírito e do pensamento. Portanto, se és tão pequeno que, comparado com as tão magníficas e superiores obras de Deus, não tens sequer o valor de um ponto mínimo, como é que poderá provir de ti seja o que for capaz de tornar pior ou melhor a condição do ar e do céu? Logo, se em ti nada existe que de alguma forma se estenda até às obras de Deus, como é que enfim crês ser possível que algo do que te pertence, quer de bom, quer de mau, pode recair sobre o próprio Criador e Senhor supremo, que criou todas estas coisas e as abarca e encerra com o Seu abraço? Se pecares, que dano Lhe causarás? Se acrescentares os teus crimes com inúmeras adições, em que diminuirás a Sua grandeza e majestade? Em quê, se abraçares a justiça? Porventura o obrigarás com algum favor que redunde em proveito d' Ele? Certamente que não. É que Ele não tem necessidade das riquezas humanas nem de quaisquer amanhos de terras, de maneira a que, por este motivo, cuides que algum dia há-de receber de ti alguma dádiva e presente que Lhe seja vantajoso.

Por conseguinte, uma vez que és homem como os restantes que provêm da mesma espécie humana, se fores ímpio, a tua impiedade há-de fazer mal [106] aos homens, e não a Deus; paralelamente, se cultivares a justiça, a tua justiça há-de ser proveitosa para os 
Iobo intulisti, eum erudires et morbos animi, quibus erat implicitus, ab illius mente depelleres, te oro et obtestor, quando is neque tantis plagis ab impia mente desistere et ad sanitatem reuocari potest, ne quidquam de puniendi seueritate remittas, sed illum, quamdiu in eo scelere perstiterit, uehementer excrucies, ut, hoc insigni seueritatis exemplo, homines iniqui ab iniquitate ad pietatem et iustitiam traducantur. Non enim Iob mediocre et usitatum improbis hominibus scelus, sed nouum et inauditum in nostris oculis suscepit et pristina flagitia impietatis infandae crimine cumulauit. Nam, cum multis et nefariis criminibus astrictus sit, sibi tamen, quasi in meritis excellentibus, applaudit tantaque superbia et arrogantia tumet ut Deo iudicium denuntiare minime uereatur. Quo quid indignius et sceleratius excogitari potest? Eadem namque opera qua sibi ipsi sanctitatis egregie testimonium tribuit, summum atque sanctissimum Dominum rectoremque iustissimum sceleris et iniustitiae condemnat.

Haec ubi Helius perorauit, alium deinde sermonem in hanc sententiam exorsus est:

- Num, cum tantis argumentis euictus sis, adhuc in ea sententia permanes ut ad certamen cum Deo in legitimo iudicio ineundum meditere? Num id confidis fore ut, si cum illo litigaueris, superior ex iudicio discedas et litem obtineas? Id enim dixisti: "Quam utilitatem ex pietate a me sancte culta percipiam? Aut quod emolumentum assequar, si scelus expiauero? Nec enim Deus sontes tantum euertit, sed etiam saepe uidemus castos et sanctos homines ab illo maximis poenis excruciari."

Tibi igitur et amicis tuis, qui adsunt, respondebo: Suspice, quaeso, caelum, et sidera contemplare, et oculorum aciem in aetheriam formam intende, et animaduerte ea omnia tam altum locum in natura tenere ut ad ea, mente et cogitatione, aspirare non possis. Si igitur tantillus es ut ad opera Dei tam magnifica et excelsa comparatus, ne puncti quidem instar obtineas, quomodo poterit ex te quidquam accidere quo aetheris et caeli condicio uel deterior uel illustrior esse possit? Ergo, si nihil est in te quod ad opera ista diuina, quae cernis oculis, aliqua ex parte pertineat, quo tandem modo fieri credis ut aliquid ex rebus tuis, uel boni, uel mali, in ipsum summum conditorem et Dominum, qui haec omnia creauit et complexu suo arcet et continet, redundare possit? Si peccaueris, quod illi detrimentum afferes? Si scelera tua fuerint multis accessionibus amplificata, quid de illius amplitudine et maiestate deminues? Quid, si iustitiam fueris amplexus? Num cum beneficio aliquo, quod ad illius fructum perueniat, alligabis? Non certe. Nec enim indiget ille opibus humanis aut ullo terrarum cultu, ut ea gratia putes eum donum aliquod et munus, quod in rem illius sit, ex te aliquando percepturum.

Homo igitur cum sis, ut reliqui qui ex eodem principio generis orti sunt, si fueris impius, [106] hominibus, non Deo, impietas tua nocebit; similiter, si iustitiam colueris, hominibus, non Deo, iustitia tua fructum importabit. Cum igitur 
homens, e não para Deus. Portanto, quando Este te atribula com incomodidades, não está a olhar pelo Seu proveito, mas trabalha unicamente em teu favor e inflige-te estes golpes para livrar-te da perdição. Por isso não te podes com justiça queixar e lamentar d' Ele.

Dirás, porém: "Então por que é que muitos, oprimidos pela injustiça, vociferam? Por que é que os inocentes, vexados pela desumanidade dos tiranos, bradam aos céus? Por que é que Deus concedeu a homens muitíssimo impuros tão grande poder que privam de todos os bens os homens fracos, que nunca os tinham prejudicado, e os perseguem com a máxima crueldade?" - Se os que são vexados pelos tiranos nunca cometeram infâmia alguma durante a vida, é com razão e justiça que se queixam. Mas se foram culpados de muitos pecados, não existe nenhum motivo para, de modo tão merecido, não padecerem estes males. É que Deus sabiamente se serve da crueldade dos desonestos para castigar os que vivem de modo infame.

Dirás: "Que delito puderam cometer os que não possuíam quaisquer riquezas? Que dizer do facto de que muitos, que nunca praticaram contra ninguém uma grave injustiça, sofrem gravíssimas injustiças da parte dos homens mais ruins?" - Para não me alongar, parece-te pouco o facto de que, deslembrados de Deus, com o mais infame olvido esquecem os Seus benefícios? Na verdade, nenhum de entre eles disse: "Onde está o Deus que me criou? Que, com a noite, resplandecente com a beleza dos astros, e com os admiráveis luzeiros e ornatos do céu inteiro, oferece imensa matéria para cânticos e louvores? Que nos ensinou a salvação de modo muito mais claro que aos animais terrestres? Que nos instruiu com muito maiores conhecimentos de sabedoria do que a todas as aves que gozam do livre céu?"

Os homens não vêem isto, nem nisto reflectem, nem concluem da superioridade da natureza humana que Deus lhes concedeu o senhorio sobre todos os seres vivos. E, assim, porque não se lembram dos benefícios de Deus, nem Lhe agradecem, nem Lhe tributam as devidas honras, é com toda a justiça que recebem os merecidos castigos de uma alma desagradecida. Mas depois que caem nas mãos dos homens malvados e são oprimidos pela sua tirania, clamam por Deus e imploram o Seu auxílio, mas não são escutados. É que Deus não atende às rogativas dos homens ingratos, provocadas pelas injustiças e desgraças, momentaneamente fingidas de modo sacrílego, nem dá ouvidos aos clamores daqueles a quem incitam, não a detestação do crime praticado, mas o sentimento da dor padecida. Por conseguinte, todas as desgraças humanas, todas as penalidades da vida, todas as dores e tribulações devem ser atribuídas ao santíssimo juízo d' Aquele que castiga os crimes humanos com a merecida pena.

Todavia dizes: "Perturba-me assaz o facto de que não atinjo o motivo do juízo com que me fere e atribula nem consigo vê-Lo presente nesta minha desgraça, por forma a poder confiadamente dirigir-me a Ele." - Como se fosse necessário, todas as vezes que Ele determina e decide alguma coisa, conheceres as causas de todas as Suas decisões e desígnios. É, porém, de toda a evidência que, quer tu o vejas, quer não vejas, isto é, quer tenhas conhecimento, quer não tenhas, dos motivos das decisões de Deus, um rectíssimo juízo precede tudo quanto Ele faz, e nada determina [107] em desarmonia com a mais elevada lei e razão. Se atinges a Sua razão, lança da alma essa tristeza. Se não atinges, 
is te incommodis uexat, non rem suam curat, sed tua tantum gratia laborat atque, ut te ab exitio redimat, eas tibi plagas imponit. Non igitur de illo iure conqueri atque lamentari potes.

Sed dices: "Cur igitur multi, iniuria oppressi, uociferantur? Cur innocentes, tyrannorum immanitate uexati, clamores in caelum tollunt? Cur tantam potestatem concessit Deus hominibus impurissimis ut homines tenues, a quibus numquam laesi fuerant, omnibus bonis expellant, et crudelitate summa persequantur?" - Si ii qui a tyrannis uexantur nullum in uita flagitium suscepere, iure atque merito queruntur. Si uero multis se peccatis obstrinxere, nulla causa est cur ea mala ita indigne patiantur. Deus enim improborum crudelitate ad eos castigandos, qui flagitiose uiuunt, sapienter abutitur.

"Quid", inquies, "ii, qui nullis erant opibus praediti, commitere potuerunt? Quid quod multi, qui nemini umquam grauem iniuriam intulere, grauissimas iniurias ab hominibus improbissimis accipiunt?" - Vt nihil aliud dicam, id parum esse putas quod, Dei immemores, illius beneficia scelerata obliuione contriuere? Nec enim ex illis quisquam dixit: "Vbi est Deus qui me creauit? Qui nocte, specie siderum praeclara, admirabilibusque caeli totius luminibus et ornamentis, carminum et laudum materiam ingentem praebet? Qui nos multo praeclarius quam animantia terrestria ad salutem erudiuit? Qui nos multo maioribus sapientiae disciplinis quam cunctas uolucres quae libero caelo fruuntur instruxit?"

Haec non uident homines, neque secum recogitant, nec ex humanae naturae praestantia colligunt esse sibi imperium a Deo in cunctis animantibus attributum. Itaque, cum Dei beneficia minime recordentur, neque illi gratias agant aut debitos honores instituant, merito ingrati animi debitas poenas exsoluunt. Postquam uero in maleficorum hominum manus incidunt eorumque tyrannide premuntur, ad Deum clamant illiusque praesidium implorant, non tamen exaudiuntur. Non enim Deus ingratorum hominum preces, iniuriis et calamitatibus expressas et ad tempus nefarie simulatas, ad aures admittit, nec ad eorum clamores, quos non odium admissi sceleris, sed sensus inusti doloris stimulat, attendit. Omnes igitur humanae clades, omnes uitae acerbitates, omnes dolores et aerumnae ad illius sanctissimum iudicium referendae sunt qui scelera humana debito supplicio persequitur.

Inquis tamen: "Hoc me ualde sollicitum habet, quod causam iudicii, quo me perculit et afflixit, non teneo, nec eum in hac mea calamitate praesentem intueri possum, ut ad illum fidenter adeam." - Quasi sit necesse, quotiens is aliquid statuit atque decernit, decretorum omnium atque sententiarum causas tibi notas esse. At hoc certe constat. siue tu illum uideas, siue non uideas, hoc est, siue consiliorum diuinorum rationes exploratae tibi sint, siue non sint, in omnibus illius factis rectissimum iudicium antegredi, neque quidquam ab illi sine [107] summa lege atque ratione constitui. Si rationem illius assequeris, pelle ex animo maestitiam 
mesmo assim põe n' Ele os olhos, implora o Seu auxílio, d' Ele espera ajuda e Ele acabará por libertar-te desse cuidado que te inquieta. Mas, entretanto, considera tão-só que Ele, no castigar, impôs limites à Sua ira e não te infligiu penas tão pesadas quanto pedia a grandeza dos teus crimes. E mesmo assim proclamas que és inocente, sem embargo de a tua boca pronunciar palavras tão execráveis? Ora, que se pôde imaginar de mais indigno e monstruoso do que o facto de Job, homem eminente pela fama de sabedoria, pureza e religiosidade, ter proferido palavras trasbordantes de atrevimento, ignomínia e crime, e desse modo, devido à gravidade e grandeza dos ultrajes, ter incitado contra si a majestade divina?

A fim de esmagar mais duramente Job, acrescentou o seguinte:

- Aguenta e suporta o incómodo por mais um pouco de tempo, se o meu discurso to ocasiona. É que ainda existem outras razões com que posso defender a causa de Deus. E, assim, principiando de mais atrás, vou expor o que aprendi e concluí e provarei que o meu Criador nada fez sem a mais elevada razão, e que a justiça sempre esteve unida com as Suas obras. E decerto que nas minhas palavras nada haverá de falso e enganoso, nada de irreflectido e vesânico, mas, ao invés, tudo o que disser será exposto de modo veraz, singelo e sábio.

Ora, em primeiro lugar, Deus, embora esteja dotado do poder supremo, todavia não rejeita os pedidos dos homens que se apoiam na justiça. E não só é poderoso, como também se encontra provido das mais poderosas forças da sabedoria e da inteligência. Logo, uma vez que é omnipotente e infinitamente misericordioso e sábio, sendo assim impossível que a fraqueza, a perversidade ou o erro o desviem do recto juízo, não pode acaso acontecer que lance olhos benévolos sobre os ímpios e, na desgraça, abandone os inocentes abatidos e atribulados? De modo algum. Por conseguinte, jamais dará vida aos ímpios nem, contrariando o direito divino e humano, privará da salvação os humildes. Por outro lado, nunca desviará os olhos dos justos, mas sempre há-de ampará-los com a Sua protecção e não consentirá que sejam oprimidos pelos males.

Mas como sabe que nenhum povo pode manter-se sem poder soberano, coloca no sólio régio certos homens superiores em justiça, para que eles, mediante uma lei estável, unam para sempre os povos a si sujeitos. Mas os que estão presos nas redes de muitos pecados e se deixam acorrentar por uma infinita sensualidade, atados com ferros e mergulhados nas trevas, vivem uma existência mofina, penosa e assoberbada por inumeráveis angústias e, deste modo, não só são atormentados pela consciência das culpas, mas também, em muitas ocasiões, são duramente punidos pelo juízo de Deus, pois costuma lançar-lhes em rosto os crimes que maquinaram e aplicar-lhes os castigos merecidos pela soberba. Todavia, não manifesta de forma repentina a totalidade do ódio que sente contra o crime, mas primeiro pune os homens pecadores com penas mais leves, a fim de desviá-los de uma vida depravada e, através dos golpes, lembrar-lhes que todas as actividades da vida se devem consagrar ao zelo da piedade e da justiça.

Por conseguinte, quer a inquietação de espírito, quer as incomodidades sofridas, quer [108] as dores infligidas são uma espécie de advertência e ensinamento assaz salutar para 
istam. Si non assequeris, nihilo tamen secius in illum intuere, illius auxilium implora, ab illo praesidium exspecta et is te cura ista, quae te premit, tandem aliquando liberabit. Interim uero hoc unum habeto, illum, in animaduertendo, modum irae suae statuisse neque tibi tam graues poenas irrogasse quam criminum tuorum magnitudo postulabat. Et tamen te innocentem praedicas, cum tam exsecrabilis oratio ex ore tuo exciderit? Quid enim indignius aut immanius excogitari potuit, quam Iobum, hominem sapientiae et integritatis et religionis opinione praestantem, uerba, plenissima temeritatis et flagitii atque sceleris, protulisse et ita diuinum in se numen, conuiciorum grauitate et magnitudine, concitasse?

Haec praeterea, ut Iobum acrius premeret, adiecit:

- Perfer et tolera, quaeso, paululum molestiam, si quam tibi exhibet oratio mea. Sunt enim praeterea mihi aliae rationes, quibus Dei causam tueri queam. Itaque, repetito altius principio, quid ipse cognitum et constitutum habeam, explanabo et peruincam, nihil a conditore meo sine summa ratione fieri, et semper cum operibus illius iustitiam esse coniunctam. Et certe nihil erit in oratione mea falsum et fraudulentum, nihil temerarium et insanum, immo omnia, quae tibi dixero, erunt uere, simpliciter et sapienter enuntiata.

Primum quidem, Deus, cum potentia summa praeditus sit, non tamen hominum postulata, quae sunt iure nixa, repudiat. Neque solum potens est, sed etiam maximis sapientiae et intelligentiae uiribus instructus. Ergo, cum omnipotens et clementissimus et sapientissimus sit, et ita neque imbecillitate nec immanitate nec errore possit de recto iudicio dimoueri, fieri ne potest ut is impiis benigne consulat et innocentes euersos et afflictos in calamitate destituat? Nullo modo. Numquam igitur uel impiis uitam dabit uel humilibus, contra ius et fas, salutem eripiet. A iustis autem oculos numquam deiiciet, sed eos semper tutela sua proteget et malis obrui minime patietur.

Cum uero cernat nullam gentem sine imperio posse consistere, homines quosdam iustitia praecellentes in regia sede locat, qui perpetuo populos sibi subditos stabili iure consocient. At qui se multis peccatis irretiunt infinitaeque libidini constringendos tradunt, ferro uincti et tenebris inclusi, uitam agunt miseram et acerbam multisque angoribus implicatam, itaque non solum maleficiorum conscientia discruciantur, sed Dei iudicio multis in locis acerrime plectuntur, scelera enim, quae conflarant, illis obiicere meritasque superbiae poenas irrogare solet. Non tamen totum odium, quod habet in scelus, repente profundit, sed leuioribus primum poenis homines sceleratos afficit, ut eos a prauitate uitae deterreat atque plagis admoneat omnem uitae rationem esse ad studium pietatis et iustitiae conferendam.

Est igitur uel animi sollicitudo, uel illatum incommodum, uel [108] inustus dolor, admonitio quaedam atque disciplina, illis ualde salutaris qui tantum 
os que não desprezam, com espírito desagradecido, uma tão grande mercê. É que, se os homens a quem Deus, através dos golpes, ensina e admoesta a, renunciando à iniquidade e à injustiça, porem n' Ele os olhos do entendimento, obedecerem aos Seus preceitos, hãode concluir bem e afortunadamente a carreira desta vida e gozar de grandes felicidades durante a sua existência. Pelo que, se se mantiverem rebeldes e recusarem a soberania do Senhor, ficarão expostos aos Seus dardos e serão destruídos com aquela espécie de morte com que costumam ser extintos e destruídos os que vivem sem entendimento e razão. Com efeito, arrebatados pela loucura, precipitar-se-ão na perdição e serão arrojados no castigo sempiterno do crime.

Já estás a ver quão falsa é a tua afirmação de que é por vontade de Deus que muitas coisas correm bem aos perversos e que os inocentes são frequentemente atribulados por imerecidas contrariedades? De facto, não só os que parecem ser atribulados sem o merecerem cometeram muitos crimes, que merecem ser punidos com dura servidão e arrebatamento de bens, mas também os próprios tiranos, durante o tempo em que gozam de riquezas e poderio, são atormentados por amaríssimos cuidados e sofrem o castigo do crime e da loucura e, ao cabo, são privados de todas as comodidades da vida e precipitados na região da infelicidade sempiterna.

Mas retrucarás, dizendo que há muitos cuja vida não se manchou com nenhuma nódoa de infâmia ou impureza, os quais, sem embargo, são atribulados por inúmeras incomodidades. - Continuas a corar a inocência simulada com o nome de inocência e a dar o nome de virtude à virtude fingida? Acaso existe algo de mais sacrílego do que fingir a piedade, simular a justiça e enganar o povo incauto com uma falaz aparência de santidade? Portanto, considero que devem ser designados, não como puros, santos e piedosos, mas como falsos, matreiros e manhosos aqueles que afirmas que foram oprimidos por incessantes provações. É que não há dúvida que, se tivessem cultivado a piedade deveras e com sinceridade, a divina misericórdia tê-los-ia restituído à sua originária dignidade, pois assim como Deus aplaude a verdadeira bondade, da mesma maneira sente profundo ódio pela imagem da bondade fingida. Por consequência, todos os que simulam a virtude estão a encher o tesouro da ira divina e, quando a força divina os reprime, nem sabem reconhecer o seu crime e oferecer preces, nem acabam por dizer aquela espécie de palavras capazes de chegarem aos Seus ouvidos.

Por isso, ainda que se tivessem esforçado por alcançar o título de sábios e adquirir para si o louvor de puros, todavia sofrerão as consequências do desatino e loucura juvenis e padecerão os castigos da impuríssima sensualidade e da intemperança. É esta, sem dúvida, a condição dos que, ensoberbecidos e cegos com os erros, se recusam a reconhecer o crime que praticaram e a pedir perdão por ele. Os que, porém, são humildes, mediante as preces alcançam com a maior facilidade tudo aquilo que pretendem. É que Deus, quando por causa de algum delito os atribular, não os há-de abandonar, mas há-de arrancar de toda a desgraça que os oprimia os que imploravam humildemente a Sua misericórdia. Na verdade, sempre que lhes causa algum incómodo, não o faz para os destruir, mas para misericordiosamente lhes ensinar e mostrar que eles receberam aquele golpe devido a alguma infâmia. 
beneficium non ingratis animis aspernantur. Si enim ii, quos Deus plagis erudit et admonet ut, ab iniquitate et iniuria traducti, in illum mentis aspectum referant, praeceptis illius obedierint, huius aeui cursum bene et beate conficient et magnis iucunditatibus in uita perfruentur. Quod, si rebelles exstiterint Dominique imperium detrectauerint, erunt illius telis expositi eodemque genere leti delebuntur quo exstingui atque deleri solent ii qui sine mente et ratione uitam exigunt. Amentia namque praecipites, in pestem ruent et in poenam sceleris sempiternam detrudentur.

Cernis iam quam sit falsum id quod asserebas: nempe, Dei uoluntate improbis multa feliciter euenire et innocentes immeritis saepe incommodis diuexari? Nam, qui nullo merito suo afflictari uidentur, scelera multa commisere, quae sunt dura seruitute bonorumque direptione punienda, et ipsi tyranni, quamdiu florent opibus atque potentia, curis tristissimis agitantur et sceleris et amentiae poenas luunt atque tandem, omnibus uitae commodis expulsi, in miseriae sempiternae regionem praecipites eiiciuntur.

Sed inquies, multos esse, quorum uita nulla turpitudinis aut impuritatis labe notari potest, qui tamen multis incommodis afficiuntur. - Pergisne tu innocentiae simulationem innocentiae nomine cohonestare fictaeque uirtuti virtutis nomen imponere? An est quidquam scelestius quam pietatem ementiri, iustitiam simulare, incautis populis fallaci specie sanctitatis illudere? Illos igitur quos dicis aerumnis diuturnis oppressos fuisse, non castos et sanctos et pios, sed fallaces et ueteratores et callidos appellandos existimo. Certe enim, si uere et ex animo pietatem coluissent, diuina clementia et in pristinam dignitatem restituti fuissent, ut enim Deus uerae bonitatis fauet, ita est fictae bonitatis imagini uehementer infensus. Omnes igitur qui uirtutem simulant, irae diuinae thesaurum coaceruant et, cum ui diuina constringuntur, neque scelus confiteri neque preces adhibere norunt, nec eas denique uoces ad Deum fundere quae ad aures illius perueniant.

Quamuis igitur in eo elaborassent ut sapientiae nomen obtinerent et castimoniae laudem uenarentur, tamen factum iuuenilis temeritatis et amentiae subibunt et impurissimae libidinis et intemperantiae poenas sustinebunt. Haec quidem est eorum condicio qui superbia inflati et erroribus excaecati, scelus admissum agnoscere et ueniam petere recusant. At, qui humiles sunt, omnia facillime quae uolunt precibus assequuntur. Deus enim, cum propter delictum aliquod eos afflixerit, illos minime deseret, sed illius clementiam suppliciter implorantes ab omni calamitate, quae eos premebat, eripiet. Quotiens enim eis aliquod incommodum affert, non id agit ut eos interimat, sed clementer erudiat et admoneat eos, propter aliquod flagitium, plagam illam accepisse. 
Por outro lado, desejaria que trouxesses à memória aquilo que atrás disse: [109] ou seja, que Deus mostra aos mortais o Seu entendimento de duas maneiras. Com efeito, ou dá a conhecer através de visões nocturnas os segredos do Seu entendimento, ou mostra, através dos golpes infligidos, que está indignado com os crimes humanos. Passando-se as coisas desta forma, conclui-se com toda a evidência que deves entender como avisos esses males que Ele fez caírem sobre ti e compreender que sofres o merecido castigo pelas infâmias cometidas. Se o tivesses feito e, atormentado pelos golpes, tivesses compreendido que tinhas padecido tão pesadas tribulações por causa dos crimes perpetrados, e humildemente Lhe tivesses suplicado ajuda, já há muito que Ele compassivamente te teria arrancado das angústia dessa desgraça, que nunca há-de ter termo enquanto de modo sacrílego simulares a piedade, e ter-te-ia concedido uma existência totalmente tranquila e a abundância de todos os bens, e a tua mesa teria sido cheia dos mais refinados manjares.

E, apesar disso, persistes obstinadamente na simulação da justiça, como se, com uma fingida aparência de santidade, pudesses apagar as manchas do crime e da desonestidade em ti gravados. Por conseguinte, uma vez que desses males que te cercam se colige de modo forçoso que tu, em contradição com a lei, decidiste a favor do ímpio: os interesses da justiça exigiam que sofresses o castigo pela tua injustiça. É que, ainda que no julgar tenhas conculcado tudo o que é justo e lícito, foi impossível quebrantar e abater o direito e o juízo sempiternos. Reconhece, portanto, as tuas infâmias e, através da confissão da culpa, trata de curar as enfermidades do espírito e esforça-te por jamais apartar-te da equidade. Por conseguinte, que, ao julgares, a ira não te perturbe, que nenhum entendimento com os homens perversos te desencaminhe para o crime, que nenhuma grande quantidade de dádivas e mercês te corrompa, se desejas escapar àquele santíssimo juízo de Deus, pois, caso contrário, não poderás evitar a Sua ira.

Pois, que é que cuidavas? Acaso diante d' Ele as tuas riquezas hão-de possuir algum peso? Mas nem as riquezas, nem as fortalezas, nem as fortificações, nem quaisquer obras de defesa poderão livrar-te da perdição, porquanto a vontade de Deus não se deixa dobrar pela grandeza da dignidade, nem pela altura das muralhas, nem pelo vigor das forças, mas pela inocência, pela fé, pela justiça e pela santidade.

Por consequência, não há motivo para, durante a noite, quando o espírito está livre dos restantes cuidados, te inquietares demasiado com este pensamento, perscrutando ansiosamente a causa e o motivo pelo qual certos povos se apoderam das riquezas e fortificações de outros e, depois de expulsarem os antigos possuidores, se senhoreiam impunemente de tudo que pertencera aos outros. É que, para te libertar de toda a preocupação deste género, bastar-te-á compreender que Deus nada determinou sem extraordinária deliberação e motivo. Logo, quando destrói uns povos e coloca outros no poder, está a castigar a soberba, a iniquidade e o crime e, com este exemplo de severidade, a ensinar o dever às restantes raças.

Por conseguinte, não empregues debalde os teus desvelos nem, com pensamentos totalmente vãos, te esforces por libertar-te da desgraça que te oprime. Com efeito, se seguires a senda da vaidade, quanto mais te empenhares em livrar-te dos males, tanto 
Velim autem ut in memoriam redigas quod ante dixi: [109] nempe, Deum duplici ratione mentem suam mortalibus aperire. Aut enim per uisum nocturnum arcana mentis suae patefacit, aut, plagis impositis, se iratum esse sceleribus humanis ostendit. Hoc cum ita sit, restat plane ut ista mala, quae tibi ab illo inuecta sunt, in loco admonitionis ponas, et intelligas te, propter admissa flagitia, debitam poenam subiisse. Quod si fecisses et, plagis cruciatus, intellexisses te, propter admissa scelera, in tam graues aerumnas incidisse, et opem illius suppliciter implorasses, iamdudum is te ex miseriae istius angustiis, quae nullum finem, quamdiu pietatem nefarie simulaueris, est habitura, clementer abstraxisset, tibique summam uitae tranquillitatem bonorumque omnium affluentiam contulisset, mensaque tua conquisitissimis epulis exstructa fuisset.

Et tamen obstinate in iustitiae simulatione persistis, quasi ficta specie sanctitatis possis maculas insiti sceleris et improbitatis eluere. Ergo, cum ex istis malis quae te circumueniunt, necessario colligatur te causam impio, contra leges, adiudicasse, iustitiae ratio flagitabat ut iniustitiae tuae poenam sustineres. Vt enim in iudicando ius et fas omne deleueris, ipsum ius atque iudicium sempiternum infringi et labefactari non potuit. Flagitia igitur tua recognosce et, peccati confessione, morbos animi curandos suscipe operamque da ne umquam ab aequitate discedas. Non igitur te in iudicando iracundia perturbet, non ullus cum improbis hominibus in scelere consensus inflectat, non donorum atque munerum multitudo corrumpat, si cupis illud sanctissimum Dei iudicium effugere, aliter enim iram illius uitare non poteris.

Quid enim censebas? Num apud illum opes tuas pondus aliquod habituras? At neque opes, nec arces, neque munitiones, nec ulla praesidia te poterunt a peste redimere, non enim est, non est dignitatis amplitudine, non moenium altitudine, non uirium robore Dei uoluntas allicienda, sed innocentia, fide, iustitia, sanctitate.

Non ergo est cur te nocte, cum animus reliquis curis uacuus est, ea cogitatio sollicet, nimis anxie perscrutantem causam atque rationem quare quidam populi in aliorum opes et munitiones inuadant et, antiquis possessoribus eiectis, ipsi cuncta, quae fuerant aliorum, impune possideant. Satis enim erit tibi, ad omnem eiusmodi curam leuandam, intelligere nihil a Deo sine singulari consilio et ratione constitui. Ergo, cum alios populos euertit et alios in dominatu constituit, superbiam et iniquitatem et scelus ulciscitur et, eo seueritatis exemplo, reliquas gentes ad officium erudit.

Caue igitur ne studium tuum inanitate consumas et cogitationibus uanissimis te ex miseria, quae te premit, expedire coneris. Si enim uanitatem consectarus fueris, quo magis e malis emergere contendes, eo citius, omnium miseriarum 
mais prestes hás-de perecer, esmagado pela aluvião de todas as desgraças. Deus senhoreia o baluarte de uma coragem e poder imensos: logo, que fundador de Estados e legislador é a Ele comparável, quer em forças quer em sabedoria? Quem pode chamar a juízo as Suas obras, [110] ou falsamente assacar-Lhe iniquidade naquilo que fez? É que de modo algum jamais poderá o medo desviá-Lo da equidade, pois é poderosíssimo, nem o erro do entendimento apartá-Lo da verdade, pois é sapientíssimo. Por isso, empenha-te em lembrar o que Ele fez e em encarecer com as tuas palavras as obras divinas que se encontram colocadas diante dos olhos e vista dos homens. É que nenhum louvor atribuído às obras de Deus há-de ser tão elevado que elas de longe o não superem, quer em grandeza, quer em nobreza, quer em utilidade.

Todos os homens $\mathrm{O}$ contemplam e até aqueles que parecem estar afastados do conhecimento da sempiterna divindade, mesmo assim são constrangidos a, mais tarde, ver e observar de longe a Sua força e sabedoria. Na verdade, são muitas as coisas oferecidas para proveito dos homens e colocadas diante dos olhos de todos, brilhantes pela aparência e salutares pela utilidade, as quais são extraordinária prova da sabedoria e bondade divinas. É que às restantes, que são muito maiores e mais elevadas, porque não estão à vista e se escondem sob as trevas, não é possível esquadrinhá-las nem observá-las. De facto, é tão elevado que é impossível a alguém abarcá-Lo com o entendimento e a razão, pois quem há-de examinar a Sua natureza, a Sua majestade e a Sua eternidade?

Tão-pouco alcançamos as causas e motivos das Suas obras, que divisamos com nossos olhos: de tal modo estamos longe de lograrmos um conhecimento perfeito d' Ele. Quando Lhe apraz, impede a nuvem de deixar cair uma gota de água sobre a terra; depois, quando quer, derrama copiosas chuvas. É que, impelidos por Sua decisão e ordem, os vapores são arrastados para o alto e, juntando os humores, condensam-se em nuvem por forma a, deixando cair do alto abundantes águas, regarem o solo e fecundarem os campos lavrados pelos homens. Quem alcança pelo entendimento a diversidade das nuvens, desdobrada para coisas muito admiráveis, de maneira a compreender o modo como Ele estende a escuridão delas, como se fosse uma tenda coberta e revestida por todos os lados? De feito, onde quer que se encontre encerrada a Sua força, aí se deve presumir que Ele habita. Quando estende a Sua luz, até o fundo do mar se ilumina com o Seu resplendor. Com as inundações destrói os povos impiedosos e depois, com o derramamento profuso das águas, prodigaliza grande abundância de searas, para alimentar os mortais. Encerra nas nuvens uma força de fogo originada na terra e ordena-lhe que vá ao encontro e se oponha ao vapor que a rodeia. Por conseguinte, com chamas muito pequenas, espremidas por todos os lados pela força contrária do humor que está em volta e reunidas num único lugar, faz que uma provoque a eclosão da outra. Logo, depois que aquele fogo, acrescido e aumentado, ajunta forças, ateia-se mais intensamente e, rompendo as nuvens, irrompe, e, arremessando-se, dissipa o humor provocado e, no embate, produz ruídos tão grandes que faz tremer a terra com repetidos trovões, raios e relâmpagos.

Ao dar-se conta destas coisas, o meu espírito aterroriza-se e confunde-se. Apercebeivos de quão grande é aquele terror, quando, diante da voz d' Ele, certos horrendos estrépitos e ruídos espantam de medo os mortais, e, quando Ele fala, o estrondo transe 
colluuione depressus, interibis. Deus arcem immensae uirtutis atque roboris tenet: quis ergo rei publicae conditor legumque lator est cum illo, uel uiribus uel sapientia, comparandus? Quis illius opera in iudicium uocare [110] potest aut ei in eo, quod ille gessit, iniquitatem affingere? Nec enim uel metu ab aequitate deduci, cum sit potentissimus, nec mentis errore a uero auerti, cum sit sapientissimus, ullo umquam modo poterit. Da igitur operam ut illius facta recorderis et opera diuina, quae sunt in hominum oculis et aspectu proposita, uerbis amplifices. Nulla enim laus operibus diuinis attributa erit tam ampla quam non illa facillime, uel magnitudine, uel claritate, uel utilitate, superent.

Omnes homines illum intuentur et illi etiam, qui uidentur esse a numinis sempiterni cognitione remoti, uim tamen illius atque sapientiam longe in posterum speculari et contemplari coguntur. Multa enim sunt utilitatibus humanis exposita et oculis omnium subiecta, ad speciem illustria et ad utilitatem salutaria, quae diuinae sapientiae atque bonitatis egregiam significationem dant. Reliqua enim, quae sunt multo maiora et altiora, cum non sint in promptu et in caligine lateant, perscrutari et speculari non licet. Altior enim est quam ut illum quisquam mente ratione comprehendere queat, quis enim illius naturam, quis maiestatem, quis aeternitatem peruestigabit?

Nec enim causas et rationes operum illius, quas oculis aspicimus, assequimur: tantum abest ut illius perfectam notitiam capiamus. Cum ei uidetur, nubes continet ne guttam aquarum in terras demittat; cum illi rursus placuerit, imbres satis largos effundit. Excitati namque illius decreto et instituto, uapores in sublime feruntur et, humorem colligentes, in nubem concrescunt ut, aquarum copia superne demissa, tellurem irrigent et aruis ab hominibus cultis fecunditatem dent. Quis nubium uarietatem, ad res ualde admirandas extensam, rationem consequitur, ut intelligat quomodo is illarum caliginem, quasi tabernaculum undique tectum atque laqueatum, subeat? Vbicumque enim uis illius inclusa delitescit, ibi illum habitare putandum est. Cum porrigit lumen suum, maris etiam fundamenta illius splendore collustrantur. Aquarum eluuione populos impios euertit, aquarum rursus effusione magnam frugum copiam alendis mortalibus elargitur. Igneam uim e terris excitatam in nubes includit eique praecipit ut uapori circumdato obuiam prodeat et obsistat. Flammulis igitur exiguis, contraria ui ambientis humoris undique expressis et in locum unum compulsis, fit ut alia aliam ad eruptionem excitet. Ergo, ubi ignis ille, auctus et amplificatus, uires colligit, acrius exardescit et, nubes perrumpens, emicat et excitatum humorem, impetu facto, dissipat tantosque, in pugna, fremitus edit ut orbem terrarum frequenti tonitru, fulgure, fulmine tremefaciat.

Haec animaduertens, animus meus pauet atque de statu deiicitur. Percipite, quaeso, quantus ille terror sit, cum, ad illius uocem, horrendi quidam strepitus atque fremitus metu mortales exanimant, et fragor, cum ille loquitur, auditus 
de horror o entendimento de todos. É que cumpre considerarem-se vozes da natureza as d' Aquele mediante cujo senhorio e [111] divindade toda a natureza se move e que dá a conhecer o Seu poder através de obras admiráveis. Conduz e dirige a nuvem por baixo de toda a natureza celeste e espalha a Sua luz nas regiões mais afastadas da Terra. Por detrás d' Ele ouvir-se-á uma espécie de voz retumbante; soará e brilhará; e, sem qualquer interposição de tempo, um trovão suceder-se-á ao outro e com golpes frequentes há-de ferir os ouvidos. O Senhor trovejará e produzirá espantosos ruídos Aquele que tem a seu cargo as máximas coisas, cujas causas e motivos desconhecemos. Obedecendo ao Seu mandado a neve cai sobre a terra; obedecem às Suas ordens a chuva e os aguaceiros; e, quando Lhe apraz, enviadas pela Sua potência divina, as trombas de água e as tempestades espalham o terror. Mantém encerrados nas casas e lugares, defendidos pela natureza ou pelo artifício, os homens aterrorizados com a violência da tempestade, a fim de que, assombrados com o medo de um tamanho fragor, meditem nas obras d'Ele. E até os animais selvagens se precipitam para os seus esconderijos e, para se esquivarem à tempestade, se mantêm nos seus covis. Do seio das nuvens saem redemoinhos e, logo que, soprando fortemente o aquilão, as nuvens se dispersarem, de repente toda a Terra se endurece enregelada com um violentíssimo frio. Com um vento forte a água gela nas nuvens, e, daquele gelo já partido e despedaçado e em grande parte liquefeito devido ao atrito, derrama-se de novo uma grande quantidade de água misturada com granizo. Estando a atmosfera limpa e serena, Deus carrega a nuvem com densas águas, para que dela, depois de dissolvida pelo calor, as chuvas voltem a cair sobre a Terra.

E o próprio Senhor, estendendo-se e circulando pela natureza de todas as coisas, de tal sorte por elas se movimenta que, ao percorrer tudo, dá ser ao orbe e, uma vez que detém o leme do mundo inteiro, de tal modo governa todas as coisas e as liga com o Seu senhorio que nada existe na natureza que, sem Sua ordem, seja capaz de levar a termo a sua obra. Por conseguinte, tudo quanto Ele ordena, executa-se, todo o mundo obedece às Suas ordens, e são a Sua majestade e poder os que conservam a natureza inteira. Quer Ele olhe por um único povo, quer vele por uma região que está assegurada pela especial protecção d' Ele, quer pretenda proteger cada um dos homens: reconhecemos que é graças à misericórdia d' Ele que se conserva e aumenta tudo quanto vive e viça e se encontra provido com os dons da vida.

Repara atentamente e reflecte nisto, Job, de maneira a te aperceberes de quão admiráveis são as obras de Deus. Porventura compreendeste a forma como Deus impunha leis às nuvens e fazia o raio sair da Sua nuvem? Porventura compreendes exactamente a ordem, maneira e modo com que as nuvens estão suspensas no ar, equilibradas por pesos certos, por forma a que delas nasçam efeitos tão variados e maravilhosos? Porventura imaginas o modo como Deus de tal sorte variou a natureza das coisas que o frio repele o calor e o calor repele o frio e, depois de aquietado e suspenso o setentrião, as tuas roupas se aquecem ao soprar o austro? Quando Ele estendia os globos celestes e os acepilhava com artifício e trabalho tão excelentes, e os escorava com uma natureza firme e constante, por forma a que os olhos não pudessem contemplar nada de mais formoso para a vista, 
mentes omnium perterret. Naturae namque uoces illius putandae sunt cuius imperio et [111] numine natura uniuersa mouetur illiusque potentiam admirandis operibus exponit. Subter omnem caelestem naturam nubem dirigit atque moderatur lucemque suam in extremas oras terrae diffundit. Pone illum horrisona quaedam uox audietur; tonabit et fulgurabit; nullaque mora interposita, tonitrum unum aliud tonitrum consequetur et ictibus crebris aures uulnerabit. Intonabit Dominus mirosque fremitus edet is qui res maximas gerit, quarum causas et rationes ignoramus. Ad illius imperium nix in terram decidit; illius iussu exsistit nimbus et pluuia; et, cum illi uisum fuerit, imbres atque procellae, ui numinis illius emissae, horrorem incutiunt. Vi tempestatis homines exterritos, in aedibus et locis, aut natura aut arte munitis, inclusos tenet, ut, metu tanti fragoris attoniti, opera illius mente considerent. Quin etiam ferae se ad latibula sua proripiunt et in cubilibus suis, procellae uitandae gratia, commorantur. Ex nubium penetralibus exsistunt turbines et, ubi primum nubes fuerint, flante uehementer aquilone, dispulsae, maximis repente frigoribus obrigent omnes terrae. Aqua in nubibus uento uehemente conglaciat, ex illa uero glacie, fracta iam et comminuta et attritu maxima ex parte liquefacta, rursus uis ingens aquae grandine commista diffunditur. Aere puro atque sereno, Deus nubem densis aquis onerat, ut rursus ex illa, calore dissipata, pluuiae in terras spargantur.

Ipseque Dominus, per omnium rerum naturas intentus atque commeans, ita se uersat ut orbem, cuncta lustrando, conficiat et, cum gubernaculum mundi uniuersi teneat, ita res omnes moderatur imperioque deuincit ut nihil sit in natura quod opus suum, iniussu illius, exsequi possit. Quaecumque igitur ille praecipit, fiunt, omnisque terrarum orbis illius iussis obtemperat, et uniuersa natura numine illius atque potestate continetur. Siue ille uni genti prospiciat, siue regionem in praecipuo illius praesidio latentem tueatur, siue singulis hominibus consultum esse uelit: quae uiuunt et uigent et uitae muneribus instructa sunt, illius misericordia conseruari et augeri reperiemus.

Ad haec diligenter attende, Iob, et animo consiste, ut quam sint admiranda Dei opera ratione consideres. Num id intelligentia percepisti, quomodo Deus nubibus leges imponeret et e nube sua fulgorem eliceret? Num tenes exacte modum et numerum et rationem qua nubes, certis examinatae ponderibus, in aere pendeant, ut ex illis tam uarii atque mirabiles effectus oriantur? Num rationem tenes qua Deus ita rerum naturam uarietate distinxit ut frigus calorem, calor frigus expelleret, et, septemtrione compresso atque sedato, uestes tuae, austro flante, concalescerent? Num, cum is caelestes globos dilataret atque, tam excellenti artificio et opere, perpoliret, naturaeque, firmitate et constantia, stabiliret, ut nihil ad speciem pulchrius nec ad utilitatem melius nec ad permanendum aptius, 
nem de maior utilidade, nem mais apto para durar: porventura ajudaste-O então com trabalho ou com conselho, $[\mathbf{1 1 2}]$ ou ao menos pudeste compreender o modo como levou a cabo uma obra tão excelente?

Se te avantajas tanto em inteligência, ensina-nos como falar com Ele e chamá-Lo a juízo, quando for preciso. É que nós não nos arrogamos essa sabedoria que ostentas, nem estamos aparelhados nem preparados para falar diante d' Ele, nem podemos expor o que de melhor deve fazer-se, uma vez que nos arrastamos em tão grandes trevas e desconhecimento das coisas. Nós reconhecemos que somos ignorantes e desconhecedores das coisas divinas: por isso compete-te a ti, se abundas em tão grandes riquezas de sabedoria, transmitir-nos esses mistérios de sabedoria, que só tu conheces, a fim de que, instruídos por eles, nos atrevamos a pleitear em juízo com Deus, tal como tu fazes.

Que pode afirmar-se de mais desatinado do que isto? - Que o homem, que é a coisa mais fraca que existe na Terra, não se arreceie de litigar com Aquele Senhor supremo, que com o Seu poder divino tudo abarca?! Com efeito, se litigar com Ele, porventura terá necessidade de um medianeiro e defensor do seu direito, para Lhe sugerir o que deve responder? Até estando Ele calado, o homem que se atrever a um tamanho atentado não emudecerá espantado com a grandeza de uma tão grande majestade e não há-de morrer na presença do próprio Senhor? Portanto, de que modo há-de enfim algum varão litigar com Deus em igualdade de direitos?

Ora, assim como, estando o tempo muito sereno, cobrindo o céu de densas nuvens, suprime a luz e priva os homens da visão do Sol, da mesma maneira, quando a escuridão recobre o céu e as nuvens subtraem a luz aos mortais, ao fazer soprar o setentrião, dispersa as nuvens, afasta a escuridão e restitui ao tempo a serenidade. Isto mostra claramente que as tempestades dos males são suscitadas por decisão d' Ele e que é também graças à Sua vontade e poder divino que surge a tranquilidade e que, para os que são destruídos pela tempestade e pelas tormentas, o único remédio de salvação é refugiarem-se na Sua ajuda. É que, assim como Ele, com a força e ímpeto do puríssimo aquilão, afasta as trevas e devolve pura e brilhante a forma do ar, que anteriormente tinha estado envolvida pela espessa cerração, assim, com o encanto e pureza do Seu Espírito restituirá à primitiva luz e serenidade da dignidade os homens esmagados pelas ruínas e desfigurados pela imundície. É que o setentrião, provido da mais completa serenidade e comparável com a pureza do ouro, de tal maneira repele todas as trevas que na atmosfera não ficam quaisquer resquícios de sombra e trevas. E assim o louvor e glória de todas essas obras pertence exclusivamente a Deus, cuja majestade é muito de temer.

Suportas a muito custo o facto de ignorares o lugar em que Ele esteja à tua disposição e te responda, de maneira a finalmente assim ganhares a questão. Mas isto não só é impossível, como tão-pouco é conveniente e necessário, porquanto, uma vez que a Sua majestade é infinita, não podemos inquirir com o entendimento e abranger com o pensamento algum lugar certo no qual Ele se fixa, e, sendo certo que é sublime e excelso e dotado de extraordinárias forças e muitíssimo claro devido ao resplendor do direito e da justiça, de forma alguma o responder-te se adequa à Sua grandiosidade. Tão-pouco pode, quer apartar-se da equidade por causa do temor de algum mal, uma vez 
oculis uideri possit: illum uel opera uel consilio iuuisti, [112] uel saltem rationem, qua ille tam excellens opus absoluit, intelligere potuisti?

Si tantum excellis intelligentia, doce nos quomodo illum, cum opus fuerit, alloquamur et ad iudicium prouocemus. Nos enim non eam nobis sapientiam, quam ostentas, asciscimus, nec ad dicendi coram eo parati atque meditati sumus, nec, cum in tanta rerum caligine et ignoratione uersemur, quid optimum factu sit explicare possumus. Nos idiotas et diuinarum rerum ignaros esse fatemur: proinde tuum est, si tantis sapientiae opibus abundas, nobis ista sapientiae mysteria tradere, quae tibi soli nota sunt, ut, illis initiati, perinde atque tu facis, cum Deo iudicio decertare audeamus.

Quo quid asseri potest amentius? - Homo, quo nihil est in terris imbecillius, ut cum illo summo Domino, qui omnia numine suo coercet, pedem in iudicio conferre minime uereatur?! Si enim cum illo egero, num interprete et cognitore sui iuris indigebit, ut ei suggeret quid illi respondendum sit? Illo etiam tacente, homo, qui tantum facinus ausus fuerit, non amplitudine tantae maiestatis attonitus obmutescet et in ipsius Domini conspectu exanimatus interibit? Quo tandem igitur modo uir ullus cum Deo aequo iure disceptabit?

Vt autem in magna serenitate, densis nubibus obductis, lucem adimit et homines solis aspectu priuat, ita, cum caelum caligine tectum est et nubes lucem mortalibus eripiunt, inducto septemtrione, dispellit nubes, discutit caliginem et serenitatem restituit. Quod quidem facile declarat illius iudicio malorum tempestates importari, illius rursus numine et uoluntate tranquillitatem exsistere et unicum remedium salutis esse iis, qui procella atque turbine peruertentur, ad illius opem confugere. Vt enim is, purissimi aquilonis ui et impetu, tenebras pellit aerisque formam, quae fuerat antea crassa caligine circumfusa, puram atque nitentem reddit, sic homines, ruinis oppressos et squalore deformatos, ad pristinam dignitatis lucem atque serenitatem Spiritus sui iucunditate atque puritate reuocabit. Septemtrio namque, serenitate summa praeditus et cum auri puritate conferendus, ita cunctas tenebras expellit ut nihil in aere turbidum atque tenebricosum relinquatur. Itaque omnium operum istorum laus et gloria penes solum Deum, cuius maiestas est ualde pertimescenda, consistit.

Indignissime pateris quod locum ignoras ubi is sui copiam faciat et tibi respondeat, ut sic demum litem obtineas. At id neque fieri potest neque conueniens et necessarium est, cum enim illius maiestas infinita sit, nullum certum locum, in quo is consistat, mente peruestigare et cogitatione complecti possumus, et, cum altus et excelsus et robore praecellens et iuris atque iustitiae splendore clarissimus sit, minime consentaneum est illius amplitudini ut tibi respondeat. Nec enim ab aequitate propter alicuius mali formidinem deduci potest, cum sit potentissimus, neque iustitiae sanctitatem uiolare, cum sit in iudicio rite 
que é poderosíssimo, quer violar a santidade da justiça, porquanto é escrupulosíssimo em estabelecer o juízo segundo as regras. Logo, uma vez que Ele nada faz [113] sem a máxima ponderação e equidade, quando atribula alguém, ainda que o motivo da desgraça inferida não seja exposto, mesmo assim será evidente que esta foi inferida com razão e justiça por deliberação da santíssima majestade divina. Os homens que no seu íntimo reflectem sobre estas coisas hão-de arrecear-se do Seu poder divino e, assim, com toda a facilidade hão-de procurar torná-lo propício. Os que, porém, se arrogam a sabedoria e não se humilham na presença d' Ele, serão desamparados pelo Seu socorro, pois Ele não vela por aqueles que de modo assaz insolente se ensoberbecem com o título de sábios.

Depois de Eliú ter concluído com estas palavras, a tempestade, subitamente provocada, com o seu redemoinho lançou por terra Job e os seus amigos: é que tanto o assustador estrondo da terra, como o fragor dos ares e os brilhantes relâmpagos e outros fenómenos assaz temíveis demonstravam de sobejo a presença da divindade. Ora, do meio do redemoinho e da tempestade Deus encorajou com as seguintes palavras o prostrado e abalado Job:

- Quem é este que, disse Ele, com palavras ignorantes oculta o desígnio e intenção, empenhando-se em lançar as trevas sobre uma doutrina claríssima? Como se não soubesses que Eu absolutamente nada empreendo sem a máxima ponderação, motivo e equidade. Mas atormenta-te o facto de desconheceres os motivos das minhas deliberações. Porventura tens necessidade de saber as causas de todas as obras que empreendo e levo a cabo? E entrementes nem te dás conta das limitações do teu espírito, nem reflectes na profundidade do Meu entendimento nem na grandeza da Minha majestade? A qual indubitavelmente é tão grande que é impossível que haja alguma inteligência, por mais extraordinária e cultivada que a imagines, capaz de entendê-la.

Por outro lado, dizias que facilmente haverias de defender a tua causa, contanto que Eu apartasse o medo e as ameaças. Força! Liberto-te daquele medo da majestade divina, que poderia impedir-te de livremente te queixares a Mim dos golpes que te foram infligidos. Enche-te de coragem e fortalece-te com o vigor do varão denodado, e interrogar-te-ei, para que Me faças saber as razões em que se apoia a tua causa. Com efeito, davas-Me a possibilidade e a opção de escolher, se antes queria responder aos quesitos ou, interrogando-te, inquirir os fundamentos do teu direito. Tais condições aprazem-Me. Por conseguinte, em primeiro lugar pergunto-te: Onde é que te encontravas quando lançava os fundamentos da Terra? Se a tua inteligência e agudeza intelectual são tão grandes, gostaria que Me expusesses a razão daquela firmeza com que, conglobada no meio do mundo e apoiada unicamente no seu peso, ela se mantém estreitamente unida. Quem é que a delimitou de acordo com uma medida certa? Quem é que a dispôs em conformidade com uma norma e regra e a modelou de acordo com uma ordem e distribuição fixas? Pergunto: qual a base em que se apoia e sustém? Quem é que nos seus ângulos colocou imensas pedras, para que assim se mantivesse mais firme?

Que fazias, quando, no começo do mundo acabado de nascer, surgiram ao mesmo tempo todos os astros resplandecendo com um brilho admirável e deram a conhecer a 
constituendo sanctissimus. Ergo, cum nihil ab illo fiat [113] nisi summo consilio et aequitate, cum aliquem affligit, quamuis minime ratio inuectae calamitatis explicetur, certe constabit eam iure atque merito, consilio sanctissimi numinis, inuectam fuisse. Homines qui haec animis recogitant numen illius extimescent et ita illud sibi facillime placabunt. At qui sibi sapientiam arrogant neque se in conspectu illius abiiciunt, ab ope illius deserentur, nec enim is illis prospiciet qui nomine sapientiae nimis insolenter efferuntur.

Haec cum Helius perorasset, excitata repente tempestas turbine Iobum et amicos illius abiecit: nam et horrendus terrae fremitus et aetheris fragor et micantias fulgura et res aliae nimis metuendae, satis aperte numinis praesentiam declarabant. E medio autem turbine atque procella, Deus eiusmodi uerbis Iobum perculsum et stratum excitauit:

- Quis, inquit, is est qui uerbis imperitis mentem atque sententiam occultat et consilio clarissimo tenebras afferre conatur? Quasi tibi minime compertum sit me nihil omnino sine summo consilio, ratione, aequitate moliri. Sed id te pungit, quod consiliorum meorum rationes exploratae tibi minime sint. An necesse est tibi notas esse operum omnium causas quae molior et efficio? Nec interim tui pectoris angustias agnoscis, neque meae mentis altitudinem et maiestatis amplitudinem mente consideras? Quae profecto tanta est ut illam nullum ingenium, quantumuis excellens et disciplinis excultum, consequi ulla ratione possit.

Dicebas autem te facile, modo metum atque minas remouerem, causam tuam defensurum. Age! Te illo numinis metu libero, qui tibi impedimento esse poterat quominus libere mecum de plagis tibi inflictis expostulares. Excita uires animi uirique fortis robur assume, et interrogabo te, ut me rationibus, quibus causa tua nititur, erudias. Potestatem namque mihi et optionem faciebas, utrum uellem, eligerem, uel ad quaesita respondere, uel, interrogando de te, rationem tui iuris exquirere. Condicio placet hoc igitur te primum interrogo: Vbinam eras quando terrae fundamenta iaciebam? Si tantum ingenio et intelligentia uales, uelim mihi exponas illius soliditatis rationem qua, in medio mundi conglobata suoque tantum pondere nixa, cohaeret. Quis illam certa mensura definiuit? Quis ad normam atque regulam direxit et certo numero atque ratione formauit? Quanam, quaeso, base fulta, sustinetur? Quis in angulis illius lapides ingentes posuit, ut ea uidelicet ratione firmior permaneret?

Quid agebas, cum, in mundi nascentis exordio, sidera cuncta, mirabili splendore collucentia, simul exstiterunt insitamque naturae laetitiam, incitatis 
instintiva alegria da natureza, com movimentos causados por um incrível entusiasmo, e com a suavíssima harmonia das rotações invariáveis e uniformes, e com vozes diferenciadas em ordem e ritmo? Que fazias, quando incontáveis anjos, que na forma, aparência, beleza e dignidade reproduziam a imagem e semelhança de Deus, começaram a exultar e a exaltar com louvores sempiternos o melhor dos progenitores, que os ornamentara com tão grandes e tão preclaras mercês?

[114] Sabes de que maneira o tão imenso mar e tão profundo saiu do seio materno à luz? Com que portas e barreiras foi fechado para impedir que irrompesse para destruição e devastação da Terra? De que modo o tapei com as nuvens, como se fosse uma roupagem, e, cobrindo-o com a cerração, o cingi como com uma espécie de faixa? Além disso, por decisão Minha estabeleci-lhe um limite, para que de modo algum o transpusesse, e, como se fosse com portas fechadas e trancadas, contive com a Minha lei a sua ira. Com efeito, disse-lhe: "Chegarás até aqui e de maneira alguma avançarás para além do limite que te foi prescrito, mas quebrarás neste lugar as túmidas vagas."

Porventura, desde que nasceste, impuseste leis à luz da manhã e entendeste em que momento o resplendor da aurora deveria erguer-se do seu poiso: resplendor que espalha a luz ao largo e ao longe pela Terra e aterroriza os ímpios e os constrange a apartarem-se das infâmias? É que, assim como procuram a ocasião favorável da noite e das trevas, a fim de mais facilmente poderem maquinar as abomináveis acções criminosas, da mesma maneira odeiam e execram a luz, porque os desvia dos crimes devido ao medo da infâmia e dos julgamentos, na medida em que podem ser vistos e censurados. Na verdade, embora sejam impuros e de comportamento escandaloso, todavia por instinto natural arreceiam-se do desdouro e sentem grande temor de que possa descobrir-se o estado de infâmia em que vivem e, por esse motivo, quando chega a luz do Sol, desaparecem a grande velocidade expulsos pelo medo. Por conseguinte, quando sob a luz, modelam para si um semblante como se fosse feito de argila e afivelam a fingida máscara da honestidade e, como se se tratasse de uma espécie de roupagem, ocultam sob a falsa aparência da dignidade o crime que conceberam. Por isso é com justiça que aos ímpios é tirada toda a luz, como a seus inimigos, e que as forças da soberba, apoiadas na vaidade e na mentira, hão-de ser destruídas, para que os perversos, condenados às trevas sempiternas e atormentados por suplícios perpétuos, sofram o castigo do abominável erro.

Acaso foste capaz de contar as gotas do mar ou percorreste o seu fundo e abismos? Acaso se te abriram as portas da morte e se te franqueou o acesso à sombra mortal, para que te fosse possível observar tudo que se encerra nas entranhas da terra? Sabes qual é a extensão da Terra? Se conheces perfeitamente as suas dimensões, di-las. Conheces o caminho que conduz à morada da luz? Ou estás inteirado de qual é o poiso das trevas? Porventura imporás fronteiras à luz e às trevas, e prescreverás em que sítios se devem manter uma e outras, e quais os limites que devem circunscrevê-las? Pois quê? Lembras-te sequer daquele dia em que nasceste? Ou abranges o número dos dias em que se deve encerrar o espaço da tua vida? Conheces com exactidão qual é a fonte e origem da neve ou de onde procede a força do granizo? Tens noção e conhecimento da grande ordem e providência com que concebi e reparti todos estes fenómenos naturais pelo tempo e 
incredibili alacritate motibus, et suauissima ratae et aequabilis conuersionis harmonia, et distinctis numero et ratione uocibus, expresserunt? Quid, cum innumerabiles angeli, forma, specie, pulchritudine, dignitate Dei similitudinem et speciem referentes, exsultare sempiternisque laudibus optimum parentem, qui eos tantis atque tam praeclaris muneribus ornarat, [114] efferre coeperunt?

Nosti quomodo mare tam uastum atque tam profundum ex utero matris in lucem prodierit? Quibus ostiis atque repagulis interclusum sit, ne ad perniciem et uastitatem orbis terrarum possit erumpere? Qua ratione illud nube, quasi uestimento, contexerim et, inducta caligine, quasi fascia quadam, cinxerim? Illi praeterea terminum, quem nullo modo transiliret, decreto meo constitui et, quasi occlusis foribus atque inducto uecte, furorem illius lege mea compescui. Dixi namque: "Hucusque peruenies nec ultra terminum tibi praefinitum ullo modo prosilies, sed hoc in loco tumidos fluctus franges."

Num, ex quo primum in lucem editus fuisti, legem matutinae luci dedisti et intellexisti, quo tempore esset a loco suo aurorae splendor excitandus, qui quidem lucem in terras longe lateque diffundit et impios exterret et a flagitiis inuitos abducit? Vt enim noctis et tenebrarum opportunitatem sequuntur, ut liberius possint taetra facinora machinari, ita lucem oderunt et exsecrantur, eo quod illos infamiae atque iudiciorum metu, tantisper dum uideri atque notari possunt, a sceleribus auertit. Quamuis enim impuri et flagitiosi sint, natura tamen dedecus exhorrent et ne turpitudo, in qua uersantur, animaduerti possit, animo ualde sollicito reformidant, et, ea de causa, cum lux solis aduentat, metu praecipites expelluntur. Luce igitur uultum quasi ex argilla sibi fingunt et fictam honestatis personam induunt et falsa dignitatis specie, quasi quadam ueste, conceptum scelus inuoluunt. Merito igitur impiis, quasi lucis hostibus, omnis lux eripitur, et superbiae uires, uanitate et mendacio nixae, perfringentur, ut improbi, sempiternis tenebris damnati sempiternisque suppliciis excruciati, poenas erroris detestabilis exsoluant.

Num maris guttas, enumerando, recensere potuisti aut illius imam sedem atque fundum peragrando lustrauisti? Num ostia mortis tibi reserata sunt et aditus umbrae mortiferae patuit, ut omnia, quae sunt terrae uisceribus inclusa, perspiceres? Tenesne quanta sit terrae latitudo? Si eam animo perfecte dimensam habes, edissere. Nostine uiam quae ferat in lucis domicilium? Aut intelligis quam sedem caligo possideat? Num terminos luci atque tenebris assignabis, et quibus regionibus utraque uis continenda, et quo fine circumscribenda sit ratione praescribes? Quid? Illum ipsum diem, quo natus es, memoria tenes? Aut numerum dierum, quo uitae tuae spatium terminandum est, mente et ratione consequeris? Quae sit fons et origo niuis aut unde uis grandinis oriatur explorate cognouisti? Estne tibi perspectum et cognitum quanta ratione et consilio haec omnia designaui et temporibus distinxi et spatio definiui, ut ea uel ad hominum salutem, uel 
os delimitei pelo espaço, por forma a utilizá-los quer para salvação dos homens, quer para a sua ruína e destruição? E assim, mediante o Meu poder divino, ou os faço cair ou os mostro em consonância com as imposições da bondade ou do rigor. Por conseguinte, por vezes reservo-os para, ao monstruoso inimigo que não teme fazer guerra aos que se encontram sob a minha tutela, [115] destruí-lo com a tempestade e o turbilhão e esmagá-lo com pedras lançadas do céu e exterminá-lo com a matança que provoquei.

Conheces o caminho e modo com que o resplendor do Sol irrompe, espalha a luz sobre a Terra e, ao nascer, impele o vento de leste sobre diferentes regiões da Terra? Quem é que, em determinada região da atmosfera, edificou um aqueduto para que principalmente através dele corresse para a Terra uma imensa quantidade de água? Quem em outros tempos abriu outro caminho para que através dele os raios corressem com enorme estrondo? E os homens não podem indicar a razão pela qual estas obras são levadas a efeito mais numa região do que em outra e por que é que, quando uma não goza de nenhuma humidade do céu, outra é molhada pelas chuvas. E deste modo sucede frequentemente que estes fenómenos de tal maneira actuam em uma certa face de todo o céu que o ermo, privado dos cuidados dos homens, é regado pelas chuvas e o inculto deserto fica cheio de grande abundância de água, por forma que um local abandonado, inculto e despovoado devido à sua rudeza se enche de água e desde então produz pasto para fornecer abundante alimento aos brutos animais. Por outro lado, da mesma forma, quando Me praz ocasiono a devastação a locais muito férteis e abundantes e, às terras ermas, torno a revesti-las com o ornato das ervas e árvores e a ornamentá-las com variadas folhagens.

Tem a chuva progenitor de cuja semente proceda? E que mãe encerrou em seu seio as gotas do orvalho, de maneira a dá-las à luz no devido momento? Do ventre de quem surdiu o gelo? E quem gerou a geada caída do céu? Depois de expulso e desaparecido com a grandeza do frio aquele calor que, misturado à agua, fazia com a sua força que a água derretida caísse, o líquido endurece como pedra e perde aquela aparência de natureza líquida e fluída, e não apenas os pequenos rios, como também em muitos lugares imensas extensões de águas param o seu curso normal, endurecidas pelo frio e gelo, e permanecem imobilizadas. Entendes a razão pela qual a variação do calor e frio obedece a uma ordem e sucessão e, ao combinarem-se de uma certa maneira, estabelecem as condições que permitem que todas as regiões da Terra possam ser povoadas pelos seres vivos? Conseguirás refrear as Plêiadas para que elas, ao nascerem, não impeçam o solo fecundado com sementes de produzir flores e frutos e oferecer abundantemente as incontáveis delícias da vida? Acaso soltarás depois Órion e conceder-lhe-ás que, com o nascimento dele, a Terra, despojada de folhas e folhagem, não se torne triste nem faça sair do seu interior coisa alguma capaz de cativar os olhos com alguma aparência de alegria?

Porventura são tão grandes as tuas riquezas, inteligência e talento que podes inverter ou corrigir a ordem da natureza, que o Criador das coisas estabeleceu? Acaso às estrelas errantes, em tempos regularmente predefinidos, fá-las-ás nascer, de maneira a, de acordo com uma lei e ordem, percorrerem órbitas regulares e invariáveis? Acaso destruirás as revoluções do Arcturo ou do Setentrião ou da Ursa ou da Ursa Maior, depois de 
ad exitium et uastitatem conuerterem? Itaque meo numine uel recluduntur, uel depromuntur, prout ratio benignitatis aut seueritatis flagitat. Aliquando igitur ea reseruo ut, hostem immanem, qui bellum iis, qui in mea tutela sunt, [115] inferre minime ueretur, procella atque turbine peruertam et, lapidibus e caelo coniectis, obruam et edita strage conficiam.

Nostine uiam et rationem qua splendor solis erumpit, lucem in terras spargit exoriensque Eurum in uarias terrae partes impellit? Quis aquae ductum in aeris certa regione exstruxit, per quem potissimum uis ingens aquarum deriuata in terram deflueret? Quis aliam aliis temporibus uiam aperuit, qua fulgura cum ingenti fragore discurrerent? Nec potest ab hominibus assignari ratio quare potius in una regione quam in alia haec opera efficiantur et, cum una nullo caeli rore fruatur, alia imbribus madefiat. Itaque saepe fit ut haec omnis caeli facies eo conferatur ut solitudo, hominum curatione destituta, pluuiis irrigetur et uastitas inculta aquarum copia redundet, ut locum neglectum et incultum et asperitate uastatum aquis expleat et inde herbam eliciat, ut brutis animantibus pabulum abunde subministret. Ad hunc autem modum, cum mihi placet, uastitatem locis ualde cultis atque nitidis affero et uasta rursus herbarum atque arborum cultu uestio uariisque frondibus exorno.

Habetne pluuia parentem, cuius satu procreata sit? Roris uero stillas, quae mater aluo continuit ut partum exactis temporibus in lucem ederet? E cuius uentre prodiit glacies? Et pruinam e caelo demissam quis generaui? Calore illo, cuius admixti ui aqua dilapsa fluebat, magnitudine frigoris expulso et eiecto, durescit humor instar lapidis speciemque illam naturae liquidae atque fluentis amittit, neque solum parua flumina, uerum etiam multis in locis aquarum immensitates, frigore atque gelu constricta, se a solito cursu sustinent et immobiles in loco consistunt. Percipisne mente rationem qua calorum et frigorum uarietates ordine et modo dispensantur et, temperatione quadam adhibita, sic instituuntur ut omnes orbis terrarum regiones ab animantibus frequentari possint? Poterisne coercere Pleiadas quominus, illis orientibus, tellus grauidata seminibus, flores et fruges efferat innumerabilesque uitae delicias effundat? Num rursus Oriona laxabis idque illi concedes ne, in illius exortu, terra, nudata foliis et frondibus, tristitiam contrahat nihilque e se promat, quod oculos specie aliqua iucunditatis alliciat?

Tantumne uales opibus, ingenio, facultate ut ordinem naturae, quem opifex rerum instituit, inuertere aut emendare queas? Num errantes stellas, temporibus ratione praefinitis, ut oriantur excitabis, ut ratos et aequabiles cursus ordine atque lege definiant? Num Arcturi aut Septemtrionis aut Vrsae aut Helices conuersiones, ordine, quo circum axem caeli uersantur, perturbato, dissipabis? Quid? Tenesne 
perturbada a ordem em que se encontram em torno do eixo do céu? Pois quê? Estás ciente das leis com que o céu é iluminado pelos luzeiros, se atavia com riquezas, se reparte com variedade, é sustido pelo firmamento, por forma a, com grande proveito de todas as coisas que abarca no seu âmbito, conservar incessantemente a coesão e estabilidade da natureza? Acaso é de acordo com a ordem e disposição que prescreveste que toda a Terra se encontra sob a influência e domínio do próprio céu? [116] É que dele provêm para a Terra inumeráveis proveitos, também de lá se originam muitos perigos para os homens, graças ao seu calor vivificante tudo é gerado, cresce e chega à sua maturidade, sendo também pelo poder dele que aos poucos tudo se extingue, envelhece e é consumido pela morte. Estimulados com a visão dele os homens podem obter o conhecimento de Deus e, a partir das obras tão magníficas, contemplar a sabedoria e bondade do Criador; também por vezes com a sua horrenda aparência muitos, que se tornaram culpados de crimes abomináveis, costumam ficar impressionados e perturbados, de maneira a tornar-se manifesto que toda a Terra se encontra abarcada pelo poder do céu.

Posto isto, pergunto: quem estabeleceu a lei, ordem e governo deste poder? Certamente que não te terás em tão grande conta que o atribuas aos teus recursos e sabedoria. Logo, de que maneira pleitearás sobre sabedoria e equidade com Aquele que com tamanha adequação e regularidade fundou, e com tão sólidas guardas estabeleceu esta estabilidade? Acaso, ao invocares a nuvem, de imediato te cobrirá uma enorme quantidade de água? Acaso às tuas ordens acudirão os relâmpagos e, logo que o ordenares, irromperão e sem qualquer tardança cumprirão os teus mandados? Quem é que instruiu os espíritos humanos nos conhecimentos da sabedoria? Quem é que ensinou os entendimentos a compreenderem as coisas mais alevantadas? Porventura não é manifesto que toda a sabedoria proveio de Mim, como de uma fonte inesgotável e perene? Quem é que sabiamente deu luzimento à natureza do éter e colocou na região média do mundo as vasilhas, nas quais se lançam todas as coisas que são repelidas de todas as partes do céu, de maneira a manter-se sempre firme no mesmo lugar? É que assim sucedeu que o pó, expelido por todos os lados com pesos iguais e ligando-se reciprocamente entre si, uniu-se no fundo, de maneira a servir de receptáculo às águas que, do mesmo modo, tinham sido expulsas dos extremos para o meio, e a todos os demais corpos pesados que a rotação do céu espalha por todos os lados.

Porventura já percebes que é tão grande em todas as partes da natureza a sagacidade do entendimento divino, tão grande a sua inteligência e razão que é impossível que alguém a explique por palavras ou a abarque com o entendimento e a razão? Por conseguinte, não é lícito imaginar-se que Deus faz seja o que for sem a máxima sabedoria nem é justo que te entristeças, sempre que vês que Ele decide algo cuja causa e motivo ignoras. Com efeito, se não entendes aquilo que divisas com os olhos, aquilo que tocas com as mãos e aquilo que se encontra à vista para a utilização quotidiana dos seres vivos, como é que te empenhas em esquadrinhar as deliberações de Deus, tomadas a respeito das coisas mais importantes, que são muito mais secretas e ocultas? E, para que melhor possas entender a grande ignorância das coisas em que te encontras, não me refiro à vastidão da totalidade do céu, nem à claridade das estrelas, nem ao ardor do éter, nem à variada potência do ar, 
leges quibus caelum luminibus illustratur, opibus ornatur, uarietate distinguitur, firmamento sustinetur, ut perpetuo naturae statum et continentiam, cum magna rerum omnium, quas ambitu coercet, utilitate retineat? Num ordine et instituto, quod praescripsisti, terrae uniuersae caeli ipsius imperio atque [116] dominatu continentur? Ex illo enim utilitates innumerabiles ad terras emanant, inde etiam multa pericula hominibus intenduntur, illius uitali calore omnia gignuntur et adolescunt ad maturitatemque perueniunt, illius etiam ui paullatim deficiunt et senectute languescunt et interitu consumuntur. Ad illius aspectum excitati homines Dei cognitionem capere et, ex tam magnificis operibus, conditoris uim et sapientiam et benignitatem intueri possunt; illius etiam interdum horrenda specie multi, qui se nefariis sceleribus astrinxere, commoueri atque perturbari solent, ita ut facile constet uniuersas terras caeli imperio coerceri.

Quaero igitur: quis huius imperii lege et ordinem et moderationem instituit? Non tantum tibi certe tribues ut hoc tuis opibus et consiliis ascribas. Quomodo ergo consilio aut iuris aequabilitate certabis cum eo qui hunc statum tanta conuenientia et aequitate fundauit et tam firmo praesidio stabiliuit? Num, cum inclamaueris ad nubem, aquarum ingens uis te confestim operiet? Num ad imperium tuum accurrent fulgura et, cum primum iusseris, emicabunt et imperata absque ulla mora conficient? Quis animos humanos sapientiae disciplinis instruxit? Quis mentes ad maximarum rerum intelligentiam erudiuit? Annon perspicuum est a me, tamquam ab inexhausto atque perenni fonte, omnem sapientiam dimanasse? Quis aetheris naturam sapienter expoliuit et uasa, in quae omnia, quae a caelo undique pelluntur, influerent, in media mundi regione collocauit, ut in eadem semper sede firma consisteret? Sic enim factum est ut puluis, undique paribus momentis expulsus atque sibi inuicem adhaerescens, in fundo conglutinaretur, ut capacitate sua aquas, similiter in medium ab extremo pulsas, et reliqua omnia pondere grauia, quae caeli conuersio undique fundit, excipiat.

Iamne sentis tantam esse in omnibus naturae partibus diuinae mentis sollertiam, tantum consilium atque rationem ut nemo possit illam uel explicare dicendo, uel mente et ratione complecti? Non igitur fas est suspicari aliquid sine summa sapientia a Deo fieri neque par est ut maestitia conflicteris, quotiens uides aliquid ab eo decerni, cuius causam et rationem ignoras. Si enim quae cernis oculis, quae manibus attrectas, quae sunt animantium usibus quotidianis exposita, non intelligis, quomodo Dei consilia, de maximis rebus inita, quae multo magis recondita et abstrusa sunt, peruestigare contendis? Atque, ut magis in quanta rerum ignoratione uerseris intelligere queas, omitto caeli totius amplitudinem, siderum claritatem, aetheris ardorem, uimque aeris multiplicem, et nubium atque uentorum uarietatem, terrae soliditatem, aquarum terras ambientium latitudinem 
nem à diversidade das nuvens e ventos, nem à firmeza da terra, nem à extensão das águas que a cingem, nem à total adequação da natureza: mas descerei àquelas coisas que são muito inferiores a ti, que estão formadas por um corpo tão imperfeito que carece de razão e inteligência, e que por vezes servem para teu proveito, mas cuja essência e natureza a tua razão não alcança e de cuja ferocidade também te temes.

[117] Pois quê? Caças porventura para dares alimento à leoa e saciares os seus filhotes famintos? Eu, porém, olho por eles; são sustentados com a Minha ajuda; dei-lhes força e disposições naturais que os capacitem para, ensinados por elas, se alimentarem. Nem sequer lhes falta a Minha ajuda no covil onde se deitam para prepararem as emboscadas. Quem é que fornece os alimentos aos corvos? Com efeito, as crias abandonadas pelos pais chamam por Mim e, desprovidas de toda a espécie de alimento, vagueiam e erram por todos os lados, mas por benefício Meu são alimentadas. Daqui se pode coligir quão fraco é o espírito dos que, em toda a sorte de dificuldades, não se apoiam confiantes na Minha bondade. Com efeito, se bondosamente me ocupo dos animais selvagens, se não abandono os corvos, como é que hei-de votar à destruição os homens, dotados de razão e entendimento, que confiam na Minha bondade e invocam a Minha ajuda?

Sabes em que época se reproduzem as camurças? Ou observas a forma como as corças costumam dar à luz? Contaste os meses em que estão prenhes por forma a saberes o momento em que hão-de parir? Jazem dobradas, ao darem à luz as suas crias, pois, devido à opressão das dores, não podem levantar-se para mais facilmente se apoiarem para parir e, rasgando-se as membranas interiores no próprio esforço de dar à luz, são violentamente atormentadas pelas dores até parirem as crias. Ora, quem é que olha por elas na aflição e as liberta de toda a dor? Sem dúvida que o Meu poder divino, graças a cuja providência tudo se conserva. Daqui pode concluir-se quão grande é o eficaz socorro com que hei-de acudir aos homens que confiam em Mim, visto como nem sequer sou indiferente aos partos das corças.

Mas os jovens corços engordam comendo o pasto, fartam-se com as produções da terra e crescem e procuram correr livremente pelos prados e bosques e não tornam a regressar para junto das mães. Quem é que deixou em liberdade o onagro e isentou de prisões a sua natureza? Dei-lhe por lar um lugar deserto e inculto e estabeleci-lhe por morada o ermo e a solidão, para dar a entender que o desprezo das comodidades é um coadjuvante da liberdade, mas que, por outro lado, no desejo de muitas coisas, que se obtêm nas terras férteis e fecundas, a virtude tem um preço a pagar. Por conseguinte, para preservar a sua condição, provi-o de ligeireza e de desprezo por uma alimentação mais abundante. E deste modo zomba dos homens citadinos que se encontram sujeitos a intoleráveis tributos, e não se teme do brado do recebedor de impostos, porquanto não tem medo de ser destinado ao serviço de alguém, depois de capturado pelo caçador. Com efeito, uma vez que pode satisfazer-se com escasso passadio, aparta-se para muito longe da vizinhança dos homens e, sem qualquer receio, busca o alimento nos montes e procura qualquer género de ervagem verde que lhe permita facilmente sustentar-se e afastar a fome. E sem dúvida que ele, graças ao amor pela solidão, afasta o jugo da servidão. Mas o rinoceronte facilmente salvaguarda e conserva a liberdade mercê da 
totiusque naturae conuenientiam: ad illaque descendam quae te longe inferiora sunt, quae corpore non ita magno constant, quae ratione et intelligentia carent, quae tuis usibus interdum seruiunt, quorum tamen uim atque naturam ratione non percipis et quorum etiam feritatem exhorres.

[117] Quid igitur? Num tu uenaris ut escam praebeas leaenae et illius catulos esurientes expleas? Atqui illis ego prospicio; mea ope sustentantur; illis uim et ingenium donaui, quo instructi possint enutriri. Nec in lustro quidem, ubi cubant ut insidias tendant, a mea ope deseruntur. Quis coruis alimenta suppeditat? Pulli namque a parentibus neglecti ad me clamant et, omni cibo carentes, passim uagantur et errant, meo tamen beneficio aluntur. Ex quo intelligi potest quam imbecillo animo sint qui non, in omni rerum asperitate, fide meae benignitatis innituntur. Si enim feris animantibus benigne consulo, si coruos minime desero, quo tandem pacto homines, mentis et rationis compotes, mea benignitate fretos, meam opem inclamantes, in calamitate despiciam?

Nostine tempus quo pariunt ibices? Aut obseruas quomodo ceruae partum edere soleant? Enumerastine menses quibus uterum ferunt, ut scias quo tempore sint pariturae? Incuruae iacent cum hinnulos suos edunt, angoris enim cruciatu erigi non possunt ut ad pariendum facilius enitantur, intestinisque membranis in ipso pariendi conatu disruptis, ipsae doloribus acerrime conflictantur, usque eo dum subolem emittunt. Quis igitur illas in angustia tuetur et dolore omni liberat? Meum profecto numen, cuius prouidentia omnia conseruantur. Vnde concludi potest quam praesenti subsidio sim hominibus, qui mihi fidunt occursurus, cum ne ceruarum quidem partus a me negligantur.

Hinnuli uero pabula laeti carpunt et frugibus saginantur et crescunt et liberos cursus per saltus atque nemora requirunt nec ad matres ultra reuertuntur. Quis liberum dimisit onagrum illiusque naturam e uinculis exemit? In loco deserto et inculto illi domicilium assignaui et sedem in solitudine et uastitate constitui, ut intelligi possit deliciarum contemptionem esse libertatis administram, contra uero in multarum rerum appetitione, quae in terra fertili et opima comparantur, esse uirtutis auctoramentum. Eum igitur et pernicitate et laetioris pabuli contemptu, ad sui status custodiam, armaui. Itaque illudit urbanis hominibus qui sunt tributis intolerandis obnoxii, neque clamorem exactoris extimescit, nec enim ueretur ne, captus a uenatore, alicui in seruitutem addicatur. Cum enim tenui uictu contentus esse possit, ab hominum uicinitate se longe segregat et pabulum in montibus, sine ullo metu, conquirit et quodlibet genus herbae uirentis inuestigat, quo facillime sustentari famemque depellere possit. Et hic quidem seruitutis iugum, solitudinis amore, depellit. At rhinoceros, robore et fortitudine libertatem facile tuetur atque conseruat. Numquid illum impelles ut tibi seruiat aut, praesepi hordei pleno, inuitabis et allicies ut apud te commorari uelit? Numquid illi iugum impones 
força e vigor físico. Porventura o obrigarás a servir-te ou seduzi-lo-ás e atraí-lo-ás com a manjedoura, cheia de cevada, para que ele queira permanecer junto de ti? Porventura lhe imporás o jugo e o amarrarás com uma soga, para que lavre o teu campo com o arado e atrás de ti desterroe a gleba? Porventura, uma vez que é tão forte, lhe confiarás a tua vida e entregarás à sua guarda as produções dos teus campos, obtidas com muito trabalho? [118] Estarás à espera de que ele fielmente te entregue as sementes das searas e recolha o teu trigo no celeiro? Certamente que não seria atitude de homem prudente confiar naqueles servos que não podem suportar a servidão e que são mais alentados, em forças e ânimo, do que a pessoa que os quer manter sob o seu domínio.

Do que se disse pode compreender-se claramente que a fraqueza dos homens está exposta a muitos acasos, visto como existe tão grande número de seres vivos capazes de destruir-lhes a vida, e ao mesmo tempo é possível conjecturar-se a grande resistência com que estão protegidos os que se fortificam com a confiança na Minha divindade. Com efeito, se armei de tão grandes forças esta espécie de seres vivos para que pudesse proteger-se, com quão grandes defesas convém que eu proveja aqueles que acreditaram e se fiaram totalmente na Minha divindade? Ora, para que vejas mais claramente que guardo com a Minha divindade toda a espécie de seres vivos, lembrar-te-ei um outro que se conserva, não graças à astúcia, nem à força, nem à escápula das penas, mas unicamente mercê da Minha providência. A cegonha, ainda que se avantaje às demais aves pelo instinto filial e paternal, todavia as suas penas não são de forma alguma comparáveis, em beleza e elegância, com as da avestruz, que não tem qualquer preocupação com a sua descendência. Daqui se vê que a ornamentação mais elegante do corpo e a aparência mais brilhante do lustre exterior e fortuito nem sempre são prova da virtude e afectos mais verdadeiros. Mas Eu não descurei nem sequer a avestruz. Com efeito, põe os ovos e deixa-os escondidos debaixo da terra. Em seguida vai-se embora e, deslembrada do perigo, não cuida que lhe diga respeito a guarda dos ovos e não dá conta de que pode acontecer que as patas dos animais selvagens os quebrem, acolhe de mau modo as crias recém-nascidas e expulsa-as como se fossem alheias e, como se tivesse sido em vão o trabalho de dá-las à luz, nem toma conta delas, nem receia por elas, nem sente qualquer preocupação por olhar por elas. Ora, Deus privou-a de sabedoria e não the concedeu qualquer inteligência, como aos restantes animais. Mas o pinto da avestruz, alimentado graças à Minha providência, levanta as asas para a corrida e desloca-se com tamanha velocidade que zomba dos cavalos e dos cavaleiros. Vês de que modo a sabedoria e a inteligência são um dom de Deus e como a salvação de todos os seres vivos se deve atribuir à Sua bondade?

Além disto, de bom grado te perguntaria se é obra tua a força inata do cavalo e se és tu quem, mediante a instigação da sua feroz natureza, o obriga a levantar a cerviz e a soltar horrendos relinchos. Acaso o farás agitar-se com incessantes movimentos, como um gafanhoto, e farás que se sinta excitado com a arrogância do seu valor e com violência exale ar pelas narinas e incuta o terror? Na planície escavará a terra com os cascos, alegrarse-á com a sua força, arremessar-se-á contra os homens armados. Ousado e fogoso nas situações críticas, manter-se-á senhor de si e não sentirá medo das ameaças dos inimigos 
eumque fune alligabis, ut agrum tuum aratro proscindat atque post te glebas frangat? Numquid illi, cum tantum ualeat robore, uitam tuam credes et fructus agrorum tuorum, multo labore quaesitos, [118] fidei illius committes? Sperabisne ut ille bona fide tibi frugum semina restituat et frumentum tuum in horreum conuehat? Non esset certe prudentis hominis officium illis seruis confidere qui seruitutem ferre nequeunt et sunt illo, qui eos premere dominatu cupit, uiribus et animo robustiores.

Ex quo intelligi sane potest hominum imbecillitatem esse multis casibus infestam, cum tam multa sint animantia quae illorum uitam euertere queant, et simul coniicere licet quanto robore saepti sint illi qui se numinis mei fiducia communiunt. Nam, si tantis uiribus armaui hoc animantis genus ut se tueri posset, quantis a me praesidiis illos oportet esse constipatos qui se totos numini meo crediderunt atque commiserunt? Vt autem clarius uideas omne genus animantis numine meo custodiri, aliud tibi memorabo quod non astu, non robore, non pennarum effugio, sed mea unius prouidentia conseruatur. Ciconia quidem, quamuis inter omnes uolucres pietate in liberos et in parentes excellat, tamen illius pennae non sunt ulla ex parte cum struthocameli pennis, qui generis sui nullam rationem ducunt, pulchritudine et elegantia conferendae. Vnde perspicitur non semper cultum corporis elegantiorem et speciem externae et aduenticiae dignitatis illustriorem dare uirtutis atque pietatis uerissimae testimonium. Sed ne struthocamelus quidem a me neglgitur. Parit enim oua eaque sub terram abdita derelinquit. Deinde abit et, periculi immemor, ouorum custodiam ad se pertinere non putat neque animaduertit fieri posse ut ferarum pedibus confringantur, eductos autem pullos inclementer accipit et quasi alienos expellit et, perinde atque frustra laborem in pariendo suscepisset, nec illos curat, nec illis timet, nec ulla sollicitudine in illis tuendis afficitur. Deus autem spoliauit illam sapientia neque ei intelligentiam ullam, ut reliquis animantibus, impertiuit. At pullus, mea prouidentia enutritus, alas erigit ad cursum tantaque pernicitate fertur ut equos et equi agitatores insequentes irrideat. Videsne quomodo sapientia et intelligentia donum Dei sit et salus cunctorum animantium sit ad illius beneficentiam referenda?

Libenter ex te praeterea quaesierim, num opera tua sit equo robur ingenitum et tu illum, naturae ferocis instinctu, ceruicem attollere atque horrendos fremitus edere compelles. Num crebris illum motibus, tamquam locustam, agitabis, et facies ut laudis spiritu concitetur et acrem uim naribus spiret atque terrorem incutiat? In planitie terram ungulis fodiet, robore laetus exsultabit, impetu armatis hominibus occurret. In rebus trepidis erectus et alacer, animo consistet nec hostium minas expauescet neque micantium gladiorum metu in fugam uertetur. Pharetrae, sagittis 
nem se porá em fuga com receio das luzentes espadas. As aljavas, cheias de frechas, ressoam diante da sua vista; cintilam as luzidas pontas das lanças; os dardos brilham e zunem; soa um estrépito horrendo: mas ele intrépido percorre a galope sem hesitação o espaço de terra que se interpõe e espera o clangor da tuba com tamanha ânsia [119] que, quando ela dá o sinal, devido ao seu contentamento quase nisto não acredita, mas, ao tempo em que ela ressoa, lança relinchos indicadores da sua alegria. E é possuído de um tamanho desejo de pelejar que, antes de avançarem os guerreiros formados em linha de batalha, pressente os brados de mando dos capitães e chefes e o som das trombetas de guerra.

Pois quê? Acaso é por ordem e mandado teu que o falcão levantará voo e, ao soprar o austro, abrirá as suas asas? Pois quê? É por decisão tua e graças ao teu poder divino que a águia se dirige voando para as regiões mais elevadas do ar e faz ninho num local alto e cimeiro? Estabelece a sua morada nas rochas e nas escarpadas fragas, singularmente protegidas pela natureza para que ninguém possa facilmente chegar até elas. E daí observa de onde pode obter alimento, estendendo a sua penetrante vista sobre regiões muito distantes. As suas crias lambem sangue e tanto a sua natureza como a sua criação as ensinam a alimentar-se da carne dos outros animais. Daqui procede que, onde quer que houver um morticínio, para aí de imediato voa rapidamente a águia a fim de se cevar no sangue dos mortos.

De entre quase infinitas espécies de animais, a título de exemplo escolhi poucas para que compreendesses que todos os que existem, quer grandes, quer muito pequenos, quer médios, são sustentados pela Minha providência. Já te dás conta do modo extraordinário como conservo tanto as coisas em geral, como cada uma em particular? Da maneira como, com o Meu poder e sabedoria, velo por todos os seres vivos? Da providência admirável com que dotei várias espécies de animais com diferentes defesas naturais, de acordo com o que pedia a índole de cada um, para que qualquer um deles pudesse salvaguardar a sua condição e viver sem dificuldade? É que provi a uns de astúcia, a outros de rapidez, a outros de força e vigor, e a outros, finalmente, muni-os de outros dons e recursos naturais, para que se veja claramente que na natureza não existe nenhum ser privado da Minha ajuda, mas que todos são abrangidos pela Minha sabedoria e bondade. Desconheces as causas pelas quais estão estreitamente ligadas estas coisas, mesmo as mais pequenas, que se encontram muito abaixo da tua condição; és incapaz de esquadrinhar com a inteligência a grande sagacidade e artifício com que fabriquei tudo isto; não podes examinar a grande potência e sabedoria com que olho por aqueles a quem concedi vida. Portanto, como é que te empenhas em perscrutar e investigar aquelas deliberações do entendimento divino, de acordo com as quais realiza e planeja coisas muito mais elevadas e importantes?

E, se no modo de ser de todas as coisas não podes ver nada que na sua espécie não seja perfeito e provido e ornado dos mais adequados recursos da natureza, como é que poderá com justiça alguém duvidar da equidade e coerência do juízo divino? $\mathrm{E}$, se favoreço as brutas alimárias mediante um poder tão imediato que não consinto que nenhuma seja privada da Minha influência, por que razão se deve suspeitar que deixei sem a Minha ajuda e patrocínio o homem, ser dotado de entendimento e razão, a quem 
plenae, in illius aspectu cirumsonant; hastarum cuspides extersae coruscant; iacula micant atque uibrant; horrendi fremitus eduntur; tumultus excitantur: ipse tamen intrepidus interiectum terrae spatium cursu facillime transmittit et tanta cupiditate [119] tubae clangorem exspectat ut, cum illa signum dat, uix id prae gaudio credat, illa uero canente, uoces laetitiae indices ore fundit. Tantoque bellandi desiderio tenetur ut, multo antequam instructa bellatorum acies appropinquet, ipsam ducum et principum uociferationem et classicum belli praesentiat.

Quid? Accipiterne iussu et imperio tuo pennis extolletur austroque flante alas suas expandet? Quid? Numine et consilio tuo factum est ut aquila uolatu altissimam aeris regionem petat et nidum in alto loco et excelso constituat? Domicilium collocat in rupibus et in praeruptis saxis, egregie natura munitis, ad quae nemo facile possit euadere. Inde uero speculatur unde sibi escam paret et oculorum aciem in longinquas oras intendit. Illius pulli sanguinem lambunt et sic natura et educatione instituuntur ut aliorum animantium carnibus saginentur. Ex quo fit ut, ubicumque caedes edita fuerit, illuc repente aquila festinanter inuolet, ut occisorum sanguine pascatur.

Pauca ex infinitis prope generibus animantium, exempli gratia, collegi, ut intelligeres omnia quae sunt, siue maxima, siue minima, siue mediocria, mea prouidientia sustentari. Iamne perspicis quam singulari ratione res tum uniuersas, tum singulas conseruem? Quomodo animantibus cunctis numine et consilio meo prospiciam? Quam admirabili prouidentia uaria animantium genera uariis naturae praesidiis, prout cuiuslibet condicio postulabat, instruxerim, ut quaelibet posset statum suum tueri uitamque sine difficultate traducere? Aliis namque sollertiam, aliis celeritatem, aliis uires et robur inseui, alia denique aliis muneribus et opibus naturae muniui, ut facile appareat nullam esse in rerum natura formam ope mea destitutam, sed omnes meo consilio et benignitate contineri. Harum quidem rerum, etiam minimarum, quae longe infra condicionem tuam sunt, causas, quibus cohaerent, ignoras; quanta sollertia et artificio haec omnia sim fabricatus ingenio peruestigare nequis; quanta ui et consilio illis, quibus uitam dedi, prospiciam, explorare non potes. Quomodo igitur illa mentis diuinae consilia, quibus multo altiora atque praestantiora molitur atque machinatur, excutere atque perscrutari conaris?

Et, si nihil, in omni rerum condicione, intueri potes, quod non sit in suo genere perfectum et aptissimis naturae opibus instructum et ornatum, quo tandem modo iure poterit quisquam de iudicii diuini aequitate et constantia dubitare? Et, si tam praesenti numine brutis animantibus faueo ut nullum a meis opibus orbatum esse patiar, qua tandem ratione suspicandum est hominem, mentis et rationis compotem et a me iustitiae ornamentis excultum, quem, ut mecum amicitiae 
ataviei com os ornamentos da justiça e a quem, para o unir comigo por um vínculo de amizade, fiz brotar da terra e provi de dons divinos? Por conseguinte, afasta esses pensamentos importunos que te assaltam a inteligência. Refreia o desatino; reprime os arrebatos de hostilidade; não deixes que a perfídia te faça cair; [120] reconhece a tua fraqueza; arreceia-te unicamente da Minha divindade e convence-te de que tudo o que Eu fizer é feito com sabedoria e clemência e, se te acudir ao espírito algo que pretenda opor-se a essa fé, abomina-o como à ruína da tua vida, para que possas conservar a dignidade e a firmeza em todas as provações.

Depois o Senhor acrescentou o seguinte:

- Porventura quem disputa com Deus colherá algum fruto de ciência deste desatino e confiança? Porventura, quando Deus o refutar, poderá dar alguma resposta?

Ora, Job, abalado e prostrado, respondeu ao Senhor dizendo:

- Falei inconsideradamente e com ligeireza, mas, agora, que posso responder ao Senhor, que provou a minha loucura? Por isso, com o máximo cuidado doravante manterei sob vigilância a minha boca, para que à insensata não lhe escape alguma palavra que possa escandalizar o meu Deus. Reconheço que repetidas vezes disse muitas coisas desatinadas, todavia prometo que nunca mais cometerei semelhante má acção.

Mas o Senhor, de dentro do turbilhão com que aterrorizava Job, falou-lhe de novo, dizendo:

- Fortifica o teu ânimo com vigor varonil e expulsa o temor e interrogar-te-ei e instruirei o teu entendimento com conhecimentos salutares. Porventura hás-de anular as sentenças que dei e ab-rogar as Minhas decisões? Hás-de acusar-Me de iniquidade a fim de poderes justificar-te de toda a espécie de crimes? Com que direito, com que lei e com que confiança te atreveste a tamanho atentado? Se tens tão grandes forças que podes contender com Deus, procede de maneira a que vejamos alguma prova dessa tão grande coragem. Produz trovões, destrói os ímpios com a tempestade e o turbilhão, atavia-te com a beleza do primor e dignidade divinos, aspira à mais alta grandeza da majestade e abrilhanta-te com os ornamentos da glória e honra sempiternas, manifesta a tua ira e penetrante ódio contra os homens perversos e depravados e assinala com os olhos todos os que são insolentes e soberbos, a fim de os fazeres cair da sua posição. É que as obras do poder divino são estas: gorar os esforços dos ímpios, punir o crime dos homens sacrílegos, destruir e abater os soberbos, arremessar-se contra e derrubar toda a altivez e arrogância dos entendimentos ensoberbecidos, expulsar do poder os soberbos e desterrar por completo os seus nomes da memória dos homens.

Por conseguinte, tu, se pretendes rivalizar com Deus, realiza obras semelhantes a estas que referi, para que adquiras um nome divino a partir das coisas realizadas por ti mediante uma virtude divina. Procura todos os que possuem um entendimento orgulhoso e se abrasam em intolerável soberba e afasta-os de todas as posições, expulsa os ímpios do lugar onde se parecem avantajar pelo poder e lança-os na desgraça sempiterna. É que, contrariamente ao que muitos desatinadamente cuidam, Eu não favoreço os iníquos, com a minha ajuda não fortifico o poder dos desonestos, embora por vezes costume servir-me 
foedere coniungerem, humo excitaui et muneribus diuinis affeci, a mea ope atque patrocinio derelinqui? Repelle igitur istas cogitationes molestissimas, quae mentem tuam oppugnant. Coerce temeritatem; reprime hostiles impetus; caue ne te labefactent [120] insidiae; imbecillitatem tuam recognosce; meumque solum numen extimesce et, quidquid a me factum fuerit, sapienter et clementer factum esse statue et, siquid occurrerit animo tuo quod fidem istam oppugnare contendat, id tamquam pestem uitae tuae detestare, ut possis in omni rerum discrimine dignitatem et constantiam retinere.

Hoc deinde Dominus adiecit:

- Num is, qui cum Deo contendit, ullum ex ea temeritate et confidentia disciplinae fructum percipiet? Num, cum Deus eum redarguerit, responsum ullum dare poterit?

Iobus autem, animo perculsus et abiectus, Domino respondens, ait:

- Leuiter et inconsiderate locutus sum, nunc uero quid Domino, qui me conuicit amentiae, respondere possum? Summa igitur custodia os meum asseruatum post hac continebo, ne umquam imprudenti aliquod uerbum quod offensionem Deo meo afferre possit elabatur. Fateor me semel et iterum multa temere protulisse, quod tamen facinus numquam me amplius admissurum promitto.

Dominus uero, e turbine quo Iobum exterrebat, illum rursus affatus est, dicens:

- Animum tuum robore uirili confirma timoremque depelle et interrogabo te mentemque tuam salutaribus disciplinis erudiam. Numquid tu quod a me iudicatum est infirmabis decretaque mea rescindes? Mene iniquitatis insimulabis, ut te de omni crimine purgare queas? Quo iure, qua lege, qua fiducia tantum facinus ausus es? Si tantas uires habes ut cum Deo congredi possis, age, istius tantae uirtutis signum aliquod uideamus. Ede tonitrua, impios procella atque turbine peruerte, ornare diuini decoris atque dignitatis elegantia, ad summam amplitudinem maiestatis aspira sempiternaeque gloriae et honestatis ornamentis illustrare, iramque tuam et acerbum odium in perditos atque profligatos homines profunde et omnes qui insolentes atque superbi sunt oculis designa, ut eos de statu deiicias. Haec enim sunt numinis opera: impiorum conatus frangere, sceleratorum hominum scelus ulcisci, superbos perdere atque profligare, omneque mentis elatae fastidium et arrogantiam, impetu facto, prosternere, et superbos dominatu pellere eorumque nomen ex hominum memoria funditus exterminare.

Tu igitur, si cum Deo certare uis, ede opera, his, quae commemoraui, similia, ut diuinum nomen, ex rebus a te diuina uirtute gestis, inuenias. Circumspice omnes elata mente praeditos et intoleranda superbia flagrantes et illos de omni statu detorque et impios in loco, ubi uidentur opibus excellere, de gradu dimoue in sempiternamque miseriam detrude. Non enim, ut multi temere opinantur, iniquis faueo, non ope mea improborum opes communio, quamuis interdum eorum operis ad aliorum hominum scelera punienda uti soleam et, ea de causa, 
da mediação deles para punir os crimes dos outros homens e, por esse motivo, consinto o seu poder, mas consinto-o de modo tal que do mesmo passo atribulo violentamente os seus espíritos e, ao cabo, sumo nas sepulturas os seus nomes e destruo-os com morte sempiterna. [121] Tu, portanto, se procuras ser semelhante a Mim, abate e enterra todos os que maquinam monstruosos crimes, e encerra em lugares sombrios e tenebrosos e oculta sob grandes amontoados de escombros a aparência daqueles que tanto presumiam de si mesmos, por forma a que jamais apareça na Terra alguma lembrança da raça criminosa e perversa. Se fizeres isto, reconhecerei que estás dotado de virtude divina e proclamarei que tu, apoiado nas tuas forças, podes obter para ti mesmo a salvação. É que é próprio da mesma virtude ocasionar a perdição dos criminosos, dar a salvação aos inocentes e resgatar os homens da eterna perdição.

Mas, como de forma alguma podes fazer nem uma coisa nem outra, resta que te comportes humildemente e desconfies de ti e reconheças a tua fraqueza e te capacites de que deves colocar na Minha guarda toda a esperança de vida, salvação e dignidade. De facto, como poderás, sem o Meu auxílio, fazer frente a tão grande número de forças de monstruosos inimigos que te cercam por todos os lados? Queres conhecer a fundo as grandes forças que possui o teu adversário, que se enrosca nos sentidos humanos, que perturba o espírito com paixões ferinas, lhe ateia o fogo e, depois de o espicaçar, o deixa em grande agitação?

Ora, ele é muito parecido em corpulência e violência com o elefante. De facto, o elefante é tão corpulento e está dotado de tamanha astúcia que é comparável ao mesmo tempo com as naturezas de muitos animais, devido à grandeza do corpo e à diversidade de desejos e manhas. Eu criei-o para habitar contigo e estar ao teu serviço. Ele, todavia, embora seja tão grande e esteja dotado de tamanha força e vigor, não se alimenta de sangue, mas nutre-se de feno e de outras forragens deste género, à semelhança do boi. O vigor dele está sobretudo à vista no lombo e vê-se também no meio do ventre. Também estima muito as partes mais vis do corpo, de tal maneira que contrai a cauda curta, delgada e desprovida de pêlos, e a quer protegida, como se com ela, à semelhança de um ramo de cedro, pudesse afastar quer os demais insectos, quer todas as moscas; tem os testículos cobertos com um admirável entrelaçamento de nervos. Os seus dentes, pela força, são comparáveis a canos de bronze, e os ossos do seu esqueleto, pela dureza e solidez, são semelhantes a bastões de ferro. Este sem hesitação alcança a primazia entre todos os animais quadrúpedes que Deus criou desde o princípio, quer se atenda à corpulência, quer à ferocidade, quer à esperteza e astúcia.

Todavia, para que na natureza não exista coisa alguma tão confiante que não tenha algo de que receie lhe advenha mal, quem o fez a ele aparelhou para sua destruição uma espada de que ele se arreceasse. É que sente horror da ponta de que está guarnecido o nariz do rinoceronte e fica extraordinariamente perturbado com ela, como se fosse uma espada preparada para matá-lo. Por outro lado, é tão voraz que parece que os montes produzem feno só para ele. Os restantes animais aplaudem-no e lisonjeiam-no e pastam sem temor o feno por ele deixado. Segue as sombras das imensas árvores para que o protejam do ardor do Sol deitando-se debaixo delas e descansa em lugares pantanosos 
illis dominatum permitto, ita enim permitto ut interim eorum animos uehementer excruciem eorumque tandem nomen tumulis obruam et interitu sempiterno conficiam. [121] Tu igitur, si mihi similis esse studes, eos omnes, qui scelera immania conflant, in terram deprime atque demerge, illorumque speciem, qui sibi tantum arrogabant, locis opacis atque tenebricosis include, et, congestis molibus, occulta, ne umquam exstare possit in terris ullum gentis sceleratae atque perditae monumentum. Quod si feceris, ego te diuina uirtute praeditum confitebor atque testificabor te, uiribus tuis fretum, posse tibi ipsi salutem parere. Eiusdem namque uirtutis est perniciem inferre sceleratis et innocentibus salutem dare et homines ab exitio sempiterno redimere.

Cum uero neutrum ullo modo praestare possis, reliquum est ut te submisse geras tibique diffidas imbecillitatemque tuam recognoscas atque intelligas omnem uitae, salutis, dignitatis spem esse tibi in meo praesidio collocandam. Nam, sine meo auxilio, quo tandem modo poteris tam multis hostium immanium uiribus, quae te undique circumstant, obsistere? Visne penitus explorare quantas uires habeat aduersarius tuus, qui se in sensibus humanis implicat, qui animum ferinis motibus perturbat et, facibus coniectis, inflammat et, stimulis admotis, exagitat?

Est autem ille elephanto, uastitate atque impetu, natura persimilis. Elephantus enim tam uastus atque tanta sollertia praeditus est ut sit cum multorum simul animantium naturis, corporis magnitudine atque multiplice cupiditate et sollertia, comparandus. Hunc ego creaui ut tecum habitaret utilitatibusque tuis seruiret. Qui tamen, quamuis tantus sit atque tantum uiribus et robore ualeat, non sanguine pascitur, sed feno et reliquis eiusmodi pabulis, instar bouis, enutritur. Robur illius maxime in lumbis cernitur et in uentris etiam umbilico perspicitur. Partes etiam corporis uilissimas nimis caras habet, ita ut caudam exiguam et exilem nullisque munitam pilis astringat et conseruatam uelit, perinde atque si posset illa, tamquam ramo cedrino, cum reliqua insecta, tum muscas omnes abigere; testes habet admirabili neruorum implicatione tectos. Dentes illius sunt cum aeneis fistulis robore conferendi et ossa illis inclusa sunt cum ferreo baculo duritie atque soliditate comparanda. Is, inter omnia animantia quadrupedia quae Deus a principio condidit, facile obtinet principatum, siue tu corporis uastitatem, siue uirium immanitatem, siue sollertiam et acumen consideres.

Ne tamen quidquam sit in rerum natura tam confidens ut non habeat aliquid a quo sibi malum metuat, qui fecit illum, gladium, quem ille pertimesceret, in illius exitium comparauit. Rhinocerontis enim mucronem naso parefixum exhorret et illo, tamquam gladio in exitium suum conflato, mirum in modum perturbatur. Tam uorax est ut ei soli montes fenum profundere uideantur. Reliqua animantia illi plaudunt et lenocinantur et sine timore feno ab eo relicto pascuntur. Vmbras ingentium arborum, quae ab illo solis ardorem arceant, sequitur, sub quibus accumbat, et in locis palustribus et arundineto uestitis conquiescit. [122] Operam 
e cobertos de canavial. [122] Aplica-se afincadamente a que a sombra do seu corpo seja coberta por uma sombra maior e por isso frequentemente se lança sob a sombra dos imensos salgueiros. Por outro lado, quando quiser beber mais parecerá esvaziar o rio do que beber e não mostrará pressas no beber, mas ingerirá o líquido aos poucos e calmamente, pois está seguro de que nada há-de impedi-lo de esgotar todas as águas do Jordão. Todavia por decisão de Deus sucede que cai em armadilhas colocadas diante dos seus olhos e que a sua tromba perfurada seja ligada com cordas a fim de servir em proveito dos homens.

Ora, que monstro pode melhor simbolizar a ferocidade da sensualidade e do desejo? Com efeito, em primeiro lugar estes não são pequenos nem simples, mas desmesurados, variados e multiformes, e agitam o espírito não com uma só, mas com infinitas paixões. É que na ferocidade deles se encerram todas as paixões dos irracionais. Por outro lado, de tal modo estão inculcados na natureza de cada um que ninguém, mediante as suas forças e esforço, é capaz de afastá-los de si. Além disso, são sagazes e perspicazes, imaginando por muitos modos todas as vias e maneiras com que possam satisfazer-se e saciar-se. Ora, para mais facilmente poderem gozar aquilo que desejam, a tal ponto se abaixam que parece que não procuram o sangue, mas um ameno pasto, e que não buscam a ruína dos outros, mas o seu próprio prazer. Mas, embora seja assaz feroz o desejo de alimento, de bebida e de riqueza, todavia nenhuma força é mais monstruosa e nenhuma mais furiosa do que a da sensualidade, que se encerra no lombo e no umbigo, isto é, na potência venérea. Com efeito, ela provoca a destruição e, por onde quer que arremete, tudo arruina. Além disso, é próprio dela com o máximo desvelo correr atrás de tudo que é mais vil e mais próximo da indignidade, e vivamente o acolher como coisas salutares, conquanto disso não possa obter para si qualquer proveito e vantagem. Com efeito, ainda que faça todas as diligências a fim de desfrutar de um prazer sem cuidados, mesmo assim atormenta o espírito com muitas inquietações e tortura-o com cuidados variados. O entrelaçamento dos nervos, que cobre inteiramente os testículos, representa a violência da própria sensualidade e os múltiplos disfarces com que se encobrem as actividades mais torpes e o violento lenocínio. Está armada com dentes para que não haja coisa alguma que ela furiosa não derrube quando é mais fortemente provocada.

Mas, no início, foi criada a fim de que qualquer ser vivo, induzido pelo amor a si mesmo, se conservasse a si e à sua situação e vivamente procurasse tudo o adequado à sua natureza e repelisse o prejudicial. Mas por culpa dos homens aconteceu que, aquilo que foi dado para a salvação, se transformou para a ruína. A violência dela é tamanha que só e exclusivamente pode ser submetida pela espada de Deus; nenhumas riquezas a saciam; nenhumas comodidades da vida a enchem; procura prazeres, folga com locais húmidos e viçosos, mergulha em lameiros e a sua sede não se extingue com todas as deleitações, afluindo de todos os lados. Todavia ela, ao arrancar o entendimento, faz que os homens fiquem enredados, percam a liberdade e sofram uma duríssima tirania.

Já estás a ver quão grande é a força e ferocidade da sensualidade ou, para me exprimir com maior rigor, daquele inimigo Demónio que incendeia, abrasa e ateia as 
enixe dat ut umbra corporis sui maiore quadam umbra contegatur et ideo sub ingentium salicum umbra frequenter abiicitur. Cum autem bibere uoluerit non tam bibere quam fluuium haurire uidebitur neque in bibendo festinabit, sed sensim atque leniter potum sumet, confidet enim nihil sibi impedimento fore quominus omnes Iordanis aquas exhauriat. Dei tamen consilio fit ut is in foueam ante oculos positam ruat et nasum illius perforatum funibus alligetur, ut usibus humanis seruiat.

Quod autem monstrum magis potest exprimere libidinis et cupiditatis immanitatem? Primum enim illa neque parua neque simplex, sed immensa et uaria et multiplex est, nec ullo solo motu, sed infinitis animum frequenter exagitat. Omnes enim quadrupedum motus illius feritate continentur. Est autem insita in natura cuiusque, ita ut nemo possit illam a se uiribus et industria sua repellere. Est praeterea sagax et acuta, multis modis excogitans omnes uias et rationes quibus expleri atque satiari possit. Vt autem facilius eo quod optat perfruatur adeo se submittit ut appareat illum non sanguinem, sed pabulum iucundum petere, nec aliorum perniciem, sed uoluptatem suam exquirere. Cum uero cibi, potus, pecuniae cupiditas satis fera sit, nulla tamen est immanior, nulla furiosior uis libidinis ea, quae lumbis et umbilico, hoc est, Veneris impotentia, continetur. Ea namque strages edit et, quacumque impetum fert, omnia disturbat. Est illius praeterea uilissima quaeque turpitudini proxima summo studio consectari et quasi salutaria uehementer asciscere, cum tamen ex illis nullam sibi utilitatem et emolumentum parare queat. Nam, ut omnia, sine cura uoluptatis perfruendae gratia, conquirat, multis tamen curis animum stimulat atque sollicitudinibus uariis excruciat. Neruorum implicatio, quae per omnes testes pertinet, uim ipsius libidinis et obductum rebus turpissimis multiplex integumentum uiolentumque lenocinium designat. Est dentibus armata ut nihil sit quod non, cum est irritata uehementius, furibunde prosternat.

A principio uero condita fuit ut quodlibet animans, amore sui inductum, se statumque summ conseruaret et naturae consentanea uehementer ascisceret et noxia propulsaret. Sed hominum culpa factum est ut, quod fuit ad salutem datum, in pestem uerteretur. Vis illius tanta est ut, nisi Dei gladio, confici ullo modo possit; nullis opibus satiatur; nullis uitae commodis expletur; amoenitates exquirit, humidis atque uirentibus locis gaudet, lutulentis lustris immergitur, nullis uoluptatibus, undique affluentibus, sitis illius exstinguitur. Ea tamen, cum mentem eripiat, facit ut homines irretiti capiantur et libertatem amittant durissimumque dominatum subeant.

Cernis iam quanta sit libidinis uis et immanitas aut, ut rectius dicam, illius daemonis infestissimi qui libidinem irritat et inflamat et faces subiicit, 
chamas da sensualidade, cujo incêndio é impossível de se apagar, excepto pelo Meu Espírito e potência divina.

[123] Queres ver a violência de outro animal feroz e indomável, muitíssimo semelhante em monstruosidade à serpente marinha? Com efeito, que existe de mais forte que o desejo de mandar? Que há de mais sólido do que a tirania, armada e aparelhada com os maiores recursos? Por conseguinte, que existe de mais monstruoso que aquele tirano que mantém as terras oprimidas sob o seu poder? O Leviatão é uma espécie de dragão marinho, que ergue enormes vagas de imensa grandeza para onde quer que se desloca, dotado das maiores forças, que impede o caminho aos restantes peixes e que mantém cercados todos os animais que quiser, e que liga, com fortíssimos liames, todos os que quer impedir de avançar, conservando-os estreitissimamente reunidos, para que não possam deslocar-se. Por conseguinte, pergunto-te: acaso a um tamanho monstro hás-de tirá-lo da água depois de o pescares com um anzol? Acaso atarás a sua língua com uma corda metida através das guelras? Acaso lhe farás passar pelas narinas um junco, como é costume os pescadores fazerem, e lhe perfurarás a queixada com uma espinha, para, pendurado na mão, facilmente o carregares para casa? Acaso, se te lançares sobre ele, há-de arrecear-se de ti, a tal ponto que se humilhe diante de ti e com palavras te desvie do propósito de o matares? Acaso, ao menos, se empenhará contigo para que, vencido, o retenhas com tal condição que ele te sirva e, ligado por firme compromisso, hás-de retê-lo com perpétuo senhorio? Porventura hás-de brincar com ele como se fosse um passarinho e farás que não apenas os teus filhos varões, mas até as tuas filhas o conservem facilmente atado? Os amigos reparti-lo-ão entre si ou os mercadores dividi-lo-ão para o transportarem para regiões distantes, a fim de o venderem? Acaso encherás nas tendas a pele dele com madeira seca e, da mesma maneira, conservarás a sua cabeça num sítio sombreado, onde se embalsamam os peixes, como extraordinário troféu de pescaria?

A verdade é que estás tão longe de fazer algo deste género que nem com as mãos te atreves a tocar-lhe. Pelo que, se avançares a mão para ele, lembrar-te-ás de que há-de atacar-te tão violentamente que nunca depois hás-de pelejar com ele. Certamente que a esperança da vitória engana os homens incautos, os quais, embora, iludidos pela opinião, imaginem que há-de advir-lhes grande honra dessa guerra, todavia não são capazes de encarar a figura do violentíssimo inimigo, mas, ao tempo que olham para ele, perdem a coragem e, aterrados só com o seu aspecto, de imediato caem inanimados. Ora, Eu sou o único capaz de apanhar com um anzol este dragão marinho, de trespassá-lo com um dardo, de torturá-lo, de sujeitá-lo ao meu poderio, de entregá-lo acorrentado aos que vivem sob a Minha guarda, de quebrantar os seus ataques, de zombar das suas vãs ameaças e de, sem custo, conseguir que quanto mais ele se esforça por obscurecer a Minha glória e honra, tanto mais abrilhante o Meu nome e, contra a sua vontade, se torne em instrumento da Minha dignidade. Portanto, derrubo-o, abato-o e disperso os seus membros e, com a máxima rectidão e equidade, reparto os despojos pelos que militam gloriosamente sob o Meu pendão, e ergo perpétuos monumentos comemorativos da vitória, para inflamar o ânimo dos que se juntam ao Meu nome com a esperança da honra e dignidade sempiternas. Para que possas ver melhor quão grande é a ferocidade 
quarum incendium nulla ratione potest, nisi meo tantum numine atque Spiritu, restingui.

[123] Visne cernere aliam animantis feri et indomiti truculentiam, marini serpentis immanitati simillimam? Quid enim dominandi cupiditate ualentius? Quid tyrannide, opibus summis instructa et armata, robustius? Quid igitur illo tyranno, qui terras dominatu oppressas tenet, immanius? Leuiathan est draco quidam marinus, ingentis magnitudinis, maximos fluctus, quocumque se confert, attolens, summis uiribus praeditus, uiam reliquis piscibus intercludens et omnia quae uelit animantia obsesse tenens et, fortissimis adhaesionibus, quaecumque uult impedire uinciens et, ne se loco moueri possint, artissime colligans. Quaero igitur: num hoc tantum monstrum ex aquis, hamo captum, extrahes? Num fune, per branchias immisso, linguam illius alligabis? Num iuncum, quemadmodum a piscatoribus fieri solet, per illius nares transmittes, maxillamque illius spina perforabis, ut id e manu pendens domum facile deferas? Num, si in illud incideris, te metuet, usque adeo ut tibi supplex sit teque uerbis inflectat, ne illi necem afferas? Num id saltem a te contendet ut ea condicione uictum serues, ut tibi seruiat, illudque, firmo foedere deuinctum, dominatu perpetuo continebis? Numquid illo, quasi auicula, ludes, atque perficies ut non solum uiri, uerum etiam puellae tuae alligatum facillime teneant? Diuidentne illud inter se socii aut partientur mercatores, ut id, pecuniae comparandae gratia, in longinquas oras asportent? Num arida materia cutem illius in tabernaculis implebis et caput illius similiter in umbraculis, ubi pisces condiuntur, asseruabis, ad piscationis egregiae monumentum?

Tantum certe abest ut aliquid eiusmodi moliri studeas ut neque manibus illud attingere audeas. Quod, si illi manum admoueris, memineris futurum ut tam acre illius in te proelium concitetur ut numquam postea sis cum illo congressurus. Spes profecto uictoriae homines incautos fallit, qui, quamuis magnum sibi decus ex isto bello, opinione decepti, proponant, hostis tamen truculentissimi uultum aspicere nequeunt, sed, simul atque illum intuentur, animis concidunt et, sola specie conterriti, confestim exanimantur. Ego enim solus sum qui draconem istum marinum hamo capere, telo transfigere, supplicio torquere, dominatu premere, constrictum illis, qui in meo praesidio latent, tradere, illiusque conatus frangere et inanibus minis illudere possum atque ludibundus perficere ut, quo magis ille eo pugnat ut meam gloriam atque decus obscuret, eo clarius meum nomen illustret inuitusque fiat meae dignitatis instrumentum. Illum igitur euerto et affligo membraque illius dispergo et praedam iis, qui sub meis signis egregie militant, summa fide et aequitate distribuo, et uictoriae sempiterna monumenta constituo, ut eorum animos, qui sese ad nomen meum adiungunt, spe sempiterni decoris atque dignitatis inflammem. Quod ut melius inspicere ualeas quanta sit huius taetrae et immanis belluae feritas, in eodem simili uersabor, ut clarius 
deste horrível e medonho monstro insistirei no mesmo símile, de maneira a colocar mais claramente [124] sob os teus olhos a aparência assustadora e a grandiosidade da inaudita força e da desmedida violência dessa serpente.

Ora, não é de admitir que alguém seja tão inimigo de si mesmo que, apoiando-se em si mesmo, a provoque para o combate. É que só Eu desafio aquele meu inimigo, ao qual com a maior facilidade posso derrubar, esmagar e punir com suplício eterno e, à excepção de Mim, não existe ninguém capaz de combater com ele. Por conseguinte, quem não tem medo de pelejar com ele empenha-se em aspirar ao Meu poder e glória militar: que pode imaginar-se de mais louco do que isto? Com efeito, quem é que nesta pugna se coloca na linha de batalha antes de Eu combater? Quem é que antes de Mim travou luta com este medonho inimigo, para que Eu o galardoe com o merecido prémio e recompensa e o anteponha a todas as coisas que existem sob o céu? É que, quem vence esta ferocidade e violência é manifesto que foi certamente provido de forças divinas e, por isso, deve de longe ser preferido a todas as coisas que o âmbito do céu abarca. Para que isto se possa distinguir mais claramente, não passarei em silêncio nem a imensidão dos membros deste monstro, nem o vigor da sua força, nem a perícia em dispor a linha de batalha.

Quem lhe arrancará a vestimenta e porá freios à sua boca? Quem lhe abrirá a boca para que se veja o que nela se esconde? Os dentes que, a toda a volta, como uma paliçada, cercam e defendem a sua boca, infundem um penetrante terror. Coberto por todas as partes por duríssimas escamas que, à semelhança de escudos, recobrem a totalidade do corpo e, estreitamente ligadas e coladas entre si, o encerram, enche-se de uma imensa arrogância, pois não há dardos que possam feri-lo por parte alguma, visto que cada escama está presa a outra e, de tal maneira todas se encontram encaixadas e ligadas com admirável conexão, que entre os intervalos delas nem sequer pode penetrar um ténue sopro. É que de tal modo estão reciprocamente unidas e entrelaçadas que é impossível afastar e separar umas das outras. Ao espirrar surge o relâmpago e os seus olhos brilham como a aurora. Da sua boca elevam-se tochas e irrompem chamas resplandecentes. Das suas narinas sai fumo, como da água a ferver de uma panela posta ao lume ou de uma lagoa aquecida pelos raios do Sol ao nascer. Ao respirar vomita carvões em brasa e pela boca lança violentas chamas. O seu cachaço é tão forte que não teme o senhorio de ninguém nem se arreceia do mando seja de quem for.

Regozija-se por causar temor a todos e por todos se perturbarem ao vê-lo e por a todos atormentar com as maiores dores, pois com todo o empenho se esforça, não em ligar a si os súbditos através do amor, mas em aterrorizá-los com o medo. Aquelas partes do corpo que nos restantes animais são autónomas e costumam agitar-se com mobilidade, nele estão ligadas umas às outras com uma extraordinária solidez e só se movem com um único e mesmo impulso para pôr em movimento a totalidade do corpo: é que nele nada existe de mole, nada de flácido, nada que não possua músculo, nada que destoe da monstruosidade do todo do corpo. A dureza do seu coração é comparável à dureza da pedra e uma lasca de uma mó de pouso lançada com toda a força [125] não conseguirá picá-lo ou mortificá-lo. Para onde quer que se arremessar, tudo encherá de medo e perturbação, todos os mais fortes, abalados por um súbito temor, hão-de sucumbir e 
oculis [124] tuis subiiciam serpentis istius horrificam speciem et roboris inauditi atque intolerandae truculentiae magnitudinem.

Nec enim ferendum est ut quisquam tam sibi sit inimigus ut, per se nixus, eum ad certamen lacessat. Solus enim illum mihi hostem deposco, quem sternere, quem trucidare, quem sempiterno supplicio mactare facillime possum neque, praeter me, quisquam est qui cum illo certamen inire ualeat. Qui igitur illius congressum minime exhorret ad meam potentiam atque bellicam laudem aspirare nititur: quo quid amentius excogitari potest? Quis enim in hac pugna antequam ego proeliarer in acie consistit? Quis ante me manum cum hoc immani hoste conseruit, ut illum debito praemio atque mercede remunerem et omnibus rebus, quae sub caelum sunt, anteponam? Qui enim hanc immanitatem et truculentiam superat, diuinis certe uiribus instructum esse constat et idcirco omnibus rebus, quae caeli ambitu coercentur, longissimo interuallo praeferendus. Quod ut clarius cerni possit neque membrorum monstri huius uastitatem, neque roboris uim, neque aciei instruendae silentio praeteribo.

Quis illi uestem detrahet orique illius frenos iniiciet? Quis illius rictum aperiet, ut ea, quae in illo latent, pateant ${ }^{2}$ ? Dentes quidem, qui illius os circumquaque tamquam uallo saepiunt atque communiunt, terrorem uehementer incutiunt. Durissimis squamis undique tectus et, tamquam scutis, per totum corpus obductis et inter se artissime deuinctis et obsignatis, inclusus, ingentes spiritus assumit, nec enim potest ullis telis aliqua ex parte uiolari, una siquidem squama ex alia nectitur, et ita sunt omnes admirabili colligatione consertae contextaeque, ut inter earum commissuras ne tenuis quidem spiritus penetrare possit. Sic autem inuicem commissae et complicatae sunt ut una ab altera disiungi atque diuelli nequeat. In illius sternutamentis fulgor eminet et illius oculi instar aurorae collucent. Ex ore illius lampades exsistunt et flammae scintillantes erumpunt. E naribus fumus egreditur, tamquam ex olla subditis ignibus ebulliente aut ex palude radiis solis orientis incensa. Anhelitu carbones ignitos euomit oreque flammas impetu quodam iaculatur. Ceruices illius sunt robustissimae, ita ut nullius imperium uereatur aut dominatum extimescat.

Gaudet se timori esse cunctis et omnes ad illius aspectum conturbari doloribusque summis excruciari, nec enim ut subditos amore deuinciat, sed ut metu perterreat summo studio contendit. Illae partes corporis quae in reliquis animantibus laxae sunt et mobiliter palpitare solent, in eo incredibili soliditate cohaerent neque, nisi ad totius corporis motum, uno et eodem impetu commouentur: nihil est enim in illo molle, nihil languidum, nihil eneruatum, nihil ab uniuersi corporis immanitate disiunctum. Duritia cordis illius est cum silicis duritia conferenda neque fragmentum inferioris molae, magnis [125] uiribus

2 pateant] om. editio Romana 
perder a coragem e não serão capazes de atinar com o rumo que hão-de tomar. Se alguém se atrever a aproximar-se muito perto dele, ele embotará o gume das espadas, quebrará as lanças e despedaçará os dardos, rasgará as cotas de malha e destruirá o ferro como se fosse palha e, ao bronze, esmigalhá-lo-á e pulverizá-lo-á como se fosse madeira podre. Nenhumas setas poderão pô-lo em fuga, e as pedras arremessadas pela funda não o preocuparão mais do que palhas dispersas pelo vento, não se arreceará mais das catapultas do que das palhas e zombará do horríssono estrépito das lanças. É que o antro dele encontra-se recoberto com pontas de duríssimas carapaças e, mergulhado nas profundezas, deita-se sobre aguilhões estendidos no lodo.

Provoca uma enorme ondulação e obriga as ondas a cachoarem, como panela, nas profundezas, e agita e convulsiona todo o mar. Atrás de si deixa assinalado um largo caminho no mar, pois faz rolar as vagas e revolve as espumantes ondas e agita o pélago com movimentos tão grandes que, para onde quer que se desloque, parece que o próprio mar embranquece. Na terra não há poder nem soberania perante os quais ceda, não há força de que se arreceie. Propõe-se coisas grandes e muito elevadas, abrasa-se no desejo de dominação e senhorio. Alcança o poder sobre as terríveis bestas-feras e abarca com o seu domínio todos os tiranos que constroem o mesmo caminho para o poderio e se apoiaram nas raízes da soberba. É que ele é o autor da arrogância, o mestre da insolência, o príncipe da soberba, o arquitecto da tirania, furiosamente agitando, com o desejo de domínio e honrarias, o espírito de todos de quem se apercebe que, padecendo da máxima cegueira de entendimento, aspiram às mais remontadas posições.

Já estás a ver e a dar-te perfeita conta, a partir da imagem desta violenta serpente, de como é grande a monstruosidade e quão grande é a força e intolerável o poder daquela antiga serpente, que sob o seu senhorio mantém subjugada a Terra? E como se encontra protegida por todas as partes, de maneira a não poder ser penetrada por nenhuns dardos nem receber nenhum ferimento? E como está confiante nas suas forças? Como é grande a tirania a que aspira? Quão grande é a crueldade e quão grande o crime que respira? Quais as vagas e procelas que, como nas profundezas do mar, desencadeia na existência? Com que violência e impetuosidade levanta turbilhões para sorver todas as riquezas humanas? Ela certamente está dotada de tão grandes forças e inteligência naturais e possui a ajuda de tão terrível escolta, ligada por firme aliança e pacto para perdição dos homens, que, se não tivesse sido enfreada pelo Meu poder divino, facilmente se precipitaria para qualquer lugar para onde a monstruosa e importuna sensualidade a levasse, e tudo perturbaria e confundiria de alto a baixo, e precipitaria todos os mortais na desgraça sempiterna. Ela é aquela que instiga os homens abrasados no desejo de poder, que ateia os seus espíritos com as tochas das Fúrias, que provê de defesas os tiranos e os incita e estimula, para que, com destruição e perdição do género humano, através da violência e do crime procurem o poder e, precipitados pela ambição, perturbem todas as coisas.

[126] Os homens, por conseguinte, rodeados por todos os lados por estas ciladas, não apenas abrasados pelos ardores da impuríssima sensualidade, mas igualmente inflamados 
emissum, illud pungere aut stimulare poterit. Quocumque tulerit impetum omnia metu atque trepidatione complebit, fortissimi quique, subita formidine perculsi, concident et exanimabuntur et, quo se uertant, animis explicare non poterunt. Siquis eum aggredi comminus ausus fuerit, ille retundet gladiorum aciem, perfringet hastas et iacula discindet atque dilacerabit loricas, ferrum, tamquam paleam, conteret et, quasi lignum putridum, aes comminuet atque dissipabit. Non poterit ullis sagittis in fugam uerti, lapides uero funda coniectos non pluris quam aristas uento dispulsas aestimabit, catapultam non magis quam aristas metuet, hastarum uero horrisonum fremitum deridebit. Illius enim cubile durissimarum testarum aculeis instratum est et, in profundo demersus, super cuspides in luto expansas decumbit.

Ingentes fluctus excitat undasque, tamquam ollam, efferuescere in profundo compellit mareque totu perturbat atque commiscet. In aquis post se uiam latam signat, fluctus enim torquet et spumantes undas prouoluit tantisque motibus profundum uersat ut, quacumque ille se incitet, ipsum mare canescere uideatur. Nulla est potestas, nulla dominatio in terris cui cedat, nulla uis quam extimescat. Magna et excelsa sibi proponit, dominationis et imperii cupiditate flagrat. Regnum in uastas belluas affectat et omnes tyrannos, qui eamdem sibi uiam ad opes muniunt superbiaeque radicibus innixi sunt, dominatu coercet. Ille namque est elationis auctor, insolentiae magister, arrogantiae princeps, tyrannidis architectus, animos omnium, quos intelligit esse in summa mentis caecitate, maximarum rerum appetentes, imperiorum et honorum cupiditate furibunde sollicitans.

Cernisne iam et animo recte consideras, ex huius truculentae serpentis imagine, quanta sit illius antiqui serpentis, qui terras oppressas dominatu tenet, immanitas, quantum robur et quam intoleranda potentia? Quomodo tectus undique sit, ne telis ullis penetrari aut uulnus accipere possit? Quantum uiribus suis fidat? Ad quantam tyrannidem aspiret? Quantam crudelitatem et quantum scelus anhelet? Quos fluctus in uita, tamquam in profundo pelago, et quas tempestates excitet? Qua ui et impetu uertices suscitet ut omnes opes humanas exsorbeat? Qui certe tantum naturae uiribus et ingenio ualet tantisque sceleratorum satellitum praesidiis, ad hominum perniciem firmo foedere atque pactione coniuratis, instructus est ut, si meo numine frenatus minime fuisset, facile rueret quocumque illum immanis et importuna libido deferret, et omnia sursum deorsum turbaret atque commisceret, et cunctos mortales in sempiternam miseriam detruderet. Hic est ille qui homines imperii cupiditate incensos instigat, qui eorum animos Furiarum facibus inflammat, qui tyrannos praesidiis armat et stimulis urget atque sollicitat, ut per uim et scelus, cum generis humani strage atque pernicie, dominationem quaerant ambitioneque praecipites omnia perturbent.

His [126] igitur insidiis homines undique circumuenti, non modo impurissimae libidinis ardoribus incensi, uerum etiam bonorum et imperiorum cupiditatibus 
pelos desejos de bens e mando, ficam privados de sentidos e, cegos, são perturbados pela demência e ensandecem, a tal ponto que, por livre e espontânea vontade, se precipitam na perdição e são atados pelos grilhões de ferocíssimos inimigos, de maneira a, com tormentos sempiternos, sofrerem o castigo do desatino e da loucura. Resta, portanto, que te persuadas de que nem deves julgar de forma temerária acerca dos Meus juízos, uma vez que a limitação da inteligência humana é tão grande que pelo entendimento e razão não é possível abarcar o grande artifício com que criei a natureza das coisas terrestres, nem deves apoiar-te nas forças do teu espírito e na constância da tua coragem, ao veres a fraqueza da tua natureza e ao compreenderes que é tão grande o poder do teu inimigo que com nenhumas forças humanas é possível resistir-lhe.

Que cumpre então fazer-se? Ora, em primeiro lugar, se te causa inquietação o facto de ignorares o motivo pelo qual os justos recebem golpes, deves compreender que nem Deus negligencia a situação dos justos nem é sem uma razão suprema que eles por vezes são atribulados. Se nem sempre não alcanças esta razão tal não deve espantar, mas cumpre assentar-se que Eu nada faço sem suma sabedoria. Em segundo lugar, se te perturba a lembrança da tua fraqueza, e te arreceias da ferocidade do inimigo, deves considerar que não cumpre ter na conta de fracos os que estão defendidos com a Minha ajuda e socorro. É que aquilo que não consegues mediante as tuas forças, obtê-lo-ás rodeado das Minhas tropas, de maneira a facilmente alcançares vitória sobre todos os teus inimigos, e até sobre a monstruosíssima serpente, cuja cruel natureza descrevi.

Por consequência, organizam sabiamente a existência, não os que com excessiva curiosidade perscrutam os desígnios de Deus, mas os que suportam com ânimo inalterável tudo quanto Ele determina e decreta. E são fortes e animosos e sempre invictos em todos os conflitos, não os que se arrogam alguma coisa, mas os que reconhecem a debilidade da sua natureza e, por isso, desconfiando das suas forças, por inteiro se apoiam no amor de Deus e são defendidos pela força d' Ele.

Este é o sentido das palavras de que o Senhor se serviu para mais claramente ensinar Job e instrui-lo naqueles conhecimentos que lhe permitissem manter-se muito mais forte e confiante na sua situação. Ora, nestas palavras é muitíssimo digno de consideração o facto de que, embora o Senhor pareça repreender o santíssimo varão, todavia não o acusa de crime, nem o condena por deslealdade, nem diz que incorreu em infâmia, nem lhe lança em rosto a simulação de piedade, mas censura-lhe somente aqueles pensamentos que lhe assaltavam o entendimento, e afasta todos os dardos que contra ele lançava o hostil Demónio, de tal maneira que com todo o discurso não faz outra coisa senão ensinar ao sábio varão conhecimentos mais claros, tornar mais comedido o comedido, proteger o forte com uma defesa mais forte, inflamar o santo e religioso num zelo deveras mais ardente da piedade e da santíssima religião. É que, caso contrário, tal como já a seguir se verá, nunca teria dito que as palavras dele eram rectas nem teria dado testemunho de justiça em relação à vida e opiniões dele.

[127] Mas Job, aturdido com a presença da divina majestade e iluminado por uma espécie de luz mais clara do entendimento divino, compreendeu que na Terra nada existe 
inflammati, sensibus orbantur et, caeci, furore commouentur et insaniunt, usque adeo ut, sponte sua, in pestem ruant et immanissimorum hostium uinculis astringantur, ut, cruciatibus sempiternis, temeritatis et amentiae poenas luant. Reliquum igitur est ut tecum statuas neque esse tibi de meis consiliis temere iudicandum, cum ingenii humani tarditas tanta sit ut neque rerum terrestrium naturam quanto sit a me artificio perfecta mente complecti atque ratione ualeat, neque esse tibi uiribus animi tui et uirtutis tuae constantia nitendum, cum uideas imbecillitatem naturae tuae et hostis tui tantas opes esse ut illis nullis humanis uiribus obsisti possit.

Quid ergo faciendum? Primum quidem, si te ea cura sollicitat quod causam ignoras quare iusti plagis afficiantur, intelligere debes neque iustorum res a Deo negligi neque sine summo consilio illos interdum affligi. Quod consilium si non semper assequeris mirandum non est, sed statuendum nihil a me sine summa sapientia geri. Deinde, si te tuae imbecillitatis recordatio conturbat et hostis immanitatem extimescis, considerare debes non esse imbecillos existimandos qui ope mea atque praesidio muniuntur. Id enim quod uiribus tuis non potes, meis copiis stipatus obtinebis, ut de omnibus inimicis tuis, atque adeo de serpente immanissimo, cuius importunam naturam descripsi, uictoriam facile consequaris.

Non igitur qui nimis curiose Dei consilia perscrutantur, sed qui aequo animo, quidquid ille statuit atque decernit, patiuntur, sapienter uitam instituunt. Neque illi qui sibi quidquam arrogant, sed qui naturae suae imbecillitatem recognoscunt et, ideo, uiribus suis diffidentes totos, se ad Dei studium applicant illiusque robore muniuntur, fortes et animosi sunt et in omni certamine semper inuicti.

Haec est orationis sententia qua Dominus usus est, ut Iobum clarius erudiret et illis disciplinis instrueret, quibus multo fortius et confidentius in statu suo permaneret. In qua quidem oratione illud est consideratione dignissimum quod, quamuis Dominus uirum sanctissimum obiurgare uideatur, non tamen illum sceleris accusat, neque perfidiae condemnat, neque flagitio affinem esse dicit, neque ei simulationem pietatis obiectat, sed tantum illas cogitationes castigat quae mentem illius oppugnabant, atque tela omnia, quae in illum daemon infestus iniiciebat, depellit, ita ut nihil aliud tota oratione moliatur quam ut uirum sapientem illustrioribus disciplinis instituat, modestum modestiorem reddat, fortem multo fortiore praesidio saepiat, sanctum et religiosum ardentiore quodam studio pietatis atque sanctissimae religionis inflammet. Aliter enim numquam, ut statim apparebit, orationem illius rectam esse dixisset nec, illius uitae et sententiae, iustitiae testimonium tribuisset.

[127] At Iobus, praesentia diuinae maiestatis attonitus et clariore quodam lumine diuinae mentis illustratus, intellexit nihil esse in terris tam purum quod 
de tão puro que diante da Sua claríssima luz não se mostre ensujentado de imundície e, por isso, condena ardentemente os pensamentos que ocupavam o seu espírito e a guerra que se fazia contra a sua fé. Por conseguinte, disse:

- Sei e confesso que o Teu poder é imenso e que nenhumas forças Te podem impedir de levar a cabo tudo que planejaste. Portanto, quem existe tão privado de entendimento que creia que as Tuas deliberações não se apoiam na ciência e razão mais elevadas? Quem se encontra subjugado por uma tão grande loucura que em alguma obra divina pergunte pela sabedoria divina e fale de tal maneira que parece que quer ocultar a sabedoria de Deus? Afirmei desatinadamente muitas coisas e, sem qualquer ponderação, disse monstruosidades. Com efeito, cheguei ao ponto de dizer: "Ouve-me, Senhor, e provar-Te-ei a minha causa, e interrogar-Te-ei, e Tu esclarecer-me-ás aquilo acerca do qual Te pergunto." Mas agora vejo, agora tenho discernimento, agora estou provido de conhecimentos salutares e, aquilo que anteriormente conhecia somente por fama e de outiva, vejo-o agora claramente com os olhos e compreendo-o com o entendimento e dou-me perfeita conta de que afirmei muita coisa de forma assaz insensata. Por conseguinte, estou arrependido do desatino e da loucura e por isso cobrir-me-ei de pó e cinza.

Depois de Deus ter dito aquelas palavras a Job, voltou-se para Elifaz e disse:

- Estou fortemente irritado contigo e com os teus dois amigos, pois não falastes rectamente diante de Mim, como fez o meu servo Job, cujo pensar foi sábio quanto à autoridade, santo quanto à religiosidade e defendido pelo direito divino. Por consequência, fazei por expiar com um sacrifício o vosso crime: assim, tomai sete novilhos e sete carneiros e ide ter com Job, como se fosse o sacerdote, e imolai as vítimas sacrificiais e, depois de ritualmente mortas, queimai-as no altar, para que Eu me torne propício a vós. Por outro lado, o Meu servo Job rezará em vosso favor. É que, por causa dele conterei a Minha ira por forma a não vos punir com os castigos que mereceis, porquanto não falastes com rectidão, como o meu servo Job. É que vós quisestes defender a Minha justiça com falsas razões e acusar de crime um homem inocente. Ora, ele, ao empreender a legítima defesa da sua inocência, não proferiu contra Mim nenhuma injúria, embora por vezes a pungente dor lhe arrancasse graves queixumes, que eram, não uma prova de deslealdade, mas um sinal da pesadíssima desgraça que o [128] oprimia.

Por conseguinte, Elifaz de Teman, Bildad de Chua e Sofar de Naamá partiram a fim de realizar o que se lhes mandara. Depois de devidamente realizados estes sacrifícios, a majestade de Deus, devido aos rogos de Job, reconciliou-se de imediato com aqueles três homens. Mas, por que é que neste apaziguamento da divindade se suprimiu o nome de Eliú? Acaso porque aquilo que dissera, dissera-o com ânimo sincero, e o seu erro merecia ser atribuído ao ardor da juventude e ao zelo da religião e, por isso, não precisava daqueles sacrifícios? Ou antes porque atacara muito mais violentamente o santo varão depois da sua defesa, algo que mais cumpria atribuir-se à petulância e à arrogância do que ao zelo da piedade, razão pela qual este crime abominável teria de ser expiado com maior número de vítimas sacrificiais? Ou, enfim, deverá dizer-se que expiou e pagou pelo 
non in conspectu illius clarissimae lucis illitis sordibus obsoletum appareat, et ita cogitationes, quae animum illius peruagabantur, et bellum in illius fidem comparatum acerrime condemnat. Inquit igitur:

- Scio et confiteor potentiam tuam immensam esse nullisque te uiribus impediri posse quominus omnia quae designasti perficias. Quis igitur est tam sine mente qui statuat consilia tua non esse summa scientia atque ratione nixa? Quis tanta est oppressus amentia ut in aliquo opere diuino Dei sapientiam requirat atque ita loquatur ut appareat illum Dei sapientiam occultare uelle? Multa temere enuntiaui et portenta, sine ulla consideratione, locutus sum. Eo namque prouectus sum ut dicerem: "Audi me, Domine, et probabo tibi causam meam, et interrogabo te, tu uero me, de quibus rebus te percunctabor, erudies." At uero nunc uideo, nunc sentio, nunc sapio, nunc salutari disciplina instructus sum et, quae ante fama et auditione tantum acceptaram, nunc oculis clare cerno et mente percipio et intelligo sane me multa nimis insipienter protulisse. Paenitet igitur me temeritatis et amentiae et idcirco in puluere atque cinere uersabor.

Haec ubi Deus cum Iobo locutus est, ad Heliphasium conuersus ait:

- Et tibi et duobus amicis tuis grauiter iratus sum, nec enim apud me recte locuti fuistis, ut fecit seruus meus Iobus, cuius sententia fuit et auctoritate sapiens, et religione sancta, et iure diuino munita. Date igitur operam ut scelus uestrum sacrificio expietis: proinde capite saptem iuuencos et arietes septem et ad Iobum, tamquam ad sacerdotem, accedite et uictimas immolate easque, rite caesas, flammis in ara consumite, ut uobis propitius sim. Iobus autem, seruus meus, pro uobis orabit. Illius enim gratia iram meam continebo, ne uos debitis poenis afficiam, nec enim recte locuti estis, ut seruus meus Iobus. Vos enim falsis rationibus iustitiae meae patrocinari hominemque innocentem sceleris arguere uoluistis. Is autem, cum innocentiae suae patrocinium legitimum suscepisset, nullum in me maledictum coniecit, quamuis interdum dolor acerbus ab illo graues querellas exprimeret, quae non perfidiae testimonium, sed grauissimae cladis, quae illum [128] premebat, indicium continebant.

Abierunt ergo Heliphasius Themanita et Bildadus Suhita et Sopharius Naamathita, ut imperata conficerent. His autem rite procuratis, Dei numen, Iobi precibus, illis tribus hominibus placatum repente fuit. Sed, cur in hac numinis placatione Helius nomen suppressum fuit? An propterea quod ea, quae dixerat, simplici animo dixerat et erratum illius erat ardori iuuentutis et religionis studio condonandum, et idcirco non ita sacrificiis illis indigebat? An potius quod multo asperius fuerat in uirum sanctum post illius defensionem inuectus, quod magis erat proteruiae et insolentiae quam studio pietatis ascribendum, et ideo nefas illud erat pluribus hostiis expiandum? Vel postremo dicendum quod simul cum reliquiis tribus amicis Iobi expiatus atque solutus scelere fuit, quamuis nomen 
crime ao mesmo tempo que os restantes três amigos de Job, ainda que o seu nome não seja referido? É que a idade e autoridade dos outros obscurecia e como que ofuscava com o seu brilho o nome de um homem moço. Por consequência, como Job dirigiu a Deus preces pelos amigos, Deus fez as pazes com eles e olhou pelo atribulado estado do próprio Job e deu-lhe em dobrado uma abundância de todos os bens maior do que a que possuíra anteriormente. Por conseguinte, já restituído à sua primitiva saúde, foram ter com ele todos os seus irmãos, familiares, parentes e amigos e comeram na casa dele. Ora, o sentimento de humanidade a todos fez chorar e comoveu, ao lembrarem a violenta desgraça que oprimira aquele varão, que era um modelo de honestidade e religiosidade. Consolaram-no e cada um deu-lhe uma ovelha e uma arrecada de ouro. E o Senhor aumentou-o e acrescentou-o de bens muito mais do que anteriormente. Pois ficou com catorze mil ovelhas e seis mil camelos e mil juntas de bois e mil jumentas. Teve, além disso, sete filhos e três filhas. Ora, a uma deu o nome de Jemima, a outra o de Quecia e a terceira chamou-se Quéren-Hapuc, nomes estes que significavam a formosura, elegância e graciosidade delas, pois em beleza e primor avantajaram-se a todas as mulheres daquele tempo, tendo-as o pai estabelecido como herdeiras juntamente com os seus irmãos. Ora, depois disto Job viveu cento e quarenta anos e viu os filhos, os netos, os bisnetos e os tetranetos. E, ao cabo, gasto por uma avançadíssima e feliz velhice, partiu desta vida para gozar da imortalidade. 
illius non explicetur? Aliorum enim aetas et auctoritas hominis adulescentis nomen obscurabat et, quasi luminibus, altius obstruebat. Cum igitur Iobus pro amicis ad Deum preces adhibuisset, Deus illis placatus est afflictumque Iobi ipsius statum respexit duploque maiorem illi bonorum omnium copiam donauit quam antea possederat. Illo igitur iam in pristinam sanitatem restituto, conuenerunt omnes illius fratres et affines et familiares et necessarii et apud illum epulati sunt. Omnibus autem sensus humanitatis lacrimas excussit et animis commoti sunt, cum recordarentur quanta ui calamitatis oppressus fuerat ille uir, qui erat probitatis atque religionis specimen. Illum autem consolati sunt, singuli uero singulas oues ei donarunt et item singulas inaures aureas. Dominus uero illius bona multo magis quam antea auxit et amplificauit. Fuerunt igitur illi quattuordecim millia ouium et sex millia camelorum et mille iuga boum et mille asinae. Suscepit praeterea septem filios et tres filias. Imposuit autem nomen uni Iemina, alteri uero Cessia, tertia porro nomen habuit Cerenhaphuch, quae nomina earum splendorem, suauitatem et elegantiam designabant, fuerunt enim illae forma et uenustate omnium mulierum illius aetatis praestantissimae, quas pater, cum earum fratribus, heredes instituit. Post haec autem uixit Iob centum et quadraginta annos uiditque filios et nepotes et pronepotes et abnepotes. Atque tandem, summa atque beata senectute consumptus, ex hac uita migrauit ut immortalitate frueretur. 
D. JERÓNIMO OSÓRIO

II

\section{PARÁFRASE \\ À SABEDORIA \\ DE SALOMÃO}


HIERONYMVS OSORIVS

II

\section{PARAPHRASIS \\ IN SAPIENTIAM \\ SALOMONIS}




\author{
PARÁFRASE \\ À SABEDORIA DE SALOMÃo, \\ PELO PORTUGUÊS JERÓNIMO OSÓRIO
}

\title{
CAPÍTULO I
}

Ó príncipes que com o vosso senhorio abarcais a Terra, ponderai em como é grande e dificultosa a carga que vos foi imposta. Que vos não ensoberbeçam as imoderadas riquezas, nem os cortesãos e os servidores, nem as lisonjas dos aduladores, nem os vãos aplausos, nem a loucura popular. É que, quanto mais elevada é essa posição em que estais colocados, tanto maior, quando de improviso se abater sobre vós o mal, será a ruína e mais encarniçada contra todas as vossas coisas. Lembrai-vos amiúde da vossa fraqueza e não penseis tanto nas vossas riquezas quanto nos perigos que impendem sobre vós. Com efeito, por um lado a inveja, o ódio, a ambição da nobreza, o desatino da multidão e as incessantes malquerenças adquiridas por causa de qualquer acto justo ou injusto vos ameaçam os dias e as noites com a ruína, por outro, e sobretudo, vos aterroriza sobremaneira o santíssimo juízo de Deus. Por conseguinte, cercados por todos os lados por tão grandes perigos, como conseguireis ao cabo esquivar-vos ao desastre que está iminente? Certamente que o único meio é abraçardes a justiça com a totalidade do espírito, porquanto ela é a que contém as sedições, a que reprime as paixões, a que refreia o desatino, a que concilia a paz, a que desperta o amor e, por derradeiro, a que liga Deus aos homens mediante um amor santíssimo, visto como não há coisa que mais leve ao amor do que a imagem da virtude. Logo, uma vez que Deus é justíssimo, só ama aqueles que se aformosearam com os divinos ornamentos e riquezas da virtude. Por conseguinte, se quereis ser unidos a Deus, cultivai exclusivamente a justiça. É que deste modo, fortificados com a Sua ajuda, olhareis com desprezo para as forças [954] e ciladas dos homens.

Mas algum de entre vós perguntará quais são os princípios da justiça, donde é que ela provém ou em que espíritos toma assento. - Ora, a justiça não pode ter outra origem que não seja aquele Senhor supremo, progenitor e criador da verdade sempiterna, arquitecto da equidade, da ordem e da razão, inexaurível e perene fonte e princípio da totalidade do 


\author{
HIERONYMI OSORII LVSITANI \\ IN SAPIENTIAM SALOMONIS \\ PARAPHRASIS
}

\title{
CAPVT I
}

O principes, qui terras imperio continetis, reputate quantum onus et quam difficile sit uobis impositum. Non uobis efferant animos opes immodicae non satellites atque ministri, non adulatorum assentationes, non plausus inanes atque popularis amentia. Quo enim altior iste gradus est in quo locasti estis, eo erit ruina, si male rem publicam gesseritis, cum uos malum improuiso oppresserit, grauior omnibusque rebus uestris infestior. Veniat uobis saepenumero uestrae imbecillitatis in mentem neque tam de opibus uestris quam de periculis, quae uobis imminent, cogitetis. Nam, cum inuidia, cum odium, cum nobilitatis ambitio, cum multitudinis furor, cum offensiones assiduae, quouis iure uel iniuria sumptae, uobis dies atque noctes exitium minitentur, tum uel maxime sanctissimum Dei iudicium uos uehementer exterreat. Quo tandem igitur modo, cum tantis periculis undique cincti sitis, poteritis impendentem cladem effugere? Hoc uno certe, si iustitiam toto animo complexi fueritis, ea enim est quae motus compescit, quae libidinem resecat, quae temeritatem coercet, quae pacem conciliat, quae rem publicam florentem efficit, quae amorem excitat atque, postremo, quae Deum hominibus amore sanctissimo deuincit, nihil est enim quod magis ad amorem alliciat quam uirtutis similitudo. Ergo, cum Deus iustissimus sit, eos tantum amat qui diuinis iustitiae opibus et ornamentis exculti sunt. Si uultis igitur Deo coniungi, unice iustitiam colite. Sic autem, ope illius communiti, hominum uires et $[\mathbf{9 5 4}]$ insidias contemnetis.

Sed quaeret aliquis uestrum quae sit iustitiae disciplina, unde ad nos emanet aut in quorum animis insideat. - Iustitiae quidem principium aliud esse non potest, nisi summus ille Dominus, sempiternae ueritatis parens et auctor, aequitatis, ordinis et rationis architectus, inexhaustus atque perennis totius 
direito. Por consequência, aos que pretenderem consagrar-se ao zelo da justiça, é-lhes mister aplicarem-se do modo mais santo à religião e propiciarem a majestade divina mediante os ofícios da piedade. Requer-se todavia a maior das prudências no desempenho destes deveres da religião. É que existem certas pessoas a tal ponto destituídas de entendimento que pensam que com a maior facilidade se pode expiar com dádivas e presentes um crime cometido com injustiça, e, deste modo, sucede que se expõem a aumentar o crime perpetrado contra os homens com outro crime muito mais grave cometido contra Deus. De facto, que poderá existir de mais ímpio do que conceber uma opinião ruim acerca da santíssima majestade de Deus? Porventura há-de imitar Deus aqueles homens celerados que, seduzidos por dádivas, concedem ganho de causa aos perversos? Porventura os presentes $O$ impedirão de castigar os tiranos pela sua tirania? Porventura, mediante alguma porção da presa, pactuará com os ladrões por forma a não estabelecer o merecido castigo para os monstruosos crimes? Quem pensa tais coisas acerca de Deus incorre na mancha do mais monstruoso dos crimes, que nenhuns sacrifícios purificatórios serão capazes de expungir. Portanto, quem oprime com injustiças o povo, quem faz presa dos bens alheios, aquele a quem, ao tempo que satisfaz a sua avareza, nenhum juízo de Deus inibe de oprimir muitos mortais com inumeráveis injustiças, pensando, entretanto, que pode aplacar o poder divino com as práticas religiosas, ainda que persevere no mesmo crime: quem assim procede está a injuriar a santidade de Deus da forma mais indigna. Por consequência, compreendei algum dia que o início e fundamento [955] da santíssima religião é pensar bem acerca de Deus. Portanto, aproximai-vos d' Ele com pureza e sem qualquer piedade simulada, pois uma religião momentaneamente simulada não desvia Deus de aplicar o castigo. Por conseguinte, se quereis obter a Sua ajuda, adorai a Sua majestade com entendimento puro e singelo e aplicai todos os vossos passos a procurá-Lo com ardente desvelo.

É que Ele é encontrado por aqueles que não O tentam, pois certamente que os que se aproximam d' Ele com uma tal disposição de ânimo que experimentam se Ele quer ou pode auxiliar os que Lhe pedem socorro, não se apoiam na Sua fé e poder. Mas Deus só se mostra àqueles que não têm dúvidas acerca da Sua virtude e descansam na Sua fé: ao contrário do que fazem os que hesitam, duvidam e experimentam todas as coisas antes de pensarem que devem pedir a ajuda divina e, pela inconstância do entendimento, ora são arrastados para aqui, ora para ali, aplicando-se à religião com dobrez de entendimento, de tal maneira que não consideram suficiente enganar os homens, a menos que também dêem visos de iludir Deus com preces simuladas. Que pode fazer-se mais desatinado do que isto? É que os pensamentos astuciosos e manhosamente endereçados ao engano, apartam os homens da união com Deus, e a loucura dos homens poderosos é refutada e convencida pelas acções realizadas irreflectidamente. Logo, nem aqueles que se olham como muito engenhosos podem dar qualquer definição da sabedoria, uma vez que foram afastados da própria fonte da sabedoria, nem aqueles que se ensoberbecem com as riquezas hão-de colher algum fruto salutar das riquezas dela, mas, pelo contrário, hão-de afrontar um perigo muito maior de perdição. É que as riquezas fora do comum encerram uma prova ou de prudência ou de irreflexão, porquanto o que está provido 
iuris fons et origo. Opus igitur est illis, qui sese ad iustitiae studium adiungere uoluerint, ut colant sanctissime religionem pietatisque muneribus Dei numen sibi propitium reddant. In hoc tamen religionis officio prudentia summa requiritur. Sunt enim quidam adeo mentis expertes ut arbitrentur scelus iniuria contractum posse facillime donis et muneribus expiari, et ita fit ut conceptum scelus in homines alio scelere multo grauiore in Deum commisso cumulandum suscipiant. Nam, quid poterit esse scelestius quam malam opinionem de sanctissimo Dei numine recipere? Num Deus scelestissimos homines imitabitur qui, muneribus deleniti, causas hominibus impuris adiudicant? Num donis impedietur quominus poenas a tyrannis de tyrannide repetat? Num aliqua praedae parte cum latronibus paciscetur, ne debitum supplicium scelerum immanitati constituat? Hoc qui de Deo cogitat sceleris immanissimi maculam concipit, nullis piaculis eluendam. Qui igitur iniuriis multitudinem opprimit, qui praedam de bonis aliorum agit, qui, dum auaritiam expleat, nullo Dei iudicio impeditur quominus multos mortales innumerabilibus iniuriis afficiat, et interim arbitratur se posse cultu religionis Dei numen placare, quamuis in eodem scelere perseueret: indignissimam in Dei sanctitatem contumeliam iacit. Intelligite igitur aliquando initium atque fundamentum sanctissimae [955] religionis esse de Deo bene sentire. Ad illum igitur pure et sine ulla simulatione pietatis accedite, non enim Deus religione ad tempus simulata a se supplicio inferendo deducitur. Si uultis igitur illius opem consequi, pura et simplici mente numen illius ueneramini ardentique studio illum uestigiis omnibus inquirite.

Inuenitur enim ab illis qui non temptant illum, certe enim qui eo animo ad illum adeunt ut periclitentur an is uelit aut possit supplicibus opitulari, minime fide atque potentia illius innituntur. At Deus non se ostendit nisi illis tantum qui minime de uirtute illius dubitant et in fide illius acquiescunt: quod quidem minime faciunt illi qui haerent et dubitant et omnia prius experiuntur quam opem diuinam flagitandam censeant, et modo huc, modo illuc mentis inconstantia rapiuntur, et duplici mente religioni operam dant, ita ut non satis habeant homines fallere, nisi etiam Deo simulatis precibus illudere uideantur. Quo quid fieri potest insanius? Astutae enim cogitationes et ad fraudem callidae, homines a Dei coniunctione diuellunt, et hominum potentium amentia rebus temere gestis redarguta conuincitur. Ergo neque illi qui sibi peracuti uidentur ullam significationem sapientiae dare possunt, cum sint ab ipso sapientiae fonte segregati, nec illi qui opibus efferuntur ab ipsius opibus ullum salutis fructum capient, immo multo grauius exitii periculi adibunt. Opes enim eximiae continent uel prudentiae uel temeritatis argumentum, nam qui sapientia praeditus est muneribus sibi commissis utitur ad salutem, at munera homini temerario et insano permissa, ad pestem et perniciem conferuntur. Quo igitur maior illius potentia 
de sabedoria usa para a salvação as funções que lhe foram cometidas, ao passo que se empregam na ruína e perdição as funções confiadas ao homem desatinado e irreflectido. Por conseguinte, quanto maior for o seu poder, tanto maiores indícios dá de loucura e demência, pois para onde quer que se arremessar, tudo destruirá e maquinará tanto a sua perdição como a da pátria. Logo, nem a inteligência trará qualquer ajuda aos homens engenhosos nem as riquezas e honrarias e senhorio serão capazes de socorrer os homens poderosos, visto que são totalmente desatinados, porquanto a sabedoria não entrará no espírito apoiado na malícia, nem morará no coração sujeito aos pecados.

Na verdade, o Espírito Santo, que é o único que ensina a sabedoria, foge do ensino do engano e aparta-se de deliberações irreflectidas e perversas e, depois de provido o olhar de rigorosa capacidade de juízo, repele o assalto da injustiça que ataca, e assim há-de acontecer que castigará com as merecidas penas os pensamentos e falas dos que participam dos crimes e, em proporção com a grandeza das infâmias, infligirá as penalidades a todos os que não só oprimem os homens com injustiças, mas também ultrajam a Deus. É que o espírito de sabedoria é salutar e benéfico ao género humano e é impossível que isente de crime os que violam o direito da sociedade humana, não apenas com actos funestos, mas também com a maledicência, e aos quais nenhum temor da majestade divina desvia de praticar a injustiça: os quais a tal ponto estão loucos que supõem que aquilo que guardam em segredo no espírito não pode ser conhecido por Deus e que as suas conversas não chegam aos ouvidos d' Ele. Deus, porém, esquadrinha e vê tudo quanto se oculta no interior dos seus entendimentos [956] e examina e conhece com a máxima precisão os íntimos recessos dos espíritos e, de tal maneira escuta as suas falas, que nenhuma deliberação secreta escapa ao Seu conhecimento. Com efeito, o Espírito do Senhor, como abarca com imenso poderio a totalidade da Terra e, estendendo-se por todas as partes do mundo, percorre todas as coisas e nada existe de tão oculto em que não penetre, nem coisa alguma escondida por tão grandes trevas que não a consiga examinar (uma vez que ocupa toda a natureza com a Sua divindade), conhece perfeitamente todas as línguas dos homens e aprecia com toda a exactidão as opiniões dos mortais. Portanto, não passará despercebido quem se servir de uma linguagem abominável nem as falas impuras ficarão impunes. É que cumpre que se examinem com toda a diligência as conversas impiedosas, porquanto as próprias falas que escandalizam os ouvidos do Senhor testemunharão contra os próprios maldizentes e mostrarão com toda a clareza o erro das suas iniquidades. Que dizer do facto de que o ouvido do Senhor, hostil e adverso aos ruins e incitado pelo zelo da punição (pois assim o pedem os interesses do direito), não precisa dos testemunhos dos homens, visto que de tudo se dá conta, de tal maneira que, embora alguém fale com um tom de voz baixo de forma impiedosa, ou às ocultas trame a perdição do próximo, ou com linguagem sacrílega maquine crimes contra a santíssima religião: essa pessoa de nenhum modo consegue desviar a sua ruína.

Ó mofinos mortais, fugi da maledicência, que não vos trará qualquer fruto; reprimi a língua insolente, que vos há-de acarretar a imensa enxurrada de todos os males! Com efeito, que poderá existir de mais funesto que uma língua pestilenta? É que dela nascem os enganos, as injustiças, os desdouros, as rebeliões, as dissensões e a ruína dos Estados. 
fuerit, eo maius indicium furoris et amentiae facit, quocumque enim impetum dederit, omnia peruertet et tam sibi quam patriae exitium machinabitur. Ergo nec ingenium acutis hominibus opem ullam afferet, neque diuitiae et honores et imperia homines potentes subleuare poterunt, cum omnes sint amentissimi, nec enim in animum malitia subnixum intrabit sapientia, neque sedem collocabit in corde peccatis obnoxio.

Spiritus enim Sanctus, qui solus sapientiam tradit, fraudis disciplinam fugit et a temerariis atque perditis consiliis se remouet et, iudicii seueritate in oculis constituta, impetum irruentis iniustitiae retundit, et ita fiet ut cogitationes et orationes eorum qui sceleribus affines sunt poenis debitis insequatur et, pro flagitiorum magnitudine, supplicium irroget omnibus qui et iniuriis onerant homines, et in Deum maledicta conferunt. Est enim spiritus sapientiae hominis generi salutaris atque beneficus, et ita fieri non potest ut eos scelere soluat qui ius humanae societatis, non actionibus tantum pestiferis, uerum et maledicentia uiolant, nec ullo numinis metu ab inferenda iniuria reuocantur: qui quidem ita sunt amentes ut opinentur id, quod secretum animis tenent, a Deo animaduerti non posse et eorum colloquia ad illius aures minime peruenire. At Deus quidquid intra mentem latet scrutatur [956] et inspicit, et intimos animorum recessus exactissime perspectos et cognitos habet, et orationem auribus ita percipit ut nullum arcanum consilium illius cognitionem fugiat. Nam Spiritus Domini, cum immensa potestate orbem terrarum complexus sit, cum, per omnes mundi partes pertinens, omnia perlustret et nihil sit tam abditum in quod non penetret, nihil tantis tenebris inuolutum quod non inspiciat (uniuersam enim naturam numine suo complet), omnes hominum linguas probe nouit et sententias mortalium exactissime perpendit. Qui igitur nefaria oratione fuerit usus minime latebit nec sermo impurus erit impunitus. In colloquia enim impia diligenter inquirendum est, nam orationes ipsae, quae Domini aures offendunt, contra maledicos ipsos testimonium ferent et illorum iniquitates aperte redarguent. Quid quod auris Domini, improbis infensa et inimica et studio uindictae (sic enim iuris ratio postulat) incitata, non eget hominum testimoniis, cum omnia percipiat, ita ut, quamuis submissa uoce quispiam sceleste loquatur et, uel clanculum de proximi pernicie coniuret, uel impia oratione in sanctissimam religionem scelera moliatur, nulla ratione queat pestem auertere.

O miseri mortales, maledicentiam fugite quae uobis nullum fructum afferet; linguae petulantiam comprimite, quae immensam malorum omnium colluuionem uobis importabit! Quid enim poterit esse pestilenti lingua funestius? Ex ea namque fraudes, iniuriae, dedecora, tumultus, dissensiones, rerum publicarum euersiones 
Ela destrói os inocentes com o falso testemunho; ela marca os bons com o labéu da indignidade; ela lisonjeia os ímpios, ela arroja-se contra os pios; ela perturba a paz, arranca a luz, suprime tudo que é justo e sagrado e coloca a tirania no poder. Finalmente, para não dizer mais, nunca existiu alguma conversação impura, embora se verificasse às ocultas entre poucos companheiros de crime, da qual não procedesse algum grande mal: pois a boca que mente arranca a vida, visto que sempre visa à destruição quer do corpo, quer do espírito, quer da dignidade, quer do proveito, e incessantemente se esforça por, através do maior dos crimes, despojar os homens da vida ou das riquezas, em que assenta a vida. Por conseguinte, tomai providências para que, cegos pelo erro do entendimento, não consumais o vosso trabalho e desvelo numa coisa tão mortífera, a fim de evitar aparelhardes a vossa perdição com as vossas próprias mãos. Acreditai-me: fareis mal, não tanto àqueles contra os quais sois sumamente perniciosos, quanto a vós, pois a eles ferir-lhes-eis os corpos, mas ocasionareis a ruína eterna aos vossos espíritos, a eles manchar-lhes-eis a fama, mas expor-vos-eis a uma eterna ignomínia, a eles arruinar-lheseis o património, mas, da vossa parte, manter-vos-eis para sempre despojados de todos os bens. É que jamais alguém desejou fazer mal a outrem que não acarretasse para si mesmo muito maiores prejuízos do que para a pessoa a quem odiava com sanha desumana.

Ora, para dizer em poucas palavras os males da maledicência, sobeja ter presente que ela com todo o esforço maquina a morte; o homem, porém, que pensa em inferir uma morte violenta, é inimigo de Deus e [957] prepara uma guerra ímpia contra a Sua bondade. É que Deus não fez a morte nem se compraz com o aniquilamento dos viventes, pois criou todas as coisas para que se mantivessem, e fixou a natureza de todas as formas de tal maneira que velassem pela sua condição e a conservassem, e em nenhuma natureza implantou qualquer veneno que pudesse destrui-la, e não estabeleceu na Terra o reino do Orco. A justiça não pode deixar a sua condição por força de qualquer caso fortuito, porquanto está protegida pela protecção divina e goza do benefício da imortalidade, ao passo que os ímpios, como se não tivessem nenhuma outra actividade e ofício, esforçam-se o mais que podem com as mãos e palavras no sentido de incessantemente se aplicarem a chamar a morte, a travar amizade e a celebrar pacto com ela. E assim sucedeu que, devido à intervenção dela, definhavam, pois fizeram acordo com ela. E deste modo, com estas preocupações, pensamentos, costumes e procedimentos, vivem uma vida que os torna muitíssimo merecedores de que lhes caiba a herança da própria morte.

\section{CAPÍTULO II}

$\mathrm{Na}$ verdade, pensam sacrilegamente o seguinte para consigo, e é assim que com a íntima linguagem do entendimento são levados com monstruoso crime à completa morte da piedade, pois dizem:

- A nossa vida está limitada por um breve período de tempo e envolta por muitas tribulações e inúmeras enfermidades a atormentam, pois fomos criados de tal modo que, neste breve prazo em que o espírito nos alenta, vivemos imersos em muitos perigos, 
oriuntur. Illa falso testimonio innocentes interimit; illa dedecoris maculam bonis inurit; illa impiis adulatur; illa in pios irruit; illa pacem turbat, lucem eripit, ius et fas omne delet et tyrannidem in dominatu constituit. Denique, ne plura persequar, nullus sermo impurus, quamuis latenter inter paucos sceleris socios haberetur, exsistit umquam, ex quo non magnum aliquod malum proueniret: os siquidem quod mentitur uitam eripit, ad interitum enim uel corporis, uel animi, uel dignitatis, uel utilitatis semper spectat, idque perpetuo molitur, ut homines uita uel opibus, quibus uita continetur, per summum scelus spoliet. Cauete igitur ne, errore mentis obcaecati, in re tam mortifera operam et studium consumatis, ne uobis ipsi manibus uestris pestem comparetis. Mihi enim credite: non tantum mali illis, in quos estis taeterrimi, quam uobis ipsis inferetis, illorum enim corpora sauciabitis, animis autem uestris exitium sempiternum afferetis, illorum famam maculabitis, at uos sempiternam ignominiam subibitis, patrimonium illorum imminuetis, at uos interim in perpetuum omnibus bonis nudati permanebitis. Nemo enim umquam alicui nocere concupiuit qui non longe plura detrimenta ipse sibi quam ei, quem odio immani persequebatur, importaret.

Vt autem in summam maledicentiae mala conferam, satis est animaduertere eam mortem omni contentione machinari; at, qui necem inferre meditatur, Dei aduersarius est et in [957] illius benignitatem impium bellum comparat. Deus enim mortem non fecit nec uiuentium interitu delectatur, omnia enim condidit ut permanerent, et ita omnium formarum naturam constituit ut statum suum tuerentur et conseruarent, in nullaque natura ullum uenenum, quod eam euertere possit, inseuit nec Orci regnum in terra collocauit. Iustitia nullo casu de statu migrare potest, diuino namque praesidio saepta est et immortalitatis munere fruitur, impii uero, quasi nihil aliud operis et muneris haberent, ita quantum, manibus et orationibus eniti, possunt, operam assidue dant ut mortem arcessant, ut amicitiam cum illa iungant, ut foedus cum ea percutiant. Ita porro factum est ut interuentu mortis intabescerent, pactionem enim cum illa fecerunt. Itaque his studiis, cogitationibus, moribus et institutis uitam degunt ut dignissimi sint qui ad mortis ipsius hereditatem pertineant.

\section{CAPVT II}

Haec enim secum nefarie meditantur, intimaque mentis oratione sic ad interitum totius pietatis immani scelere feruntur, aiunt enim:

- Vita nostra est breuis aeui spatio circumscripta multisque angoribus implicata et morbis innumerabilibus exercita, ea enim condicione suscepti sumus ut, hoc exiguo tempore quo spiritu ducimus, in multis periculis et laboribus et acerbitatibus uersemur. Mortis enim imminentis impetu quis a se poterit ratione 
trabalhos e penalidades. Com efeito, quem poderá por alguma forma desviar de si a arremetida da morte iminente? Que espécie de medicina pode ter eficácia para curar com salutar remédio as feridas que a morte inflige? Acaso, quando a vida se precipita para o ocaso, será de alguma maneira possível evitar-se que a não termine um fim horrível? Por conseguinte, é forçoso que todos pereçamos por completo. Certos, porém, costumam apelar para aquela consolação de dizerem que só a natureza do corpo é destruída pela morte, ao passo que o espírito permanece e não se extingue, mas muda de estado, e dizem que depois da morte existe outra condição de vida que nenhum tempo há-de destruir, na qual estão estabelecidos prémios de felicidade eterna para os bons e suplícios para os maus. Mas com que argumentos provam isto? Com que testemunhos o corroboram? Quem é que regressou do outro mundo que pudesse asseverar com firmeza que as coisas se passam tal como muitos afirmam? Somos enganados por fábulas e debalde nos esforçamos por expulsar a tristeza com uma vã consolação, pois a verdade é que entramos na vida por acaso e depois da morte recairemos no nada. Com efeito, a alma, que, aspirando, introduzimos pelo nariz, dura o mesmo que o fumo, e a razão é uma espécie de centelha que provoca pulsações no coração: uma vez esta extinta, o corpo regressará à cinza e o espírito desvanecer-se-á como ligeiro ar. A nossa vida dissolver-se-á como um rasto de nuvem, que corre com grande velocidade, e dissipar-se-á à semelhança de uma espécie de neblina, ferida pelos raios do Sol e destruída e evaporada pelo seu calor. E o nosso nome será aniquilado pelo passar do tempo e não existirá quem conserve a lembrança das nossas obras; o curso da nossa vida é comparável ao vazio da sombra. Que nos cumpre, pois, fazer? Ocupar-nos-emos com o futuro, de que não teremos qualquer consciência? Dedicar-nos-emos à glória e à imortalidade, [958] quando é certo que o nosso nome deve ser consumido pelo esquecimento eterno? Por amor da vida futura, aplicar-nos-emos ao zelo da justiça e da piedade, quando é certo que todas as faculdades do espírito devem extinguir-se na morte juntamente com o corpo? Decerto que será o cúmulo da demência pensar naquelas coisas que nunca veremos, fazendo caso omisso do fruto do proveito presente, que agora se nos oferece. É que, uma vez nós mortos, não se proporcionará um regresso à vida, pois as portas da morte estão encerradas para sempre e todas as saídas de tal sorte obstruídas e embaraçadas, e de tal forma escrupulosamente seladas, que jamais a alguém foi possível sair das trevas da morte, e, assim, todas as esperanças da vida se extinguem com a destruição do corpo.

Por conseguinte, enquanto nos é possível, adiante! Gozemos destes bens, que são os únicos que merecem ser chamados bens: pois as virtudes, os elogios pelos merecimentos, a reputação da glória, as recompensas da piedade e da justiça não passam de nomes vãos, que não encerram em si nada de sólido e concreto, mas limitam-se a desviar, com uma certa aparência brilhante, os homens ignorantes dos verdadeiros bens, por forma a incessantemente os atribular com sofrimentos. Desprezemos aquilo que não existe, a fim de podermos gozar a tempo aquilo que existe. Portanto, recreemo-nos com as coisas criadas, enquanto são doces e tenras; caminhemos em todas as direcções cheios do melhor vinho e untados com os mais perfumados unguentos. E, para não deixarmos escapar-se sem fruto a flor da sazonada Primavera, coroando-nos, antes que murchem, 
aliqua propulsare? Quod medicinae genus uim potest ad uulnera, quae mors infligit, salutari remedio sananda? Num, cum uita semel impulsa in occasum praecipitat, poterit ullo modo sustineri ne fine horribili terminetur? Omnes igitur necesse est ut funditus pereamus. Sed illo solacio uti quidam solent, quod dicant corporis tantum naturam morte deleri, animum uero permanere nec exstingui, sed statum commutare, esseque dicunt post mortem aliam uitae condicionem nullis saeculis interituram, in qua sunt bonis praemia felicitatis sempiternae proposita, impiis autem supplicia constituta. Sed hoc quo argumento probant? Quo testimonio confirmant? Quis ab inferis reuersus est qui ea sic esse, quemadmodum multi perhibent, constanter asseueret? Fabulis deludimur inanique solacio maestitiam depellere frustra nitimur, temere enim in uitam ingressi sumus et post mortem ad nihilum recidemus. Anima enim, quam naribus aspirando ducimus, fumi instar obtinet, et ratio est quaedam scintilla motus in corde ciens: qua quidem exstincta, corpus in cinerem redigetur et spiritus, ut mollis aer, diffluet. Vita nostra, ut nubis uestigium, discurrens impetu, euanescet et, quasi quaedam nebula, radiis solis impulsa et calore illius depressa et consumpta, dissipabitur. Nomen uero nostrum uetustate temporis obruetur nec erit qui operum nostrorum memoriam retineat; uitae nostrae cursus est cum umbrae inanitate conferendus. Quid igitur faciendum? Posteritati consulemus cuius nullum sensum sumus habituri? Gloriae et immortalitati [958] seruiemus, cum nomen nostrum sit obliuione sempiterna conterendum? Vitae futurae gratia in iustitiae atque pietatis studium incumbemus, cum in morte sint cum corpore omnes animorum sensus exstinguendi? Summa certe dementia erit, fructu praesentis utilitatis, quae se nunc offert, omisso, ea, quae numquam uidebimus, cogitare. Nec enim, nobis exstinctis, reditus in uitam patebit, mortis enim fores in sempiternum tempus occlusae sunt et omnes exitus ita molibus obstructi et impediti, et ita diligenter obsignati, ut nemini umquam liceat e leti tenebris emergere, omnes itaque spes uitae in exitio corporis exstinguuntur.

Agite igitur, dum licet, iis bonis fruamur, quae sola bona dicenda sunt: uirtutes enim, meritorum laudes, gloriae celebritas, pietatis et iustitiae praemia, nomina uana sunt, nihil in se expressi atque solidi continentia, sed tantum, specie quadam illustri, imperitos homines a ueris bonis auocantia, ut cum aerumnis assidue conflictentur. Nos uero ea, quae non sunt, negligamus, ut iis, quae sunt, tempore frui possimus. Conditis igitur rebus, dum dulces et tenerae sunt, oblectemur; optimo uino pleni et unguento suauissimo delibuti, passim incedamus. Et, ne ueris tempestiui florem sine fructu praeterfluere sinamus, sertis rosarum, antequam marcescant, redimiti, multiplicis odoris suauitatem percipiamus. Nemo nostrum ita sit insipiens ut non omnem fructum quem poterit ex petulantia 
com grinaldas de rosas, aspiremos a suavidade dos diversos perfumes. Que nenhum de nós seja de tal modo ignorante que não extraia da nossa impudência todo o fruto que puder. Deixemos gravadas por toda a parte as pegadas do nosso prazer, pois esta é a nossa herança, este é o único património que nos foi concedido. E como o severo senhorio da lei é empecilho às deleitações da vida (é que, se formos escrupulosos respeitadores da lei, não poderemos possuir a grande abundância de riquezas que nos são mister para a satisfação da sensualidade), destruamos todas as leis. Por conseguinte, oprimamos com o nosso poder o pobre justo, não mostremos qualquer benevolência para com as viúvas nem respeitemos as cãs do ancião. Coloquemos a lei da nossa justiça na força e no poder, pois não tem qualquer dignidade o direito publicamente adoptado pelo povo: como é evidente, porque é amparo dos homens mais baixos, e não uma prova de elevada honra. De facto, o direito da natureza visa a que as riquezas dos que são fracos e não conseguem repelir a injustiça sejam consagradas ao proveito daqueles que detêm o poder no Estado. Por conseguinte, empenhemo-nos, com o máximo esforço e eficácia, em aproveitar-nos do nosso poder para acrescentar as nossas riquezas. Com efeito, depreende-se que aquilo que é fraco é totalmente inútil e está sujeito a inúmeras injustiças, e quem não vê que submeter-se às leis é indício da mais completa debilidade?

Mas opõe-se-nos como obstáculo o facto de que temos como enérgico adversário o homem que se avantaja pela extraordinária justiça, por tal guisa que diante dele não nos é possível fazer com grande facilidade aquilo que empreendemos. Por consequência, é mister apartá-lo do nosso caminho através de perfídias, pois vivamente se opõe às nossas acções e denodadamente increpa as infâmias que cometemos contra os preceitos da lei, frequentemente nos lança em rosto a destruição e corrupção da doutrina. Proclama que possui o conhecimento de Deus [959] e intitula-se por isso filho de Deus, e, o que é mais grave, verbera não só as nossas acções e desígnios, mas igualmente os nossos pensamentos secretos, que ainda não pusemos por obra, mas que apenas meditamos, e põe diante da vista a sua fealdade e indignidade. Mostra-se molesto, hostil e severo em relação a nós, e concebemos um tão grande ódio contra ele que não conseguimos pôr os olhos nele, pois a sua vida é diferente da vida comum. Com efeito, segue um novo e desconhecido modo de vida, que sobremaneira se desvia dos costumes admitidos pelos homens. Considera-nos manhosos, farsantes e simuladores de uma dignidade fingida e, como se se tratasse do infamíssimo contacto com tudo quanto é sujo, aparta-se o mais que pode dos nossos caminhos. E até repete por todos os lados opiniões que estão em oposição com os pareceres e modo de ver de todos os mortais, porquanto julga que a sorte atribulada do justo é de longe preferível à condição muitíssimo próspera dos iníquos, a tal ponto que afirma que, quando o varão probo e inocente é atormentado pela fome e sede, agredido, infamado por falsos testemunhos, crucificado e dilacerado por toda a espécie de crueldades, então ele até é muito mais feliz que os que possuem em abundância muitas riquezas e detêm um poder extraordinário e gozam dos mais refinados prazeres, se estes homens tiverem sido injustos.

Ora, este modo de ser todos o repelem, quer dos ouvidos quer do espírito, e é impossível que alguma pessoa considere que de alguma maneira se deve seguir uma 
nostra percipiat. Vbique nostrae uoluptatis impressa uestigia relinquamus, haec enim est hereditas nostra, hoc unum est nobis patrimonium constitutum. Cum uero uitae deliciis seuerum legis imperium sit impedimento (nec enim poterimus tantis opibus affluere, quantis opus est ad libidinem explendam, si iuris nimis obseruantes fuerimus), iura omnia conuellamus. Opprimamus igitur dominatu pauperem iustum, nullam ueniam tribuamus uiduis neque longaeui canitiem uereamur. Iustitiae nostrae lex sit in uiribus et potentia posita, ius enim quod est a populis publice receptum nullam dignitatem habet: nempe, quod sit hominum infirmorum subsidium et non honoris praecellentis argumentum. Naturae namque ius est ut opes eorum qui tenues sunt et iniuriam propulsare nequeunt ad eorum utilitates, qui principatum obtinent in re publica, conferantur. Quantum igitur eniti et efficere possumus, elaboremus ut potentia nostra ad opes amplificandas abutamur. Quod enim imbecillum est, inutile prorsus et iniuriis permultis obnoxium esse deprehenditur, at, legibus submitti, quis non uidet esse extremae imbecillitatis indicium?

Sed hoc nobis obstat incommodum, quod hominem insigni iustitia praecellentem acrem aduersarium habemus, ita ut per illum nobis non ita facile liceat id quod conamur efficere. Est opus igitur ut illum per insidias de medio tollamus, actionibus enim nostris uehementer obsistit et flagitia, quae contra legis praescripta suscipimus, acriter incusat, disciplinae labem et corruptelam nobis frequenter obiectat. Profitetur se cognitionem Dei tenere [959] atque adeo se Dei filium nominat et, quod grauius est, non modo nostras actiones et consilia, sed etiam intimas cogitationes, quas nondum exsecuti sumus, sed tantum animis agitamus, oratione coarguit, earumque turpitudinem et deformitatem in oculis defigit. Molestus et acerbus atque difficilis nobis est, tantumque odium in illum concipimus ut oculis eum intueri nequeamus, est enim uita illius communis uitae dissimilis. Rationem enim uiuendi sequitur nouam et inauditam et plurimum a receptis hominum moribus abhorrentem. Nos subdolos et nugaces et ementita dignitate fucatos arbitratur et a uiis nostris, quasi a turpissima sordium omnium contagione, se longissime segregat. Quin etiam sententias, quae cum omnium mortalium opinione et sententia pugnant, passim ingerit, afflictam enim iusti fortunam florentissimo statui iniustorum longe praeferendam statuit, usque adeo ut tum etiam, cum uir probus et innocens fame et siti cruciatur, plagis conciditur, falsa infamia deformatur et in crucem tollitur et omni crudelitate laceratur, eum affirmet esse multo feliciorem illis qui multis opibus abundant et insigni potentia praediti sunt et uoluptatibus exquisitissimis afficiuntur, si fuerint iniusti.

Quod quidem omnes et animis et auribus aspernantur fierique non potest ut quisquam eam sententiam, quae cum natura pugnat, aliqua ratione sequendam 
opinião que está em contradição com a natureza. E entretanto, apesar de proferir tantas aberrações, infla-se e ensoberbece-se com tamanha insolência que chama Pai a Deus. Vejamos pois se as suas palavras são verdadeiras e ponhamos à prova com os resultados aquilo que publicamente sustenta. É que, se o justo, que parece que se mostrou excelente em toda a espécie de santidade, é filho de Deus, Deus defenderá a sua causa e libertá-lo-á das mãos dos inimigos, pois não é de crer que Deus menospreze a vida do Seu filho e entregue ao poder dos adversários alguém a quem ama dum modo singular. Logo, se nos for concedido aplicar-lhe castigos da mais desumana crueldade, certamente tornar-se-á manifesto que eram totalmente falsas as suas palavras, com as quais atribuía a Deus a sua linhagem. E, quando for privado da ajuda de Deus e torturado, conseguiremos não só tornar evidente que mentiu acerca da sua origem, mas também poremos à prova a sua virtude e firmeza e verificaremos se pratica a virtude deveras e com sinceridade, ou se se mantém pouco firme na sua opinião: é que a dor quebranta as convicções e a linguagem brilhante e guindada emudece com o temor da morte a aproximar-se. Por conseguinte, ponhamo-lo à prova através de insultos e torturas, de maneira a experimentarmos a sua probidade e ajuizarmos da sua inocência. Condenemo-lo a uma morte muito ignominiosa, para avaliarmos o entendimento deste homem a partir das palavras que a sua violenta dor proferir.

Pensaram isto e o erro turbulento levou-os a precipitarem-se num engano funesto. Esta loucura de forma alguma os isentou de crime, visto que foi por sua livre e espontânea vontade que preferiram as trevas à luz e perseguiram com ódio a verdade, pois a sua malícia os cegou. E assim [960] sucedeu que não se deram conta dos mistérios de Deus nem foram empós da esperança do galardão que está prometido à santidade nem pensaram nos prémios das almas, oferecidos aos que não se mancharam com nenhumas nódoas de infâmias. E deste modo foram eles mesmos os causadores da sua desgraça e infortúnio sempiternos. De facto, no que toca à misericórdia de Deus, dela não teriam sido excluídos, se tivessem querido regressar ao caminho da justiça. É que Deus não criou o homem para o precipitar na ruína, mas para o dotar com graças sempiternas, pois com admirável sabedoria o moldou e formou desde a origem, para que gozasse de vida imortal, e gravou no entendimento dele a imagem do Seu brilho. O diabo, ao ver esta sua formosura, abrasou-se em inveja por ver o homem, feito de terra e provido de mercês divinas capazes de o colocarem naquele estado do qual o próprio diabo tinha caído, pelo que considerou que tal não era de admitir. E, assim, urdiu todas as maquinações a fim de separar o homem da união com Deus, na qual consiste a verdadeira vida, e deste modo o esbulhar de todos os bens. Por consequência, com esta queda, a morte, livre de todos os grilhões, lançou-se violentamente sobre a Terra e oprimiu o género humano. Experimentam-na todos os que seguem a facção do diabo e se entregam ao seu mando. 
arbitretur. Et interim, cum tanta portenta dicat, tanta insolentia elatus et inflatus est ut Deum Patrem appellet. Videamus igitur an orationes illius uerae sint et, quae publice disserit, exitu periclitemur. Si enim iustus, qui excellenter se in omni genere sanctitatis gessisse uidetur, filius Dei est, Deus illius causam suscipiet eumque ex manibus hostium liberabit, nec enim credibile est Deum filii sui uitam negligere et quem unice diligit inimicorum potestati dedere. Ergo, si concessum nobis fuerit in illum exempla immanissimae crudelitatis edere, certe constabit illius orationem, qua genus suum ad Deum referebat, fuisse uanissimam. Neque solum hoc assequemur ut, cum ille fuerit Dei praesidio destitutus et in cruciatum actus, appareat eum fuisse genus ementitum, uerum etiam uirtutem et constantiam illius in quaestionem uocabimus et experiemur, an uirtutem uere et ex animo coluerit, an parum firme in sententia manserit: frangit enim sententiam dolor orationisque splendor et magnificentia, appropinquantis mortis formidine, conticescit. Contumelia igitur et cruciatu in illum inquiramus, ut probitatem illius exploremus et de innocentia illius iudicium faciamus. Morte ualde ignominiosa condemnemus eum, ut ex uerbis illius, quae dolor uehemens expresserit, de hominis mente statuamus.

Haec quidem cogitauerunt et errore turbulento praecipites in capitalem fraudem inducti sunt. Quae quidem dementia nullo modo eos crimine liberauit, cum sponte sua tenebras luci praetulerint et ueritatem odio persecuti sint, eorum namque malitia eos excaecauit. Ita uero [960] factum est ut Dei mysteria perciperent neque spem mercedis quae est sanctitati constituta sequerentur neque praemia animorum, eis proposita qui nullis se flagitiorum maculis inquinarunt, cogitatione complecterentur. Itaque ipsi sibi causam sempiternae miseriae et calamitatis attulerunt. Nam, quod ad Dei clementiam attinet, ab ea minime exclusi fuissent si in iustitiae uiam redire uoluissent. Nec enim Deus hominem condidit ut eum in exitium praecipitem daret, sed ut muneribus sempiternis afficeret, illum enim a primordio mirabili consilio finxit et informauit, ut immortali uita frueretur, in illiusque mente imaginem suae claritatis impressit. Hanc illius speciem intuens diabolus, inuidia flagrauit, cum cerneret hominem, humo excitatum muneribusque diuinis affectum, ut in eo statu locaretur, unde diabolus ipse conciderat: id igitur minime ferendum existimauit. Itaque omnes machinas admouit ut hominem a Dei coniunctione, qua uera uita continetur, distraheret, et sic eum omnibus bonis euerteret. Eo igitur casu, mors, omni uinculo soluta, in orbem terrarum uiolenter inuasit humanumque genus oppressit. Illam uero experiuntur omnes qui diaboli factionem sequuntur seseque ad illius ductum applicant. 


\section{CAPÍTULO III}

As almas dos justos, porém, permanecem seguras sob a tutela e patrocínio de Deus e por isso não podem ser quebrantadas e enfraquecidas pelas torturas. Aos olhos dos ignorantes pareceram morrer, os quais consideravam mofino e calamitoso o fim deles e uma ruína funestíssima o separarem-se de nós, embora gozem da mais tranquila paz. É que, ainda que os bons aos olhos dos homens sejam atormentados com penalidades, todavia são arrebatados pela firmíssima esperança da imortalidade e da glória sempiterna. Aperfeiçoados por golpes muito ligeiros, hão-de obter os máximos prémios, pois Deus afligiu-os com penas e aprovou a firmeza que revelaram em toda a espécie de perigos e rigorosas provações, e julgou que, por causa da superior virtude, eram merecedores de que os unisse consigo na comunhão de todos os bens. Tal como o ouro com o fogo, assim com os trabalhos limpou-os até da mais leve escória de infâmias, para que se tornassem muito mais puros e desta maneira fossem acrescentados com dádivas mais consideráveis. Além disso, quis que naquele santíssimo sacrifício, que eram os tormentos deles, se instituíssem honras para Si, as quais consistem na fé, na perseverança, na paciência, no ardor do entendimento e no incêndio da caridade. É que não pede sacrifícios de quadrúpedes nem defumações de essências, mas exige espíritos puros e vivamente inflamados no Seu amor. Ora, destarte sucede que nenhum presente Lhe pode ser mais aceito do que a obediência e entusiasmo daqueles que não se esquivam a quaisquer tormentos em prol da prática da justiça e da glória de Deus. Portanto, quando se prestar atenção a estas acções humanas, hão-de luzir com maravilhoso esplendor e espalhar-se-ão como fogo ateado em colmo seco, pois saltarão com uma rapidez tão extraordinária que nesse meio tempo hão-de aniquilar o nome e riquezas dos homens ímpios. Julgarão os povos e senhorearão as nações e o Senhor será [961] o seu Rei para sempre, de tal modo que jamais podem deixar a sua posição, visto como se encontram defendidos pela protecção do supremo e sempiterno Rei. Os que põem a esperança em Deus compreenderão a verdade e os que são perfeitamente fiéis, abrasam-se no amor d' Ele e deste modo perseveram na Sua adoração e não podem separar-se d' Ele, enquanto estiver vivo este zelo. É que a fé, que confia em Deus, consegue que Deus a encha com luz celestial.

Por outro lado, deste modo o homem piedoso vê aquelas coisas que para ele se encontravam envoltas em trevas e pasma atónito com a beleza da verdade que contempla e dá-se conta de que são totalmente vãs as coisas que anteriormente julgava formosas e apetecíveis. É que não existe nada de verdadeiro nos bens que o vulgo dos homens admira. Com efeito, procuram obter falsas honrarias, vão empós de deleitações totalmente enganadoras, perseguem vaníssimos proveitos e, impelidos pela simulada imagem da beleza, desviam-se da razão e prudência. Logo, quando os espíritos de tal maneira se transformam que aplicam a penetração do entendimento, afastada dos falsos bens, às riquezas eternas e verdadeiras, e compreendem a grande diferença que há entre ambas, com o mais justo dos juízos condenam a vida passada e estabelecem outro género de vida e, abrasados no amor da formosura divina, ligam-se a Deus na medida em que isto é possível. É que Deus acrescenta e aumenta os Seus santos com os dons e dádivas da graça 


\section{CAPVT III}

At iustorum animae in Dei tutela et patrocinio latent et idcirco cruciatu frangi et debilitari non possunt. Visi sunt oculis insipientium mori, qui exitum eorum dirum et calamitosum et discessum a nobis exitium funestissimum existimabant, cum illi pace tranquillissima perfruantur. Quamuis enim boni oculis hominum poenis torqueantur, ad spem tamen firmissimam immortalitatis et gloriae sempiternae rapiuntur. Minimis plagis eruditi, maxima praemia consequentur, Deus namque illos poenis exercuit et eorum, in omni rerum discrimine et in omni laborum asperitate, constantiam approbauit et, ob uirtutem diuinam, dignos esse iudicauit quos secum bonorum omnium societate coniungeret. Vt aurum igne, sic eos laboribus ab omni leui etiam flagitiorum scoria secreuit, ut multo puriores euaderent et ita amplioribus muneribus cumularentur. Praeterea illo sanctissimo sacrificio in eorum cruciatibus honores sibi institui uoluit, quod est in fide, in constantia, in patientia, in ardore mentis, in caritatis incendio constitutum. Non enim quadrupedum uictimas aut odorum suffimenta requirit, sed animos puros et amore illius acriter inflammatos exposcit. Sic autem fit ut nullum illi munus acceptius esse possit illorum oboedientia et alacritate, qui pro iustitiae cultu et pro Dei gloria nulla cruciamenta recusant. Ergo, cum fuerit in actiones humanas animaduersum, splendore mirifico coruscabunt et, tamquam ignis in culmis aridis implicatus, discurrent, sic enim admirabili celeritate micabunt ut interim impiorum hominum nomen et opes absumant. Iudicabunt de gentibus, populos imperio continebunt et erit Dominus [961] rex eorum in perpetuum, ita ut non possint ullis umquam saeculis, cum sint regis summi atque sempiterni praesidio muniti, de statu demigrare. Qui spem in Deo ponunt intelligent ueritatem et qui egregie fidem colunt illius caritate incenduntur, et ita in illius cultu permanent nec ab eo, quamdiu id studium uiget, seiungi possunt. Fides enim hoc assequitur, ut a Deo, cui se committit, caelesti lumine compleatur.

Sic autem cernit homo pius ea, quae erant illi tenebris circumfusa, et, specie ueritatis, quam intuetur, attonitus, obstupescit et intelligit, quae ante pulchra et expetenda iudicabat, esse uanissima. Nulla enim ueritas est in bonis quae hominum uulgus admiratur. Nam falsos honores ambiunt, fallacissimas uoluptates exquirunt, emolumenta fallacissima consectantur, simulata pulchritudinis imagine commoti, a mente et consilio deducuntur. Ergo, cum ita commutantur animi ut mentis aciem, a falsis bonis auersam, in opes ueras atque sempiternas intendant, et intelligant quantum inter utrumque differat, actam uitam iudicio uerissimo damnant et aliud uitae genus instituunt, amoreque diuinae pulchritudinis inflammati, Deo (quoad fieri potest) adhaerescunt. Deus enim sanctos suos donis atque muneribus gratiae et benignitatis auget et cumulat nec ab eis oculos umquam deiicit quos elegit ut opibus diuinis locupletaret. At impii in supplicium 
e da bondade e jamais desvia os olhos daqueles a quem escolhe para enriquecer com os Seus tesouros. Os ímpios, porém, são precipitados no suplício que receavam, pois os homens perversos e corruptos não conseguiram passar tranquilamente a vida, visto que, ainda que pareçam possuir as maiores riquezas e tenham muitos servos da sensualidade e inúmeros mortais lhes obedeçam, todavia frequentemente os atormenta a consciência do crime e o medo do juízo divino. É que lhes é impossível a tal ponto subjugar o senso moral que desprezem por completo aquilo que a natureza em todos implantou, ou seja, que os criminosos estão sujeitos a terríveis castigos. Por conseguinte, estes homens hão-de lançar-se desvairadamente naqueles males de que amiúde se arreceavam, eles que todavia de tal forma foram desatinados que, embora frequentemente pensassem que deveriam ser castigados, persistiram no crime, impelidos pelo senhorio da sensualidade, à qual estreitamente se tinham ligado.

Foi, por conseguinte, este o motivo pelo qual desprezaram o justo e se rebelaram contra Deus. Ora, é infeliz quem menospreza a sabedoria e os ensinamentos, e as suas esperanças são enganadoras, vãos os seus cuidados e totalmente inúteis as suas obras. As mulheres dos ímpios são loucas, os seus filhos manchados de infâmias e desprezível a sua descendência. Os homens, por conselho da natureza, desejam filhos herdeiros do seu nome, a fim de que, quando morrerem, não pareça que pereceram por completo, visto como deixam viva uma imagem sua. Mas, quão mais acertada decisão teriam tomado, se jamais tivessem gerado filhos herdeiros do crime cometido! É que, quando os costumes se degradam e tudo visa à ruína da virtude e da dignidade, quanto maior for o número de descendentes, tanto mais acrescido será o castigo de toda a linhagem. Oh afortunada a mulher que não páre filhos por não querer manchar-se com a sensualidade, a saber, para não decair do estado de pureza; na verdade, não será obrigada a suportar, com tormento do espírito, a perversidade do marido, nem verá os filhos, desonrados pelas infâmias, precipitarem-se na perdição eterna, nem enxergará a ruína e fim da funesta prole. [962] No que tange, porém, à lembrança do nome, a lembrança da virtude é eterna, ao passo que a descendência dos ímpios será destruída pelo eterno esquecimento. Por conseguinte, a mulher que, por todos os modos, depois de dominada a sensualidade, com admirável virtude alcançou insigne vitória sobre a natureza do corpo, é mais afortunada que todas as mulheres que não quiseram esforçar-se por um merecimento tão grande. Portanto, quando se fizer a indagação acerca da vida das almas, alcançará um singular fruto do juízo de Deus.

Do mesmo modo, também o eunuco, que é eunuco, não tanto por defeito da natureza ou agressão dos homens, mas por ardente amor da pureza e, por este motivo, se proibiu a si mesmo toda a espécie de sensualidade, de forma alguma será excluído do foro da Cidade celestial: ou seja, quem nem oprimir os homens com quaisquer injustiças nem maquinar qualquer crime contra Deus. Por conseguinte, embora antigamente não se permitisse aos eunucos a entrada na casa do Senhor, a estes eunucos de maneira alguma se lhes impedirá o acesso: é que antigamente aquelas ameaças de desdouro só se promulgavam a fim de que se entendesse que aqueles que não tivessem gerado nenhum fruto de virtude não deveriam ser acolhidos na Cidade celestial. E hoje, expostos já mais 
quod metuebant detrudentur, numquam enim homines profligati atque perditi uitam quiete traducere potuerunt, quamuis enim summas opes habere uideantur et multos habeant libidinis administros multique mortales illis obtemperent, conscientia tamen sceleris et iudicii diuini metus eos frequenter exanimat. Non enim ita possunt animorum sensus opprimere ut negligant omnino id quod natura omnibus inseuit: nempe, sceleratos esse poenis diris obnoxios. In ea igitur mala quae saepenumero formidabant furenter incurrent, qui tamen adeo fuerunt amentes ut, cum saepe cogitarent esse sibi subeunda supplicia, in scelere persisterent, imperio libidinis, cui se constringendos dediderant, impulsi.

Hoc igitur fuit in causa cur iustum contemnerent et a Deo rebellarent. Qui autem sapientiam et disciplinam aspernatur infelix est et spes illius fallaces et sollicitudines inanes et opera prorsus inutilia. Impiorum uxores sunt amentes et filii flagitiis inquinati eorumque suboles exsecranda. Homines quidem, naturae admonitu, filios sui nominis heredes expetunt ut, cum ipsi fuerint consumpti, non omnino mori uideantur, eo quod imaginem suam in uita relinquant. Sed, quanto rectius illis consultum fuisset, si nullos umquam liberos instituti sceleris heredes suscepissent! Cum enim mores labuntur et omnia ad interitum uirtutis et dignitatis spectant, quo plures posteri fuerint, eo magis erit poena totius generis amplificata. O felicem mulierem, quae filios non peperit eo quod noluerit se libidine commaculare, ne uidelicet ab integritatis statu decideret; non enim cogetur uiri improbitatem, cum animi cruciatu, sustinere, non uidebit filios, flagitiis infames, in pestem sempiternam ruere, non ruinam et occasum pestiferae prolis [962] intuebitur. Quod uero ad memoriam nominis, uirtutis memoria sempiterna est, impiorum autem propago obliuione sempiterna delebitur. Omnibus igitur modis mulier quae, compressa libidine, uictoriam insignem de natura corporis fuit uirtute admirabili consecuta, est omnium mulierum felicissima, quae minime ad tantam laudem eniti uoluerunt. Fructum igitur iudicii diuini, cum de animarum uita inquisitio fiet, eximium consequetur.

Similiter et eunuchus, qui non tam naturae uitio aut hominum iniuria, quam ardenti studio puritatis eunuchus est, et ea ratione sibi ipsi omni genere libidinis interdixit, nullo modo erit a iure caelestis ciuitatis exclusus: nempe, qui nec homines iniuriis ullis affecerit, nec in Deum scelus ullum conflauerit. Quamuis igitur olim eunuchis aditus in domum Domini minime pateret, his eunuchis nullo modo erit aditus interclusus: nam nec olim lege erant illae dedecoris minae propositae nisi ut intelligeretur eos, qui nullum uirtutis partum ediderint, non esse in caelestem ciuitatem recipiendos. Et nunc, mysteriis diuinis iam clarius explicatis, cerni facillime potest eunuchis, qui, pietatis exemplo, gignere filios 
claramente os mistérios divinos, pode compreender-se com a maior facilidade que aos eunucos, que, com o exemplo de piedade, podem gerar filhos, procriados, não através da semente humana, mas através da imitação da santidade, é-lhes concedido subirem ao Céu. Com efeito, ser-lhes-á concedido o magnífico galardão da fé e da religião e no templo do Senhor verão uma felicíssima herança, pois é glorioso o fruto das boas obras e imutável e eterna a raiz da verdadeira prudência.

Mas os filhos dos adúlteros, que seguem as pegadas dos pais, não poderão ser expiados, uma vez que são repelidos da entrada do templo e de todas as cerimónias religiosas, e a linhagem nascida de leito sacrílego perecerá por completo e será aniquilada a lembrança da semente adulterina. Pelo que, se acontecer que algum destes viva durante muito tempo, todavia será tido na conta de ninguém e a sua extrema velhice ver-se-á cercada de todo o desdouro; mas, se morrer novo, perecerão juntamente com o seu corpo todas as esperanças de salvação, e, quando se instituir o juízo, não se lhe concederá nenhum alívio do castigo e tormento, porquanto terrível e funesto é o fim de uma raça injusta.

\section{CAPÍTULO IV}

Por conseguinte, quanto mais ilustre não é para a dignidade do prestígio e mais sólido para a imortalidade do nome, por amor do zelo da piedade carecer de filhos e ser celebrizado pelo resplendor de uma virtude extraordinária, do que correr por aqui e por ali cercado por uma prole numerosa e, a exemplo dos tiranos, criar filhos para a perdição? É que a grandeza da glória imortal funda-se, não tanto no grande número de filhos, mas na grandeza da virtude, porquanto a lembrança da virtude não pode ser destruída pelos desastres nem gasta pelo passar do tempo, pois é agradável a Deus e admirável para os homens. Muitos, tendo-a à vista, nela porão os olhos, para se consagrarem a imitá-la. Na sua ausência, sentem saudades dela e consideram que a sua formosura deve ser celebrada com incessante louvor, pois celebra um nobilíssimo triunfo por toda a eternidade, uma vez que conseguiu a vitória num glorioso combate, e, como [963] se mostrou vencedora de todas as guerras, exulta ornamentada com prémios imaculados e eternos. A numerosa descendência, porém, da raça ímpia, não produzirá fruto de proveito, nem os rebentos adulterinos hão-de lançar raízes profundas, nem possuir alguma morada estável. Por outro lado, embora momentaneamente, com o viço da folhagem, apresentem à vista alguma aparência de encanto, todavia hão-de medrar não sem risco de destruição e ruína, pois serão agitados pelos ventos e, ao cabo, sacudidos pelo redemoinho, hão-de ser arrancados de raiz; os ramos serão quebrados antes de terem atingido a maturidade, o fruto será azedo e verde, impróprio para comer e sem qualquer proveito. É que os filhos nascidos do ajuntamento dos iníquos são prova da iniquidade dos pais sempre que a vida destes é apreciada em juízo. Com efeito, como os costumes são corruptos, perversos e ruinosos, pode tornar-se manifesto aos homens que tipo de educação os pais lhes deram, ao verem que os filhos imitam o crime dos pais e até competem em malícia e desonestidade com 
possint, non seminis humani ratione, sed sanctitatis imitatione propagatos, ascensum in caelum dari. Dabitur enim illis praemium fidei atque religionis amplissimum et in templo Domini iucundissimam hereditatem cernent, bonorum enim operum gloriosus est fructus et uerae prudentiae radix immutabilis atque sempiterna.

At adulterorum filii, qui parentum uestigiis ingrediuntur, expiari non poterunt, cum ab aditu templi et ab omnibus sacris arceantur, et genus e lecto nefario susceptum funditus interibit memoriaque incesti seminis obruetur. Quod, si alicui ex illis contingat ut diuturnam uitam degat, pro nihilo tamen putabitur et extrema illius senectus erit omni dedecore cumulata; si uero cito e uita discesserit, simul cum corpore omnes illi spes salutis interibunt et, cum fuerit iudicium constitutum, non erit ei ullum supplicii et angoris alleuamentum, nationis enim iniustae diri et exitiales exitus sunt.

\section{CAPVT IV}

Quanto igitur est praeclarius ad decoris elegantiam et firmius ad nominis immortalitatem propter pietatis studium filiis carere et splendore egregie uirtutis illustrari quam, subole multiplici circumsaeptum, uolitare et, tyrannidis exemplo, filios ad perniciem instruere? Non enim tam in filiorum multitudine quam in uirtutis amplitudine immortalis gloriae amplitudo consistit, nec enim memoria uirtutis calamitate peruerti aut temporis uetustate consumi potest, Deo namque grata est et hominibus admiranda. Illam multi praesentem intuentur, ut ad illius imitationem se conferant. Eam absentem desiderant illiusque pulchritudinem perpetua praedicatione celebrandam existimant, nam in omni aeternitate, cum sit coronam ex glorioso certamine consecuta, clarissimum triumphum ducit, et, cum [963] bellorum omnium uictrix exstiterit, ornata praemiis incontaminatis atque sempiternis exsultat. At multiplex nationis impiae propago utilem fructum non efferet, nec adulterini stolones altas radices agent, nec ullam stabilitatem sedis habebunt. Quamuis autem, frondium uiriditate, aliquam amoenitatis speciem oculis ad tempus obiiciant, non sine stragis atque ruinae periculo grandescent, uentis namque agitabuntur atque tandem, turbine concussi, radicibus euellentur; rami, antequam ad perfectionem perueniant, defringentur, fructus erit acerbus et immaturus et nec ad cibum utilis nec ad usum idoneus. Filii enim ex iniquorum coniunctione propagati parentibus iniquitatis testimonium dant, quotiens eorum uita ad iudicii examen perpenditur. Cum enim mores corrupti sint et ad perniciem profligati atque perditi, constare potest hominibus qualis parentum disciplina fuerit, cum uideant filios parentum scelus imitari atque adeo cum iis, a quibus 
aqueles por quem foram gerados e criados. Por conseguinte, quanto mais tempo viverem, tanto maior pena do crime hão-de suportar.

Ora, o justo, ainda que pareça ter sido arrebatado por uma morte precoce, repousará na mais completa tranquilidade. É que não pode sobrevir uma morte precoce a quem chega com glória à maturidade da virtude perfeita, para a prática da qual nascemos: e até, quanto mais depressa alcançou o fruto da virtude, com tanto maior felicidade conclui a carreira da vida. De facto, assim como não se deve considerar como cantor quem dia e noite lança vozes desentoadas com enorme desagrado dos ouvintes, mas sim quem canta com conhecimento e afinadamente, ainda que consagre pouquíssimo tempo a cantar, e da mesma maneira que não é bom médico quem declara que foi médico durante longo tempo, ainda que não tenha produzido qualquer fruto de cura nos enfermos, mas sim quem em curto prazo repele a doença, assim não deve considerar-se como velho a pessoa que prolongou durante muitíssimo tempo a existência sem qualquer harmoniosa temperança e por tal forma passou a vida que nunca se libertou das enfermidades das infâmias, mas antes aquele que durante um período breve de tempo conservou a boa harmonia da virtude e empregou em si uma medicina salutar, pois viveu o tempo bastante quem cumpriu à perfeição as obrigações da virtude perfeita. E assim merece o devido acatamento aquela velhice que não se funda no tempo dilatado nem no grande número de anos, mas aquela a que a grandeza da virtude cumulou com toda a espécie de prestígio. Por conseguinte, as cãs do homem consistem na maturidade da prudência e a idade da velhice é uma existência que não foi manchada por qualquer contacto com a perversidade: donde se conclui que o moço que só praticou a piedade, que nunca se apartou do dever, que se aplicou afincadamente a obter o fruto da virtude, se falecer, não morreu antes do tempo. É que, uma vez que preencheu as medidas da virtude perfeita, deve ser tido na conta de velho, e não de moço. E porque não é possível que o mais excelente dos pais despreze os interesses dos bons, por isso, uma vez que aquele moço probo viveu com justiça e piedade, obterá de Deus a graça e, por conseguinte, foi, por benefício divino, libertado da sujidade dos males e levado para outra vida. Por consequência, [964] a vida não lhe foi desapiedadamente arrebatada, mas antes a morte misericordiosamente oferecida, para que não caísse na perdição eterna. Com efeito, se tivesse permanecido durante muito tempo nesta vida, a sua consciência teria podido ser modificada pela malícia dos homens perversos e, com enganos, ser levada, do zelo da piedade e da pureza, para o desprezo da religião e para uma vida impura. Por este motivo, pois, Deus arrebatou-o e não permitiu que fosse manchada por alguma nódoa impura a pessoa que Lhe era querida. É que os homens perversos não podem suportar o resplendor da honestidade e, por isso, aplicam todos os esforços no sentido de derrubarem da sua posição a virtude, onde quer que a vejam reluzir. De facto, a pestilencial doença da perversidade e os espinhos do desatinado ódio acossam o amor da honestidade, até ao ponto de cobrirem de sombras as coisas mais claras e levarem a sofrer desonra aqueles que se empenhavam na virtude. Junta-se a insolência da cobiça, que impele o entendimento singelo para o funesto engano e o precipita, empurrando-o com as seduções do prazer. 
geniti et educati sunt, malitia et improbitate contendere. Quo igitur diutius uixerint, eo grauiorem sceleris poenam sustinebunt.

Porro autem iustus, quamuis immatura morte sublatus esse uideatur, in requiete summa uersabitur. Non enim immatura mors illi potest contingere qui ad uirtutis perfectae, cuius colendae gratia nati sumus, maturitatem cum gloria peruenit: immo, quo citius est fructum uirtutis assecutus, eo felicius cursum uitae conficit. Vt enim cantoris habendus non est qui dissonas uoces dies et noctes, cum insigni auditorum molestia, iacit, sed qui scienter atque modulate canit, quamuis ad canendum breuissimum tempus assumat, nec ille bonus medicus est qui se medicum fuisse longo tempore profitetur, cum nullum aegrotis fructum sanitatis attulerit, sed qui breui tempore morbum depellit, ita neque senex ille numerandus est qui, sine ulla modestiae concinnitate, uitam diutissime propagauit et ita aetatem traduxit ut numquam flagitiorum morbis euaserit, sed ille potius qui breuis aeui spatio uirtutis concentum seruauit salutaremque sibi medicinam adhibuit, satis enim diu uixit qui uirtutis perfectae perfecto functus est munere. Itaque illa senectus iustam uenerationem habet quae non temporis diuturnitate aut annorum multitudine continetur, sed quam uirtutis amplitudo omni dignitatis genere cumulauit. Hominis igitur canities in prudentiae maturitate consistit et aetas senectutis est uita nulla prauitatis contagione maculata: unde concluditur adulescentem qui pietatem unice coluit, qui numquam ab officio discessit, qui operam enixe dedit ut uirtutis fructu potiretur, si a uita discesserit, non ante tempus diem obiisse. Cum enim numeros absolutae uirtutis expleuerit, senex et non adulescens est existimandus. Non enim fieri potest ut bonorum res ab illo optimo parente negligantur, ergo, cum ille probus adulescens cum iustitia et pietate uixerit, a Deo gratiam inueniet et idcirco fuit diuino beneficio ex malorum colluuie liberatus et in aliam uitam traductus. Non fuit igitur illi [964] uita inclementer erepta, sed mors potius clementer oblata, ne in sempiternam pestem incideret. Potuisset enim, si in hac uita diutius mansisset, sensus illius, hominum improborum malitia, immutari et, fraudibus, a studio pietatis et continentiae ad religionis negligentiam et ad uitae impuritatem traduci. Hac igitur de causa Deus illum abripuit neque eum, quem carum habebat, aliqua labis impuritate contaminari permisit. Non possunt enim homines improbi honestatis splendorem sustinere et ideo omnes conatus eo comparant ut uirtutem, in quocumque elucere illam perspexerint, de statu deiiciant. Improbitatis enim pestilens morbus et inuidiae furentis aculei studium honestatis exagitant, usque eo dum clarissimis rebus tenebras offundant et eos, qui uirtuti operam nauabant, turpitudinem subire compellant. Accedit cupiditatis impotentia, quae mentem simplicem in capitalem fraudem impellit et uoluptatis illecebris impulsam praecipitat. 
De todos estes males foi arrancado o que morreu na mocidade, pois em escasso período de tempo se guindou à perfeição dos muitos anos: é que a sua alma era singularmente cara a Deus. Aconteceu por isso que, com muitíssima brevidade, partiu da vida, à qual cercam tão grande perigos de infâmias. Os homens, porém, como vêem a morte do moço probo, e não entendem a razão dela, nem se capacitam de que é impossível que Deus de alguma maneira se descuide dos interesses dos que se cingem a um teor de vida santo e permita que sejam oprimidos pelos males os que a Ele se entregaram, consideram que é totalmente intolerável a morte do homem que julgavam muitíssimo merecedor de uma longa vida, e queixam-se vivamente da violência deste fim e acusam o próprio Senhor de todas as coisas por não ter repelido dos bons a arremetida da morte, acabando por chegar ao ponto de dizerem que o zelo da piedade é totalmente inútil. Com efeito, de tal maneira são loucos que não vêem que a graça e bondade de Deus nunca se apartam dos homens santos e que os que foram por Ele escolhidos são guardados com a Sua extraordinária protecção e vigilância.

Dizem, porém: "- Vemos que os homens mais impuros vivem até à mais extrema velhice, ao passo que, pelo contrário, são não poucos aqueles, abrasados no zelo da honestidade e da religião, a quem enfermidades repentinas e inesperadas matam na flor da idade."

Continuais a antepor a longa vida do homem perverso à vida daquele que, pela grandeza da virtude, chega à idade da mais honrada velhice? Ardeis em tão grande desatino que cuidais que toda a condição do homem probo é destruída pela morte? E que as faculdades do próprio entendimento, que foi criado à imagem do entendimento divino, são aniquiladas pela violência da morte, que ocasiona o fim do corpo?

Oh detestável e abominável cegueira do mais impuro dos entendimentos! Não acabareis de entender, desatinadíssimos homens, que a intervenção da morte não pode suprimir a esperança daqueles que foram recebidos sob a protecção do Senhor? É que os seus espíritos, uma vez que são imortais e se encontram ornados e acrescentados com as riquezas divinas, não podem ser consumidos pela morte: e até, quando a morte tudo abater, quando com o passar do tempo apagar a lembrança das coisas, [965] quando destruir os monumentos da antiguidade e até quando desabarem todas as coisas que os olhos vêem, ainda que pareçam muitíssimo firmes, os bons hão-de ficar esplendidamente cheios de riquezas e ornamentos e serão largamente providos da glória eterna e, o que é mais digno de admiração, possuirão autoridade sobre todos os mortais. É que o nome e a glória do justo morto proferirá sentença contra os ímpios que continuam vivos, e a mocidade, que em breve prazo de tempo alcançou o fruto da virtude, arguirá o desatino daquele velho que durante todo o tempo de vida desprezou o zelo da virtude. E deste modo há-de acontecer que a morte do justo será honrosa e ilustre, ao passo que a vida do perverso estará marcada com todas as manchas das infâmias, e será eterno o louvor do jovem que praticou a virtude, e o juízo dos bons deverá abominar veementemente o nome do velho perverso. Além disso, no juízo divino os bons rodearão o Juiz supremo e celebrarão a equidade do direito eterno e, com admiração da justiça divina, verão quão justo Ele é em castigar os crimes dos homens, e deste modo proferirão ao cabo, com a 
Ex his malis omnibus ereptus est is qui in adulescentia mortem obiit, breui autem tempore multorum annorum perfectionem consecutus fuit: anima enim illius erat Deo egregie cara. Idcirco factum est ut celerrime e uita, quam tanta flagitiorum pericula circumstant, excederet. At homines, cum probi iuuenis mortem uideant, et illius rationem minime percipiant, neque mente secum statuant fieri non posse ut Deus res eorum, qui sancte uitam instituunt, aliqua ratione negligat et eos, qui se illi commiserunt, malis opprimi sinat, obitum illius, quem longa uita dignissimum multi iudicabant, indignissime ferendum arbitrantur et de casus acerbitate conqueruntur ipsumque rerum omnium Dominum in crimen uocant, quod non a bonis mortis impetum represserit, eoque tandem progrediuntur ut pietatis studium inutile prorsus esse dicant. Ita namque sunt amentes ut non uideant Dei gratiam et beneficentiam numquam a sanctis hominibus remoueri et eos, qui electi ab eo sunt, singulari illius praesidio et uigilantia custodiri.

At inquiunt: "Cernimus homines impurissimos ad summam senectutem uitam perducere, contra uero non paucos, studio probitatis et religionis incensos, in aetatis flore morbis repentinis et improuisis exstingui."

Pergitisne uos longam hominis perditi uitam, uitae illius qui, uirtutis amplitudine, ad senectutis ornatissimae aetatem peruenit anteferre? Tantane flagratis amentia ut opinemini omnem hominis probi statum morte deleri? Et sensus ipsius mentis, quae est ad imaginem diuinae mentis expressa, ui mortis, quae corpori interitum affert, exstingui?

O detestabilem et exsecrandam mentis impurissimae caecitatem! Non tandem intelligetis, homines amentissimi, non posse spes illorum, qui in Dei fidem recepti sunt, interuentu mortis incidi? Animi enim illorum, cum sint immortales opibusque diuinis ornati et amplificati, morte consumi non possunt: immo, cum mors omnia strauerit, cum rerum memoriam uetustate contriuerit, [965] cum antiquitatis monumenta confecerit atque adeo cum omnia, quae uidentur oculis, quamuis fundatissima uideantur, euersa corruerint, boni diuitiis et ornamentis magnificentissime redundabunt gloriaque sempiterna circumfluent et, quod magis admirandum est, iurisdictionem in omnes mortales habebunt. Iusti namque mortui nomen et gloria contra impios qui manent in uita sententiam feret et iuuenta, uirtutis fructum breuis aeui spatio consecuta, senis illius amentiam coarguet qui toto uitae tempore uirtutis studium neglexit. Itaque fiet ut iusti mors illustris et clara sit, improbi autem uita omnibus turpitudinum maculis inusta, et adulescentis, uirtute perfuncti, laus sempiterna sit, et senis improbi nomen omnium bonorum iudicio uehementer exsecrandum. Praeterea boni in diuino iudicio summum iudicem stipabunt sempiternique iuris aequitatem celebrabunt et quam iuste sit in scelus hominum uindicatum, cum iustitiae diuinae admiratione, conspicient, et sic demum ipsi, comprobatione sua, sententiam contra improbos proferent. Tunc igitur apparebit quam parum referat qua aetate quisque ex hac 
Sua aprovação, sentença contra os ímprobos. Portanto, tornar-se-á então evidente a pouca importância que tem a idade com que alguém partiu desta vida, e a muita que tem o desvelo com que se dedicou à justiça e à piedade. Os perversos não vêem isto e, como possuem um entendimento cheio de trevas, antepõem os enganos da injustiça à equidade da lei santíssima.

Decerto que eles enxergarão o fim do homem sábio, todavia não compreenderão o que o próprio Deus determinou acerca dele ou com que defesas consolidou a sua posição. Repito, eles enxergarão o fim nesta vida do homem justo e terão na conta de coisa nenhuma a sua condição. O Senhor, porém, rir-se-á deles, e acabarão por ser consumidos por uma morte infame e, entre os mortos, aviltados por um desdouro sempiterno, pois Deus destruirá e abaterá a posição deles, precipitá-los-á e arremessá-los-á por terra, amedrontados e aturdidos com um terror tão grande que não conseguirão lamentar-se. Seguidamente, abalará os seus fundamentos e há-de destrui-los, infligindo-lhes tamanha desgraça que há-de aniquilar toda a raça. E eles, atacados pelos inúmeros castigos dos crimes, ao cabo serão destruídos por uma terrível e medonha ruína e atormentados pela dor e a memória deles perecerá por completo. Por consequência, ensinados pelos castigos, olharão sem proveito para a fealdade das suas infâmias e, mais vivamente esmagados pela consciência dos crimes, sofrerão castigos pesadíssimos e, para além de outros tormentos, as iniquidades e injustiças que praticaram contra inúmeros mortais muito mais violentamente os hão-de atacar, mais veementemente hão-de demonstrar a culpa do seu desatino e mais cruelmente atormentá-los, por tal forma que o horror e medo eternos fortemente torturem sem cessar os seus espíritos nos maiores suplícios.

\section{CAPÍTULO V}

Então o justo, levantado e confiante, erguer-se-á contra aqueles por quem fora vexado com muitos incómodos, ferido por indigníssimos ultrajes e esbulhado de todas as riquezas, adquiridas com enorme trabalho; [966] castigá-los-á, perturbar-lhes-á a visão com a sua presença e agitá-los-á com um terror imenso. Portanto, que hão-de fazer os perversos, quando virem todas as coisas de tal maneira mudadas que se apercebem que se encontram colocados na mais completa desgraça e cobertos de eterna desonra, e divisarem cheio da luz divina e ligado à glória imortal aquele a quem atacaram com tão grandes prejuízos e ultrajes? Perturbados por um medo horrível, hão-de tremer e perderão o tino e, paralisados pelo pasmo, porão os olhos naquele que, tão em oposição com o que opinavam, hão-de ver que está salvo e incólume e colocado num elevado grau de dignidade. E assim tarde de mais se arrependerão da sua loucura e assaz dolorosamente hão-de gemer por causa do tormento e tribulação do espírito. Por isso dirão:

- Acaso é este aquele de quem zombávamos e cujo nome frequentemente utilizávamos como exemplo de afronta? Com efeito, ao vermos que ele desprezava as riquezas e dava de mão a todas as comodidades da vida e, para não violar de alguma maneira o que é justo e sagrado, menosprezava os prazeres, e, para não manchar o espírito com alguma 
uita migrauerit, sed quanto studio iustitiam et pietatem coluerit. Hoc non uident improbi et, cum mentem tenebris oppletam gerant, iniustitiae fraudes aequitati sanctissimae legis anteponunt.

Cernent illi quidem hominis sapientis exitum, non tamen intelligent quid de illo statuerit aut quo praesidio statum illius stabilierit ipse Dominus. Cernent, inquam, illi, iusti hominis in hac uita finem illiusque statum pro nihilo ducent. At Dominus eos irridebit eruntque tandem infami funere consumpti ignominiaque sempiterna inter mortuos deformati, Deus enim illorum statum perfringet et labefactabit, eosque praecipites exturbabit atque, tanto terrore perculsos et obstupefactos, in terram prosternet ut lamentari non possint. Eorum deinde fundamenta conquassabit et, inuecta calamitate, peruertet ut omne genus exscindat. Ipsi uero, multis scelerum poenis agitati, ad extremum dira et horrida uastitate conficientur et dolore cruciabuntur eorumque memoria funditus interibit. Poenis igitur eruditi, sine fructu flagitiorum suorum deformitatem considerabunt et, scelerum conscientia uehementius oppressi, grauissimas poenas exsoluent et, praeter alia cruciamenta, iniquitates et iniuriae quas mortalibus multis intulerant, multo truculentius eis occurrent, illorum amentiam uehementius conuincent et illos crudelius exagitabunt, ita ut eorum animos, in summis suppliciis, sempiternus horror atque trepidatio sine fine uehementer excruciet.

\section{CAPVT V}

Tunc uero iustus, erectus atque confidens, in eos surget a quibus multis incommodis uexatus et indignissima contumelia laceratus, cunctis opibus, labore summo quaesitis, expoliatus, [966] exstiterat; ab illis poenas expetet, illorum oculos aspectu conturbabit et ingenti pauore concutiet. Quid igitur improbi facient, cum sic omnia commutata conspexerint ut se in summa miseria constitutos et dedecore sempiterno cumulatos esse uideant, illum uero, quem tantis damnis atque probris affecerant, luce diuina completum et immortalem gloriam consecutum contemplentur? Horribili metu conturbati, trepidabunt et a mente deserentur, admirationeque defixi, intuebuntur eum quem, tam contra suam opinionem, saluum et incolumen, in excelso dignitatis gradu locatum esse sentient. Itaque sero paenitebit illos amentiae et, propter animi cruciatum et angorem, nimis dolenter ingemiscent. Inquient igitur:

- Hicine est ille quem ludibrio habebamus et cuius nomen erat a nobis ad exemplum contumeliae frequenter usurpatum? Cum enim cerneremus illum opes negligere et omnia commoda uitae contemnere, ne ius et fas aliqua ex parte uiolaret, uoluptates aspernari, ne animum ulla labe turpitudinis inquinaret, uirtutis 
nódoa de indignidade, seguia o áspero e sáfaro caminho da virtude, dela não era afastado por quaisquer grandes trabalhos ou pungentes dores e, por derradeiro, por amor da virtude e do dever, rejeitava com a máxima firmeza tudo o que a natureza oferece para recreação, supúnhamo-lo privado de entendimento e destituído de sentidos. De facto, julgávamos próprio do mais rematado desatino antepor a fé ao proveito e a pureza ao prazer e preferir a reputação de virtude e piedade às vantagens e honrarias da vida comum. E, assim, cuidávamos que a vida dele era mofina e atribulada e que também a sua morte participava de infâmia, pois na sua existência não apareceu nenhum vislumbre de modo de vida um pouco refinado e na morte não vimos qualquer ornato e esplendor de funerais sumptuosos. Agora, porém, como é que foi incluído no número dos filhos de Deus e, juntamente com os santos, recebeu a herança do património celestial?

Por conseguinte, é manifesto que nós, cegos pelo erro do entendimento, nos desviámos do caminho da verdade. É que nem a luz da justiça nos iluminou nem nasceu para nós o esplendor do Sol divino. Por consequência, mergulhados nas trevas, desabávamos e, arrastados pela demência, em vez dos verdadeiros bens, fomos atrás dos enganos da vida e dementadamente tomámos os múltiplos caminhos da iniquidade e da morte, com satisfeito desvelo percorremos ermos, hórridos e incultos desertos, e ignorámos o caminho certo e direito que o Senhor nos mostrou. De que nos aproveitou a soberba e a intolerável altivez? De quê a insolente arrogância em meio das enormes riquezas? Com efeito, desvaneceu-se como sombra tudo aquilo com que nos ensoberbecíamos, passou como um mensageiro que corre com a máxima velocidade e como um navio sulcando o mar cheio de ondas que não deixou qualquer vestígio da sua passagem: é que nas ondas é impossível que a rota do navio fique assinalada por quaisquer marcas, tal como, quando o ar é rasgado pelo voo da ave, não se encontra nenhuma prova da sua passagem, pois o ar, ligeiro e recuando sem esforço, é atravessado pelas asas e, cortado por um impulso sibilante, oferece passagem e imediatamente a seguir ocupa o espaço atravessado, de tal maneira que [967] é impossível notar-se qualquer marca da travessia realizada. E, da mesma maneira que a flecha, lançada para o lugar para que se apontou, corta o ar, que todavia, depois de repentinamente espalhado, retorna para o mesmo sítio, de tal modo que de forma alguma pode perceber-se por qualquer sentido a passagem daquela seta, também de forma idêntica nós, postos no caminho da vida, de súbito morremos e não pudemos dar qualquer sinal de virtude, mas fomos devorados pela maldade.

E com estas palavras se lastimam no Inferno os perversos. É que a esperança do ímpio é como uma penugem que é dispersa pelo vento, ou como uma ténue espuma que é dissipada pela violência da tempestade, ou semelhante ao fumo que o vento desfaz, ou como a lembrança do hóspede de um único dia, que desaparece num brevíssimo espaço de tempo, visto como são caducas e frágeis todas as coisas que arrastam os homens desviados de Deus, as quais estão sujeitas a inúmeras desgraças e incessantemente passam e fogem, acabando por se dissipar num ápice. Mas os justos gozam da vida eterna e obtêm de Deus o prémio e recompensa do trabalho e são conservados graças ao cuidado, desvelo, vigilância e protecção do excelente Senhor, de tal maneira que 
uiam asperam et incultam sequi, nec ab ea, ulla laborum magnitudine aut dolorem acerbitate, depelli, et denique, uirtutis et officii gratia, omnia, quae rerum natura ad oblectationem profundit, constantissime respuere, illum hominem mentis expertem et sensibus orbatum putabamus. Extremi namque furoris opinabamur fidem utilitati, castimoniam uoluptati praeponere et uirtutis atque pietatis nomen communis uitae emolumentis et honoribus anteferre. Itaque huius uitam miseram et aerumnosam et mortem etiam dedecori affinem censebamus, in illius namque uita nullum elegantioris cultus uestigium apparuit et in morte nullum magnifici funeris ornatum et splendorem uidimus. At nunc quomodo Dei filiis annumeratus est et cum sanctis hereditatem patrimonii caelestis adiuit?

Constat igitur nos errore mentis obcaecatos a ueritatis uia deflexisse. Nec enim nobis iustitiae lumen illuxit neque diuini solis splendor nobis exortus est. Tenebris igitur oppressi, ruebamus, furoreque praecipites, pro ueris bonis uitae ludibria consectati sumus multiplicesque uias iniquitatis et interitus furenter inuimus, uastas, horridas et incultas solitudines contento studio peragrauimus, certamque et directam uiam uitae, quam Dominus monstrauit, ignorauimus. Quid nobis profuit arrogantia et intolerandum fastidium? Quid in immanibus diuitiis insolens ostentaio? Omnia namque illa, quibus efferebamur, ut umbra euanuerunt et, ut transcurrens cum summa celeritate nuntius, praeterierunt et ut nauis undosum mare sulcans, quae nullum sui cursus uestigium reliquit: nec enim potest in undis nauis incitatae semita ullis notis designari, quemadmodum etiam, cum alitis inuolatu aer discinditur, nullum inuenitur itineris illius argumentum, aer namque, leuis et facillime cedens, alis transuerberatur, impetuque stridenti dissectus, transitum praebet et continuo transmissionis locum opplet, ut nulla [967] nota possit confecti cursus animaduerti. Et, quemadmodum sagitta, in destinatum locum emissa, aerem dissecat, qui tamen, repente confusus, ad eumdem locum redit, ita ut nullo modo possit ullo sensu sagittae illius traiectio comprehendi, similiter et nos, in uitam ingressi, repente defecimus nullumque uirtutis signum dare potuimus, sed improbitate consumpti sumus.

Et haec quidem iniqui apud inferos acerbissime lamentantur. Nam spes impii est quasi lanugo quae a uento dispellitur, aut spuma tenuis quae impetu procellae dissipatur, aut tamquam fumus qui a uento dissoluitur, aut quasi memoria hospitis diei unius, quae breuissimo spatio temporis obruitur, siquidem omnia quibus homines, a Deo auersi, ducuntur, sunt caduca et fragilia, casibus multis obnoxia et continenter labuntur et fluunt, atque tandem temporis momento dissipantur. Iusti uero sempiterna uita perfruuntur laborisque mercedem et praemium a Deo consequuntur praecellentisque Domini cura, studio, uigilantia, patrocinio conseruantur, ita ut nullo modo possit eorum status infringi aut aliqua 
é impossível que a posição deles seja abatida ou abalada por qualquer parte. Por isso receberão um reino embelezado com os mais amplos atavios da dignidade e cumulado de riquezas divinas, e terão uma coroa abrilhantada com as mais elevadas luzes da formosura e encanto, que o Senhor lhes coloca na cabeça por merecimento da virtude. Com efeito, Ele protegê-los-á com a Sua dextra e com o poder invencível do Seu braço afastará deles a crueldade dos inimigos e, coberto com todas as armas, empreenderá guerra em defesa da salvação e dignidade dos Seus. Por conseguinte, irado com a violenta aversão ao crime, armar-se-á com o zelo da vingança e incitará vivamente toda a natureza, aparelhada com armas, a castigar os crimes dos inimigos. Ora, como armadura envergará a justiça e como capacete cobrir-se-á com um juízo rectíssimo, não manchado por nenhum contágio de engano; como escudo, tomará a inexpugnável santidade e, como terrível lança, aguçará a ira, e o próprio mundo juntamente com Ele aparelhará as armas e empreenderá grande parte da guerra, por forma a derrubar em combate os loucos e dementes. Os dardos dos raios serão lançados com perfeita pontaria e as armas de arremesso cairão como frechas violentamente arrojadas pelo arco assaz retesado; cairá denso granizo, cheio de violentíssima fúria. Com horrendo rugido, levantar-se-ão contra eles as terríveis vagas do mar e contra eles furiosamente se arremessarão os rios, por tal forma que não se lhes abra nenhum refúgio para a desgraça. Também um violentíssimo vento levantar-se-á contra eles e destruí-los-á com o turbilhão e tempestade. Enfim, a iniquidade devastará toda a Terra e o instintivo gosto de fazer mal arruinará as moradas dos poderosos e provocará a perdição e destruição às riquezas humanas.

\section{[968]}

\section{CAPÍTULO VI}

Por conseguinte, escutai, ó reis, e entendei, ó vós que com extraordinário poderio abarcais com a vossa vasta soberania os limites da Terra; recebei a doutrina salutar; ouvi, todos vós que dais leis à multidão, vós que, inchados com a turba dos homens, vos ensoberbeceis de sobejo e vos encheis de ousadia e entusiasmo porque todos põem os olhos em vós e vivem em consonância com o vosso arbítrio. Ora, em primeiro lugar compreendei que esta soberania de que vos gloriais foi-vos concedida por Deus para que cuideis da multidão, não para que insolentemente vos jacteis e governeis o Estado de modo arbitrário. Portanto, uma vez que Deus vos confiou esta função, pensai amiúde que vos é mister prestar-Lhe contas do vosso ofício, pois informar-se-á das vossas acções e examinará diligentemente as vossas deliberações. Por conseguinte, que fareis então? A que advogados recorrereis? Com que dádivas aplacareis a ira do juiz irritado? Ou com que artimanhas vos esquivareis ao Seu julgamento? Debalde implorareis então ajuda, pois não poderão nenhuns discursos obscurecer coisas muitíssimo claras, nem nenhumas dádivas desviar para a graça o Senhor de tudo, hostil aos crimes, nem nenhuns embustes enganar a Sua imensa sabedoria. 
ex parte conuelli. Idcirco regnum amplissimis honestatis ornamentis excultum et opibus diuinis exaggeratum accipient, et coronam, summis decoris et elegantiae luminibus illustratam, habebunt, quam Dominus illis merito uirtutis imponit. Ipse namque eos dextera sua proteget inuictisque brachii sui uiribus omnem ab eis hostium immanitatem propulsabit et, omnibus armis tectus, bellum pro suorum incolumitate atque dignitate suscipiet. Acri igitur sceleris offensione irritatus, studio ultionis armabitur et naturam uniuersam, armis instructam, ad poenas scelerum de hostibus repetendas acriter incitabit. Induet autem pro thorace iustitiam iudiciumque rectissimum, nulla contagione fraudis inquinatum, pro galea sumet; pro scuto, inexpugnabilem sanctitatem corripiet, porro, dira pro lancea, iram exacuet, ipseque mundus simul arma comparabit magnamque belli partem suscipiet, ut furiosos et insanos in acie concidat. Fulgurum iacula probe collimata et, tamquam sagittae ab arcu nimis intento uehementer emissae, tela desilient; densae grandines furoris uehementissimi plenae contorquebuntur. Maris fluctus immanes, cum horrendo fremitu contra illos insurgent et flumina in eos furenter irruent, ita ut nullum illis perfugium miseriae pateat. Ventus etiam uehementissimus illis obuiam prodibit eosque turbine atque procella peruertet. Iniquitas demum omnem terram uastabit insitumque nocendi studium potentium sedes conuellet et humanis opibus pestem et exitium molietur.

\section{CAPVT VI}

Audite, igitur, reges, et mente percipite, uos qui imperio late continuato fines terrae estis insigni potentia complexi; disciplinam salutarem accipite; aures praebete, uos omnes qui iura multitudini datis, qui, hominum turba constipati, spiritus ingentes assumitis et erecti et alacres, eo quod uos omnes intueantur uitamque ad arbitrium uestrum degant, inceditis. Primum quidem intelligite hoc imperium, quo gloriamini, esse uobis a Deo commissum ut multitudini consulatis, non ut uos insolenter de potestate iactetis et immoderate rem publicam geratis. Cum igitur hoc munus uobis a Deo delegatum sit, cogitate saepenumero rationem illi uestri muneris esse reddendam, nam in actiones uestras inquiret et consilia uestra diligenter examinabit. Quid igitur tunc facietis? Quos uobis aduocatos adhibebitis? Quibus muneribus irati iudicis iram placabitis? Aut quibus artibus illius iudicium eludetis? Frustra tunc opem implorabitis, nec enim oratio ullius poterit tenebras clarissimis rebus obducere, nec ulla munera rerum omnium Dominum, sceleribus infensum, ad gratiam inflectere, nec ullae fraudes immensam illius sapientiam fallere. 
Resta, portanto, que Ele vos condene em juízo e vos precipite no tormento eterno. É que a soberania não era vossa, mas d' Ele, e vós detínheis o poder em Seu lugar, para que fôsseis servidores da Sua vontade, mui ao invés do que fizestes. De facto, nem no julgar seguistes as puras normas do direito, nem respeitastes a lei santa, nem dirigistes a vossa função de acordo com o conselho de Deus: pelo contrário, apartados dos desígnios divinos, por amor das vossas paixões destruístes todos os vínculos do direito. Por isso, pende sobre vós uma horrível e repentina desgraça, pois serão objecto de um rigorosíssimo julgamento, sem qualquer esperança de misericórdia, os homens que possuem as maiores riquezas. É que o homem obscuro e de condição humilde conseguirá facilmente o perdão, ao passo que os que sobressaem pelo poder devem ser também potentemente castigados, pois as contas das despesas devem ser pedidas em proporção com a mercê recebida. Por conseguinte, quem recebeu mais coisas de Deus, se administrou mal o que lhe foi entregue, será castigado com maior severidade, porquanto o Senhor de todas as coisas não se impressiona com a posição seja de quem for, nem se arreceia de príncipe algum, visto que foi Ele quem fez o pequeno e o grande e quer ocupar-se de todos por igual. Todavia, a vida dos príncipes será examinada com maior diligência e rigor.

Por isso, ó tiranos, é a vós que se dirigem as frases do meu discurso, para vos avisar do grande perigo que vos ameaça. Aprendei, portanto, a sabedoria, para não cairdes de modo mofino, pois as riquezas não vos ajudarão, nem a grandeza do senhorio poderá afastar-vos da perdição, nem a graça, nem a eloquência, nem os vassalos, nem a turba dos súbditos, nem, finalmente, quaisquer ornamentos de dignidade totalmente vã, [969] terão poder para no julgamento vos salvar. O único caminho da salvação é o que se funda inteiramente na sabedoria. Ora, esta ensina que se deve aplacar Deus com a santidade da religião e velar pelos homens através da santidade do direito. Por conseguinte, quem escrupulosamente cultivar a santidade, será contado no número dos santos, e quem diligentemente se entregar aos princípios da piedade e da justiça, arguirá com felicidade a sua causa e encontrará a defesa da acusação que se lhe move. Daqui se conclui que no zelo da justiça se encerra o fruto da salutar eloquência. Portanto, desprezai todas as coisas humanas que não podem ajudar-vos nos maiores perigos; aprendei a fundo os princípios da sabedoria divina; inflamai-vos no desejo dela; e guardai na memória as minhas palavras, com as quais me esforço por desviar-vos da eterna infelicidade, e com todo o cuidado empenhai-vos em que jamais desapareçam do vosso espírito.

O início e fundamento das maiores coisas é o ardente desejo delas. Por conseguinte, se vos capacitardes de que as riquezas da sabedoria devem ser vivamente desejadas, se denodadamente vos consagrardes ao estudo delas, se vos abrasardes no seu amor e cobiça, certamente ficareis muitíssimo instruídos nos seus princípios. Que poderá existir de mais bem-aventurado do que isto? Com efeito, a sabedoria é nobre pela dignidade, opulenta pelas riquezas, salutar pela providência, invencível pela força da virtude, de tal maneira que quem se ligar por inteiro ao seu nome, não pode ser atacado por nenhuns males. Além disso, é imortal e divina. E assim, uma vez que tudo o resto que o vulgo dos humanos com excessiva avidez apetece, é caduco e frágil e sujeito a inúmeras 
Reliquum igitur est ut uos ille iudicio peruertat et in cruciatum sempiternum praecipites agat. Nec enim regnum uestrum erat, sed illius, uos uero illius uice imperium gerebatis, ut essetis uoluntatis illius administri: quod longe secus effecitis. Nec enim in iudicando iuris integritatem secuti estis, neque legem sanctam habuistis, nec ad Dei consilium uestrum munus direxistis: immo, a diuina mente diuersi, prae uestra libidine omnia iuris uincula reuellistis. Horribilis igitur atque repentina uobis calamitas impendet, seuerissimum enim, sine ulla clementiae spe, iudicium in homines qui summas opes habent exercebitur. Nam tenuis et obscurus homo facile ueniam impetrabit, in eos uero, qui potentia praecellunt, est etiam potenter animaduertendum, nam pro muneris accepti ratione expensi ratio reposcenda est. Qui igitur plura a Deo recepit, si rem commissam male gesserit, acrius punietur, nec enim rerum omnium Dominus ullius hominis personas respicit, neque principis alicuius potentiam ueretur, nam paruum et magnum ipse fecit et ex aequo omnibus consultum esse uult. In principum tamen uitam diligentius atque uehementius inquiretur.

Ad uos igitur, o tyranni, orationis meae sententiae conferuntur, ut admoneam quantum uobis discrimen impendeat. Discite igitur sapientiam, ne miserrime concidatis, non enim opes uos subleuabunt, non amplitudo imperii poterit a peste seducere, non gratia, non eloquentia, non clientela, non subditorum turba, non denique ulla inanissimae dignitatis ornamenta uobis in iudicio [969] salutem afferre poterunt. Vnica tantum salutis uia est quae tota in sapientia consistit. Haec autem docet Deum religionis sanctitate placandum et homines iuris sanctitate conseruandos. Qui igitur sancte sanctitatem coluerit, is inter sanctos numerabitur, et qui diligenter pietatis et iustitiae disciplinis operam dederit, causam suam feliciter dicet et defensionem intenti criminis inueniet. Vnde concluditur salutaris eloquentiae fructum studio iustitiae contineri. Omnia igitur humana contemnite quae uobis in maximo periculo opitulari non possunt; diuinae sapientiae disciplinam perdiscite; ad illius cupiditatem exardescite; orationesque meas, quibus uos a miseria sempiterna conor abducere, memoriae tradite, in eoque uigilanter elaborate, ne umquam ex animis uestris elabantur.

Rerum maximarum initium atque fundamentum est ardens illarum appetitio. Si igitur sapientiae opes uehementer expetendas esse statueritis, si uos acriter ad illarum studium applicueritis, si earum amore et cupiditate flagraueritis, eritis certe illarum disciplinis instructissimi. Quo quid beatius esse poterit? Est enim sapientia, dignitate praeclara, copiis opulenta, prouidentia salutaris, ui uirtutis inuicta, ita ut qui se totum ad illius nomen adiunxerit, nullis malis affici possit. Est praeterea immortalis atque diuina. Itaque, cum reliqua omnia, quae uulgus hominum nimis sitienter appetit, sint caduca et fragilia et casibus innumerabilibus obiecta, sola sapientia statum suum perpetuo retinebit lumenque illius saeculis interibit. 
circunstâncias fortuitas, só a sabedoria conservará perpetuamente a sua condição e a sua luz não será apagada pelo passar do tempo.

Mas dir-me-ás: “- Decerto que todos reconhecemos que a sabedoria é o que existe quer de mais sólido em resistência, quer de mais belo em dignidade, quer mais bem provido de todas as vantagens. Mas, quanto maior é a sua dignidade e utilidade, tanto menos a ela podemos aspirar, pois somos homens e só nos arrastamos na terra; as nossas forças são fracas e débeis e à natureza humana não foi concedido obter o fruto das coisas divinas."

Muitos talvez hão-de falar com estas palavras, nas quais transluz o grande erro em que vivem os homens. Na verdade, ainda que a maioria consagra o trabalho exclusivamente a coisas passageiras; ainda que gasta toda a vida a adquirir aquelas riquezas que não hão-de trazer nenhum fruto nas adversidades; ainda que, por derradeiro, é atribulada por prolongada inquietação para poder aumentar aquilo que ao cabo deve ser destruído pela terrível morte: todavia não consegue isto e, quanto mais se empenha e sua e aplica todos os esforços nestas coisas, tanto mais é atormentada pela indómita cobiça: algo que é prova da mais completa pobreza e indigência. Não obstante, ninguém se aparta do amor e cobiça destas coisas, mas, pelo contrário, despreza-se o zelo pelas coisas divinas, que com a máxima facilidade teriam podido alcançar-se. E deste modo preferem, com imensa canseira e sem qualquer fruto, correr atrás de todas as desonras da vida, a, com suma alegria e enorme fruto das coisas celestiais, abundar nas riquezas eternas.

Mas dizes que é extraordinariamente difícil chegar à sabedoria. Ora, seria lícito dizer isto se eu te ordenasse que adquirisses a sabedoria apoiado nas tuas forças. Mas não é assim. É que a própria [970] sabedoria mostra-se com a maior facilidade àqueles que a amam e está ao alcance e disponível para todos os que se esforçam por procurá-la. E até se antecipa às diligências dos homens, e a todos se oferece de livre e espontânea vontade, e a todos convida e atrai a que dela desfrutem, e liberalmente reparte as suas riquezas, de bom grado estendidas e expostas, com aqueles que se abrasam no amor dela. Por consequência, quem quiser ao romper da alva consagrar-se a ela, não se esforçará, pois encontrá-la-á sentada à porta, de maneira a acolher benignamente quem a procura.

Meditar acerca dela é a função da perfeita prudência. Quem não dorme por causa dela alcança em breve a condição da vida bem-aventurada, porque ela desterra os vãos cuidados, suprime as inquietações, arranca as falsas opiniões, inflama os entendimentos no zelo da verdade e, assim, acaba por tornar a condição do homem totalmente pacífica e tranquila. É que não espera até que os homens sigam todas as suas pegadas, mas é antes ela (tão admirável é a sua bondade!) quem vai atrás de todos os que a merecem, isto é, os que se deixam instruir e não rejeitam obstinadamente o benefício divino. E assim examina tudo à sua volta procurando descobrir se encontra alguém a quem fazer seu senhor. Portanto, em todas as funções, acções e usos da vida e formas de governar o Estado, põe indulgentemente por diante a sua imagem, e vai ao encontro dos entendimentos abrasados no desejo dela. Daqui se conclui que o mais verdadeiro fundamento da sabedoria se encerra em desejá-la e amá-la inflamadamente. Quem quer, pois, que a desejar, há-de consegui-la, pois o desejo inflama o espírito e torna-o activo e atento em toda a espécie 
Sed dices mihi: "- Hoc quidem fatemur uniuersi nihil esse sapientia uel robore ualentius, uel honestate pulchrius, uel omnibus commodis affluentius. Sed quo dignitas et utilitas illius amplior est, eo minus ad illam aspirare possumus, homines enim sumus et humi tantum repimus; uires nostrae fragiles sunt et imbecillae nec est humanae naturae concessum diuinarum rerum fructu potiri."

Haec quidem multi fortasse dicent, in quo apparet quantus error in hominum uita uersetur. Cum enim plerique tantum laboris in res fluxas impendant; cum omnem uitam in eo consumant ut eas opes parent quae nullum fructum sunt in rebus asperis allaturae; cum denique diuturna sollicitudine conflictentur ut augeant ea quae sunt tandem diritate mortis euertanda: ea tamen minime consequuntur et, quo magis laborant et sudant et omnes neruos in iis quaerendis intendunt, eo magis cupiditate indomita cruciantur: quod est extremae inopiae et egestatis argumentum. Tamen ab eorum studio et cupiditate remouetur, contra uero rerum diuinarum, quae parati facillime potuissent, studium contemnitur. Itaque malunt, cum ingenti labore et sine ullo fructu, ludibria uitae consectari, quam, cum summa iucunditate et amplissimo rerum caelestium fructu, opibus sempiternis affluere.

Sed inquis esse longe difficillimum ad sapientiam peruenire. Hoc quidem dicere licuisset, si tibi ut, uitibus tuis innixus, sapientiam patres praescriberem. Sed non ita est. Ipsa namque [970] sapientia se facillime illis, qui eam diligunt, ostendit et prompta atque parata est omnibus qui illam peruestigare nituntur. Quin etiam hominum studium anteuertit, et omnibus se ultro atque libenter offert, et ad se fruendam cunctos allicit et inuitat, opesque suas, libenter explicatas et euolutas, cum illis, qui studio illius flagrant, large communicat. Qui igitur primo diluculo ad illam se conferre uoluerit minime laborabit, foribus enim assidentem inueniet, ut adeuntes clementer excipiat.

Cogitare de illa perfectae prudentiae munus est. Qui gratia illius uigilat, beatae uitae statum breui consequitur, illa namque expellit curas inanes, demit sollicitudines, euellit falsas opiniones, studio ueritatis mentes inflammat et ita tandem statum animi reddit quietis et tranquillitatis plenissimum. Non enim exspectat dum homines eam uestigiis omnibus persequantur, sed ipsa potius (tam admirabilis est illius benignitas!) omnes se dignos, hoc est, ad disciplinam dociles, qui non obstinate beneficium diuinum repudiant, inuestigat. Itaque omnia circumquaque lustrat inquirens si quem reperiat quem sui compotem efficiat. In omnibus igitur uitae officiis et actionibus et institutis rei publicaeque gerendae uiis, speciem suam clementer obiicit, et mentibus, sui cupiditate incensis, occurrit. Vnde colligitur uerissimum sapientiae fundamentum illius cupiditate et inflammato studio contineri. Quisquis igitur illam concupierit, eam consequetur, cupiditas enim incendit animum et industrium reddit et in omni officio uigilantem, 
de funções, porquanto repele a preguiça, aguça a penetração do entendimento e incita fortemente o espírito ao amor do conhecimento. Ora, o amor do conhecimento funda-se na caridade. Por outro lado, a caridade abarca o respeito e a observância da lei divina. Ora, a escrupulosa observância da lei contém a base da imortalidade e a imortalidade está muito próxima de uma condição divina. Por conseguinte, o desejo de sabedoria conduz à majestade e grandeza do Reino de Deus. Portanto, ó príncipes e tiranos, se vos encantam os tronos, se os ceptros vos causam alegria e pensais que a função de reinar deve ser anteposta a todas as coisas, cultivai exclusivamente a sabedoria a fim de reinardes para sempre.

Ora, exporei qual é a essência da sabedoria e qual a sua origem, e não manterei guardados em silêncio os seus mistérios, mas examinarei como é que se mostrou desde o começo, de maneira a dar-vos conhecimento dela e pôr à luz a sua divina forma. Não omitirei a verdade, nem no curso desta vida me exporei a ser destruído pelo flagelo da inveja. É que quem, por causa da inveja, esconde o fruto da sabedoria, e não suporta que outros se tornem dela quinhoeiros, opõe-se à bondade da própria sabedoria e é excluído da sua comunhão; além disso, está a privar de saúde o género humano, porquanto a saúde do mundo consiste na multidão dos que sabem e o rei prudente é o esteio da totalidade do povo. Logo, uma vez que é tão grande o fruto da sabedoria, compete-me a mim expor a todos vós as eternas riquezas dela, e a vós [971] prestar diligente atenção às minhas palavras, para que colhais um extraordinário proveito.

\section{CAPÍTULO VII}

E, para que possa levar isto a cabo mais facilmente, propor-me-ei como exemplo, para que nele ponhais os olhos e o imiteis, se quereis, com os mesmos métodos com que aspirei à sabedoria, esforçar-vos semelhantemente por a ela vos dedicardes. É que eu mesmo também sou um homem mortal, gerado com a mesma condição de todos os restantes. Com efeito, reconheço como minha causa o primeiro progenitor da raça humana, que foi moldado e feito com terra, e estou ciente de que, juntamente com a transmissão do sangue, me foi transfundida também a fraqueza e fragilidade da natureza dele, como por direito hereditário. Além disso, se reflectimos no modo da geração, que pode imaginar-se de mais baixo e abjecto? Com efeito, a minha carne foi moldada e formada durante dez meses no útero da minha mãe, pois primeiro o sémen do varão, derramado com violento prazer, agarrou-se no lugar; em seguida, sobreveio uma justa medida de sono apropriado, acomodado ao amadurecimento da semente, que, lançada no sangue, aos poucos foi crescendo, até sair à luz, depois de consolidada e animada com ossos e músculos e impelida por uma espécie de força maior do espírito vital. Enfim dado à luz, respirei o ar comum e fui lançado para a mesma terra, infestada por variadas doenças e perigos, para a qual são lançados os restantes mortais, e, à semelhança do que fazem os outros homens, soltei o primeiro vagido com choro e triste queixume. Então, envolto em faixas, fui alimentado com não pequeno cuidado e inquietação, pois uma tão 
ignauiam enim repellit et aciem mentis exacuit et in studium disciplinae animum uehementer incitat. Studium uero disciplinae in caritate consistit. Porro autem, caritas cultum et obseruationem legis diuinae complectitur. Legis autem diligens obseruatio immortalitatis firmamentum continet, immortalitas uero ad diuinum statum proxime accedit. Cupiditas igitur sapientiae ad diuini regni maiestatem et amplitudinem perducit. Si igitur, o principes et tyranni, uos regiae sedes oblectant, si uobis sceptra iucunditatem afferunt regnandique munus rebus omnibus anteponendum arbitramini, unice sapientiam colite, ut in perpetuum regnetis.

Quae uis autem sapientiae sit et unde ortum habuerit, neque mysteria silentio compressa tenebo, sed quomodo edita ab initio fuerit peruestigabo, ut uobis notitiam illius explanem et diuinam illius formam in luce constituam. Veritatem minime praeteribo, neque in huius uitae cursu committam ut inuidiae tabe conficiar. Qui enim sapientiae fructum ob inuidiam celat, neque patitur alios participes illius fieri, benignitati sapientiae ipsius aduersatur et communione illius excluditur; praeterea, genus humanum salute priuat, salus enim mundi in sapientiam multitudine consistit et rex prudens est populi totius firmamentum. Ergo, cum tantus fructus in sapientia sit, meum est uobis omnibus opes illius sempiternas exponere, uestrum uero [971] meis uerbis animum diligenter intendere, ut utilitatem eximiam capiatis.

\section{CAPVT VII}

Atque, ut id facilius praestare queam, in me exemplum proponam quod intueamini et quod imitemini, si uultis iisdem rationibus, quibus ad sapientiam aspiraui, ad illius studium similiter eniti. Sum quidem etiam ipse homo mortalis, eadem cum reliquis omnibus condicione generatus. Primum enim generis humani parentem, qui e terra fictus et informatus fuit, auctorem mei generis agnosco et exploratum habeo fuisse ad me cum sanguinis propagatione, illius etiam imbecillitatem naturaeque fragillitatem, tamquam hereditario iure, transfusam. Iam uero, si generationis rationem animis agitemus, quid humilius et abiectius excogitari potest? Caro namque mea in matris utero decem mensibus figurata et informata fuit, primum enim uiri semen, cum turbulenta uoluptate diffusum, in locis inhaesit; accessit deinde conuenientis somni temperamentum, ad maturitatem seminis accommodatum, quod, in sanguinem uersum, paulatim concreuit usque eo dum, ossibus et neruis consolidatum et animatum, et maiore quadam ui spiritus uitalis impulsum, in lucem prodiret. Editus demum in lucem, aerem communem duxi et in eamdem terram, uariis morbis et periculis infestam, in quam reliqui mortales exponuntur, abiectus fuit, primamque uocem, similiter atque homines alii faciunt, cum fletu et lugubri querimonia, misi. Tum, pannis inuolutus, non mediocri cura et sollicitudine enutritus fui, nam tam insignis 
desmedida fragilidade da natureza, sujeita a tão grandes perigos, não pode conservar-se sem uma grande guarda e vigilância dos pais. Ora, nenhum rei pôde ter um princípio de vida diferente do dos demais homens.

Além disso, todos estão plenamente cientes de que espécie é o fim da vida. De facto, nada parece ser mais violento do que a morte, nada mais horrível e nada que mais deva dar um golpe decisivo na soberba humana, visto como extingue e destrói tudo o que o vulgo dos homens admira, corta as vãs esperanças e vence as imaginações da vaidade e do desatino. Por consequência, que motivo existe na vida pelo qual nós, os que detemos o poder, devamos antepor-nos aos restantes homens, uma vez que todos entram da mesma maneira na vida e igualmente partem de modo semelhante da vida comum?

Portanto, ao aperceber-me disto, vi que só existia um modo que me permitia libertar-me dos perigos e doenças com que a vida mortal está ligada, e salvar-me das ondas com que a natureza nos assoberba. Ora, este funda-se exclusivamente na sabedoria, pois esta cura as doenças, afasta os perigos, robustece as forças, ilumina o entendimento e conduz a natureza dos homens à semelhança com o entendimento divino. Decidi, por conseguinte, que deveria consagrar todos os meus pensamentos ao estudo da sabedoria. E valerá a pena prestar atenção $[\mathbf{9 7 2}]$ ao modo como a alcancei.

Acaso percorri o mundo por causa da sabedoria? Acaso mandei vir mestres de longínquas terras para os contratar com grande salário? Acaso com ardentíssimo zelo me apliquei a diversas e múltiplas artes, descobertas pelas inteligências humanas? Nada disto. É que, embora não tenha desprezado os ensinamentos da sabedoria humana, todavia compreendi que o conhecimento da mais verdadeira sabedoria não é uma descoberta dos homens, mas uma dádiva e benefício de Deus. Por consequência, em primeiro lugar desejei ardentissimamente a sabedoria e imediatamente depois os meus desejos alcançaram os frutos ubérrimos da prudência. Invoquei-a com rogos puros e incessantes e logo de seguida o espírito de sabedoria penetrou no meu espírito. Daqui pode concluir-se que o fortíssimo desejo de sabedoria, junto com preces dirigidas a Deus e votos ardentíssimos, é o caminho e método com que se alcança a mais verdadeira sabedoria. Logo, uma vez cumprido o meu desejo, não afrouxei do zelo em que antes mui fortemente me abrasava. É que negligencia-se isto, e não se procura desveladamente nem se conserva com o devido cuidado e solicitude, e assim, àqueles que não pesam com cuidado a importância das coisas mais elevadas, acontece que se lhes desvanecem todas as riquezas. Ora, esforcei-me com todo o empenho por não incorrer nesta infâmia, pois antepus a sabedoria aos maiores impérios e reinos; em comparação com ela, tive as imensas riquezas na conta de coisa nenhuma; em cotejo com a sabedoria, desprezei as gemas e pedras preciosas. De facto, se olhas com atenção para as riquezas da sabedoria, até os imensos montões de ouro valerão o mesmo que um pouco de areia e toda a prata não será avaliada em mais do que a lama. E, ao aspirar à sabedoria, não apenas não dava qualquer importância às coisas que se encontram fora do corpo, como também, em comparação com a dedicação a ela, considerava desprezíveis as que no corpo parecem muito desejáveis. É que desejei-a muito mais ardentemente do que a saúde e a beleza e decidi contemplá-la sempre em vez da luz, pois o seu esplendor jamais morre, nem é ocultado pela Terra, nem obscurecido 
naturae fragilitas, tantis periculis obiecta, non potest absque magna parentum custodia et uigilantia conseruari. Nullus autem rex diuersum habere potuit a reliquis hominibus uitae principium.

Iam uero exitus uitae qualis tandem sit, est omnibus explorate cognitum. Nihil enim morte truculentius esse uidetur, nihil horribilibus, nihil quod magis debeat humanae superbiae securim infligere, omnia namque, quae hominum uulgus admiratur, exstinguit et delet, spes inanes incidit, cogitationes uanitatis et amentiae conuincit. Quid est igitur in uita cur ii, qui in imperio sumus, debeamus nos reliquis hominibus anteferre, cum eadem sit omnibus in uitam ingressio et eadem similiter a uita communi digressio?

Cum id igitur cernerem, unam solam rationem uidi qua possem e periculis et morbis, quibus est uita mortalis implicita, liberari, et e fluctibus, quibus natura circumuenti sumus, emergere. Ea autem in una sapientia posita est, ea namque sanat morbos, depellit pericula, firmat uires, illustrat mentem hominumque natura ad similitudinem mentis diuinae perducit. Statui igitur omnes meas cogitationes esse ad studium sapientiae conferendas. Quomodo uero eam consecutus sum, opera [972] pretium erit animaduertere.

Num orbem terrarum sapientiae causa peragraui? Num e longinquis terris magistros asciui quos magna mercede conducerem? Num artes uarias atque multiplices, humanis ingeniis excogitatas, acerrimo studio consectatus sum? Nihil horum. Quamuis enim humanae sapientiae disciplinam minime contempserim, intellexi tamen uerissimae sapientiae rationem, non hominum inuentum esse, sed Dei munus atque beneficium. Primum igitur sapientiam ardentissime concupiui uotaque mea continuo prudentiae fructus uberrimi consecuti sunt. Illam castis et assiduis precibus inclamaui et spiritus sapientiae confestim in animum meum penetrauit. Vnde colligi potest acerrimam sapientiae cupiditatem, cum precibus ad Deum fusis et uotis ardentissimis, esse uiam et rationem qua uerissima sapientia comparatur. Ergo, cum uoti compos essem factus, studium, quo ante nimis acriter exarseram, minime remisi. Quae enim negliguntur, neque studiose quaeruntur neque cura et sedulitate debita conseruantur, et sic fit ut omnes opes iis, qui rerum altissimarum pondus non expendunt, euanescant. Quod quidem flagitium ne admitterem, operam sedulo nauaui, sapientiam enim imperiis maximis et regnis anteposui; diuitias ingentes, comparatione illius, pro nihilo putaui; gemmas et lapides pretiosos, prae sapientia, contempsi. Nam auri etiam ingentes acerui, si ad sapientiae opes respicias, arenae exiguae instar obtinebunt et omne argentum nihilo plus quam lutum aestimabitur. Neque solum ea, quae sunt extra corpus, ad sapientiam spectans, minimi faciebam, uerum et ea, quae in corpore ualde expetenda, prae illius studio, contemnenda iudicabam. Illam enim multo ardentius quam sanitatem et pulchritudinem expetiui statuique illam pro luce perpetuo contemplari, splendor enim illius non occidit umquam, neque terris occulitur, neque obductis nubibus obscuratur, neque ab eorum aspectu, qui eam carissimam habent, ulla tempestate remouetur, ita ut solis claritati longissimo interuallo praeferenda. 
pelas nuvens interpostas, nem nenhuma tempestade o afasta da vista dos que a amam muitíssimo, de tal maneira que é de muito longe preferível à claridade do Sol.

Ora, com ela sobrevieram-me todos os bens e, graças à sua benevolência, foram-me concedidas todas as riquezas que ela encerra no seu seio. Com efeito, assim como, na ausência dela, não existe na vida nada que possa chamar-se bom, visto como, devido à demência e loucura dos homens, todas as coisas se aplicam à perdição e ruína, da mesma maneira, quando ela está presente, tudo é vasto, claro e útil e ajustado à salvação e dignidade. E assim eu retirava extraordinário prazer das formas de todas as coisas: como é óbvio, porque todas se encontravam colocadas em obediência ao mando e senhorio da sabedoria. E todavia, antes de ter sido inundado por esta luz, ignorava que no seio da sabedoria se encerra a geração de todos os bens. É que são salutares todas as coisas que são dirigidas por ela, ao passo que as que carecem da sua providência são perniciosas e mortíferas. Daqui se conclui que [973] quem está provido de sabedoria possui em abundância todos os bens.

Aprendi-a sem qualquer dissimulação, reparto-a sem inveja, pois ela odeia o engano e o embuste e afasta a sua luz dos invejosos, porquanto quer que todos larga e liberalmente se enriqueçam das riquezas divinas. Não ocultarei, portanto, as suas riquezas. É que tão-pouco existe o perigo de a excessiva generosidade as consumir, porque o seu tesouro é inesgotável e perene, oferecido para proveito dos homens. Os que o usarem unem-se com Deus através de um estreitíssimo pacto de amizade, recomendados devido aos dons da instrução. Ora, Deus concedeu-me falar correctamente e de acordo com a opinião do espírito e, antes de me exprimir, ter uma consciência ajustada à grandeza das dádivas que cumpre expor por palavras. É que Ele é o guia da sabedoria e o que corrige os que se aplicam deveras ao amor da sabedoria. E assim é mister que se atribuam ao autor e criador de todos os bens tanto as riquezas da eloquência como a compreensão das coisas divinas, pois encontramo-nos na Sua mão, não só nós, mas também os nossos discursos e toda a prudência e conhecimento de todos os deveres. Por conseguinte, tudo quanto aprendi, o que com desvelo e perseverança alcancei, quanto avancei na investigação da natureza, reconheço que devo atribui-lo àquele Senhor supremo, porquanto foi d' Ele que recebi o conhecimento de todas as coisas, completamente livre de todas as trevas.

Portanto, foi por mercê d' Ele que consegui compreender a estrutura e formosura do mundo todo, ou seja, de que modo a Terra, impelida por todos os lados, se mantém firme no meio, apoiada em pesos iguais; depois, como o mar a cerca e, penetrando no seu interior, lhe ministra a abundância através de inúmeros rios e fontes; de que maneira o ar rodeia ambos os corpos, o qual, embora seja frio por natureza, todavia misturado com o calor do éter, transmite uma força salutar a todos os seres vivos, pois absorvido e puxado pela frequente respiração, refrigera o calor ardente do coração, e fornece abundantemente o alimento vivificante, de que se nutrem os espíritos vitais; de que forma, seguidamente, o último fogo, que ocupa a posição mais elevada, encerra no seu seio todas as coisas e, circulando através de todas as coisas, aquenta toda a natureza de tal maneira que até penetra nas mais profundas trevas da Terra, para que em toda a natureza, que o âmbito do céu abarca, não exista coisa alguma que possa estar privada 
Cum illa porro omnia bona mihi feliciter obuenerunt et diuitiae innumerabiles, quas illa complexu suo continet, ad me, benignitate illius, delatae sunt. Vt enim illa seclusa nihil est in uita quod bonum possit appellari, cum omnia ad pestem et exitium hominum furore et amentia conferantur, ita, cum illa praesens adest, omnia sunt ampla, clara et utilia et ad salutem et honestatem accommodata. Itaque ex omnibus rerum formis insignem uoluptatem capiebam: nempe, cum essent omnia sub ductu et imperio sapientiae constituta. Atqui, antequam essem hac luce perfusus, ignorabam generationem bonorum omnium sapientiae gremio contineri. Quae enim illius moderatione diriguntur salutaria sunt, quae uero illius prouidentia carent exitiosa sunt atque mortifera. Vnde concluditur eum, qui sapientia [973] praeditus est, esse omnibus bonis affluentem.

Eam sine ulla simulatione didici, sine inuidia communico, illa namque dolum et fraudem odio persequitur, et ab inuidis lucem remouet, uult enim omnes opibus diuinis large atque munifice locupletari. Minime igitur diuitias illius occultabo. Nec enim periculum est ne largitione nimia consumantur, inexhaustus enim atque perennis est thesaurus illius, ad hominum utilitatem propositus. Quo qui utuntur cum Deo artissimo foedere amicitiae coniunguntur, propter disciplinae munera commendati. Mihi autem Deus largitus est recte et ex animi sententia dicere et, antequam eloquar, sensum dignum magnitudine donorum, quae uerbis explicanda sunt, mente et cogitatione complecti. Ipse enim est sapientiae ductor et omnium, qui sapientiae uere student, emendator. Itaque tam opes eloquentiae quam diuinarum rerum intelligentiae ad auctorem et architectum bonorum omnium reuocandae sunt, in illius enim manu sumus, et nos, et orationes nostrae omnisque prudentia et officiorum omnium disciplina. Quaecumque igitur didici, quae studio et uigilantia consecutus sum, quantum in naturae peruestigatione profeci, illi summo Domino in acceptis referendum esse confiteor, ab illo enim rerum omnium cognitionem, nullis errorum tenebris impeditam, accepi.

Illius igitur beneficio id adeptus sum, ut intelligerem mundi totius fabricam et ornatum, quomodo, uidelicet, terra, undique pulsa, in medio, aequalibus nixa ponderibus, firma consistat; eam deinde mare circumfundat et, in illius uiscera penetrans, fontibus innumerabilibus et fluuiis, copiam subministret; qualiter aer utrumque corpus ambiat, qui, cum frigidus natura sit, aetheris tamen ardore temperatus, uim salutarem animantibus cunctis impertit, haustus enim et frequenti respiratione ductus, cordis incendium refrigerat, animalemque cibum, quo spiritus uitales aluntur, abunde suppeditat; quo pacto deinde ignis extremus, qui supremum locum obtinet, omnia complexu suo contineat et, per omnia commeans, ita uniuersam naturam concalefaciat ut in profundissimas etiam terrarum tenebras intret, ne quidquam sit in uniuersa natura, quam caeli ambitus coercet, quod illius fomento carere possit; quae sit elementorum connexio et 
do seu alimento; qual é ligação e união dos elementos, a recíproca alternância com o decurso do tempo transcorrido, quando um qualquer, transformado na natureza do outro, circula num e noutro sentido, e não abandona a sua posição antes de obter, como direito de cidadania, a natureza daquele cujo lugar vem substituir, pois a não ser assim dar-se-ia a confusão das formas e seguir-se-ia a ruína de todas as coisas; qual é utilidade e poder destes corpos; com quão extraordinária sabedoria os vapores despertados são impelidos paro o alto para, na região superior, se condensarem em nuvens e fazerem chuvas e aguaceiros, com que se leve a fecundidade à terra e as fontes se aumentem com as águas, e a terra, fecundada com as sementes, ofereça com extraordinária abundância alimento a todos os seres vivos.

Também do mesmo modo compreendo o início e progressão do tempo e o fim da idade seguinte. Também fixo com a razão o curso do Sol [974] e abarco com o entendimento a sua aproximação e afastamento e as duas revoluções em cada ano, uma de Sul para Norte, a outra de Norte para Sul, que se realizam com regularidade e equilíbrio extraordinários. Para quê referir aqui as sucessões dos tempos, a mudança dos anos, a posição dos astros e o curso dos orbes celestes, harmoniosamente ajustados entre si do modo mais conveniente? Para quê lembrar as naturezas dos seres vivos, nas quais é possível divisar a sagacidade admirável do supremo criador e progenitor de todas as coisas? Para quê aludir ao facto de ter implantado maravilhosamente nos animais selvagens um instinto de ferocidade para repelir o perigo? É que o arquitecto da totalidade do mundo não quis que nenhum animal estivesse privado de uma defesa natural, que lhe permitisse quer evitar, fugindo, o ataque dos outros, quer rechaçá-lo, lutando, quer iludi-lo, ocultando-se em inacessíveis esconderijos. Para quê hei-de citar a força dos ventos, graças aos quais se obtêm admiráveis proveitos? Com efeito, eles produzem as chuvas; trazem a bonança; provocam as tempestades; voltam a provocar a calmaria e, finalmente, são servidores não apenas da ira de Deus, mas também da Sua misericórdia e bondade. Igualmente são de utilidade a todos os seres vivos por, com o seu movimento, tornarem salubre o ar, porquanto, se os ventos não agitassem incessantemente o ar, teria sido forçoso que aquele corpo se corrompesse, à semelhança da água encerrada nos pântanos, e desse modo acabaria por contagiar com a peste todos os mortais.

Além disso, se quisermos esquadrinhar a natureza do homem, o mais importante dos restantes seres vivos, veremos expostas as riquezas da sabedoria divina. É que, já não falando na figura do corpo, adequada e apropriada para o uso da razão, nem na posição erecta, nem nos olhos colocados de modo a olhar o céu, quem poderá enumerar quão grande é a capacidade da memória, quão grande a sagacidade de que está dotado o entendimento, quão grande é a perspicácia das inteligências para a descoberta da verdade e quão excelente é o senhorio da razão sobre a totalidade do espírito? Mas aquele supremo Senhor de todas as coisas criou para utilidade do homem não apenas todos os animais, mas igualmente a inumerável multidão das plantas. Ora, quem poderá expor por palavras os suavíssimos cheiros das plantas, o encanto das frondes e o agrado e beleza dos frutos? Quem também descreverá a natureza das raízes, não só muitíssimo adequada 
conspiratio, mutuaque temporis exacti decursu uicissitudo, dum quodlibet, in aliorum naturam conuersum, ultro citroque commeat, nec prius a suo loco demigrat quam naturam illius, in cuius locum succedit, quasi ciuitatem adipiscatur, aliter enim formarum confusio fieret et interitus rerum omnium sequeretur; quae sit eorum corporum utilitas, efficientia; quam singulari consilio uapores excitati in sublime ferantur, ut in supera regione cogantur in nubes, et pluuias et imbres efficiant, quibus fecunditas in terras inducitur, et fontes aquis augentur terraque, grauidata seminibus, cunctis animantibus pabula admirabili largitate profundat.

Similiter etiam temporis initium et progressionem atque consequentis aetatis exitum mente percipio. Solis etiam cursum ratione definio [974] illiusque accessum atque recessum et binas singulis annis conuersiones, unam ab austro ad septemtriones, alteram a septemtrionibus ad austrum, quam singulari ordine et moderatione fiant, cogitatione comprehendo. Quid hic temporum uicissitudines, annorum conuersiones, astrorum situs et orbium caelestium cursus, ad numerum inter se aptissime concinentes, oratione commemorem? Quid animantium naturas, in quibus licet miram sollertiam summi rerum omnium parentis et conditoris inspicere? Quid illud quod in belluis acrem feritatis impetum ad periculum arcendum mirabiliter inseuit? Nullum enim animal uoluit mundi totius architectus esse naturae praesidio nudatum, quo possit a se impetum aliorum, uel effugiendo uitare, uel pugnando reprimere, uel, se abstrusis latibulis occultando, deludere. Quid referam uentorum impetus, quibus utilitates mirabiles afferuntur? Illi namque pluuias effundunt; illi serenitatem referunt; illi tempestates excitant; illi rursus tranquillitates efficiunt; illi denique sunt non irae tantum diuinae, uerum etiam clementiae et benignitatis administri. Illud etiam emolumentum cunctis animantibus praestant quod aerem, agitatione sua, salubrem reddunt, si enim uenti aerem non assidue concitarent, necesse fuisset corpus illud, ut aquam paludibus inclusam, corrumpi, et ita tandem omnes mortales lue conficere.

Iam uero, si naturam hominis, reliquorum animantium principis, perscrutari uelimus, sapientiae diuinae opes explicatas intuebimur. Vt enim corporis figuram ad rationis usum aptam et habilem, ut statum erectum, ut oculos ad caeli conspectum excitatos, omittamus, quis poterit enumerando recensere quanta sit memoriae uis, quanta in mente sollertia, quam admirabile sit ingeniorum ad inuentionem ueritatis acumen, quam excellens sit rationis in toto animo principatus? Ad illius uero utilitatem non solum animantia cuncta fabricatus est summus ille rerum omnium Dominus, uerum etiam innumerabilem plantarum multitudinem. Quis autem florum suauissimos odores, frondium amoenitatem, fructuum iucunditatem et pulchritudinem explicare dicendo poterit? Quis etiam uim radicum, non solum ad stabilitatem et nutrimentum, ipsarum plantarum, 
para a firmeza e alimentação das mesmas plantas, mas também sobremaneira eficaz para repelir as doenças?

Mas tenho conhecimento das naturezas destas coisas, quer ocultas e escondidas, quer colocadas diante dos olhos e vista, na Terra nada existindo cujo modo de ser esteja apartado da minha compreensão, graças ao facto de que a sabedoria, artífice de todas as coisas, me ensinou tudo. É que possui um espírito provido da mais elevada inteligência, muitíssimo santo pela pureza do entendimento, de natureza simplicíssima, múltiplo pela infinita virtude, com uma subtileza e mobilidade que tudo penetram, não enleado pela obscuridade dos conhecimentos nem manchado pelo sujo contágio de qualquer erro, mas que, com singular clareza e pureza, expõe e coloca em público as riquezas da sabedoria, propenso à benevolência e que com a máxima perspicácia [975] tudo prevê. Nem à sua força se pode impedir nem à sua probidade obstar a que façam participantes do seu esplendor todos os que dela se aproximam; além disso, ama os homens, com inabalável fidelidade cumpre as promessas, consolida a saúde dos seus com firme e invencível protecção e liberta de todo o cuidado e inquietação os espíritos piedosos: pois que receia a pessoa a quem o Espírito divino acolhe sob a Sua protecção? É que não é de recear que não possa prestar ajuda, visto que é omnipotente, e tão-pouco a Sua ausência é de temer, visto que está presente em toda a parte e se estende por toda a natureza e encerra no Seu seio todos os entendimentos puros e totalmente apartados de toda a materialidade terrena.

A sabedoria supera com a congénita rapidez todo o movimento impelido com grande celeridade e, devido à grandeza da inexplicável pureza, insinua-se em todas as naturezas. É que é um sopro e como que uma espécie de bafo da virtude e poder de Deus e uma abundância puríssima do esplendor eterno, que emana da glória de Deus Todo-poderoso, pelo que nela nada pode cair que esteja em alguma parte manchado com sujidade. É que é um esplendor da luz divina e um espelho da acção divina e uma imagem nítida da probidade divina. Ora, por outro lado, como é simples e una, contém e encerra todas as coisas, e como, permanecendo sempre em si mesma, não passa por nenhuma mudança, altera e renova todas as coisas. Além disso, como em variadas épocas se abraça com as almas santas, estabelece os amigos de Deus e os profetas: pois não ama Deus senão quem vive com a sabedoria. De facto, ela é mais luminosa que o Sol, mais bela que os astros e avantaja-se a todas as outras estrelas pela grandeza da claridade, porquanto a esta luz, que vemos com os olhos, expulsam-na as trevas da noite. A cerração da maldade, porém, não pode extinguir a luz da sabedoria, pois não existe coisa alguma que esteja livre da sua direcção.

\section{CAPÍTULO VIII}

De facto, com o máximo poder abrange o princípio e o fim da natureza inteira e com a máxima prudência estabelece a condição e conservação de todas as coisas, por tal forma que em qualquer género não existe seja o que for que, quanto o pede a natureza de cada 
commodissimam, uerum ad morbos etiam depellendos efficacissimam, oratione consequetur?

At omnium harum rerum naturas, uel reconditas et abstrusas, uel in oculis et aspectu propositas, animo perceptas habeo, nec est aliquid in orbe terrarum cuius ratio sit ab intelligentia mea remotum, omnia siquidem me docuit artifex rerum omnium sapientia. Continet enim spiritum intelligentia summa praeditum, mentis puritate sanctissimum, natura maxime simplicem, uirtute infinita multiplicem, subtilitate et mobilitate omnia penetrantem, non disciplinae obscuritate implicitum, non erroris ullius sordida contagione maculatum, sed insigni claritate, puritate, sapientiae diuitias explicantem et propalam collocantem, ad benignitatem propensum, acutissime omnia [975] prouidentem. Neque uis illius impediri neque probitas teneri potest quominus omnes, ad se adeuntes, participes sui splendoris efficiat; homines praeterea caros habet, promissa immutabili fide conficit, suorum salutem firmo et inuicto praesidio communit, animosque pios omni cura et sollicitudine liberat: quid enim metuat is quem Spiritus diuinus in fidem recipit? Nec enim metuendum est ne opem afferre non possit, cum sit omnipotens, nec absentia illius extimescenda est, cum ubique sit praesens et per omnem naturam pertineat omnesque mentes puras et ab omni terrestri concretione remotissimas complexu suo contineat.

Sapientia omnem motum quantauis celeritate concitatum insita celeritate superat et, propter inexplicabilis puritatis magnitudinem, in omnes se rerum naturas insinuat. Halitus enim est et quasi quidam uapor uirtutis et potentiae diuinae et purissima sempiterni splendoris affluentia, a gloria Dei omnipotentis emanans, propter quod nihil potest in illam incidere quod sit aliqua ex parte sordibus inquinatum. Est enim diuinae lucis splendor et diuinae actionis speculum et expressa diuinae probitatis imago. Porro autem, cum simplex et una sit, omnia coercet et continet, et cum in se perpetuo manens, nullam mutationem subeat, omnia commutat et renouat. Variis autem aetatibus, cum se animis sanctis implicet, amicos constituit atque prophetas: neminem enim diligit Deus nisi illum qui cum sapientia uiuit. Est enim illa illustrior sole, pulchrior astris et inter omnes stellas magnitudine claritatis excellit. Hanc enim lucem, quam oculis intuemur, tenebrae noctis expellunt. At improbitatis caligo non potest sapientiae lucem exstinguere, nihil est enim quod illius moderatione uacet.

\section{CAPVT VIII}

Summa namque potentia principium et finem naturae uniuersae complectitur et summo consilio rerum omnium statum et salutem constituit, ita ut nihil sit in quolibet genere, quantum rei uniuscuiusque condicio postulat, quod melius 
coisa, possa imaginar-se de melhor no que respeita à utilidade, ou de mais gracioso no que toca à formosura, ou de mais firme no que tange à estabilidade. A ela amei, dela segui as pisadas desde a mocidade, a ela ardentemente desejei como esposa, com o amor da sua beleza me abrasei admiravelmente. Quanto a sua nobreza é ilustre e gloriosa é algo que claramente se colige a partir do facto de que goza da perpétua convivência de Deus e o passar do tempo nunca a aparta da união com Ele, pois o Senhor de todas as coisas ama-a com o maior amor. De facto, é sacerdote e intérprete da ciência de Deus; com a máxima religiosidade realiza todas as cerimónias das obras divinas e com ardentíssimo desvelo segue todas as acções da divindade. Se na vida se devem desejar as riquezas, que pode imaginar-se de mais opulento do que a sabedoria, que, como é evidente, moldou e fabricou todas as formas das coisas? Se os negócios mais importantes são realizados pela inteligência, [976] para o propósito de agir-se na perfeição, que pode modelar o espírito mais engenhosamente do que a sabedoria, que é a autora do mundo inteiro? Se a justiça, pela aparência e beleza, parece amável e desejável, todos os trabalhos da sabedoria são consagrados ao zelo de todas as virtudes, pois instrui na moderação, ensina a prudência, dá a luz da justiça, consolida com o invencível vigor da fortaleza. Para a existência humana nada pode haver de mais salutar do que estas riquezas e ornamentos.

Mas se existe alguém que pense que o conhecimento de muitas coisas é útil para o desígnio de viver sabiamente, ela recorda toda a antiguidade, antevê por conjectura o que há-de acontecer muito antes que suceda, destrói os retorcidos sofismas, vê claramente o que está recoberto pelo disfarce das palavras, prevê os sinais e prodígios, observa todos os sucessos da época vindoura. Por conseguinte, decidi adoptá-la como companheira da vida e jamais me apartarei da sua amizade, pois estou certo de que, se seguir os seus conselhos, hei-de possuir sempre bens em abundância e jamais serei oprimido por quaisquer males. É que ela há-de livrar-me de cuidados e afastará do ânimo toda a inquietação, pois instrui com sãos conselhos os seus seguidores e incita ao amor da suprema bem-aventurança, isenta de preocupações o espírito e inunda-o de incrível felicidade. E não há motivo para que ninguém desconfie de poder alcançar os seus frutos devido à mocidade, porquanto as mercês divinas são oferecidas não apenas à velhice, mas também à juventude e até à infância, contanto que a fé, a piedade e o ardor dos espíritos frequentemente incite os entendimentos ao desejo das coisas celestiais e divinas. Com efeito, a sabedoria funda-se não no desvelo humano, mas em benefício divino, e para se obterem benefícios divinos requer-se não longa duração de idade, mas grandeza de piedade e virtude.

Portanto, ainda que seja jovem, brilharei diante da multidão com extraordinária glória graças à sabedoria e diante dos velhos serei sumamente honrado, nos julgamentos darei provas de penetração intelectual e de integridade, causarei admiração aos poderosos. Sempre que calar, esperarão que fale, e acolherão com enorme atenção o parecer de quem fala, mas se me alongar no discurso, calar-se-ão imobilizados pela admiração. Graças ao amor pela sabedoria alcançarei a imortalidade e o meu nome será votado a eterna lembrança e toda a posteridade cantará os meus merecimentos com frequentes loas. Governarei nações, povos acatarão de muitíssimo boa vontade o meu 
ad utilitatem, aut elegantius ad pulchritudinem, aut ualentius ad stabilitatem excogitari possit. Hanc amaui, hanc ab adulescentia uestigiis persecutus sum, hanc mihi sponsam ardenter expetiui, amore pulchritudinis illius mirabiliter inflammatus sum. Quam illustris et clara sit nobilitas illius ex hoc clare cernitur, quod perpetuo Dei conuictu perfruitur nec ab illius coniunctione tempore ullo diuellitur, nam rerum omnium Dominus eam amore summo prosequitur. Est enim sacerdos et interpres scientiae Dei; omnia diuinorum operum sacra cum religione summa conficit omnesque diuini numinis actiones ardentissimo studio consectatur. Si diuitiae in uita expetendae sunt, quid sapientia, nempe, quae omnes rerum formas finxit et informauit, excogitari potest opulentius? Si prudentia res maximae geruntur, quid sapientia, [976] mundi totius opifice, informari animo potest ad res perfecte gerendas artificiosius? Si iustitia, specie et pulchritudine amabilis et expetenda uidetur, omnes sapientiae labores in uirtutum omnium studium consumuntur, ad temperatiam enim instruit, prudentiam tradit, iustitiae lumen porrigit, fortitudinis inuicto robore confirmat. Quibus opibus et ornamentis nihil esse potest hominum uitae salutarius.

Si uero est quisquam qui multarum rerum cognitionem ad uitae sapienter degendae rationem proficere arbitretur, haec totius antiquitatis memoriam replicat, futura, multo ante quam eueniant, coniectura consequitur, sophismata contorta dissoluit, uerborum inuolucris obducta perspicit, signa et prodigia prouidet, totius consequentis aetatis euentus explorat. Illam igitur mihi uitae sociam asciscere decreui nec ab illius umquam familiaritate disiungar, certus enim sum, si consilia eius fuero secutus, fore ut bonis semper affluam et nullis umquam malis afficiar. Illa namque me leuabit curis omnemque ab animo molestiam dimouebit, illa enim sectatores suos consiliis salutaribus erudit et ad studium summae felicitatis adhortatur, et animum sollicitudine liberat et incredibili iucunditate perfundit. Nec est cur quisquam, propter adulescentiam, se fructum illius assequi posse, diffidat, munera enim diuina non senectuti tantum, sed etiam iuuentae atque adeo pueritiae conferuntur, modo fides et pietas et ardor animorum mentes ad rerum caelestium atque diuinarum cupiditatem frequenter exsuscitet. Sapientia enim, non studio humano, sed beneficio diuino continetur, ad beneficia uero diuina comparanda, non aetatis longitudo, sed pietatis atque uirtutis amplitudo requiritur.

Quamuis igitur iuuenis sim, sapientiae opera apud multitudinem insigni gloria florebo et apud senes honore summo cumulabor, in iudiciis acuminis et integritatis documenta statuam, potentibus admirationem commouebo. Quamdiu tacuero, exspectabunt dum eloquar, dicentis uero sententiam animis ualde attentis excipient, si autem fuero longius dicendo prouectus, admiratione defixi conticescent. Studio sapientiae immortalitatem adipiscar et nomen meum erit sempiternae memoriae consecratum omnisque posteritas laudes meas crebris sermonibus usurpabit. Regam populos, gentes imperium meum libentissime 
mando, os cruéis tiranos temerão a fama do meu nome; mostrar-me-ei misericordioso e benévolo em defender a multidão, singularmente destemido em castigar energicamente os inimigos. Quando recolher a casa, repousarei no seio dela, pois a intimidade e familiaridade com ela afastam para muito longe toda a moléstia. É que a consciência do crime não atormentará aquele que, aconselhado pela sabedoria, não se torna culpado de qualquer crime, nem o medo afligirá aquele que está cercado pela protecção divina, nem a pobreza torturará o espírito daquele que possui em abundância as mais verdadeiras riquezas, nem a dor atingirá o entendimento daquele homem que está cheio de extraordinário prazer.

Ora, a sabedoria faz tudo isto não só para afastar todos os males, mas também [977] para cumular de todos os sumos bens os que inteiramente se consagraram ao seu zelo. E deste modo, nem em casa nem fora, nem quando a guerra arder, nem quando se estabelecer a paz, nem nos negócios nem na ociosidade há-de existir tempo algum em que não reparta muita bondade e doçura com todos os que com ânimo ardente se aplicaram ao estudo dela.

Ao reflectir nisto comigo mesmo e ao aperceber-me de que todas as coisas boas se encerram no conhecimento da sabedoria, visto que ela constrói o caminho para a imortalidade, ela recreia os entendimentos que ama com um prazer estável e honesto, ela com acções ilustres ajunta riquezas eternas, o seu exercício e uso aguça a inteligência, o seu trato ocasiona celebridade e glória de nome: ao revolver, pois, isto no espírito, percorria todas as coisas, investigando se existiria alguém graças a cujo ensino eu pudesse apossar-me dela. Ora, eu estava provido de tais dotes naturais que me parecia que não devia perder as esperanças de alcançá-la, pois era um menino de inteligência perspicaz e obtive uma alma dotada de singular bondade ou, para me expressar mais correctamente, como era bom por natureza, porquanto devo ser avaliado não tanto pelo corpo quanto pelo espírito, introduzi-me num corpo limpo de todas as infâmias, e assim parecia que não haveria nenhum obstáculo para que chegasse à sabedoria. Todavia acabei por compreender que nem uma natureza superior, nem a penetração intelectual, nem a saúde do corpo, nem a máxima aplicação contêm a sabedoria, porque é um bem celestial, uma luz do esplendor eterno e um benefício divino que é mister pedir-se, não ao desvelo humano, mas à misericórdia divina. Por conseguinte, capacitei-me de que nunca viria a partilhar da sabedoria, a menos que Deus me oferecesse a Sua luz. Certo que já foi não pequena prova de sensatez compreender de quem era este tão imortal benefício, por forma a não gastar em vão tempo e trabalho. Considerei, portanto, que não deveria apoiar-me em nenhuns recursos da inteligência ou na superioridade da natureza ou na eloquência do mestre, mas depositei na misericórdia de Deus toda a esperança de sabedoria. Por consequência, aplicando-me à prece e oração, dirigi-me com todo o espírito a Deus e com estas palavras ardentemente Lhe pedi que me desse a sabedoria: 
sequentur, immanes tyranni nominis mei famam pertimescent; in multitudine conseruanda clemens et benignus, in hostibus acri bello coercendis egregie fortis apparebo. Cum me domum recepero, in gremio illius acquiescam, illius enim familiaritas et consuetudo omnem acerbitatem longissime repellit. Nec enim sceleris conscientia torquebit eum qui, a sapientia monitus, nullum in se scelus admisit, neque metus afflictabit eum qui est diuino praesidio circumsaeptus, neque inopia cruciabit animum illius qui uerissimis opibus abundat, nec dolor attinget hominis illis mentem qui est admirabili uoluptate cumulatus.

Haec autem omnia praestat sapientia ut non modo mala omnia depellat, uerum [977] etiam ut omnibus summis bonis expleat eos qui se totos ad illius studium contulerunt. Itaque neque domi neque foris, neque cum bellum exarserit, neque cum pax constituta fuerit, nec in negotio nec in otio tempus erit ullum quo non omnibus, qui sese ardentibus animis ad studium illius adiunxerint, non plurimum benignitatis atque suauitatis impertiat.

Cum haec reputarem et animaduerterem, omnia bona cognitione sapientiae contineri, illa namque ad immortalitatem uiam munit, illa stabili et honesta uoluptate mentes caras oblectat, illa praeclaris actionibus sempiternas diuitias congerit, illius exercitatio et consuetudo prudentiam exacuit, illius colloquium, nominis claritatem et gloriam confert: haec igitur cum animo uersarem, omnia circumibam, inuestigans ecquis esset cuius disciplina possem compos illius euadere. His autem naturae opibus instructus eram ut ea minime mihi desperanda uideretur, puer enim eram ingenio acri animamque nactus sum egregia bonitate praeditam aut, ut rectius dicam, cum ipse natura bonus essem, nec enim tam corpore quam animo censendus sum, in corpus nullis flagitiis inquinatum immigraui, itaque nihil fore uidebatur impedimento quominus ad sapientiam peruenirem. Verumtamen id tandem intellexi neque naturae praestantiam, nec acumen ingenii, neque corporis sanitatem, neque summum studium sapientiam continere, caeleste namque bonum est, splendoris sempiterni lumen diuinumque beneficium non ab humana industria, sed a Dei clementia postulandum. Mente igitur percepi me umquam sapientiae participem futurum, nisi Deus lumen suum mihi porrigeret. Quod quidem iam fuit prudentiae non mediocris argumentum, intelligere nempe cuius esset hoc tam immortale beneficium, ne tempus et operam frustra consumerem. Nullis igitur ingenii uiribus aut naturae praestantia aut doctoris eloquentia mihi nitendum existimaui, sed omnem sapientiae spem in clementia diuina constitui. Ad preces igitur et uota conuersus, toto animo me ad Deum contuli et his uerbis, ut mihi sapientiam traderet, ardenter flagitaui: 


\section{CAPÍTULO IX}

Senhor, que por singular beneficio uniste a Ti os meus antepassados, que lhes concedeste as extraordinárias mercês da Tua misericórdia, que, com a Tua palavra, criaste tudo quanto existe por cima e por baixo, e com a Tua sabedoria formaste o homem, para que se avantajasse em dignidade às coisas criadas por Ti, e dominasse sobre todos os seres vivos, $e$ governasse o mundo com piedade e justiça e, modelado com equidade de espírito, julgasse com a máxima rectidão: concede-me a sabedoria, que sempre toma assento junto ao Teu sólio, peço-Te que não rejeites o meu pedido nem me feches o acesso à Tua família, pois sou Teu servidor, destinado a esta santíssima servidão já desde o ventre da minha mãe, Tua escrava, para que, com o melhor dos direitos, deva ser contado no número dos Teus escravos. [978] Sou homem, frágil e fraco e vivendo uma vida delimitada por um prazo de breve tempo e, por mim, não posso aspirar ao conhecimento dos juizos e das leis. Ora, ainda que estivesse perfeitamente munido de todas as defesas quer da natureza, quer do conbecimento, quer de todos os bens que se encontram na vida, como poderia ao cabo, privado do auxílio da Tua sabedoria, desempenhar a função que me foi cometida? É que, ainda que um homem esteja extraordinariamente cumulado de todas as restantes coisas e se avantaje a todos os homens em inteligência, conhecimentos e riqueza, se todavia estiver privado da Tua sabedoria, deverá ser tido na conta de coisa nenbuma. E quanto maior peso se impuser a alguém, tanto mais deverá ser iluminado pela luz e claridade da Tua sabedoria.

Vê, portanto, Senhor, quão grande é a função de que me encarregaste. Escolheste-me como rei, para me colocares à frente do Teu povo, a fim de que tomasse a defesa dos Teus filhos e filhas e edificasse o templo no Teu monte e erguesse um altar na cidade, que elegeste para morar, tomando como modelo aquele tabernáculo que traçaste desde toda a eternidade, para nele colocares a Tua eterna morada e domicílio. Jamais nada fizeste sem admirável desígnio, sem a maior deliberação, sem extraordinária razão, de maneira a que em cada coisa se possa notar a perfeição da natureza e o poder da sagacidade divina. De facto, esteve sempre desde o princípio contigo aquela sabedoria dotada do exactíssimo conbecimento das Tuas obras, a qual estava presente quando fazias o mundo e dispunha e realizava tudo o que sabia que viria a ser do Teu agrado. É que ela sabe o que é agradável aos Teus olhos e em que coisas se funda a santidade da Tua lei e a equidade do direito eterno e até o essencial de toda a perfeição. Ora, nós, em tão grandes trevas da vida, em tão grande fraqueza da natureza, nem sabemos o que se deve fazer nem conseguimos perseverar durante muito tempo naquilo que nos pareceu certo.

Portanto, envia-a da Tua santíssima morada situada no altíssimo Céu, para que do sólio da Tua glória chegue até mim e suporte juntamente comigo o trabalho, a fim de que, instruído pelos seus ensinamentos, eu compreenda o que me cumpre fazer para receber a Tua graça e conservá-la com perpétuo desvelo da vida. Com efeito, ela sabe tudo e não existe nada, por mais oculto e difícil de compreender, que não entenda perfeitamente. E ela guiar-me-á sempre e de tal maneira me conduzirá que nada farei sem regra, mas levarei a cabo todas as acções de modo sensato e comedido, e a glória da Sua virtude velará por mim, 


\section{CAPVT IX}

Domine, qui maiores meos singulari tibi beneficio deuinxisti, qui eximia in illos clementiae tuae munera contulisti, qui omnia, quae super subterque sunt, uerbo tuo construxisti, sapientiaque tua bominem formasti, qui rebus a te conditis dignitate praecelleret, et cunctis animantibus imperaret, et mundum cum pietate atque iustitia gubernaret, et animi aequitate conformatus rectissime iudicium exerceret: tribue mibi sapientiam, solio tuo semper assidentem, ne meum, quaeso, postulatum repudies, nec aditum ad familiam tuam intercludas, seruus enim tuus sum, iam ex utero matris meae, ancillae tuae, ad seruitutem hanc sanctissimam destinatus, ut optimo iure debeam uernis tuis annumerari. [978] Homo sum, fragilis et imbecillus et in uitam ingressus, breuis aeui spatio definitam, neque per me possum ad notitiam iudiciorum atque legum aspirare. Quamuis autem essem omnibus uel naturae, uel doctrinae, uel bonorum omnium, quae uersantur in uita, praesidis instructissimus, quo tandem modo possem munus mihi commissum, auxilio sapientiae tuae priuatus, administrare? Quamuis enim homo reliquis rebus omnibus egregie cumulatus sit et omnibus bominibus ingenio et disciplina et opibus antecellat, si tamen fuerit expers sapientiae tuae, pro nibilo ducendus erit. Quo uero maius onus fuerit cuilibet impositum, eo magis erit sapientiae tuae lumine et claritate collustrandus.

Vide igitur, Domine, quantum mibi munus administrandum permiseris. Regem elegisti, quem populo tuo praeficeres, ut patrocinium filiorum atque filiarum tuarum susciperem, et templum in monte tuo aedificarem et in ciuitate, quam ad habitandum delegisti, aram exstruerem, ad exemplum illius tabernaculi quod ex omni temporis aeternitate designasti, in quo sempiternam tibi sedem et domicilium collocares. Nibil a te umquam effectum fuit sine admirabile mente, sine summo consilio, sine singulari ratione, ita ut in singulis rebus possit cuiuslibet naturae perfectio diuinaeque sollertiae numen animaduerti. Nam tecum semper ab initio fuit sapientia illa, operum tuorum exactissima cognitione praedita, quae simul aderat cum mundum efficeres et omnia designabat et efficebat, quae nouerat tibi fore gratissima. Illa namque tenet quid sit oculis tuis iucundum, et quibus in rebus legis tuae sanctitas et aequitas iuris sempiterni, atque adeo totius perfectionis summa, consistat. Nos autem, in tantis uitae tenebris, in tanta naturae imbecillitate, nec intelligimus quid gerendum sit nec in eo quod iudicamus stare diu possumus.

Mitte igitur illam ex sanctissimis sedibus tuis in summo caelo collocatis, ut ex gloriae tuae solio ad me perueniat et mecum laborem suscipiat, ut, illius doctrinis instructus, intelligam quod mibi faciendum sit ad gratiam tuam colligendam perpetuoque uitae studio retinendam. Illa namque nouit omnia nec est quidquam tam abstrusum et abditum quod non exacte percipiat. Illaque ducet me semper et sic praeibit ut nibil immoderate geram, sed omnes actiones prudenter et temperate perficiam, uirtutisque suae gloria me tuebitur, omniaque 
e afastará de mim todos os perigos. Por isso, as minhas obras ser-Te-ão então muitíssimo aceitas e governarei com justiça o Teu povo, e parecerei digno do reino e senhorio do meu pai. Na verdade, que homem existe capaz de atingir pelo entendimento e pensamento as deliberações de Deus? Quem compreenderá qual é a Sua vontade ou o fim para que se encaminham as Suas determinações? Com efeito, os pensamentos dos mortais são tímidos, inconstantes e arriscadas as suas razões, de tal maneira que ou a deliberação não se mantém, ou nos impele para a perdição o que tínhamos concebido para a salvação, pois o corpo frágil e mortal arrasta com o seu peso o espírito para a terra, e a morada terrestre abate o entendimento atribulado pelos cuidados e [979] inquietado com a preocupação pelo corpo e impede-o de poder olhar para as coisas celestiais e divinas. Vivemos em tão grande ignorância das coisas que dificilmente conseguimos esquadrinhar, com o máximo trabalho, o modo de ser daquelas que estão colocadas diante dos sentidos e que apalpamos com as mãos. Por consequência, quem poderá investigar as que estão escondidas no céu? E quem alcançará com o entendimento e inteligência os Teus desígnios, senão aquele a quem Tu iluminares com a luz da Tua sabedoria e a quem ensinar o Espírito Santo, por Ti enviado da altíssima morada? Se, portanto, durante a vida alguém praticou a piedade pura e santamente, se regulou sabiamente a vida, se cumpriu as máximas virtudes e nunca se desviou do recto caminho da equidade, se, finalmente, permanecendo na Terra, vinculou todas as deliberações da vida aos ensinamentos celestiais e à imortalidade, tudo isto foi realizado por mercê da Tua sabedoria. Com efeito, dela aprenderam os homens santos com que coisas de Ti alcançariam a graça, e por mercê e beneficio dela alcançaram a salvação.

\section{CAPÍTULO X}

Ela encorajou, depois de prostrado, o primeiro autor e origem da raça humana, que no princípio do mundo foi o único a ser moldado pelas Tuas mãos, quando caiu e se precipitou no crime da rebelião, e ela o purificou de toda a mancha do delito e o restituiu à perdida graça, e fez que de novo se conservasse senhor de todas as coisas. Mas aquele varão sacrílego que, enlouquecido pela fúria, matou o irmão, tornou-se culpado de um crime tão grande porque se afastara da sabedoria e recusara o seu senhorio. Mas como a descendência, seguindo as pisadas do malvado e impuro homem, se entregava a toda a espécie de infâmias e acrescentava sempre alguma coisa à perversidade dos progenitores, acabou por acontecer que os crimes atingiram o seu ápice e os pecados aumentaram com acréscimos tão grandes que provocaram a divindade à devida vingança. Por isso a Terra foi submergida pelas águas e extinta toda a linhagem da impura semente. Mas a sabedoria arrancou o justo daquelas vagas vingadoras e conservou-o em frágil lenho, para que as almas puras já pudessem ver que a salvação comum deveria ser oferecida à Terra pelo sagrado mistério do santo lenho. Logo, para que isto mostrasse antecipadamente, era então a sabedoria quem segurava o leme, naquela imensidão de águas e naquelas assustadoras ondas e procelas, ela quem traçava a rota, ela quem mantinha a nau incólume. E deste modo, através do timão da sabedoria, se produziu a salvação do justo e o género humano se renovou. 
a me pericula repellet. Tunc igitur opera mea tibi erunt acceptissima populumque tuum cum iustitia regam, dignusque uidebor regno et imperio patris mei. Quis enim inter homines est qui possit Dei consilium mente et cogitatione percipere? Quis, quae uoluntas illius sit aut in quem finem statuta illius dirigantur, intelliget? Cogitationes enim mortalium timidae sunt, lubricae et periculosae rationes, ita ut aut consilium minime consistat aut, quod erat a nobis ad salutem excogitatum, in perniciem impellat, corpus enim mortale et caducum pondere suo animum in terram deprimit, terrestreque domicilium mentem curis anxiam et [979] de corporis cura sollicitam abiicit et impeditam tenet ne possit supera atque diuina contueri. In tanta rerum ignoratione uersamur ut uix rationes earum rerum, quae sensibus obiectae sunt et quas manu contrectamus, inuestigare cum maximo labore possimus. Ea igitur quae sunt in caelo recondita, quis poterit explorare? Et consilium tuum quis mente et ingenio consequetur, nisi is quem tu sapientiae tuae luce collustraueris et quem Spiritus Sanctus, a te ex altissima sede missus, erudierit? Si igitur aliquis in uita pure et sancte pietatem coluit, si uitam sapienter instituit, si maximarum uirtutum functus est munere et numquam ab aequitatis directa uia deflexit, si denique, in terris manens, omnia uitae consilia ad instituta caelestia et immortalitatem retulit, omnia haec sapientiae tuae munere gesta sunt. Ab ea namque sancti bomines, quibus rebus a te gratiam inirent, didicerunt, illiusque munere et beneficio salutem consecuti sunt.

\section{CAPVT X}

Haec primum humani generis auctorem et principem, qui solus in mundi primordio tuis manibus informatus fuit, cum prolaberetur et in crimen rebellionis incideret, iacentem excitauit, omnique labe sceleris expiauit et in gratiam amissam restituit, et, ut rursus omnia potestate contineret, effecit. At uir ille sceleratus qui, furens iracundia, fratrem occidit, ideo tanto se crimine constrinxit, quia a sapientia desciuerat illiusque imperium detrectauerat. At uero, cum posteritas, hominis malefici et impuri uestigiis ingressa, in omni genere flagitiorum uersaretur et semper aliquid ad parentum improbitatem adderet, factum est tandem ut scelera ad summum peruenirent et peccata tantis accessionibus cumularentur, ut numen diuinum ad ultionem debitam prouocarent. Fuit igitur orbis terrarum aquis obrutus et omne subolis impurae semen exstinctum. Sapientia uero ex undis illis ultricibus iustum eripuit fragilique ligno conseruauit, ut posset iam a puris animis animaduerti communem salutem orbi terrarum sacro sancti ligni mysterio conferendam. Ergo, ut id praemonstraret sapientia, tunc in illa aquarum immensitate, in illis horrendis fluctibus atque procellis, clauum tenebat, illa cursum dirigebat, illa nauigium illaesum conseruabat. Itaque sapientiae gubernaculo fuit iusto salus allata et humanum genus instauratum. 
Como, porém, a conspiração e conjura dos crimes de novo contaminasse e infectasse toda a Terra, a divindade pôs um entrave à monstruosa soberba e reprimiu as tentativas dos homens perversos e os povos foram espalhados por variadas regiões por causa da confusão das línguas. Todavia, naquele caos de infâmias e ruína da justiça e da piedade, a sabedoria descobriu o justo, a quem conservou ileso do contágio do crime e fortificou com tão grande firmeza de espírito que o amor ao único filho não pôde desviá-lo dos deveres da piedade, pois pela sua própria mão se dispôs a degolar o filho, a fim de obedecer aos mandados de Deus, [980] e obteve para si uma extraordinária vitória sobre a natureza, ao repudiar o sentimento do sangue e ao decidir com a máxima firmeza que, por amor da piedade, lhe cumpria pôr de parte todos os deveres do mais estreito parentesco. Do mesmo modo, quando o fogo, lançado do céu, abrasou cinco cidades corrompidas por crime abominável, ela preservou o justo que fugia daquele incêndio e arrancou-o ao castigo dos ímpios. Dão testemunho deste castigo exemplar aplicado aos homens sacrílegos a desolação da terra abrasada, a aridez do solo fumegante e as plantas produzindo frutos que não prestam, pois desfazem-se em cinza. Além disso, na coluna de sal levantou-se para eterna lembrança um memorial do espírito desleal, pois quando a esposa, contra aquilo que lhe fora ordenado, olhou para trás e mostrou uma disposição de espírito ligado aos usos e costumes da pátria, padeceu o castigo da perfídia, para que se possa entender que os que desprezam os preceitos da sabedoria e desdenham a ajuda que se lhes oferece, não apenas são pesadamente punidos com o castigo de não verem o esplendor e beleza da própria dignidade, mas também com o de deixarem a recordação da sua loucura, para que nos seus erros seja impossível ocultar-se e esconder-se o seu desdouro e infâmia.

E deste modo com enorme ignomínia sucumbem, esmagados por todas as ruínas, aqueles que abandonam a sabedoria, ao passo que os que com todo o desvelo a seguem, são arrancados de todos os males. Ela levou pelo caminho certo o varão dotado de extraordinária religiosidade, que fugia da ira do irmão, e mostrou-lhe a luz e revelou-lhe o reino de Deus e instruiu a sua inteligência no conhecimento das coisas santas. Com efeito, quando o santo varão viu em sonhos o Senhor apoiado a uma escada que entrava no céu aberto e franco, quando olhou com pasmo para os anjos que desciam e depois subiam para o céu, compreendeu com toda a clareza que o Reino de Deus, que deveria ser concedido aos homens piedosos, se encerrava no poder e benefício daquele, por cujos merecimentos se oferece a ascensão ao Céu aos que com fé se abrasam no zelo da piedade e, devido à excepcional misericórdia do melhor dos pais, são apoiados com a ajuda dos anjos. E, assim, com o auxílio da sabedoria pessoalmente presente, aconteceu que os trabalhos e inquietações de Jacob tiveram um desfecho afortunadíssimo e, quanto mais parecia esmagado pelas tribulações, tanto era acrescentado com maiores riquezas, e quando os que o avantajavam em poder, cegos pela avareza, o cercavam, a sabedoria socorreu-o, prestou-lhe ajuda, evitou os enganos, afastou a injustiça, enriqueceu o justo e arrancou-o aos inimigos, impediu as ciladas e cercou-o de uma defesa invencível e, por derradeiro, conseguiu que ele, em todas as situações extremamente perigosas, ficasse sempre vitorioso e alcançasse um glorioso triunfo, para que através da experiência compreendesse que nada existe de mais forte do que a piedade. 
At, cum scelerum consensus et conspiratio, iterum terras uniuersas inficeret et contaminaret, fuit immanis superbiae consilium impeditum et perditorum hominum conatus numine repressus et gentes propter linguarum confusionem in uarias regiones dissipatae. In illa tamen flagitiorum colluuione et iustitiae atque pietatis interitu, inuenit sapientia iustum, quem a sceleris contagione tutum conseruauit tantoque robore animi confirmauit, ut nec unici filii caritate potuerit ab officio pietatis abduci, filium enim, ut Dei iussis obtemperaret, manu propria iugulandum [980] suscepit, insignemque uictoriam de natura sibi peperit, cum sanguinis sensum repudiauit et constantissime decreuit omnia artissimae coniunctionis officia esse sibi, gratia pietatis, omittenda. Similiter cum ignis, e caelo demissus, quinque ciuitates infando scelere corruptas exureret, ipsa iustum, illud incendium horrificum fugientem, tutata est et ab impiorum poenis eripuit. Illius autem exempli, in homines consceleratos editi, testimonium dat telluris exustae uastitas, solique fumantis ariditas et plantae fructus efferentes inutiles, in cinerem namque dissoluuntur. Infidelis animi praeterea monumentum in salis columna est ad aeternam memoriam constitutum, cum enim uxor, contra id quod fuerat imperatum, retro respexit animumque affixum patriae moribus et institutis ostendit, perfidiae supplicium subiit, ut intelligi possit eos qui sapientiae praescripta contemnunt oblatumque illius praesidium aspernantur, non modo ea poena grauissime puniri quod ipsius dignitatis splendorem et pulchritudinem minime cernunt, uerum in eo quod amentiae memoriam relinquunt, ut in illorum erratis eorum dedecus et turpitudo celari et occultari non possit.

Itaque illi, qui eam deserunt, omnibus ruinis oppressi, cum insigni ignominia concidunt, qui eam uero omni studio sectantur, ab omnibus malis eripiuntur. Illa eadem uirum insigni religione praeditum, qui fratris sui iram fugiebat, recta uia deduxit, illique lucem praetulit et regnum Dei monstrauit mentemque illius sanctorum disciplinis erudiuit. Cum enim uir sanctus in somniis uidit Dominum scalae innixum, quae in caelum patens et apertum penetrabat, cum angelos a caelo descendentes et rursus ascendentes admiratus est, liquido perspexit regnum Dei, quod erat piis hominibus deferendum, illius numine et beneficio contineri, cuius meritis ascensus in caelum datur iis qui, cum fide, studio pietatis incenduntur, angelorumque ministerio, propter insignem parentis optimi clementiam, fulciuntur. Itaque, sapientiae praesentis auxilio, factum est ut Iacobi labores et sollicitudines euentus felicissimos haberent et, quo magis oppressus esse uidebatur aerumnis, eo amplioribus diuitiis augeretur, et cum ii, qui eum potentia superabant, auaritia caeci, illum circumuenirent, sapientia illi praesto fuit, opem attulit, fraudes elusit, iniuriam propulsauit, iustum copiis locupletauit et ab hostibus eripuit, insidias repressit eumque inuicto praesidio cinxit et perfecit denique ut is, in omni maximo certamine, uictor semper euaderet et clarum triumphum duceret, ut experiundo sentiret nihil esse pietate ualentius. 
Do mesmo modo, ela de forma alguma abandonou o justo vendido e conservou-o puro, não deixando que se manchasse com abominável crime e, quando lançado no cárcere, fortificou-o e encheu-o de luz, até o colocar em posição real e lhe transmitir a soberania sobre aqueles mesmos pelos quais fora indignamente vexado e oprimido. E não só velou pela sua vida e salvação, como também libertou o seu nome da calúnia e mostrou que mentiam os que tinham testemunhado contra ele, [981] e finalmente concedeu-lhe a glória eterna.

Ela com ajuda muitíssimo eficaz libertou a santa raça e a linhagem pura, isenta de toda a mancha do crime, do povo que a atribulava com injustiças. Com efeito, penetrou profundamente no entendimento do servo de Deus a fim de fortalecê-lo com o invencível vigor da coragem. Depois, fez frente a terríveis reis, com prodígios e sinais aterrorizou os inimigos, aos homens santos concedeu-lhes o prémio dos trabalhos. Naquela espantosa jornada ofereceu-se como guia do caminho; durante o dia, para impedir o ardor do Sol, protegeu os seus com uma nuvem interposta, e, durante a noite, dissipou as trevas com uma luminosidade claríssima, e depois de fender o mar, abriu caminho no meio das ondas, conduziu os seus, incólumes, através do profundo abismo, sepultou os inimigos com as vagas que se abateram de ambos os lados e afogou toda a multidão dos ímpios com o horrendo estrondo das águas que desabam. E deste modo os homens piedosos arrancaram os despojos aos ímpios e louvaram, ó Senhor, o Teu nome santíssimo e celebraram a Tua invictíssima mão com cânticos entoados com extraordinária harmonia. Tudo isto aconteceu deste modo a fim de que os homens não pudessem atribuir a si mesmos nenhum merecimento, uma vez que até os cânticos e hinos e a própria harmonia dos sons e a extraordinária suavidade da música devem ser considerados como mercês do Teu espírito. É que a Tua sabedoria abriu a boca dos mudos e soltou a língua das crianças por forma a se expressarem clara, elegante e abundantemente.

\section{CAPÍTULO XI}

E, assim, as acções daqueles que cantavam os Teus louvores, por obra de um santo profeta tiveram afortunadíssimos desfechos; atravessaram um deserto ermo e selvagem, montaram as tendas em locais desabitados, rechaçaram corajosamente o ataque dos inimigos; quando se abrasavam em sede, pediram a Tua ajuda e imediatamente, por singular benefício Teu, a água jorrou de uma rocha quebrada. Oh coisa merecedora da máxima ponderação: em lugares apartados de toda a civilização humana e queimados por ardentíssimos sóis, de uma fraga duríssima correu uma fonte de água doce e perene para matar a sede dos que tinham depositado em Ti toda a esperança de salvação. Deste modo aconteceu que, o que para os inimigos foi um violentíssimo castigo, seria para os bons na adversidade um benefício e um refrigério muitíssimo agradável, pois os inimigos, embora habitassem perto de um larguíssimo rio, foram atormentados por uma fortíssima sede, visto que as águas se transformaram em sangue, para castigo da monstruosíssima crueldade dos ímpios que por ordem do malévolo e injusto rei tinham 
Illa similiter iustum uenditum haudquaquam deseruit illumque, ne se crimine nefario pollueret, purum conseruauit et, in carcerem coniectum, robore muniuit et luce compleuit, usque eo dum sede regia collocaret imperiumque illi traderet in eos ipsos a quibus indigne uexatus et oppressus exstiterat. Neque solum illius uitae et saluti consuluit, uerum etiam nomen illius calumnia liberauit et eos, qui testimonium in illum [981] dixerant, mendaces ostendit, atque postremo gloriam illi sempiternam contulit.

Illa Dei populum sanctum semenque purum, nulla labe sceleris infectum, a gente, quae illum iniuriis afflictabat, ope praesentissima liberauit. Nam in mentem serui Dei penitus intrauit ut illum robore uirtutis inuicto stabiliret. Deinde se regibus metuendis opposuit, hostibus horrorem, signis atque portentis, incussit, sanctis hominibus laborum mercedem constituit. In itinere illo mirabili se uiae ducem praebuit; die, ut ardorem solis arceret, suos, inducta nube, protexit, nocte uero tenebras clarissimo splendore discussit, marique discisso, in mediis undis iter aperuit, per profundum gurgitem suos incolumes deduxit, hostes, effusis utrimque fluctibus, obruit, et, horrendo aquarum irruentium fremitu, uniuersam impiorum multitudinem demersit. Itaque pii impiis spolia detraxerunt, nomenque tuum, o Domine, sanctissimum laudibus extulerunt, inuictissimamque manum tuam carminibus egregio concentu modulatis celebrarunt. Haec omnia ita facta sunt ut nullam laudem possent sibi homines ascribere, cum etiam carmina et hymni ipseque sonorum concentus et incredibilis harmoniae suauitas ad spiritus tui munera referenda sint. Tua namque sapientia os mutorum aperuit et infantium linguas expediuit, ut clare et ornate et copiose dissererent.

\section{CAPVT XI}

Itaque illorum actiones qui laudes tuas concinebant, prophetae sancti opera exitus felicissimos habuerunt; uastam et incultam solitudinem peragrarunt, tentoria in locis desertis collocarunt, hostium a se impetum fortissime represserunt; cum siti flagrarent, opem tuam flagitauerunt et confestim ex praerupta rupe, singulari beneficio tuo, aqua profluxit. O rem consideratione dignissimam: in locis ob omni hominum cultu derelictis et solibus ardentissimis exustis ad sitim eorum, qui in te omne praesidium salutis constitutum habebant, restinguendam, e saxo durissimo fons aquae dulcis atque perennis emanauit. Ita factum est ut, quod hostibus acerrimum supplicium fuit, bonis esset admirabile, in afflictis rebus, alleuamentum beneficiumque gratissimum, hostes enim, cum sedes haberent prope fluuium latissimum, siti uehementissima cruciati sunt, aquae enim uersae sunt in sanguinem, ut poenas ab impiis immanissimae crudelitatis expeterent qui, iussu regis malefici et iniusti, in eumdem fluuium pueros infantes abiecerant. 
lançado ao mesmo rio as crianças recém-nascidas. E assim, ao verem o Nilo correr com sangue, ficaram perturbados e, impedidos de usarem as águas, sofriam duramente, para compreenderem que nenhum crime de desumanidade haveria de ficar impune. Ao invés, porém, encontrando-se os Teus em solo muitíssimo árido, contra o que seria previsível, a água jorrou de repente com incrível abundância. Ora, deste modo poderia conhecer-se de forma segura que aqueles que estão separados de Ti até na máxima abundância de coisas sentem sempre privações, ao passo que, mesmo na mais completa privação de coisas, nada há-de faltar aos que Te seguem com ardente desvelo, [982] porquanto não existe nada de mais indigente do que a grandeza da impiedade nem nada de mais rico do que a santidade da puríssima religião. De facto, que poderá faltar àqueles que estão perpetuamente unidos à fonte de todos os bens?

Mas dirá alguém: "Por que é que Deus permitiu que os Seus fossem atribulados durante tanto tempo pela sede e pela falta de coisas?" - Como é evidente, para, como clementíssimo Pai, ensiná-los e com alguns golpes fazer voltar ao cumprimento do dever, depois de castigados, os que se tinham manchado com alguma nódoa de impureza. E nesta sede que experimentaram tomaram consciência do violento castigo com que os inimigos foram maltratados. É que, se aquela sede, circunscrita a um breve prazo de tempo, ocasionava tamanho tormento aos justos, que deveria pensar-se relativamente àquela sede que, durante tanto tempo e tão violentamente, torturava os inimigos como castigo do crime? Com efeito, a sede dos Hebreus era um castigo unido à paternal benignidade, ao passo que a sede dos inimigos era um violentíssimo suplício infligido pela severidade do mais potente dos reis. Daqui se conclui a distância que existe entre as incomodidades com que por vezes são atribulados os bons e os tormentos com que são torturados os ímpios. É que os bons são atribulados para, depois de provados, serem cumulados de galardões e prémios, ao passo que os perversos e obstinados no crime o são para serem destruídos pela funesta ruína.

Assim, os homens perversos eram castigados, não só os ausentes, após a partida de Israel, como também os presentes, antes de que Israel se separasse deles, e na funestíssima desgraça não podiam encontrar qualquer consolação, pois jaziam prostrados por uma dupla tristeza e angústia, uma vez que, por um lado, conservavam com gemidos e pranto a memória daquilo que tinham sofrido e, por outro, chegava aos seus ouvidos a fama da benignidade com que Israel tinha sido restaurado de modo maravilhoso. É que não só os angustiava a recordação dos males por que tinham passado, como também a observação dos benefícios que Deus neste mesmo tempo ofereceu aos Seus: é que a tortura da inveja é muitíssimo pungente, ferindo o espírito com uma cruel mordida e atribulando-o com uma moléstia perpétua. Esta tortura atormentava incessantemente os Egípcios, pois, quando eram atribulados por ardentíssima sede, os Hebreus saciavam alegremente a sede; quando estavam imersos em densíssimas trevas, os Hebreus gozavam de uma luz claríssima; quando eram retalhados pelas picadas dos insectos e pelas mordidas das brutas alimárias, nenhuma espécie de animal molestava os Hebreus; quando eram oprimidos por variadas aflições de enfermidades, os Hebreus, anchos com o vigor e saúde corporais, exultavam com o sofrimento da raça malvada. 
Itaque, cum cernerent Nilum cruore fluentem, conturbati sunt et, aquis exclusi, acerbissime uexabantur, ut animaduerterent nullum immanitatis scelus impunitum fore. Contra uero, tuis in solo aridissimo constitutis, praeter opinionem, aqua repente, incredibili copia, redundauit. Sic autem poterat explorate cognosci eos, qui a te seiuncti sunt, in summa etiam rerum copia semper egere, at eis, qui te ardenti studio sequuntur, nihil, in rerum etiam summa inopia, defuturum, [982] nec enim quidquam est uel magnitudine impietatis egentius, uel purissimae religionis sanctitate locupletius. Quid enim poterit deesse illis qui sunt bonorum omnium fonti perpetuo coniuncti?

Sed inquiet aliquis: "Cur suos Deus tamdiu siti et rerum paenuria uexari permisit?" - Vt eos uidelicet, tamquam clementissimus pater, erudiret et, qui erant labe aliqua impuritatis aspersi, castigatos, aliquot plagis ad officium reuocaret. In ea uero siti, quam experti sunt, intellexere quam acri supplicio fuerant hostes afflicti. Si enim sitis illa, modico tempore definita, tantum cruciatum piis afferebat, quid erit de illa siti, quae hostes in poenam sceleris diu atque uehementer excruciebat, existimandum? Hebraeorum enim sitis erat flagellum cum benignitate patria coniunctum, hostium uero sitis erat acerbum supplicium seueritate potentissimi regis irrogatum. Vnde colligitur quid inter asperitates rerum, quibus boni interdum afflictantur, et cruciamenta, quibus impii torquentur, intersit. Boni namque ideo uexantur ut probati mercede et praemio cumulentur, improbi uero et in scelere pertinaces ut exitio pestifero consumantur.

Ita perditi homines, et absentes post Israelis abscessum, et praesentes antequam Israel ab illis semigraret, poenis agitabantur, nec ullum poterant reperire in funestissima calamitate solacium, duplici enim maestitia et angore confecti iacebant, cum, et eorum, quae passi fuerant, memoriam cum gemitu et fletu retinerent, et fama benignitatis, qua Israel erat mirifice recreatus, ad aures eorum perueniret. Nam non solum eos angebat malorum, quae fuerant perpessi, recordatio, uerum etiam beneficiorum, quae Deus eo ipso tempore in suos conferabat, animaduersio: est enim inuidiae cruciatus acerbissimus, animum immani morsu lacerans et perpetua tabe conficiens. Quo quidem Aegyptii assidue torquebantur, cum enim essent ardentissima siti conflictati, Hebraei sitim iucundissime depellebant; cum essent in densissimis tenebris immersi, Hebraei clarissima luce fruebantur; cum illi insectorum spiculis et brutorum animantium morsibus laniarentur, nullum genus animantis Hebraeis molestiam exhibebat; cum uariis morborum doloribus essent oppressi, Hebraei, uiribus et sanitate corporis erecti, in dolore maleficae gentis exsultabant. 
E, para não nos referirmos a toda a espécie de castigos e benefícios, basta dizer que em toda a sorte de castigos com que eram atormentados os inimigos do nome de Deus, os benefícios opostos aos castigos exaltavam com maravilhoso contentamento os adoradores da santíssima divindade, e de ambos os modos Deus mostrava o Seu poder, por forma a destruir os inimigos e premiar os Seus com dádivas divinas. E com sinais admiráveis mostrava quão recto é o Seu juízo: castigando-os precisamente com as mesmas coisas com que $\mathrm{O}$ tinham ofendido a Ele. Com efeito, a virtude e nobilíssimas acções daquele a quem, exposto e abandonado, no princípio tinham julgado morto, e em cuja ruína se tinham rido (julgando-o vencido e sem futuro), no final acabaram [983] por olhá-las com admiração, ao verem que foram destruídos e violentamente atormentados, de um modo muito diferente àquele em que depois os justos o foram. É que aos justos acudiu-lhes de repente o benefício divino, ao passo que eles foram privados de toda a ajuda de Deus.

Ora, diante da vesânia e cegueira com que transferiram as honras devidas a Deus para serpentes, desprovidas de entendimento, e alimárias selvagens, e colocaram na morada de Deus monstros horríveis aos quais, atribulados por terrível superstição, imolavam vítimas sacrificiais, o Senhor lançou contra eles, como vingança de um atentado tão sacrílego, uma multidão de brutas alimárias, para que todos compreendessem que a essência do direito divino pede que qualquer pessoa seja punida mediante aquelas coisas através das quais ofendeu a majestade de Deus e a Sua santíssima religião. Algo que todavia aconteceu no princípio gradualmente, pois eram animais pequenos os que castigaram o sacrílego crime dos Egípcios.

É que a Tua mão omnipotente, que a partir de matéria informe modelou e aperfeiçoou o mundo, não tinha necessidade de forças recolhidas de outra parte para com elas destruir na primeira arremetida os inimigos do Teu nome. Com efeito, teria sido muitíssimo fácil impelir um grande número de ursos, ou violentos leões, ou feras desconhecidas e criadas com uma natureza nova, arrebatados pela fúria e expirando um incêndio de fogo pela boca e nariz, lançando horrendos rugidos com espessas nuvens de fumo e ameaçando com olhos fulgurantes, para que eles não só estraçalhassem os Egípcios com as suas mordidas, mas também os matassem com o susto da sua mera visão. E até sem quaisquer feras, feridos pelo castigo dos crimes, teriam sido destruídos pelo ímpeto de um único turbilhão, prostrados pela grandeza de uma tempestade violentíssima. Mas Tu, Senhor, governas tudo com conta, peso e medida, pois sempre detiveste um poder imenso, e quem há-de resistir ao vigor do Teu braço? É que todo o mundo aos Teus olhos é como um pequeno peso na balança, que quase nada conta para com ligeiríssima inclinação fazer pender um dos pratos, e é semelhante à gota de orvalho matutino, que se desfaz assim que cai na terra. Mas compadeces-Te de todos e a Tua natural bondade impede-Te de, quando alguém erra, imediatamente o castigares. E assim, a fim de concederes aos homens tempo para se arrependerem, adias a vingança para muito mais tarde, pois amas tudo que existe na natureza e não odeias nada do que criaste.

É que não foi o ódio, mas sim o amor, quem Te impeliu a criares todo o mundo e as suas partes. Com efeito, a não ser assim, de que maneira teriam podido ao cabo manter-se e estar estreitamente unidas, se Tu te tivesses mostrado hostil às coisas que 
Et, ne omnia suppliciorum et beneficiorum genera persequamur, in omni genere poenarum, quibus diuini nominis hostes affligebantur, contraria suppliciis beneficia numinis sanctissimi cultores laetitia mirabiliter efferebant, et in utraque ratione suam Deus potentiam declarabat, ut hostes euerteret et suos muneribus diuinis afficeret. In hoc uero quam rectum sit illius iudicium signis admirabilibus indicabat, quod rebus eisdem, quibus Deum offenderant, poenas exsoluebant. Nam illius, quem expositum et abiectum in principio exstinctum crediderant et in cuius oppressi atque desperati (ut opinabantur) exitio cachinnos sustulerant, tandem in fine uirtutem et praeclarissimas actiones [983] admirati sunt, cum se euersos esse cernerent et longe aliter, quam iusti postea fuerunt, uehementer excruciatos. Iustis enim caelesti beneficio subuentum repente fuit, illi uero fuerunt omni Dei subsidio destituti.

Pro sceleris autem amentia et caecitate qua honores, Deo debitos, ad serpentes, rationis expertes, et immanes belluas transtulerunt, et monstra horribilia in diuina sede posuerunt quibus, dira superstione conflictati, hostias immolabant, immisit in illos Dominus, in tam scelesti facinoris ultionem, brutorum animantium multitudinem, ut posset ab omnibus intelligi iuris diuini rationem postulare ut per ea quisque puniatur per quae Dei maiestatem sanctissimamque illius religionem uiolauit. Quod tamen sensim in principio factum est, minuta namque animantia poenas ab Aegyptiis nefarii sceleris expetiuerunt.

Nec enim omnipotens manus tua, quae mundum ex informi materia finxit et expoliuit, uiribus aliunde collectis indigebat, quibus hostes nominis tui primo impetu deleret. Facillime namque potuisset ursorum multitudinem, uel leonum truculentiam, uel belluas recenti condicione formatas et incognitas, iracundia furentes et ignis incendium ore atque naribus anhelantes, cum densa fumi caligine horrendos fremitus edentes et oculis fulgurantibus coruscantes incitare, quae non solum eos morsu dilacerarent, uerum et ipso aspectu perturbatos interimerent. Quin etiam sine ullis feris, scelerum poenis impulsi, unius turbinis impetu concidissent, magnitudine turbulentissimae tempestatis agitati. Verum tu, Domine, omnia mensura, numero et pondere moderaris, immensa namque potestas penes te semper exstitit, et brachii tui robori quis obsistet? Vniuersus enim mundus in conspectu tuo est instar momenti in statera, quae nullum ferme pondus habet ad alterutram lancem inclinatione leuissima deprimendam, et est similis guttae roris matutini, quae, cum primum in terram delabitur, euanescit. Verum enimuero omnium misereris et insita benignitate impediris quominus, ubi quisque delinquit, supplicium repente sumas. Itaque, ut hominibus resipiscendi spatium concedas, uindictam in longum tempus differs, omnia enim quae sunt in rerum natura diligis nihilque eorum, quae condidisti, odio prosequeris.

Non enim odium, sed amor te impulit ut omnem mundum illiusque partes exstrueres. Aliter enim, quo tandem modo cohaerere et permanere potuissent, si tu rebus a te designatis et constitutis infensus exstitisses? Verbum tuum est quod 
concebeste e criaste? A Tua palavra é que faz e conserva todas as coisas, é o Teu poder sempre presente quem por elas vela. Aquilo que não existe, assim que o invocas, ganha ser na natureza. Por conseguinte, o benefício da natureza e da forma encerra-se no poder da Tua voz. Portanto, como é que aquilo que não foi chamado por Ti, ou seja, aquilo que não foi formado pela potência divina da Tua palavra, será por Ti conservado, uma vez que não existe em absoluto? Por consequência, visto que Tu tudo criaste, segue-se como consequência que todas as coisas são boas, em conformidade com a essência da natureza nelas implantada, e assim não são desprezadas por Ti. É que todas as coisas são Tuas, ó clementíssimo Senhor, progenitor e amador das almas.

[984]

\section{CAPÍTULO XII}

É que o Teu espírito, incontaminado por qualquer mancha, está presente ao lado de todos, para aos poucos provar as quedas do erro e mostrar em que coisas delinquiram, e exortar a que, desviados de todas as infâmias, volvam os olhos para Ti, creiam que Tu és vida e salvação e tornem a colocar a esperança de todos os bens exclusivamente na Tua bondade. E, com efeito, odiaste os antigos habitantes desta terra santa devido ao grande número de crimes, pois hostilizas vivamente os pecados e travaste com eles incessante guerra; eles, porém, aplicavam grande diligência e trabalho a abomináveis feitiços, praticavam terríveis sacrifícios, privados de todo o sentimento de humanidade, degolavam monstruosamente os filhos, em honra dos falsos deuses, e devoravam as entranhas das carnes humanas em nefastos rituais, e os iniciados nos mistérios organizavam um sinistro banquete no meio do sangue que tinham derramado para aplacarem a Tua divindade (tão grande era a loucura nos homens). É que, como se Tu pedisses o sangue dos inocentes, assim eles arrastavam para o sacrifício os desafortunados homens, completamente privados do auxílio de todos, e, com o pretexto da religião, eram responsáveis por deploráveis assassínios e monstruosos actos de crueldade, pelo que decidiste destrui-los através dos nossos antepassados, para, depois de destruídos os ímpios, fundares uma colónia dos Teus filhos na terra, que acima de todas quiseste embelezar e acrescentar com os maiores benefícios.

Todavia, quiseste cuidar daqueles mesmos que tinham maquinado atentados tão monstruosos, e, por isso, lançaste vespas à frente do Teu exército, como uma espécie de soldados de vanguarda, para destruir os inimigos aos poucos, ainda que muito facilmente terias podido desbaratá-los em linha de batalha e submetê-los ao poder dos justos, ou exterminá-los com medonhos animais selvagens, ou, enfim, com o inflexível rigor da Tua inquebrantável palavra. Mas como, na punição dos maiores crimes, de tal forma atendes aos interesses do direito que também não deixas de dar grande importância à brandura e à misericórdia, até àqueles sacrílegos homens deste oportunidade para o arrependimento e foste-lhes desferindo desde o princípio golpes mais leves para, pelo medo, os desviares 
omnia conficit et conseruat, opeque praesentissima tuetur. Ea quae non sunt, ubi primum ea uocas, in natura consistunt. Naturae igitur atque formae beneficium tuae uocis potentia continetur. Quomodo igitur id quod a te uocatum minime fuerit, id est, quod uerbi tui numine non fuerit informatum, a te conseruabitur, cum nullo modo sit? Cum igitur omnia a te creata sint, consequens est ut omnia, secundum insitam naturae uim, bona sint, et ita a te minime negligantur. Omnia namque tua sunt, o Domine clementissime, animarum parens et amator.

[984]

\section{CAPVT XII}

Spiritus enim tuus, nulla labe incontaminatus, omnibus praesens adest, ut lapsos erroris paulatim coarguat et quibus in rebus deliquerint ostendat, et admoneat ut, a flagitiis omnibus auersi, in te respiciant, tibi uitam et salutem credant et bonorum omnium spem in sola tua benignitate reponant. Et enim antiquos huius sanctae telluris incolas odio propter scelerum multitudinem habuisti, peccatis enim es acriter infensus inexplicabileque bellum cum illis perpetuo suscepisti; at illi in taeterrimis ueneficiis multum operae et studii consumebant, dira sacrificia peragebant, omni sensu humanitatis spoliati, filios in honorem falsorum deorum immanissime iugulabant et humanarum carnium uiscera in sacris funestissimis deuorabant, mystaeque ex medio sanguine, quem fuderant, funestum epulum ut numen tuum (tanta erat in hominibus amentia) placarent instituebant. Quasi enim tu innocentium cruorem exquireres, ita illi miseros homines, omnium auxilio penitus orbatos, ad sacrificium pertrahebant, et, religionis obtentu, erant miserandae caedis immanissimaeque crudelitatis auctores, hos igitur delere, maiorum nostrorum opera, statuisti, ut, euersis impiis, in terram, quam tu praecipue maximis beneficiis ornare et amplificare uoluisti, filiorum tuorum coloniam deduceres.

Attamen illis ipsis, qui tam immania facinora conflauerant, consultum esse uoluisti, et idcirco ante exercitum tuum, quasi milites antesignanos, uespas immisisti, ut paulatim hostes exscinderes, cum eos facillime potuisses acie instructa profligare et in iustorum potestatem redigere, aut bestiis immanibus, uel denique inflexibilis uerbi rigida seueritate conficere. Cum uero, in summis sceleribus uindicandis, ita iuris rationem habeas ut magnas etiam lenitatis et clementiae partes suscipias, illis etiam scelestissimis hominibus paenitentiae locum dedisti, et leuioribus eos a principio plagis attriuisti ut illos ab insita prauitate deterreres: et hoc, cum scires genus illud esse insita impietate deprauatum et ab origine 
da inata perversidade: e isto, embora soubesses que aquela raça estava estragada por uma impiedade inata e desde a origem tinha mamado erros sediciosos juntamente com o leite e, com os exemplos dos antepassados e costumes domésticos e pelo prolongado hábito de pecar, de tal maneira a doença se tinha arreigado nos seus espíritos que, devido à sua contumácia, nenhum remédio os poderia curar. É que todo aquele povo há muito que estava ligado pela maldição e a tal ponto se obstinara nas infâmias que desprezava toda a espécie de ensino.

Ora, ainda que antevisses que isto haveria de suceder, todavia tal não Te impediu de fazeres a Tua obrigação e de os atraíres ao fruto da Tua misericórdia. Não adiavas o castigo por temeres alguém, ou por consideração pela pessoa de alguém, e misericordiosamente concedias-lhes o perdão dos pecados, se quisessem entrar no caminho da justiça. De facto, quem temerias, uma vez que tudo vale nada diante da Tua máxima e superior majestade divina? Quem te há-de pedir contas do que fazes? Quem te há-de criminar por destruíres os povos que fizeste, irritado com os seus crimes? [985] Ou quem, ao constituíres o tribunal, se há-de interpor, com o propósito de tomar a defesa dos homens perdidos e perversos? É que, além de Ti, não há nenhum Deus que cuide, dirija e governe todas as coisas, para que Te seja necessário demonstrar que não sentenciaste injustamente. Nem existe qualquer rei ou tirano que se atreva a levantar os olhos quando Tu condenas os homens criminosos, pois, como és justo, tudo governas justamente e nada é mais alheio ao Teu poder do que condenar o inocente. E, assim, deve assentar-se que, quando destróis os homens, quando aniquilas os impérios, quando acabas com uma raça, quando fazes esquecer por completo a lembrança e o nome de uma raça, procedeste assim irritado por crimes abomináveis. É que o Teu poder jamais se afasta da equidade, a qual, como é evidente, é o fundamento da própria justiça, e a Tua misericórdia, com a qual abraças com infinito poderio todas as coisas, faz que queiras perdoar a todos. E, deste modo, os que perecem, perecem por sua culpa, porque, com a sua inata perversidade e obstinação, não quiseram tornar-se quinhoeiros da Tua misericórdia.

Na verdade, quando os homens põem de lado o medo, não temem os Teus juízos, recusam crer em quão grande é o Teu poder e não querem compreender que a Tua potência divina não pode ser impedida de levar a cabo tudo o que quer, então com espantosas obras dás a conhecer a Tua potência, castigas com a máxima energia o atrevimento dos maus e severissimamente lhes reprimes a impudência. Por conseguinte, os homens maus é que Te desafiam, e o costume dos crimes e das infâmias, fortificado pela longa duração, faz que despertes a força da oculta severidade e arranques os rebentos da ruindade, para que não frutifiquem mais nem devastem a Terra. De facto, no que depende de Ti, reprimes o Teu poder e julgas com a máxima equidade, e governas-nos de tal modo que misericordiosamente perdoas a todos os que se aproximam de Ti em atitude suplicante. $\mathrm{E}$, desta forma, a justiça que exerces sobre os homens para protegê-los e desviá-los do crime encontra-se unida com a máxima misericórdia. Todavia, uma vez que a essência do direito assim o pede, quando é impossível reprimir-se de outra maneira o atrevimento dos maus, quando a salvação dos Teus o exige, está sempre à Tua disposição o poder, para com ele aterrares, quando quiseres, os adversários. 
turbulentissimos errores cum lacte suxisse et, maiorum exemplis et domesticis institutis et diuturna peccandi consuetudine, sic esse morbum in eorum animis inueteratum ut sanari nullo medicamento, propter eorum contumaciam, possent. Erat enim uniuersa illa natio iampridem exsecratione deuincta et ita in flagitiis obstinata ut omnem disciplinam respueret.

Quamuis autem id futurum prospiceres, non tamen id tibi fuit impedimento ne tuum officium faceres eosque ad clementiae tuae fructum alliceres. Non quod aliquem ueritus esses, aut alicuius personam respiceres, supplicium differebas, et eis peccatorum ueniam, si uellent in iustitiae uiam ingredi, clementer impertiebas. Quem enim metuas, cum omnia ante numen tuum maximum et precellentissimum pro nihilo sint? Quis a te eorum quae geris rationem repetet? Quis te in crimen uocabit, cum gentes, quas fecisti, eorum sceleribus infensus, [985] euerteris? Aut quis se, cum iudicium constituas, interponet, ut pro hominibus profligatis atque perditis causam dicat? Nullus enim Deus est, praeter te, qui omnia curet, regat et moderetur, ut sit tibi necesse demonstrare te non iniuste sententiam tulisse. Nec rex neque tyrannus est ullus qui oculos attollere audeat cum tu facinorosos homines iudicio peruertis, iustus enim cum sis, iuste omnia gubernas nihilque est a potentia tua magis alienum quam innocentem condemnare. Itaque statuendum est, cum homines euertis, cum imperia deles, cum genus exstinguis, cum ex omni memoria nomen gentis exterminas, id te fecisse sceleribus infandis irritatum. Potentia namque tua numquam ab aequitate seiungitur, nempe, quae sit ipsius iustitiae fundamentum, et clementia tua, qua omnia cum infinita potestate complecteris, facit ut omnibus ignoscere uelis. Itaque qui pereunt, sua culpa pereunt, eo quod insita prauitate et pertinacia fieri noluerint clementiae tuae participes.

At uero, cum homines metum deponunt, iudiciaque tua minime pertimescunt, et quanta uis potentiae tuae sit credere recusant, neque uolunt intelligere numen tuum teneri non posse quominus omnia quae uelit efficiat, tum potentiam tuam admirandis operibus ostendis, improborumque audaciam acerrime coerces et impudentiam seuerissime retundis. Improbi igitur homines te prouocant, et consuetudo scelerum et flagitiorum, diuturnitate confirmata, facit ut uim reconditae seueritatis excites et plantaria improbitatis euellas, ne plus nimio fructificent et terras uastitate consumant. Nam, quod in te est, potentiam tuam cohibes et iudicium cum summa aequitate moderaris, et ita nos gubernas ut omnibus, qui ad te suppliciter adeunt, clementer ignoscas. Itaque iudicium quod in hominibus tuendis et a scelere reuocandis exerces est cum clementia summa coniunctum. Attamen, cum id ratio iuris efflagitat, cum aliter improborum audacia coerceri nequit, cum id tuorum salus exposcit, praesto tibi semper est potentia, qua aduersarios, cum uelis, exterreas. 
Mas apresentaste uma claríssima prova da Tua integridade, para que o Teu povo compreendesse que convém juntar-se a justiça com a humanidade e a bondade. Com efeito, como a justiça se funda em Te termos sempre diante dos olhos, como o mais puro exemplo de toda a virtude e probidade, a nós oferecido para o imitarmos, e em vermos que nas Tuas obras nunca sobressai o rigor da justiça, antes primeiro avulta a admirável marca da misericórdia, claramente vemos que não pode ser justo senão quem se avantaja nos merecimentos da bondade e da misericórdia. Nisto decerto deste aos Teus filhos grande esperança de salvação, pois não duvidam de que, quando delinquirem, se se arrependerem da impureza e deixarem os pecados para voltarem ao cumprimento do dever, Tu os acolhes de novo sob a Tua protecção. É que, se não destruíste os inimigos dos Teus servos, culpados de crimes capitais, antes de adverti-los mais frequentemente e insistires muito para que não se precipitassem na eterna desgraça, e também protelaste a vingança [986] para que tivessem tempo e lugar que lhes permitisse execrar as infâmias da perversidade, com quão maior entusiasmo e desvelo se deve considerar que hás-de vir a cuidar dos Teus filhos, com cujos pais outrora fizeste aliança, a quem, com promessas dos máximos bens, alçaste à solidíssima esperança de imortalidade e com os quais também Te comprometeste, por santíssimo juramento, a alcançarem da Tua misericórdia a salvação?

Por conseguinte, quando nos castigas com golpes moderados, infliges inúmeras pancadas aos nossos inimigos, para que incessantemente pensemos na Tua integridade, ao tempo em que cuidadosamente observamos o castigo dos inimigos, estabelecido para eles por nossa causa, e para que, quando de novo somos julgados, sejamos arrastados para a esperança da Tua misericórdia. Precisamente daqui procedeu que aos homens injustos, que viviam ímpia e abominavelmente na mais completa ignorância da verdade, Tu os atormentavas com os instrumentos da própria execrável maldade com os quais se manchavam. De facto, embora tivessem podido, por caminho breve e directo, chegar ao conhecimento de Ti sem qualquer erro, desviaram-se completamente do caminho e, apartados do Céu, enquanto procuravam na Terra uma divindade, seguiram uma estrada muitíssimo desviada, iludidos como crianças insensatas, de tal maneira que, entre as trevas de tão grandes erros, não conseguiram nenhum resultado. Ao cabo, avançaram até tal grau de loucura que atribuíram também a divindade a animais que rastejam no chão e são violentos inimigos do género humano. Razão pela qual, para irrisão do erro inato, lhes infligiste golpes mais leves, como a crianças privadas de razão, de maneira a que não só fossem fortemente atormentados por aquelas mesmas bestas-feras que adoravam, mas também pelos insectos que desprezavam com a razão; suplício este, todavia, que, em comparação com os outros, que ficavam por suportar, se deveria considerar como uma brincadeira.

É que, os que não querem ser aconselhados acerca das suas obrigações através de golpes mais leves, acabam por sofrer um suplício pesadíssimo, estabelecido pelo rigor do juízo divino, que lhes cabe porque no crime mostraram uma enorme obstinação, conquanto não tivessem tido nenhuma desculpa para a injustiça. De facto, como, esmagados pelas desgraças, se lamentavam intensamente, e viam que eram castigados porque consideravam deuses aqueles por quem não podiam ser ajudados na calamidade, 
Verum tuae probitatis clarissimum documentum statuisti, ut intelligeret populus tuus oportere iustitiam cum humanitate et beneficentia coniungi. Cum enim in eo posita iustitia sit ut te semper ob oculos, ut absolutissimum totius uirtutis et probitatis exemplum, ad imitandum propositum, habeamus, et in operibus tuis uideamus numquam iuris seueritatem eminere, quin prius clementiae significatio mirabilis antecedat, clare cernimus iustum esse non posse nisi eum qui benignitatis et clementiae laudibus excellat. In quo quidem magnam spem salutis filiis tuis effecisti, nec enim dubitant, cum deliquerint, quin, si eos paenituerit impuritatis et fuerint a peccatis ad officium traducti, eos rursus in fidem recipias. Si enim hostes seruorum tuorum, capitalibus criminibus alligatos, non prius euertisti quam eos saepius admoneres et in eo nimis insisteres ne se praecipites in sempiternam miseriam darent, et uindictam etiam distulisti [986] ut tempus et locum haberent quo possent improbitatis flagitia detestari, quanto studiosius et diligentius existimandum est te curaturum ut filii tui, cum quorum patribus olim foedus percussisti, quos, summorum bonorum promissis, ad firmissimam spem immortalitatis erexisti, quibus etiam sanctissimo iureiurando fidem tuam obligasti, salutem e clementia tua consequantur?

Cum nos igitur moderatis uerberibus castigas, plagas innumerabiles hostibus nostris imponis, ut de probitate tua perpetuo cogitemus, dum hostium supplicium, illis nostri gratia constitutum, exacte perpendimus, et, dum rursus de nobis iudicium fit, ad spem misericordiae tuae rapiamur. Inde adeo factum est ut iniustos homines, qui in summa ueritatis ignoratione uitam impie ac nefarie degebant, ipsius exsecrandae improbitatis instrumentis, quibus se contaminabant, excruciares. Etenim, cum breui atque directa uia potuissent ad tui cognitionem sine ullo errore peruenire, a uia prorsus aberrauerunt et in uiam longissimam, a caelo deiecti, dum numen in terris exquirunt, se dederunt, more stolidorum infantium delusi, ita ut nullum exitum, in tantis errorum tenebris, inuenirent. Eoque tandem dementiae progressi sunt ut etiam animantibus humi repentibus et hominum generi uehementer infestis, diuinitatem tribuerent. Quocirca, ut pueris ratione carentibus, in erroris insiti ludibrium, leuiores plagas inflixisti, ut non modo ab illis ipsis belluis, quas colebant, sed etiam ab insectis, quae ratione contemnebant, acerbissime uexarentur: quod tamen supplicium, aliorum comparatione quae subeunda restabant, erat pro ludo reputandum.

Nam, qui leuioribus plagis de officio suo admoneri nolunt, grauissimum tandem supplicium perferent, diuini iudicii seueritate constitutum, quod illis contigit eo quod in scelere insignem contumaciam adhibuerunt, cum nullam iniustitiae excusationem habuissent. Cum enim, cladibus oppressi, grauiter ingemiscerent, et uiderent se sceleris poenas luere ob id quod deos opinarentur eos a quibus iuuari in calamitate non poterant, inter ipsos enim et eorum causa torquebantur, et ita, 
pois por causa deles e no meio deles eram atormentados, e deste modo, ensinados pelos males, compreenderam que era verdadeiro Deus quem diziam que ignoravam totalmente e por quem eram castigados, e não aqueles a quem, com impiedoso e sacrílego erro do entendimento, tinham adorado. Como eles, todavia, nem ensinados pelos golpes se arrependeram do erro enraizado, foi adequado que, ao cabo, caíssem na mais terrível desgraça e fossem castigados com a pena última. Deste modo foi enfim abatida a insolência do povo perverso e refutada a suma loucura dos que se arrogavam a suma sabedoria. É que a verdadeira sabedoria se funda no conhecimento de Deus.

\section{CAPÍTULO XIII}

Daqui se conclui que são completamente loucos todos os que, ou não receberam o conhecimento de Deus, ou ingrata e impiamente o rejeitaram. De facto, que pode existir de mais demente do que desprezar a luz oferecida e abraçar furiosamente as trevas? Mas os que ignoram Deus odeiam a luz, [987] abraçam as trevas, desprezam a verdade, recreiam-se com mentiras, fogem da vida e precipitam-se na morte e são arrastados para o suplício eterno com toda a paixão. É que, como a partir da diversidade e beleza das coisas facilmente teriam podido conhecer a sabedoria, poder e santíssima majestade do supremo Artífice, nem aplicaram o seu entendimento às coisas divinas, nem agradeceram ao melhor dos pais, e desprezaram as vozes de toda a natureza, que proclamavam os louvores de Deus. E assim, afastados do conhecimento da verdade e cegos pelo crime da impiedade, votando a desprezo o verdadeiro Deus, adoptaram deuses vãos, porquanto estabeleceram que eram deuses e governavam o mundo quer o ardor do fogo, quer a força dos ventos, quer a natureza do ar envolvente, quer a esfera celeste adornada pelas constelações, quer o ímpeto das águas, quer o Sol e a Lua e a aparência dos outros astros.

Ora, que é que impeliu ao engano os mofinos homens? Acaso a brilhante aparência e formosura? Mas compreendam quão mais formoso é o Senhor destas formas, pois Ele que as criou é o arquitecto da formosura toda, de tal maneira que nada pode ser apropriado, elegante e belo e, em virtude de uma espécie de graça inata, agradável aos olhos, a não ser aquilo a que Deus concedeu a beleza e graça. Acaso a força e poder destas coisas que referi provocou nos homens tão grande admiração que consideraram que lhes deviam conceder uma morada divina? Mas a partir da força delas era fácil concluir quão grande seria a força d' Aquele que as criou a todas e lhes repartiu a força de desempenhar a função que foi ordenada a qualquer uma! É que a partir da grandeza e formosura das coisas criadas conhece-se o poder do Criador e progenitor que moldou a natureza inteira. Todavia, estes homens não merecem ser tão criticados, porquanto pensavam que deviam procurar Deus com a máxima diligência e, como consagravam toda a inteligência à investigação da natureza, maravilhados com a contemplação das coisas celestiais, persuadidos pelos olhos caíram no erro de atribuírem a divindade àquelas coisas que para a vista eram o que de mais belo podiam contemplar. 
malis edocti, percepere uerum Deum esse quem se prorsus ignorare dicebant, a quo plectebantur, et non eos quos fuerant, errore mentis impio atque nefario, uenerati. Qui tamen, cum neque plagis eruditi ab inueterato crimine resilirent, consentaneum tandem fuit ut in dirissimam calamitatem inciderent et extremo supplicio mactarentur. Sic demum fuit perditae gentis insolentia compressa et summa eorum, qui sibi summam sapientiam arrogabant, amentia redarguta. Vera namque sapientia in Dei cognitione consistit.

\section{CAPVT XIII}

Vnde colligitur omnes qui Dei cognitionem aut non acceperunt aut ingrate et impie repulerunt esse dementissimos. Quid enim amentius esse potest quam lucem oblatam aspernari et tenebras furenter amplecti? At qui Deum ignorant lucem odio [987] persequuntur, tenebras amplexantur, ueritatem despiciunt, mendaciis oblectantur, uitam fugiunt et in mortem se praecipites dant omnique studio in supplicium sempiternum rapiuntur. Cum enim, ex uarietate et pulchritudine rerum facillime potuissent artificis summi sapientiam et potestatem sanctissimumque numen agnoscere, nec in opera diuina mentem intenderunt, nec optimo parenti gratiam habuerunt, uniuersaeque naturae uoces, quae Dei laudes enuntiabant, aspernati sunt. Itaque, a disciplina ueritatis auersi et scelere impietatis excaecati, Deo uero neglecto, inanes sibi deos asciuerunt, nam aut ignis ardorem, aut uentorum uim, aut aeris circumfusi naturam, aut orbem caelestem sideribus distinctum, aut aquarum impetum, aut solem et lunam et astrorum aliorum species, deos esse ab illisque mundum gubernari statuerunt.

Quid autem miseros homines in fraudem impulit? Num clara species atque pulchritudo? At intelligant quanto pulchrior sit earum formarum Dominus, is enim qui eas creauit est pulchritudinis totius architectus, ita ut nihil esse possit aptum, elegans atque decorum et oculis insita quadam uenustate iucundum, nisi cui Deus decoris et uenustatis causam attulerit. Num uis et efficientia earum rerum quas memoraui tantam hominibus admirationem commouit ut illas in sede diuina collocandas existimarent? At ex eorum ui facile erat concludere quanta esset uis illius qui eas omnes condidit et singulis uim efficiendi muneris quod cuilibet imperatum esset impertiuit! Ex magnitudine enim et pulchritudine rerum conditarum conditoris atque parentis numen, qui naturam uniuersam finxit, agnoscitur. Hi tamen minore uituperatione digni sunt, Deum enim sibi summo studio inquirendum existimabant et, cum omnem mentem in naturae peruestigatione contulissent, rerum caelestium admiratione defixi, in eum errorem, ab oculis persuasi, delapsi sunt ut iis rebus diuinitatem attribuerent quibus nihil ad aspectum pulchrius intueri poterant. 
Ainda que nem mesmo estes possam ser absolvidos de crime, pois os que tanto se avantajavam em inteligência que penetravam aquilo que se encontrava encoberto pela obscuridade da natureza e mergulhado em trevas, e aplicavam o entendimento à eternidade e percorriam com a imaginação as regiões celestes, de que modo não acabaram por descobrir muito mais facilmente o príncipe e soberano de todas estas coisas? De facto, como é que a totalidade das coisas pode manter-se sem um poder supremo, ou conservar-se a ordem sem um governo, ou compreenderem-se, sem as regras da sabedoria, os movimentos uniformes e delimitados por medidas certas, ou, finalmente, entender-se o acordo de toda a natureza em ordem à utilidade comum, sem o conhecimento do poder que a dispôs? Por conseguinte, era forçoso que os que observavam a natureza facilmente se apercebessem, através da inteligência, de que existe uma força sempiterna, progenitora da natureza, provida de imenso poder, suma sabedoria e infinita bondade, que deve ser venerada com toda a religiosidade e adorada com ardentíssimo desvelo de piedade. Por consequência, os que gastavam toda a vida em esquadrinhar a natureza, e mesmo assim não adoravam o verdadeiro Deus, $[\mathbf{9 8 8}]$ não podem ter nenhuma desculpa para o crime. Estes, todavia, foram enganados pela formosura e utilidade das coisas por forma a atribuírem as honras da divindade às coisas criadas por Deus.

Por outro lado, que cumpre dizer acerca da vesânia e desatino dos que julgaram que se deviam estabelecer honras divinas a obras humanas? Pôde acaso imaginar-se algo de mais funesto e lamentável do que a sua demência? Ou mostrar-se alguma esperança de salvação àqueles que vivem obstinadamente em tamanho desvario? É que, em lugar de Deus, adoram ouro e prata, fundido por obra do artífice e moldado com forma de animal, ou uma inútil imagem de pedra feita antigamente.

Vede o marceneiro. Com a madeira que talhou e desbastou com a enxó, esculpiu com saber a vasilha para os usos necessários da vida; em seguida, com as aparas de madeira faz o fogo para se alimentar com a comida, ou assada ou cozida. E de entre os sobejos, que vê que são inúteis, toma de um pedaço de madeira nodoso e torto, com o qual, durante o tempo livre que lhe sobrevem, alisando-o artisticamente com grande diligência e graças à prática prolongada que lhe ocasionou uma salutar despreocupação pela arte, talha uma forma semelhante a um homem ou a um animal qualquer, pinta-a de zarcão e aplica-lhe cores, de maneira a deleitar a vista de quem olha com uma aparência vermelha, e a revestir todas as manchas com os pigmentos aplicados, para que se não possam notar. Adapta, em seguida, um sítio e lugar adequados ao simulacro, coloca-o na parede, prende-o com ferro para impedir que balouce para um lado ou para outro: com o que com certeza está a dar uma claríssima prova da enorme fragilidade do mesmo, pois despende tanto trabalho em colocá-lo e guardá-lo porque vê que ele não pode ajudar-se a si mesmo. Com efeito, é uma estátua muda e necessita de uma ajuda externa para ser deslocada de um sítio para outro ou para, no caso de cair, se erguer. Então o mofino homem, dominado pela loucura, cego pelo crime e impelido pelo desvario do entendimento, lança-se aos pés do simulacro e, em atitude suplicante e submissa, dirige-lhe súplicas pelo aumento dos bens, por um casamento auspicioso e pela vida e saúde dos filhos. E não sente pejo em falar a uma estátua muda e vã e em lhe pedir a paz, a 
Quamquam nec hi quidem absolui scelere possunt, qui enim tantum ingenio ualebant ut ea, quae erant obscuritate naturae inuoluta et tenebris demersa, perspicerent, et mentem in aeternitatem intenderent caelestesque plagas cogitatione peragrarent, quo tandem modo principem et dominatorem earum rerum omnium non multo facilius inuenerunt? Quomodo enim potest rerum uniuersitas sine imperio consistere, aut ordo sine moderatione conseruari, aut motus aequabiles certoque numero definiti sine sapientiae praescriptis intelligi, aut denique naturae uniuersae ad communem utilitatem consensio, sine moderatoris qui eam concinnauit notitia comprehendi? Necesse igitur erat ut ii, qui naturam speculabantur, ingenio facile perciperent esse uim sempiternam, naturae parentem, immensa potentia et summa sapientia et probitate infinita praeditam, omni religione uenerandam et pietatis ardentissimo studio colendam. Qui igitur in natura peruestiganda omnem uitam consumebant, et tamen uerum Deum minime colebant, [988] nullam sceleris excusationem habere possunt. Hi tamen rerum pulchritudine et utilitate decepti sunt ut rebus a Deo conditis diuinitatis honorem tribuerent.

Quid autem dicendum est de illorum uesania et temeritate qui humanis operibus honores diuinos instituendos esse decreuerunt? Potuitne aliquid eorum dementia miserius atque funestius excogitari? Aut aliqua salutis spes illis, qui pertinaciter in tanto furore uersantur, ostendi? Aurum enim et argentum, artificis opera conflatum et animantis forma figuratum, aut inutilem imaginem ex lapide, opere antiquo perfectam, in Dei loco uenerantur.

Quin etiam faber materiarius. Ex ligno, quod secuit abraso et ascia dolato, uas ad usus uitae necessarios scienter exsculpsit; e rescissamentis deinde ignem facit ut cibo, uel asso uel elixo, saturetur. Ex reliquis autem, quas esse uidet inutiles, lignum tortuosum atque nodosum capit, ex quo summo studio, per otium quod nactus est, artificiose leuigato et usu diuturno, quem attulit illi artis salutaris incuria, formam facit ad hominis aut cuiusuis animantis similitudinem, illamque tingit minio et fucatis coloribus illinit, ut rubra specie intuentium oculos oblectet, et omnem maculam, ne possit animaduerti, adhibitis pigmentis obducat. Tum sedem et locum simulacro idoneum accommodat, id in pariete collocat, ferro reuincit, ne labare aliquam in partem possit: in quo quidem illi certe imbecillitatis summae clarissimum testimonium dat, enim tantam operam in eo collocando et continendo ponit, quia uidet illud sibi ipsi opitulari non posse. Signum enim mutum est et, ut a loco in locum moueri aut abiectum erigi possit, indiget ope extrinsecus allata. Tum miser homo, uexatus amentia et obcaecatus scelere furoreque mentis instinctus, se ad simulacri pedes abiicit illique, suppliciter atque demisse, pro possessionibus accessione cumulandis, pro nuptiis auspicio felici coniungendis, pro filiorum uita et incolumitate uota facit. Nec eum pudet statuam mutam et inanem alloqui et ab ea, quae nihil omnino sentit, pacem petere. $\mathrm{Ab}$ infirmo signo sanitatem flagitat, a mortuo uitam postulat, ab egentissimo ut 
ela que é completamente privada de sentidos. Pede a saúde a uma imagem frágil, roga vida a um morto, suplica à mais pobre das coisas que lhe dê ajuda. Quando empreende alguma jornada, implora o auxílio de quem não pode caminhar. Finalmente, pelo lucro, para concluir com felicidade uma obra e pelo bom êxito dos negócios presta-se a adorar aquilo que é completamente privado de sentidos, de movimentos e actividade de mãos.

\section{CAPÍTULO XIV}

Ora, outro, a ponto de expor-se à navegação, quando se prepara para atravessar o imenso mar e as terríveis vagas, invoca um lenho muito mais frágil do que aquele em que viaja. É que a nave, embora seja feita de madeira, todavia foi construída com a razão, e não pela rematada loucura e demência. De facto, foi projectada pelo desejo de lucro; veio depois o artífice para construi-la. Mas ela segue uma próspera viagem e é levada até ao porto que demanda não graças à inteligência, força ou artifício dos homens, mas graças à Tua prudência, ó Pai supremo. É que Tu patenteaste aos navios a passagem no mar profundo e abriste no meio das ondas uma rota segura, para mostrares que nada está rodeado de perigos tão grandes, nem cercado por tão grandes monstruosidades, [989] nem enleado por tão grandes dificuldades das quais Tu não arranques os homens a quem queres preservar. E, assim, homens, até inteiramente privados de conhecimentos náuticos, perdendo o medo, embarcam e percorrem todos os litorais, pois não quiseste que existisse nenhuma obra Tua que não fosse de utilidade para os homens. É que não criaste nada ao acaso e sem causa; não deixas que nenhuma forma se imobilize na inactividade; finalmente, nada fizeste que não esteja ao serviço dos humanos. Por isso afastas os homens do medo, para que se atrevam a confiar a vida a uma exígua embarcação e expor a cabeça a cruéis tempestades, superadas as quais alcançam a salvação mediante a fraqueza.

De facto, desde o princípio, quando destruíste os gigantes, confiantes na sua força inata, enlouquecidos pela intolerável soberba e que com excessiva insolência se revoltaram com desprezo pela divindade, e quando submergiste sob as águas aquela raça impura, a esperança de restaurar e renovar o mundo inteiro fundou-se numa jangada, dirigida pela Tua mão. Foi aquele o único refúgio do género humano, no meio de uma tão grande calamidade e destruição; naquela embarcação conservaram-se os restos, para que com as sementes deles tornasse a existir a nova raça; Tu, com a Tua sabedoria, dirigia-la e conservava-la com o Teu poder para a multiplicação da descendência do género humano. $\mathrm{E}$, deste modo, aquele lenho representava o símbolo e a imagem do outro lenho, que há-de trazer a salvação aos homens. Oh lenho que merece ser exaltado com os maiores louvores de todos, através do qual há-de nascer o esplendor da justiça! É que ele há-de afastar a sensualidade; há-de desviar a ira divina; há-de ligar, com o amor sumo, Deus com os homens piedosos, que nas vagas e procelas desta vida confiam a salvação à bondade divina. 
sibi ferat auxilium precatur. Cum instat aliquod iter, illius opem implorat quod ingredi nequit. Pro lucro denique, pro opere feliciter absoluendo, pro prospero rerum exitu illud, in quo nullus omnino sensus uiget, nullus motus, nulla manus industria, ueneratur.

\section{CAPVT XIV}

Porro autem alius, se nauigationi commissurus, cum se comparat ut uastum mare immanesque fluctus transeat, lignum inclamat eo quo uehitur longe fragilius. Nauis enim, quamuis e ligno facta sit, ratione tamen et non extremo furore et dementia exstructa fuit. Cupiditas enim lucri illam excogitauit; ars deinde fabrilis accessit ut eam aedificaret. Sed illa nec hominum ingenio, neque robore, nec artificio, sed prudentia, o Pater summe, tua, cursum secundum tenet et in portum, quem petit, inuehitur. Tu enim in mari profundo nauibus transitum praebuisti et in mediis fluctibus securum iter aperuisti, ut ostenderes nihil esse tantis periculis cinctum, neque tantis monstris, [989] obsessum, neque tantis difficultatibus implicatum ex quo tu non homines, quos seruare uelis, eripias. Itaque homines, etiam totius nauticae artis expertes, naues, deposito metu, conscendunt omniaque litora peragrant, nullum enim opus tuum exstare uoluisti quod non aliquid utilitatis hominibus afferret. Nihil enim temere et sine causa molitus es; nullam formam sinis otio torpescere; nihil denique est a te constitutum quod non usibus humanis seruiat. Idcirco metum depellis hominibus, ut audeant exiguo ligno uitam credere et saeuis tempestatibus caput obiicere, quibus superatis, fragilitate salutem adipiscuntur.

Etenim a principio, cum gigantes, insito robore confidentes et intoleranda superbia furentes et ad numinis contemptionem nimis insolenter erectos, euerteres, et aquis impurum illud genus obrueres, mundi totius instaurandi atque renouandi spes in rate constitit, tua manu gubernata. Illud fui unicum, in tanta calamitate et interitu, generis humani perfugium; in illa naui reliquiae conseruatae sunt, ex quarum semine rursus nouum genus exsistere; illam tu sapientia tua dirigebas et ad generis humani prolem multiplicandam numine tuo conseruabas. Itaque lignum illud alterius ligni signum et imaginem gerebat, quod est salutem hominibus allaturum. O lignum summis omnium laudibus efferendum, per quod iustitiae splendor exorietur! Illud enim libidinem resecabit; iram diuinam auertet; Deum cum hominibus piis, qui salutem, in huius uitae fluctibus atque procellis, probitati diuinae committunt, amore summo coniunget. 
Mas regressando com o fio do discurso ao ponto onde nos desviámos: foi a deliberação e senhorio divinos que estiveram na origem da navegação; e simboliza uma outra navegação muito mais afortunada; e o uso e costume da navegação é dirigido pela misericórdia de Deus. Daqui resulta manifesto que não é execrável e detestável aquele lenho com que os homens cruzam os mares; aquele lenho ou madeiro, porém, ao qual os homens perversos e perdidos pedem a felicidade da navegação, uma vez que é instrumento da mais rematada impiedade, deverá ser destruído pela mais terrível maldição. Tão grande desvario cegou os entendimentos dos homens que adoravam como Deus aquilo que foi feito por obra do homem e pediram a saúde a um lenho detestável? Por conseguinte, o próprio lenho e quem faz uma imagem do lenho acabarão por ser completamente destruídos pelo juízo de Deus; o artífice que esculpiu a imagem, porque fez um funestíssimo ídolo, que arrastaria tantas desgraças, e a imagem, porque, embora fosse corruptível, usurpou o santíssimo nome de Deus. É que Deus é por igual inimigo da impiedade e do autor da impiedade, e assim a obra embelezada pelas mãos ímpias e o próprio artífice sofrerão o merecido castigo. Por esta razão a divindade castiga os simulacros dos pagãos.

Com efeito, ainda que os homens, a partir da perfeição do mundo criado por Deus, tivessem podido compreender a força, potência, desígnio e bondade do entendimento divino e adorar com a devida piedade a Sua eminentíssima natureza, entregaram-se com todo o espírito ao execrável crime da impiedade, para maquinarem a destruição das almas e embaraçarem os pés dos simples com funestos laços. É que o início do sacrílego atentado pelo qual os homens [990] abandonaram Deus consistiu no culto dos simulacros e a invenção deles trouxe consigo a perdição da vida. De facto, nem existiu desde o princípio nem há-de permanecer para sempre na vida comum. Ora, valerá a pena observar qual foi o princípio desta cegueira tão funesta, pois invadiram a Terra a ambição e vão desejo de glória em que o género humano começou a abrasar-se de modo desmedido.

Ora, atalhou-se a esta doença e desvario com uma duração breve da vida, porquanto, se tivesse sido concedida aos homens uma existência mais longa, a insolência e orgulho dos homens ter-se-iam mostrado insuportáveis. Mas o desatino e arrogância inatos nem sequer com a morte se puderam reprimir. E, assim, os homens lembraram-se de consagrar as imagens dos mortos, para que o seu nome, que a morte extinguira, vivesse durante muito mais tempo na boca dos seus semelhantes. Por consequência, o pai, ao ficar prostrado pelo luto e desolação, por causa do filho arrebatado por uma morte precoce, e ao ver-se atribulado por uma dor lancinante, encontrou este monstruoso refrigério para a sua angústia e tormento: moldou uma imagem semelhante ao filho e colocou-a num santuário e, deste modo, adorou como deus quem há pouco era homem mortal, ligou toda a família com o mesmo vínculo de uma religião absurda e instituiu mistérios e rituais abomináveis e cerimónias bárbaras. Em seguida, o ímpio atentado, corroborado com o passar do tempo, começou a ter força de lei, de tal forma que, por ordem dos príncipes, aquele que desprezasse este costume deveria sofrer o castigo da impiedade, como se sacrilegamente tivesse violado a religião. De facto, com horrível superstição, os tiranos 
Sed, ut eo redeat oratio unde deflexit, nauigandi initium a diuino consilio et imperio ductum fuit: signumque alterius nauigationis multo felicioris expressit; et nauigationis usus et consuetudo Dei clementia gubernatur. Ex quo liquet non esse lignum quo homines maria transmittunt exsecrabile et detestandum; at lignum illud, a quo profligati atque perditi homines nauigandi felicitatem petunt, cum sit extremae impietatis instrumentum, erit exsecratione dirissima consumendum. Tantusne furor hominum mentes excaecauit ut, quod est hominis opere factum, pro Deo colerent et a ligno detestabili salutem postularunt? Lignum igitur ipsum et qui ex ligno signum facit, Dei tandem iudicio funditus interibit; artifex quidem qui exsculpsit imaginem, quia portentum funestissimum, quod tantum calamitatis inueheret, imago uero, quia, cum corruptibilis esset, Dei sanctissimum nomen obtinuit. Ex aequo enim infensus est Deus impietati et impietatis architecto, itaque opus impiis manibus expolitum et opifex ipse debitum supplicium subibunt. Idcirco numen diuinum in simulacra gentium animaduertet.

Nam, cum, ex mundi a Deo conditi perfectione, potuissent homines uim, numen, consilium, probitatem diuinae mentis intelligere praecellentissimamque illius naturam debita pietate uenerari, ad exsecrandum impietatis scelus tota mente conuersi sunt, ut animis ruinae periculum struerent et simplicium pedes laqueis pestiferis impedirent. Initium enim scelestissimi facinoris, quo homines a Deo [990] defecerunt, in cultu simulacrorum consistit illorumque inuentum uitae pestem comparauit. Nec enim ab initio exstitit nec in perpetuum in communi uita manebit. Quod autem fuerit huius tam funestae caecitatis initium operae pretium erit attendere, ambitio enim et inanis gloriae cupiditas, qua genus hominum flagrare immodice coepit, in orbem terrarum inuasit.

Huic autem morbo et insaniae celeri e uita discessu occursum fuit, si enim longior uita hominibus concessa fuisset, hominum insolentia et fastus minime ferendus exstitisset. Verum nec morte quidem potuit insita temeritas et arrogantia coerceri. Itaque fuit ab hominibus excogitatum, quo diutius eorum nomen, quod mors exstinxerat, in ore hominum uersaretur, ut mortuorum imagines dedicarent. Pater igitur, cum propter filium, immatura morte sublatum, in luctu et squalore iaceret, eximioque dolore cruciaretur, hoc immanissimum reperit angoris et cruciatus alleuamentum: imaginem ad filii similitudinem effinxit et in sacrario collocauit, et ita mortalem nuper hominem pro Deo ueneratus est, uniuersamque familiam eodem absurdae religionis alligauit et mysteria et sacra nefaria et caerimonias diras instituit. Deinde facinus impium, temporis diuturnitate confirmatum, uim legis habere coepit, ita ut illi, qui id institutum negligeret, esset impietatis poena, quasi religionem nefarie uiolasset, principum imperio sustinenda. Tyranni enim exsculpta simulata, superstione dira consecrabant et ad eorum cultum homines comminatione acerrima compellebant. 
consagravam as imagens esculpidas e, com violentíssimas ameaças, obrigavam os homens a adorá-las.

Sobreveio a adulação, que encerra em si o manancial de todas as infâmias. É que, os homens, ao desejarem alcançar as boas graças de algum príncipe ausente e ao não conseguirem, devido à ausência, tributar-lhe as máximas honrarias, tratavam de ter diante dos olhos uma reprodução dele, para lhe dirigirem súplicas, o elogiarem, o adularem, lhe pedirem favores e instituírem para a imagem do próprio rei aquelas honras que julgavam que deviam ser atribuídas ao rei em pessoa. Por conseguinte, naquela imagem (tão grande e tão cego era o desejo de adular!) divisavam o príncipe ausente, como se estivesse presente, e atribuíam-lhe a divindade.

Todavia, entre os ignorantes mais fez avançar este desvario, tendente a estabelecer a falsíssima religião, a arte consumada dos que aplicavam todo o cuidado a, quando copiavam a figura daquele a quem sobremaneira desejavam agradar, esforçarem-se por conferir a máxima formosura à sua imagem reproduzida. É que estas artes não foram tão cultivadas desde o princípio que cativassem os olhos dos homens, mas, como a ambição incentivou a aplicação e cada novo artista acrescentava algo à arte com que superava a graça e formosura da obra mais antiga, acabou por acontecer que nada parecia ser mais ilustre do que aquelas obras. Ora, a multidão, impressionada pela graça e beleza da obra, chegou a tanto que decidiu que deveria adorar com honras divinas, como divindade celestial, aquele a quem pouco antes conhecera provido de honras humanas. Por conseguinte, esta descoberta foi perigosa para a perdição, pestilencial para a ruína da vida, insidiosa para iludir os espíritos com uma falsa aparência de religião, e dela manaram inumeráveis crimes. [991] É que, assoberbados pela violência da desgraça ou oprimidos pela crueldade da tirania, os homens perderam a liberdade e, imbuídos de erros perniciosos, chegaram a tal ponto que deram a pedras e madeiros aquele nome santíssimo que não se pode declarar com nenhumas palavras nem repartir com alguma natureza, ainda que esta se avantaje em dignidade celestial.

E não lhes basta desviarem-se completamente do conhecimento de Deus e apartarem-se para muitíssimo longe do caminho da verdade, mas também, embora estejam envoltos nas pestilenciais guerras de todas as infâmias e crimes, designam por Paz aquela execrável condição. Com efeito, celebram abomináveis rituais com o assassínio dos filhos; ou perpetram atentados em mistérios secretos; ou, precipitando-se na vesânia e loucura, sob pretexto de religião, ocupam os dias festivos com outras cerimónias, celebradas com divertimentos impudentes e excessos de comida e bebida, para que nas suas vidas nada exista de puro nem nada de inviolado nos seus casamentos. E, assim, ou através de ciladas matam-se uns aos outro, ou inquietam-se mutuamente com enorme tristeza e dor, violando as mulheres dos outros. Todos erram indiscriminadamente por toda a espécie de voluptuosidades e não existe crime algum com que não se contaminem, usando da maior audácia e impudência. Vivem no sangue e no assassínio; roubam; furtam; maquinam embustes; corromperam-se com toda a sorte de depravações; são completamente desleais; não têm qualquer amor pelos homens; não respeitam nenhum pacto de amizade; provocam 
Accessit adulatio, quae continet in se flagitiorum omnium seminarium. Cum enim homines ab aliquo absente principe gratiam inire cuperent et eum honoribus summis prosequi, propter absentiam, non possent, id curabant ut expressam illius imaginem ante oculos haberent, ut illi supplicarent, illius laudes extollerent, illi adularentur, ab illo beneficia postularent et eos denique honores imagini ipsius regis instituerent, quos ipsi regi tribuendos esse decernebant. Absentem igitur principem in illa imagine (tanta erat adulandi et tam caeca cupiditas!), ut praesentem, intuebantur illique diuinitatem tribuebant.

Prouexit tamen magis hunc furorem apud imperitos, ad fallacissimam religionem sanciendam, summum artificium eorum qui imagines faciebant, quorum omnis cura in eo consumebatur ut, cum faciem illius, cui placere ualde cupiebant, exprimerent, illius similitudinem ad summam pulchritudinem reuocare niterentur. Artes enim hae a principio non ita fuerant cultae ut oculos hominum tenerent, cum uero ambitio studium incitauisset et quilibet aliquid ad artem addidisset quo antiquioris operis elegantiam et pulchritudinem superaret, effectum tandem est ut nihil esse uideretur operibus illis illustrius. Multitudo autem, operis elegantia atque uenustate commota, eo progressa fuit ut quem paulo ante hominem humanis honoribus affectum nouerat, diuinis, ut numen caeleste, sibi colendum statueret. Fuit igitur inuentum hoc ad perniciem lubricum, ad euersionem uitae pestiferum, ad animos imperitorum, ficta specie religionis decipiendos, insidiosum, ex quo innumerabilia scelera proruperunt. [991] Homines enim, ui calamitatis afflicti aut immanitate tyrannidis oppressi, libertatem amiserunt et, erroribus perniciosis imbuti, eo progressi sunt ut nomen illud sanctissimum, quod nullis uerbis explicari nec cum aliqua rerum natura, quamuis illa caelesti dignitate praecellat, communicari potest, lapidibus atque lignis imponerent.

Neque satis habent a Dei cognitione prorsus aberrare et longissime a uia ueritatis auerti, sed etiam, cum sint omnium flagitiorum scelerumque bellis pestiferis impliciti, statum illum exsecrandum Pacem nominant. Aut enim sacra nefaria cum filiorum caede procurant; aut in clandestinis mysteriis facinora conflant; aut furore et amentia praecipites, obtentu religionis, aliis ritibus, cum iocorum petulantia epularique licentia et ebrietate celebratis, dies festos agitant, ut nihil sit in eorum uita purum neque in nuptiis aliquid inuiolatum. Itaque alius alium uel per insidias interimit, uel uxorem illius uiolando, ingenti maestitia et dolore conturbat. Omnes sine ullo discrimine per omnia libidinum genera uagantur nec ullum scelus est quo se non, cum summa audacia et impudentia, contaminent. In sanguine atque caede uersantur; furantur; latrocinantur; dolos concinnant; insidias intendunt; omnibus corruptelis deprauati sunt; nulla est in illis fides; nulla hominum caritas; nullum amicitae foedus; tumultus excitant; falso testimonio proximum circumueniunt; bonorum ordinem perturbant; 
a rebelião; acabrunham o próximo com falsos testemunhos; perturbam a ordem dos bons; esquecem-se dos benefícios; mancham as almas com o crime; devido à impudente sensualidade contra os lares alheios, tornam incerta a paternidade da prole dada à luz; infringem as leis do casamento; não trepidam diante de nenhum crime de adultério nem de nenhuma infâmia de amor impuro.

Daqui se conclui que a medonha superstição, pela qual os homens, desprezada a santíssima religião de Deus, transferiram as honras divinas para abomináveis simulacros, foi para os homens o início e a causa de todos os males, e que o mesmo crime se refinou com o desenvolvimento do mesmo erro e, com abominável acréscimo, foi aumentando, de tal maneira que parece que de forma alguma já nada mais se lhe pode aditar. Com efeito, ou, quando se divertem, estão loucos, ou, quando vaticinam, enganam-se, ou, no trato da vida, transgridem todas as leis, ou, com perjúrio, ofendem sem qualquer escrúpulo a santíssima majestade de Deus. É que, como se apoiam em simulacros totalmente vãos, não podem ser levados a crer que o castigo de Deus os ameaça. Por conseguinte, acabarão por sofrer o merecido castigo de dois delitos, pois foram tão dementes que, desprezando Deus, fizeram sacrifícios a mudos simulacros, e mostraram-se tão atrevidos que violaram a santidade dos juramentos. De facto, no divino juízo o poder dos que se comprometeram mediante juramento não há-de livrar de culpa os sacrílegos, mas as penas do crime hãode perseguir os que perpetraram um atentado tão ímpio.

\section{CAPÍTULO XV}

Por conseguinte, assim como são dementes e loucos e se encontram oprimidos pelas ruínas da derradeira miséria e totalmente rodeados pelas trevas todos os que abominável e impiamente se afastaram de Deus para adorarem divindades falsas, fazerem sacrifícios a repugnantes monstruosidades e colocarem num lugar divino imagens de brutos animais, [992] assim, Senhor, devem ser considerados sábios, felizes e bem-aventurados os que Te temem, adoram, desejam, amam e só em Ti têm todas as esperanças, todo o refúgio dos trabalhos e toda a protecção da vida. De facto, que há de mais bem-aventurado do que ter conhecimento de Deus, contemplar sempre Deus, ser defendido pela invencível protecção de Deus, ser socorrido pela contínua ajuda de Deus pessoalmente presente? É que Tu, Senhor, és totalmente misericordioso e verdadeiro, de tal maneira que jamais a Tua bondade pode faltar nem vacilar a Tua lealdade. Por conseguinte, só a Ti confiamos e entregamos a nossa vida e salvação, pois se o Teu poder, que nenhuns limites podem circunscrever, não estivesse unido com admirável bondade e lealdade, restava que a lembrança do Teu nome aterrorizar-nos-ia, esmagados pela consciência das infâmias, e não existiria nenhuma consolação que nos desviasse da desesperação. Mas não é assim, pois a força do Teu poder não é superior à luz da Tua misericórdia. E, assim, uma vez que estás provido de infinita misericórdia, somos incitados a esperá-la; uma vez que a Tua verdade é constante e eterna, alentados pelas Tuas promessas, prometemo-nos a salvação; uma vez que não és inclinado à ira (pois não lanças os dardos do Teu rigor logo que 
beneficiorum memoriam deponunt; animas scelere contaminant; proiecta in aedes alienas libidine, incertam cognationem editae prolis efficiunt; connubiorum iura perrumpunt; nullum adulterii crimen, nullum ueneris impurae flagitium reformidant.

Vnde colligitur diram superstitionem, qua homines, Dei sanctissima religione neglecta, honores diuinos ad infanda simulacra transtulerunt, initium et causam omnium malorum rebus humanis attulisse, eiusdemque erroris incremento fuisse idem scelus conclusum et additamento nefario cumulatum, ita ut iam ad illud addi nihil omnino posse uideatur. Aut enim, cum oblectantur, insaniunt, aut, cum uaticinantur, fallunt, aut, in uitae cultu, omnia iura uiolant, aut facillime periurio Dei sanctissimum numen offendunt. Cum enim inanissimis simulacris innitantur, adduci non possunt ut credant sibi a Deo supplicium impendere. Vtriusque igitur sceleris debitas tandem poenas exsoluent, nam tam sine mente fuerunt ut, Deo neglecto, mutis simulacris immolarent, et tam audaces exsisterunt ut iurisiurandi religionem uiolarent. In diuino enim iudicio non eorum, qui iusiurandum dederunt, potentia scelestos crimine liberabit, sed sceleris poenae eos, qui tam scelestum facinus susceperunt, insequentur.

\section{CAPVT XV}

Vt igitur omnes qui a Deo nefarie et impie desciuerunt ut commenticia numina uenerentur, et taeterrimis monstris immolent, et imagines brutorum animantium in diuino statu collocent sunt furiosi et insani extremaeque miseriae ruinis oppressi et tenebris undique circumfusi, [992] qui te, Domine, metuunt, colunt, admirantur, amant et in te solo habent omnes spes, omne laborum perfugium, omnia praesidia uitae constituta, sapientes, felices atque beati existimandi sint. Quid enim beatius quam Dei notitiam habere, Deum semper intueri, Dei inuicto praesidio muniri, Dei praesentis ope perpetuo sustentari? Tu enim, Domine, clementissimus, tu uerissimus es, ita ut neque benignitas tua deficere neque fides labare umquam possit. Tibi igitur soli uitam et salutem nostram credimus et committimus, si enim potentia tua, quae nullis terminis circumscribi potest, non esset cum admirabili benignitate et fide coniuncta, reliquum erat ut memoria nominis tui nos, flagitiorum conscientia oppressos, formidine perterreret, nec ullum esset solacium quod nos a desperatione reuocaret. Verum non ita est, nec enim potentiae tuae uis clementiae lumen superat. Itaque, cum infinita clementia praeditus sis, ad spem illius excitamur; cum ueritas tua constans et sempiterna sit, promissis tuis erecti, salutem nobis pollicemur; cum non sis ad iram procliuis (non enim simulatque delinquimus seueritatis tuae tela iacis, sed paenitendi spatium concedis), confidimus minime nobis aditum ad clementiam tuam interclusum iri. 
delinquimos, mas concedes um prazo para o arrependimento), confiamos em que não nos há-de ser fechado o acesso à Tua misericórdia.

Quem poderá duvidar da Tua clemência, ao ver que todas as coisas são governadas pela Tua extraordinária misericórdia? De facto, os que desfrutam da glória sempiterna, alcançaram aquele estado muitíssimo bem-aventurado graças à Tua misericórdia; os homens, que permanecem nesta vida, gozam da luz da Tua misericórdia e são frequentemente atraídos para o cumprimento do dever. Os que padecem os castigos dos crimes, sofrem tormentos muito menores do que tinham merecido. O firmamento, a Terra, os astros, os seres vivos e, em suma, tudo o que abarca o âmbito do céu, que criaste para a conservação dos homens, fazem que a Tua singular misericórdia seja merecedora dos máximos e eternos louvores. Por conseguinte, que nos cumpre fazer, a nós a quem deste preferência em acolher sob a Tua protecção? Imaginaremos que nos há-de vir a faltar a Tua misericórdia, com a qual vemos que todas as coisas são amparadas? Seguramente que não. É que, se pecarmos, mesmo assim somos Teus; reconhecemos o Teu poder e majestade, por tal forma que compreendemos que ser-Te-á muito fácil apagar a mancha do nosso crime e restituir-nos ao estado de que caímos. Ora, não pecaremos se nunca perdermos esta preocupação que incessantemente deve ocupar as nossas almas, ou seja, que nós somos Teus e que não pode imaginar-se nada de mais infame do que serem oprimidos pelas trevas dos pecados os que se encontram ligados à luz suprema, e serem abalados por alguma perturbação os que estão rodeados pela Tua protecção, e serem manchados por alguma nódoa de impureza os que contemplam a suma pureza.

Com efeito, a justiça, completa em todas as suas partes, encerra-se no conhecimento de Ti, e a raiz da imortalidade é abarcar com o pensamento o Teu poder. É que, quem pensar incessantemente acerca de Ti, quem contemplar com entendimento puro a Tua majestade, a Tua bondade, o Teu esplendor e a Tua formosura, nunca será impelido ao engano de atribuir a divindade a um quadro do maior pintor, desenhado com pestilencial artifício e tingido com cores variadas, tal como fazem os homens loucos e ignorantes. É que, ao olharem para uma aparência, artificiosamente figurada com traços no quadro, [993] ornada com sombras e relevos e intervalos, e pintada com pigmentos completamente fingidos, a tal ponto ficam pasmados que pensam que aquela obra sem fruto deve ser religiosamente adorada. Que poderá existir de mais ruim do que isto para o eterno desdouro e infâmia? Os homens perversos e depravados recreiam os olhos numa vã pintura; desejam contemplar a imagem de um homem morto privada de espírito; o amor por ela apodera-se deles; por fim, consideram que devem dirigir-lhe súplicas. Com esta disposição de espírito se tornam amadores daquela pestífera nulidade, de tal maneira que desviam os olhos da verdadeira formosura e fixam a atenção numa falsa aparência de beleza fingida, e, sem qualquer fruto, por causa do desejo da imundície que o homem impuro espalhou pelos quadros, vêem-se abandonados pelo entendimento e capacidade crítica. Dignos, sem dúvida, de que os recreie a esperança da nulidade e da mentira, dignos, sim, de engano capital, não só os que pintam quadros desta espécie, como também os que se abrasam no desejo e amor deles e, enfim, os que consideram que 
Quis poterit de clementia tua dubitare, cum cernat a te omnia insigni misericordia gubernari? Qui enim gloria sempiterna florent, statum illum beatissimum misericordia tua consecuti sunt; homines, qui manent in hac uita, clementiae tuae luce fruuntur et ad officium frequenter alliciuntur. Qui poenas sceleris luunt, multo minora cruciamenta quam fuerant meriti patiuntur. Caelum et terra, sidera, animantia et omnia denique quae caeli ambitu coercentur, quae ad hominum salutem condidisti, tuam misericordiam insignem faciunt summis atque sempiternis laudibus efferendam. Quid igitur nobis faciendum est, quos in fidem tuam praecipue recepisti? Misericordiam tuam, qua omnia fulciri conspicimus, nobis defuturam censebimus? Minime certe. Si enim peccauerimus, tui tamen sumus; potentiam tuam atque numen agnoscimus, ita ut intelligamus facillimum tibi fore sceleris nostri maculam delere et nos ipsos in statum, unde concidimus, restituere. Non peccabimus autem si numquam eam curam dimiserimus, quae in nostris animis insidere perpetuo debet: nempe, nos tuos esse neque quidquam turpius excogitari posse quam eos, qui sunt ad summam lucem adiuncti, flagitiorum tenebris obrui, et, qui praesidio tuo cincti sunt, aliqua perturbatione conuelli, et, qui summam puritatem intuentur, aliqua labe impuritatis inquinari.

Iustitia namque, omnibus suis partibus expleta, tui cognitione continetur, et potentiam tuam cogitatione complecti est radix immortalitatis. Qui enim de te perpetuo cogitauerit, qui numen, qui probitatem, qui splendorem, qui pulchritudinem tuam pura mentis acie contemplatus fuerit, numquam in eam fraudem impelletur ut tabulae summi pictoris, pestilenti artificio deformatae et coloribus uariis infectae, diuinitatem tribuant: quod homines amentes et imperiti faciunt. Speciem enim in tabula artificiose lineamentis effictam, [993] et umbris et eminentiis et interuallis distinctam, et pigmentis inanissimis illustratam, intuentes, obstupescunt usque adeo ut opus illud sine fructu religiose colendum arbitrentur. Quo quid esse poterit magis insigne ad dedecus et infamiam sempiternam? Inani pictura pascunt oculos homines profligati atque perditi; hominis mortui speciem spiritu uacuam intueri cupiunt; illius amore capiuntur; illi denique supplicandum arbitrantur. Hac mente sunt pestiferae inanitatis amatores ut a uera pulchritudine deiiciant oculos et in ementita fucatae pulchritudinis specie animum defigant, et, sine ullo fructu, cupiditate sordium, quas impurus homo tabulis aspersit, a mente atque iudicio deserantur. Digni certe sunt quos spes inanitatis et mendacii et capitalis fraudis oblectet, et qui tabulas eiusmodi pingunt, et qui earum studio et cupiditate flagrant et, postremo, qui eas religione conseruandas et ueneratione summa colendas esse statuunt. Maximum namque supplicium est pestiferi erroris insania. 
eles devem ser conservados com grande respeito e adorados com a máxima veneração. É que o maior castigo é a loucura do pestilencial erro.

E, entretanto, o oleiro não pensa que deve incorrer no mesmo crime. É que, na verdade, de modo idêntico, põe-se decididamente ao serviço da impiedade, porquanto, com não pequeno trabalho, revolve com os pés a terra amolecida pela água; em seguida, com o mesmo barro faz vasilhas, umas adequadas para os usos puros da vida corrente, outras apropriadas para receber a sujidade. Ora, o próprio oleiro é quem julga e avalia qual é o uso de ambas as variedades. Mas, esquecido de que não há muito tempo foi feito com terra e pouco tempo volvido a sua alma deve ser chamada a juízo para pagar a merecida pena do crime, e o corpo devolvido à terra, de onde foi tomado, para ser destruído pela morte: não cuida que isto lhe diga respeito, mas tanto se arroga e presume de si mesmo que, do mesmo barro com que moldou as vasilhas para as mais baixas finalidades, tenta fazer, com obra assaz laboriosa e ímpia, um deus falso. E entrementes não se inquieta com quão frágil e sujeita a quão grandes doenças é a sua natureza, e quão breve é o prazo de tempo dentro do qual lhe cumpre morrer, mas, com aplicado esforço, unicamente se dedica a emular os que moldam deuses de ouro ou de prata ou de bronze e a imitar os sacrílegos artífices, e pensa que se lhe não deve atribuir menos glória se moldar um deus de barro do que a que aqueles alcançaram pela mesma abominação feita com matéria-prima diferente. É que aqueles fraguam deuses de ouro, prata e bronze, ao passo que o oleiro se esforça por moldar um deus de barro e está a tal ponto privado de entendimento que, embora faça uma obra frágil e de barro, que se recomenda por uma aparência falsa e vã, dela espera algum monumento de extraordinária nomeada. Realmente é forçoso que um espírito a tal ponto atado às coisas terrenas e mergulhado no pó se torne semelhante à matéria na qual louca e impiamente reside. Por consequência, deve ser considerado como cinza, uma vez que se revolve na cinza, e a sua esperança é mais baixa que a própria terra que assiduamente trabalha com as mãos, e a sua vida muito mais vil que o próprio barro, pois desconheceu aquele supremo artífice, pelo qual foi feito e moldado, de quem recebeu um espírito perspicaz e industrioso e de cujo poder e bondade alcançou o alento vital.

[994] Mas os perversíssimos homens consideraram a nossa vida como um jogo e negócio, estabelecido com o fito num vasto lucro, e que não cumpre inquirir o que está bem, o que é lícito e ilícito e o que é sancionado pela lei divina, mas apenas indagar com que podem fazer riqueza, quer seja de modo justo, quer injusto. É que julgam que nenhum ganho, por mais sórdido, impuro e infame que se imagine, é indigno da superioridade do homem. E, entretanto, não há motivo para que o mofino homem se defenda com a desculpa da ignorância, pois sabe muito bem que se avantaja em infâmia e desonestidade aos restantes artífices, uma vez que obra ao mesmo tempo com material terreno tanto as frágeis vasilhas como, para perdição dos homens, as imagens dos falsos deuses.

Mas devem reputar-se como os mais infelizes e loucos de todos aqueles que votaram ao Teu povo um ódio desumano e o mantiveram oprimido sob um domínio duríssimo, visto que atribuíam divindade a todas as falsas deidades dos pagãos, embora vissem que eram simulacros mudos e vãos e que não se devia pedir e esperar qualquer ajuda 
Neque figulus interea eidem sceleri minime seruiendum putat. Nam strenuam similiter operam impietati nauat, terram enim, aqua perfusa mollitam, pedibus, cum non mediocri labore, subigit; deinde ex eodem luto uasa, partim ad usus communis uitae puros apta, partim ad sordes excipiendas accommodata facit. Qualis autem utriusque generis usus sit, ipse figulus est aestimator et iudex. Oblitus porro se non ita pridem e terra genitum esse atque non multo post tempore animum illius in iudicium uocandum ut debitam poenam sceleris exsoluat, et corpus terrae, unde fuit assumptum, reddendum, ut interitu dissoluatur: id ad se pertinere non putat, sed tantum sibi arrogat et assumit ut, ex eodem luto, ex quo uasa in usus uilissimos effinxit, opere ualde laborioso et impio, deum inanem efficere conatur. Neque laborat interim quam fragilis et quantis morbis obnoxia sua natura sit, et intra quam breue spatium sit sibi uita cedendum, sed id tantum contento studio suscipit, ut certet cum iis qui ex auro aut argento aut ex aere deos formant et sceleratos artifices imitetur, neque minus sibi gloriae tribuendum putat si ex luto deum finxerit quam illi fuerant, ex alia materia dissimili, eodem scelere consecuti. Illi namque ex auro et argento et aere deos figurant, figulus uero e luto deum fingere nititur adeoque mentis expers est ut, cum opus luteum et fragile, falsa et inani specie commendatum, moliatur, speret ex eo aliquod nominis egregii monumentum. Animus profecto adeo terrenis rebus infixus in pulueremque demersus necesse est ut similitudinem materiae, in qua furenter et impie uersatur, arripiat. Est igitur cinis existimandus, cum in cinere uolutetur, et spes illius sit ipsa terra, quam manibus assidue tractat, abiectior, omnisque illius uita ipso luto longe uilior, illum enim summum artificem, a quo fictus et informatus est, a quo animum sagacem et industrium hausit, cuius numine et beneficio fuit uitalem spiritum consecutus, ignorauit.

[994] Verum enimuero perditissimi homines uitam nostram ludum existimarunt atque mercatum, causa lucri multiplicis institutum, nec esse quid deceat, quid ius et fas sit, quid lex diuina sanciat inquirendum, sed tantum unde, siue iure, siue iniuria, pecuniam faciant indagandum. Nullum enim quaestum, quantumuis sordidum et impurum et flagitiosum, hominis praestantia indignum esse iudicant. Nec est interim cur se miserabilis homo, ignorationis excusatione, defendat, nouit enim probe se reliquos omnes artifices flagitio et improbitate superare, cum et uasa fragilia simul et falsorum deorum effigies ex terrena materia ad hominum perniciem machinetur.

Sed omnium amentissimi et infelicissimi censendi sunt illi qui populum tuum immani odio persecuti sunt et durissimo dominatu oppressum tenuerunt, omnia siquidem gentium numina commenticia diuinitate donabant, cum cernerent esse muta et inania simulacra nec esse ab illis, quae sensibus omnino carebant, ullum 
de quem totalmente carecia de sentidos. É que os seus membros não tinham qualquer utilidade, pois nem viam com os olhos, nem aspiravam ar pelo nariz, nem os ouvidos escutavam sons, nem com os dedos agarravam coisa alguma, nem possuíam pés aptos e apropriados para caminhar, pois fabricara-os o homem, que era incapaz de dar-lhes sensibilidade e movimento e, por conseguinte, vida. É que o homem não moldou por si próprio a sua alma, mas tomou-a, de empréstimo, de alhures, de maneira a devolvê-la quando fosse pedida por Aquele que a tinha dado. De que modo, por conseguinte, poderia acabar por suceder que o homem mortal fizesse Deus, visto como nem sequer é capaz de criar o homem? E assim o homem mortal com mãos ímpias faz não Deus, mas uma obra mortal. Ora, quanto o próprio artífice de deuses se avantaja aos próprios deuses que faz é algo que claramente se vê a partir do facto de que vive, tem viço e está dotado de sentidos, algo que de forma alguma jamais aqueles deuses alcançarão.

Que dizer do facto de que adoram também animais muitíssimo hostis às coisas humanas? Ora, que levou os dementados homens a atribuírem-lhes divindade? É que até eles, embora estejam privados de razão, se quiserem esforçar-se, hão-de concordar em que aquelas são as mais odiosas de todas as bestas-feras. Porventura os impeliu a engano capital alguma aparência graciosa, postada diante dos seus olhos? Provavelmente não podiam convencer-se ser possível que, numa tão admirável beleza, não se escondesse algo de divino... Assim, é verosímil que uma aparência tão brilhante atraísse a si, para que a contemplassem, os olhos de todos... E deste modo foram seduzidos pela forma e elegância e levados pela grande utilidade a colocarem em lugar divino a natureza das bestas-feras... Pois quê? Se era impossível imaginar-se outra de mais disforme aparência ou de violência mais feroz! E, todavia, os perdidos homens estavam a tal ponto oprimidos e cegos por tão detestável desvario que concediam honras divinas a abomináveis serpentes e até lhes ofereciam execráveis sacrifícios. Mas Deus, supremo Criador de todas as coisas, não quis que se desse qualquer louvor às serpentes, e até as maldisse, como claramente se viu na serpente que armou a cilada aos nossos primeiros pais.

\section{[995]}

\section{CAPÍTULO XVI}

Por isso os Egípcios, como tinham cometido um crime tão monstruoso, do mesmo modo que os outros, cúmplices dos mesmos crimes, sofreram os merecidos castigos da loucura, sendo atormentados pela multidão das alimárias. Mas, Senhor supremo, embora atribulasses os inimigos com tormentos desta espécie, reconfortaste o Teu povo, que sofria com o desejo de comida, com peregrinos manjares, pois mandaste-lhe codornizes arrastadas pelo vento, que saciaram a sua fome. E, assim, aconteceu que os inimigos, sobremaneira prostrados pela fome, diante do grande número de animais selvagens que se arremessavam contra eles, rejeitavam com asco até a comida fácil de obter e, devido à repugnância, não podiam gozar à vontade dos seus bens, ao passo que os Hebreus, pelo contrário, para não serem atormentados por uma fome prolongada, encheram-se 
auxilium postulandum et exspectandum. Membra namque illorum nullum usum habebant, nec enim oculis cernebant, neque spiritum naribus hauriebant, nec auribus uocem accipiebant, nec aliquid digitis attrectabant, neque pedes aptos et habiles ad ingressum habebant, homo enim ea fabricatus fuerat, qui non poterat illis sensum et motum, atque adeo uitam, dare. Nec enim homo animam sibi ipsi finxit, sed aliunde mutuo sumpsit, ut eam redderet, cum fuisset ab eo, qui dederat, repetita. Quo tandem igitur modo fieri poterat ut mortalis homo Deum faceret, cum nec hominem quidem effingere queat? Itaque mortalis homo impiis manibus non Deum, sed opus mortuum efficit. Quantum autem ipse deorum artifex ipsis diis, quos efficit, antecellat, ex eo clare cernitur quod uiuit et uiget et sensibus instructus est, quod illi dii numquam ulla ratione consequentur.

Quid quod animalia etiam rebus humanis infestissima uenerantur? Quid autem induxit homines amentissimos ut illis diuinitatem tribuerent? Illi etiam, quamuis sint ratione spoliatus, si contentionem facere uoluerint, iudicabunt illa esse belluarum omnium taeterrima. An species aliqua praeclara, eorum oculis obiecta, illos in fraudem capitalem impulit? Non uidelicet induci poterant fieri posse ut non aliquid diuinum in tam admirabili pulchritudine lateret... Ita credibile est tam illustrem speciem omnium oculos ad se spectandam rapuisse... Itaque forma et elegantia capti sunt et magnitudine utilitatis allecti ut belluarum naturam in sede diuina collocarent. Quid? Si non aliud uel aspectu deformius uel feritate truculentius excogitari poterat! Et tamen tam detestabili furore oppressi et excaecati sunt homines profligatissimi ut taeterrimis serpentibus honores diuinos haberent et sacra etiam exsecranda conficerent. Atqui Deus, summus rerum omnium conditor, nullam laudem attributam serpentibus esse uoluit, nempe quibus etiam maledixit, ut in serpente, qui primis parentibus insidias instruxit, clare perspectum fuit.

\section{[995]}

\section{CAPVT XVI}

Quocirca Aegyptii, cum tam immane scelus suscepissent, similiter atque alii eisdem sceleribus affines dignas amentiae poenas pertulerunt, bestiarum multitudine cruciatu. At uero, summe Domine, cum hostes eiusmodi tormentis affligeres, populus tuus, ciborum cupiditate laborantem, escis peregrinis refecisti, nam coturnices uento inuectas immisisti, quae famem illius expleuerunt. Itaque factum est ut hostes, fame propemodum enecti, propter belluarum multitudinem quae in eos impetum ferebant, parabiles etiam dapes fastidiose reiicerent neque, propter nauseam, bonis suis impune frui possent, contra uero Hebraei, ne diuturna paenuria uexarentur, cibis e longinquo importatis saturati sunt. Ius enim erat ut illi qui tyrannide fuerant abusi extrema indigentia premerentur, et hos, qui in tuo 
com os alimentos trazidos de longe. De facto, era justo que aqueles que abusaram da tirania fossem assoberbados pela mais violenta fome, e que a falta de comida atribulasse os que se encontravam sob a Tua guarda durante o tempo suficiente para sentirem, pela experiência, com que espécie de suplício os inimigos eram atormentados. Com efeito, não só a cruel fúria das feras se lançou contra eles, mas também muitos nascidos na raça de Israel sucumbiram, no deserto da Arábia, feridos pelas mordidas pestilenciais das serpentes. Mas não caíram mortos numa matança, pois fixaste uma justa medida para a Tua ira. É que quiseste infligir castigo aos culpados durante o tempo em que foi necessário que o povo, perturbado pelos exemplos dados a conhecer, voltasse ao cumprimento do dever, e, para sua salvação, se sancionassem os ensinamentos da lei e, por derradeiro, todos, através de um sinal admirável, fossem advertidos de que, ao cabo, a essência e força da lei se deve escrever, não em tábuas de pedra, mas no espírito.

É que os que punham os olhos na serpente de bronze não recuperavam a saúde por causa da coisa vista. De facto, que eficácia tão grande podia existir quer na composição do bronze, quer na forma da serpente, capaz de dar remédio salutar para as feridas mortais e restituir a vida a homens quase mortos, só mediante a aparência do que viam? Mas aquele sinal encerrava um sacratíssimo mistério, representava a grandeza da Tua misericórdia, tornava presente a Tua imensa bondade e simbolizava o modo pelo qual haverias de oferecer aos homens a salvação eterna. Com efeito, a protecção da nossa vida obtémse, não com sinais, mas graças ao Teu poder pessoalmente presente, que representaste através de sinais. Só Tu é que podes dar a salvação; só na Tua protecção nos apoiamos; fortalecemo-nos com a esperança na Tua misericórdia; em Ti unicamente colocamos toda a causa da nossa salvação e dignidade. E quiseste que também os Teus inimigos soubessem que Tu és o único que arrancas dos males aqueles que unicamente em Ti põem os olhos. É que aqueles pereceram com as picadas dos gafanhotos e das moscas e não encontraram remédio que lhes permitisse repelirem o ataque dos mortíferos insectos, porquanto se tinham tornado merecedores de pagarem a pena da sua insolência com as picadas dos animais mais pequenos. Ao invés, porém, quando as serpentes peçonhentas atacaram os Teus filhos para os dilacerarem com os dentes, não conseguiram derribá-los, pois a Tua clemência acudiu de repente aos Teus e curou-os.

De facto, foi-lhes vantajoso, a fim de conservarem durante muitíssimo tempo a lembrança dos Teus preceitos, serem atormentados pelas picadas dos animais, de maneira a, vencidos pela dor, voltando-se para Ti, a quem tinham ofendido com infâmias, serem de repente curados [996] e compreenderem que a salvação se encontra na Tua presença e a perdição na Tua ausência. É que, a não ser assim, havia o perigo de se apossar deles o perpétuo esquecimento da bondade divina e, desse modo, obstinados nos crimes e apartados da Tua benignidade, serem arrastados para o suplício eterno sem qualquer esperança de salvação. Na verdade, ó Senhor, receberam a saúde não graças a quaisquer ervas ou cataplasmas, mas livraram-se de enfermidades pestilenciais graças às Tuas palavras, que tudo curam. É que Tu tens o poder de vida e de morte; Tu levas os culpados até às portas do Inferno, quando o interesse da justiça assim o exige; Tu amiúde arrancas das fauces do próprio Inferno os que gritam pela Tua ajuda. 
patrocinio erant, tantisper inedia cruciaret, dum experiundo sentirent quo genere supplicii hostes torquerentur. Etenim et in eos immanis bestiarum furor inuasit, et multi Israelis satu editi, in Arabiae solitudine, serpentium pestiferis morsibus icti, conciderunt. Verum non occidione caesi sunt, irae namque tuae modum statuisti. Tamdiu enim supplicio sontes afficere uoluisti, quamdiu fuit necesse populum, exemplis editis perturbatum, ad officium reuocari, ad eorumque salutem, legis disciplinam sanciri et admoneri denique omnes, signo mirabili, quod tandem erat legis uis et ratio non in tabulis lapideis, sed in animis scribenda.

$\mathrm{Nec}$ enim qui serpentem aeneum respectantes intuebantur propter rem uisam sanitatem recuperabant. Quae enim tanta uis inesse poterat uel in aeris temperamento, uel in serpentis forma, ut mortiferis uulneribus salutare remedium adhiberet et homines propemodum exstinctos, specie tantum perspecta, in uitam reuocaret? Sed signum illud mysterium sacratissimum continebat, et clementiae tuae magnitudinem referebat, et memoriam benignitatis immensae repraesentabat, designabatque rationem qua eras salutem sempiternam hominibus allaturus. Nec enim signis, sed praesenti numine tuo, quod signis expressisti, uitae nostrae praesidium comparatur. Tu solus es qui salutem dare potes; tui solius praesidio nitimur; spe tua misericordiae confirmamur; in te uno omnem salutis atque dignitatis rationem collocamus. Hoc uero hostibus etiam tuis notum esse uoluisti, te solum esse qui ex omnibus malis eos, qui in te unum intuentur, educis. Illos enim locustarum atque muscarum ictus interemerunt neque remedium inuenerunt quo a se mortiferum insectorum impetum repellerent, digni namque fuerant qui minutissimorum animantium ictibus poenas insolentiae luerent. Contra uero, cum serpentes uenenati in filios tuos, ut eos dentibus dilacerarent, impetum ferrent, non eos de statu deiiecere potuerunt, clementia namque tua repente subsidio tuis occurrit eosque sanauit.

Fuit enim illis commodum, ut memoriam praeceptorum tuorum diutissime conseruarent, bestiarum ictibus torqueri, ut, uicti dolore, ad te, quem flagitiis offenderant, conuersi, repente sanarentur [996] et intelligerent salutem, praesentia tua, perniciem, absentia contineri. Aliter enim periculum erat ne caperet eos perpetua diuinae benignitatis obliuio et ita, in sceleribus obstinati et a beneficentia tua diuulsi, sine ulla spe salutis ad perpetuum supplicium truderentur. Nec enim ullis herbis aut fomentis, o Domine, sanitatem receperunt, sed oratione tua, quae sanat omnia, e morbis pestiferis emerserunt. Tu enim uitae necisque potestatem habes; tu ad Erebi portas sontes, cum id ratio iuris efflagitat, inducis; tu saepenumero ex ipsius Erebi faucibus opem tuam inclamantes eripis. 
O homem, é certo, arrastado pela desumanidade do crime, arranca a vida, que uma vez perdida ninguém pode restituir, pois o espírito, depois de sair do corpo e apartado do princípio vital com o qual se associara para velar pelo corpo, por nenhuns recursos humanos pode ser restituído à condição original, de modo a receber de novo o sopro vital e desempenhar, por mediação do corpo, os actos que dizem respeito à vida corrente. E, assim, quem inferiu morte a alguém, porque suprimiu um inimigo pensa que pode passar a vida sem qualquer preocupação, porquanto, uma vez extinto o corpo, no morto não se alojam nenhuns sentidos ou capacidade com que vingue por sua mão a malfeitoria ou reivindique em juízo a injustiça, e, desta maneira, sucede que os que perpetraram homicídios não receiam que lhes venha algum mal da parte daqueles que vêem ser enterrados. Mas quem poderá ao cabo, Senhor, fugir da Tua mão ou evitar o Teu julgamento? É que nem precisas de acusadores que se ocupem apaixonadamente da causa, uma vez que a Tua justiça persegue os culpados, nem interrogas testemunhas, porque vês claramente tudo, até o que se faz nas trevas, nem reúnes conselho, dado que a Tua imensa sabedoria não precisa da opinião de ninguém, mas de tal maneira exerces a justiça que não deixas nenhum crime impune, tal como se viu à perfeição na punição dos que tinham afogado muitos milhares de crianças.

É que os que negavam que Te conheciam e desprezavam o Teu poder com uma soberba intolerável, abatidos com violentíssimos golpes sentiram a força dele, pois, embora no Egipto seja algo de anormal ver chuva, eles todavia, foram confundidos e espantados e, na sua maioria, tragados de forma lastimável pelas estranhas e imoderadas chuvas, pela imensa violência de granizo, pelos aguaceiros caídos com horrendo estrondo e pelo fortíssimo ardor do fogo que o embate amiudado das nuvens agitadas fizera cair. Viu-se também algo sobremaneira espantoso, pois, ainda que a grande cópia de águas apague facilmente o fogo, todavia aquele fogo não diminuía a sua violência no meio das águas remexidas com grande ímpeto, e, embora aquela inundação, por onde quer que se precipitasse, tudo despedaçasse e destruísse, e a todas as coisas causasse uma monstruosa devastação, o fogo, para perdição dos homens, inflamava-se com as águas muito mais do que se não se tivesse misturado com quaisquer águas. É que o mundo, para servir ao Criador de todas as coisas, torna-se vingador dos crimes, entra em peleja em defesa dos justos e pune as injustiças praticadas contra eles. E, assim, por vezes continha o calor, para que não abrasasse os animais lançados contra os ímpios, e em seguida, a fim de destruir por completo a raça impura, das águas lançava chamas que ultrapassavam a natureza do próprio fogo, [997] para que os homens impuros vissem que não eram inquietados por acaso e de modo fortuito, mas que eram destruídos pelo rectíssimo juízo de Deus.

E com estes castigos atormentavas, numa região fértil e abundante, os inimigos do Teu nome e atribulavas com fome e sede um povo opulento, mas, ao invés, no inculto deserto reconfortaste com alimento de anjos o Teu povo, na mais completa penúria de recursos e em completa privação de víveres e mantimentos, e quiseste que estivesse à disposição e alcance deles um pão que de longe superasse o sabor de todos os manjares, que fizeste cair do céu, por forma a que sustentassem a vida sem qualquer trabalho e com extraordinário contentamento. Os restantes manjares, ainda que sejam doces e salutares 
Homo quidem, sceleris immanitate ductus, uitam eripit, quam amissam reddere nemo potest, spiritus enim, e corpore excedens et ab anima, cum qua consilia corporis tuendi consociauerat, diuulsus, nullis humanis opibus in pristinum statum reuocari potest, ut animas rursus assumat et actionibus ad uitam communem pertinentibus, corporis ministerio, perfungatur. Itaque is qui necem intulit alicui, eo quod inimicum sustulerit, existimat se posse sine ulla cura uitam traducere, exstincto enim corpore, nullus sensus aut facultas in mortuo residet qua uel facinus manu uindicet uel iniuriam iudicio persequatur, et ita fit ut, qui caedis auctores exstiterunt, nullum sibi malum, ab iis quos sepultos esse uident, extimescant. Sed quis tandem, o Domine, manum tuam effugere aut iudicium eludere poterit? Nec enim indiges accusatoribus qui acriter causam agant, cum tua iustitia nocentes insequatut, non testes interrogas, cum omnia, etiam quae agitantur in tenebris, clare uideas, non consilium cogis, cum sapientia immensa nullius sententiam requirat, sed ita iudicium exerces ut nullum scelus impunitum dimittas: quod perspectum sane fuit in eorum cruciatu qui multa infantium millia aquis demerserant.

Qui enim negabant se nosse te numenque tuum superbia minime ferenda contemnebant, illius uim, plagis acerrimis contusi, senserunt, cum enim monstri simili sit in Aegypto pluuiam cernere, illi tamen peregrinis et immodicis pluuiis, ingenti ui grandinis, imbribus cum horrendo fremitu demissis et uehementissimo ignis ardore, quem micantium nubium frequens conflictus expresserat, conturbati, exanimati magna ex parte consumpti sunt. Illud etiam nimis admirandum exstitit, cum enim aquarum magna copia ignem facillime restinguat, ignis tamen ille, in mediis aquis magno impetu contortis, uim suam minime remittebat, et, cum eluuio illa, quocumque rueret, omnia perrumperet et dissiparet immanemque uastitatem cunctis rebus inferret, ignis tamen ex aquis multo uehementius ad hominem perniciem excitabatur, quam si non fuisset ullis aquis admixtus. Mundus enim, ut rerum omnium conditori seruiat, scelerum uindex est, et pro iustis pugnam capessit et iniurias eis illatas ulciscitur. Itaque tunc ignis interdum, ne bestias in impios emissas inflammaret, ardorem continebat; rursus, ut genus impurum funditus euerteret, supra ignis ipsius naturam ex aquis flammas iaciebat, [997] ut cernerent homines impuri se non temere et casu exagitati, sed rectissimo Dei iudicio peruerti.

Et his quidem poenis hostes tui nominis in regione fertili et opima excruciabas et fame et siti gentem opulentam conficiebas, contra uero populum tuum in uastissima solitudine, in summa rerum paenuria summaque uictus et annonae desperatione, angelorum pabulo refecisti, panemque illis promptum et paratum esse uoluisti, omnium ciborum suauitatem longe superantem, quem e caelo demisisti, ut sine ullo labore et cum insigni iucunditate uitam sustentarent. Reliqui quidem cibi, quamuis dulces atque salutares et optime conditi sint, non 
e muito bem preparados, todavia não podem agradar por igual a todos, visto que uns gostam mais de certos sabores, e as coisas doces agradam a alguns, ao passo que a outros as que são um pouco mais amargas. Aquele manjar celestial, porém, de tal modo se adaptava ao paladar de todos que parecia ter sido feito para a natureza de cada um. De facto, a constância da Tua bondade, causadora do prazer e contentamento mais cabais, aliviou os Teus filhos com uma nova e insólita deleitação e, com aquele sinal, mostrou de forma maravilhosa que o fruto do prazer firme e eterno se funda exclusivamente na Tua misericórdia, e que só os que se ligaram ao Teu nome se enchem de todos os bens e são cumulados de extraordinário contentamento e alegria.

As inteligências dos homens são variadas; diferentes e dissemelhantes as vontades; múltiplos apetites agitam os espíritos, e há outros que se ocupam mais em obter e gozar outras coisas. Com efeito, certos aplicam-se ao dinheiro; outros, antepõem os prazeres a todas as restantes coisas; há aqueles a quem vivamente incita a ambição de honrarias; outros pensam que devem tudo abandonar em troca de alguma aparência de uma forma um pouco mais bela que se lhes põe por diante; por derradeiro, existem aqueles que por todas as vias abraçam a ociosidade, opulenta da abundância de bens. Deste modo sucede que aquilo que assaz deleita a um não pode satisfazer o desejo do outro. Acresce que geralmente um só e o mesmo homem é dominado pelo desejo de todos estes proveitos e, assim, porquanto não pode alcançá-los todos ao mesmo tempo, quando se torna possuidor de uma única coisa, é atormentado pela falta das outras. Desta maneira acontece que a vida de todos os mortais que não buscam as verdadeiras riquezas é penosa e atribulada por muitas preocupações, ao passo que os que acataram inteiramente as orientações do Teu espírito, de tal modo incessantemente abundam em todos os bens que nada procuram além disso. É que estão copiosamente providos das maiores riquezas; gozam do mais verdadeiro prazer; em grandeza de dignidade aproximam-se da dignidade e esplendor dos seres celestiais; abrasados no amor da formosura divina, encontram descanso na protecção divina.

Ora, simbolizava este agradabilíssimo alimento, que enche com tão grandes proveitos o entendimento, aquele pão celestial, que com tanta largueza e generosidade ofereceste ao Teu povo. Por isso aconteceu que o gosto dele obedeceu aos desejos de todos, conquanto fossem diferentes, e se adaptou de imediato ao sabor do alimento que cada um mais apetecesse. E muitas coisas maravilhosas aconteciam na utilização daquele pão admirável. De facto, embora a natureza dele fosse semelhante ao orvalho e não distasse muito da da neve e do gelo, todavia suportava de modo espantoso a força do fogo [998] e, quer embebido em água, quer frito na frigideira, quer sujeito ao lume de qualquer outra maneira, conservava sem dificuldade a sua forma. É que o fogo, que, misturado com muito granizo, destruía as searas dos inimigos e irrompia nas maiores tempestades e procelas, para ocasionar aos inimigos a destruição, esquecido da sua natureza, para que os justos fossem alimentados, não destruía o maná (pois foi assim que se designou aquele alimento), mas aquecia-o com um calor mediano, por forma a ser comido com maior gosto. É que, como a natureza acata as ordens do seu Criador, Lhe obedece, incessantemente O serve: quando é preciso, o fogo desperta a sua força e dirige-a de 
possunt tamen omnibus ex aequo placere, cum aliis alii magis capiantur, et quosdam dulcia, alios uero paulo austeriora delectent. At caelestis ille cibus ita gustatui omnium seruiebat ut cuiuslibet naturae factus esse uideretur. Tuae namque benignitatis constantia, summae uoluptatis et iucunditatis effectrix, filios noua et insolita uoluptate deleniuit et, illo signo, mirabiliter ostendit in tua solum clementia uoluptatis stabilis atque sempiternae fructum consistere, et eos tantum qui ad nomen tuum adiuncti sunt esse bonis omnibus expletos et insigni iucunditate et gaudio cumulatos.

Varia sunt hominum ingenia; uoluntates dispares atque dissimiles; multiplices appetitiones animos uersant, et alii in aliis rebus parandis atque fruendis sunt magis occupati. Quidam enim in pecuniae studium incumbunt; quidam, uoluptates rebus omnibus anteponunt; sunt quos honorum ambitio uehementer stimulet; alii specie aliqua formae pulchrioris obiecta prae amore illius omnia deserenda putant; sunt postremo qui otium, bonorum copia refertum, omnibus modis amplexantur. Ita fit ut quod unum ualde delectet, alterius cupiditatem explere minime possit. Accedit quod plerumque unus et idem homo omnium horum commodorum cupiditate tenetur et ita, nec enim simul omnia adipisci potest, cum rei unius compos est, aliarum inopia cruciatur. Sic fit ut omnium mortalium uita, qui non ueras opes exquirunt, acerba sit et multis curis implicita, at qui se totos ad spiritus tui ductum contulerunt, ita bonis omnibus continuo redundant ut nihil praeterea requirant. Nam summis opibus affluunt; uoluptate uerissima fruuntur; dignitatis amplitudine proxime ad caelitum decus et splendorem accedunt; amore diuinae pulchritudinis inflammati, in praesidio diuini numinis acquiescunt.

Huius autem pabuli iucundissimi, qui mentem tantis commoditatibus explet, imaginem gerebat panis ille caelestis, quem populo tuo large atque munifice contulisti. Ideo factum est ut illius suauitas omnium cupiditatibus, quamuis essent dissimiles, inseruiret, et ad saporem cibi, quem quisque appeteret, se confestim accommodaret. Multa uero mirabilia in panis illius admirabilis usu contingebant. Cum enim natura illius esset roscida neque multum a niuis atque glaciei natura distaret, ignis tamen uim mirifice [998] sustinebat, formamque suam, uel aquis elixus, uel sartagine frictus, uel quacumque alia ratione ignis ardore tostus, facillime conseruabat. Ignis enim, qui multa cum grandine confusus, hostium fruges absumebat et in summis tempestatibus atque procellis emicabat, ut exitium hostibus inferret, suae naturae oblitus, ut iusti alerentur, manna (sic enim fuit illi cibo nomen impositum) minime consumebat, sed calore modico temperabat, ut cum maiore iucunditate sumeretur. Cum enim natura conditori suo pareat, illi seruiat, illi perpetuo ministret, cum est opus, ignis uim suam excitat et intendit, ut in homines iniustos inuehatur; cum rursus id praescribis, uim suam remittit ut se 
modo a lançá-la contra os homens injustos; em seguida, quando assim ordenas, afrouxa a sua violência, por forma a adaptar-se às necessidades dos que só em Ti estabeleceram todas as defesas da vida.

O maná também cumpria as ordens da Tua clemência, graças à qual todos os seres vivos são sustentados, transformando-se em vários sabores e deleitando os que comiam de acordo com o gosto de cada um, a fim de que os Teus filhos, a quem abraças com extraordinário amor, aprendessem que a vida dos homens não se sustenta com os mais abundantes frutos da Terra, mas que a vida e imortalidade dos que se apoiam na fé na Tua bondade se encerra no poder da Tua palavra. Ora, para isto se tornar mais evidente, o maná, que não podia ser destruído pelo calor de um fogo violento, dissolvia-se depois de aquecido por qualquer raio de Sol. Por consequência, era necessário que todos, antes do nascer do Sol, apanhassem maná na quantidade suficiente, por forma a evitar que pagassem com fome prolongada o castigo do sono e da negligência. É que, de outro modo, aquele manjar caído do céu, depois de aquecido durante algum tempo pelo Sol, desfazia-se.

Com este sinal querias significar que nas coisas divinas não se deve protelar, nem fazer nada de modo lento e enfadado; e que se considere como crime abominável toda a negligência, preguiça e desleixo, e que por isso é impossível que os homens dados ao sono, paralisados pela indolência, amolecidos e enfraquecidos pela ociosidade colham fruto da Tua graça. Por conseguinte, é necessário, a todos os que desejarem ser providos com as Tuas mercês, que, antes de o Sol despontar, despertos do sono, Te dêem graças, Te louvem e admirem e Te dirijam piedosas preces, porquanto o entusiasmo e o zelo constituem uma prova certíssima de estima, visto como trabalhamos e nos esforçamos por causa das coisas que temos em grande apreço e aplicamos muito trabalho e desvelo em procurá-las. Por outro lado, diminuímos o trabalho e aplicação para a obtenção das coisas que consideramos de muito menor importância. Logo, quando não nos desvelamos e apressamos para ser cumulados com os frutos da graça divina, estamos a mostrar de sobejo que sacrilegamente a desprezamos. Mas é delito de ingratidão, crime de perfídia, insolência e infame esquecimento sacrílego não conceder qualquer importância às mercês misericordiosamente concedidas pela graça de Deus. Ora, a esperança do homem ingrato desvanecer-se-á como o gelo invernal e escoar-se-á como água inútil. Por conseguinte, assim como para aqueles que, ao raiar da aurora, não se apressavam para apanhar o maná, este imediatamente se lhes desfazia, da mesma maneira se extinguem todos os frutos da graça divina para os que não são rápidos em acolher com abrasado desvelo as mercês divinas.

[999]

\section{CAPÍTULO XVII}

Mas valerá a pena prestar de novo atenção a como são grandes os Teus juízos, ó Senhor, e como são difíceis de expor. Com efeito, os que estão privados dos Teus ensinamentos e, por este motivo, de nenhuma maneira podem ver a verdade, de forma 
eorum usibus accommodet qui in te solo habent omnia uitae praesidia constituta.

Ideo etiam manna ut benignitatis tuae, qua cuncta animantia sustentantur, imperium sequeretur, se in uarios sapores transferebat et pro cuiusque sensu comedentes oblectabat, ut discerent filii tui, quos amore singulari complecteris, non uberrimis agrorum fructibus hominum uitam sustentari, sed potius uitam et immortalitatem eorum, qui fide tuae benignitatis innituntur, uerbi tui numine contineri. Vt autem id magis perspicuum fieret, id, quod ignis uehementis ardore corrumpi non poterat, quouis solis radio calefactum diffluebat. Erat igitur opus ut omnes, ante solis exortum, quantum sat esset colligerent, ne somni atque negligentiae poenam diuturna fame sustinerent. Aliter enim epulum illud e caelo demissum, tepore solis modico tepefactum, dilabebatur.

Quo signo designabas in rebus diuinis non esse cunctandum, nihil lente et fastidiose gerendum; omnem negligentiam, pigritiam et ignauiam esse in nefario crimine ponendam, et ideo fieri non posse ut homines somno dediti, segnitie torpentes, otio fracti et debilitati, e gratia tua fructum colligant. Est igitur necesse, omnibus qui muneribus tuis affici concupierint, ut, antequam sol oriatur, e somno suscitati, tibi gratias agant, te laudent et admirentur, piasque tibi preces adhibeant, nam alacritas et industria certissimum continet aestimationis argumentum, rerum enim quas plurimi facimus, causa laboramus et uigilamus multumque in illis quaerendis operae et studii consumimus. In rebus autem, quas multo minoris aestimamus comparandis, laborem et industriam remittimus. Ergo, cum minime uigilamus et properamus ut fructibus diuinae gratiae cumulemur, apparet certe illam a nobis nefarie contemni. Atqui minimi facere munera, Dei gratia nobis a Deo clementer oblata, est ingrati animi crimen, perfidiae et insolentiae facinus, turpissimae negligentiae fastidium, scelestissimae obliuionis infamia. Porro autem spes hominis ingrati ut hiberna glacies euanescet et ut inutilis aqua dilabetur. Vt igitur illis qui, primo diluculo, non accelerabant ad manna colligendum, manna protinus dissolutum effluebat, ita illis qui non, in muneribus diuinis incenso studio percipiendis, celeritatem suscipiunt, omnes gratiae diuinae fructus intereunt.

[999]

\section{CAPVT XVII}

Sed operae pretium erit rursus animaduertere quam magna sint iudicia tua, Domine, et quam explicatu difficilia. Qui enim disciplinae tuae expertes sunt et, ea de causa, nullo modo queunt uerum cernere, non possunt ullo modo iudiciorum tuorum aequitatem et sanctitatem mente percipere, nec enim mens, 
alguma são capazes de compreender a equidade e santidade dos Teus juízos, pois o entendimento cheio de trevas não suporta a luz, nem o espírito mergulhado na terra ergue os olhos para o céu, porque é impedido pelo peso fortíssimo da perversidade. Por este motivo, os enlouquecidos pelo erro do entendimento, que tinham repudiado os Teus ensinamentos, abandonando o caminho da salvação entraram nos caminhos da desgraça sempiterna. Por conseguinte, atacados pela demência, ao pensarem que mantinham o povo santo oprimido sob duríssimo jugo, sofreram a violenta tirania de uma abominável servidão.

Com efeito, jazeram prostrados, atados pelos grilhões das infâmias e embaraçados pelas trevas de uma longuíssima noite, encerrados sob os tectos forrados de uma horrenda cerração e abandonados pela Tua providência. O Sol, dirigindo-se do nascente para o ocaso, realizava, da forma costumada, um movimento triplo durante três dias e três noites, todavia sobre eles estendia-se durante a totalidade deste período de tempo uma horrível noite, de tal forma que lhes era impossível moverem-se do lugar. É que, uma vez que nas trevas tinham cometido muitos crimes e infâmias e como, por este motivo, tivessem pensado que passavam despercebidos, ocultados pela cobertura do esquecimento, o direito divino exigia que fossem condenados às trevas e que os que, confiantes na cerração, tinham concebido tão grande quantidade de crimes, não encontrassem naquela medonha cerração nenhuma possibilidade para as suas actividades. E entretanto, expulsos e afastados da sua posição, aterrorizados por um imenso temor e estarrecidos com visões horrendas, não podiam respirar, pois nem nos esconderijos em que se tinham ocultado podiam permanecer sem sentir medo e inquietação. É que então muitíssimo os perturbava a consciência do crime, os atemorizava a lembrança das malfeitorias, cuidados tristíssimos os afligiam com incessantes golpes e, finalmente, sofriam o castigo da impiedade. Horrendos estrondos retumbando por todos os lados amedrontavam-nos e, acabrunhados pela aflição, observavam terríveis aparições, nem o fogo, conquanto se precipitasse com mais vigor e força que a usual, lhes comunicava um pouco de luz, nem sequer o fulgor dos astros tinha eficácia para de alguma maneira dispersar aquelas trevas. Só uma fogueira acesa, plena de horror, se encontrava diante dos seus olhos e, embora tremessem, abalados por um imenso pavor, todavia consideravam muito mais agradável isto que viam do que aquilo cuja aparência não podiam ver claramente.

Entretanto jaziam sem préstimo os embustes da arte mágica; a vã ostentação da sabedoria, escondida, mantinha-se em silêncio; o labéu do supremo desdouro, neles gravado, comprovava o desatino da ridícula insolência. Com efeito, os que se jactavam e gabavam, dizendo que possuíam a ciência que lhes permitia libertarem os espíritos de enfermidades, expulsarem todos os medos e fazerem passar completamente o estado da mente, da mais completa perturbação para a mais completa tranquilidade, padeciam de um ridículo temor. De facto, embora nada de temível e assustador lhes ocorresse, mesmo assim, [1000] sucumbiam assustados com o passar dos animais selvagens e com os silvos das serpentes rastejando com estridor, e morriam perturbados com coisas totalmente vãs. Ora, de tal maneira se encontravam privados de sentidos que se negavam a ver o próprio ar que forçosamente os rodeava. De facto, nada é mais violento, nada mais horrível do 
tenebris oppleta, lucem sustinet, nec animus, in terra demersus, in caelum oculos attollit, quia pondere grauissimae prauitatis impeditur. Idcirco, errore mentis insanientes, qui disciplinam tuam repudiauerant, deserta salutis uia, in sempiternae miseriae uias ingressi sunt. Amentia igitur uexati, cum opinarentur se gentem sanctam durissimo dominatu oppressam tenere, exsecrandae seruitutis acerbissimum iugum subierunt.

Nam flagitiorum uinculis astricti atque longissimae noctis tenebris impediti, et tectis laqueatis horrendae caliginis inclusi et a prouidentia tua derelicti iacuerunt. Sol quidem, ab ortu ad occasum commeans, trinam conuersionem tribus diebus atque noctibus, more solito, conficiebat, illis tamen hoc toto spatio erat taeterrima nox offusa, ita ut moueri loco non possent. Cum enim in tenebris multa scelera et flagitia suscepissent et, ea de causa, se latere putauissent, obliuionis integumentis occultati, ius diuinum postulabat ut tenebris damnarentur et qui, caligine freti, tam multa scelera concepissent, nullum in taeterrima illa caligine rebus suis exitum reperirent. Interim uero, de gradu disiecti atque dissipati, et ingenti formidine perterriti et horrendis uisis attoniti, respirare non poterant, neque enim latebrae, in quas se abdiderant, illos sine metu et sollicitudine consistere sinebant. Illos enim tunc uel maxime conscientia sceleris exagitabat, maleficiorum recordatio perterrebat, curae tristissimae uerberibus assiduis concidebant et poenae denique impietatis insectabantur. Horrendi sonitus undique perstrepentes illos exanimabant, terribiles species eis, maestitia confectis, obuersabantur, nec ignis, quamuis esset solito acrius et uehementius incitatus, eis quidquam lucis afferebat, neque siderum quidem fulgores uires habebant quibus illas tenebras aliqua ex parte dispellerent. Incensa solum pyra, horroris plenissima, ob eorum oculos uersabatur et, quamuis ingenti pauore concussi trepidarent, multo tamen leuior ducebant ea, quae uidebant, iis quorum speciem clare uidere non poterant.

Interim magicae disciplinae ludibria iacebant; inanis ostentatio sapientiae compressa silebat; macula summi dedecoris, illis inusta, temeritatem insolentiae deridendae conuincebat. Nam qui in eo se iactabant et ostentabant, quod scientiam se tenere dicerent qua morbis animos liberarent, metus omnes expellerent, totiusque mentis statum a summa perturbatione ad summam tranquillitatem traducerent, formidine ridicula laborabant. Quamuis enim nihil horrendum et metuendum illis occurreret, bestiarum tamen transitionibus [1000] et serpentium cum stridore repentium sibilis exanimati concidebant, et conturbati rebus inanissimis exspirabant. Sic autem erant orbati sensibus ut aerem ipsum, quo erant necessario circumfusi, se uidere negarent. Et enim nihil est improbitate propriae conscientiae testimonio redarguta turbulentius, nihil horribilius. Agitat et insectatur animum; minas iactat; faces intentat; assiduo angore et cruciatu 
que a ruindade refutada pelo testemunho da própria consciência. Agita e atormenta o espírito; lança ameaças; ataca com tochas; dilacera com angústia e tortura incessantes e não deixa parar em nenhum lugar, porquanto tristíssimos cuidados inquietam sem cessar os ímpios e cercam-nos com medo e terror perpétuos.

Por conseguinte, enquanto a consciência das malfeitorias os aterroriza, não podem pensar em nada que não seja lutuoso e penoso e merecedor de prantos e lamentos, pois a essência e razão do medo não tem outra causa senão a traição, por via da qual o espírito se separou do senhorio da razão e desse modo se despojou a si mesmo de toda a protecção. É que o entendimento, oprimido pela tirania do desejo, não só perde a liberdade e as forças, mas também repele para muito longe de si a ajuda divina, e, assim, fica nu e desarmado, tornando-se absolutamente forçoso que seja atribulado por incessante inquietação e pelo horrível receio de todos os males. E como a esperança que resta no espírito é fraca e ténue, a razão conclui que são muito mais graves as coisas que ainda não conheceu mediante a experiência do que aquelas que já foram causa do suplício e ruína infligidos.

Mas se os que naquela noite, que não podia em absoluto trazer qualquer consolação aos mofinos homens (pois saíra das profundezas do cruel Inferno, nas quais não pode existir nenhum repouso, estabelecido por algum tempo para os fatigados pelo excessivo trabalho), adormeciam, o sono em que caíam era totalmente idêntico ao sono dos manes dos infernos. É que, em parte, eram inquietados por horrendas visões, em parte, abandonados pelo entendimento e privados da protecção de todo o vigor e firmeza, caíam, de tal modo que era impossível erguerem-se e regressarem a alguma esperança, pois atacava-os um medo repentino e inesperado. Ora, quem quer que caía por terra estarrecido pelo pavor, permanecia prostrado, como se tivesse sido agrilhoado e lançado no cárcere. De facto, quer se tratasse do agricultor, quer do pastor, quer do jornaleiro contratado para, com grande trabalho, cultivar terrenos ermos, encontravam-se oprimidos pelas trevas; de tal maneira se achavam forçados pela necessidade que não podiam sair dali e mudar do lugar em que caíram, pois todos se encontravam estreitissimamente ligados por um único vínculo de trevas. Entretanto nada existia que os não assustasse, pois quer o sussurro do ar ligeiramente agitado, quer os cantos das aves poisadas nos densos ramos das árvores, soando melodiosamente, quer o murmúrio, grato aos ouvidos e que ressoa harmoniosamente, da água, ao correr com ímpeto natural, quer o fragor um pouco mais forte das pedras que caem, quer a corrida dos animais a brincar, que os olhos então não podiam ver, quer o rugido das cruéis bestas-feras, quer o som que, com eco nada desagradável, retumba das cavernas e vales das montanhas, batidos por palavras bradadas, quer soasse alguma outra coisa que, pela sua natureza, fosse insusceptível de impressionar as pessoas um pouco mais sãs: aterrorizava-os e frequentemente os prostrava com um medo enorme. [1001] O espírito consciente do seu próprio crime é de tal maneira abalado pelo temor que sente receio até de coisas em parte totalmente inócuas, em parte vãs.

O mundo estava iluminado pelo claríssimo esplendor do Sol e os restantes homens estavam prontos e entusiasmados para se aplicarem às suas obras, e todos ocupados 
dilacerat; nec ulla in sede consistere permittit, curae namque tristissimae impios assidue uexant et metu et horrore perpetuo circumuallant.

Nihil igitur, quamdiu eos maleficiorum conscientia perterret, cogitare possunt, nisi luctuosum et acerbum, eiulatu et plangore dignissimum, uis enim et ratio metus non ortum habet aliunde quam a proditione, qua animus a rationis imperio desciuit et ita se ipsum omni praesidio nudauit. Mens enim, tyrannide cupiditatis oppressa, non solum libertatem atque uires amittit, sed etiam opem diuinam a se longissime repellit et ita inermis et nuda relinquitur, et sic demum est necesse ut assidua sollicitudine et horribili malorum omnium formidine torqueatur. Cum uero reliqua spes in animo tenuis et imbecilla sit, multo grauiora colligit esse ratio ea, quae nondum experiundo cognouit, illis, quae causam irrogati iam supplicii et uastitatis attulerant.

At uero si qui nocte illa, quae nullum prorsus alleuamentum hominibus miseris afferre poterat (erat enim ex impotentis Orci penetralibus emissa, in quibus nulla requies esse potest, nimio labore defatigatis ullo in tempore constituta) somnum capiebant, somnus quo erant consopiti erat inferorum manium somno simillimus. Partim enim horrendis uisis exagitabantur, partim, a mente deserti omnique firmitatis et roboris praesidio destituti, concidebant, ut erigi et ad aliquam spem reuocari minime potuissent, improuisus enim atque repentinus metus in illos impetum dabat. Vt autem quilibet pauore exanimatus in terram deciderat ita iacebat, quasi ferro uinctus et in carcerem coniectus esset. Siue enim agricola, siue pastor, siue operarius, ad agrum in solitudine magno labore colendum, mercede conductus esset, tenebris oppressus erat; ita necessitate, quam nemo uitare poterat, astrictus tenebatur, ne posset inde discedere et locum, in quo deciderat, commutare, uno siquidem omnes tenebrarum uinculo erant artissime colligati. Nihil erat interim quod illos minime perterreret, siue enim aeris leniter agitati susurrus, siue auium densis arborum ramis insidentium uoces, modulate sonantes, siue aquae, impetu naturae fluentis, ad numerum resonans, non iniucundum auribus murmur, siue paulo uehementior saxorum decidentium fragor, siue animantium ludentium cursus, quem tunc oculis cernere non licebat, siue belluarum immanium fremitus, siue sonus, ex montium speluncis et conuallibus, emissa uoce, percussis, clamore non ingrato resultans, siue quid aliud sonaret, quod natura sua paulo saniores mouere non posset: illos horrore concutiebat et ingenti metu fretu [1001] frequenter exanimabat. Ita est animus sibi sceleris conscius formidine perculsus ut res etiam partim lenissimas, partim inanes extimescat.

Mundus quidem erat clarissimo splendore solis illuminatus et homines reliqui ut operibus suis incumberent erant alacres et expediti, omnesque in negotiis suis transigendis occupati, illisque tantum, qui bellum inexpiabile cum numine 
em realizar os seus negócios, e só sobre aqueles que tinham empreendido uma guerra implacável contra a majestade divina se estendera uma medonha noite, semelhante àquela com que deveriam ser violentamente oprimidos na região da sempiterna desgraça. Na verdade, embora estivessem rodeados por tão terríveis trevas, todavia eles próprios eram para si mesmos muito mais prejudiciais do que as próprias trevas, porquanto é no íntimo que se esconde o que arranca a luz, o que atormenta com a loucura, o que perturba a paz, o que provoca a rebelião, o que angustia, o que tortura, o que dilacera, o que dia e noite aterroriza os culpados com o medo do suplício. É que o espírito, por natureza apto para a semelhança com Deus, assim como não pode receber um prazer estável de outra coisa que não seja a imitação da bondade divina, da mesma maneira é forçoso que seja sobretudo atormentado pela fealdade do crime e sofra tanto maior tortura com a lembrança da infâmia, quanto mais monstruosa for a infâmia e mais oposta à lei divina. E assim são punidos com dois castigos: ou seja, por um lado, com a assustadora visão do próprio crime, e, por outro, com o receio da ruína iminente.

\section{CAPÍTULO XVIII}

Mas os Teus santos naquele tempo estavam rodeados por uma luz intensíssima; os inimigos ouviam a sua $\mathrm{VOZ}$, mas, devido às trevas estendidas, não podiam ver-lhes a forma. Ora, porque os justos não sofriam o mesmo, os Egípcios proclamavam-nos bem-aventurados; e porque, embora anteriormente tivessem sido vítimas de muitas injustiças, não vingavam as malfeitorias infligidas, agradeciam-lhes e rogavam-lhes afincadamente que se afastassem das fronteiras da terra. É que receavam que, se os varões superiores pelo merecimento da piedade permanecessem durante muito mais tempo naquela região, seria completamente aniquilada toda a raça dos homens que se tinham esforçado por empecer-lhes a saída. Por outro lado, também aconteceu que os justos, esquecidos das injustiças, com admirável equidade de espírito salvaguardaram a inocência e não fizeram mal a nenhum daqueles que os tinham atribulado com muitas agressões. Por consequência, por esta razão deste-lhes uma coluna chamejante para lhes mostrar o caminho desconhecido, e providenciaste no sentido de que o Sol não lhes fizesse mal com aquele fortíssimo calor, e procedeste de modo a que considerasse que lhe haveria de ser título de glória se tratasse os Teus benigna e hospitaleiramente, e de tal maneira os ajudasse que entretanto não lhes causasse qualquer moléstia.

E, além disso, aqueles que tinham metido na prisão os Teus filhos, pelos quais a luz da Tua santíssima lei sempiterna deveria ser oferecida a todos os homens, tinham-se tornado merecedores de ser privados da luz e mantidos encerrados no cárcere e nas trevas. Eles tomaram uma decisão totalmente criminosa que visava matar os filhos dos que santamente praticavam a piedade; de entre estes, houve um que foi abandonado nas águas e libertado com a Tua ajuda, para se tornar o vingador das maldades, para que por obra dele privasses os ímpios da multidão dos filhos e, ao cabo, os submergisses sob as violentíssimas ondas. [1002] Aquela noite, que trouxe aos iníquos a desgraça e aos justos 
diuino susceperant, erat taeterrima nox offusa, illi similis qua erant in sempiternae miseriae regione grauiter opprimendi. Verum, cum tam diris essent tenebris circumuenti, ipsi tamen sibi erant tenebris ipsis longe grauiores, intus enim latet quod lucem eripiat, quod amentia uexat, quod pacem turbat, quod seditionem excitat, quod angit, torquet atque dilacerat, quod sontes, metu cruciatus, dies atque noctes exterret. Animus enim, natura sua ad Dei similitudinem aptus, ut non potest ex re alia nisi ex diuinae probitatis imitatione stabilem uoluptatem percipere, ita necesse est ut sceleris deformitate maxime crucietur tantoque maius ex flagitii recordatione supplicium subeat, quanto flagitium immanius exstiterit et magis legis diuinae contrarium. Itaque duplici poena puniuntur: nempe, et horrifico sceleris ipsius aspectu, et imminentis exitii formidine.

\section{CAPVT XVIII}

At uero sancti tui erant eo tempore maxima luce circumfusi; quorum quidem uocem hostes audiebant, formam, propter offusas tenebras, uidere non poterant. Porro autem quod non iusti eadem paterentur, eos Aegyptii beatos praedicabant; quod uero, cum multis antea fuissent iniuriis affecti, non illata maleficia uindicarent, eis gratias agebant illosque ut e terrae finibus excederent enixe precabantur. Timebant enim ne, si diutius uiri pietatis laude praestantes in tellure illa consisterent, omne genus hominum, qui illorum exitum intercludere conati fuerant, funditus interiret. Accidit autem ut iusti, iniuriarum immemores, innocentiam admirabili animorum aequitate tuerentur et nemini nocerent eorum, a quibus multis plagis afflicti fuerant. Ob id igitur columnam flammis coruscantem illis ducem itineris ignoti tribuisti, et sol, ne ardoribus summis illis noceret, prouidisti, atque perfecisti ut gloriae sibi fore duceret, si tuos benigne et hospitaliter exciperet, et ita eos iuuaret ut nullam interim illis molestiam exhiberet.

Illi porro qui filios tuos in custodiam tradiderant, per quos erat sempiternae legis tuae sanctissimae lux cunctis hominibus afferenda, digni fuerant qui luce spoliarentur et carcere ac tenebris inclusi tenerentur. Consilium illi quidem sceleris plenum habuerunt ut filios eorum, qui pietatem sancte colebant, interimerent; e quibus unus in aquis expositus et ope tua liberatus fuit, ut maleficiorum uindex exsisteret, cuius opera filiorum multitudine impios orbares eosque tandem uehementissimis undis obrueres. Nox [1002] quidem illa, quae cladem iniquis, libertatem iustis attulit, fuit olim praenuntiata patribus nostris, ut firma fide percipientes eos qui diuinis promissis, maxime autem iureiurando sanctissimo 
a liberdade, foi antigamente profetizada aos nossos antepassados, a fim de que, sabendo com fé firme que os que se apoiam nas promessas divinas, mas sobretudo corroboradas por santíssimo juramento, não podem ser privados do santíssimo fruto da piedade, alentados pela esperança da suprema felicidade, mantivessem sempre a perseverança. E deste modo o Teu povo já estava confiante em que haverias de dar aos Teus a salvação e infligir aos inimigos a ruína e a perdição. E a sua esperança não os defraudou, pois castigaste violentamente o crime dos inimigos e cumulaste de extraordinária glória os que invocavam o Teu nome. É que os santos, descendentes da linhagem dos bons, em segredo celebravam as cerimónias religiosas e faziam de acordo com os ritos os votos e, unidos por admirável uniformidade de sentimento religioso, avaliavam os deveres da vida em conformidade com a lei eterna da santidade. E não ignoravam que todos os que perseverassem no zelo da santidade haveriam de associar-se nos bens e nos perigos. E, assim, melodiosamente entoavam cânticos, cujo sentido muito tempo antes, por inspiração do Espírito Santo, os pais tinham cantado.

Enquanto, porém, os homens piedosos celebravam o Teu nome com extraordinário acordo e harmonia, as vozes desentoadas dos inimigos escutavam-se com queixumes e prantos, e as vozes mal cadenciadas das crianças soltavam tristes lamentações. A vingança, através da morte dos filhos, atingiu violentamente todos por igual. O escravo sofreu o mesmo castigo juntamente com o senhor, a punição alcançou do mesmo modo tanto os homens obscuros e desconhecidos como a majestade e grandeza do rei. Não havia nenhuma casa que de modo idêntico, devido à morte de muitos com uma única palavra, não tivesse sido desfigurada pela ruína e pelas lamentações. Jaziam inúmeros cadáveres e os vivos eram insuficientes para se ocupar dos funerais e sepultar os mortos. Com efeito, a flor e força daquele povo tinha sucumbido abatida por um único golpe.

Mas antes, como se ensoberbeciam com os feitiços e conheciam artes funestas, atribuíam à magia todas as coisas fora do comum e não se resolviam a crer que estes sinais, que viam com os olhos, eram obra da força e poder divinos. E até inúmeros, para disto convencerem os homens, empenhavam-se em imitar muitos destes sinais, embora acabassem por sucumbir, vencidos pela verdade. Embora, porém, convencidos por muitos sinais, acabassem por reconhecer que isto que se fazia de nenhum modo poderia ser feito por artifício humano, todavia tiveram disto uma experiência muito mais clara, ao verem devorados por um passamento repentino todos os filhos primogénitos dos Egípcios, herdeiros do património e do nome, e nos quais os pais tinham colocado a esperança da descendência e um refúgio contra a morte. Compreenderam então que conservas o Teu povo com amor paternal e que tinhas empreendido guerra em defesa dos Teus filhos (pois alcançaram este título da Tua imensa bondade). É que velaste por eles com amor paterno em todas as situações de perigo.

De facto, ao jazerem todos em tranquilo silêncio e, depois de estabelecida a ordem, ao concluir a noite metade da carreira do costumado percurso, de repente a Tua voz omnipotente desceu do céu, e precisamente das moradas régias nas quais se divisa a grandeza da Tua majestade, e, com a impetuosa paixão da merecida vingança, penetrou no meio da terra sacrílega e ímpia, e, vibrando a afiada espada, [1003] executou, com 
confirmatis, innituntur, pietatis certissimo fructu priuari non posse, ad spem firmissimam summae felicitatis erecti, constantiam perpetuo retinerent. Itaque iam populus tuus futurum confidebat ut tuis salutem dares et hostibus pestem atque perniciem inferres. Spes uero eos minime fefellit, nam inimicorum scelus acriter ultus es et eos qui nomen tuum inuocabant insigni gloria cumulasti. Sancti enim bonorum satu propagati, secreto sacra procurabant et uota rite faciebant et, admirabili pietatis consensione conspirantes, ad sanctitatis legem sempiternam officia uitae perpendebant. Nec ignorabant fore omnibus qui sanctitatis studio tenerentur societatem bonorum et periculorum ineundam. Et ita carmina modulate concinebant, quorum sententiam patres, Sancti Spiritus instinctu, multo ante cecinerant.

At, cum pii, singulari concentu et harmonia, nomen tuum celebrarent, dissonae uoces hostium, cum eiulatu et plangore, audiebantur, et lugubris lamentatio puerorum inconditas uoces emittebat. In omnes enim pariter fuit, filiorum nece, acerrime uindicatum. Eamdem poenam seruus cum domino pertulit, idem supplicium fuit de obscuris et ignotis hominibus et de regis maiestate et amplitudine sumptum. Nulla domus erat quae similiter non esset, uno nomine, multorum interitu, et exitio et ploratibus deformata. Innumerabilia cadauera iacebant neque uiui poterant funera curare et mortuos in sepulcrum inferre. Nam gentis illius flos atque robur, uno ictu perculsum, conciderat.

Antea uero, cum essent ueneficiis elati artibusque pestiferis instructi, omnes res mirandas ad magiam referebant nec animum inducebant ut crederent ea signa, quae cernebant oculis, ui atque numine diuino fieri. Quin etiam multi, ut id hominibus persuaderent, multa conabantur imitari, quamuis tandem, ueritate uicti, succumberent. At, cum tandem multis signis conuicti, faterentur ea, quae fiebant, nullo modo artibus humanis effici, id tamen multo clarius experti sunt, cum uiderent omnes Aegyptiorum filios, qui primi geniti fuerant, patrimonii atque nominis heredes, in quibus parentes posteritatis spem et mortis perfugium collocauerant, exitio repentino consumptos. Intellexere demum populum tuum a te patria caritate conseruari et pro filiis tuis (hoc enim nomen ab immensa benignitate tua consecuti sunt) bellum susceptum fuisse. Nam caritate patria illis in omni rerum discrimine prospexisti.

Cum enim omnes in quieto silentio iacerent et nox, ordine constituto, medium uiae solitae cursum conficeret, omnipotens sermo tuus e caelo atque adeo a regiis sedibus, in quibus tuae maiestatis amplitudo conspicitur, repente desiluit, et, cum acri debitae ultionis studio, in medium sceleratae et impiae telluris inuasit, acutumque gladium uibrans, quod tu [1003] praescripseras, optima fide et absque ulla cunctatione aut tergiuersatione, peregit. Ergo cuncta caede compleuit: caelum 
inexcedível fidelidade e sem qualquer adiamento ou evasiva, aquilo que Tu tinhas ordenado. Portanto, tudo encheu com a morte violenta: por uma parte, tocando no céu, para desempenhar a função que lhe fora cometida, e, pela outra, causando na terra enormes danos, para castigar os crimes. E, entretanto, horríveis visões inquietavam em sonhos os infelizes, temores repentinos fortemente os aterravam, e uns, lançados por aqui e por ali e meio-mortos, contavam por que motivo morreram. É que os próprios sonhos, ao aterrorizá-los e perturbá-los de modo ameaçador, tinham-lhes profetizado por que é que morriam assim, para que ninguém ao morrer ignorasse a causa de tão funesta destruição.

E da profundíssima comoção nem sequer ficaram isentos aqueles que se tinham proposto em toda a sua vida respeitar a justiça e não violar a piedade. Com efeito, no ermo deserto, como muitos caíam e não perseveravam com a devida lealdade no cumprimento do dever, foram feridos pela severidade do juízo divino e uma multidão nada pequena foi destruída. Sem embargo, este morticínio logo de seguida parou e se acalmou a ira do Teu poder divino. É que para tornar propício o Teu poder divino levantou-se como defensor um varão muitíssimo denodado nas armas, aparelhado com a máxima inteireza e com virtudes divinas, pegando nas armas da congénita religiosidade e piedade, ou seja, as orações e as fumigações. E, assim, pôs-se no meio e com a máxima coragem fez frente à ira e não se esquivou a nenhum perigo, contanto que afastasse a perdição de perto do povo que se encarregara de dirigir e cuidar. Por conseguinte, pôs fim à desgraça e mostrou com os factos que era Teu servidor e cumpria todos os deveres da vida em conformidade com os preceitos da lei eterna, pois, como sabia que o que mais Te agradava era a justiça, respeitou especialmente a justiça; como via que as rogativas e votos dos santos Te fazem mudar do rigor para a benignidade, passou a vida em oração e zelo da religião; como estava ciente de que o apaziguamento da divindade ofendida se cifra no amor, a tal ponto abraçou com o amor o povo de que foi encarregado que pessoalmente se postou no meio e de bom grado se ofereceu a receber no seu corpo, se tal fosse necessário, os dardos lançados contra o povo; finalmente, compreendia que não se devia apoiar nem nas forças corporais, nem nos recursos humanos, nem na arte de fazer a guerra, mas que era mister confiar na Tua bondade, e deste modo venceu grandes guerras graças à fé, e não às armas.

É que venceu aquele que causava a perdição e repeliu energicamente o ataque do anjo vingador sobre o povo, não com forças nem com armas nem com o esforço da disciplina militar, mas unicamente graças à oração. Com efeito, impediu que prosseguisse no morticínio aquele que, por ordem Tua, castigava os erros dos homens, ao referir-Te com zelo assaz apaixonado os juramentos com que confirmaras o pacto celebrado com os antepassados. É que, como a terra tinha sido coberta de montões de cadáveres e devendo muitos, ainda vivos, morrer em breve às mãos do anjo vingador, o santo varão foi ao encontro da fúria que se desatava no meio do acampamento, a fim de cortar o caminho por onde se dirigia contra os vivos e, com invencível denodo, impediu-a que prosseguisse, ocasionando muito maior perda. Com efeito, aquele aparato da veste sagrada caída até aos tornozelos, simbolizava muito bem a condição e natureza do mundo inteiro: no peito, [1004] doze pedras repartidas por quatro fileiras representavam a glória dos patriarcas, 
quidem, ut commissum munus exsequeretur, attingens, et in terra, ut scelerum poenas expeteret, insignem stragem faciens. Interim uero in somniis horrenda uisa miseros exagitabant, improuisique metus uehementer exterrebant, et alius, alibi proiectus atque semiuiuus, quam ob causam cecidisset enuntiabat. Ipsa namque somnia, cum illos minaciter terrerent atque perturbarent, cur ita perirent illis praenuntiarant, ne quisquam tam funesti exitii causam moriens ignoraret.

Nec illi quidem, quibus erat propositum in omni uita seruare iustitiam et minime uiolare pietatem, grauissimae commotionis expertes exstitere. In deserta namque solitudine, cum multi prolaberentur neque debita fide in officio manerent, diuini iudicii seueritate percussi sunt et non mediocris multitudo concisa fuit. Caedes tamen illa repressa continuo fuit et tui numinis ira sedata. Vir enim in armis acerrimus, integritate summa, uirtutibus diuinis instructus, insitae religionis et pietatis arma corripiens: nempe, preces atque suffimenta, propugnator egregius exstitit, ut numen propitium redderet. Itaque se medium interposuit et irae, animo maximo, repugnauit neque periculum ullum recusauit, dummodo a populo, quem regendum et tuendum susceperat, pestem repelleret. Calamitati igitur finem imposuit atque rebus ostendit se tuum famulum esse omniaque officia uitae ex praescripto legis sempiternae moderari, cum enim iustitiam maxime tibi cordi esse sciret, unice iustitiam coluit; cum cerneret te sanctorum precibus et uotis a seueritate ad benignitatem inflecti, uitam in precibus et religionis studio consumpsit; cum haberet cognitum numinis offensi placationem caritate contineri, usque eo populum sibi commissum caritate complexus est ut ipse in medium prodiret seque libenter offerret ut tela, in populum coniecta, corpore suo, si ita opus esset, exciperet; postremo, intelligebat neque uiribus corporis, neque humanis opibus, neque bellandi artificio nitendum, sed benignitate tua confidendum, itaque fide, non armis, bella magna profligauit.

Illum enim, qui perniciem inferebat, non uiribus, non armis, non disciplinae militaris industria, sed oratione tantum superauit angelique uindicis impetum a populo constantissime repressit. Eum enim, qui poenam flagitiorum ab hominum erratis, iussu tuo, repetebat, a caede ulterius facienda continuit, cum tibi iuramenta, quibus foedus, cum patribus ictum, confirmaueras, studio nimis ardenti suggereret. Cum enim cadauerum aceruis terra constrata fuisset et multis, adhuc uiuis, esset iamiam ultoris angeli manu moriendum, uir sanctus furori, qui in mediis castris uersabatur, obuiam prodiit, ut uiam, qua in uiuos ferebatur, intercluderet et, ne ulterius, cum multo maiore clade, tenderet, inuicta uirtute prohibuit. Ille namque sacrae uestis ad talos usque demissae cultus totius mundi statum atque naturam luculenter exprimebat: in pectore [1004] duodecim lapides, ordine quaduplici distincti, ita ut terni singulis uersibus inclusi tenerentur, patrum gloriam referebat, singuli namque lapides nomen unum ex duodecim 
de tal maneira que se continham três inscritos em cada linha, pois cada pedra tinha gravado um nome dos doze patriarcas, e, deste modo, expunha nominalmente à Tua vista todos os filhos de Jacob. Por último, um diadema colocado sobre a cabeça simbolizava o esplendor do Teu santíssimo nome, a estabilidade de vida e a magnificência da glória. Ora, com este atavio simbolizava-Te a Ti, que criaste e conservas o mundo inteiro, e que, com singular cuidado e protecção, diriges Israel, e frequentemente ofereces a claridade da luz eterna a todos os que com ardente fé e incessantes preces invocarem o Teu nome. Além disso, representava a imagem do santíssimo sacerdócio, que haveria de ser oferecido para a salvação do mundo, e haveria de expor a santidade do nome divino aos homens abrasados no zelo da piedade, e haveria de iluminar todo o género humano com os raios do Sol eterno. Por consequência, avançou ornamentado com este atavio da caridade, da humanidade, da religiosidade, da fé e da mais ardente piedade; diante destas coisas recuou o vingador do crime, que preparava a ruína e perdição; o ministro de Deus, sentindo temor destes enfeites, destes ornatos e deste trajo da santíssima religião, pôs termo à matança. É que, no que tangia ao ensinamento da piedade, usara-se de rigor bastante para que os restantes, advertidos pelo exemplo de severidade, regressassem ao cumprimento do dever, pois castigas o crime do Teu povo de tal maneira que fixas limites à Tua ira e acabas por tudo encaminhar à glória dos que acolheste sob a Tua protecção.

\section{CAPÍTULO XIX}

E o violento rigor perseguiu os ímpios para exterminá-los sem qualquer misericórdia. É que conhecera e vira antecipadamente a grande obstinação com que haveriam de perseverar no crime. De facto, mudando subitamente de decisão, perseguiram ferozmente os mesmos a quem com a máxima violência tinham exigido que partissem (até com extraordinário cuidado os acompanharam, pois tamanho terror neles nascera que não tinham esperança de qualquer salvação se os Hebreus vivessem durante mais tempo dentro das fronteiras do Egipto, e, por isso, não só lhes concediam autorização para partirem, como também lhes rogavam suplicantemente que se fossem embora depressa). Embora ainda fosse recente o luto, e os queixumes, pranto e sentidíssimos gemidos junto dos sepulcros dos mortos mostrassem a dor que os atribulava; embora ainda não tivessem perdido o vivo sentimento pela pungentíssima dor nem feito aos mortos as cerimónias fúnebres, conforme aos usos da raça: inflamados em loucura, aumentam com novo crime o crime cometido e perseguem como fugitivos aqueles a quem, por entre imprecações, tinham expulso. É que o máximo crime, aumentado com a congénita obstinação, rejeita todo o remédio e a tal ponto cega o entendimento com erros e o precipita na perturbação que este, ímpia e sacrilegamente, maquina a sua própria perdição.

Com efeito, a terrível necessidade como punição do sacrílego atentado acabou por lançar no merecido castigo aqueles a quem não comoveu a Tua bondade, nem ensinou o desastre sofrido, nem quebrou o medo de maiores males. De facto, fez que, esquecidos daquilo que tinham sofrido, [1005] fossem arrastados para a destruição, por forma a 
patribus insculptum continebant et, hac ratione, omnes Iacobi filios nominatim in tuo conspectu proponebant. Postremo, capiti impositum diadema sanctissimi nominis tui splendorem, uitae stabilitatem et gloriae magnificentiam designabat. Hoc autem ornatu te, mundi totius conditorem et conseruatorem, et Israelem, singulari cura et patrocinio, dirigentem, sempiternique luminis claritatem omnibus, qui nomen tuum ardenti fide et assiduis precibus inclamarent, frequenter offerentem, significabat. Imaginem praeterea sacerdotii sanctissimi gerebat, quod erat salutem mundo allaturum, nominisque diuini sanctitatem hominibus pietatis studio incensis explicaturum, uniuersumque genus humanum solis sempiterni radiis illustraturum. Hoc igitur cultu caritatis, humanitatis, religionis, fidei et ardentissimae pietatis, ornatus in medium processit; his cessit sceleris ultor, qui pestem et exitium comparabat; has infulas, haec ornamenta, hunc sanctissimae religionis habitum ueritus Dei minister, manum a caede continuit. Quod enim ad eruditionem pietatis attinebat, satis erat saeuitum ut reliqui, exemplo seueritatis admoniti, ad officium redirent, ita enim in populi tui scelus animaduertis ut irae modum termines omniaque tandem ad eorum gloriam dirigas quos in fidem tuam recepisti.

\section{CAPVT XIX}

Impiis uero ad internecionem absque ulla clementia. Euenturum namque prospexerat atque futurum nouerat quanta pertinacia erant in scelere permansuri. Eos enim ipsos, a quibus, ut abirent, ope summa contenderant (quos etiam abeuntes insigni studio prosecuti fuerant, tantus enim terror hominibus erat iniectus ut omnem salutem desperarent, si Hebraei diutius in Aegypti finibus uersarentur, et ideo non solum eis discedendi licentiam permittebant, uerum, ut celeriter excederent, eos suppliciter obsecrabant), consilio repente commutato, ferociter insecuti sunt. Cum adhuc recens luctus esset, et eiulatus atque plangor et acerbissimi fletus ad mortuorum sepulcra dolorem, quo premebantur, indicarent; cum necdum uiui sensus grauissimi doloris amisissent neque mortuis fuissent iusta funerum, gentis instituto, facta: amentia flagrantes, nouo scelere institutum scelus augent et quos precibus extruserant, eos ut fugaces insequuntur. Summum enim scelus, insita contumacia cumulatum, omnem medicinam repudiat et usque eo mentem excaecat erroribus et praecipitem exturbat ut ipsa sibi pestem impie et nefarie machinetur.

Dira namque necessitas in scelesti facinoris poenam eos, quos non tua benignitas mouit, non accepta clades erudiuit, non maiorum malorum metus infregit, tandem in meritum supplicium detrusit. Perfecit enim ut eorum, quae perpessi fuerant, [1005] obliti, in exitium raperentur, ut, quod ad debitum supplicium deerat, tandem magnitudine extremae calamitatis exsoluerent. Sic 
acabarem por pagar com a grandeza do derradeiro desastre o que faltava para a merecida punição. Ora, assim sucedeu que, contra a opinião de todos e em contradição com a natureza, no meio das ondas se abriu aos Teus uma estrada directa e expedita e atravessaram o mar a pé, ao passo que os inimigos morreram de uma nova e insólita espécie de morte, ao tempo que procuravam vingar-se. É que, toda a natureza, que permanece no seu modo de ser, a fim de obedecer às Tuas ordens toma nova forma, de maneira a realizar, ao mesmo tempo, acções diferentes e dissemelhantes. E, assim, todas as coisas se empenhavam activamente em que os Teus filhos se conservassem incólumes. A nuvem opunha-se aos ardores do Sol, de maneira a, com gratíssima sombra, preservar o acampamento da agressão do Sol; do profundo abismo das águas a seca terra erguia-se de forma a poder ser vista pelos olhos; pelo meio do Mar Vermelho abria-se uma estrada expedita; ao apartarem-se as violentas vagas aparecia uma planície coberta de erva e através dela passaram facilmente todos a quem protegias com o Teu poder pessoalmente presente, olhando para as Tuas obras maravilhosas. E, assim como os cavalos, alimentados com abundantes pastos, rincham amiúde, e como os cordeiros, brincando nos prados, correm de um lado para o outro, da mesma maneira também eles soltavam brados como sinal da imensa alegria e exultavam ao beneficiarem de inúmeros benefícios, dando os devidos louvores ao Teu nome, ó Senhor, que os libertaras arrancando-os às fauces dos inimigos.

É que então traziam à memória muitas coisas que Tu, contra a ordem costumada da natureza, maravilhosamente levaste a efeito, por amor deles, durante o tempo em que estiveram no exílio, atribulados pela crueldade dos inimigos. Com efeito, a terra, em vez de animais de utilidade para os homens, tinha produzido mosquitos, para picarem e ferirem os inimigos; o rio, em vez de peixes, criara uma imensa multidão de rãs, para atormentar os Egípcios com o seu dissonante coaxar e medonho fedor. Mas, depois que saíram das fronteiras do Egipto, eles mesmos, que se lembravam da pobreza e ruína que os inimigos padeciam numa terra sobremaneira fecunda, viram, no desoladíssimo deserto, no qual era impossível que nascesse coisa alguma acomodada à alimentação humana, uma nova raça de aves para satisfazerem o desejo dos que estavam com vontade de comer carne. Deste modo aconteceu que, pela Tua bondade, os que se escondiam sob a Tua protecção obtiveram liberal e copiosamente não apenas o que era necessário para a vida, mas também o prazenteiro. De facto, como certas pessoas, devido ao constante consumo, sentissem fastio por aquele alimento de todos os dias, embora ele fosse muitíssimo gostoso, a fim de remediares misericordiosamente a intolerável repugnância do estômago, fizeste que o vento trouxesse da região de além-mar uma grande quantidade de codornizes, de maneira a saciares com inesperados manjares o apetite dos Teus.

Mas vingaste com suplícios o crime dos que tinham perpetrado abomináveis atentados e, para que se tornasse mais manifesto que isto não tinha acontecido por acaso, com frequentes raios davas a conhecer o desagrado do Teu poder divino. Mas suportavam o merecido castigo pelo sacrílego crime, pois abominavelmente violavam o santíssimo direito de hospitalidade. Com efeito, ou não recebiam como hóspedes homens desconhecedores de tão grande desumanidade, [1006] ou arrancavam a liberdade a hóspedes de quem tinham recebido benefícios; e, algo que merecia ser castigado com o 
autem factum est ut tuis, praeter omnium opinionem et praeter naturam, iter rectum et expeditum mediis in fluctibus pateret et mare pedibus transfretarent, hostes uero nouo, dum uindictam exquirunt, et insolito genere mortis interirent. Vniuersa namque natura, in suo genere permanens, ut praescriptis tuis obtemperet formam nouam induit ut, uno tempore, diuersas atque dissimiles actiones efficiat. Itaque, ut filii tui incolumes seruarentur, omnia operam strenue nauabant. Nubes, ut a castris solis iniuriam umbra gratissima prohiberet, se contra solis ardores opponebat; ex profundo aquarum gurgite arida terra, ut conspici oculis posset, eminebat; per medium Maris Rubri expeditum iter patebat; herbida planities, cum uiolenti fluctus abscederent, apparebat, per illam uero omnes quos praesenti numine protegebas, opera tua mirabilia intuentes, facillime transierunt. Et, ut equi, laetissimis pabulis saginati, frequenter hinniunt, et, ut agni, in pratis lasciuientes, huc et illuc cursitant, ita et illi clamores, laetitiae ingentis indices, edebant et, innumerabilibus affecti beneficiis, exsultabant, nomen tuum, o Domine, qui eos, ex hostium faucibus ereptos, in libertatem uindicaueras, debitis laudibus efferentes.

Multa enim tunc in memoriam reuocabant quae, quamdiu erant in exsilio, hostium importunitate uexati, fuerant a te, eorum gratia, contra solitum naturae ordinem, mirabiliter effecta. Terra enim, pro animantibus ad hominum usum accommodatis, culices innumerabiles, ut hostes pungerent et cruentarent, ediderat; fluuius, pro piscibus, ingentem ranarum multitudinem, ut Aegyptios, dissonis clamoribus et odore taeterrimo, diuexaret, extulerat. At, postquam Aegypti finibus excesserunt, in uastissima solitudine, in qua nihil omnino, quod ad hominum uictum accommodatum esset, gigni poterat, uiderunt iidem ipsi, qui hostium inopiam et uastitatem in terra ualde opima memoria tenebant, recentem auium generationem, ut eorum cupiditatem, qui carnes appetebant, explerent. Ita factum est ut non modo eis, qui in tuo praesidio latebant, quod erat ad uitam necessarium, sed etiam quod ad delicias pertineret, esset large et copiose beneficentia tua comparatum. Cum enim quotidianum illum cibum, quamuis exstitisset omni iucunditate refertus, quidam, propter usum assiduum, fastidirent, ut stomachi minime ferendum offensionem clementissime subleuares, uim coturnicum a transmarina regione uento inuexisti, ut inexspectatis dapibus tuorum auiditatem satiares.

At uero scelus eorum, qui facinora taetra consciuerant, suppliciis ultus es atque, ut magis appareret non illa temere contigisse, crebris fulminibus offensam tui numinis explicabas. Dignam uero criminis scelestissimi poenam sustinebant, ius enim hospitii sanctissimum nefarie uiolabant. Nam uel homines tantae immanitatis ignaros hospitio minime recipiebant, [1006] uel hospitibus, a quibus beneficia acceperant, libertatem adimebant; et quod erat seuerissime uindicandum, omnes peregrinos acerbo odio persequebantur. Si uero aliqui, hilari fronte et inter sollemnia sacra, diebus festis, accepti fuissent, ut eiusdem iuris atque ciuitatis 
máximo rigor, votavam violento ódio a todos os viajantes. E se alguns, nos dias festivos, tinham sido acolhidos com rosto alegre e entre cerimónias solenes, por forma a obterem a participação nos mesmos direitos e cidadania, pouco depois, posta de parte a boa-fé, atacavam-nos e atormentavam-nos duramente com injustiças. Logo, não só jazem por terra abatidos por muitos golpes como castigo do crime cometido, mas também foram condenados pela cegueira, pois, assim como antigamente os homens, dementados pela paixão, ao arremeterem contra a porta do justo para cometer um atentado abominável, de tal maneira foram privados de luzes e oprimidos pelas trevas que nem sequer encontravam o caminho que levava à casa de cada um deles, do mesmo modo também, no meio de tão grandes trevas, não conseguiram encontrar nenhuma saída do Egipto. $\mathrm{E}$, de facto, os elementos variavam os seus lugares e funções, de tal maneira todavia que se harmonizavam entre si e dirigiam as suas forças para um único fim.

É que, assim como nas liras os mesmos sons, divididos de modo diferente, fazem melodias diferentes, assim as naturezas das coisas, em conformidade com a lei e regra da Tua vontade, realizam acções diferentes, quando tal Te apraz, porquanto a natureza não é senão o efeito da Tua vontade, e o governo do Teu santíssimo poder e a simetria ornada com o senhorio da Tua razão. É que, se a Terra, apoiada no seu peso, conserva a estabilidade no meio do mundo; se a água, quando não é impedida, é levada a escoar-se pela sua natural mobilidade; se o ar envolve a terra e os mares; se o fogo é impelido para o alto; se a terra produz frutos; se os peixes nascem nas águas; se as aves com voo livre cruzam os ares; se, finalmente, cada forma conserva a sua posição e cumpre a sua função: tudo isto foi estabelecido pelo Teu poder, razão e vontade. Por conseguinte, da mesma maneira que o citaredo toca diferentes melodias com a mesma cítara, assim Tu, ó supremo Pai e Senhor da natureza, consoante Te apraz, modulas a natureza inteira e modificas as acções dela de acordo com as regras da Tua inexplicável sabedoria, de tal modo todavia que nunca permites que ela discrepe do harmonioso acordo da Tua vontade. Tal como pôde concluir-se das obras que com os olhos se viram naquele tempo.

Com efeito, os animais terrestres lançavam-se na água, os aquáticos penetravam na terra, o fogo mantinha fortemente o seu vigor no meio das águas, e a água, como que completamente esquecida da sua natureza, não extinguia o ardor do fogo; as chamas, de novo em terra, embora esvoaçassem num e noutro sentido e causassem a morte a muitos homens, todavia não abrasavam as carnes dos brutos animais que se movimentavam por todos os lados, nem na terra deserta consumia aquela variedade de alimento que tinha a aparência de gelo e, pela sua natureza, se liquefazia com grande facilidade.

Por derradeiro, em todas as coisas, Senhor, enobrecias o Teu povo com os ornamentos de uma extraordinária dignidade e enchia-lo de singular glória e, como estavas sempre presente ao lado dele, em nenhum tempo ou lugar descuravas a sua salvação.

\section{Imprima-se.}


communionem obtinerent, eos paulo post, neglecta fide, iniuriis afficiebant et acerbissime diuexabant. Ergo, non solum multis plagis afflicti in sceleris admissi poenam iacuere, uerum et caecitate damnati sunt, ut enim homines olim, libidine furentes, cum in iusti fores irruerent, ut facinus infandum facerent, ita luminibus orbati et tenebris oppressi fuerunt ut ne uiam quidem, quae in cuiusque eorum aedes ferret, inuenirent, ita et Aegypti nullum, in tantis tenebris, exitum reperire potuerunt. Et enim elementa uarie sedes atque officia commutabant, ita tamen ut inter se apte concinerent et in unum finem uires intenderent.

Vt enim in fidibus iidem soni, uaria ratione distincti, uarios concentus efficiunt, ita et rerum naturae, pro tuae uoluntatis lege atque ratione, diuersas actiones, cum id tibi placet, exsequuntur, nec enim est aliud natura quam tuae uoluntatis effectus, numinisque tui sanctissimi moderatio atque rationis tuae imperio ornata concinnitas. Si enim terra, pondere suo nixa, in mundi medio stabilitatem retinet; si aqua, insita mobilitate, cum non est impedita, dilabitur; si aer terras atque maria circumfundit; si ignis in sublime fertur; si terra fruges effert; si pisces in aquis oriuntur; si uolucres uolatu libero aera tranant; si denique singulae formae proprium statum tuentur et suum quaeque munus sustinet: id totum est numine, ratione, uoluntate tua constitutum. Vt igitur citharoedus eadem cithara harmonias dissimiles efficit, ita tu, summe naturae parens et Domine, ut tibi uisum est, uniuersam naturam modularis et, pro inexplicabilis tuae sapientiae ratione, illius actiones immutas, ita tamen ut numquam eam a uoluntatis tuae symphonia discrepare permittas. Quod quidem ex operibus, quae illo tempore oculis perspecta sunt, coniicere sane licuit.

Animantia namque terrestria in aquas insiliebant, aquatilia in terris incedebant, ignis in mediis fluctibus uim suam fortissime retinebat, aqua uero, quasi naturae suae penitus oblita, ignis ardorem minime restinguebat; flammae, rursus in terra, cum ultro citroque uolitarent exitiumque multis hominibus inferrent, brutorum tamen animantium, quae passim gradiebantur, carnes non adurebant, nec in terra deserta illud diuinum genus alimenti quod glaciei speciem referebat et, natura sua, facillime liquefactum diffluebat, minime dissipabat.

In omnibus denique rebus, summe Domine, populum tuum eximiae dignitatis ornamentis illustrabas et insigni gloria cumulabas et, cum illi praesens semper adesses, nullo in tempore aut loco salutem illius negligebas.

\section{Imprimatur.}


(Página deixada propositadamente em branco) 


\section{NOTAS}

Prefácio de Jerónimo Osório Júnior à Paráfrase A Job do Português Jerónimo Osório, ao Excelentíssimo e Reverendíssimo Senhor D. Jorge De Ataíde, antigo Bispo de Viseu, Comendatário Perpétuo de Alcobaça, Capelão e Esmoler-Mor de D. Filipe I de Portugal, Conselheiro do Seu Conselho Supremo e Presidente da Real Mesa da Consciência

${ }^{1}$ D. Jorge de Ataíde (23/4/1535-17/1/1611) era filho do $1^{\circ}$ conde de Castanheira, D. António de Ataíde, vedor da fazenda e valido da máxima confiança de D. João III, e de sua esposa D. ${ }^{a}$ Ana de Távora, filha de Álvaro Pires de Távora: "foi bispo de Viseu, capelão-mor del-rei D. Anrique e dos reis Filipe II e Filipe III e de seu conselho de Estado no Conselho Supremo de Portugal, tendo sido presidente da Mesa da Consciência e Ordens (...) foi abade de Alcobaça." Para a biografia deste prelado, consulte-se: 1) Para o período que abrange os anos até 1571, a Vida que dele nos ficou, escrita em 1617 pelo sobrinho D. António de Ataíde, $1^{\circ}$ conde de Castro Daire e $5^{\circ}$ conde de Castanheira, e que se encontra manuscrita e incompleta na Biblioteca da Ajuda (Códice 51-IX-9, fls. 260-265 e 274-281), e donde extraímos o passo acabado de citar (fl. 260); 2) José de Castro, Portugal no Concílio de Trento, Lisboa, União Gráfica, volume IV, 1945, passim, mas sobretudo pp. 63-71, e volume VI, 1946, passim; 3) Barbosa Machado, Biblioteca Lusitana, sub nomine; 4) Compêndio Histórico do Estado da Universidade de Coimbra, Lisboa, Régia Oficina Tipográfica, 1771, pp. 20-38.

${ }^{2}$ Referência aos Estóicos.

${ }^{3}$ Em carta, dirigida provavelmente ao confessor de Filipe II de Portugal, datada de San Benito el Real, Madrid, a 15 de Agosto de 1603, e cujo original se conserva no códice da Biblioteca da Ajuda já citado, fols. 254-256, D. Jorge de Ataíde refere-se nos termos seguintes ao descalabro da sua saúde desde que transferira a sua residência para a capital de Espanha: "Vim mancebo e são ao serviço de Sua Majestade. De maneira gastei nele a saúde e os anos que me vou agora de sessenta e oito sem pés, nem mãos, nem dentes, nem vida (...)." (Fol. 255)

${ }^{4}$ Permaneceu em Itália entre 1561 e 1564, participando na fase final do Concílio de Trento a título particular, conquanto recomendado pelo monarca português ao cardeal que, por legação papal, se achava à testa das sessões conciliares. Aqui "começou a fazer ũa história diária de tudo o que procedia naquele santo ajuntamento, com todas as particularidades, ainda 
que mínimas, que está em o convento da Cartuxa do Vale da Misericórdia, junto a Lisboa, a quem deixou toda a sua livraria." Cf. Vida citada, fl. 264 vo. Da história citada existem duas versões, uma em português e outra, mais completa, em língua latina, as quais foram transferidas do convento da Cartuxa de Laveiras para a Biblioteca da Ajuda. A 1 a , com a cota 44-XII-10, é um volumoso códice, com 573 fólios elegantemente caligrafados, intitulado Actos do sagrado ecuménico geral concílio tridentino celebrado em tempo de Pio papa IV. Por D. Jorge de Ataíde, presbitero português, cuja narrativa abrange até à $248^{\text {a } ~ " c o n g r e g a c ̧ a ̃ o ~ d o s ~ p a d r e s " ~ e ~ s e ~ e n c e r r a ~}$ com estes dizeres: "Até aqui tinha prosseguido esta história em linguagem português quando em Trento me deram novas do falecimento do muito ilustre Senhor D. António de Ataíde, $1^{\circ}$ conde de Castanheira, meu pai e senhor, e com elas mudei o propósito, porque só pera ele a fazia em língua vulgar, e de novo a fiz em latim como em outro volume se verá." (Fl. 573 $\mathrm{v}^{\mathrm{o}}$ ) Esta versão latina, com o título Acta Sacri (...) per G. de Atayde lusitanum collecta, é um códice manuscrito de 679 fls., com a cota 44-XII-10, e abarca o diário das sessões até à congregação $313^{a}$. - É de lastimar o silêncio que, ao que supomos, tem rodeado este vastíssimo e importante repositório de notícias directamente colhidas por uma testemunha ocular de uma assembleia de tamanha transcendência para o mundo católico.

5 "El-rei D. Sebastião me fez bispo de Viseu, sendo de trinta e dous anos." (Carta citada, fl. 254) As bulas de nomeação episcopal foram expedidas por Pio V e a sagração fez-se "no convento de Nossa Senhora da Graça, da Ordem de Santo Agostinho, em Lisboa, a 7 de Novembro de 1568, sendo presentes os Senhores reis D. Sebastião e rainha Dona Caterina, infantes D. Duarte e Dona Maria, sagrou-o o bispo capelão-mor D. Julião de Alva, foram assistentes D. Gaspar Cão, bispo de São Tomé, e D. Manuel de Almada, bispo de Angra.” (Vida citada, fl. 275).

${ }^{6}$ D. Jorge de Ataíde fez a entrada solene na sua diocese a 14 de Março de 1569 e renunciou a mitra viseense a 4 de Julho de 1578: o que nos leva a pôr em remissa a cifra adiantada pelo cónego eborense, a quem uma deficiente informação ou o desejo de lisonjear terão induzido em erro. Vd. José de Castro, o. c., IV, pp. 68-69.

7 Se D. Jorge de Ataíde deveras acalentou então este propósito de apartar-se do mundanal bulício, tal sonho teve duração fugacíssima, uma vez que, cinco meses volvidos sobre a renúncia à mitra, em Dezembro de 1578, já uma carta do núncio Fontana ao secretário de Estado da Santa Sé o aponta como capelão-mor da corte e, a 31 de Janeiro de 1579, assiste pela primeira vez a uma reunião do Conselho de Estado convocada pelo cardeal-rei D. Henrique. Vd., respectivamente José de Castro, o. c., ibi., e Queiroz Veloso, O Reinado do Cardeal D. Henrique, Lisboa, Empresa Nacional de Publicidade, 1946, p. 116.

8 Além dos cargos já atrás citados que deveu à munificência de Filipe I de Portugal, segundo o sobrinho D. António de Ataíde: "renunciou o ofício de inquisidor-geral depois de ter as bulas apostólicas (...) não aceitou os arcebispados de Braga, Lisboa e Santiago, que se lhe ofereceram em diversos tempos, nem os priorados de Pombeiro e de Guimarães (...)." Vida citada, fl. 260. Todas estas mostras de desinteresse não embargaram a que apetecesse e rogasse com pertinácia o barrete cardinalício, que o nosso primeiro monarca Áustria lhe foi matreira e sucessivamente prometendo e protelando. Vejam-se as cartas transcritas no Compêndio Histórico do Estado da Universidade de Coimbra, o. c., pp. 22-38. 
Proémio à Paráfrase a Job do Português Jerónimo Osório

${ }^{1}$ Trabalhos e Dias, vv. 90-105.

Segundo Livro da Paráfrase a Job do Português Jerónimo Osório

${ }^{1}$ Aos conceitos de "dignidade", "bom nome", "glória", tão do agrado dos tratadistas éticos renascentistas, consagrou D. Jerónimo Osório a sua $2^{\mathrm{a}}$ obra publicada: o De gloria libri $V$, Coimbra, Francisco Correia, 1549. Neste diálogo desenvolve largamente o tema sob uma óptica cristã coincidente com a das linhas acabadas de ler.

${ }^{2}$ Recorde-se que o último livro dado à estampa por D. Jerónimo Osório versava exactamente o tema da "verdadeira sabedoria": De uera sapientia libri quinque, Lisboa, Francisco Correia, 1578.

Terceiro Livro da Paráfrase a Job do Português Jerónimo Osório

${ }^{1}$ Cf. $J b$ 7. 1. e Ef 6. 11-17.

${ }^{2} \mathrm{Na}$ esteira, por um lado, do chamado neoplatonismo do Pseudo-Dionísio, e, por outro, de Marsílio Ficino, a obra de D. Jerónimo Osório oferece-nos vários exemplos da importância que a sua espiritualidade atribuía à experiência mística, quer em si mesma, quer como grau supremo da sabedoria. Veja-se o que sobre este tópico dizemos e os passos que citámos nas pp. 364-367 do tomo $2^{\circ}$ da nossa obra Humanismo e Controvérsia Religiosa. 
(Página deixada propositadamente em branco) 


\section{ÍNDICE ONOMÁSTICO}

A

África, 21

Agostinho, Ordem dos Eremitas de Santo, 20, 418

Águas Santas, (mosteiro de), 18

Agustín, António, 10, 13, 14, 16, 31, 33, 43, 426

Ajuda, Biblioteca da, 7, 417, 418

Alba, Duque de, 23

Alberto, Cardeal-arquiduque, 49

Albuquerque, Martim de, 29

Alcácer do Sal, 9

Alcácer Quibir, 23, 33

Alcalá de Henares, 7

Alcântara, Batalha de, 23

Alcobaça, 64, 417

Alenquer, 37

Algarve, 7, 8, 10, 21, 22, 23, 24, 25, 26, 42

Almada, D. Manuel de, 39, 40, 41, 418

Almeida, D. Lopo de, 9

Almeirim, 14, 16, 17, 23, 24, 27

Alva, D. Julião de, 20, 418

Amsterdão, 50

Amaseo, Romolo, 13

Andrada, Francisco de, 6

Andrada, Jacinto Freire de, 18

Andrade, Diogo de Paiva de, 16, 47, 51, 54,58

Angra, Bispo de. Vd. Almada, D. Manuel de.
Anticristo, 52

António, D., Prior do Crato, 16, 17, 23, 42

Antuérpia, 13, 40, 49, 53, 58

Arábia, 80, 81, 84, 85, 112, 113, 392, 393

Arias Montano, Benito, 51, 58

Aristóteles, 10

Arrais, D. Amador, 23

Ascham, Roger, 38, 47

Ataíde, D. António de, $1^{\circ}$ Conde de Castanheira, 418

Ataíde, D. António de, $1^{\circ}$ Conde de Castro

Daire e $5^{\circ}$ Conde de Castanheira, 417

Ataíde, D. Jorge de, 59, 64, 417, 418

Atenas, 10

Áustria, Dinastia de, 23, 418

Avis, Dinastia de, 42

B

Babel, 51, 52

Baraquel, 238

Bárbara, Colégio de Santa, 11

Barcelona, 22

Barreto I, D. Francisco, 8

Barreto II, D. Francisco, 8

Barros, João de, 6, 36

Bartolomeu Ferreira, frei, 33, 37

Basileia, 6, 29

Bataillon, Marcel, 11, 12

Beatriz, Dona (mãe do rei D. Manuel), 8

Beira, 7, 8, 15, 18 
Belém, Mosteiro de, 19

Beliago, Belchior, 16

Benatius, Alexandre, 22, 50

Benito el Real, San, 417

Bernardo da Cruz, frei, 23

Bigalli, Davide, 30

Bildad de Chua, 96, 97, 118, 119, 120, 121, 168, 169, 170, 171, 182, 183, 204, 205, 302, 303

Birckmann, Herdeiros de Arnaldo, 13, 45, 47,50

Birckmannica, Officina, 13

Blávio, João, 17, 20, 37

Bodley, Sir Thomas, 25

Boccadiferro, Ludovico, 13

Bocchi, Achille, 13

Bogemius, Bartholomaeus, 13

Bolonha, 12, 13, 14, 15, 22, 27, 29, 31, 50, $52,53,57$

Bonfadini, Bartolomeu, 5

Bourdon, Léon, 22, 23, 40, 43, 44, 45

Bracciolini, G. F. Poggio, 28

Braga, 29, 34, 36, 44, 418

Brandão, Mário, 17

Brás (filho de Jerónimo Osório), 18

Brasil, 7

Briesemeister, Dietrich, 30

Bruxelas, 40

Buchanan, Jorge, 49, 50

Burgos, André de, 25

\section{C}

Cabral, Pedro Álvares, 7

Calíope, 27

Calligari, Giovanni Andrea, 21

Câmara, Luís Gonçalves da, 25, 43

Câmara, Martim Gonçalves, 25

Cambridge, 47

Canto, Belchior do, 17

Canziani, Guido, 30

Cão, D. Gaspar, 418

Cardon, Horatius, 59
Cardoso, Jerónimo, 9

Carlos V, 13, 14

Castanheda, Fernão Lopes de, 6, 36

Castanheira, Condes de. Vd. D. António de Ataíde.

Castela, 11

Castro, José de, 14, 417, 418

Castro, León de, 10, 11

Castro Daire, Conde de. Vd. D. António de Ataíde.

Castro Marim, 42

Catarina, Santa, 55

Catarina, Rainha Dona, 11, 18, 43

Cecil, William, 40

Cesures, 18

Chãs de Tavares, Santa Maria de, 18, 19

China, 7, 31

Chinear, 52

Cícero, 7, 40, 57, 78, 79

Coimbra, 17, 19, 20, 23, 25, 27, 30, 31, 32, $33,34,35,37,40,43,44,48,50,52,57$, $417,418,419$

Colónia, 13, 45, 47, 48, 50, 58, 368, 369

Colonna, Marco António, 52

Como, Cardeal de, 22

Correia, Francisco, 6, 27, 30, 32, 33, 39, 54, 419

Coulão, 6, 7

Couto, Aires Pereira do, 15

Couto, Diogo do, 6

Crasbeck, Pedro, 25

Crato, 17, 18

Crato, Prior do. $V d$. D. António.

Cristo, 27, 31, 52, 54, 80

Cruz, Lígia, 16

Cunha, Jerónimo da, 18

Cunha, Nuno da, 9

D

David, 50

Day, John, 10

Décio, Pedro, 53 
Demónio, $V d$. Satanás

Demóstenes, 10, 78

Deus: passim,

De Witte, Charles-Martial, 21

Diabo, $V d$. Satanás,

Dias, J. S. da Silva, 20

Dias, Osório, 6

D' Intino, Raffaela, 31

Diu (2 $2^{\circ}$ Cerco de), 30

Duarte, Rei D., 8

Duarte, Infante D., 8, 22, 418

Duarte, Senhor D., 22

\section{E}

Egipto, 394, 410, 412, 414

Elías de Tejada, Francisco, 32

Elifaz de Teman, 96, 100, 108, 118, 156, 162, 190, 236, 302

Elísio, Filinto, 37

Eliú, 236, 237, 238, 239, 248, 249, 258, 259, $274,275,302,303$

Erasmo, 27, 29

Érebo, 170, 202

Espanha, 25, 43, 417

Espanha, João de, 32

Essex, Conde de, 24, 25

Estienne, Robert, 40

Estocolmo, 58

Estóicos, 417

Etiópia, 214

Euclides, 55

Eulália, Santa, 18

Eurípides, 74, 75

Europa, 35, 36, 40, 45, 48

Évora, 6, 8, 17, 19, 20, 25, 27, 41, 57

Ezequiel, 58

\section{$\mathrm{F}$}

Fabro, Pedro, 24

Faria, Francisco Leite de, 30

Farnésio, Alexandre, 22, 40

Faro, 8, 21, 22, 24, 25
Fernando, Infante D., filho do rei D. Duarte, 8

Ferreira, João, 34

Ficino, Marsílio, 34, 419

Figueiró da Granja, 7, 18

Filipe II de Espanha, I de Portugal, 24, 25, 417

Filipe III de Espanha, II de Portugal, 417

Flandres, 22

Flores Sellés, Cándido, 13, 14, 15, 27

Fonseca, Beatriz da, 6

Fonseca, Bernardo da, 7, 12, 31

Fonsecas, 6, 7

Fontana, Roberto, 22, 418

Fornos de Algodres, 7

França, 11, 39, 40

Francisco Foreiro, frei, 37

Franco-Condado, 13, 43

Freire, Anselmo Braancamp, 7

Funchal, 20

Fúrias, 150, 156, 298

\section{G}

Gaia, Vila Nova de, 18

Gama, Vasco da, 9

Garin, Eugenio, 28

Génova, 22

Goa, 9

Góis, Damião de, 35, 36, 37

Gomes, Brás, 19

Gonçalves, António, 35

Gonçalves, Beatriz, 18

Gouveia, António de, 11

Gouveia, Diogo de, o Velho, 11, 12

Gouveia, Diogo de, Prior de Palmela, 11, 20

Gouveia, Francisca Gil de, 6

Gouveias, 7

Gracianus, Ioannes, 7

Grécia, 66

Gregório XIII, 22, 33, 43

Grifi, Giovanni, 46 
Gryphius, Sebastianus, 11

Guimarães, Priorado de, 418

Guzmán, Hernán de, 11

$\mathrm{H}$

Haddon, Walter, 6, 7, 9, 10, 20, 24, 27, 38, $39,40,41,54$

Harding, Thomas, 41

Henrique, D., Cardeal, Infante e Rei de Portugal, 18, 19, 20, 23, 27, 29, 35, 37, 43, $50,51,68,70,418$

Henrique VIII, Rei de Inglaterra, 47

Henriques, Guilherme, J. C., 49

Hesíodo, 74

Hósio, Estanislau, 20, 21, 22, 34, 41, 43, 44

Hurtado de Mendoza, Diego, 14

\section{I}

Inácio de Loiola, Santo, 24, 25

Índia, 6, 7, 9, 12

Inglaterra, 37, 39, 40, 54

Inocêncio Francisco da Silva, 7, 8, 9

Inquisição, 11, 20, 49

Irlanda, 39

Isabel, Rainha de Inglaterra, 37, 39, 40, 54

Isabel, Senhora Dona (mulher do Infante

D. Duarte), 22

Isaías, 16, 49, 50, 58

Israel, 364, 365, 392, 393, 410, 411

Itália, 12, 13, 14, 15, 21, 22, 23, 50, 417

\section{$\mathrm{J}$}

Jacob, 360, 410

Jemima, 304

Jeremias, 58

Jesus, Companhia de, 12, 19, 24, 25, 43

João Evangelista, São, 52, 55, 56

João III, Rei D., 6, 8, 9, 11, 12, 14, 15, 16, $17,18,30,31,417$

Job: passim

Jordão, 292
$\mathrm{L}$

Lagares, S. Martinho de, 18

Lagos, 44

Lambeth, 47

Laveiras, Cartuxa de, 418

Leiria, 8, 17

Lemos, D. Jorge de, 20

Leonor, Rainha Dona, (mulher de D. João II), 8

Leonor, Rainha Dona, (mulher de D. Manuel e de Francisco I de França), 11

Leviatão, 294

Leyden, 29

Lisboa: passim

Londres, 10

López Rueda, José, 11

Lovaina, 40

Luís, Infante D., 12, 13, 16, 17, 18, 28

Luís de Granada, frei, 54

Luís de León, frei, 11

Luís de Sousa, frei, 9, 15

Luís, António, 9

Lutero, Martinho, 29, 39, 48

Lyon, 59

M

Macedo, Jorge Borges de, 37

Machado, Diogo Barbosa, 6, 7, 8, 9, 16, 18, 19

Madrid, 11, 28, 32, 417

Magalhães, Joaquim Romero de, 21

Maia, 18

Malabar, 6

Malta, Ordem de, 18

Mangualde, 18

Manuel I, Rei D., 7, 8, 35, 36, 50

Manuel II, Rei D., 39

Manuel (filho de Jerónimo Osório), 18

Maquiavel, Nicolau, 29, 31

Marcos de Lisboa, frei, 17, 19

Maria Tudor, Rainha de Inglaterra, 47 
Maria, Infanta Dona, 22, 418

Maria, Senhora Dona, 40

Marrocos, Xerife de, 21

Mascarenhas, D. Fernando Martins de, 25

Matal, Jean, 13, 31, 45, 50

Matos, Luís de, 8, 12

Mayer, Thomas F., 47

Mazagão, 21

Melo, D. João de, 2’0, 25, 59

Meneses, D. Francisco de Sá e, 32

Merêa, Paulo, 33

Mesopotâmia, 238, 239

Metafraste, Simeão, 55

Migne, 55

Milão, 30

Miranda do Douro, 20

Moisés, 66, 234

Mondego, 16

Moniz, António, 31

Montemor, Jorge de, 5

Moreira, Domingos, 18

Mylius, Arnoldus, 45, 50, 52, 58

$\mathrm{N}$

Nascimento, Francisco Manuel do, 37

Nilo, 364

Nunes, Pedro, 9

Nutius, Martinus, 13

\section{$\mathrm{O}$}

Oliveira, Santiago de, 18

Oliveira do Douro, 18

Orco, 314

Oseias, 45

Osório, Família, 7, 18, 49, 272-277

Osório, D. Jerónimo: passim

Osório Júnior, Jerónimo, 9, 16, 19, 26, 32, $47,50,51,52,53,55,56,59,64,417$

Osório da Fonseca, João, 6

Osório, Jorge Alves, 30

Ozores, 7
$\mathrm{P}$

Países Baixos, 40, 53

Paleotti, Gabriel, 53

Palmela, Prior de, $v d$. Diogo de Gouveia

Pandora, 74, 75

Paris, 8, 11, 12, 15, 24, 25, 37, 40, 49

Parma, 22

Pato, Bulhão, 9

Paulo, São, 16, 50, 52, 55

Paulo III, 14

Penafiel, 18

Pereira, D. Martinho, 50

Perna, Petrus, 6, 29

Piacenza, 14

Pignatti, Franco, 30

Pinheiro, D. António, 9, 20, 54

Pinho, Sebastião Tavares de, 6, 17, 27, 39, 43,59

Pinto, António Guimarães, 3, 5, 7, 10, 27, $30,32,34,38$

Pio IV, 20

Pio V, 7, 418

Plantinus, Christophorus, 49

Platão, 10, 11, 32, 66

Pole, Reginald, 47

Polónia, 43

Pombeiro, Priorado de, 418

Portalegre, Isabel de, 18

Portimão, Vila Nova de, 45

Porto, 12, 18, 59

Porto de Mós, 9

Portugal: passim,

Portugal, D. Francisco de, 32

Priuli, Alvísio, 47

Pseudo-Dionísio, 34, 419

Q

Quecia, 304

Queirós, Eça de, 9, 21

Querén-Hapuc, 304 
$\mathrm{R}$

Radermakers, Jean., 58

Ramalho, Américo da Costa, 35

Rame, 238

Real, Mário Guedes, 7

Resende, André de, 9

Reszka. Estanislau, 21, 45

Ribeiro, António, 16, 39

Rodrigues, Francisco, 12, 19, 25

Rodrigues, Luís, 28

Rodrigues, Manuel Augusto, 44

Roma, 14, 15, 21, 22, 30, 44, 48, 50, 53, 72

Ruas, João, 39

\section{S}

Sacchi, Bartolomeo, 28

Sagres, 22

Salamanca, 9, 10, 13

Salomão, 45, 58

Sampaio, Lopo Vaz de, 6, 9

Santa Cruz de Coimbra, Mosteiro de, 16, 17

Santa Maria da Graça, Mosteiro de, 20

Santa Sé, 21, 22, 418

Santarém, 23, 42

Santiago de Compostela, 418

Santo Ofício, $V d$. Inquisição,

Santos, D. Manuel dos, 19

São Francisco de Tavira, Convento de, 26

Satanás, 84, 85, 86, 87, 88, 89, 90, 91, 92, $93,94,150$

Sé Apostólica, $V d$. Santa Sé,

Sebastião, Rei D., 18, 20, 21, 22, 23, 25, 31, $56,70,418$

Séneca, 42

Sigonio, Carlo, 13, 30

Silva, João Gomes da, 21, 22

Silva, D. Miguel da, 14, 15

Silves, 5, 10, 20, 21, 22, 25, 28, 29, 39, 41, 45,50

Silvius, Guglielmus, 40

Simancas, Arquivo Geral de, 24, 42

Smith, Thomas, 40
Soares, Nair de N. de Castro, 32

Sofar de Naamá, 96, 130, 176, 182, 302

Sousa, João de Melo e, 59

Sparwenféldt, 58

$\mathrm{T}$

Tarouca, 7

Tarragona, Arcebispo de, Vd. António Agustín,

Tártaro, 206

Tavira, 8, 21, 24, 26

Távora, Álvaro Pires de, 417

Távora, Ana de, 417

Távora, Lourenço Pires de, 32

Teive, Diogo de, 54

Teles, Basílio, 59

Tomás de Aquino, Santo, 34

Torga, Miguel, 59

Tormes, 10

Torrão, João M. Nunes, 31

Trento, 14, 47, 68, 417, 418

V

Valentim da Luz, frei, 20

Valier, Agostino, 46, 47

Valvassore, Giovanni Andrea, 46

Vanderaa, Petrus, 29

Vaticano, 7, 8, 20

Veloso, J. M. Queirós, 21, 418

Veneza, 14, 15, 40, 46, 48

Vicente, Cabo de São, 37

Viçosa, Vila, 39

Viseu, 7, 8, 14, 15, 18, 64, 68, 417, 418

Viterbo, Joaquim de Santa Rosa de, 18

W

Wetstenius, Henricus, 50

Wilson, Thomas, 10

Z

Zacarias, 45, 51

Zileti, Giordano, 46 


\section{ÍNDICE GERAL}

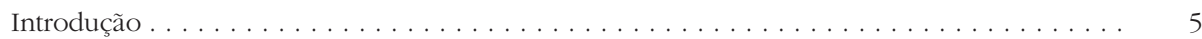

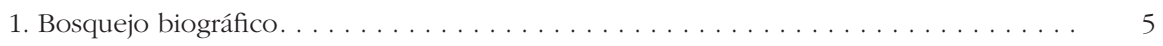

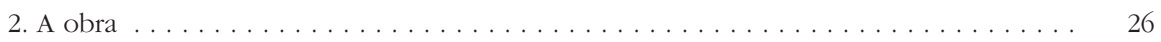

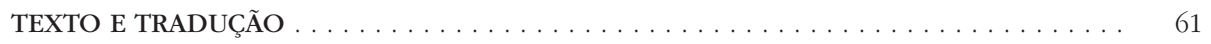

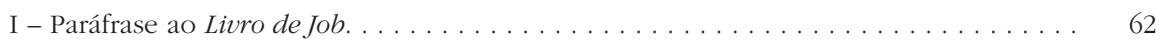

Prefácio de Jerónimo Osório Júnior da Paráfrase ao Livro de Job a D. Jorge de Ataíde . . . 64

Proémio de D. Jerónimo Osório à Paráfrase ao Livro de Job . . . . . . . . . . . . . . . . 74

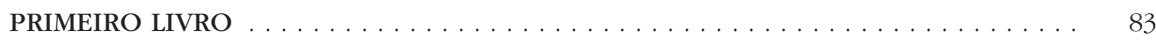

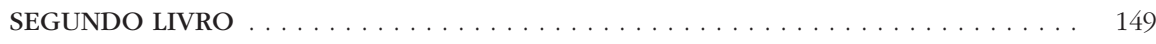

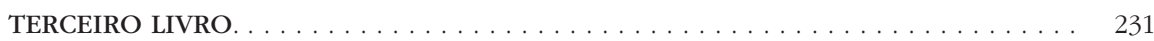

II - Paráfrase à Sabedoria de Salomão . . . . . . . . . . . . . . . . . . . . . . . . 306

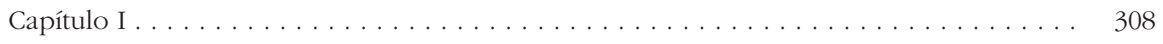

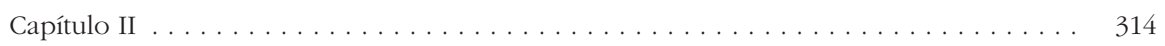

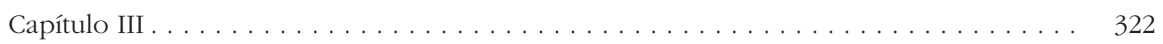

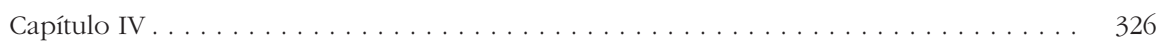

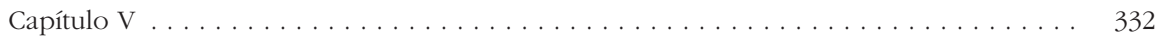

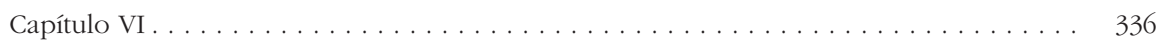

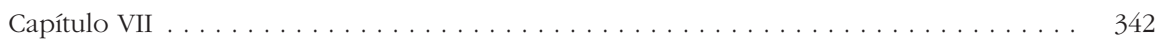

Capítulo VIII . . . . . . . . . . . . . . . . . . . . . . . . . . . . . . 350

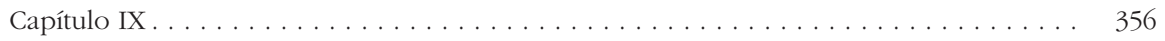

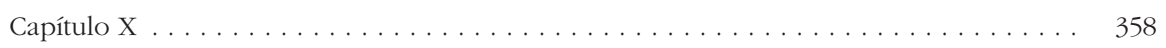

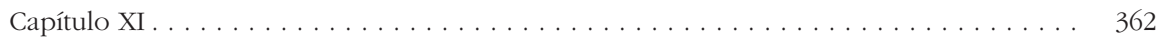

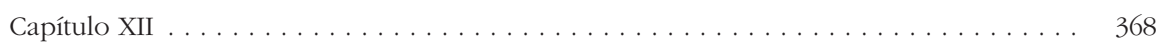

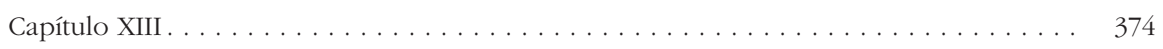

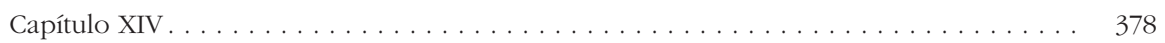

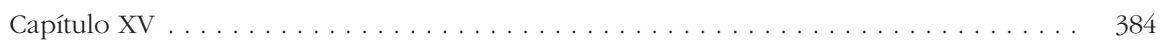


Capítulo XVI. . . . . . . . . . . . . . . . . . . . . . . . . . . . 390

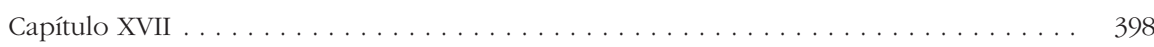

Capítulo XVIII. . . . . . . . . . . . . . . . . . . . . . . . . . . 404

Capítulo XIX ................................. 410

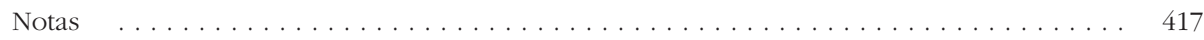

Índice Onomástico . . . . . . . . . . . . . . . . . . . . . . . . . . . . . . . . . 421 
(Página deixada propositadamente em branco) 


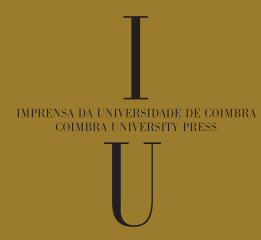

(2)

C 